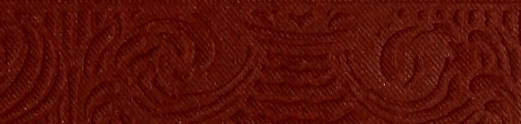

(2.
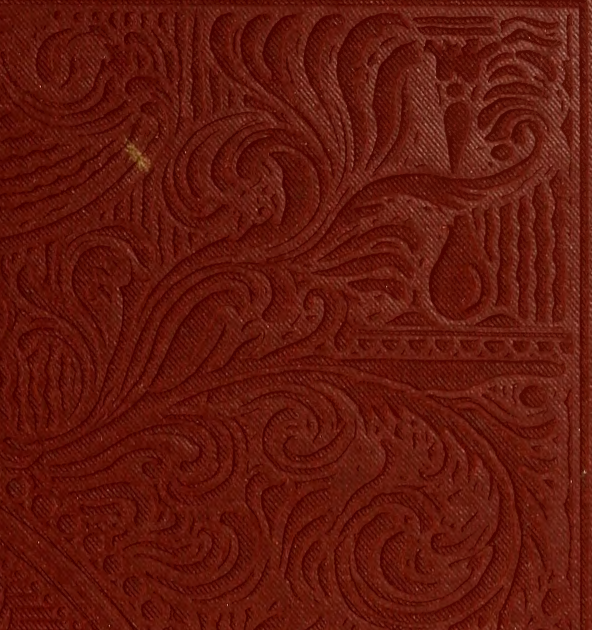

(1)
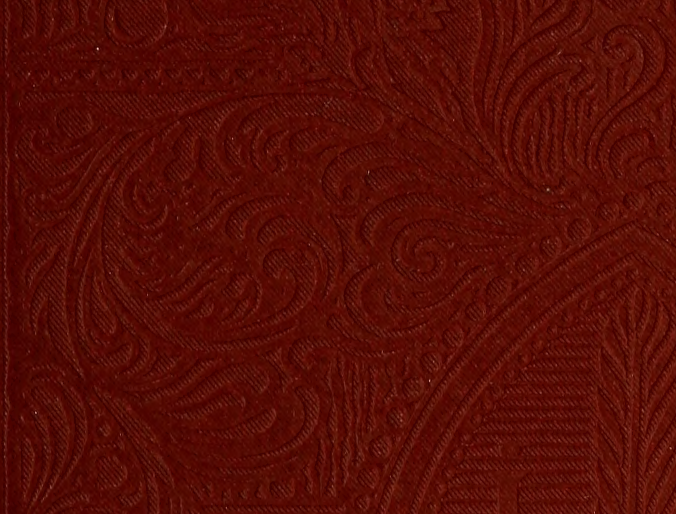
Afene 93

Fother 





THE AUTOBIOGRAPHY OF JOSEPH JEFFERSON 




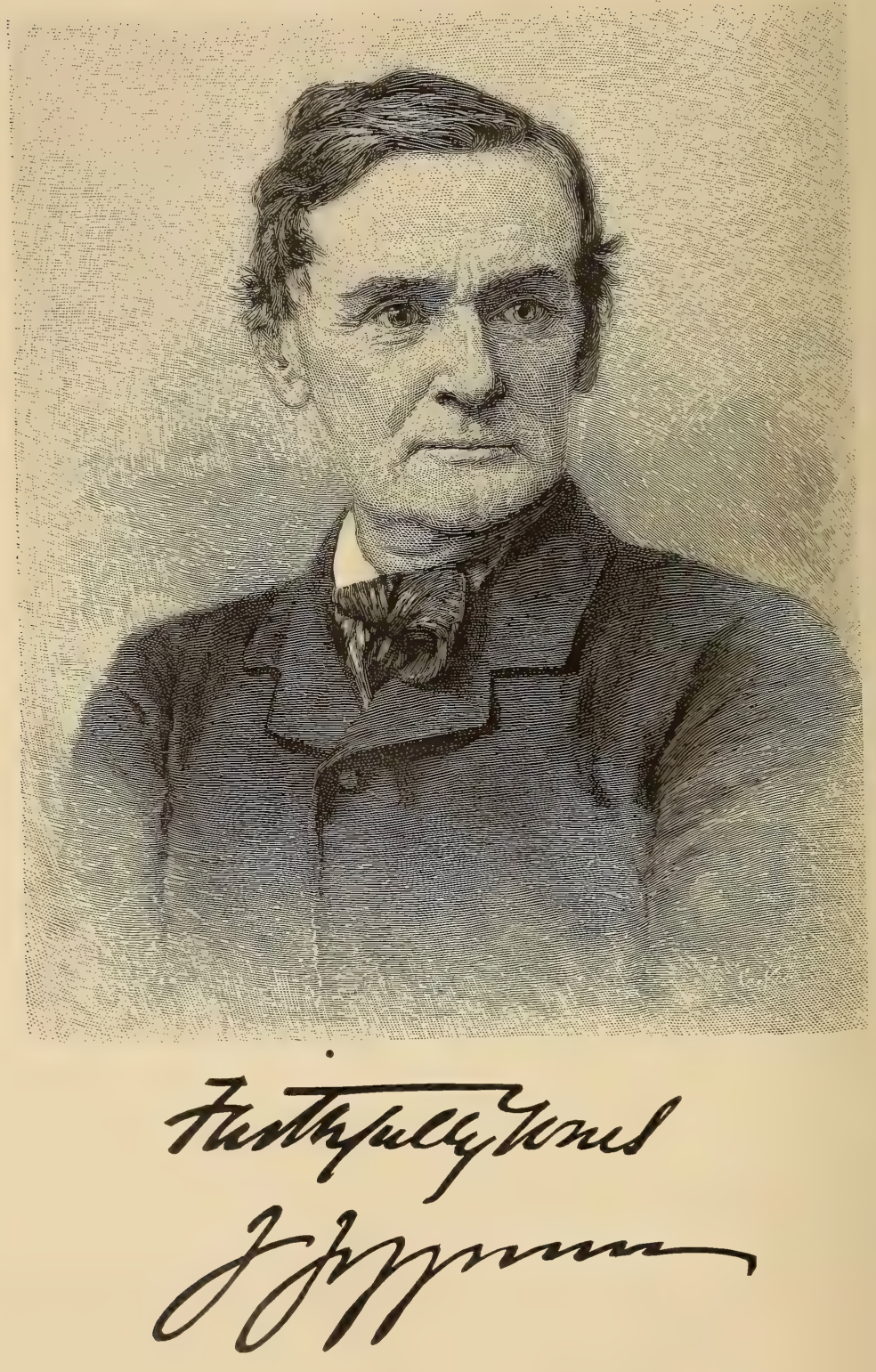




\section{THE AUTOBIOGRAPHY OF JOSEPH JEFFERSON}

\section{$\underline{\underline{ }}$}

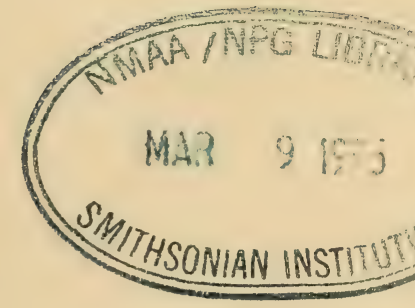

THE CENTURY CO., NEW YORK 
Copyright, 1889, 189o, by JOSEPH JEFFERSON.

(All rights reserved.)

THE DE VINME. PRESQ 


\section{PREFACE.}

$1 N$ Irishman once exclaimed that no man should not quite precise in his expression, still we can arrive at what he meant.

One's own history will naturally be clearer when told by one's self than it could be if passed through the esteem of a friend or the prejudice of a foe; besides a man can with impunity chastise his own acts in a manner that would look cruel in an enemy, and will naturally avoid that kind of praise a friend might lavish, knowing that he would only be ridiculed for vaunting his own merits. The curious memories that rush upon one when alone are fresher and more vital than those that are coldly drawn out by a succession of premeditated interviews. Thoughts, too, should be jotted down as quickly as they come, and are more vigorous if shaped by the simple language that usually accompanies them; labored alteration will sometimes rob them of their value, as a master stroke of the brush is often ruined by elaboration.

How often the painter, after having spoiled his first work by some intellectual modification, has said to himself, "Oh, how I wish I had let it alone." 
The autobiographer, if he be not a literary man, first hesitates through sheer cowardice - I know I did. He no sooner dips his pen than the thought at once rushes upon him that book-making is a trade like every other, and he is aghast at his own vanity which made him think for a moment that he could at once accomplish a task which men of learning, taste, and experience would hesitate to undertake. The dread of censure, the fear of ridicule start up like specters, and he drops his pen in dismay. But let him reflect upon the real nature of his task and he will take courage, for he will realize that what he has undertaken can be best done by himself.

It is the loose and rugged style in which Tate Wilkinson's Memoirs are written that renders them so pleasing; fearlessly ungrammatical but extremely interesting; the man, the whole man, and nothing but the man from beginning to end. The cool effrontery and unruffled temper with which he bears the buffets of fortune and the abuse of his contemporaries prove him to have been inclosed in the hide of a rhinoceros, and the unblushing vanity with which he quotes Shakspere, line after line, apparently under the impression that it is entirely his own, is delightful, because it reveals the man. Of course no other kind of book could be tolerated if it were so crudely written.

I do not mean by these remarks to bid for favor, or beg for mercy towards my own clumsiness; I neither ask it nor expect it.

So, as I now place my life in the hands of the public and the critic, I can exclaim with Touchstone, "An ill-favored thing, sir, but mine own." 


\section{CONTENTS}

\section{Recollections of Childhood.}

My First Playhouse. Earliest Appearances. My Friend Mrs. Neal. First Appearance in New York. A Strange Playground. .

II BoyHOOD.

Westward Ho! Chicago in 1839. An Adventure in Springfield, Illinois. Hard Times. James Wallack, Sr. The Elder Booth. Macready. Our Voyage on a Flatboat............... I7

III BARN-STORMing AND Mexican Episode.

Barn-storming in Mississippi. Pudding Stanley. In Mexico. Mr. and Mrs. James W. Wallack, Jr. John E. Owens........ $5^{\mathrm{r}}$

IV Early Days in Philadelphia and New York. Crossing the Alleghanies. My Friend the Scene Painter. William E. Burton. An Effort in Greek Tragedy. Charles Burke ...... $8_{3}$

V Stock, Star, and Stage Management.

From Stock to Star. From Star to Stock. The Elder Booth as Sir Giles Overreach. The Southern Theatrical Circuit. A Wandering Star. The Balcony Scene. Julia Dean. Legitimate Comedy. James E. Murdoch. Henry Placide. A Play an Animated Picture. Edwin Forrest .......................... II I

VI First Visit to Europe.

From London to Paris. An Early Comedy. In the Second-hand Shops. Return to America...................... I I I

VII With Laura Keene.

"The Heir-at-Law." Dramatic Action. "Our American Cousin." A Theatrical Quarrel. Changes in Old Plays. "The Duchess.". I 183 
VIII At the Winter Garden; ANd "Rip Van Winkle."

The Winter Garden. Caleb Plummer. I Receive Good Advice. "The Octoroon." Some Remarks on Guying. The Comedian's Disadvantage. The First Successful Star Comedian. How I Came to Play "Rip Van Winkle." Failure in San Francisco. Harry Perry. 207

IX In Australia, Van Diemen's Land, and New Zealand.

From California to Australia. Sydney. Melbourne. The Skeleton Dance. The Shepherd. An Australian Tragedy. A Terrible Audience. The Keans. A Chinese Theater ............. 231

$\mathrm{X}$ In South America.

Callao. Lima. A Midnight Funeral. A Beggar on Horseback. The Theater in Callao. A Religious Tableau. A Tropical City.

Leaving South America. An Incident in Panama........... 275

XI IN London.

The New "Rip Van Winkle." English Relatives. John Brougham.

Tom Robertson. Artemus Ward .................... 302

XII East and West.

Edwin Adams. The Combination System. George D. Prentice. Tom Glessing again. George Holland. "The Little Church Around the Corner." Charles Fechter ............... 322

XIII Scenes and Thoughts Abroad.

Once More in Paris. French Acting. French and English Painters. English Acquaintances. The Reverend Joseph Jefferson.

Gainsborough. In Scotland. In Ireland . . . . . . . . . 346

XIV At Home Again.

Booth's Theater. Talks with Charles Mathews on Acting. John

B. Rice. "The Rivals." William Warren................ $3^{81}$

XV Some Old Friends.

Mr. and Mrs. Barney Williams. John Drew. Charlotte Cushman. Mrs. Drake. F. S. Chanfrau. John T. Raymond. John McCullough. The Lester Wallack Benefit. Actors of To-day and Yesterday ........................... 4 I10

XVI Reflections on the Art of Acting.

The Dramatic Instinct. Spontaneity and Preparation. Rehearsals. A Warm Heart and a Cool Head. Taking Time. Advice to Beginners. Remarks suggested by “ Rip Van Winkle." Realism and Idealism. Dramatic Writing. . . . . . . . . . . . . 425

XVII In Louisiana.

The "Pirate of the Gulf." Pierre Landry and his Wife. Under the Live-Oaks. Conclusion...................... 464 


\section{ILLUSTRATIONS}

Joseph JefFerson. Frontispiece

OPPOSITE PAGE.

Engraved by G. Kruell, from a photograph by Pach Brothers.

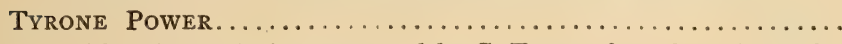

After the steel plate engraved by C. Turner, from the painting by

John Simpson. Published by W. Kenneth.

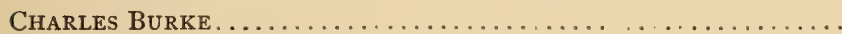

From a painting in possession of the author.

Old Jewish Burying-Ground, Pearl Street, near Chatham, New YoRk CitY ........................ $\mathbf{1 6}$

Joseph JefFerson (Grandfather of Joseph JefFerson) in the CHARACTER OF "SOLUS," IN THE COMEDY “EVERY ONE HAS His FaUlTS."

From the painting by Neagle.

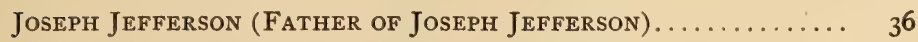
From a painting, artist unknown.

Portrait of James Wallack..................... 40

From the collection of Thomas J. McKee.

Macready as “ William Tell.". After the painting by Henry Inman, owned by Joseph Jefterson.

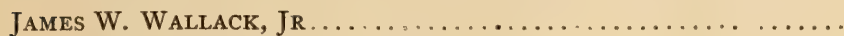
From a photograph by Gurney.

Mrs. James W. Wallack, JR .................... 76

From a photograph by Fredericks.

JoHn E. Owens. ............................ 80

From a photograph by Bachrach.

John E. OWens as "Solon Shingle." ................ 82

William E. Burton as “ Doctor Ollapod.”............. 96

From the painting by Inman, after an engraving by Sartain. 
William E. Burton as "Captain Cuttle.". IOO

From a daguerreotype by Meade Brothers, after a lithograph by Sarony \& Major.

Mr. C. Burke, American Comedian. In Comedy, Drama, Farce, AND BuRlesque.

From a lithograph by J. L. Magee.

Cornelia Jefferson (Mother of Joseph Jefferson) as "JESSICA.".

After the painting by Neagle.

Junius BRutus Booth as "Richard the Third."............

From a copperplate engraving, after a drawing by C. Shoosmith. From the collection of Edwin Booth.

The Savannah Theater Previous to 1884

From a photograph lent by J. D. Johnson.

Sir William Don........................... I36

Mrs. J. H. Allen.......................... I40

Engraved by Charles State, from a photograph by Fredericks. From the collection of Thomas J. McKee.

Julia DeAN.

After a photograph by Bradley \& Rulofson.

Henry Placide................................ 148

From a photograph by Fredericks.

Chestnut Street Theater, Philadelphia

From a print published by William Birch in 1823 .

JAMES E. MURDoch.......................... $\mathbf{1 5}_{52}$

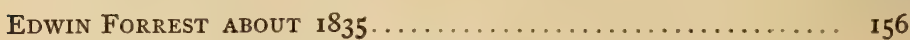

Drawn by S. Lawrence. Lithographed by E. Morton.

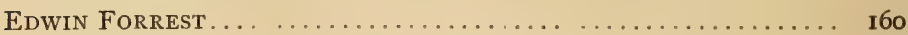

Photographed by Gutekunst. Engraved by T. Johnson.

EdWin Forrest as "Metamora." ..................... I64

Photographed by Brady. Engraved by T. Johnson.

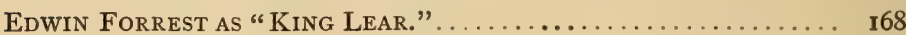
Photographed by Brady. Engraved by T. Johnson.

Joseph JefFerson as “ Dr. Pangloss." “Put all the Honorable Mr. Dowlas's Clothes and Linen Into His Father's

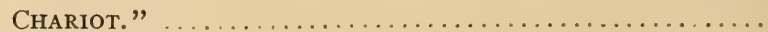
Engraved by Charles State. Photographed by Falk.

Joseph Jefferson as “ Dr. Pangloss, LL. D., A. S. S.," in “ The Heir-at-Law." "Doctor Pangloss, the Philosopher, Teach Dancing ! ".......................... I 88

Engraved by R. G. Tietze. Photographed by Falk.

LAURA KeEnE.

Drawn from a lithograph lent by Thomas J. McKee. 
“Wait, I Ain't Through Yet." Joseph Jefferson as “Asa Trenchard," in “OUR American Cousin.".......... I96 From a photograph taken in $185^{8}$ by Meade Brothers.

E. A. Sothern as “Lord Dundreary," in “OUr American Cousin."

From a photograph by Sarony.

W. R. BLAKE

From an etching by H. B. Hall, lent by Thomas J. McKee.

Joseph Jefferson as "Caleb Plummer," in "The Cricket on THE Hearth." . . . . . . . . . . . . . . . . . . . . . . .

Drawn from a photograph by Morrison, Chicago.

Joseph JefFerson as "Newman Noggs," in "Nicholas Nickleby." Engraved by R. G. Tietze. From a photograph formerly owned by John Brougham, lent by Peter Gilsey.

"Take Care, Jacob, Don't Rile Me!" Joseph Jefferson as "SAlem Scudder," in “ The Octoroon.".............. Engraved by H. Davidson. Photographed by Falk.

Tyrone Power as "Corporal O'Conor." . ................. From the lithograph by Gooding \& Gulliford, after the portrait by Wageman.

BARNey Williams .

From a photograph by Bogardus.

HARRY A. PERry.

From a print in the collection of Thomas J. McKee.

Mr. Charles Kean as "King John." Engraved by E. Clement.

Mrs. Charles Kean as "Hermione." 208 212 216 Engraved by J. H. E. Whitney.

PAUL BEDFORD. From a photograph by Walker \& Sons.

Benjamin Webster ................................ 308 From a photograph by Elliott \& Fry.

John Brougham as the "O'Grady," in "Arrah na Pogue".. From a photograph by Chancellor, Dublin. From the collection of Thomas J. McKee.

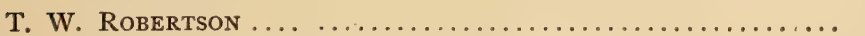
From a photograph by Walker \& Sons.

ARTEMUS WARD From a photograph by Walker \& Sons.

EDWIN ADAMS From a photograph by Gurney in the collection of Thomas J. McKee.

George Holland

From the collection of Thomas J. McKee. 
Charles Fechter ..................................

From a photograph by Heath \& Bean, of the lithograph by D'Almaine \& Co.

The Reverend Joseph Jefferson . . . . . . . . . . . . . 364

From a photograph by Baker.

Agnes Robertson ............................... 368

Engraved by R. G. Tietze, from a photograph by Fredericks. From the collection of Thomas J. McKee.

Booth's Theater, Twenty-third Street and Sixth Avenue,

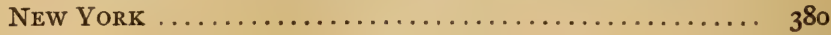

John Gilbert as “Sir Peter Teazle." ................ 384

C. J. Mathews ...................................... $3^{88}$

Engraved by R. G. Tietze, from a photograph by Mayall.

Charles J. Mathews as "Tim," in "Old and Young Stager." 392 From a sketch by R. J. Lane, published by J. Dickinson.

Joseph Jefferson as “ Вов ACres".................. 396

Drawn by Otto H. Bacher, from a photograph by Sarony.

Joseph Jefferson as “Вов ACres"................. 400

Engraved by F. S. King, from a photograph by Sarony.

William Warren as "Herr Weigel," in " My Son " ....... 404 Engraved by E. H. Delorme, from a photograph by C. F. Conly.

William Warren as “Jefferson Scattering Batkins"..... 408 Engraved by $\mathrm{H}$. Velten, from a photograph by Notman.

John Drew As "Handy Andy." ................. 412 From a photograph.

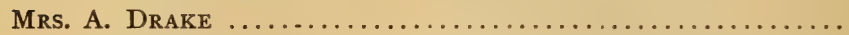

From miniature in the possession of her granddaughter, Mrs. Blanche Ford.

John Howard Payne.

From a daguerreotype.

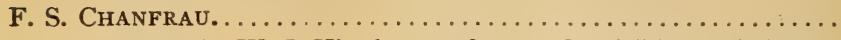
Engraved by W. J. Hirschman, after a colored lithograph in the collection of Thomas J. McKee.

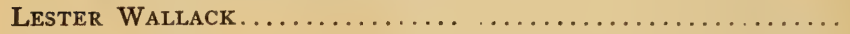

Engraved by D. Nichols, from a photograph by Fredericks taken in 1856. From the collection of Thomas J. McKee.

Mrs. Barney Williams. From a photograph by Mora.

John Drew as “The Irish Emigrant."................. Drawn by Otto $\mathrm{H}$. Bacher, from a photograph.

T. Raymond as " Col. Sellers"

Engraved by A. H. Hutchins, from a photograph by Sarony.

John McCullough as "Virginius" Engraved by T. Johnson, from a photograph by Conly. 
J. B. Buckstone ............................. 440

From a photograph by Walker \& Sons.

SARAH STEVens

Engraved by A. H. Hutchins, from a photograph by Fredericks.

From the collection of Thomas J. McKee.

Charlotte Cushman

From a photograph by Sarony.

"I Believe I Vas!" Joseph Jefferson as " Rip Van Winkle." 452

Engraved by H. Davidson. Photographed by Sarony.

“Vere is Dat Vat You Read?" Joseph Jefferson as " Rip Van WINKLE."

Engraved by J. H. E. Whitney. Photographed by Sarony.

"Is Dat the Village of Falling Vater." Joseph Jefferson as "Rip VAN Winkle." . . . . . . . . . . . . . . . .......... 460 Engraved by T. Johnson. Photographed by Walker \& Sons.

Pierre Landry and His Wife.

Engraved by Henry Marsh, from a photograph.

A Memory of Louisiana

Monotype by Joseph Jefferson. Photo-engraved reproduction of the wood-engraving by J. H. E. Whitney. 



\title{
THE AUTOBIOGRAPHY OF JOSEPH JEFFERSON
}

\author{
ChAPTER I \\ RECOLLECTIONS OF CHILDHOOD
}

My First Playhouse-Earliest Appearances--My Friend Mrs. Neal-First Appearance in New York-A Strange Playground

T MAY almost say that I was born in a theater. At all events, my earliest recollections are en1 tirely connected with one; it was a rickety old frame building with a broad gable, facing on a wide avenue, and situated in the city of Washington. The door from our back entry opened upon the stage, and as a toddling little chap in a short frock I was allowed full run of the place. So "behind the scenes" was my first playhouse. And what a playhouse it was, filled with all sorts of material for the exercise of my youthful imagination. At the back was the Bay of Naples, with its conventional blue sky just faintly clouded with the distant 
smoke of slumbering Vesuvius. Upon one side stood long and stately rows of Corinthian columns, a triumphal arch, and next to that a Roman palace. These marvels of ancient architecture were all leaning up against the wall, not only in an uncomfortable position, but at a dangerous angle, looking as though they had been toppled over during the last days of Pompeii. Upon the other side, heaped in a compact mass, were many scenes of various countries-there a five-storied brownstone-front with modern improvements, and here a tiny thatched cottage of the eighteenth century, with a lovely little door in it just large enough for me to go in and out of, slamming it after me and pretending it was mine. Then there was that dear little white paling fence, exactly two feet high: no legitimate theater of the old school could possibly be complete without this curiosity, and nobody ever saw such a thing anywhere else. Then came the throne-steps, with two Gothic arm-chairs set thereon for the king and queen, and in front of these the old familiar green bank from which stray babies are usually stolen when left there by affectionate but careless mothers. Upon the top of this were two flat swans hitched in double harness to a shell for traveling fairy queens. A little farther down there stood a low and dismal vault having a square, dark opening with some mysterious letters painted over it, setting forth, as I learned in after years, that it was the private "Tomb of the Capulets." Close to this was another piece of real estate belonging to the same family and known as "Juliet's balcony." In a dark 
corner stood a robbers' cave with an opening through which old Ali Baba used to lug the bags of gold he had stolen from the Forty Thieves. Through the narrow and secluded pathways of "behind the scenes" I have often wandered out upon the open stage and wondered at this grove of wings and flats, and I could see that many ropes were hanging from above to which were fastened boats and baskets, tubs and chandeliers, and those sure tokens of bad weather, the thunder-drum and rain-box.

Such were the objects that my childish eyes were wont to look upon, and in this huge and dusty toy-shop, made for children of a larger growth, I got my first experience. I had seen many rehearsals, and sometimes enjoyed a peep at the play, having been taken on "in arms" as a property child in groups of happy peasantry. Naturally, therefore, I was stage-struck at an early age; and as I had a theater stocked with scenery and properties, I could indulge my passion at small expense, especially as my stock company were volunteers consisting of two little boys and their sister, who used to play with me on Saturdays. This was before the star system had set in, and at a period when combinations were unknown.

Of course I was stage-manager by the right of possession, and had to compile all of the plays. The plots were very simple and made to conform with what set pieces we could get at, or what properties we could secure and hide during the absence of the property man. If the set cottage 
was handy I would come out of the door as an old man (the age represented by a spinal affection) with a daughter and a market-basket: old man cross, daughter rebellious; old man locks daughter in cottage, goes off to market shaking his fist (spine still weak). The favored lover enters, claps his hands three times; daughter appears at window, kisses her hand; old man coughs outside, favored lover conceals himself; enter old man with marketbasket full of gilded pasteboard goblets, accompanied by unfavored lover; they sit down and drink wine out of goblets till overcome. Favored lover steals key from old man's pocket, releases rebellious daughter; the sleepers awaken, general pursuit; favored lover and rebellious daughter escape over bridge, old man and unfavored lover fall into the water. Curtain.

Then there were the private boxes to play hideand-seek in, with mysterious nooks and ample curtains to creep into, and such chances to kiss the little girl in the dark. I am quite convinced that there is no such playground as a deserted theater in the daytime.

In the greenroom there was a noble mirror. I loved to stand in front of it and act. But I was not alone in this. Many of the great players, long since passed away, have stood before this stately glass; and often in the evening, when clad in my night-gown, I have escaped from the nurse, and stealing on tip-toe to the greenroom door have peeped in and beheld these magnates with dignified satisfaction surveying themselves in their kingly 


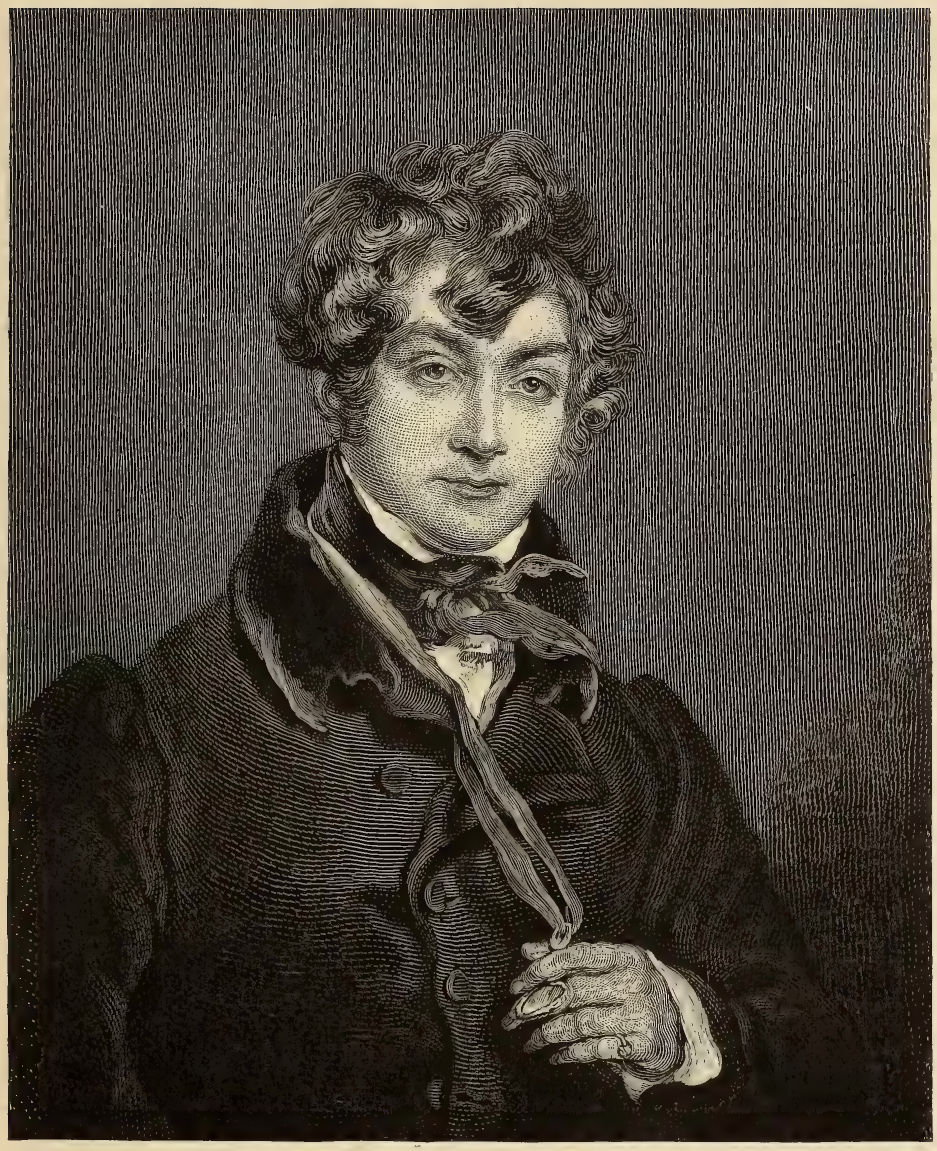

TYRONE POWER. 

robes: now a small man with piercing steel-gray eye, possibly the elder Booth; then a tall, gaunt figure, weird and majestic, Macready most likely; at another time a young and beautiful queen in white satin - this must have been Fanny Kemble; again a tall and graceful figure in a scarlet military coat posing with an extravagant swagger and evidently admiring himself - undoubtedly Tyrone Power, the great Irish comedian.

As a matter of course, being the son of the manager, and almost living in the theater, I was always pressed into the dramatic service whenever a small child was wanted. Even before I can remember I was taken on to do duty in long clothes; in fact, such was the histrionic ambition of my mother that I believe if Tilly Slowboy had existed in those days I should have been confided to her tender mercies at the risk of a collision between my head and the tea-kettle.

The first dim recollection I have of a public appearance comes before me as a startled child in a white tunic beautifully striped with gold bands, and in the grasp and on the shoulders of an infuriated tragedian crossing a shaky bridge amid the deafening report of guns and pistols and in a blaze of fire and smoke. To me the situation seemed perilous, and in order to render my position more secure I seized Rolla by the hair of his head. "Let go," he cried; but I was obeying the first law of nature, not Rolla, so I tightened my grasp upon his tragic top-knot. The battle was short but decisive, for in the next moment I had pulled off his feather- 
duster head-dress, wig and all, thereby unintentionally scalping the enemy; and, as he was past the prime of life, the noble Peruvian stood bald-headed in the middle of the bridge before an admiring audience. This story has the flavor of an old anecdote, but I am credibly informed that I was the original scalper.

About this time - I was three years old-there dawned upon the public a new entertainment in the shape of the "Living Statues," by a Mr. Fletcher. I was much taken with these novel tableaux, and became so statue-struck that I could do nothing but strike attitudes, now posing before the greenroom glass as "Ajax Defying the Lightning," or falling down in dark corners as the "Dying Gladiator." These postures appear to have been so successful with the family that they were, as usual, tried upon the public. I am in the dark as to whether this entertainment was the "talk of the town" or not, but I fancy not: an attenuated child representing Hercules struggling with a lion could scarcely excite terror; so I presume I did no harm if I did no good.

To go from white to black, "Jim Crow," in the person of T. D. Rice, now burst upon the town. The legitimate drama has at all times been subject to startling innovations, and surely here was a great blow. The success of this the first and certainly the best knight of the burnt cork was quite marvelous; he drew more money than any star of the season. It is reported that his first hit in Washington was repeated in all the great cities 
of the country, and his advent in Europe even surpassed his career here. In London he acted in two theaters nightly, the same people in many instances following him from one theater to the other.

Of course this fantastic figure had a great influence upon me, and I danced Jim Crow from the garret to the cellar. The comedian saw my imitation of him, and insisted that I should appear for his benefit; so on that occasion I was duly blacked up and dressed as a complete miniature likeness of the original. He put me in a bag, which almost smothered me, and carried me upon the stage on his shoulders. No word of this proceeding had been mentioned in the bills, so that, figuratively speaking, the public were as much in the dark as I was. After dancing and singing the first stanza he began the second, the following being the two lines which introduced me:

O Ladies and Gentlemen, I 'd have you for to know That I 've got a little darky here that jumps Jim Crow;

and turning the bag upside down he emptied me out head first before the eyes of the astonished audience. The picture must have been a curious one; it is as vividly before me now as any recollection of my past life.

Rice was considerably over six feet high, I was but four years old, and as we stood there, dressed exactly alike, the audience roared with laughter. Rice and I now sang alternate stanzas and the excitement increased; showers of pennies, sixpences, and shillings were tossed from the pit and 
thrown from the galleries upon the stage. I took no notice of this, but suddenly the clear, ringing sound of a dollar caught my ear, and as the bright coin was rolling from the stage into the orchestra I darted forward and secured the prize. Holding it triumphantly between my finger and thumb I grinned at the leader of the orchestra as much as to say, "No, you don't." This not only brought down the house, but many half-dollars and dollars besides. At the fall of the curtain twenty-four dollars were picked up and given into my delighted hands. For years afterwards I was made to understand that this money was placed in bank to my credit, and I fear that I often borrowed small sums on the strength of my prospective wealth.

Our family about this time consisted of father and mother, my half-brother, Charles Burke, and myself; but there was one other member of the household who deserves special mention. She was not one of the family, certainly, but the group would be very incomplete without her. Her name was Mary. She was that strange kind of woman who, while housekeeper, nurse, friend, and attendant, will never take any wages (which I think must have been rather fortunate in this case), and whom everybody depends upon. We would not have parted with her for all the world, and could not have driven her away if we had tried — a faithful, loving, truthful friend, with no ambition or thought for herself, living only for us, and totally unconscious of her own existence. I have no doubt that there is some such being attached to many a family, but I 


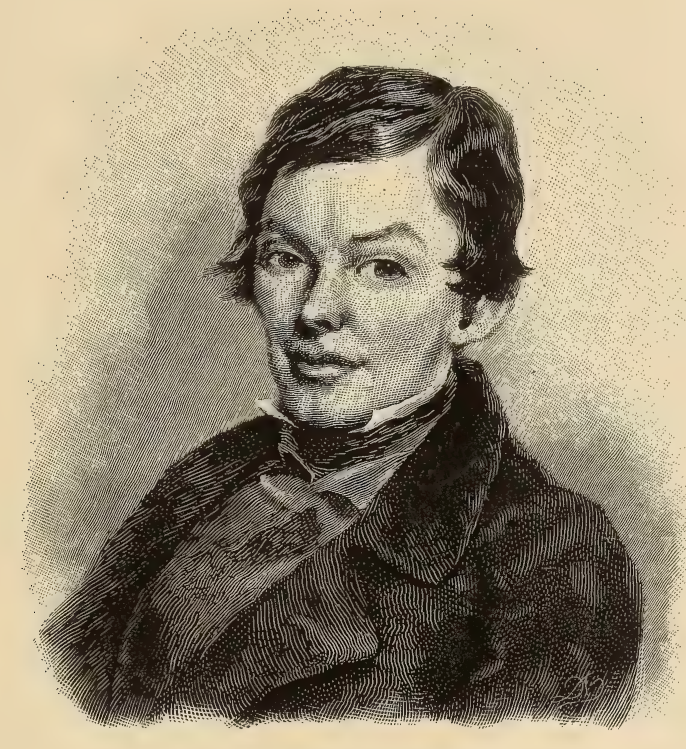

CHARLES BURKE 

know that our family was just that queer sort of party that could not have done without one. This lady (for she was a lady) was my foster-mother dear Mary!- always taking my faults on herself, finding excuses for my badness, and spoiling me, of course.

A year or two rolled by and I find we were in Baltimore, where my sister was born. She divided the honors with me then, and I was, in consequence of this new arrival, not made quite so much of. I remember as a boy I was always being injured,at least, according to my account,- so that people were rather suspicious of me; and I find this theory holds good as we grow older: that whenever a man comes to us with a tale of his injuries we look on him with distrust, and as he recounts the details of his persecution the question revolves itself in our minds, "I wonder what rascality this fellow has been up to." The world has no time to injure any one; these unfortunate people injure themselves, and so turn into some other channel the current of happiness that might have flowed to them.

But to return to my early persecutions. A neighbor, whose weak points I had discovered, bestowed on me one day a smooth sixpence. I showed it to my brother Charlie, who, looking at it with some disparagement, said that in its present obliterated state it would pass for only about four cents, but that if I would bury it for an hour the original figures would show themselves and it would pass for its full value; or, what would be better, let it remain in the ground for a day and it would grow to a shilling. This 
announcement struck me with wonder and delight, so off we started for the garden to plant this smooth sixpence. After making the interment and carefully marking it with a small headstone we departed. I went back to the house and whispered the whole affair into the ears of Mary; she denounced the operation as a fraud, and bid me hurry and get my sixpence if I ever expected to see it again. I started off at a full run for the garden. The headstone was there, but the sixpence had gone. The body-snatcher had accomplished his cruel work. Throwing myself on my back and kicking my heels in the air, I soon made the neighborhood ring with my frantic yells. The family rushed out, and I detailed to them the dark plot of my guilty brother. I determined now that nothing short of a shilling should calm my feelings, and I yelled till I got it.

I am not quite sure as to dates, and many incidents come up before me in a confused form, while a number are traditional; but there are certain facts connected with my early life about which there can be no mistake, and it is quite clear that I was what is understood to be a bad boy and hard to manage. If I heard an oath I cherished it as a newly found treasure, and would practice it in private. All this was no fault of my bringing up, for both father and mother were very particular and exacting in the conduct of home. I was made to say my prayers every night, a good example was always set before me, and sound moral principles were continually instilled into my youthful mind. The prayers I used 
to rattle off - usually thinking of something else while I was saying them - as quickly as religious decorum and my mother would permit, and the sound moral principles and good examples seemed to have the effect of making me the champion executioner of all the stray cats in our neighborhood. The banging of a tin kettle tied to the tail of an unlucky dog was music to my childish ears; and much as I love animals now, in the innocence of childhood I pursued them with such energy that had Mr. Bergh held his commission in those days I should have been seen oftener in the police court than at Sunday-school.

My mother had a friend in Philadelphia, a Mrs. Neal, who kept a bookstore in Sixth street, near Chestnut; she was the mother of Joe Neal, the young author of the "Charcoal Sketches." I was a great favorite with her. She always wore a black dress with a white cap; the cap had a little fluted frill around it, very prim, and very much starched. She was a dear old lady with a sweet smile and large, wide, blue eyes; just the credulous and confiding sort of person that a boy of seven could wind around his little finger.

My imagination was wonderfully fertile: I could at the shortest notice get up a harrowing tale of woe that would make the stiff frills on her cap fairly tremble with benevolent agitation. Now it so happened about this time that I was in a state of insolvency, being heavily in debt at the candy-store, and sorely pressed by an exacting peanut-man at the corner. If I was short of a penny or two,- 
usually the case with me,- I would dishevel my hair, rush through the store into the back room, and, sinking in an exhausted condition into the little chair by the fireplace, call for a glass of water. The startled old lady would jump up crying, "What 's the matter, Joe?” "Don't ask me- water, water!" "Yes, in a moment, my dear boy." Then, in a feeble voice, "Put some raspberry syrup in it, please, Mrs. Neal ?" "Yes, my darling." And now having been refreshed with this stimulant, I would in a tremulous voice, - a little overacted, perhaps,-relate some dire calamity I had just witnessed, giving the full particulars; in fact, the greater the fabrication the more minute I was as to the details. I would perhaps tell her that I had just seen a lovely little girl with blue eyes and golden hair run over by fire-engine No. 6; her head, severed from her body, had rolled from the middle of the street into the gutter, and lay smiling at my feet; or perhaps I had pulled the little girl from under the wheels just previous to decapitation and saved her life — refusing a large reward from her father. The shock had been so great that nothing short of an immediate supply of peppermint drops would ever obliterate it from my mindand where was I to get them? I was in disgrace at the candy-store and had no money. "My dear child," the old soul would say, "there is a penny for you." "Oh, no, I could n't take it"-knowing very well that she would force it upon me. "Ah, Mrs. Neal, I do not deserve all your kindness," the only true words I had spoken to her,- " indeed 
I don't." I'm not at all sure that she swallowed all my romantic stories, and it is quite possible that she liked to draw me out just to enjoy my exaggerations.

I was one of those restless, peevish children who, no matter what they have, always want something else. The last new toy was always dissected to see what made it go, and the anticipated one kept me awake all night. "When will it be sent home?" "About two o'clock." "Well, what time is it now?"- and so on, musing, fretting, discontented, and rude. Mother said it was badness, Mary said affection.

As I look back many strange images appear that puzzle me. Some of these scenes I know are real, and others appear to have been dreams. At times this confusion resolves itself into a chaos, and I fancy that I shall not be able to disintegrate the shadows from the realities. For instance, I perfectly well remember walking through the smoky ruins of New York with my father, after the great fire of 1835. While we were looking at this charred mass and watching the busy people hunting for half-consumed treasures, and firemen pouring streams of water on the smoldering rafters, two Indians in theatrical costumes began dancing a war dance which they terminated by tomahawking each other in the most friendly way, and then bowing to the people, who applauded them. Now I am quite sure that the first part of this recollection was a reality, and it seems pretty clear that the latter part of it was a dream. It is quite possible, therefore, 
that in relating many of my juvenile adventures I may be led, or misled, into some unintentional exaggerations.

In referring to Ireland's "Records of the New York Stage," I find the following notice of my first appearance in that city:

Master Titus, whose songs and dances were much applauded, took a benefit on the 3 oth, when he appeared with Master Joseph Jefferson in a celebrated combat, it being this lad's first appearance out of the juvenile supernumerary ranks. This little fellow was the grandson of the great comedian of the same name, and is the third Joseph Jefferson known to our stage. He was born at Philadelphia, February 20, I829.

I remember this circumstance quite well-not the birth, but the combat. Young Titus was attired as an American sailor, I being dressed to represent a Greek pirate. I was much smaller than my antagonist, but as the fight was for his benefit, good taste suggested that he should overcome and slay me, - which he did, - and as the curtain came down I was flat on my back, and the American sailor, waving a star-spangled banner over me, placed his foot magnanimously on the chest of the vanquished Greek. The fight was encored, so I had to come to life again - quite a common thing for stage pirates - and die twice. I rather delighted in being the vanquished foe: nothing could possibly be more manly than a slain pirate. Mr. Ireland mentions that the combat was "celebrated"; for what, I am at a loss to conjecture. In the accounts of our last war with the Greeks there is no mention made of this circumstance. If, therefore, the com- 
bat was "celebrated," it must have been for historical inaccuracy. I remembered this battle with pride for years. The beneficiary must have remembered it too, as it was traditional in our family that I came near cutting off a big toe of little Titus in the conflict.

In New York we lived in the third story of No. 26 James street, next to the Catholic church, and opposite to the "Bunch of Grapes," a hotel kept by one George Bickford. The second floor was occupied by John Sefton, the comedian and manager, and the lower part of the house by a Mr. Titus and his family. Our fence in the rear separated us from an old graveyard. How this curious old cemetery ever got wedged in between the buildings that surrounded it is a mystery. Perhaps in times gone by an old church may have stood at the outskirts of the little village of New York, and beneath these stones "the rude forefathers of the hamlet sleep." Passing down the Bowery on the elevated railroad, by looking on the left-hand side, just after the train branches off towards Pearl street, this queer nook may be discovered, and if the inmates only had the power of noting the progress of the times, they would be considerably astonished to see their descendants whirled over their heads on a railroad in the air.

After school the boys with whom I fraternized would join me in this secluded spot for our evening games - the high tombstones for "I spy," and the flat ones to act on. The place had long since ceased to be used as a burial-ground, so our sports were uninterrupted. The boys in the neighborhood were like all other boys in all neighborhoods 
- mischievous. My arrival had given a fresh impetus in this respect, and the graveyard offered a fine field for the indulgence of sacrilegious amusements. Ornamenting the tombstones was quite a specialty with one of our playmates. He had, previous to my advent, already painted a large red face, in a broad grin, on a headstone erected to the memory of the Rev. Jacob Boul. After consultation with the artist, I cocked a battered hat, sidewise, on the top of the face, and drilling a hole in its mouth, stuck a pipe in it, thus giving a cheerful tone to the monument, and almost robbing death of its sting.

Saturday, there being no school, was generally set apart as our "Decoration Day," and it was rare sport to get a marking-brush with a pot of black paint and embellish the virtues of the departed sinners. We were astonishingly brave in the daylight, even defying the dead bones to arise and face us if they dared, but as twilight set in our courage cooled, and we would talk lower. Sometimes, as one boy after another would scamper home, leaving the place "to darkness and to me," I would saunter slowly along with my hands in my pockets, whistling a nervous defiance to ghosts in general and these ghosts in particular, but taking care not to walk over the flat tombstones, upon which in the daylight I would dance with impunity. Now, as the shadows of night gathered around me, I would increase my pace, scampering faster and faster through the tall grass, and rapidly climbing over the fence, fancying that the Rev. Mr. Boul would soon have me by the leg if I did not hurry. 


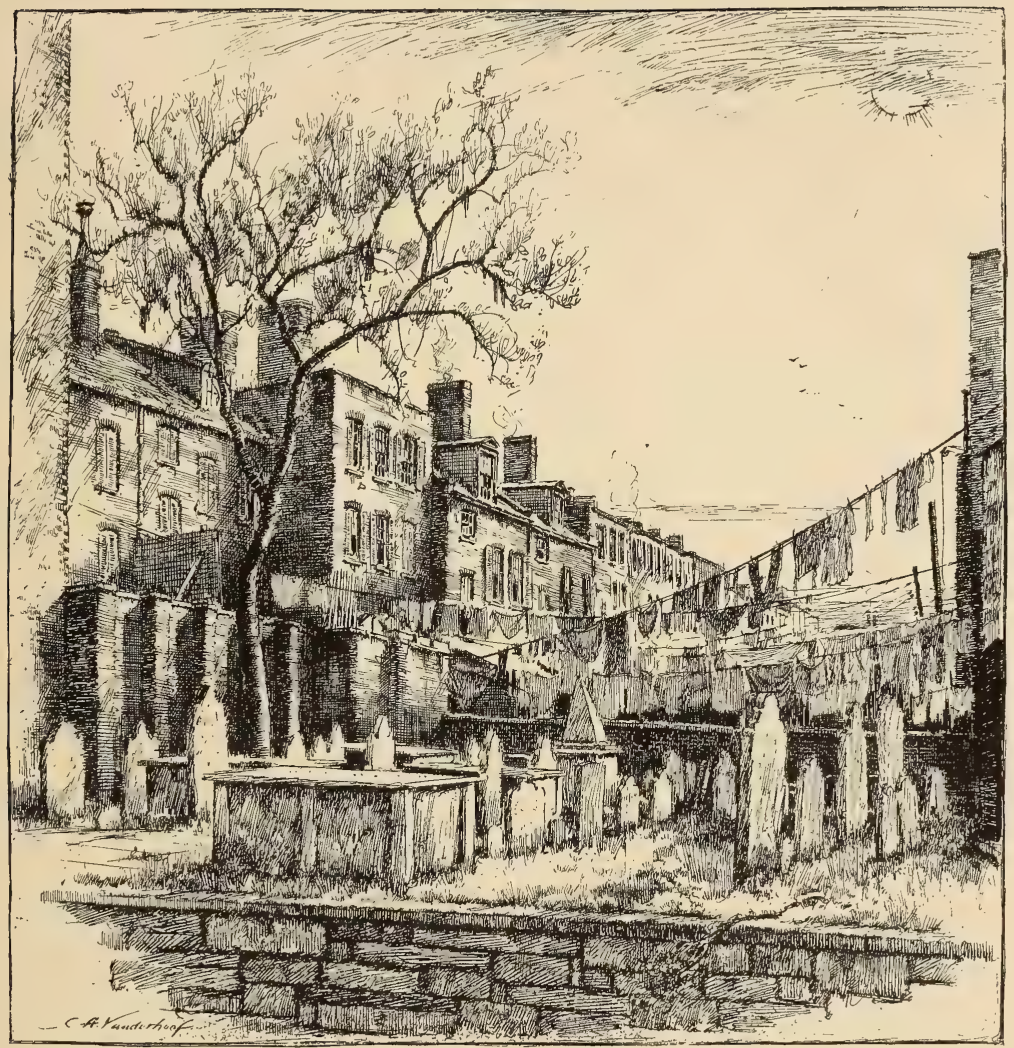

OLD JEWISH BURYING-GROUND, PEARL STREET, NEW YORK CITY. 



\section{CHAPTER II}

\section{BOYHOOD}

Westward Ho!-Chicago in 1839-An Adventure in Springfield, Illinois - Hard TimesJames Wallack, Sr.-The Elder Booth-Macready - Our Voyage on a Flatboat

$T^{\mathrm{N}}$ the year 1838 the new town of Chicago had just turned from an Indian village into a thriving lit-

1 tle place, and my uncle had written to my father urging him to join in the management of the new theater which was then being built there. As each fresh venture presented itself my father's hopeful nature predicted immediate and successful results. He had scarcely finished the letter when he declared that our fortunes were made, so we turned our faces towards the setting sun. In those days a journey from Albany to Chicago was no small undertaking for a large family in straitened circumstances ; certain cherished articles had to be parted with to procure necessary comforts for the trip. I really do not know how, but we got from Albany to Schenectady, where we acted for a few nights with 
a company that was playing there. Several of the actors, who had received no salary for some time, decided to accompany my father and seek their fortunes in the West.

As I remember it, our journey was long, but not tedious. We traveled part of the way in a fastsailing packet-boat on the Erie Canal, the only smoke issuing from the caboose stove-pipe. I can remember our party admiring this craft with the same enthusiasm that we now express in looking at a fine ocean steamer. She was painted white and green and enlivened with blue window blinds, and a broad red stripe running from bow to stern. Her name was the Pioneer, which was to us most suggestive, as our little band was among the early dramatic emigrants to the far West. The boat resembled a Noah's ark with a flat roof, and my father, like the patriarch of old, took his entire family on board, with this difference, howeverhe was required to pay his passage, it being understood between him and the captain that he should stop a night in Utica and one in Syracuse, give a theatrical entertainment in each place, and hand over the receipts in payment of our fare.

We acted in Utica for one night, and the receipts were quite good. My father and mother were in high spirits, and there is no doubt that the captain had hopes that the next night's entertainment in Syracuse would liquidate our liabilities, for there was a visible improvement in the coffee at breakfast, and an extra piece of pie all around for dinner. The next night, unfortunately, the ele- 
ments were against us: it rained in torrents and the attendance was light, so that we were short of our passage money about ten dollars.

The captain being a strict member of the Church could not attend either of the performances, and as he was in his heart most anxious to see what acting was like, he proposed that if the company would "cut up" for him and give him a private show in the cabin he would call it "square." Our actors, being highly legitimate, declined; but my mother, ever anxious to show off the histrionic qualities of her son, proposed that I should sing some comic songs for the captain, and so ransom the rest of the actors. The captain turned it over in his mind,- being, I am afraid, a little suspicious of my genius,- - but after due consideration consented. So he prepared himself for the entertainment, the cook and my mother comprising the rest of the audience. The actors had wisely retired to the upper deck, as they had been afflicted on former occasions. I now began a dismal comic song called "The Devil and Little Mike." It consisted of some twenty-five stanzas, each one containing two lines with a large margin of "whack fol de riddle." It was never quite clear whether the captain enjoyed this entertainment or not: my mother said he did, for, though the religious turn of his mind would naturally suppress any impulse to applaud, he said even before I had half finished that he was quite satisfied.

On our arrival in Buffalo we found another pioneer company, under the management of Dean 
and McKenney. Here we staid over two or three days, waiting for the steamer to take us up the lakes. Marble was starring there; he was one of the first and best of the Yankee comedians. In those days the stage New Englander was acted and dressed in a most extravagant manner. I remember seeing Marble play, and his costume was much after the present caricature of Uncle Sam, minus the stars but glorying in the stripes.

In a few days we steamed up the beautiful lakes of Erie, Huron, and Michigan. The boat would stop sometimes for hours at one of the stations to take in wood, or a stray passenger, and then the Indians would paddle out to us in their canoes offering their beadwork and moccasins for sale. Sometimes we would go ashore and walk on the beach gathering pebbles, carnelians, and agates. I thought them of immense value, and kept my treasures for years afterwards. What a lovely trip it was as I remember it! Lake Huron at sunset is before me now - a purple sky melting into a golden horizon; rich green foliage on the banks; yellow sand with many-colored pebbles making the beach of the lake; the clear and glassy water; groups of Indians lolling on the banks, smoking their pipes and making baskets; the hills dotted with their little villages with tents made of skins and painted canvas; blue smoke curling slowly up in the calm summer air; and all the bright colors reflected in the lake. I stood there as a boy, skimming flat stones over the surface of the water, and now as I write in the autumn of my life these once 
quiet shores are covered with busy cities; the furnaces glow with melted iron, the locomotive screams and whistles along the road where once the ox-teams used to carry the mail, and corner lots and real-estate agents "fill the air." When we think that all these wonderful changes have taken place within the last fifty years, it is startling to speculate upon what the next half century may bring about.

So day by day passes, till one night a light is espied in the distance, then another, and then many more dance and reflect themselves in the water. It is too late to go ashore, so we drop anchor. At sunrise we are all on deck looking at the haven of our destination, and there in the morning light, on the shores of Lake Michigan, stands the little town of Chicago, containing two thousand inhabitants. Aunt, uncle, and their children come to meet and welcome us. Then there is such a shaking of hands and a kiss all round, and "Why, how well you are looking!" and "Is this Charlie? How he has grown!" "Why, that's not Joe! Dear me, who'd have believed it?" And then we all laugh again and have another kiss.

The captain said he had enjoyed a splendid trip, such fun, such music and singing and dancing. "Well, good-bye all," "Good luck"; and off we go ashore and walk through the busy little town, busy even then, people hurrying to and fro, frame buildings going up, board sidewalks going down, new hotels, new churches, new theaters, everything new. 
Saw and hammer,_-saw, saw, bang, bang,-look out for the drays! - bright and muddy streets,gaudy-colored calicos,- - blue and red flannels and striped ticking hanging outside the dry-goods stores, - bar-rooms, - real-estate offices, - attorneys-at-law - oceans of them.

And now for the new theater, newly painted canvas, tack-hammer at work on stuffed seats in the dress-circle, planing-boards in the pit, new drop-curtain let down for inspection, "beautiful!" - a medallion of Shakspere, suffering from a severe pain in his stomach, over the center, with "One touch of nature makes the whole world kin" written under him, and a large, painted, brick-red drapery looped up by Justice, with sword and scales, showing an arena with a large number of gladiators hacking away at one another in the distance to a delighted Roman public; though what Justice had to do with keeping these gladiators on exhibition was never clearly explained by the artist. There were two private boxes with little white-and-gold balustrades and turkey-red curtains, over one box a portrait of Beethoven and over the other a portrait of Handel - upon unfriendly terms, glaring at each other. The dome was pale blue, with pink-and-white clouds, on which reposed four ungraceful ballet girls representing the seasons, and apparently dropping flowers, snow, and grapes into the pit. Over each season there floated four fat little cherubim " in various stages of spinal curvature."

My father, being a scenic artist himself, was naturally disposed to be critical, and when the 


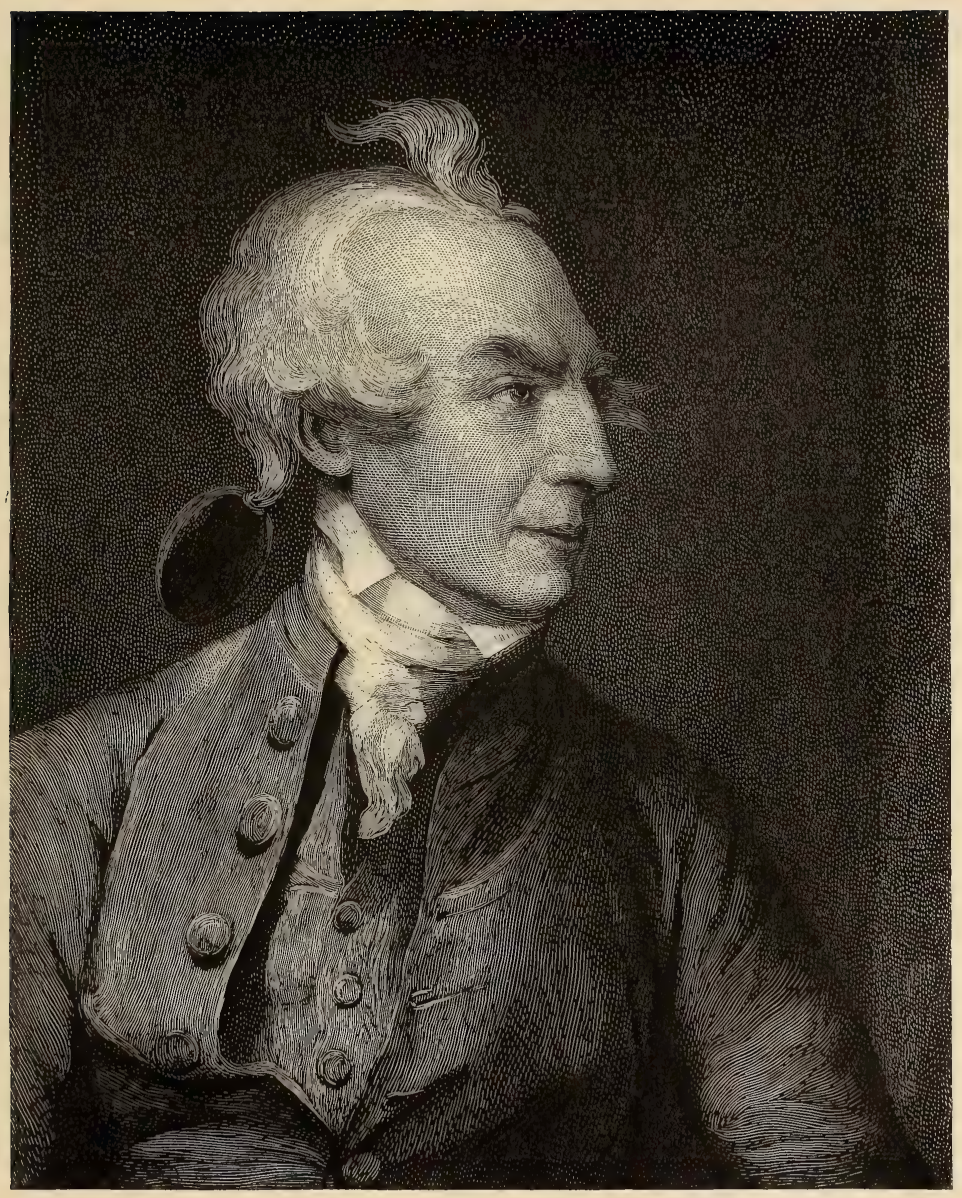

JOSEPH JEFFERSON (GRANDFATHER OF JOSEPH JEFFERSON). 

painter asked his opinion of the dome, he replied :

"Well, since you ask me, don't you think that your angels are a little stiff in their attitudes?"

"No, sir; not for angels. When I deal with mythological subjects I never put my figures in natural attitudes; it would be inharmonious. A natural angel would be out of keeping with the rest of the work."

To which my father replied that it was quite likely that such would be the case. "But why have you made Handel and Beethoven frown at each other? They are not mythological subjects."

"No, no," said the painter. "But they are musicians, you know; and great musicians always quarrel, eh? Ha, ha!"

"Yes," said my father; "but as Handel died before Beethoven was born, I don't see how any coolness could have existed between them."

The foregoing dialogue, while it may not be verbatim, is at least in the spirit of the original. I could not possibly remember the exact words of the different conversations that will naturally occur through these chapters; but I have placed them in their present form, as I believe it is the clearest and most effective way to tell the story. Many of the conversations and incidents are traditional in my family; I have good reason to take them for granted, and I must ask the reader to share my confidence.

The greenroom was a perfect gem, with a three-foot wavy mirror and cushioned seats around 
the wall-traps under the stage so convenient that Ophelia could walk from her grave to her dressing-room with perfect ease.

With what delight the actors looked forward to the opening of a new theater in a new town, where dramatic entertainments were still unknown-repairing their wardrobes, studying their new parts, and speculating on the laurels that were to be won!

After a short season in Chicago, with the varying success which in those days always attended the drama, the company went to Galena for a short season, traveling in open wagons over the prairie. Our seats were the trunks that contained the wardrobe-those old-fashioned hair trunks of a mottled and spotted character made from the skins of defunct circus horses: "To what base uses we may return!" These smooth hair trunks, with geometrical problems in brass tacks ornamenting their surface, would have made slippery seats even on a macadamized road, so one may imagine the difficulty we had in holding on while jolting over a rough prairie. Nothing short of a severe pressure on the brass tacks and a convulsive grip of the handles could have kept us in position; and whenever a treacherous handle gave way our company was for the time being just one member short. As we were not an express mail-train, of course we were allowed more than twenty minutes for refreshments; the only difficulty was the refreshments. We stopped at farm-houses on the way for this uncertain necessity, and they were far apart. If the roads were heavy and the horses jaded, those 
actors who had tender hearts and tough limbs jumped out and walked to ease the poor brutes. Often I have seen my father trudging along ahead of the wagon, smoking his pipe, and I have no doubt thinking of the large fortune he was going to make in the next town, now and then looking back with his light blue eyes, giving my mother a cheerful nod which plainly said: "I 'm all right. This is splendid; nothing could be finer." If it rained he was glad it was not snowing; if it snowed he was thankful it was not raining. This contented nature was his only inheritance; but it was better than a fortune made in Galena or anywhere else, for nothing could rob him of it.

We traveled from Galena to Dubuque on the frozen river in sleighs - smoother work than the roughly rutted roads of the prairie; but it was a perilous journey, for a warm spell had set in and made the ice sloppy and unsafe. We would sometimes hear it crack and see it bend under our horses' feet: now a long-drawn breath of relief as we passed some dangerous spot, then a convulsive grasping of our nearest companion as the ice groaned and shook beneath us. Well, the passengers arrived safe, but, horror to relate! the sleigh containing the baggage, private and public, with the scenery and properties, green curtain and drop, broke through the ice and tumbled into the Mississippi. My poor mother was in tears, but my father was in high spirits at his good luck, as he called it - because there was a sand-bar where the sleigh went in! So the things were saved at last, 
though in a forlorn condition. The opening had to be delayed in order to dry the wardrobe and smooth the scenery.

The halls of the hotel were strung with clotheslines, and the costumes of all nations festooned the doors of the bedrooms, so that when an unsuspicious boarder came out suddenly into the entry he was likely to run his head into a damp "Roman" shirt, or perhaps have the legs of a soaking pair of red tights dangling round his neck. Mildew filled the air. The gilded pasteboard helmets fared the worst. They had succumbed to the softening influences of the Mississippi, and were as battered and out of shape as if they had gone through the pass of Thermopylæ. Limp leggins of scale armor hung wet and dejected from the lines; low-spirited cocked hats were piled up in a corner; rough-dried court coats stretched their arms out as if in theagony of drowning, as though they would say, "Help me, Cassius, or I sink." Theatrical scenery at its best looks pale and shabby in the daytime, but a wellworn set after a six-hours' bath in a river presents the most woe-begone appearance that can well be imagined; the sky and water of the marine had so mingled with each other that the horizon line had quite disappeared. My father had painted the scenery, and he was not a little crestfallen as he looked upon the ruins: a wood scene had amalgamated with a Roman street painted on the back of it, and had so run into stains and winding streaks that he said it looked like a large map of South America ; and, pointing out the Andes with his cane, 
he humorously traced the Amazon to its source. Of course this mishap on the river delayed the opening for a week. In the mean time the scenery had to be repainted and the wardrobe put in order: many of the things were ruined, and the helmets defied repair.

After a short and, I think, a good season at Dubuque, we traveled along the river to the different towns just springing up in the West-Burlington, Quincy, Peoria, Pekin, and Springfield. In those primitive days, I need scarcely say, we were often put to severe shifts for a theater.

In Quincy the court-house was fitted up, and it answered admirably. In one town a large warehouse was utilized, but in Pekin we were reduced to the dire necessity of acting in a porkhouse. This establishment was a large frame building, stilted up on piles about two feet from the ground, and situated in the open prairie just at the edge of the town. The pigs were banished from their comfortable quarters, and left to browse about on the common during the day, taking shelter under their former abode in the evening. After undergoing some slight repairs in the roof, and submitting to a thorough scouring and whitewashing, the building presented quite a respectable appearance. The opening play was "Clari, the Maid of Milan." This drama was written by John Howard Payne, and his song of "Home, Sweet Home" belongs to the play. My mother, on this occasion, played the part of Clari and sang the touching ballad. 
Now it is a pretty well established fact in theatrical history that if an infant has been smuggled into the theater under the shawl of its fond mother, however dormant it may have been during the unimportant scenes of the play, no sooner is an interesting point arrived at, where the most perfect stillness is required, than the "dear little innocent" will break forth in lamentation loud and deep. On this occasion no youthful humanity disturbed the peace, but the "animal kingdom," in the shape of the banished pigs, asserted its right to a public hearing. As soon as the song of "Home, Sweet Home" commenced they began by bumping their backs up against the beams, keeping anything but good time to the music; and as my mother plaintively chanted the theme "Sweet, Sweet Home," realizing their own cruel exile, the pigs squealed most dismally. Of course the song was ruined, and my mother was in tears at the failure. My father, however, consoled her by saying that though the grunting was not quite in harmony with the music, it was in perfect sympathy with the sentiment.

Springfield being the capital of Illinois, it was determined to devote the entire season to the entertainment of the members of the legislature. Having made money for several weeks previous to our arrival here, the management resolved to hire a lot and build a theater. This sounds like a large undertaking, and perhaps with their limited means it was a rash step. I fancy that my father rather shrunk from this bold enterprise, but the senior partner (McKenzie) was made of sterner stuff, and, 
his energy being quite equal to his ambition, the ground was broken and the temple erected.

The building of a theater in those days did not require the amount of capital that it does now. Folding opera-chairs were unknown. Gas was an occult mystery, not yet acknowledged as a fact by the unscientific world in the West; a second-class quality of sperm-oil was the height of any manager's ambition. The footlights of the best theaters in the Western country were composed of lamps set in a "float" with the counter-weights. When a dark stage was required, or the lamps needed trimming or refilling, this mechanical contrivance was made to sink under the stage. I believe if the theater, or "Devil's workshop," as it was sometimes called, had suddenly been illuminated with the same material now in use, its enemies would have declared that the light was furnished from the "Old Boy's" private gasometer.

The new theater, when completed, was about ninety feet deep and forty feet wide. No attempt was made at ornamentation; and as it was unpainted, the simple lines of architecture upon which it was constructed gave it the appearance of a large dry-goods box with a roof. I do not think my father, or McKenzie, ever owned anything with a roof until now, so they were naturally proud of their possession.

In the midst of our rising fortunes a heavy blow fell upon us. A religious revival was in progress at the time, and the fathers of the church not only launched forth against us in their sermons, 
but by some political manœuver got the city to pass a new law enjoining a heavy license against our "unholy" calling; I forget the amount, but it was large enough to be prohibitory. Here was a terrible condition of affairs: all our available funds invested, the legislature in session, the town full of people, and we by a heavy license denied the privilege of opening the new theater!

In the midst of their trouble a young lawyer called on the managers. He had heard of the injustice, and offered, if they would place the matter in his hands, to have the license taken off, declaring that he only desired to see fair play, and he would accept no fee whether he failed or succeeded. The case was brought up before the council. The young lawyer began his harangue. He handled the subject with tact, skill, and humor, tracing the history of the drama from the time when Thespis acted in a cart to the stage of to-day. He illustrated his speech with a number of anecdotes, and kept the council in a roar of laughter; his goodhumor prevailed, and the exorbitant tax was taken off.

This young lawyer was very popular in Springfield, and was honored and beloved by all who knew him, and after the time of which I write he held rather an important position in the Government of the United States. He now lies buried near Springfield, under a monument commemorating his greatness and his virtues - and his name was Abraham Lincoln! 
At the end of our Springfield season my father dissolved partnership with McKenzie, and my next remembrance finds us in the town of Memphis. Bad business had closed the theater, and my father had turned from scene-painter to sign-painter.

There had been an ordinance passed by the fathers of the city requiring that all carts, drays, and public vehicles should be numbered. By some accident I heard of this, and, as I was on the alert to get work for my father, I called at the mayor's office to apply for the contract. The mayor had seen me on the stage and, to my no small delight, recognized me. I explained to him that my father was an artist as well as a comedian, and that, the theater being closed, he devoted his time to sign and ornamental painting; not, however, as an amusement. It was natural that the mayor,-a jovial, and possibly not a very dignified or dreadful person, - should be interested in a youngster having the promptness and the effrontery to be the first to apply for the contract.

My interview with the mayor was a success, and ended in my getting the contract for my father to paint the numbers. How delightful it was to go home with such good news! Then the charm of unfolding such an agreeable surprise to the family - what lovely revenge for the scolding my mother had given me the day before; and, above all, the tremendous round of applause that such an achievement must bring down.

My father was too sensitive and retiring to have ever dreamed of doing such a thing, and perhaps 
when I arrived at his age I might, under the same circumstances, have shrunk from it myself. But I was young and rash, and perhaps desperate; for if I had not received many hard knocks myself, my family had, and, feeling the blows through them, I experienced a ferocious delight in doing battle with the world, and, as I was generally victorious, my success made me bold. The new industry furnished my father and myself with a month's work, so that we were indebted to this stride in Southwestern civilization for at least a small addition to our income.

One of my father's ornamental signs, on which was painted an amiable tailor measuring a handsome young man for a fashionable suit of clothes, came under the notice of Mr. McAllister. This gentleman was the owner of a large billiardsaloon and bar-room, to which was attached a mysterious apartment where late hours were kept. A large mahogany table covered with a suspiciouslooking green cloth gave evidence of the kind of trade that was plied in this exchange, and strongly corroborated the popular tradition that Mr. McAllister's midnight visitors were "gentlemanly sports." The proprietor having, it seems, a turn for art, as well as for cards, arranged for my father to decorate his billiard-room first, and then his house. In the hall of the latter my father painted two landscapes from "The Lady of the Lake"- one representing Loch Katrine, with her ladyship paddling her own canoe in the distance, and a mountain torrent in the foreground with the bridge made 
famous by the combat of Fitz-James and Roderick Dhu. The subjects had been chosen out of compliment to Mr. McAllister, as he was of Scotch descent.

The time was drawing near for our departure from Memphis, as the season in Mobile was to begin in November, and the money due for decorating McAllister's house was necessary to defray the expenses of our journey down the river; but, to our great inconvenience, it was not forthcoming. Whether the "gentlemanly sports" had been more fortunate than the proprietor or not I am unable to say, but my father had written twice without receiving an answer, and I had been dispatched to make a personal appeal to him. We delayed our departure for two weeks, hoping to get some satisfaction; but, no notice being taken of our demands, it was decided to wait no longer.

In our straitened circumstances we were forced to take a steerage passage on one of the steamboats between Memphis and New Orleans. This was both humiliating and inconvenient. But Mary was a host, and could, by her devotion and tact, have made us comfortable even under more trying conditions. I know that my mother's pride was wounded, and that in her mortification she wondered that my father could face the degradation with such fortitude; but from what I remember of him, and all that I have heard related in connection with his character, nothing short of sickness or death in his family could induce him to complain. This kind of philosophy can be learned neither from books nor from ex- 
perience; it is a natural gift, and seems to come into the world hand in hand with the spirit that is to bear it company. No seed can sow it, and no soil can grow it; the quality is inborn, and is so deeply rooted that it defies cultivation or extermination.

After arranging ourselves as comfortably as we could, the mate gave notice that the boat would not start until late that evening. On hearing this my mother asked me some questions regarding Mrs. McAllister, whom, of course, I had seen and spoken with during the time we had been engaged in the decoration of her house. My report of the lady being quite favorable, my mother started in company with myself to make an appeal. Mrs. McAllister, who had been out driving with her children, met us at the door. On my presenting my mother, we were asked into the house and proceeded with her to the drawing-room. My mother after apologizing for our visit, explained the nature of it, calling the lady's attention to the hard and honest work of her artist husband, and contrasting the elegant surroundings of the lady and her children with the poverty of her own. In an hour afterwards the lady left the house and returned with the money. Placing it in my mother's hand, she bade us Godspeed, and away we went with a heavier purse and lighter hearts.

We hurried to the boat with our treasure,about two hundred dollars, I think, - and my mother was both delighted and triumphant. When she placed the money in my father's hands he looked at it in amazement, and after declaring that 
his wife was the most wonderful woman in the world, suggested that we should at once adjourn to the cabin; but the most wonderful woman in the world would not hear of it, and urged my father to bear the discomfiture, so that we might arrive at our journey's end with some means of support dwelling upon the fact that otherwise he would have to draw an advance from the manager on our arrival in Mobile, which not only would be humiliating, but might weaken his position. Of course he saw the force and wisdom of his wife's counsel, and, I think rather reluctantly, consented. As I reflect upon this situation, it seems strange that my mother, who felt most keenly this humiliation, was content to bear it rather than lose the means that would render our future position more secure; while my father, who could smile serenely at our condition, would willingly have parted with all the money to have given us present comfort. It can be accounted for only by the extreme contrast in their natures: he was hopeful, my mother was apprehensive. May not generosity spring from one of these causes, and caution from the other?

As usual, my father was soon contented. This novel and uncomfortable mode of traveling, instead of depressing him, seemed to raise his spirits; for I can well remember that while the boat was steaming down the river he employed the time in studying some new parts that he was to act during the approaching season, and when it stopped to take in wood he would get out his tackle and fish from the stern of the vessel. One would suppose 
that this indifference to really serious inconvenience sprang from weakness, but this was not so; for, though there was nothing of the tyrant in him, when he felt that it was time to make a stand he made a bold one, and was as solid as a rock.

We arrived at Mobile in October, I842. The yellow fever was raging in the town, but we were forced to come before the rest of the company, as my father was the scenic artist as well as the comedian of the theater, and his presence was required at an early date as the scenery needed repainting.

We had for years been traveling about the country, and my father and mother congratulated themselves upon this present permanent situation, as it afforded them not only rest, but an opportunity of sending my sister and myself to school. Sadly enough, the last desire of this hopeful man was shattered, for two weeks after our arrival he was stricken with yellow fever, and died on the 24 th of November, I842. I will not describe the effect of this awful blow on our family, not desiring to cloud the narrative of my life with the relation of domestic sorrow. It is sufficient to say that by this sad event we were deprived of a dear friend upon whom we depended for counsel and support.

My sister and myself were now engaged at the theater to act such children's parts as our size and talent warranted the manager in casting us in ; appearing in fancy dances and comic duets, added to which I was to grind colors in the paint-room,assistant artist, I was called in the play-bill,- - and 


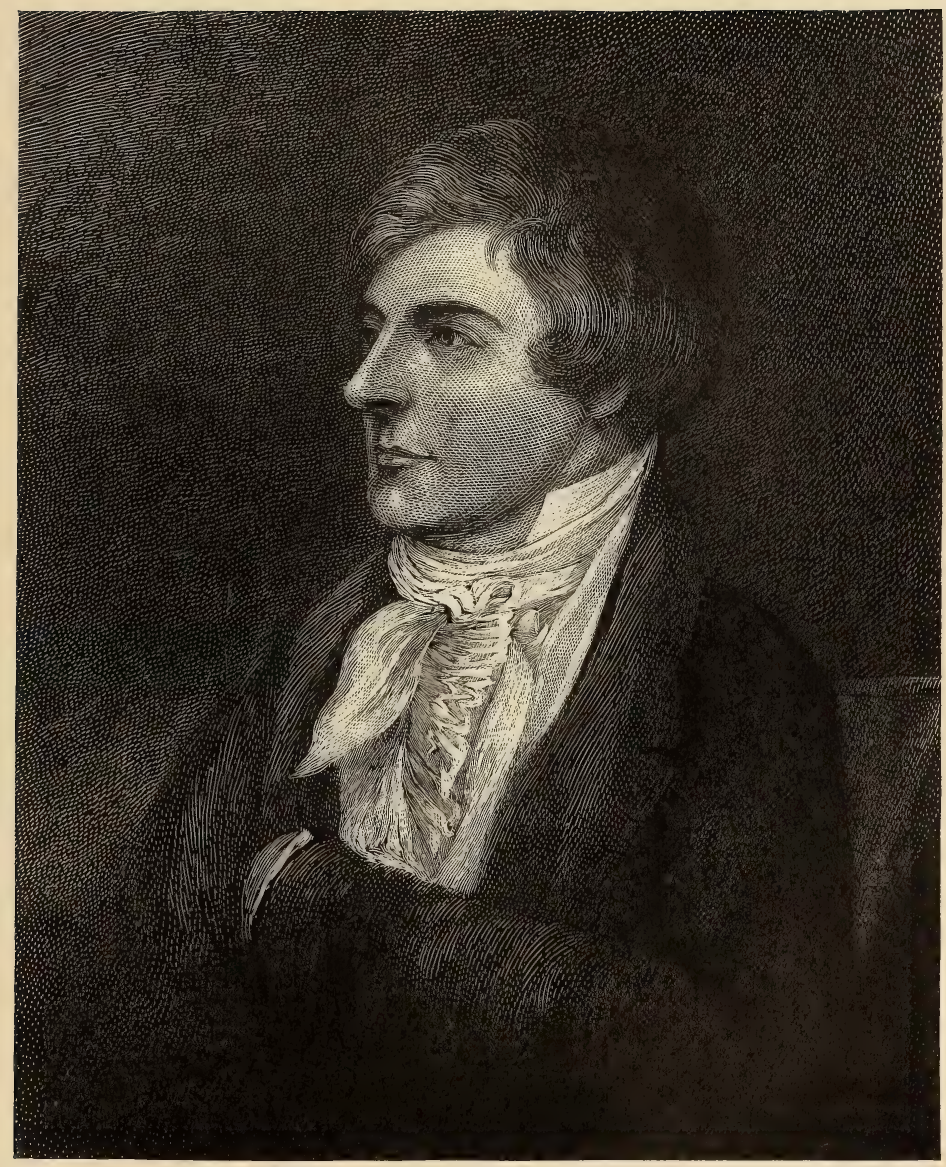

JOSEPH JEFFERSON (FATHER OF JOSEPH JEFFERSON). 

make myself generally useful, for which services we were each to receive six dollars a week. It was understood that this employment was given to us as a charity; but when I consider the numerous duties imposed upon us, and the small sum we received, my conscience acquits me of our being anything like an incubus upon the theater, and if there was any charity in the matter, I think it was on our side.

One of the programmes, I find, announces that after the play Master and Miss Jefferson were to "execute a fancy dance." Now, as our terpsichorean education had been rather limited, it is quite likely that the execution was complete.

It was soon apparent that our charity salary was not enough to support us, so my mother cast about for some means of increasing our income. She had no heart for acting now, and decided to open a boarding-house for the actors. From leading lady to landlady was rather a come-down for her; but my mother was a brave woman and endowed with the kind of pride that preferred the "degradation" of earning an honest living to the more elegant profession of getting in debt. A house had to be taken, a month's rent paid in advance, and furniture hired to fit up the establishment but where was the money to come from?

It is said that in France, when the Government made a call on the people for a loan to pay off the war indemnity, thousands of patriotic Frenchwomen stood in line, a mile in length, at the Treasury, each bearing a long worsted stocking filled with gold, 
ready to assist their native land in its great financial emergency; and I am told that in Louisiana this domestic bank is used by many of the French inhabitants as a receptacle for both small and large hoardings. My mother was a Frenchwoman, at least by inheritance, and I have no doubt came honestly by this national characteristic; for when matters were in a desperate condition the dear lady would mysteriously draw forth a long, darkblue worsted stocking in which there was always "just one little gold piece left."

Unfortunately for 'my mother's venture, the theatrical season - following in the wake of all others I had as yet been familiar with - was a failure. Naturally the settlement of the board bills was consequent upon the payment of the salaries; and as the latter occurrence was fitful and uncertain, the bills of my mother's landlord and butcher were both subjected to the same intermittent conditions.

At the time of which I write there lived in Mobile a talented and beautiful lady by the name of Madame Le Vert. She was the belle of the city and courted by the first in the land; her brilliancy and wit had placed her in the center of a rich setting, of which she was the shining jewel. Added to her worth and elegance was a kind and beneficent nature, always seeking new objects to bestow its bounty upon. She was, moreover, a patroness of art and literature; nothing was too high for her understanding, or too lowly for her kind consideration. I think all who remember this fascinating 
woman will indorse my description of her character. It is natural that I should have a grateful remembrance of this lady, as what I shall relate will show.

My father's death and the failure of the boardinghouse had attracted Madame Le Vert's attention. She called on my mother, and hinted in the most delicate manner that as the season was about closed she would like to get up a complimentary benefit at the theater for her children (though I think the widow was uppermost in Madame Le Vert's mind). Now, as the "stocking" was on the eve of suspension, my mother readily consented; so the belle of Mobile aroused the enthusiasm of her many friends, the public caught fire, and the benefit was a success.

In after years I remember to have seen Madame Le Vert surrounded by a circle of callers, entertaining them with wonderful grace and tact, always saying the right things to the right persons, and at the proper time-a genius of society. But there came a day when this noble lady and her family were reduced in fortune; she whom I as a boy had known young and beautiful, surrounded by wealth and friends, was now an old lady in the unhappy condition of "genteel poverty." I am proud to say we were friends to the last.

During the war, or at its close, Madame Le Vert had made some enemies. It would have been impossible for a person of her prominence and ability to have done otherwise. I am not sure now which cause she espoused, and, in her case, I do not care. 
Her long and useful life has passed peacefully away, and her memory is honored by all who knew her.

And now we lost poor, dear old Mary. It is perhaps vain for me to hope that I can interest the reader in any one of whom he knows so little; but how can I, her foster-son, who owe so much to her loving care, pass by her death without some tribute of affection? After sixteen years of disinterested domestic loyalty, attending us as friend, servant, and dear companion, this faithful creature died in my mother's arms. Who can say how high such a pure and loving spirit soars when it is released and takes its flight?

James Wallack, Sr., played an engagement in Mobile, and one little circumstance occurred in connection with it that I have always remembered most pleasantly. He was an actor at the head of his profession and in the height of his fame. I was only a boy holding a subordinate position in the theater. He heard some one call me by name at the rehearsal, and, turning around, asked me if I was related to Joseph Jefferson of the Chestnut Street Theater. I told him that I was a grandson of that gentleman. He said, "Let me shake you by the hand for the sake of my dear old friend." The remark was made with much feeling, and the remembrance of it has, I think, often prompted me to do the like for others. James Wallack, Sr., was an actor of rare attainments; as a legitimate tragedian and comedian he ranked very high. The parts that I remember him in are those of Ales- 


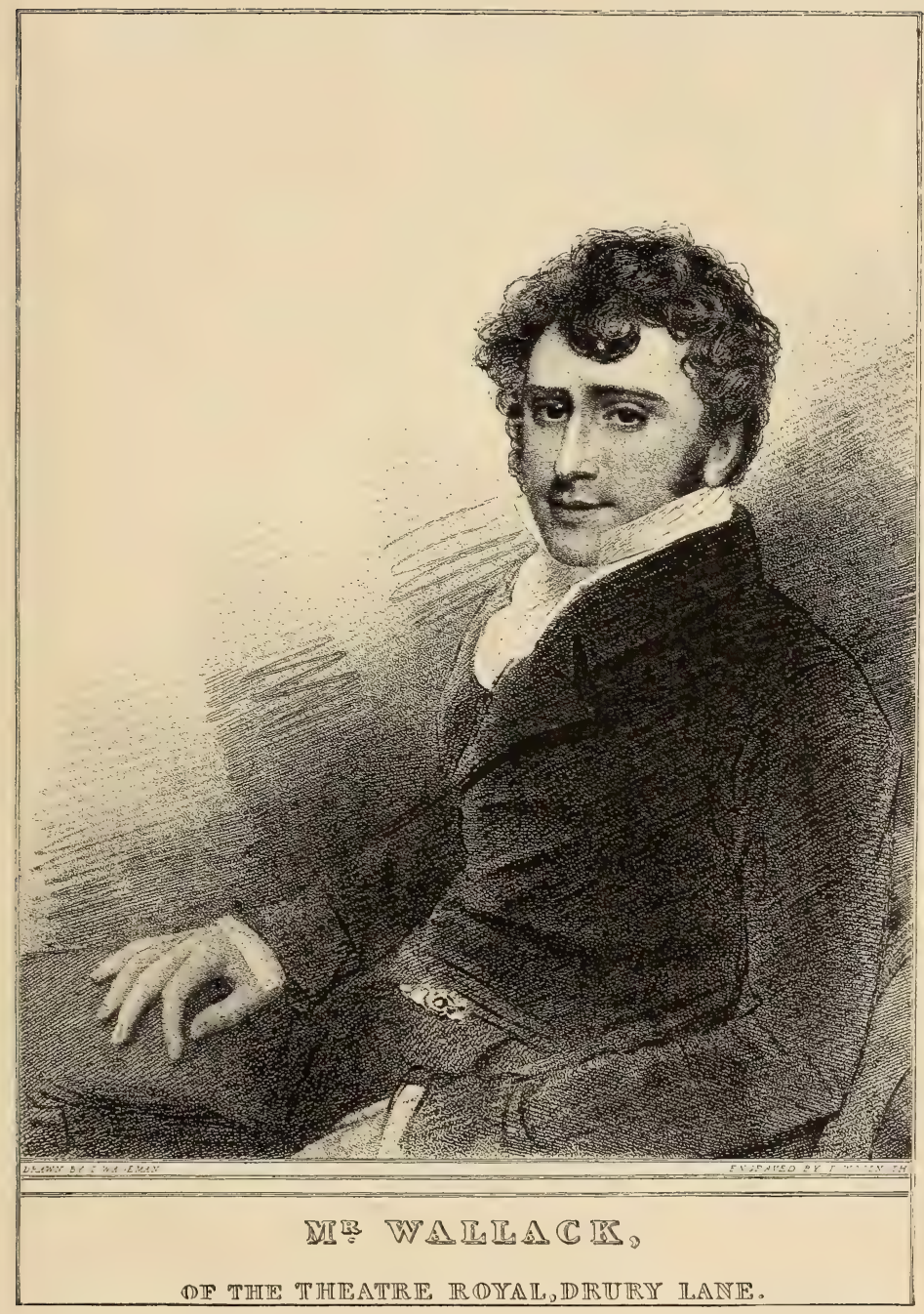

PORTRAIT OF JAMES WALLACK. 

sandro Mazzaroni, in "The Brigand," and Don Casar de Bazan.

Mr. Macready and the elder Booth both acted in Mobile during this season; and as the contrast between these tragedians was quite remarkable, I will introduce them here, although my judgment of them was formed upon a later experience.

The methods by which actors arrive at great effects vary according to their own natures; this renders the teaching of the art by any strictly defined lines a difficult matter. Macready and the elder Booth offer striking examples of these distinctions. Macready depended upon the mechanical arrangement of the scene, while Booth relied almost entirely on the impulse of the moment, caring little for set rules. As soon as Macready entered the theater he began to assume the character he was going to enact. He would remain in his dressing-room absorbed with the play; no one was permitted to enter; his dresser was not allowed to speak to him, but stood outside ready to open the door just before it was time for the actor to go upon the stage. If the mechanism of the play remained intact, he became lost in his character and produced grand effects, but if by some carelessness he was recalled to himself, the chain was broken and he could not reunite it. $\mathrm{He}$ now realized that his acting would be tame, and then his rage knew no bounds; he would seize the unlucky actor who had "ruined him," shake him, throw him aside, and rushing to his dressing-room fall exhausted upon the sofa. This was not affec- 
tation, it was real; he could not conquer his unfortunate temper. In my youthful days it was the fashion of thoughtless actors to ridicule these "Macready tantrums," and I regret to say I often joined in the sport; but as I look back on his suffering and read the pages wherein he chastises himself for his ungovernable temper, and when I know how useful and benevolent he was in the closing scenes of his life, I feel a great sympathy for him. "He poured a flagon of Rhenish on my head once," but - I forgive him.

I acted with Macready and Booth during this season, and an anecdote of each will serve to illustrate their different characteristics. Macready was acting Werner. I was cast for a minor part. In one scene a number of characters had to rush off, bearing lighted torches, in search of some delinquent. At rehearsal the tragedian particularly requested that we should all be sure and make our exit at night at just the same time and place, so that we might not disturb the arrangement of the scene. All went well up to the time for making our hurried exit, when to my horror I found Werner standing exactly in line with the place of my exit at rehearsal. I presume that when he gave his directions in the morning he did not observe me. What was I to do? The cue was given, and there was no time for argument. I rushed past him, torch in hand. I heard his wellknown groan; but as I flew by an unmistakable odor of burnt hair filled the atmosphere, and I knew that I had singed his wig. When the curtain fell 
I turned in horror to see the effect. The enraged Werner had torn his wig from his head, and stood gazing at it for a moment in helpless wonder. Suddenly he made a rush in my direction; I saw he was on the war-path, and that I was his game. And now the chase began. I dodged him up and down the stage; then around the wings and over "set" rocks and gauze waters. He never would have caught me but that in my excitement I ran head first into the stomach of a fat stage-carpenter. Here I was seized. The enraged Macready was so full of anger and so out of breath that he could only gasp and shake his burnt wig at me. Of course I was disgraced and not allowed to act again during his engagement. To make matters worse the whole affair got into the papers, and the next morning one of the critics remarked that he had never seen $\mathrm{Ma}$ cready act with so much fire! Now all of this could have been avoided if he had but moved six inches further up the stage when he saw me coming; but no, he had never shifted from that spot before, why should he do so now? I believe if I had singed his very eyebrows he would have stood his ground.

Booth's whole nature was the reverse of Macready's. He would saunter into the theater just a few minutes before the play began; robe himself, sometimes quite carelessly; converse freely upon local matters in a plain, practical way, or perhaps give some reminiscence of bygone years,his memory was wonderful,-_ending with an amusing anecdote, and in the next moment walk upon the stage in the full assumption of his character, 
overawing the audience by the fire of his acting. The following incident will serve to show the wonderful manner in which Booth could drop his character and instantly resume it.

I was acting Sampson in "The Iron Chest" to his Sir Edward Mortimer. During the play he spoke to me of my grandfather's playing the same part with him when he (Booth) was a young man. "He used," said he, "to sing the original song; it ran thus"; and assuming a comical expression he began to sing in an undertone:

A traveler stopped at a widow's gate.

At this moment his cue was given, and he rushed upon the stage, discovering Wilford at the chest. The scene is here very powerful, and I never saw him act it with more power. The audience was most enthusiastic, and as he rushed from the stage amid a storm of applause he met me at the wing, and, reassuming the comic expression of his face, began the song just where he had left off, while the approbation of the audience was still ringing in his ears.

It must not be understood by this that Booth never became absorbed in his character; on the contrary, he sometimes carried his intensity in this respect to an extreme. It is only meant to show that he had also the power of dropping his character in the midst of his concentration, resuming it again at will. Macready had no such faculty whatever. The beam once kicked, the balance was destroyed beyond recovery. 


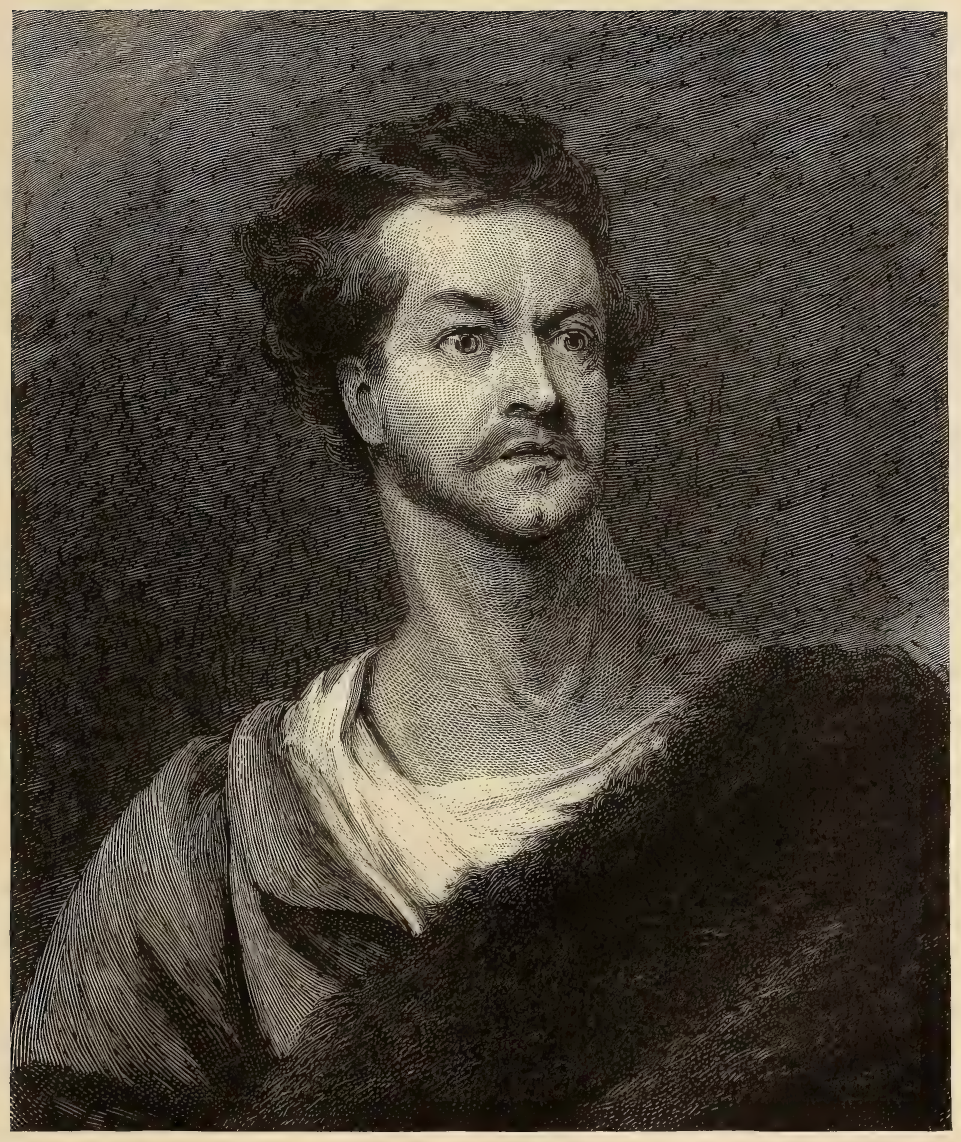

MACREADY AS "WILLIAM TELL." 

In his private character Mr. Booth was simple, unostentatious, and benevolent. I know of an instance of a curious and somewhat eccentric kindness that occurred many years ago in Baltimore.

An old and retired actor and manager had been ill for some time, and as he was held in high esteem his friends arranged for him a complimentary testimonial at the Holliday Street Theater. Mr. Booth was at that time manager of another theater, and, unsolicited, tendered a benefit at his establishment to the same gentleman. The house was crowded, Booth himself acting. After the performance he went to the box-office, collected the entire receipts, and, late as it was, took them to the house of the beneficiary, and spreading the money out on the table said to him, "There is your share."

"But will you not deduct the expenses?" said his old friend.

"The only expense incurred," said Booth, "has been the bringing of the money to you; but, as I walked, the cost is merely shoe-leather, and I will not charge for that." So saying he turned on his heel and left the room before he could be thanked.

From Mobile we went to Nashville, Tennessee, and after a short season traveled through the State. Business was bad, and on one occasion the gentle. men of the company, myself included, walked from Gallatin to Lebanon - not, however, for the exercise.

Upon our return to Nashville it was time to think of going South, as most of the company had engagements in New Orleans, Mobile, and Texas, 
but the Cumberland River had fallen so low that no steamboat could navigate it. In this dilemma there was but one course left: the company must come together, buy a barge, fit up a cabin, caboose, and sleeping-apartments. This was done. Where the money came from to pay for the boat and the lumber I cannot tell, but this floating camp was put together, and we all departed down the river in the queerest looking craft that ever carried a legitimate stock company of the old school. To a boy of my age this was heaven. To stand my watch at night gave me that manly feeling that a youngster, just before he grows his beard, enjoys beyond everything.

We stopped at Clarksville and gave one entertainment, playing "The Lady of Lyons." I acted Glavis. This was another manly stride for me; I was getting on. The whole of this trip was to me delightful. It was in that rich and mellow season when the foliage seems to change from day to day. The river was full of ducks, which I could sometimes shoot from the deck of the flatboat; great flocks of wild pigeons filled the air for days together, so that I could supply our table well with game. There was a small set of scenery on board that had been brought in case of an emergency. We had used it only in Clarksville so far, but now the time came when it could be displayed and utilized in a manner "never before attempted in the annals of the stage." When we reached the Ohio the river widened out, and some stretches were from five to six miles in length; so, if we had 
a fair wind blowing downstream, by hoisting one of the scenes for a sail we could increase our speed from two to three miles an hour. A hickory pole was cut from the shore, and a drop-scene, with a wood painted on one side and a palace on the other, was unfurled to the breeze. The wonderstricken farmers and their wives and children would run out of their log-cabins and, standing on the river bank, gaze with amazement at our curious craft. It was delightful to watch the steamboats as they went by. The passengers would crowd the deck and look with wonder at us. For a bit of sport the captain and I would vary the picture, and as a boat steamed past we would first show them the wood scene, and then suddenly swing the sail around, exhibiting the gorgeous palace. Adding to this sport, our leading man and the low comedian would sometimes get a couple of oldfashioned broadswords and fight a melodramatic combat on the deck. There is no doubt that at times our barge was taken for a floating lunatic asylum.

We would often tie up the boat for a day and go fishing in some lake in the interior, stopping perhaps at a farm-house to replenish our stock of butter and eggs. Our voyage was continued to Cairo, where the Ohio River joins the Mississippi, and so on until we reached Memphis; here we deserted the barge and took a steamboat for New Orleans.

This season I acted at the St. Charles, under the management of Ludlow \& Smith. Mr. and 
Mrs. Charles Kean, Mrs. Anna Cora Mowatt, and James H. Hackett were among the stars. At the end of the season - which does not seem to have been a very eventful one-our company, under the same management, traveled up the Mississippi River to St. Louis, acting there during the summer. The only occurrence worth noting so far as I was concerned happened on the night of the Fourth of July, when the company was called on by the management to sing "The Star-Spangled Banner." I was in a feverish state of excitement all day, having been selected to give the first stanza. I had studied it and restudied it so often that I knew it backwards; and that is about the way I sung it. But I must not anticipate. The curtain rose upon the company partly attired in evening dress; that is to say, those who had swallow-tail coats wore them, and those who were not blessed with that graceful garment did the best they could. We were arranged in the old conventional half-circle, with the "Goddess of Liberty" in the center. The "Mother of her Country" had a Roman helmetpasteboard, I am afraid - on her head, and was tastefully draped with the American flag. My heart was in my mouth as the music started up, but I stepped boldly forward to begin. I got as far as "Oh, say, can you see - " and here the words left me. My mind was blank. I tried it again: "Oh, say, can you see-" Whether they could see or not, I am quite sure that I could not. I was blind with fright; the house swam before my eyes; the thousand faces seemed to melt into one huge, 
expressionless physiognomy. The audience began to hiss - oh, that dreadful sound! I love my country, and am, under ordinary circumstances, fairly patriotic; but at that moment I cursed our national anthem from the bottom of my heart. I heard the gentle voice of the Goddess of Liberty say, "Poor fellow!" The remark was kind, but not encouraging. The hissing increased. Old Muller, the German leader, called out to me, "Go on, Yo!" But "Yo" could n't go on, so "Yo" thought he had better go off. I bowed, therefore, to the justice of this public rebuke, and made a graceful retreat. My poor mother stood at the wings in tears; I threw myself into her arms, and we had it out together.

Of course I intend this anecdote to illustrate one of my early professional distresses, but it has another and a more important side to it. The hissing and jeering that were so liberally bestowed upon me will never be vented again in this country for so slight an offense. The well-dressed, decorous audience of to-day, when an accident occurs, sit quietly, bearing it with patience and consideration, and when it is righted they break forth in encouraging applause. Look at the decorum observed by the vast assemblages that go to witness our national games. Disturbances are very rare. It would have been doubtful, if not dangerous, when I was a boy, for ladies and gentlemen to visit any public grounds containing such large masses of people, whereas now they can do so with perfect safety. What lies at the foundation 
of this improvement? People went to church in those days as readily as they do now, and the laws were administered quite as rigidly. There is only one solution to this problem - the free school has done this work. 


\section{CHAPTER III}

\section{BARN-STORMING AND MEXICAN EPISODE}

Barn-storming in Mississippi-Pudding Stanley -In Mexico-Mr. and Mrs. James W. Wallack, Jr.-John E. Owens

T $\mathrm{T}$ is to be hoped for the credit of humanity that the philosopher was in error when he said 1 that we feel a sad gratification even in the distress of our dearest friends. But, be that as it may, it is quite certain that those of our fellow-creatures whose lives have been burdened with sorrow command our respect and excite our interest more than the high and mighty. Belisarius, stricken blind, wandering a beggar in tattered rags, and asking alms of the people he once led to victory, presents a figure that calls for our deepest sympathy; while we cannot shed tears over a dethroned monarch with a corner lot. By these reflections I am strengthened in the hope that I may not be tiring my reader with the continuous recital of our misfortunes, and that he will not grow as weary of 
them as we did. If he will but patiently wade a little farther through this "slough of despond," I promise in the latter part of my narrative to give some account of my less interesting success.

Our disastrous seasons were not exceptions. The country had been in a chronic state of theatrical bankruptcy since the panic of 1837 , and continued in it for many years. Actors often had to turn their hands to something else for a livelihood besides the profession. My father painted signs for a whole summer in Vicksburg, and our leading man manufactured genuine Havana cigars in the same studio. I often acted as "drummer," and when business was slow, would sally forth among the wharf boats to solicit orders.

It is likely that some of the events I have recorded may not have followed in the order in which I have placed them, but I do not feel that this is of much importance. Accurate statistics, with dates, long rows of figures, and unimportant casts of plays, are somewhat tedious. Tony Lumpkin says, with undoubted truth, that "the inside of a letter contains the cream of the correspondence." I must therefore crave your Honor's pardon for acting on this hint by endeavoring to trace the interesting portion of this history, - if it has any interest, - casting unimportant details into oblivion.

Mary's death reduced our quartet to a trio, and I next found myself in the town of Grand Gulf, in the State of Mississippi, with my mother and sister. We were there awaiting the arrival of my half-brother, Charles Burke, who was somewhere 
in the interior of the State, with a small company of actors, struggling along from town to town. Our letters to him had crossed or miscarried; so we were obliged to remain there for several weeks until we could hunt him up. There was no telegraph in those days, and postal communication was uncertain.

The money had run out, and we were in a straitened condition, when, to our joy, my brother arrived. He burst like a ray of sunshine into the house, and we crowded about the dear fellow, smothering him with tears and kisses. It seems that his company was at Port Gibson, only eight miles away, where they had arrived the night before, and he had started at daylight, walking to Grand Gulf to meet us. After breakfast he went out for the purpose of hiring a wagon and team to take us on. This was soon done, and we started on our journey. We had got but four miles from the town when I observed my brother and the driver in close conversation. I saw that something was wrong. Presently the driver pulled up, and the wagon stopped. My brother turned round and said: "Mother, I have made a bargain with this man to take us to Port Gibson for ten dollars. I have no money, and expected to pay him out of tonight's receipts after the play. He says this arrangement will not do for him; he seems unwilling to trust me, so he must be paid now or he will turn back." I looked at my mother and hinted that perhaps, if she searched hard, something might be found in the stocking. Her eyes 
filled with tears, and I saw by her face that the bank was broken. There was nothing left us but to get out of the wagon and remain by the roadside until my brother should go back and make another trial. The rain came down, and we took shelter under a large tree, awaiting his return. My mother had once been one of the most attractive stars in America, the leading prima donna of the country, and now, from no fault of her own, was reduced to the humiliation of being put out of a wagon with her two children, in a lonely road in the far-off State of Mississippi, because she could not pay a wagoner the sum of ten dollars.

This was so far the darkest hour we had passed. About noon the sun shone bright, and shortly afterwards my brother appeared in sight, mounted on top of an ox-cart driven by an old negro. We were only four miles from Port Gibson, but it required as many hours to make the journey, so about sundown our party alighted at the hotel.

We now entered upon a course of the most primitive acting, going from town to town and giving entertainments in the dining-rooms of the hotels. As there were no papers published in these small villages, there were no printing-offices, consequently no bills; so flaming announcements of our arrival in a bold handwriting were displayed in the three important points of the town, viz.: the hotel, the post-office, and the barber-shop. It fell to my duty, being an adept with the brush, to write, or rather paint, these advertisements. The plays were acted in costume, but without scenery 
or curtain. The nightly receipts were small-just about enough to get us from place to place.

Our objective point was the town of Liberty, Mississippi; but there was some difficulty in getting there, as the distance was greater than we could accomplish in a day. A farmer who had been to the theater the night before for the first time in his life was so struck by the performance that he proposed to have his teams brought in and take us to his farm-house, about twenty-five miles distant. According to his suggestion we were to rest for a day, give an entertainment in his barn, and so go on to Liberty.

"But," said my brother, "you tell me there is no other house there but your own. What shall we do for an audience?"

"Well," said the farmer, "all my family will come, to begin with, and there 's a dozen or more on 'em; then there 's eight or ten farm-houses close by, and if one of your men will drive there with my son and blow the horn they will all come, for there ain't one on 'em ever seen a play before. I 'll insure you a full barn."

So the matter was settled, and we actually played in a barn, the house that we staid in being the only one in sight. It seemed in vain to look for an audience in such a lonely place, but the farmer was right. Soon after the sun had gone down the full harvest moon rose, and by its dim light we could faintly see family groups of people, two and sometimes three on a horse, coming from all directions over the hill- now a wagon with a 
great load. Some of them walked, but all were quiet and serious, and apparently wondering what they were going to see.

Those who have traveled through the Southern States will perhaps remember the kind of barn we acted in: there were two log-houses joined together with an opening between them which was floored and covered in. The seats were arranged outside in the open air - benches, chairs, and logs. The double barn on each side was used for dressing-rooms and for making entrances and exits, while the opening was devoted to the stage. The open air was well filled, containing an audience of about sixty persons. Our enthusiastic admirer, the farmer, collected the admission fee, a dollar being charged and freely given. The plays were "The Lady of Lyons" and "The Spectre Bridegroom." The farmer had supplied us liberally with candles, so that the early part of the entertainment was brilliantly illuminated, but the evening breeze had fanned the lights so fiercely that by the time the farce began the footlights were gone. The little "flaming ministers" had all sputtered out, so "The Spectre Bridegroom" was acted in the moonlight.

It was curious to watch the effect of a strong emotional play like "The Lady of Lyons" upon an audience that had never seen a drama before: they not only were much interested, but they became excited over the trials of the hero and heroine; they talked freely among themselves, and, at times, to the actors. One old lady insisted 
that the lovers should be "allowed their own way," and a stalwart young farmer warned the villain not to interfere again "if he knew what was best for him."

We continued traveling through the State of Mississippi, sometimes in wagons or on a stray stern-wheel steamer that was hailed from the bank of some little village where we had acted. As the spring opened the rainy season set in, and the roads became almost impassable. Fortunately at this time my mother received an offer for us to join the new theater in Galveston, to which place we proceeded, my brother and his wife going North to act under Mr. Burton's management at the Arch Street Theater, Philadelphia.

At the termination of our Galveston season the company embarked on board a small stern-wheel steamer that wound its way through a narrow, crooked stream and landed us at the city of Houston. I say the company, but it was only a remnant of it, as most of its members, being weary of the hot weather and despairing of any more regular salary days, had returned to the North. We acted for several weeks in Houston, but with a feeble kind of patronage that just enabled us to keep our heads above water; still, the ever-hopeful disposition of the itinerant actor buoyed us up, and we struggled on in the anticipation of a reaction.

We had by this time resolved ourselves into what was called a "sharing scheme," dividing the profits, when there were any, pro rata with our salaries. First the board was paid for, then the 
rent, then the printing, then the orchestra - the latter always ready to strike at a bar's notice; the rest we shared. These uncertain dividends were looked forward to with much interest, for home was far away and difficult to reach.

As the season approached its close and the disbanding of our company was under discussion, a new sensation occurred in the arrival of an old actor and ex-theatrical manager by the name of Stanley. This remnant of an earlier era had been upon the retired list for many years, and now suddenly burst upon us with enticing schemes to better our condition. I had never seen him before, but several of our company knew and recognized him as a veteran barn-stormer of the olden time. $\mathrm{He}$ had been living in San Antonio for many years, and having heard that a company of players were at Houston the slumbering old war-horse within him was awakened, and disdaining the dangers of a long journey through the chaparral,for the country was at this time full of hostile Indians, - he had ridden three hundred miles in the wild enthusiasm of an old manager-actor, thirsting for the revival of three-sheet posters and a high stool opposite that fascinating spot, the pigeon-hole of the box-office. Naturally, in the first flush of his arrival, laden as he was with flattering promises of double salaries and clear third benefits, we were in a delightful flutter of anticipation. His accounts of San Antonio and the surrounding country were dazzling. There had been no dramatic entertainment ever given there, the 
gold mines of Mexico were close at hand, and, in short, it seemed quite clear that our fortunes would be made if we concluded to embrace his offer. He further informed us that he was well known all through Texas, and that his popularity was second only to that of the late Davy Crockett; that, under the very "shadow of the Alamo," as he poetically expressed it, he kept a bar-room in conjunction with a fandango, a keno-table, and a faro-bankby which means it seems he had endeavored to refine the depraved tastes of the citizens. Mr. Stanley's figure was portly, so that his friends, in order to distinguish him from the other and less important Stanleys in town, bestowed upon him the title of "Pudding Stanley," or "Pud," as he was more briefly and affectionately called.

As I have said, we were at first overwhelmed with his amazing description of our future Eldorado, but upon holding council to consider the situation dispassionately our ardor cooled. First came the dreaded journey of three hundred miles through a wilderness of chaparral inhabited only by jack-rabbits and hostile Indians. Our leading actor remarked that he did not mind jack-rabbits, but considered the Indians an impediment. He was a courageous man, too-upon the stage. I had seen him play the Chief Osceola, and scalp one "super" after another with great nerve; but now he seemed to think with King Lear that "Nature's above art in that respect"; and while he reveled in being the hero of an artistic assassination, realistic effects of this kind were not to be thought of. 
Another reason for our not relishing the proposal was contained in the recollection of a really serious matter in connection with actors and Indians that had occurred in Florida during the Seminole war. It seems that a manager by the name of William C. Forbes had taken a theatrical company into the very jaws of the disturbance. The troupe acted at the different forts and garrisons along the line of battle, and on a certain occasion, while going from one military station to another without an escort, it was attacked and roughly handled by the savages. Forbes and most of his people escaped, but two unfortunate actors were captured and butchered. The theatrical wardrobe belonging to the company fell into the hands of the Indians, who, dressing themselves up as Romans, Highlanders, and Shaksperean heroes, galloped about in front of the very fort, though well out of gunshot, where Forbes and the more fortunate members of his company had fled for safety. Several of the Indians were afterwards taken, and as they were robed and decked in the habiliments of Othello, Hamlet, and a host of other Shaksperean characters, - for Forbes was eminently legitimate, - their identity as the murderers was established, and they were hanged in front of the garrison.

The recollection of this incident acted as anything but a stimulus to our wavering courage, and we took the liberty of mentioning to the ex-ranger that it was within the bounds of possibility that the warlike Comanches of Texas might have no more respect for the legitimate drama than the Seminoles 
of Florida, in which case history would inconveniently repeat itself.

The tempter ridiculed our fears, looking upon us, I think, with a ranger's contempt. He said there were a few Indians here and there certainly, but they were cowardly, and generally kept themselves concealed in the chaparral. On being crossquestioned as to why they concealed themselves in the chaparral, he replied, "Well, possibly ambush ; but they are great cowards." He said the safest plan would be for the entire party to keep together; going all in one wagon, we would then exhibit " the full strength of the company," and well armed with such theatrical weapons as we might possess, there would be no danger. Theatrical weapons - just think of it! The armory of a theater in those days consisted of two pairs of short broadswords, a halfdozen stuffed sticks, and a rusty flint-lock horsepistol that always snapped once and generally twice before virtue felt itself secure. A cold shiver ran down my back as I imagined myself facing a Comanche with a weapon whose uncertainty had on more than one occasion compelled the heavy villain to commit suicide with a table-spoon.

It is needless to say that I had inwardly resolved not to go, and I think the entire company were of my mind. Of course we laid it all on the leading man, who had at least been bold enough openly to express his fear; but we decided not to go!

Stanley was of course disappointed, as he had looked forward, he said, not only to the renewal of managerial responsibility and importance, but to 
donning again the sock and buskin and acting with us. Upon this hint we suggested that if he really desired to act again, and would appear one night in Houston for our benefit, we should be proud to support him. If Richard III. could tempt himwe knew this to be his weak point - it was at his service. Of course at first he pretended to demur, saying that he had no wardrobe, and that it was so long since he had acted that he "really feared." But he could not conceal an undercurrent of secret delight at the thought of again striding the stage. He consented. He was so well known in Texas we felt quite sure that, in securing his services for a joint benefit to the company, our treasury would swell from its present slender dimensions and give us the means of returning to Galveston with flying colors.

Stanley's professional and private histories were both interesting, as they covered a period when artistic, commercial, and military matters were curiously mingled. He had acted in the then far West under the management of Alexander Drake both in Louisville and in Cincinnati; he had then drifted off into Texas, joining the rangers against Santa Anna; then back again to the Mississippi, where he encountered the celebrated Chapman company, who had ingeniously fitted up a steamboat and converted it into a floating theater. This huge dramatic barge used to ply from one town to another on the Ohio, Mississippi, and Missouri rivers, giving theatrical entertainments at the various points where there were no theaters. The 
roving spirit again taking possession of him, he left the Chapmans and returned to Texas.

The night was arranged for the benefit, and such was the popularity of the volunteer that tickets amounting to the capacity of the theater, and even beyond it, were sold without delay. As I before said, Richard III. was his pet part; and while he considered himself unequaled in the character, he confided to me that he did not mind privately confessing that in the later scenes he drew his inspiration from the example of Edwin Forrest. Stanley now employed his mornings in walking as majestically as his ungainly figure would permit up and down the stage, gesticulating violently and roaring out the soliloquies of Richard; and his afternoons in accumulating raw cotton, in order that the hump and the bandy-legs of the crookbacked tyrant might be properly deformed and traditionally disfigured.

Our volunteer reminded me of an actor I once knew who used to wear upon the stage a red wig so like his own hair that whether he had it on or off there was no perceptible difference in his appearance. So with Stanley: his bandy-legs and round shoulders, even when unadorned, quite harmonized with the accepted idea of Gloucester's deformity; but, looking upon himself as an Apollo, our hero had piled such a mountain of cotton on his natural hump that it made "Ossa like a wart."

On the auspicious night the house was packed to the doors. A few ladies came; but their 
escorts, seeing that the audience were disposed to be turbulent, took them away, so that the friends and admirers of the star were unchecked in their cat-calls and noisy demonstrations. Law, order, and decorum were set at defiance. The friends of the old ranger had come for a frolic and evidently intended to have it. The placard of "No smoking" was totally disregarded. Pipes and cigars were vigorously puffed, and the house was so filled with smoke that one would have supposed that the battle of Bosworth Field had taken place before the opposing forces met. The weather was sultry, and the general heat, combined with the stifling atmosphere of a crowded house, ran the little box of a theater up to the temperature of an oven in full force.

At the rise of the curtain the expectant audience were on tiptoe to greet their comrade. At the wing stood the sweltering Richard, absorbed in his character and embedded in cotton, and as he strode upon the stage the theater rang with applause and shouts of welcome. After bowing low his acknowledgments he began the famous soliloquy. The performance proceeded quietly for a time, the silence being broken now and then by expressions of approval in complimentary but rather familiar terms. During the love scene with Lady Anne, her ladyship was warned by some one in the audience, who claimed to have an intimate knowledge of Richard's private domestic affairs, that the tyrant had already two Mexican wives in San Antonio. Nothing daunted at this 
public accusation of polygamy, "Pud" pressed his suit with ardor.

The retired actor had not forgotten some of the old-fashioned tricks of the art, and would take the stage with tremendous strides from the center to the extreme right or left after making a point, thereby signifying to the audience that if they desired to applaud that was their time. "Off with his head! so much for Buckingham!" and away he would go. In one of these flights, being over-stimulated by excitement and applause, he nearly stumbled into the private box. Straightening himself up, his ostrich plumes became entangled with a spermaceti chandelier and set him in a blaze of glory. He glared with indignation at the convulsed audience, being himself entirely innocent of the illumination until the unmistakable odor of burnt feathers warned him that his diadem was in danger. In the death scene, just as Richard expired, a voice, signifying that the game was over, shouted "Keno!" This allusion to "Pud's" commercial pursuits brought him to life, and as the curtain was descending he sat up and warned the interlocutor that he would "keno" him in the morning.

The declaration of war with Mexico caused a great stir in Galveston; speculations were rife in all quarters as to the probable result from a commercial point of view. Of course no doubt existed as to the ultimate success of our side; but the question as to how much was to be made out of it seemed to absorb the public mind. Our manager 
was a thrifty soul, and foresaw the prospect of good financial results by following up the army with his dramatic forces. My mother was considerably alarmed lest I should be conscripted, and I was not a little uneasy on those grounds myself.

In May, I846, we embarked on board a condemned Mississippi steamer for Point Isabel. This leaky old boat, crowded with soldiers, gamblers, and a few actors, feebly wended its uncertain way along the coast and arrived at its destination in about four days. Luckily, the sea was as calm as a mill-pond; for if one of those dreadful cyclones so frequent in the Gulf had overtaken us, many good soldiers, indifferent gamblers, and bad actors would have found their way to the bottom of the sea, and these important reënforcements to General Taylor never would have put in an appearance. Point Isabel, on our arrival, was all bustle and activity. It was a flat, sandy, and uninteresting place, covered with tents and boiling over with military preparations. The battle of Palo Alto was fought on the 8th of May: these were the first guns fired, and we could distinctly hear the booming sounds of opposing cannon; it ended at sunset with victory for the American army. The next morning I saw the ambulance bringing in the wounded form of Major Samuel Ringgold, who died soon after. This celebrated hero introduced into this country the flying artillery, to the efficiency of which the success of the day was attributed. The Mexicans had retreated only a few miles, and, being reënforced, gave battle the 
next day, and the memorable engagement of Resaca de la Palma was won by the gallant charge of Captain May at the head of his dragoons. Then came the bombardment of Fort Brown, and on the I8th of May the city of Matamoras was occupied by the United States army, with our gallant band of comedians bringing up the rear, elated at our military success.

The manager took advantage of the distressed position of the town, and by permission of the American commandant occupied the old Spanish theater. Victory had crowned our arms; so the soldiers, settlers, gamblers, rag-tag and bob-tail crowd that always follow on in the train of an army, like "greedy crows" that hover over the heads of the defeated party, "impatient for their lean inheritance," were ready for amusement. Here we acted to the most motley group that ever filled a theater. But in the middle of September the trumpet blast sounded in our ears again; the soldiers were ordered to march on to Monterey. The town was deserted and the theater closed. Our manager, seeing that all further hopes of their return had vanished, disbanded his company, and with all the cash he could collect, including our back salaries, "wandered away, no man knew whither." Here I was left with my mother and sister, thrown on our own resources, which were very small, in a strange country, and among a people not at all on good terms with us. The only member of the company left besides ourselves was Edward Badger. He was my brother 
comedian and friend; his father was the wellknown Alderman Badger of Philadelphia. Our situation was somewhat desperate; so we held a council of war to determine on our future movements. The soldiers had gone, but the gamblers remained; and the brilliant idea occurred to us that, as we could no longer minister to their intellectual entertainment, we might make something by furnishing them with internal comforts. So we boldly resolved to open a coffee and cake stand in their interest. We arranged to place the stand in a bar-room in the central part of Matamoras, the locality offering the best position for our commercial enterprise. The establishment was dignified by the high-sounding title of "The Grand Spanish Saloon," and consisted of a long room, with a low ceiling, having a counter, or bar, running the full length on one side, and a row of gaming-tables on the other, where roulette, keno, chuck-a-luck, and faro were industriously pursued with the usual integrity which generally attaches itself to these pastimes. The walls were beautifully whitewashed and the floor was well sprinkled with sand. In front of the bar and at regular intervals were kegs cut into halves and filled with sawdust, these being the cuspidores of the pioneers. From the ceiling were suspended chandeliers made of barrel-hoops, tastily covered with pink, blue, and white paper, cut in different patterns, in which candles were placed to illuminate the cheerful and tragic scenes that alternately occurred in this fascinating but dangerous place. 
Badger, after convincing the proprietor that the introduction of a stand for cake and hot coffee at one end of the room would not only add to the refinement of his establishment, but increase its custom by providing the patrons with refreshment during their hours of relaxation from business, came to terms with him. We were to furnish everything and give him ten per cent. of our gross receipts for rent, it being verbally understood that if either Badger or myself came to an untimely death at the hands of any of his attachés the person so offending should be discharged from his service at once.

Nothing could be more satisfactory than this arrangement, so I at once set about the decoration of our café, while Badger went off in search of an old Mexican woman, said to be an expert in the manufacture of coffee and pies. The construction of our stand was simple and effective: a large dry-goods box on which two boards were placed so as to reach the bar-counter made a permanent and secure foundation for the reception of our viands. The boards were tastefully draped and masked with Turkey-red reaching to the floor. Broad sheets of white paper were spread over the top, and on the right, next the counter, stood a large and elaborate tin coffee-urn, and beneath it an alcohol lamp emitting a beautiful blue flame. This monument was surrounded by a dozen old cups and saucers, in which, placed at right angles, gleamed a corresponding number of shining spoons, giving a pure German-silver flavor to 
everything they touched. A fat sugar-bowl and an attenuated milk-pitcher completed the coffee service. Four flat pies, two pyramids of sandwiches, a box of cheap cigars tilted up on a brick, and a large plate of home-made Mexican cakes completed the assortment. Among the dainty articles which adorned our counter were some large, round, burnt-sienna-looking cakes called mandillos. I think they must have been indigenous to the soil of Mexico, for I rejoice to know that I never saw one anywhere else. They were sparingly sprinkled with dry currants, and glazed on top with some sticky stuff that never dried during the whole summer: if an unlucky fly lit on one of these delicacies his doom was sealed. I have no idea what they tasted like, for I never had the courage to try one; nor did I ever know a customer who ventured on one for the second time. One gentleman, - an epicure from Texas, said that he would not mind giving one a trial if he could be sure which were the currants and which were the flies. This kind of pleasantry we could afford to smile at, but when a ranger remarked on one occasion that any man who would sell such things ought to be shot, we decided - for the sake of our customers - that we would remove this objectionable feature from our bill of fare; so the cakes were forthwith banished to the top shelf, well out of sight, and utilized as fly-traps for the rest of the season.

When our arrangements were first completed Badger and I stood with folded arms at the far 
end of the long room, contemplating the effect with pride and satisfaction. It was now about time for the doors to open. We were quite nervous and excited; for, in the innocence of our natures, we expected a great rush from the public. Our spirits were somewhat dampened, therefore, to find that no one seemed to know or care anything about us or the new venture in which nearly all of our available cash was invested.

As the day wore on, stragglers dropped in one by one; blear-eyed gamblers, freshly shaved, with shaky hands and gloomy looks, called for their morning cocktail at the bar. Now and then we caught a stray customer: our coffee, clear and strong, was a great success; and the pies did pretty well, too, but the "Colorado Claros" were a dead failure. Our point now was to watch the public; if an article was not in demand we discarded it at once, and offered another in its place. By these tactics, before the week was over, the cash returns were more than satisfactory. My partner and myself conformed to the regular business hours of the establishment: at about three o'clock A. M. the order to close was given, and "Vamoose!" was shouted by the stentorian lungs of the proprietor. The roulette ceased to revolve, the dice were discarded, the faro cloth was rolled up, and our alcohol lamp was extinguished. Those members of the sporting fraternity who could stand on their feet reeled home (?), and those who could not were dragged along the sanded floor and deposited on the sidewalk; the candles were 
blown out and the doors of "The Grand Spanish Saloon" were closed to the world. Badger and I would trudge to our room arm in arm, carrying our money in a shot-bag between us, and each armed with a Colt's patent "peppercaster."

The dwelling-houses in Matamoras were generally one story high, built of brick, plastered, and painted yellow; one door and an iron-barred window in front on the street, and the same at the back, leading to a courtyard which was used in common by the occupants of the house for washing, ironing, cooking, and eating. We occupied one of these establishments.

In the morning little tables, with white cloths, were brought out and set for breakfast in the open air. The different families would sit at them and drink their hot coffee, eat their fruit and bread, smoke their cigarettes, and talk away as gaily as if no war were going on. The courtyards were entered by a large gate, and hired out to passing caravans of muleteers or rancheros, who occupied the middle of the space. Here they also took their meals and sold their fruit, vegetables, chickens, and dry-goods of cheap and gaudy-colored stuffs, Mexican blankets, sombreros, and baskets. The courtyard at night was a lovely sight. The little houses surrounding it were all lighted up within, the doors wide open so that we could see the families, men, women, and children, knitting, smoking, dancing, singing, and playing cards always for money (everybody gambled in Mex- 


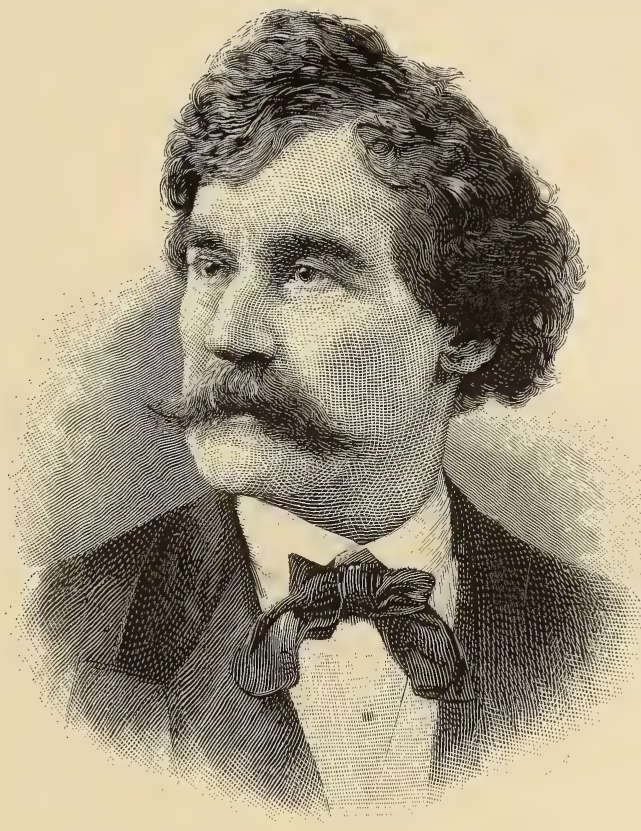

JAMES $W$. WALLACK, JR. 

ico); and groups of muleteers in the center were seated around their camp-fire, which would blaze and shed its light over the scene. I had a great fondness for this locality, for here I met my first love. Her mother was a full-blooded Mexican, but her father must have been pure Castilian, for the girl was not only beautiful, but her features were aristocratic. She had the prettiest little feet and hands that could be imagined. Her merry black eyes fairly danced and sparkled with brilliancy, and when laughing she would throw her head back in ecstasy, showing two rows of pearly teeth. Metta - that was her name - was as wild and graceful as a deer. I was quite in love with her at first sight, and when she began to teach me to play the guitar and smoke cigarettes I was entirely captured. She had that rich, olive complexion that one sees in a pale Key West cigar, and, like that article, was about half Spanish. Her great delight was to make a full half-dozen of her Mexican sweethearts jealous by flirting with me; but as she spoke not a word of English, and I was entirely ignorant of Spanish, we could only make eyes and smile at each other. Perhaps this was all for the best, because had it been otherwise I am afraid that, though I was only eighteen, my mother would have been astonished with a Mexican daughter-in-law before we left the country.

Our business aftairs were flourishing at the saloon, and but for a strong propensity that my speculative partner had for trying his luck at the side tables now and then, we should have 
made a small fortune. Of course there was a heavy risk of life and property in such a place, as the frequenters of the "Grand Spanish" were more numerous than select, and, to paraphrase an old saying, "when the rum was in, the knife was out." Several times the firm had dodged under the counter to escape contact with a stray bullet, and on one occasion the offending coffeeurn had been fatally shot.

I now divided my time between attention to commerce and learning the Spanish language from Metta, but I am afraid it was a case of pleasure before business. She was the most innocent, simple child of nature that I ever saw, and yet, with all her modesty, a perfect miniature coquette. She would jump for joy and clap her little hands together if she only could contrive to make any of her lovers jealous. The scowling brows of one of her native admirers, together with the liberal display of a small arsenal of unconcealed weapons encircling his waist, always gave me a disagreeable turn, and at these times I would insist on Metta's not lavishing so much public attention on me. I never saw the fellow's dark eyes glaring at me but there came up a vision of that old engraving of the Spanish lady on a moonlight night smiling from her window on her favorite lover, and a melodramatic-looking rival in the background peering around the corner and grasping a stiletto as big as a hand-saw, ready to stab the accepted lover in the back.

A noted character on the border line in those 
days, one Buck Wallace, was a frequenter of this place - a lump of good nature and kindness when unmolested, but the demon in him once aroused, a desperate and dangerous man. $\mathrm{He}$ was a Philadelphian by birth; and as that was my native city, Wallace and I struck up a great friendship, though he was full thirty years my senior. He was an interesting fellow, with a strange mixture of tenderness and ferocity. His life had been an adventurous and romantic one; as a boy, he had served under Captain James Bowie, after whom the famous bowie-knife is named, and was with Davy Crockett at the fall of the Alamo. After the assassination of Crockett and Bowie by the Mexicans, Wallace returned to Philadelphia, and, as extremes meet, strangely enough married a beautiful young Quakeress. He now resolved to settle down and lead a steady life, but the City of Brotherly Love was a trifle too peaceful for his belligerent nature; so, taking his young wife on his arm, he again sought the border, squatting on a ranch in the heart of a wild and lonely spot on the banks of the Nueces. This river marked the fighting line between Mexico and Texas, so it was congenial soil for "Bully Buck," as he was familiarly called, though I am afraid the friendly spirit of his gentle wife was often shocked by his deeds of daring. He used to talk to me of this sweet lady and their only child with tears in his eyes, for he was a loving savage. They had been cruelly murdered by the Comanche Indians during the absence of Wallace from his 
home. This crazed him for several months, and when he came to himself a morbid craving for revenge took possession of him. It is said that if Buck met a Comanche alone, it was all up with the redskin. His knowledge of the country made him of much importance at this time to the United States Government, by whom he was employed as spy, scout, ranger, and detective; his bold nature won for him the admiration of his friends and the fear of his enemies. He had in his way educated himself, and was very fond of quoting poetry of the morbid and romantic order. Byron's "Corsair," Poe's "Raven," and Scott's Highland tales were special favorites with him; but he had a thorough contempt for Cooper's novels, and put no faith in the existence of "Boston Indians."

One evening, - the last on earth for him, poor fellow! - just as the candles were lighted and the games in the "Grand Saloon" were in full play, Wallace, without hat or coat and with his hair disheveled, rushed wildly into the room. $\mathrm{He}$ shouted to the crowd: "Give me a knife or a pistol, for God's sake, quick, or I 'm gone!" Everybody started to his feet; the man was so well known that the sound of his voice and his desperate appearance seemed to terrify the crowd. In the midst of the confusion three dark-looking Mexicans rushed into the room and began a furious attack upon Wallace. He was unarmed, and, seizing a chair, he fought desperately for his life. $\mathrm{He}$ felled the first man to the ground, but before he could turn he was stabbed to the heart by one 


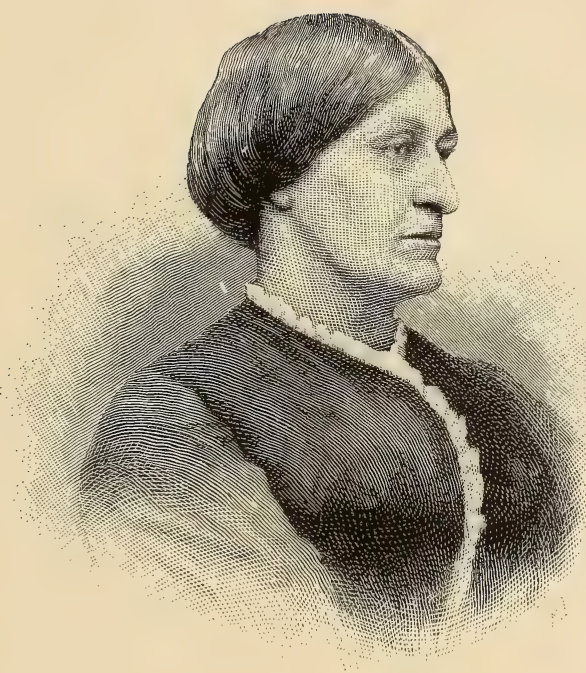

MRS. JAMES $W$ : WALIACK, JR. 

of his other assailants and fell heavily to the floor; the assassins, brandishing their knives, cleared a way through the crowd and escaped. This was the darkest tragedy I had yet seen, and that night, as I turned the matter over in my mind, I felt that, however congenial this atmosphere might be for a Texan ranger, it was no place for a legitimate comedian. So I proposed to Badger that we should at once hunt up some Mexican having a commercial turn of mind and sell out. This was easily done; the business was a thriving one, and the death of poor Wallace seemed to have made the place more popular. So we sold the good-will, divided our capital, and dissolved.

I had to break the dreadful tidings to Metta that I must go away. I do not think she cared half so much for me as I did for her; but when she realized the fact that I was about to "vamoose" she got up quite a little scene. Through our interpreter I told her I should soon make my fortune and return to her to claim her as my bride, and bear her off with the whole family there were sixteen of them - to my own country. It was pretty hard to make her understand that there was any other country but the one she was living in: she had often wondered where I and all the other cruel people had come from to make war on her family, and always fancied that the little town where she was born was the all and end of everything. In fact, Metta in Matamoras was like the minnow in the brook - she "knew not of the sea to which the brook was flowing." 
The parting between Metta and myself was very affecting; her mother and all her little barefooted brothers were weeping away in the Mexican tongue as I departed. In a month after that I had quite forgotten Metta, and the chances are that within a year she had allied herself to that animated arsenal, the dark-eyed rival.

We had a permit to leave Matamoras in one of the Government boats that was taking back wounded soldiers to Brazos Santiago. Many of the poor fellows were on board, and, having left various members of their bodies on the battle-fields of Mexico, they were anxious to get what was left of them home as soon as possible. I was an eye-witness to much of the suffering; the water, the climate, the blazing sun, and the drenching rain thinned their ranks with more effect than Mexican valor could have done. One by one they dropped off, and by the time we reached Brazos Santiago there were but few left alive. Here we left the Government steamer and took passage on a brig bound for New Orleans.

I am not aware as to how attractive their places of business may be to the members of other professions, but when I was a youth the first place an actor sought out when he arrived in town was the theater. Actors seemed to be in love with their vocation and fluttered about the footlights, whether they had anything to do or not. I scarcely think that the attachment is so strong to-day, and there are many reasons, too, why it should not be so. At the time of which I write actors mixed 
but little with the public and seldom went into society. Salaries were small, so they could not afford expensive amusements, and I cannot call to mind that there was a dramatic club in America. Now they have their yachts, their horses, their clubs, and their country homes. Then their only place of rendezvous was the theater.

It is not to be wondered at, then, that on our arrival in New Orleans the brig we came in had scarcely touched the wharf when I leaped ashore and bought a morning paper to see what theater was open. At the St. Charles - still under the management of Ludlow \& Smith - there was announced the "Tragedy of King Richard III." from the original text, the stars being Mr. and Mrs. James W. Wallack, Jr., who appeared as the Duke of Gloster and Queen Elizabeth, the evening's entertainment concluding with the farce of "A Kiss in the Dark," with the then rising young comedian John E. Owens as Mr. Pittibone. Of course I went at once to the theater. As I had acted there the season before, I knew all of the attachés and most of the company, and I naturally expected to be something of a lion, having just returned from the seat of war. In this, however, I was somewhat disappointed; for as I had arrived in a sailing vessel, they knew more of the conflict than I did. That night I saw the performance. James W. Wallack, Jr., ${ }^{1}$ was in those days at his best. Young, vigorous, and handsome, he was

1 So called to distinguish him from his uncle, who was the father of Lester Wallack. 
the most romantic-looking actor I ever saw ; there was a dash and spirit in his carriage, too, that was charming. I say he was at his best in those days, because in after years the acting of Macready, whom as an artist he idolized, had an unfortunate influence upon him, as he ultimately became imbued with the mannerisms of the English tragedian, which were so marked that they marred the natural grace of the imitator. All who remember Mrs. James W. Wallack, Jr., will attest the force of her tragic acting. In the quality of queenly dignity I think she even surpassed Charlotte Cushman, though she lacked perhaps the spirit and fire of the latter. War usually increases the nightly receipts of the theater, but the struggle with Mexico seemed to have a contrary effect. So I remember that, though the bill would have been considered an attractive one under the usual condition of public affairs, the audience was small. The American Theater, then under the management of James Place, was not open, but the company was still in town, and there were as many actors as citizens in front.

The play was finely acted but indifferently mounted, the armies of York and Lancaster being wretchedly equipped and quite limited as to quality and quantity. The faint and unmilitary efforts that they made to march with time and precision gave them anything but a warlike aspect. In keeping step there was a glaring difference of opinion, the pursuing army treading more upon their own heels than upon those of the enemy, 


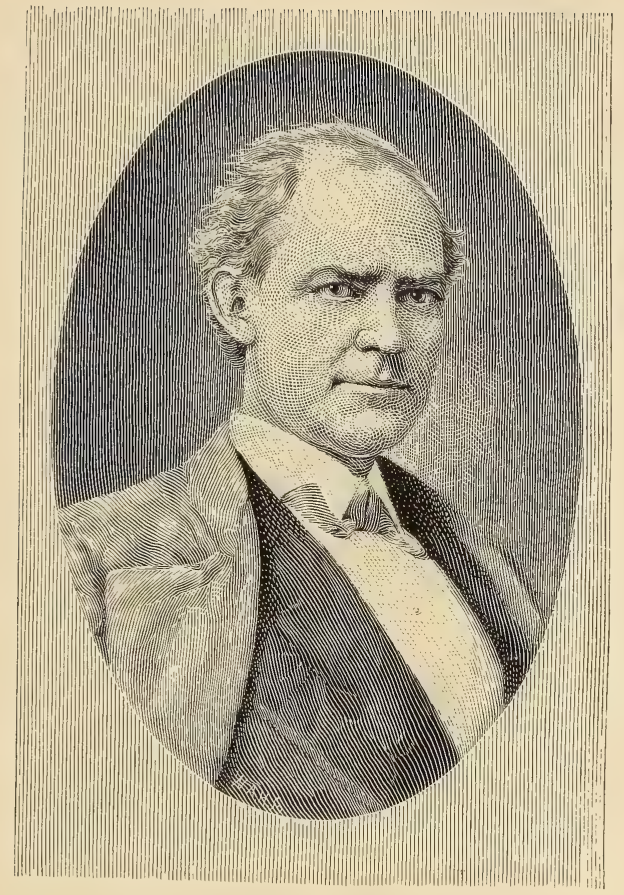

JOHN E, OWENS. 

and in the final collision there was a friendly tapping of tin spears on pasteboard helmets that told too plainly of a bloodless battle.

But the really furious fight between Richard and Richmond made amends for the docility of the rank and file. Wallack was a superb swordsman, and I do not remember to have seen a stage combat fought with finer effect.

I had for the last year at least been buffeting about in barns and tents, so that anything like a legitimate production was a great treat. But my chief interest on this occasion was centered in the farce, and my thoughts were dwelling on the approaching efforts of the rising young comedian -and why not? Was I not a rising young comedian myself? I certainly had reached that height in my own estimation, at least, and I felt a burning desire that a time should come when some newspaper would proclaim it for me as the New Orleans "Picayune" had that day announced it for Owens.

At last he came, and certainly he conquered. As he entered briskly upon the stage, humming a sprightly song, I thought him the handsomest low comedian I had ever seen. He had a neat, dapper little figure, and a face full of lively expression. His audience was with him from first to last, his effective style and great flow of animal spirits capturing them and myself too-though I must confess that I had a hard struggle even inwardly to acknowledge it.

As I look back and call to mind the slight touch of envy that I felt that night, I am afraid that I had 
hoped to see something not quite so good, and was a little annoyed to find him such a capital actor; in short, I experienced those unpleasant twinges of jealousy that will creep over us during the moments when we are not at our best - though these feelings may occasionally produce a good result. In me, I know, it stirred up the first great ambition that I remember ever to have felt, and from that night of pleasure and excitement I resolved to equal Owens some day, if I could. 


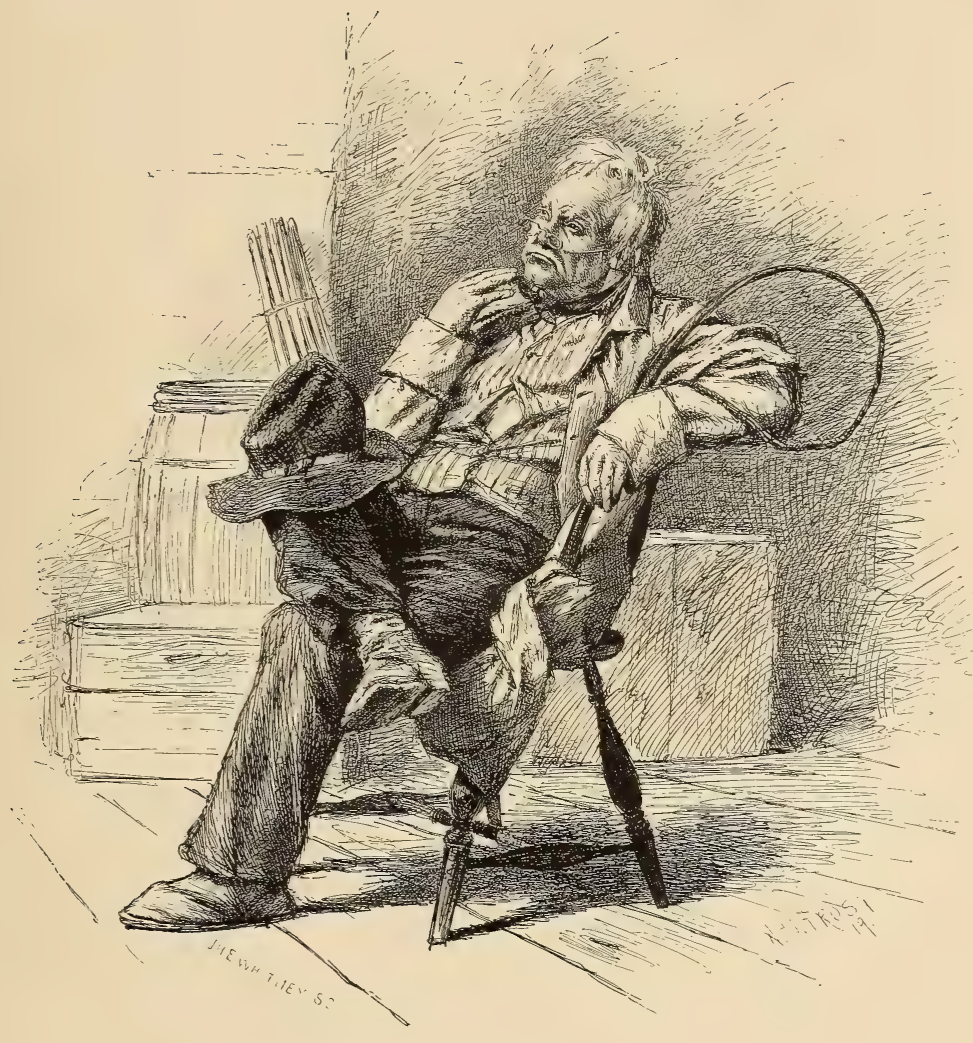

JOHN E. OWENS AS "SOLON SHINGLE." 



\section{CHAPTER IV}

EARLY DAYS IN PHILADELPHIA AND NEW YORK

Crossing the Alleghanies - My Friend the Scene Painter-William E. Burton-An Effort in Greek Tragedy-Charles Burke

T was now decided that my mother and sister should remain in New Orleans with some old 1 friends while I went to join my half-brother in Philadelphia. He had been urging us for some time to come to the North, writing that arrangements were made for me to act the second comedy to himself and W. E. Burton, then manager of the Arch Street Theater. My mother was banker, and so had charge of the money. I took enough to see me to Philadelphia, supposing that no accident would happen; but before our steamer arrived at Wheeling the river was blocked with ice, and we were delayed over a week before we could reach the line of stages that crossed the Alleghany Mountains. 
Some of the old folks of to-day, who live only in the past and stolidly witness the improvements of the present, passing no remarks upon them except when there is an opportunity to condemn, are always preaching about the delights of the olden time and extolling the comforts of the stage-coach. I will describe, by way of contrast with travel of the present day, how the Alleghany Mountains were crossed in 1846 .

It was midwinter when we arrived at Wheeling. Our steamboat was tied to the wharf about three o'clock in the morning, and as the stage-coach was to start at five no one thought of going to bed, so we wended our way along the frozen streets to secure through tickets to Philadelphia. The morning was pitch-dark and bitter cold - that damp, penetrating weather piercing wraps and overcoats until it reaches the very marrow in one's bones.

We got to the little den, by courtesy called the "office," where we found a half-dozen more passengers equally damp, cold, and ill-natured with ourselves. There was a handful of coal burning in a very small grate, about which were grouped the round-shouldered, unsympathetic people who were to be our fellow-travelers. They glanced at us as we entered, and, closing up all the open space near the fire, said as plainly as they could without speaking: "You don't get in here, we can tell you. You have no right to travel in our coach, anyhow."

At one side there was a small table on which stood a large coffee-pot, some white cups and saucers, a plate of sausages, - frozen stiff, - and 
an unattractive loaf of bread; behind this banquet was a tall darky, leaning against the wall and fast asleep. Here he remained undisturbed, not only because his refreshments were not tempting, but because we were given to understand that we could get a good breakfast twenty miles from Wheeling. At the appointed time the heavy old coach came up and we all climbed in. As our places were not designated on the ticket, we stowed ourselves in pell-mell, and I presume no one got the seat he wanted.

A short way from town there was a long hill up which the horses toiled, so this gave the inmates of the coach time to settle themselves down for a quiet nap. One snore after another announced the accomplishment of this feat, and in a few minutes at least six out of the nine passengers were oblivious of their miserable condition. I never before had so fine an opportunity to study the philosophy of snoring. A large, fat man opposite me had a short, angry snore; at one time he snored so loudly that he woke himself up, and he had the impudence to glare about at the company as though he hoped they would not make that noise again. The old lady who was crushing me up in the corner snored deeply and contentedly. Some one off in a dark corner, whom I could not see, had a genial way of joining in, as though he snored merely to oblige the passengers; but the grand, original musician of the party sat opposite me. I never heard anything approaching him, either for quality or for compass. 
It was a back-action snore that began in a bold agitato movement, suddenly brought up with a jerk, and terminated in a low whistle. As the coach steadily moved up the hill the band was in full play. The summit gained, there was a sharp crack of the whip, the horses started, and as everybody was jerked violently backward, snoring gave place to oaths and pshaws and jolting about. As soon, however, as we got used to this sensation, the chorus began again; and as I was quite overcome and tired, I joined in until the coach came to a full stop at the stable where the horses were to be changed. The sun now rose, and came in at all sorts of places, waking and blinding everybody. What a discontented and unhappy lot we were! and how we all hated one another!

Breakfast at last! Ah, hot coffee, ham and eggs, and buckwheat cakes! The meal was not half over before we were a band of brothers. We could not do enough for one another, and all was harmony and peace. Of course, under these conditions, we became more familiar, and one vied with another in making the time pass agreeably.

Two gentlemen pitted themselves against each other in telling funny stories. Their talents and qualities in this respect differed very widely: one invariably began his anecdotes by telling the joke first and then relating the story, whereas the other told his tale in a capital way until he came to the point, and that he never could remember. The fat man sang a sentimental song about "My Mother, Oh, my Mother." His voice was not bad 
if he had only kept in one key, but his natural independence set all such trifles at defiance, and in his most extravagant wanderings he would look about with an expression of countenance which clearly admonished us not to give him any advice in thematter.

Of course I was expected to contribute my share of amusement, particularly as it leaked out that I was a young actor; in fact, I should have been offended if they had not pressed me. I sang a comic song about "The Good Old Days of Adam and Eve," the passengers liberally joining in the chorus. I followed this up with some bad imitations of Forrest and Booth. These seemed to give great satisfaction, the old lady exclaiming that the imitations were wonderful; but as it afterwards turned out that she had never seen the originals, her criticism must be received with some caution. The day rolled slowly away, and as the darkness came on a mountain storm of snow and driving wind enveloped us. As we ascended the mountain the cold became intense.

It was rather late in the night when we arrived at the supper station, as in consequence of the slippery state of the roads we were fully three hours behind time; but the cheerful look of the dining-room, with its huge blazing fire of logs, repaid us for all the suffering we had endured. We found that a large pile of bricks was being heated for us in front of the fireplace: these comforting articles were intended for our feet in the coach, and nothing, not even the supper, could have been more welcome. 
The horses changed and the passengers aboard, we were again ready for our journey - more perilous now than ever, for as we reached the summit of the mountain the storm increased in its fury. At times we thought the stage would blow over; the icy roads caused the horses to slip, and several times the leaders went down. It was a night to be remembered. A little after daylight we rolled into the town of Cumberland, the terminus of the stage line and the beginning of the railroad. Shivering and benumbed with cold, we alighted and sought the hotel for warmth and shelter. The driver of the coach was frozen stiff and had to be assisted down from the box. Another hour on the road would have been fatal to him.

Twenty-four hours of suffering and peril took us from Wheeling to Cumberland - a journey now made in six, with a comfortable bed to lie on and a warm sleeping-car for shelter.

A reunion with my brother was always delightful. We took the greatest pleasure in each other's society, and he seemed never tired of making any sacrifices for my advancement, and, while we were both acting at the Arch, would often persuade Mr. Burton to cast me for parts far beyond my reach.

At the end of the season Burke joined the Bowery Theater in New York, and I was installed in his place at the Arch. I was destined to meet in this theater one of my oldest and dearest friends, Tom Glessing. Dear Tom! as I write your name how my thoughts run back to the olden time - not that we were happier then in 
each other's friendship, for it is a great comfort to reflect that throughout the many years we knew each other our affection never weakened.

Tom was the scenic artist of the Arch Street Theater, and noted for great rapidity in the execution of his work. The same generous nature that prompted him to lavish all he had upon his friends rendered him equally prodigal in the use of paint; he wasted more than he used, and bespattered everything and everybody, himself included. Such was the generosity of his double-pound brush, that it scattered benevolence in all directions, and woe betide his dearest friend if ever he came within the circumference of its bounty! His was the loudest and the heartiest laugh I ever heard. Nor had he any control over it, and often during the quiet scene of some play that was in preparation his boisterous roar of merriment would burst forth from the paint-room and, echoing through the theater, upset the serious business of the play. At such times the stage-manager would have to assert his authority, and demand of Glessing that he should stop that "dreadful roar" in order that the rehearsal might go on. If he had a fault it was that he was a trifle mischievous, and his enjoyment of a practical joke, played on any one of his companions, was delightful to behold: when he tried to tell of it he would laugh so immoderately that one could never understand half he said. Fortunately, none of his pranks resulted seriously, except sometimes to himself; and when recounting some of the mishaps that had befallen him, in con- 
sequence of indulging too freely in his sport, he seemed to enjoy his own discomfiture quite as much as that of the other party. Practical jokers, like physicians, seldom take their own prescriptions with pleasure; but Tom was an exception, and would even delight in being the victim of the game.

I recall the first time we met in the paint-room : he was hard at work, splashing in a turbulent ocean with angry billows breaking upon the rocks. The storm was very severe, and the artist must have had a narrow escape, for he was so bespattered with spray that he seemed to have been battling with the breakers.

We were friends from the first moment. Sincere attachments usually begin at the beginning. He had but one sorrow - it was a domestic one-and he bore it nobly, never uttering a word against those who had caused his unhappiness. Years afterward he married again, and so happily that it repaid him for the trouble he had passed through in his youth. Gaiety became contagious in his presence, and cheerfulness followed in his wake. He dreaded to look upon the serious side of life, for his nature was so sympathetic that he suffered the pangs of others, and at the mere recital of human grief his eyes would fill with tears. He was fond of acting, and could n't act a bit, poor fellow! - but it was delicious to hear him recount his failures.

Mr. Burton had married Tom's sister, and he and Glessing traveled together through the South 
on one of the comedian's starring trips. In Natchez, Mississippi, the manager offered to give Tom a benefit if he could prevail upon Mr. Burton to play for him. This was arranged, and for two days he practiced the speech he intended to deliver in front of the curtain, as a tribute of gratitude to a generous public. He had written it out, and had sat up all the previous night to commit it to memory. It began, "Being totally unprepared for the honor you have done me." After rehearsal he walked out to the edge of the town, so that he could practice it in the open air, where he could elevate his voice without disturbing the citizens. On his way towards the woods he met a drunken Indian, who was staggering from side to side in the road, and flourishing an empty whisky-bottle at the white man in general and Glessing in particular. When any one is anxious to avoid a drunken man, by some strange fascination the intoxicated person invariably makes directly for him; you may look the other way, or pretend to be unconscious of his existence, but it 's of no use: he will introduce himself. The Indian was no exception; for though poor Tom, who was frightened to death, whistled a lively tune and looked up at the tops of the trees, the gentle savage would not be avoided.

"Hey! you white man, look me too. Me good Indian, good Indian. Yes, ah?" said the red man.

To which Tom assented at once, most emphatically: "Certainly, you are a splendid Injun; 
you 're as good-I may say you are the best Injun I ever saw."

"You think me drunk, eh?"

"Drunk!" said Tom. "No. Let me hear any one dare to say you 're drunk, and I 'll kill him. Give me that bottle and I 'll kill him with that."

"No; me am drunk," said the savage, glaring fiercely at Tom.

"You may be a little drunk, but not much just enough, eh?" said Tom, desirous of agreeing to anything under the circumstances. The Indian became sullen and moody, as if brooding on the wrongs that the white man had inflicted on his ancestors, when it suddenly occurred to Tom that the United States Government, when the Indians got troublesome, always softened their anger by the bestowal of costly presents; so, offering a dollar to the chief, Tom bade him return to his wigwam and take some whisky home to his squaw and papoose. The offering was accepted, and had the desired effect. After two or three affectionate embraces they parted, and Tom got away in the opposite direction.

Finding himself once more alone, and in a secluded spot, he began to go through his speech. $\mathrm{He}$ tried various methods, first the cheerful; stepping forward with bright, jaunty manner, he raised his voice in a high key: "Ladies and gentlemen, being totally unprepared for this honor." On second thought, it appeared to him that his manner was a little too free and undignified, so he now assumed the grave and thoughtful. Placing one 
hand in his breast, and pulling his hair over his eyes, to give him a poetic and dreamy air, he paced slowly forward, and in a solemn, deep voice began again: "Ladies and gentlemen, being totally unprepared"- Just at this point he raised his eyes and observed the astonished heads of two farmers peering over the rails of a worm fence. He immediately gathered up his hat and manuscripts and started for the town at a brisk pace; but remembering that the "good Injun" might be in ambush awaiting his return, he was forced to skirt the town for miles before he reached his hotel.

He would go on by the hour and tell such stories, and was always the most pleased when he was the hero of them and placed in some absurd position.

About this time I was haunted by a professional borrower. Just eighteen, and in the receipt of what was considered in those days a fair salary, I was a shining mark for his skill, though I was such easy game that I think he held me in slight contempt. But, for all this, he was crafty enough to impress me with the simplicity of his nature, and what a toy and plaything he had been for fortune's sport! He was a dreadfully bad actor on the stage, but a star of the first magnitude in private life; so much so that for many weeks he tortured and defrauded me with the ease and confidence of a master.

Conventional beggars are as conventional as any other professionals. That time-honored custom of assuming a nervous and uncertain manner, as if this was the first time they were placed in such a posi- 
tion, is a favorite attitude with them; while in reality they are cool and collected. My tormentor was an expert, and his costume quite a study for an amateur in the business. Although his ample shoes were full of gaping wounds, they shone with a high polish that any man might feel proud of ; and if his tall hat was a trifle weak, it had a gloomy, ruinedtower look that won him respect from strangers; and his clothes were of a shabby black, just " sicklied o'er with the pale cast" of time. Sometimes he would meet me with a sad, sweet smile, clasping my hand warmly, and regarding me as if I was the one ray of light that illumined his gloomy path. I believe he once said these very words; at all events he looked them, and at times I really thought I was. The first thing a sly old rascal like this does is to study the weak points of his victims; and he knew mine better than I did. He had a large supply of tears that he could turn on at will, and after getting under a full headway of grief he would revolve slowly and dry his eyes with his back to me. I used to imagine that he did this so that I might not observe him weep; but since then I have thought differently of it.

He knew perfectly well when salary day came, and would waylay me at the stage door. On these occasions he would assume a surprised and startled look, as if we had met quite by accident; and then he would exclaim, in a half-retrospective tone, "Dear me! dear me! it must be nearly a week since we last met." It was just a week, to the minute, and he knew it, the villain! At such times 
Tom Glessing would fairly revel in my discomfiture. If he saw that my tormentor had buttonholed me on the corner, he would delight in passing close to us with an "Ah, how are you? At it again, eh?" And on he would go, fairly holding his sides with laughter, while my "corkscrew," as Glessing used to call him, was drawing the dollar notes out of my pocket, one by one. The most provoking thing about the fellow was the air of patronage he assumed when negotiating a loan in our early transactions he used to make me feel that he was doing me an immense favor by levying these little drafts on my slender income. He would begin by saying that if it were not for the regard he had formerly felt for my father he would not demean himself by sinking so low. I put up with this for some time, not out of any charity, for I had gradually lost all respect or pity for him, but from a kind of fear. He had an overawing and at the same time despairing look that quite terrified me, and as lately he had hinted that the time was drawing near when he thought of trying his luck in the Delaware, I really feared he might commit suicide.

I can hardly describe what I suffered from the persecutions of this man, and it was nothing but a sense of shame at being the dupe of such a low fellow that determined me to break my bondage and turn from him. When he saw that I made a bold stand against him he became abusive ; finding that this did not have the desired effect he lapsed into the dismal, whining and mourning over his crushed feelings and lamenting his personal degra- 
dation. But I had discovered his cloven foot, and it was too late for him to attempt further imposture.

Such men are to be found in all grades of life, and they are usually adroit and cunning fellows, attacking their victims right and left, and using just the sort of weapons that are the most difficult to parry. They lie in ambush for the innocent traveler, and suddenly pounce upon him with a welltold tale, so got by rote, and so often rehearsed, that they act the part of injured innocence to the life. If the victim be timid he is lost, for they recognize his nervousness at once, and browbeat him out of his benevolence.

This vile weed - the borrower - grows and luxuriates in all the capitals of States and countries. The ever-changing soil of fresh visitation seems well adapted to nourish it. Sometimes women indulge in this practice, but not often; you are at least safer with them than with the men, particularly if they are old. A feeble old mendicant generally uses her collection for some purpose that gives her comfort at least. Coal, tea, and warm worsted stockings are necessary, and they must and should have them; but the man has many avenues through which he can filter your bountythe gaming-table, the bar-room, and worse.

If Mr. Burton was not at this time a fixed star, he was certainly a managerial planet of the first magnitude, and in this position was naturally surrounded by a number of small satellites that basked in the moonshine of his affection. These lesser 


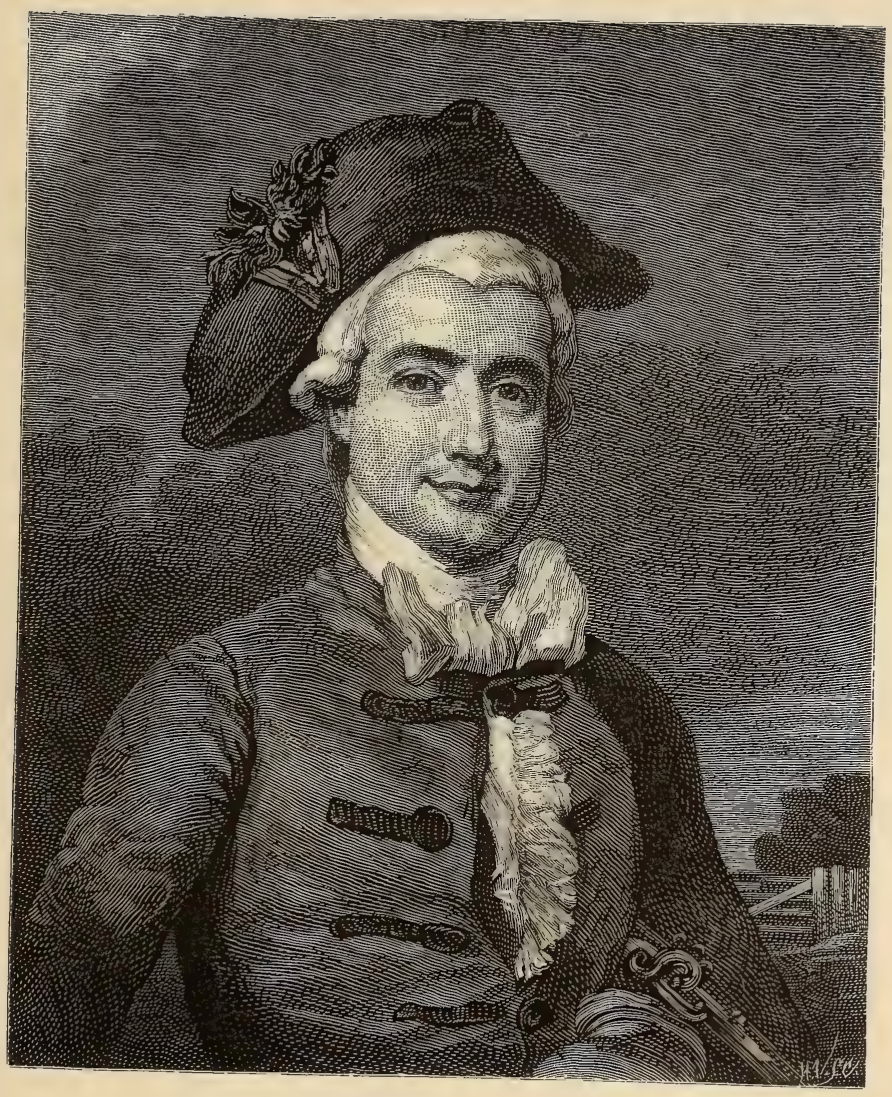

WILliAM E. BURTON AS "DOCTOR OLI.APOD." 

lights seemed to gyrate in eccentric orbits, generally going out of their way to carry tales to their superior.

Nothing is more distressing to the members of a stock company than to have spies set upon them who eavesdrop and report every little trifle to the manager. It is natural that the occupants of the dressing-room, and even of the greenroom, when the manager is not present, should now and then indulge in the harmless amusement of criticizing and even censuring the policy of the theater; it serves to pass away the time between long waits, and, like Doctor Ollapod's small dose of magnesia, does " neither harm nor good."

The tale-bearing element in Mr. Burton's theater was fully organized under the generalship of one of the most ingenious informers that I have ever met with. If I do not speak affectionately of this gentleman, it is because I was at that time smarting under the effects of one of his secretservice reports to the Star-chamber, to which apartment I had been summoned on a charge of "contemplated desertion." It seems that I had been incautiously bragging among my comrades in the dressing-room of a large offer I had received to leave the Arch and join Mr. Killmist at his theater in Washington, stating that I was shortly going to send in my resignation to Mr. Burton. I had also been abusing the management, both criticizing and condemning its shortsighted policy; and though there was no stated reward offered for the exposure of such offenses, the informer was anxious to get me out of the 
theater, looking for his compensation in being cast for some of the good parts that were already in my possession.

I was ushered into the manager's office by the call-boy, and stood there like a prisoner ready to be sentenced to the rack for daring to express my opinion of the "powers that be." Mr. Burton sat in state at the farther end of a long table, supported on each side by his stage-manager and the prompter; this august tribunal frowned on me with a most discharging countenance as I stood before it. The scene as I look back at it seems comical enough, but just at that time it was a serious matter for me, as my prospective engagement was not positively settled, and under the most favorable circumstances could not be entered upon short of two months, and a dismissal just at that time would have been financially inconvenient. The accusation of a "contemplated desertion" being made, I demanded the name of the informer. This being withheld, I declined to make any answer to the charge. Those who remember $\mathrm{Mr}$. Burton's face will recall its wonderfully comical expression, even when he was serious; but when he assumed a look of injured innocence the effect was irresistible. I did not dare laugh then, but I do enjoy it now when I think of it. The examination proceeded, and on the first question being again put I acknowledged the fact point-blank, stating also that being engaged for no stated length of time I intended to give the customary notice and to resign. 
The manager demanded to know on what grounds I presumed to take such a step without first consulting him. I told him that I had been offered double the salary I was then receiving. Upon his asking who made me worth "double the salary," I replied that I was quite willing to admit that he did, and proposed that he should give it to me. At this rather impertinent remark he waxed wroth, and said I was not worth it, and never would be worth it, but that I had been insubordinate and disloyal to him, and that he should take legal steps to prevent my appearing at any other theater if I left him.

There is no doubt that Mr. Burton thought that his denunciation and threats of an action would crush me, but he knew little of human nature, for I now went up at least one hundred per cent. in my own estimation. The very thought of being threatened with a lawsuit made me feel at least an inch taller. I, who up to the present time had thought myself of small consequence, threatened with an action for breach of contract! It was delightful; and I have no doubt that I drew myself up with much dignity as I informed him that he could pursue whatever course he pleased in the matterswaggering out of the room with the defiant air of a "heavy villain."

Of course quite a little knot of actors were waiting at the back door to hear the result of the trial and learn the verdict of the judge. When $I$ informed them with a lofty pride that I presumed the affair would end in a lawsuit, they were 
amazed. If they had never envied me before, they certainly did now. It was not a hanging matter, and the most serious result could not go beyond "damages for the plaintiff"; and what actor of my position in those days could ever have afforded to pay damages? We might have dreaded a long vacation in the summer, or quaked at the rebuke of a dramatic critic, but the law! So far as damages were concerned, we defied it! The case, however, never came to trial; for about a week after this the Washington theater was destroyed by fire, and I was only too glad to remain where I was without double the salary.

As an actor of the old broad farce-comedy Mr. Burton certainly had no equal in his day, and his dramatic pictures of the characters of Dickens would have amazed the author if he had been so fortunate as to see them. Captain Cuttle and Micawber were his greatest achievements; his face was a huge map on which was written every emotion that he felt; there was no mistaking the meaning of each expression. His entrance as $\operatorname{Van}$ Dunder, in the drama of "The Dutch Governor; or, 'T would puzzle a Conjuror," was a comic picture so full of genius that it stamped itself indelibly on the mind, an effect never to be forgotten. The great stupid face was a blank. The heavy cheeks hung down stolidly on each side of a half-opened mouth; the large, expressionless eyes seemed to look hopelessly for some gleam of intelligence. There he stood, the incarnation of pompous ignorance, with an open letter in his hand. The audi- 


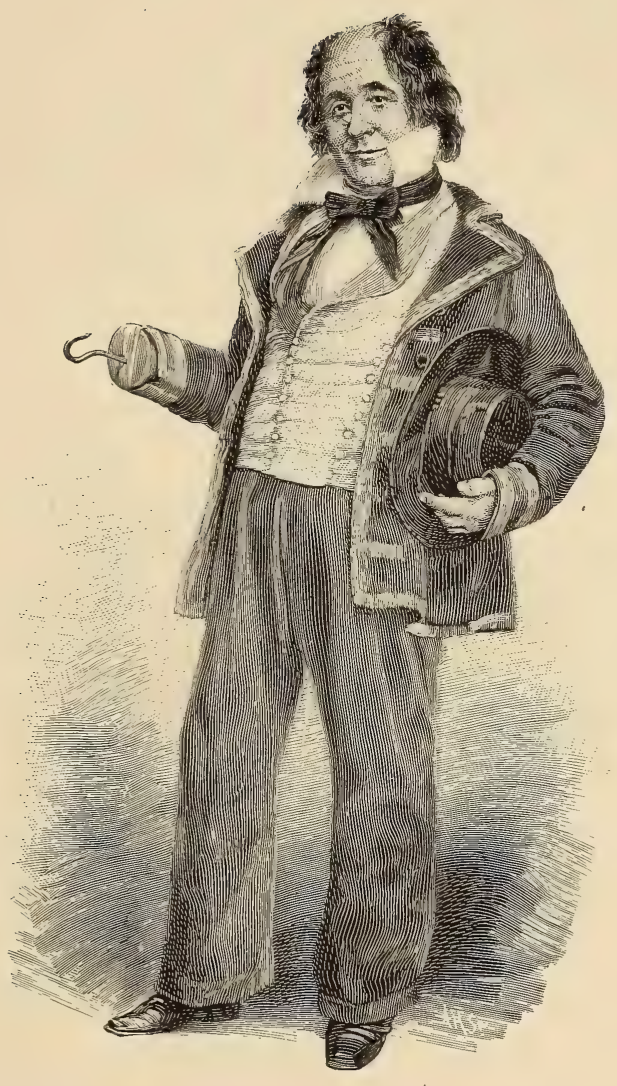

William E. BURTon as "CAptain CltTle." 

ence swayed with laughter; for, though he had not said a word, they knew that he had just received an important state document and could n't read it.

As a manager he achieved much success, but met with some disastrous failures, not seeming to understand the difference between competition and opposition. The first deals with our own affairs, and, if pursued with honesty and industry, invariably leads to good results. The latter meddles with the business of other people, and generally brings about the downfall of the opposer. Burton was always temperate, and very industrious; he had literary talent, too, as his contributions to "The Gentleman's Magazine" (which he edited) will attest. Edgar A. Poe was also a contributor to this periodical, but he and Burton were always at "daggers drawn"; they had a paper war for many months in Philadelphia, and splashed their angry ink at each other, much to the amusement of the public. Poe lost his temper, and Burton, seeing his advantage, fired off his humorous artillery, so that the comedian got the better of the poet. If people could only realize how little the public care for the private quarrels of individuals - except to laugh at them - they would hesitate before entering upon a newspaper controversy.

I have often thought that Mr. Burton must have had Irish blood in him, for he was continually spreading the tail of his coat for a fight - I mean an intellectual fight, as physically he was not pugnacious. Quarrelsome persons who do not indulge in pugilistic encounters are fond of lawsuits; it is 
only another way of having it out, and Burton must have spent a fortune in fees. His humor on the witness-stand was quite equal to that of Sam Weller. On one occasion, while the actor was going through bankruptcy, an eminent lawyer in Philadelphia thought he detected a desire on Burton's part to conceal some facts relative to a large sum of money that he had made during the production of the "Naiad Queen." Rising with great dignity, and glaring fiercely at Burton, he demanded, "What became of that money, sir ?" The comedian looked him straight in the face; then rising in imitation of an attorney, he replied, "The lawyers got it."

During the first season that I acted at the Arch great preparations were made for the production of a Greek tragedy, the "Antigone" of Sophocles. In a theater, as we have seen, there are apt to be two or three discordant spirits that criticize and condemn the course of the management, and I presume that most public institutions are honored by small private bands of conspirators; so that on being confronted by this ancient drama in the greenroom we naturally shrugged our shoulders and wondered what Mr. Burton meant by it. This same sublime tragedy of "Antigone" had been freely translated and acted in Dublin at the Theater Royal some forty years ago. The audience was quite bewildered by this performance, and at the close of the play called for the author ; whether to applaud or to chastise him does not appear. The manager came forward to apologize for the absence of Soph- 
ocles, but promised faithfully to produce him if ever he allowed one of his plays to be acted under his management again. Notwithstanding that this Greek tragedy had always failed to attract public attention, our manager determined to revive this previously unfortunate drama. It has been said that Mr. Burton was classically educated; naturally he felt justly proud of his scholastic attainments, and, having a desire to display them, he selected the Greek tragedy as just the thing for its accomplishment. Apart from his undoubted claim to erudition, he had that wonderful stage tact and executive ability that thoroughly qualified him for the management of a theater ; so that whether he had drunk deep at the "Pierian spring" or not, he certainly had quenched his thirst at the public fountains, and refreshed himself at all those little intellectual brooks that flow along the roadside of an actor's life. This kind of knowledge may be superficial, but it is most useful to an actor-manager.

But to return to "Antigone." During its rehearsals a marked change came over our manager. In arranging the lighter and more colloquial plays he was accustomed to be cheerful, and rather inclined to intersperse his directions with anecdote; but now he assumed a dignity strangely at variance with his usual manner, and we, the company, who had been in the habit of associating his comical figure with Paul Pry and Jem Baggs, could scarcely be expected at this short notice to receive this change of demeanor with the same solemnity with which it was given. Of course we did not dare 
exhibit our irreverent feelings, for there is no doubt that had Mr. Burton detected the slightest attempt to guy either him or his new venture an immediate discharge of the offending party would surely have followed. Tom Glessing, myself, and several minor members of the company had got hold of some Greek quotations, and would slyly salute one another in the classic tongue when we met at the theater in the morning, always, however, when the manager's back was turned; for if in his presence we had dared talk Greek we should certainly have walked Spanish.

I was cast for one of the unhappy Chorus,- I think there were four of us, - and when the curtain rose a more wretched looking quartet was never seen. I think the costume we wore was unfortunate, and added neither to our comfort nor to our personal appearance. We were crowned with four evergreen laurel wreaths, which sat unsteadily upon our heads, and were done up to the chin in white Grecian togas. Mr. and Mrs. James W. Wallack, Jr., were in the cast, and for their fine declamation and classic tableaux were much applauded; but when we as the Chorus attempted to explain what it all meant, the effect upon the audience was dreadful.

The failure of this sublime tragedy caused $\mathrm{Mr}$. Burton to be seriously out of pocket, as well as out of temper. He blamed first the public, then the unfortunate Chorus, and, finally, himself.

In domestic matters I had good opportunity of forming my judgment of Mr. Burton, as we were 
for some time quite intimate, and I often visited him at his house. The affection he lavished upon his children was almost feminine in its warmth and gentleness. He had three lovely little tyrants, who managed him quite as well as he managed his theater. They were extremely fond of their father, and he delighted to walk with his lovely daughters and show them off. I have often met the group strolling hand in hand in Franklin Square on a fine Sunday morning in the spring, the pretty little girls, tastefully dressed, tossing their heads and shaking their curls in childish vanity, with their portly parent looking proudly down upon them.

The Arch, during the time I was under Mr. Burton's management, had met with many of those vicissitudes that were so prevalent in theatrical ventures when the production of the "Glance at New York" struck the popular taste of that curious and uncertain element known as the "public." The "public" means in reality nobody; it is an elastic term; we are indeed prone to call every one the public but ourselves. We wonder that the public can support this or that trashy entertainment, forgetting that we have been to see it once, and perhaps twice. "Life in London," upon which the "Glance at New York" was founded, ran for two seasons in London, when both lords and ladies went in crowds to witness the vulgarities of low life; the knocking down of watchmen, the upsetting of an old woman's apple stall, and the dancing of Dusty Bob and African Sal occupied the attention and delighted the audience of seventy years ago. 
Years before, Monk Lewis's melodrama of "Castle Spectre," a ghostly and ghastly piece of business, drew crowds of people, to the exclusion of the works of Shakspere, Sheridan, and Goldsmith. Nondescript actors, of the ranting and fantastic school, were in demand, while the Kembles and a host of great comedians were playing to empty benches. Likewise, we find Colley Cibber complaining that in his day the legitimate drama had fallen so low in the estimation of the public that he and his company of fine comedians were put aside and made subservient to the Italian singers and French ballet dancers that then flooded England.

We must not always condemn the public of the present day for these curious characteristics which seem to have come to them by a legitimate inheritance. Besides, there may be a necessity for this seeming inconstancy, and it is quite possible that the mind requires now and then a change of diet as the stomach does; the palate being satiated with rich and delicate viands often craves a little coarser food, if only to assist digestion.

But to return to $\mathrm{Mr}$. Burton and his new venture. The great success of the "Glance at New York" caused him to look in that direction himself. A full treasury had excited his ambition, so he proceeded to New York and purchased Palmo's Opera House for the purpose of opening it as a comedy theater. He was an early riser, very industrious, and extremely temperate. These qualities, combined with energy and an inordinate ambition to lead, made him a formidable adver- 
sary for Mr. Mitchell, who was then in the very height of prosperity at the Olympic. This latter gentleman, like Mr. Burton, was a comedian and a manager of rare ability; he had surrounded himself with an excellent company of actors and actresses, who were so quaint and so well chosen that the dramatic treats given at the "Little Olympic" became the rage and talk of the town. Mr. Burton saw this, and his desire for a dramatic battle urged him to oppose Mitchell, and this he did with much force and judgment, bringing to bear the heaviest theatrical artillery that New York had ever seen. When I say that these great guns consisted of William Rufus Blake, Henry Placide, W. E. Burton, John Brougham, Lester Wallack, Oliver Raymond, Lysander Thompson, and Charles Burke, I think that those who remember these extraordinary actors will fully agree with the statement. I do not think that Lysander Thompson and Charles Burke were with the company at this time, but they joined it afterward. In the midst of this conflict between the managers Mr. Mitchell was stricken with paralysis; this rendered the contest still more unequal, and the "Little Olympic" surrendered.

To give some idea of the excellence with which Mr. Burton's plays were cast, I may mention that I saw Shakspere's comedy of "Twelfth Night" produced at his theater with Blake as Malvolio, Placide as the Fool, Burton as Sir Toby Belch, Lester Wallack as Sir Andrew Aguecheek, and Miss Weston as Viola. I do not believe that this 
play has been acted with greater skill since Shakspere wrote it, although there is no denying that, with regard to scenic effects, costumes, ingenious stage-management, and elaborate ornamentation, the Shaksperean productions of our own time far exceed those of the earlier revivals.

Burton's ambition to succeed in the various tasks he had set himself was strongly fortified by his quick apprehension and great versatility. He was at the same time managing the Arch Street Theater in Philadelphia, the Chambers Street Theater in New York, acting nightly, and studying new characters as fast as they came out. In addition to these professional duties, he was building a country residence at Glen Cove, writing stories for the magazines, and taking prizes at the horticultural shows for hot-house grapes and flowers. If his success and happiness were marred, it can only be attributed to his too great ambition; this trait led him to oppose everything that came within range, and at times he would even go out of his way to search for a new antagonist. In a fit of excitement, brought on by some domestic shock, he was suddenly stricken down, and never rose again. During his last hours he was lovingly attended by his daughters, who had grown up to womanhood, and I am told by one who was present that the parting with them touched the hearts of all who saw it.

It was a rare treat to see Burton and Burke in the same play: they acted into each other's hands with the most perfect skill; there was no striving to outdo each other. If the scene required that for 


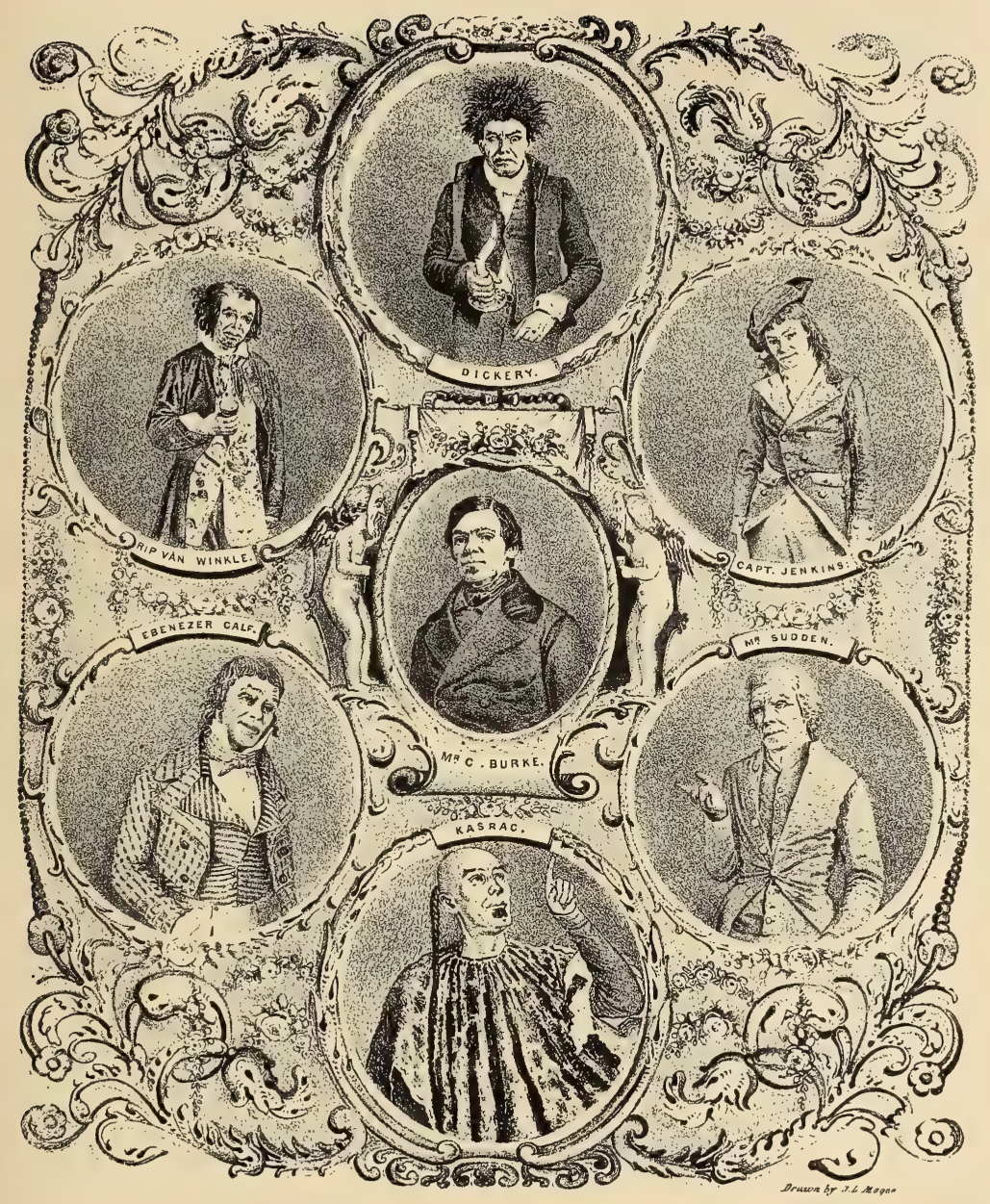

M" C. BURKE. AMERICAN COMEDIAN.

in Comedy, Drama, Farce \& Burlesque. 

a time one should be prominent, the other would become the background of the picture, and so strengthen the general effect; by this method they produced a perfectly harmonious work. For instance, Burke would remain in repose, attentively listening while Burton was delivering some humorous speech. This would naturally act as a spell upon the audience, who became by this treatment absorbed in what Burton was saying, and having got the full force of the effect, they would burst forth in laughter or applause ; then, by one accord, they became silent, intently listening to Burke's reply, which Burton was now strengthening by the same repose and attention. I have never seen this element in acting carried so far, or accomplished with such admirable results, not even upon the French stage, and I am convinced that the importance of it in reaching the best dramatic effects cannot be too highly estimated.

It was this characteristic feature of the acting of these two great artists that always set the audience wondering which was the better. The truth is there was no "better" about the matter. They were not horses running a race, but artists painting a picture; it was not in their minds which should win, but how they could, by their joint efforts, produce a perfect work. I profited very much by these early lessons.

Dying at the age of thirty-two, it is wonderful that Charles Burke left such an enduring reputation as an actor. I do not mean that his fame lives with the general public, but his professional brethren 
accorded to him the rarest histrionic genius. I have sometimes heard comparisons made between Burton and Burke, but they were so widely different in their natures and their artistic methods that no reasonable parallel could be drawn. Burton colored highly, and laid on the effects with a liberal brush, while Burke was subtle, incisive, and refined. Burton's features were strong and heavy, and his figure was portly and ungainly. Burke was lithe and graceful. His face was plain, but wonderfully expressive. The versatility of this rare actor was remarkable, his pathos being quite as striking a feature as his comedy. He had an eye and face that told their meaning before he spoke, a voice that seemed to come from the heart itself, penetrating, but melodious. He sang with great taste, and was a perfect musician. His dramatic effects sprung more from intuition than from study; and, as was said of Barton Booth, "the blind might have seen him in his voice, and the deaf have heard him in his visage."

Although only a half-brother, he seemed like a father to me, and there was a deep and strange affection between us. As I look back I can recall many social and professional sacrifices that he made for me, and my love for him was so great that if we were absent from each other for any length of time my heart would beat with delight at his approach. It is scarcely fair to intrude upon the reader one's domestic affections, but I am irresistibly impelled to write these words. And so they must stand. 


\section{CHAPTER V}

STOCK, STAR, AND STAGE MANAGEMENT

From Stock to Star - From Star to Stock - The Elder Booth as "Sir Giles Overreach"- The Southern Theatrical Circuit-A Wandering Star-The Balcony Scene-Julia DeanLegitimate Comedy-James E. MurdochHenry Placide - A Play an Animated Picture-Edwin Forrest

HERE is nothing a young actor enjoys more than itinerant theatricals. It is so grand to

1 break loose from a big tyrant manager in the city and become a small tyrant manager in the country. I was one of those juvenile theatrical anarchists who, after having stirred up a rebellion in the greenroom, would shout to my comrades, "Let 's all be equal, and I '1l be king!" I had annual attacks of this revolutionary fever, and having saved up all my salary during the regular winter season would lose it patriotically in the summer. It was on the eve of one of these excursions that I received my first telegram. It came in the form of a despatch from my partner, who 
was in Baltimore, I being in Cumberland. I could not believe it, but there it was; a reply to my letter of the day previous, which he could have received only an hour before the message was delivered to me. I called at the office to inquire if it were really so: yes, there could be no doubt about it. A small group of people had collected about the operator, some having received messages of congratulation at the establishment of the line, others sending messages away to the same effect, and all wearing a look of surprise and incredulity. We began showing one another our despatches, and, looking with respectful awe at the mysterious little machine that was ticking away as if worked by some invisible spirit of the other world, wondered what they would do next. The whole town was greatly excited about it. People were running to and fro with little messages in their hands, and stopping one another in the street to talk and wonder over the new event. If I were now to receive a message from the planet Mars offering me a star engagement, I could not be more astonished than I was on that day.

It is said that the man who invented spectacles was imprisoned for daring to improve on the eyesight that God had given us; and that these comforts of old age were called the "Devil's eyes." So, in the height of this telegraphic novelty, did many wise old Solons shake their solemn heads, declaring that the wrath of God would fall on those who dared to take a liberty with lightning. The people with universal consent made the occa- 
sion a holiday, and as this was our opening, in the evening the hall was full.

We should have considered it a good house if the receipts had reached forty dollars; but when I made up the account I found myself in possession of more than a hundred dollars, all in silver. Loaded down with this weighty fortune I started after the play for the hotel, being supported on each side by the walking gentleman and the property man, utilizing them as a body-guard lest I should be waylaid and robbed. In this flush of fortune, and as a requital for their valuable services, I stood treat to my escort and dismissed them for the night. My room was in the third story, so there was no fear of burglars from without; but as I fancied that every robber in town must by this time be in full possession of all the information concerning my acquisition, I ascended the stairs with a solitary tallow candle and a nervous step. The long, dark entry seemed so very favorable for an attack that at each landing I imagined that I should be stabbed in the back. I thought it therefore just as well to hum a tune in a careless way, as though I was quite used to this sort of thing, and thoroughly prepared for any emergency. Sauntering slowly along to the tune of "My Pretty Jane," I reached the door of my room, which I entered as quickly as possible, locking it at once. The next thing was to dispose of my treasure, which I did by placing it between the mattresses of the bed. I spread it all out so as to make it look like a good deal when my partner 
arrived. One always takes delight in showing his partner how well things have gone during his absence; it is so delightful to make him feel that he is not of half so much importance as he thinks he is. Having placed the chair under the knob of the door, I could see no chance for a successful burglary unless the operator came down the chimney. I confess this rather worried me, as I felt that in the event of his making a descent upon me by the flue I could not possibly keep him out with the blower. I went to bed with the idea that I should be found murdered in the morning, and dropped off to sleep dreaming of Jack Sheppard.

At daylight I was startled by a loud knock at the door. "Who 's there?" I said, still somewhat alarmed. "Sefton," said the voice of my partner. "Are you sure?" said I. "Of course I am," he replied. I opened the door and admitted him. "How was the house?" was the first question. I made no reply, but turned down the mattress and displayed the full receipts to his astonished gaze.

Now our managerial labors began in earnest. The town did not contain more than five hundred playgoers, so that we were obliged to change the performance nearly every night. After the play we would go out and, taking our property man with us as an assistant, put up our own bills. This we continued to do until at last our financial condition enabled us to afford the luxury of a billposter.

No one who has not passed through the actual experience of country management, combined with 
acting, can imagine the really hard work and anxiety of it-daily rehearsals, constant change of performance, and the continual study of new parts; but, for all this, there was a fascination about the life so powerful that I have known but few that have ever abandoned it for any other. It had a roving, joyous, gipsy kind of attraction in it that was irresistible. Who would not rather play a good part to a bad house than a bad part to a good house? - ay, even if he were the manager! Then just think of the eagerly looked-for criticism in the morning papers, of no consequence to the world at large, but of much importance to the actor: how anxious I used to be in the morning to see what the critic said, quickly scanning the article and skipping over the praise of the other actors, so as to get to what they said about me. Then after breakfast, sauntering down to the drug-store where the reserved seats were for sale : not to look at the diagram to see how the seats were selling - certainly not, that would appear undignified; but just to inquire if there were any letters. These were the delights that always sweetened the poverty that went hand in hand with country acting. In the present instance we were in possession of a gold mine. We had captured the town, having been the first to attack it.

It is seldom that partners in theatrical management agree. Wood and Warren, of Philadelphia, were never on very friendly terms, and Ludlow and Smith were in partnership for many years without exchanging a word except on business. 
How they managed it, or rather mismanaged it, I can't tell. Sefton and I were but human beings, and this sudden success had the same demoralizing effect on my partner and myself. He was obstinate, and so was I.

Dogberry says, "An two men ride of a horse, one must ride behind." Now as neither of us would consent to take this undignified seat, I sold Sefton my share of the animal and retired; he vaulted into the vacant saddle and rode his charger to death. About three months afterward I received a letter from him - business had been bad, and he was in great distress - urging me to play a week with him. I did so, partly to help my old partner, and partly to see my name in large letters. This was the first time I had ever enjoyed that felicity, and it had a most soothing influence upon me. My hotel was just opposite the hall, and when I arose in the morning and looked across the street I gazed delightedly upon my name in bold "Roman caps.," though I was much annoyed at seeing the citizens pass by this important announcement without taking any notice of it; and the conduct of two strangers who met precisely in front of the theater and began an earnest conversation, without deigning to bestow a glance at the bill-board, was positively insulting.

I had to contend on my opening night with a local favorite in the shape of a rival comedian. This was no easy matter, for not only was he a clever actor, but a feeling had been engendered among his many friends that I had entered into 
a dark conspiracy with the manager to dethrone him. I had acted here the season before, and was something of a favorite, so my reception was very cordial; but as soon as it ceased I was greeted with a storm of hisses. This sudden and unlookedfor demonstration took the audience and me by surprise, and of course checked the progress of the play. In the midst of this confusion my rival was loudly called for by his friends, at which the curtains of a private box were violently shaken, then jerked apart, and in the opening appeared the form of my rival. He stepped unsteadily upon the stage; one side of his trousers had crawled up his leg, revealing an untied shoe, the brim of his hat was slightly bent, and he swayed from side to side with folded arms and disheveled hair. There was a mingled air of defiance and melancholy in his looks, plainly showing that he was not only persecuted but intoxicated. The wild encouragements from his friends clearly proved that they were in the same condition, indicating that the entire party had partaken freely of "Dutch courage" in order to stimulate them for the fray. After a maudlin speech, which first amused and then bored the audience, he was led from the stage and the play proceeded.

Actors in sickness or distress are proverbially kind to one another, but little professional misunderstandings will take place now and then. Some overzealous defenders of our art have asserted, I think erroneously, that no true artist is jealous of another. This is going a little too far, 
and giving us credit for more virtue than we possess. Jealousy is unfortunately an inborn quality, entirely independent of art. If a man has this unfortunate passion he feels it whether he is a true artist or not. In this instance my rival was a good actor, but not too good to be jealous of me, and if our positions had been reversed the chances are that I would have been jealous of him.

It was during this, my first star engagement, that I received a telegram announcing the sad intelligence of my mother's death. I started at once for Philadelphia, but by some accident was detained on the road for two days, arriving too late to look upon her face. My brother, my sister, and I passed a week together after the burial of my mother, and then separated, they returning to New York, whence they had been summoned, and I remaining in the city to look after an engagement.

On the corner of Ninth and Chestnut streets stood the Amphitheater. At this establishment in the winter season the circus used to amalgamate with a dramatic company and make a joint appearance in equestrian spectacles, which were produced under the stage management of Mr. Joseph Foster. This gentleman had studied in the best school of the highly colored melodrama-Astley's, on the Surrey side of London. He came to America as property man with Cook's company somewhere about 1836 ; in this position he continued for some years, ultimately joining the Amphitheater in Philadelphia. His industry, backed up by long experi- 


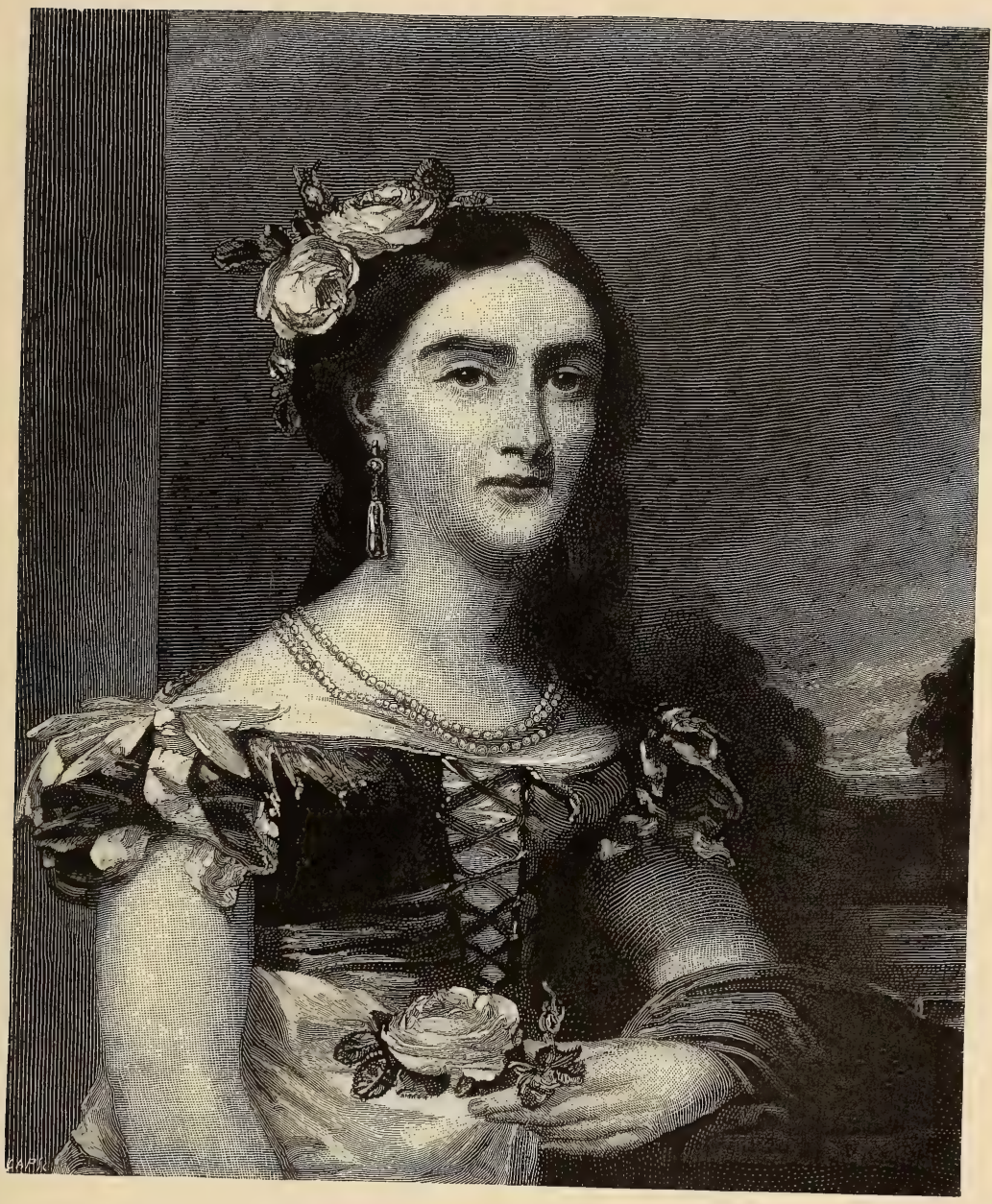

CORNELIA JEFFERSON (MOTHER OF JOSEPH JEFFERSON). 

ence, made him so valuable that he soon became stage-manager, and was holding this position when I called on him to apply for a situation as comedian. He had been prepared for the visit, having heard something to my advantage as an actor, but he was undoubtedly disappointed with me at first sight. As I entered the managerial sanctum, he lowered his bushy eyebrows and scowled at me with anything but an engaging expression of face.

" Humph!" was all I could catch of his first greeting. Then, after a slight pause, he said, "Oh, you are the new young comedian, eh?"

"Yes, sir," I replied. "There is no doubt about my being young; but how much of a comedian I am remains to be seen."

"Humph! quite modest too. Modesty is a good thing if it is not carried too far," he said. "Humph! where have you been acting lately?"

I told him that I had just finished a starring engagement in Cumberland.

"Starring, oh! Then you are not so modest after all," he replied. "I suppose you have heard that my present comedian is a failure?"

I told him that the welcome news had reached me, and as I had also been informed that in consequence of this the gentleman was about to retire from the Amphitheater, I made bold to apply for the vacancy.

"Well," said Mr. Foster, "my funny man is certainly the most dismal piece of humanity I have ever met with. I engaged him on his face. I never saw 
such a comical outside belonging to such a serious inside. The man's 'mug' is as funny as Liston'swhom he resembles, too, very much; large, round eyes, fat chops, and a turned-up nose. I thought when I first saw him that, like the milkmaid, his face was his fortune; but no, as soon as he opens his mouth all the humor seems to vanish. But now about yourself. I suppose you know that our plays, such as 'Mazeppa,' 'Dick Turpin,' 'Timour the Tartar,' 'The Terror of the Road,' are not celebrated for good low comedy parts; the actor has a great deal of hard work to do. It is what I call physical comedy; and you are too light for that kind of business, I fancy."

I told him that I regretted this, for if he engaged me by the pound, my salary would perhaps be as light as myself.

"But you do not look like a comedian," said he to me. "You have a serious, melancholy expression; you look more like an undertaker."

This last remark was rather crushing, so I endeavored to put on a jovial, quizzical expression, and failed. In a short time we arranged terms - twenty dollars a week, with a third-clear benefit. The engagement being settled, he gave me a part to study for the next play. I acted all this season at the Amphitheater, and a curious experience it was. The low comedian of a melodramatic theater is generally used as a stop-gap, and his artistic efforts are confined to going on in "front scenes" and amusing the audience, if he can, by speaking some long, dry speech, sup- 
posed to be full of humor, while the carpenters are hammering away behind and noisily arranging an elaborate set. Under these conditions it is very difficult to gain the confidence of an audience, or to distract their attention away from the painful fact that there is a hitch in the scenery. They seem to know that something has gone wrong, and decline to be consoled by a feeble comic song.

Upon the initial performance of the nautical drama of "Captain Kidd," Mr. Foster had given me a long, dismal ditty to sing, in order that I might divert the audience in case of an accident. It was privately understood between us that as soon as the scene was ready he would wave his hat at me from the wing as a sign that everything was right; then I was to finish my song and make my exit. The much-dreaded accident occurred, and I was deputed to go on and distract the audience, which I certainly did. The lines of the song ran thus:

My name is Captain Kidd, As I sailed, as I sailed, And wickedly I did, as I sailed, etc.

There were just twenty-five of these stanzas, equally humorous and grammatical. The audience bore them patiently for the first time, but when I looked towards the wing for a comforting wave of Foster's hat, to my horror he was not there; so I began again. It is said that republics will endure tyranny with more fortitude than empires, but it is possible that I had gone too far 
even for the forbearance of our free institutions, for many voices in the audience cried out: "No more! We can't stand that again." Other remarks were made too numerous and uncomplimentary to mention. I still tried to get a hearing "as I sailed"; but, with the hammering behind the scenes and the hooting in front, my efforts failed to make any impression, so I retired amidst the confusion.

Of all theatrical entertainments, the equestrian drama is perhaps the most absurd. The actor and the horse refuse to unite; there is nothing of the centaur about them. I have seen the tyrant Timour the Tartar stride about the stage tempestuously, inspiring the audience with the idea that nothing could daunt the imperious spirit within him, but as soon as he espied the prancing steed that was to bear him to victory his passion cooled, and with a lamb-like submission he would allow himself to be boosted up into the saddle, where he would sit unsteadily, looking the picture of misery.

Foster was a short, stout man, but extremely active, and as alert as a lynx. Nothing escaped his quick eye. If the house was crowded and the drama going well, he was the personification of good-nature. At such times he would stand with his legs wide apart, his hands clasped behind him, his face beaming with smiles, and his eyes fairly glistening with delight; but if the slightest hitch took place in the performance, he knew it in an instant. He would then jump as if he were 
shot, rush to the wing, shake his fist at the delinquent, and taking his high, black-silk hat off his head would trample it under his feet in frenzy.

The grand spectacular drama of "Mazeppa" was announced for the Easter holidays, and was produced with great splendor. Charles Foster, a son of the manager, was cast for the hero. He was a handsome, dashing young fellow, possessed of considerable dramatic talent, and, added to this, was one of the finest riders I have ever seen : his graceful figure and youthful appearance fitted him perfectly for the romantic lover of the Princess. The announcement that this drama was to be produced caused a slight commotion in the theater, for there was attached to the company an old melodramatic actor by the name of Cartlidge; he had been a leading man of Astley's Amphitheater in London during the days of the famous Ducrow, and was now seventy years of age. I met him at the greenroom door just as he came in to look at the cast. "I hear they are going to play " $\mathrm{Ma}$ zeppa," he said, with some agitation. "Is this true?" "Yes," I said; "there is the cast." He went over to the cast-case and looked at it in mute bewilderment, and then, as if he could not believe his eyes, took out his spectacles, wiped the glasses, put them on, and stood for a long time gazing in blank amazement at the cast. As he turned around I saw tears in his eyes. He walked slowly out of the greenroom, and, going into a dark corner of the stage, sat down despondently. I knew pretty 
well what was the matter with him, so I thought I would go up and comfort the old man, for he was usually cheerful, and it was sad to see him so dejected.

I sat down beside him and asked him what was the matter. He took out a large handkerchief, and, burying his face in it, began to sob. After he had recovered himself he said, "Foster has cast me for the Khan." Then turning on me with his eyes full of tears and a retrospective look in his face, he continued: "Young man, I was the original Mazeppa fifty years ago, and now I am cast for Mazeppa's father. Why should I not play Mazeppa still? I may be a little too old for it, but - " Here he broke down again, and as he sat there with his eyes and his spectacles both full of tears he looked more like Mazeppa's grandfather than like Mazeppa. The fact is, if he had been cast for the part he would have realized that the time had gone by for him to look or act it, and he would have declined: the self-inflicted blow would have fallen lightly on him; but to receive the stroke from another hand was more than he could bear. It made him feel that he had outlived his usefulness, and brought before his mind the glowing days of his youth when he had been the idol of Astley's. The painful truth that he was getting old and was no longer wanted came suddenly upon him.

It is natural that the world should smile at the old and senile as they are pushed aside, but no deposed emperor feels the force of compulsory 
abdication more than the stage king who has outlived the liking of the people.

"St. George and the Dragon" was the grand final production of the season. I was not in the play, so I saw the first performance from the front of the theater. The opening act ends where the seven champions of Christendom assemble to have a conference, pledging themselves to stand by one another in any emergency. The glittering armor of the knights, and the prancing of the fiery steeds as the grooms led them on, stirred the audience to enthusiasm.

Young Foster was a picture as the gallant St. George of England. His manly form was encased in a rather vulnerable armor of pure spangles, and he shone like a sheet of silver. At a given cue he vaults into the saddle, and waving his bright sword and throwing back his fine, classic head, he shouts, "Up, knights, and away!" Now St. Denis of France, St. Patrick of Ireland, St. David of Wales, St. Andrew of Scotland, and one or two other knights mount their chargers and gallop away, following their leader, the gallant St. George, as the curtain falls upon the animated scene. It so happened that St. Denis of France and St. Andrew of Scotland had been cast to two actors who were not what would be called daring horsemen. All of the knights with the exception of these two mounted their horses and galloped off in the interest of Christendom with unmistakable ardor. But the steeds of St. Denis and St. Andrew had but little faith in their knights, and the knights seemed to have no 
faith in themselves. This timidity communicated itself from one to the other, and as the riders hopped about on one leg trying to mount, the horses kept going slowly round to avoid any further intimacy. The audience was roaring with laughter, and I knew by this time that Foster was standing on his hat, if not on his head. At last the knights made a powerful effort to "bestride their foaming steeds." St. Denis, being very tall, scrambled up, but overshot the mark. "He o'erleaped his saddle," so that his head hung on one side and his heels on the other, while the horse kept going round with him in this dreadful position. At this juncture the curtain came down, cutting off the other knight, St. Andrew, and shutting him outside of it and close to the footlights. Unfortunately in the excitement of mounting this gentleman had got the wrong foot in the stirrup, so that the gallant Scotchman found himself in pursuit of glory with his face towards the horse's tail. Finding that he would make but little progress towards Christendom in this position, he slid gently off behind, still clinging to the bridle, while the horse dragged the unlucky warrior across the front of the stage. The audience shouted as the animal pulled his rider along. The horse now changed his tactics, and standing upon his hind legs came slowly but surely towards St. Andrew, who scrambled for protection into the nearest private box. The horse, still on his hind legs, looked down on the orchestra as if meditating a descent upon the musicians, at which the 
entire band fled "for safety and for succor," some of them retreating under the stage, while the majority scattered among the audience. The curtain had to be raised and a groom sent on to take the poor frenzied animal in. There was now some anxiety to know what had become of St. Andrew. That gallant Highlander, seeing that the coast was clear, jumped out of the private box where he had been concealed behind the curtains, and, half denuded of his armor, rushed frantically across the stage and darted behind the curtain amid the unqualified approbation of the audience.

I was not twenty-one at this time, but being an old young man, and looking upon life perhaps more seriously than one should at my age, I bethought me that it was time to marry and settle down in life. My brother strongly objected to this; he believed that I was too young, and I believed that he was jealous. The first serious words we ever had were in relation to my prospective marriage, he insisting that my wife and I had not known each other long enough to form any estimate as to the strength of our attachment; but I was obstinate, and the wedding came off.

I wished this marriage to take place privately, well knowing that otherwise my friends of the company, from the leading man down, would be at the wedding in full force, not so much out of compliment, perhaps, as for the purpose of indulging in that passion for quizzing which seems to be so deeply planted in the histrionic breast. My 
betrothed desired that the ceremony should be solemnized in church, fearing that ill luck would follow if it came off at any other place. I consented to this. Now I hate to be quizzed, and I think most people do; particularly those who indulge in the habit of quizzing others. Revolving in my mind, therefore, the best method of avoiding ridicule, I boldly told the company that I was to be married at church the following Sunday, after the morning service, and, well knowing that they were coming, invited them to witness the ceremony.

The important day arrived. My new lavender suit fitted me to perfection; none of your readymade affairs, but got up by a first-class Chatham street tailor, and embodying in its value the savings of two months' salary. With a beating heart, and, if I remember rightly, a pair of tight boots, I led my young bride to the altar. The wedding took place at the old church in Oliver street; Barney Williams and my sister acted as groomsman and bridesmaid. After the ceremony was over, Mr. and Mrs. Williams expressed their surprise at the extreme privacy of the whole affair. Williams hinted that he had understood that the whole company would be present in full force. "So they would have been, Barney," said I, "but I have sent them to the wrong church."

I was at the time of my marriage acting at the Chatham Theater in New York. By my brother's influence I was put forward more rapidly than my merits deserved; at least, I think so now, though 


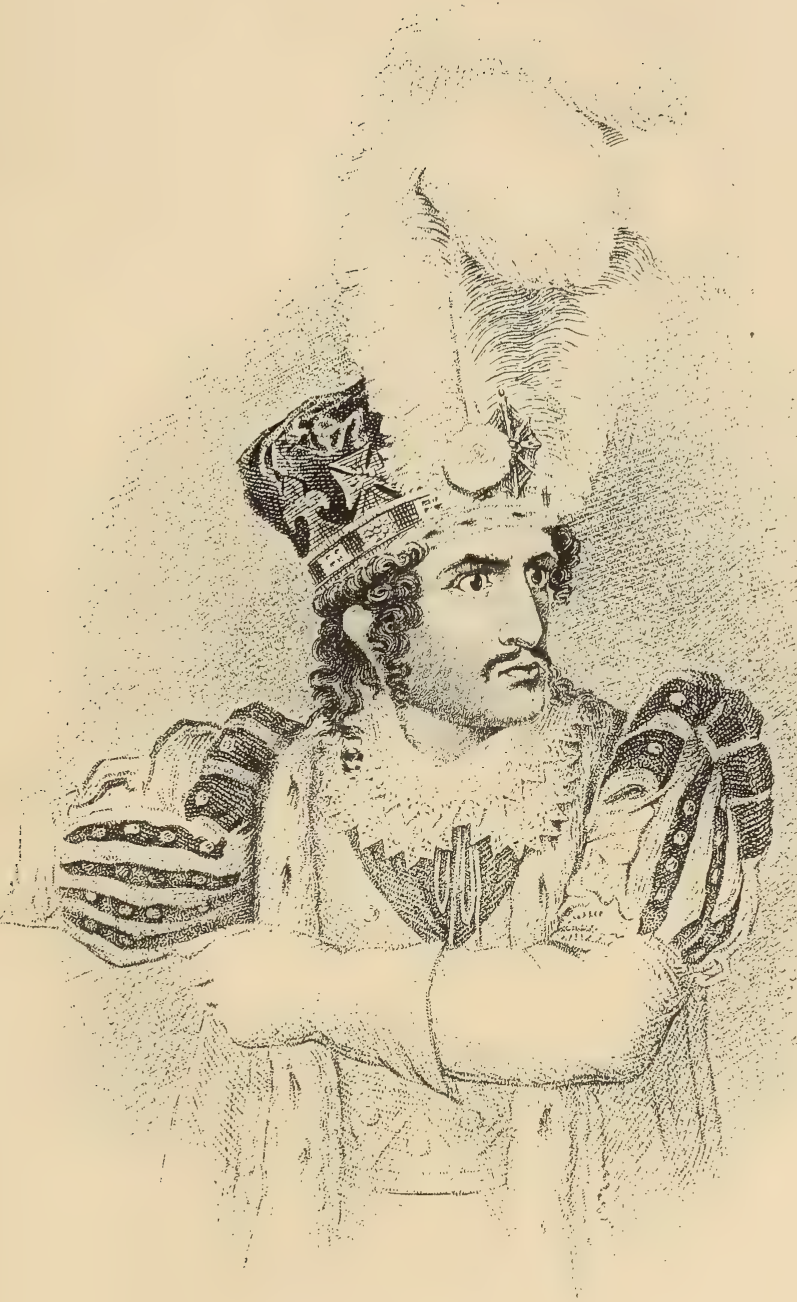

JUNIUS BRUTUS BOOTH AS "RICHARD THE THIRD." 

at that time I was quite confident that my ability was fully equal to the demands made upon it.

When but twenty-two years of age I was cast for Marrall in "A New Way to Pay Old Debts," the elder Booth playing Sir Giles Overreach. There can be no doubt about the fact that I was entirely unfit for so important a part; it is a very difficult one, and to give it effect requires that an actor should be in his prime, both as to his age and his talent. A mere boy, with but little physical or dramatic strength, coming upon the stage to rehearse so important a character, must have been rather a shock, and somewhat of a disappointment, to the great actor whom he was to support. But Mr. Booth wisely made the best of a bad bargain, and, instead of annihilating me with a look, took much pains to teach me the business of the part. Surely this was better than disapproval or petulance; for as it was I acquitted myself respectably, whereas it is most likely that I should have done the reverse had I met with discouraging treatment.

The elder Booth's acting of Sir Giles was indeed something to be remembered. During the last scene he beats Marrall, who hides for protection behind Lord Lovell. Booth's face, when he found he could not reach his victim, had the look of an uncaged tiger. His eyes flashed and seemed to snap with fire; his nostrils dilated; his cheeks appeared to quiver; his half-opened mouth, with its thin lips pressed tightly against the white teeth, made a picture of anger fearful to look upon. At 
the point where he is about to draw his sword his arm shakes, his right hand refuses to do its office, and, stricken with paralysis, he stands the embodiment of despair; then come his terrible words of anguish and self-reproach :

Some undone widow sits upon mine arm,

my sword,

Glued to my scabbard, with wronged orphans' tears.

His whole frame, shaken with convulsions, seems to collapse, his head sinks upon his breast, his jaw drops, and the cruel man is dead. There was no applause the night I speak of; the acting was so intense and so natural that the mimic scene seemed really to have happened.

Mr. Barton Hill related to me an incident that occurred during Mr. Booth's performance of this same part of Sir Giles Overreach. Mr. Hill was acting Lord Lovell, and in the scene where the crafty Sir Giles is endeavoring to court the favor of his lordship a large, white ostrich feather, which formed one of the plumes in Lovell's hat, became by some accident detached, and fell in the center of the stage. A conspicuous object like this, had it been allowed to remain where it fell, would have marred the effect of the scene. Booth, seeing the mishap, came quickly forward, and, raising the feather from the floor, presented it with becoming humility to its owner. This admirable point not only removed the obstacle, but heightened the effect of the situation. Here was a display not merely of presence of mind, but of good taste. It 
is quite likely that the audience thought it a part of the play, and a good part of it too.

After two seasons of metropolitan stock acting, a restless desire for country management again seized me. These attacks seemed to have been periodical, resolving themselves into a sort of dramatic ague, breaking out at regular intervals. The fit at this time having laid violent hands upon me, I entered into partnership with Mr. John Ellsler, whose veins became infused with the virus of my managerial enthusiasm. The inoculation must have taken admirably too, for he has been in management ever since.

I have seldom had an attack of the old complaint. In fact, I may add that the symptoms have entirely disappeared, and in the present enjoyment of my convalescence I do not see any likelihood of a relapse. I do not mean by these remarks to disparage theatrical management; on the contrary, I look upon the manager of a stock theater, containing a stock company, as a hero and a public benefactor. To be successful, he must combine force of character and self-control with artistic taste and executive talent. He stands between the public and the actor, the actor and the author; he must judge them all, and unite them harmoniously. To contemplate the amount of skill and industry that is lavished on the splendid dramatic productions of to-day is appalling to a man who wishes to enjoy a good night's rest. If you have a passion for the dog, the rod, the gun, the yacht, or the country, don't think of en- 
tering into theatrical management. The eye of the master is absolutely imperative in the conduct of a theater, and only those succeed who give it their undivided attention.

But to return to the managerial partnership between Mr. Ellsler and myself. The relations between us were very pleasant, for as our lines of business were quite distinct, there was no professional jealousy. Besides this, our duties in the management differed widely; consequently we never clashed. He had full control of the front of the house, while I managed behind the curtain, and I think we enjoyed the fullest confidence in each other.

Our season in Macon was quite good, but in Savannah our fortunes had a reverse. From some unknown cause the business here was very bad. I say "from some unknown cause," for it is characteristic of the members of the theatrical profession to attribute their failures to anything or everything else but themselves. It is so disheartening to feel that we are responsible for the disaster. In mercantile affairs, if losses are incurred, the loser can console himself with the fact that it is the merchandise that is worthless; if an artist's picture be refused admittance to the gallery, it is his work that is disregarded; but if an actor fails, it is himself who is neglected. The mortification of a personal and public slight is so hard to bear that he casts about for any excuse rather than lay the blame upon himself. This is unfortunate, for if we only had the courage to acknowledge that the fault lies 


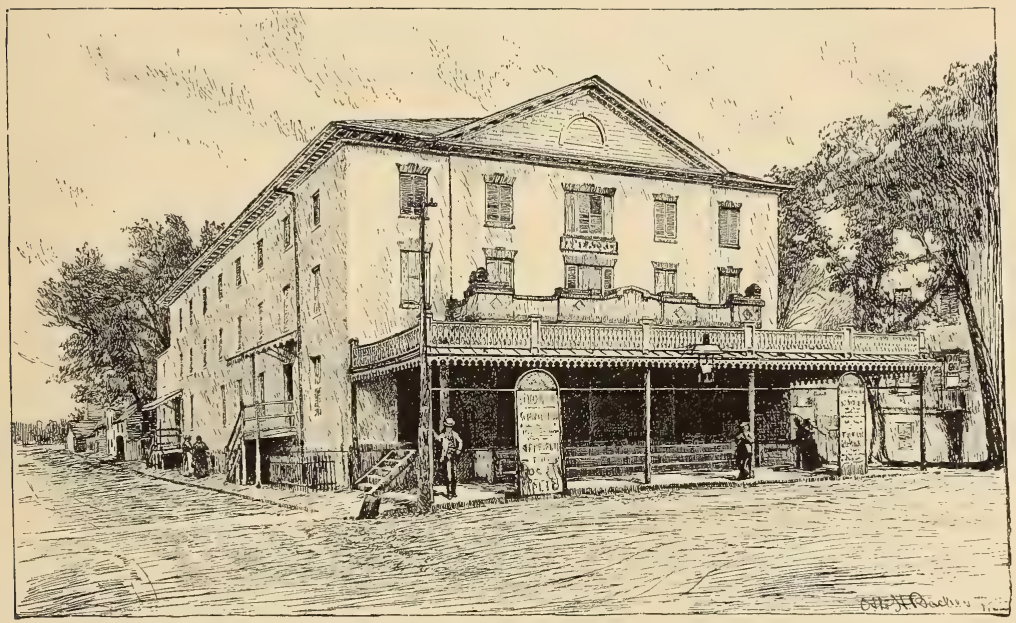

THE SAVANNAH THEATER PREVIOUS TO $\mathbf{1 8 8 4}$. 

within ourselves, we could more speedily set it right; but to go groping on in the dark, with the blind consolation that others are to blame, only retards our advancement.

As I had been married a year, and our first child had just been born, I was naturally beginning to feel the weight of a new responsibility.

It has always been my habit, when anything important is to be thought over, to get off alone somewhere in the woods, or to lock myself up in a room, where I can turn the matter over quietly. I had left the theater after rehearsal and was walking along in search of some solitary place where I could ruminate.

Savannah is a lovely city at all times, but in April it is like fairy-land. The beautiful Southern houses of semi-tropical architecture are surrounded with live-oak and magnolia shade-trees, and the gardens are laden with flowers. The city was peaceful and quiet - too much so for a manager in distress. The air was redolent of orange-blossoms and bad business. I was looking down one of the long, solitary avenues of trees for which this city is famous, when in the distance I espied the tall figure of a man walking leisurely towards me. His height was so enormous that I thought some optical illusion caused by the long vista through which I was looking had elongated the gentleman beyond his natural proportions. No; as he came nearer he seemed to get taller and taller; he was at least six feet six inches in height. He sauntered leisurely along with an elegant carriage and an aristo- 
cratic bearing, not assumed, but perfectly natural. I had never seen this man until now, but I imagined that I knew who he was, for if I was not mistaken in his height and appearance I had already heard of him. As we approached nearer, his ease and confident manner were almost impertinent. He had one hand in his pocket, and with the other slowly twirled a long, gold-headed cane. As we met, there was on his handsome face a self-sufficient smile, and he turned his large eyes from one side of the street to the other, with the air of a man who owned half of Savannah, and was contemplating the possibility of getting a mortgage on it with the ultimate view of purchasing the rest of the city. After we had passed I turned to look back, and found that he had done the same. We were both caught dead : there was no disguising it, so we approached each other.

" Pardon me, sir," said I, “ if I am mistaken, but are you not Sir William Don?"

"Quite right, old chap. How are you?" he replied. We shook hands and there was a pause. He looked at me with a quizzical twinkle in his eye, and said: "Well, which is it - Jefferson or Ellsler? You can't be both, you know."

I laughed heartily at this; not so much at what he said, which was commonplace enough, but at the way in which he said it. I thought to myself, "This must be a great comedian." He saw he had made a hit, and laughed in the enjoyment of it. "My name is Jefferson," said I. "Mr. Ellsler is my partner." 
"Well, Jeff, old fellow" (as if he had known me all his life), "I 'll be frank with you. Here I am, a star in search of a manager."

"Well," I said, "I will be equally frank with you. I am a manager in search of a star."

"Capital!" said he. "Will I do?"

"Will you do? You are the very man," I replied.

"Hurrah! We will play 'Box and Cox' together." Then throwing his arms around me, he quoted from the farce, " "You are my long-lost brother!'”

"Sit down," said I, as we came to a bench, "and we will talk terms."

"What are you going to offer me? Don't be modest - put it high. "Lay on, Macduff, and damned be him who first cries, Hold enough!'”

In our present delightful frame of mind there was no difficulty in settling terms - we both would have agreed to anything. I told him I would give him one-third of the gross receipts, with a half clear benefit at the end of the week.

"Quite right; anything you like. But will your partner ratify this?"

"Oh, yes," I said. "He attends to the financial part of the business, leaving all matters connected with the stage to me; though, of course, I must consult him before we consider the matter settled.

We walked to the theater, and I introduced Ellsler to Don, telling my partner of the arrangement we had made. He acquiesced at once, and seemed quite as much pleased at the prospect of the baronet's engagement as I was. 
"Stop," said Don; "I have just thought of it. My wardrobe is in Charleston. Can we get it here by Monday?"

"Yes; but we must send for it at once," said I.

"All right," he replied. "Just let me have fifty dollars, and I will telegraph. It 's in pawn, you know."

"In pawn?" said I.

"Yes; I lost a hundred dollars at poker (queer kind of game, is n't it?) on the steamer coming from New York; so I was dead broke when I got to Charleston, and I left my traps at my 'uncle's' for money to pay my bill at the hotel, you knowthe Charleston Hotel, is n't it? Large columns outside - tough steak inside."

Matters were all settled, and a bill for the first night was arranged - "Used Up" and "The Rough Diamond." Sir William told me that he had a number of letters to the first people in Savannah.

"Don't lose a moment," said I. "Deliver them at once. This will sound your arrival through the city."

"All right," said he; " I 'm off. I wish you could go with me; I should like you to see how I cultivate a new acquaintance. No? Very wellby-by." And away he went, taking such enormous strides that he looked like the Colossus of Rhodes at the beginning of a walking-match.

My partner and I, congratulating ourselves on this new treasure, began making preparations for the opening. As I had predicted, the quiet city 


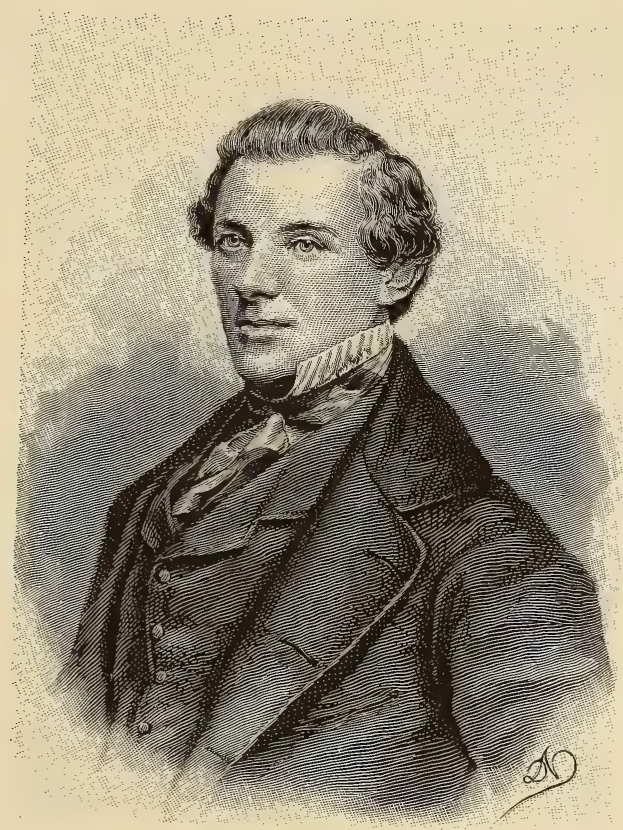

SIR WILLIAM DON. 

began to stir with an undercurrent of aristocratic emotion. As the week wore on the tide swelled, and by Monday had reached the high-water mark of excitement.

The theater on Sir William Don's opening night presented a picture of beauty and refinement. Families that seldom visited the house, except on the conventional Friday night, crowded the auditorium; costly silks and laces fluttered in the dress circle, and old-fashioned rose and table-cut diamonds glittered in the private boxes. Elderly dames with their white hair dressed à la pompadour, and with long and brilliant pendants in their ears, nodded majestically to one another, and prim old gentlemen in stiffly starched cravats looked coldly on. A live baronet was on view!

The curtain rose, and the play proceeded quietly until at last some action revealed that the new star was about to shine. The audience leaned forward as the center doors opened and the baronet stalked upon the stage. As he appeared the applause broke forth; fans and handkerchiefs were waved at him from all directions, and kid gloves were ruined in frantic enthusiasm. The audience at last quieted down and the scene proceeded. The people in front seemed anxious and nervous: I was in the same condition, for I saw that Don, with all his assurance, was suffering from stage fright. His face was pale as death, and he cast his eyes down on the stage. I knew the latter was a bad symptom; he wanted encouragement. I was at the first wing, and catching his eye gave him an 
approving nod. He seemed to take courage, and, as the audience began to enjoy his acting, warmed up. He finished the great speech of the scene, ending with, "I have been to the top of Vesuvius and looked down the crater; there is nothing in it." $\mathrm{He}$ did this admirably, receiving a tremendous round of approbation. As he sauntered up the stage he again caught my eye; and giving me a comical wink as the applause was continued, he said, so that I could hear him, though the audience could not: "It 's all right, old chap, I 've got 'em."

His engagement proved a great financial success. I was disappointed in his acting: he was amusing and effective, but he was an amateur from head to foot, which in his case meant a good deal. I am of opinion that "once an amateur, always an amateur." There are many good actors that have this peculiar, raw quality who have been on the stage for years; and it is because they begin their careers by acting leading characters. Mrs. Mowatt and James H. Hackett were examples of many in our profession who have committed this fatal error. No matter how bold and dashing they may appear, there is a shyness and uncertainty about everything they do. It exhibits itself in the casting of the eyes down upon the stage in an embarrassed way just after they have made a point. This is very disastrous. When a strong effect is made the eye, the pose, the very feeling, should be, for an instant only, a picture, till the public digest it. If it is disturbed by some unmeaning movement the strength 
is lost, and the audience will at once discover that they are not looking at a master. This characteristic of the amateur may wear off in some instances, but I do not remember any.

Sir William went with us to Wilmington, North Carolina, where we opened with the stock, he appearing at the beginning of the second week. The audience here did not like his acting; they seemed to prefer our domestic goods to the imported article. He saw this, but did not seem to mind it, and so bowed to the situation. He became very much attached to the company and remained with us some time, joining in our fishing and boating parties. His animal spirits were contagious; and as we had no rehearsals, the mornings at least were devoted to amusement. We would do the most boyish and ridiculous things. Three or four of us, himself the central figure, would go through extravagant imitations of the circus and acrobatic feats that were then in vogue. "The Bounding Brothers of the Pyrenees" was a particular favorite with him. We would pretend to execute the most dangerous feats of strength - lifting imaginary weights, climbing on one another's shoulders and then falling down in grotesque and awkward attitudes, and suddenly straightening up and bowing with mock dignity to an imaginary audience. Once he did an act called the "Sprite of the Silver Shower," pretending to be a little girl, and tripping into the circus ring with a mincing step. Then, with a shy look, he would put his finger in his mouth, and mounting a table would go through a 
daring bareback feat. Nothing that I ever saw was more extravagant.

While in New York during the next summer, I got the following note from Don:

St. Nicholas Hotel, June 25,185 I.

MY DEAR JEFF: I have just arrived from Boston, where I have been playing a bad engagement. The modern Athens was not overwhelmed by my nobility.' The critics went so far as to say that I was anything but a good actor. What execrable taste! Well, here I am at the St. Nicholas. Fine rooms, but abominable cooking; everything tastes alike. I am beginning to think that the Frenchman was right when he said that in America you had fifty religions but only one gravy. When shall I dine with you? Make it early. I will drop in just as one of the family pot-luck, you know. Do not put yourself out for me ; a pair of canvasback ducks and a bottle of Johannisberg, or two; am not particular.

Yours,

Don.

The day for the dinner was arranged - the Fourth of July; but as it would have needed a journey to the coast of Labrador to get a pair of canvasback ducks at that time of the year, I ordered roast beef and plum pudding instead. The occasion being a patriotic one, as far as the date was concerned, it struck me that an English dinner would be in good taste for Sir William. But we were doomed to disappointment, for at ten o'clock in the morning a strange man came to the door and gave me the following note from Don:

Ludlow Street Jail, July 4, 185 r.

My DEAR JEFF: You will see by the heading of this that $I$ have changed my hotel. Was it you or your father who wrote the Declaration of Independence? If it was your ancestor, you are not responsible, and I have nothing to say; but if "in the course of human events" it was yourself, never hope to be for- 


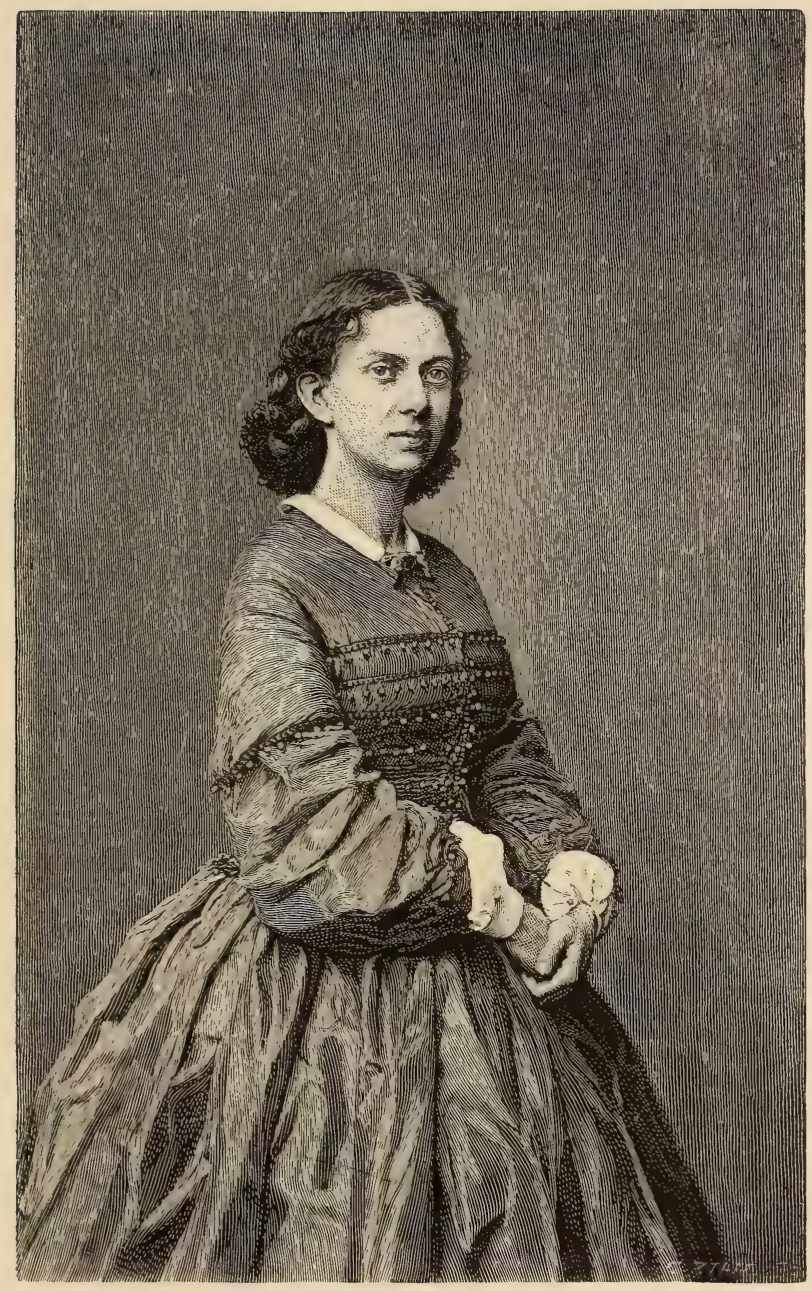

MRS. J. H. ALLEEN. 

given. See what that absurd and unimportant document has brought me to. If America were still one of her Majesty's colonies, an English nobleman would not be treated with this disrespect. Here I am languishing in prison because some old Jew says I borrowed one hundred dollars from him on false pretenses. (He may think himself lucky that it was not a thousand.) I said that I would pay him out of the money I made in Boston. Well, I did not make any money in Boston, so I looked upon the matter as settled. Come and see me. If you have never been in this establishment it will be quite a treat for you.

Yours, Don.

Don was a singular character, at once generous and unjust, genial and slightly cruel. He would borrow from his friend for the purpose of lending to his enemy. His wit was charming and original, and he was quite unconscious of his own brilliancy, apparently setting no value on it. He had that thorough contempt for tradesmen which stamps this type of English aristocracy, and he would walk ten miles to help an old woman or to escape from a tailor.

The love of management still clung to me, and my partner sharing my enthusiasm, we resolved to make another trial of our fortunes in the Southern circuit. Our limited means compelled us to adopt the most economical mode of transportation for the company. It was settled, therefore, as it was necessary, that we, the managers, should arrive at least a week in advance of the opening of the season: our passage must be made by rail, while the company were to proceed by sea.

There was in those days a line of schooners that plied between Wilmington, N. C., and New York. 
The articles of transportation from the South consisted mainly of yellow pine, tar, and resin, which cargo was denominated " naval stores." Feeling confident that we could procure cheap passages for our company by contracting with one of these vessels to take them to Wilmington, we determined to conclude a bargain with the owners.

The arrangement was made at a rate that suited all parties except, perhaps, the members of the company, who, I fear, had some slight misgivings lest they were to be conveyed to their destination as a kind of ballast. The day was fixed for their departure, and Mr. Ellsler and I went down to the wharf at Peck Slip to see them off. If we had felt any uneasiness before in the thoughts of sending our comrades off in this way, what was the depth of our remorse when we saw the dreadful old tub in which they were to depart. It was an ill-shapen hulk, with two great, badly repaired sails flapping against her clumsy and foreboding masts. The deck and sides were besmeared with the sticky remnants of her last importation, so that when our leading actor, who had been seated on the taffrail, arose to greet his managers, he was unavoidably detained. The ladies and gentlemen of the company were uncomfortably disposed about the vessel, seated on their trunks and boxes that had not yet been stowed away. There were handsome John Crocker, our juvenile actor, leaning with folded arms and a rueful face against an adhesive mast; pretty Mrs. Allen, then only eighteen years old and just married, nestling upon the bosom of 
her husband, with her lovely dreaming eyes serenely wondering, not when they would start, but whether they ever would return; Mrs. Ray, the first old woman, with an umbrella in one hand and a late dramatic paper in the other, sitting on a coil of rope and unconsciously ruining her best black dress. It was a doleful picture. The captain, too, was anything but a skipper to inspire confidence. He had a glazed and disheveled look that told of last night's booze. Our second comedian, who was the reverse of being droll on the stage, but who now and then ventured a grim joke off it with better success, told me in confidence that they all had been lamenting their ill-tarred fate. Ellsler and I bade our company as cheerful an adieu as we well could, but there must have been a tinge of remorse in our farewell, for, on talking the matter over as we watched the wretched old craft being towed away to sea, we concluded that we should not forgive ourselves if our comrades were never heard of again.

On our arrival in Wilmington the days were spent in preparing the dusty old rat-trap of a theater for the opening, and our nights in wondering if our party were safe. The uneasiness was not lessened, either, by the news that there had been bad weather off Cape Hatteras.

Within a week, however, they arrived, looking jaded and miserable. Another week for rest and rehearsal, and our labors began. It was customary in those days, particularly with provincial companies, to vary the dramatic bill of fare so as 
to suit the different tastes of the public. Comedy and tragedy were therefore dished up, and I may say hashed up, alternately, as for instance Monday: Colman's comedy of "The Poor Gentleman," fancy dances by the soubrette, comic songs by the second comedian, concluding with the farce of "The Spectre Bridegroom." The next evening we gave "Romeo and Juliet."

The name of this latter play calls to mind an anecdote connected with its performance in Wilmington that will not be amiss at this point. I have before said that a portion of my early theatrical education was drawn from hard work in the paint and property room of a theater, so that when I became a manager I delighted in the "get-up," as it was technically called, of plays, so far as our slender means would permit. To fashion and paint a rustic bridge, with a wide board behind it, set upon two shaky trestles, for Rob Roy to cross over, was a special privilege. A profile boat for the "Lady of the Lake" was another delight. This perfectly unsafe-looking skiff was always set on a trunk mounted upon four little wooden wheels that no amount of black-lead could induce to keep from squeaking. The rope must be steadily pulled - the slightest jerk and over goes her ladyship into the gauze waters. But let us return to the story.

"Romeo and Juliet" being announced, I felt that the balcony scene should have some attention, and I conceived a simple and economical idea that would enable me, at a day's notice, to produce 
the effect in a manner "hitherto unparalleled in the annals of the stage." Skirmishing about the wharves and the ship-chandlers', I chanced to light upon a job lot of empty candle-boxes. By taking a quantity the cardboards were thrown in, and nothing makes a finer or more imposing but unsubstantial balustrade than cardboard. The boxes, placed one by one on top of each other and painted a neat stone color, formed a pleasing architectural pile. Before the play began I had cautioned $J u$ liet that when "she leaned her cheek upon her hand" she should let her elbow rest gracefully but lightly on the frail structure that was to support it. Romeo also had to be cautioned, for as the house of Capulet was already about his ears, it was necessary that at least his shins should escape any contact with the foundation. The scene opened with a backing of something, supposed to represent the distant city of Verona, with my new balcony in the foreground. Romeo and Juliet were warm and energetic in their love passages, but still acted with becoming care and gentle consideration for the balcony about which they fluttered. All seemed to be going well till presently there came the sound of half-suppressed laughter from the audience. "Crocker," said I from the wing, "are you shaking the balcony?" "No," he whispered; "I have n't touched it." "What are they laughing at, then?" "Can't imagine," said he. The laughter increased, and it was quite evident that something not announced in the bills had gradually attracted the attention of the audi- 
ence till at last the whole house had discovered the mishap. Juliet retreated in amazement and Romeo rushed off in despair, and down came the curtain.

I rushed upon the stage to find out what had occurred, when to my horror I discovered that one of the boxes had been placed with the unpainted side out, on which was emblazoned a semicircular trade-mark, setting forth that the very corner-stone of Juliet's balcony contained twenty pounds of the best "short sixes."

From Wilmington we journeyed to Charleston, South Carolina, where, after three weeks of stock and star, we were joined by Julia Dean. Julia Dean and I had been in the utility ranks of the Mobile Theater during the management of Ludlow $\&$ Smith, and as this firm was noted for the economy of its organization, we were made good use of. In the various dramas produced during this season Julia and I had gone hand in hand, alternately espousing the cause of tyranny and virtue for the small sum of six dollars a week. For this reward we were content to change our politics and our costumes at the will of the stage-manager. As brigands, gentle shepherds, or communists we gained our daily bread together. We changed our religion without the slightest compunction; as Catholics we massacred the Huguenots, while as Pilgrims we bade a sad adieu to our native land, from which we had been driven by religious persecution. Lay or secular, it mattered not to us. So we trudged on, with perhaps a lurking thought that some day we might lead to victory as we were then 


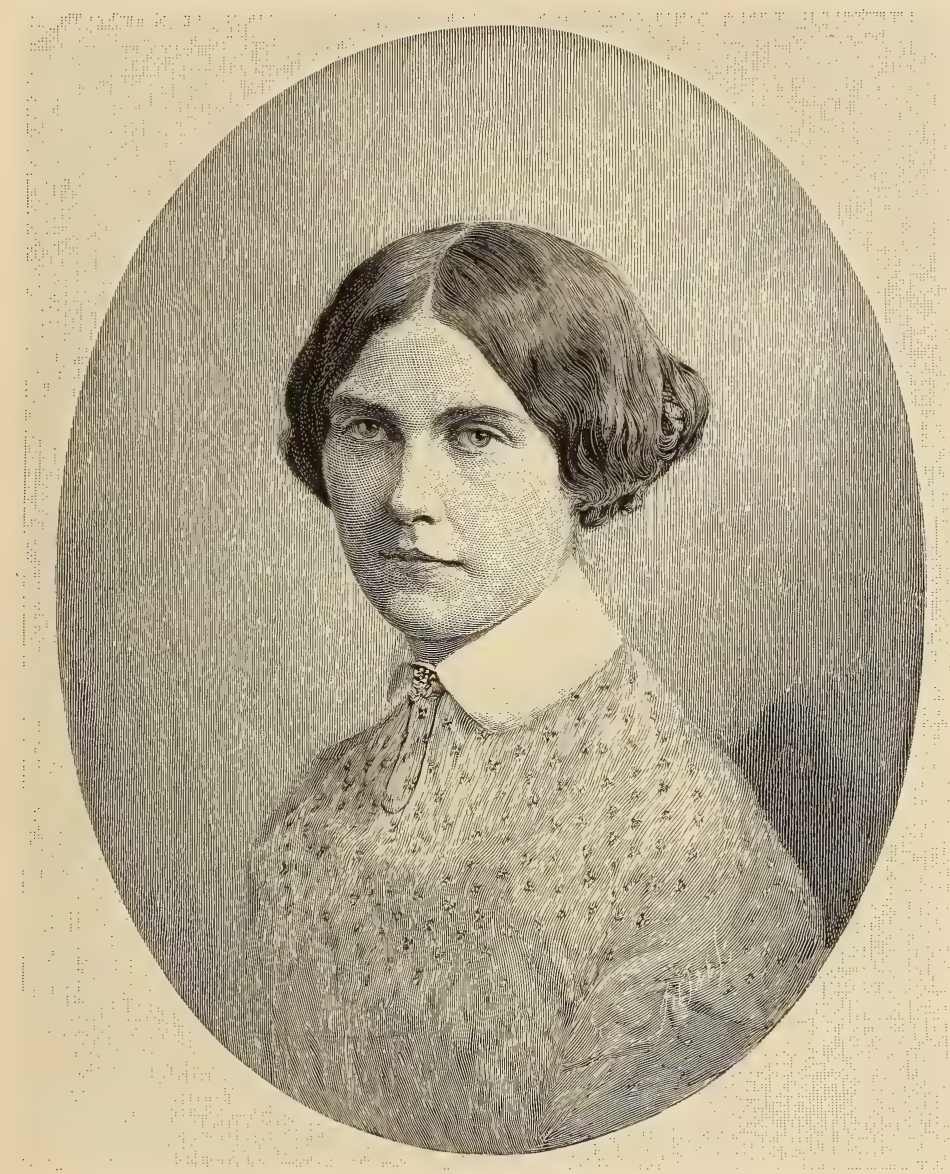

JULIA DEAN. 

following to the death. Straightway comes a change; not for me, but for my gentle comrade. Let me recall the scene. The greenroom is in a high state of excitement; a lady has fainted and is borne to her dressing-room "insensible"; the prompter, George Stanley, brings intelligence to the stage-manager that she is too ill to act. The play to be given is "Wives as They Were and Maids as They Are." The audience must be dismissed unless some one can be found to read the part. The economy before referred to has permitted no overflow of genius to glut our dramatic corps, so that impromptu talent is a scarce commodity with us. Stanley suggests, "Perhaps Miss Dean can do it." "Oh, no, impossible!" replies the manager; and then a gentle but clear and steady voice says, "I think I can, sir." What, quiet, shy, and modest Julia! Whence comes the courage to avow all this? It does not spring from vanity - she has none; it is begot of that honest confidence which often underlies ability; it wins the manager, who in his dilemma clutches at a straw. While the sweet volunteer is robing herself in the dress of Lady Priory, left by the invalid, a friend reads the lines of the first scene to Julia, who drinks them in with eagerness; and the audience are told that they must be charitable to the young novice.

The play proceeds and Lady Priory enters; we, her comrades, are standing at the wing. Take courage, girl! There beats not here one heart that envies you. The gentle eyes are raised, so full of innocence and truth, and now she speaks. Who ever thought that Julia harbored such a voice 
— so low, so sweet, and yet so audible! It sinks deep into the hearts of all who listen. They are spellbound by her beauty, and as she gives the lines with warm and honest power a murmur of delight runs through the house, and from that moment our lovely friend is famous.

Just seven years after this I found myself manager in Charleston, and Julia Dean, then the leading juvenile actress of America, engaged to play a star engagement in my theater. I was rather proud to feel that while my young friend had in the mean time risen to be a brilliant star I was at least a manager, if not a successful one. On the morning of her arrival in Charleston I called at the hotel to pay my respects. I sent up my card. I knew she would smile at the very idea of my having a card; so I wrote in pencil under my name, "All the utility people wanted at ten for the country dance." As the door opened I entered her drawing-room. She burst out laughing, and, giving me both hands in the frankest way, said, "So here we are again." The tall lanky figure of a girl of sixteen, with deep blue eyes and golden hair, had rounded into the graceful figure of a charming woman.

Mr. Ellsler and I had been struggling along in the old up-and-down way, but were looking forward to an improvement in business as soon as our new star should shine - and shine she did. The town fairly went wild with enthusiasm. The star was fêted and entertained by those to whom she would vouchsafe her presence. All vied in paying homage to her beauty and her virtue. She received these attentions with simple dignity and grace un- 


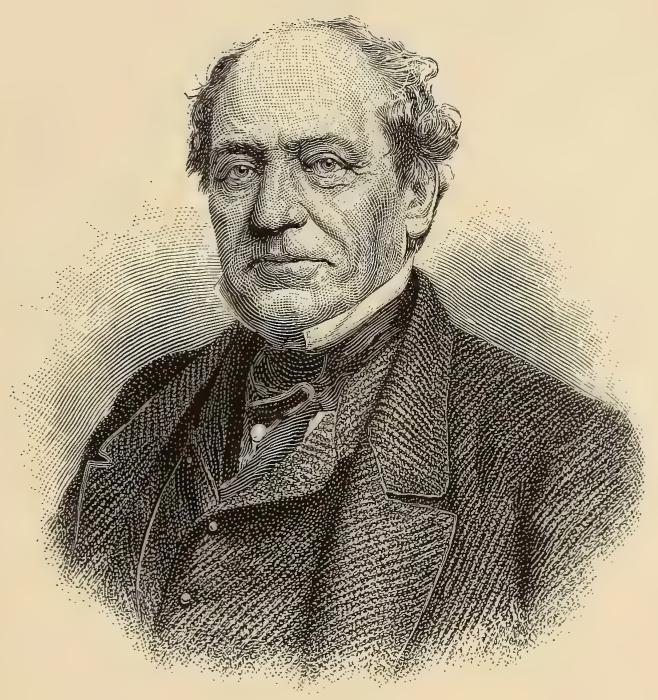

HENRY PLACIDE. 

spoiled by flattery or success, and in those days of her artistic splendor she delighted to laugh and chat over the olden time when we marched together in the glorious preparatory ranks. The success of this engagement was an event in the annals of Charleston theatricals. At the end of the first week we shared $\$ 900$ each - think of it, \$9oo. My partner was more sedate than I, and I fancy took his good fortune with a quiet, philosophic air. But for me, I was in the clouds, a plutocratic comedian! During the whole week I had been covetously eying two watches in the jeweler's window of Hayden \& Greg - one a small, blue enameled one, having a real diamond in the center, with which I intended to, and did, surprise my wife; the other a patent eighteen-carat lever, with which I was bent upon astonishing myself. These purchases were eventually made, absorbing a large portion of our profits.

I had my watch for many years. It was a true and valuable friend. I will not say that we never parted; there were moments of embarrassment when a temporary separation was imperative.

The following season I was engaged to act the "first comedy" under the stage-management of Mr. John Gilbert, at the Chestnut Street Theater. This being a period when stars were rare and combinations unknown, the regular companies were fully commissioned, and generally supplied with excellent actors.

At the Arch, Wheatley \& Drew had a most popular stock company, and the ladies and gentle- 
men attached to it were undoubtedly the dramatic heroes of the city.

Our company at the Chestnut Street was not quite so capable, but we produced the standard plays with considerable effect, and were thought, by ourselves at least, to be formidable rivals of the other actors. I had played Dr. Ollapod and Bob Acres before, so that in these characters I was comparatively at home; but when the cast of the "Heir-at-Law" appeared in the greenroom I felt rather nervous, though, of course, I was delighted at the prospect of acting the important part of Dr. Pangloss. But now there came upon me a dreadful mortification. The speeches of the erudite doctor are filled with classical quotations, and as I knew but little of Latin and nothing of Greek there was only this course left me, I must go to Mr. Gilbert and confess my ignorance. That gentleman kindly offered to assist me in mastering the classics, at least so far as the learned doctor was concerned.

The first thing to be accomplished was to get at the exact meaning of the quotations, that they might be delivered with intelligence. And the next and really most important point was to familiarize myself with the correct pronunciation of them. In two or three days we accomplished this to our mutual satisfaction, and when acting the part I gave out the quotations with such gusto and confidence that I am quite sure the audience was convinced that it was listening to a very learned fellow. I do not feel any remorse, however, at the imposition, for I have no doubt that 


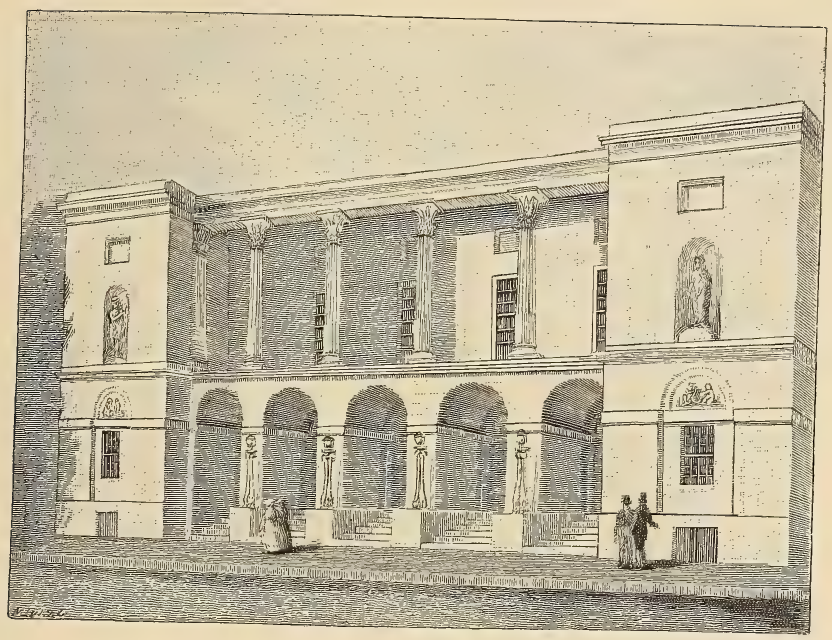

CHESTNUT STREeT THEATER, PHILADELPHIA 

two-thirds of the spectators who applauded my pronunciation of Greek and Latin knew as little about the matter as I did.

In I853 I became stage-manager at the Baltimore Museum for Henry C. Jarrett. He was known as the railroad manager, from a habit he had contracted of getting up excursions between Washington and Baltimore. These flying trips were both startling and inconvenient for nervous actors, as he would frequently arrange for one of his stars to play a short piece for the opening performance in Baltimore, and then hasten him, on a-mile-a-minute trip, to Washington, in a special train, terminating the entertainment in the latter city with the same attraction.

On one occasion he produced the "School for Scandal" at the capital with a cast so strong, including as it did the first comedians of the day, that some account of it here may be interesting. The characters were distributed as follows:

Sir Peter Teazle . . . . . . . Mr. Henri Placide.

Charles Surface . . . . . . Mr. J. E. Murdoch. Joseph Surface. . . . . . . Mr. J. W. Wallack.

Sir Benjamin Backbite . . . . . Mr. I. M. Dawson.

Crabtree . . . . . . . . . Mr. Thomas Placide.

Sir Oliver Surface . . . . . . Mr. George Andrews.

Moses . . . . . . . . . . Mr. Joseph Jefferson.

Snake . . . . . . . . MR. EdWIN AdAMS.

Careless, with song. . . . . . Mr. A. H. Davenport.

Rowley . . . . . . . . . . MR. Ellis.

Sir Harry Bumper . . . . . . . Mr. J. M. BARRoN.

Trip . . . . . . . . . . . Mr. J. B. Howe.

Lady Teazle . . . . . . . Miss Lizzie Weston.

Mrs. Candor . . . . . . . Miss Kate HoRn.

Maria . . . . . . . . Miss Mary Devlin.

Lady Sneerzell . . . . . Mrs. Jane Germon. 
Being stage-manager, of course I was delighted to have this vast array of talent under my direction. Naturally my position on this occasion was a sinecure, as there was but little to do in the way of management. These great lights had been accustomed to manage themselves, and were not likely to expect advice or to brook it from a youngster like me; so I was contented to get the credit of arranging the whole affair, which had really cost me but little thought or labor. I fancy though, from what I remember of myself about that time, that I went about with a wise and profound look, as though the destiny of nations rested on my head. I have since seen older men than I was assume this importance.

The undoubted hero of this occasion was Murdoch in the character of Charles Surface. James E. Murdoch, as an actor, was not only extremely versatile, but entirely original. Neither the popularity of Forrest nor the fame of Booth could tempt him to an imitation of either of these tragedians, and his comedy was equally free from resembling the style of the Wallacks or that of Charles Kemble-for the school of the latter was still lingering upon the stage. I do not mean to say that the traditions of these great actors were not worth preserving. On the contrary, they possessed, from all accounts, a dignity and finish that would be welcome at any time. I cite the fact to show that Mr. Murdoch,- though I feel sure that he admired the great ones that had gone before and were surrounding him,- while he strove to emulate, dis- 


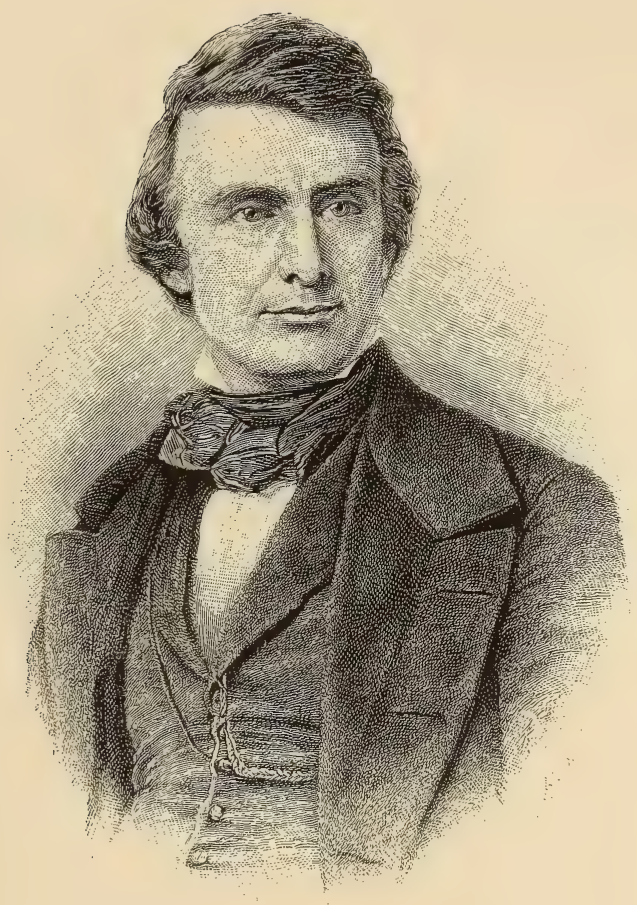

JAMES E, MURDOCH. 

dained to imitate them. He stood alone, and I do not remember any actor who excelled him in those parts that he seemed to make especially his own. He was one of the few artists that I can call to mind who were both professed elocutionists and fine actors.

There was a manliness about his light comedy that gave it more dignity than the flippant style in which it was usually played. This method elevated the characters exceedingly. Charles Surface, Major Oakly, and young Mirabel cannot be acted with the same free and easy manner that might be thrown into Richard Dazzle, Littleton Coke, or Mr. Golightly. I do not say this in contempt of these latter characters; they are natural pictures of modern men, but they are eccentric rather than elegant. I saw Charles Mathews in the part of Charles Surface, and it was a failure. $\mathrm{He}$ had been for years acting the London manabout-town style of character, and the modern air and rather trifling manners, which were admirable when introduced into those parts, were entirely out of place in old English comedy. The quaintness of the language and the fashion of the costume seemed to demand a courtly carriage, which a modern swagger, with one's hands thrust into one's breeches pockets, will fail to give. It was the finish and picturesque style of Murdoch's acting that agreeably surprised the audience of the Haymarket Theater when this actor played there some forty years ago. The public was unprepared to see comely old English manners so conspicuous 
in an American actor, and he gained its sympathy at once. The modern light comedians, with a few exceptions, seem to have discarded the quaint manners of the stage, thinking them antiquated and pedantic. And so they were, for modern plays; but it is dangerous to engraft new fashions upon old forms. I should as soon expect to see Mercutio smoke a cigarette as to find him ambling about the stage with the mincing manners of a dude.

And speaking of this very character, Charles Mathews told me that, during Macready's Shaksperean revivals at Drury Lane Theater, he was engaged to play Roderigo, in which light and frivolous part he made such a hit that Macready tried to persuade him to act Mercutio. He was delighted with the idea at first, but upon reading and pondering over the part he felt convinced that it was beyond him. Macready urged, but Mathews would not undertake the part. Some years afterward Charles Kemble returned to the stage for a short farewell engagement and acted Mercutio. "Oh," said Mathews, "when I saw this elegant and manly actor dash across the stage with the confident carriage of a prince, and heard him read the lines of Shakspere as though they had been written for him, I felt that I had made a fortunate escape in dodging this first gentleman of Verona."

The next important figure to James E. Murdoch, in the powerful cast of the "School for Scandal" just referred to, was the Sir Peter 
Teazle of Henry Placide. It was one of this actor's most striking characters. His style, during the latter part of his career, was said to have been founded on that of William Farren, the great English actor. If so, from all the accounts we get of Mr. Farren, the model was superb. Henry Placide was considered a finished artist, but somewhat cold and hard in his manner. These features, however, though they mar the more delicate points in acting, would be less objectionable in Sir Peter than in most of the old men in English comedy. Except in the scene where he speaks feelingly of his wife to Joseph Surface, the part is stiff, testy, and formal; the humor is dry rather than unctuous. The career of Henry Placide was long and brilliant. He was a strong feature of the old Park Theater for many seasons, and starred in the principal cities of America with success. He was an acknowledged favorite, whose talents as an actor made him a valued member of the theatrical profession.

I remember that during the rehearsal of the "School for Scandal" I was impressed with the idea that the performance would not go well. It is always a difficult matter to bring a company of great artists together for a night and have them act in unison with one another; not from any illfeeling, but from the fact that they are not accustomed to play together. In a fine mechanical contrivance, the ease and perfection with which it works often depend upon the fact that the cogwheels have their different proportions. On this 
occasion they were all identical in size, highly polished, and well made, but not adapted to the same machinery. Seeing a hitch during the rehearsal in one of the important scenes, I ventured, in my official capacity, to make a suggestion to one of the old actors. He regarded me with a cold, stony gaze, as though I had been at a great distance, - which I was, both in age and in experience,- and gave me to understand that there was but one way to settle the matter, and that that was his way. Of course, as the company did not comprise the one regularly under my management, I felt that it would be becoming in me to yield; which I did, not, however, without protesting that the position I took was the proper and only one under the circumstances; and when I saw the scene fail and virtually go to pieces at night, I confess that I felt some satisfaction in the knowledge that my judgment had been correct. In fact the whole entertainment, while it had been a financial success, was an artistic failure. People wondered how so many great actors could make a performance go off so tamely.

Harmony is the most important element in a work of art. In this instance each piece of mosaic was perfect in form and beautiful in color, but when fitted together they matched badly and the effect was crude. An actor who has been for years the main attraction in his plays, and on all occasions the central and conspicuous figure of the entertainment, can scarcely be expected to adapt himself at once to being grouped with others in 


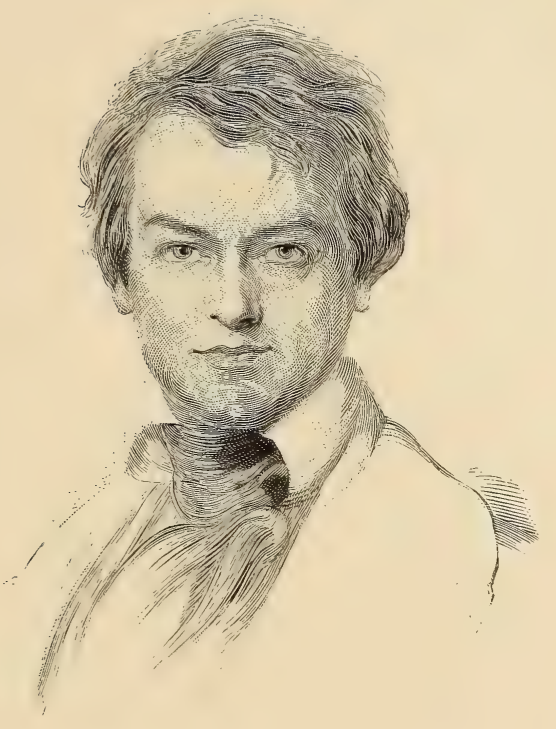

EDWIN FORREST ABOUT 1835 . 

one picture: having so long performed the solo, it is difficult to accompany the air. A play is like a picture: the actors are the colors, and they must blend with one another if a perfect work is to be produced. Should they fail to agree as to the value and distribution of their talents, then, though they be ever so great, they must submit their case to the care and guidance of a master hand.

In the year I 854 I became manager for John $T$. Ford of the theater in Richmond, Virginia. The romantic drama of "The Sea of Ice" was produced with splendid success, and was followed by "The Naiad Queen," which enjoyed equal popularity. The season was altogether quite a brilliant one, and included among its attractions some of the first stars of the country. Miss Agnes Robertson, known as the "Fairy Star," accompanied by her husband, Mr. Dion Boucicault, headed the list, which terminated with Edwin Forrest. This popular tragedian was then in his prime, and what a handsome fellow he was! The form of an Apollo, with the strength of a Hercules: his deep, musical voice was under perfect control, and in the pathetic scenes of Cade and Virginius full of tears. As a melodramatic actor he stood ahead of all his competitors. In Shaksperean characters he was considered too robust and extravagant. So far as matters relating to his own profession were concerned, he was undoubtedly a student, his readings being faultless, and full of feeling. In private he could be very agreeable; his conversation was both humorous and witty, and his anecdotes were told 
with excellent effect. During my long professional life I met him frequently, and I should say that much of his unhappiness - for he was a very unhappy man - came from an irritable temper, under little control. His nature, unfortunately, was not softened by that sweet and gradual ascent to good fortune that is so humanizing. Happy are those who in the race for fame advance steadily and by degrees, making no hurried strides, but losing no ground; shaking hands with their competitors as they go by them, and making honest room for them to pass should they come up again. Forrest with one leap bounded to the front. No new triumphs awaited him, and as old age came on he could only witness younger and fleeter metal pass him by. During those fits of anger which came upon him from the inefficiency of his dramatic support he was childish and unreasonable - having no power of recognizing the distinction between a man who tries his best and fails, and he who fails because he does not try at all.

During the engagement of which I am about to speak, and on one occasion while we were rehearsing "Damon and Pythias," Edwin Adams, who was cast for Pythias, was going through the exciting scene in which that character parts with $C a$ lanthe. Forrest took exception to the business arrangements of the stage; but as this was one of his quiet, dignified mornings, he made his objections with respectful deference, saying that if $\mathrm{Mr}$. Adams would allow him he would suggest some new business that might improve the scene. 
Adams expressed himself as quite willing to receive any instruction; so Forrest went through the parting with Calanthe, giving some new and very good suggestions. Adams tried but failed to catch Forrest's idea. It was tried over and over till finally Forrest became impatient. Again taking Adams's place, he rushed towards the fainting form of $\mathrm{Ca}$ lanthe, and as he dropped upon his knee, throwing his head tragically forward, his hat fell off. Now it is always a comical thing to see a man's high black-silk hat tumble from his head, but especially when he is going through a tragic scene. Forrest for a moment hesitated whether he should pause and pick up the hat or not; at last he made a savage grab for it, but it eluded his grasp, and, slipping through his fingers, rolled round the stage, he pursuing it with tragic passion. The company, one by one, turned their heads away, quietly enjoying his discomfiture. At last he secured it, and fixing it firmly on his head, he proceeded with the action of the scene. He felt we had been laughing at him, and became furious. Rushing upon $\mathrm{Ca}$ lanthe, he embraced her again and again. "Farewell, my love," cried he in dire woe. He then tore himself from her embrace, and madly careering up the stage ran head first into a scene that the carpenters were moving across the stage, mashing the unlucky hat over his eyes. $\mathrm{He}$ struggled manfully to get it off, but with no effect till Adams and I came to the rescue. We were now all in a roar of laughter. For a moment he looked bewildered and even angry, but as the 
absurdity of the scene dawned upon him he joined in the merriment, and declared it was the most ridiculous thing that had ever occurred.

At the conclusion of the Richmond engagement the company journeyed to Washington, where we were to open with Forrest as Metamora - a character that he detested, and one that the public admired. Forrest was always in a state of intense irritation during the rehearsal and performance of this drama. Irregularities that he would have overlooked under ordinary circumstances were now magnified to an enormous size, so that when he donned the buckskin shirt, and stuck the hunting-knife of the American savage in his wampum belt, he was ready to scalp any offending actor who dared to cross his path. The copper-colored liquid with which he stained his cheeks might literally have been called "war paint."

At the rehearsal the poor property man, old Jake Search, got in a dreadful state of nervousness, and everything went wrong. The tragedian naturally held me, as stage-manager, responsible for these accidents, particularly as the unlucky Jake would conceal himself behind set pieces, or mysteriously disappear through traps as each mishap occurred. In the midst of this dreadful confusion, principally brought about by his own ill humor, Forrest turned on me, saying he would not act that night, and strode out of the theater. I hurried through the front of the house, and heading him off in the alley addressed him, as nearly as I can remember, in the following words: 

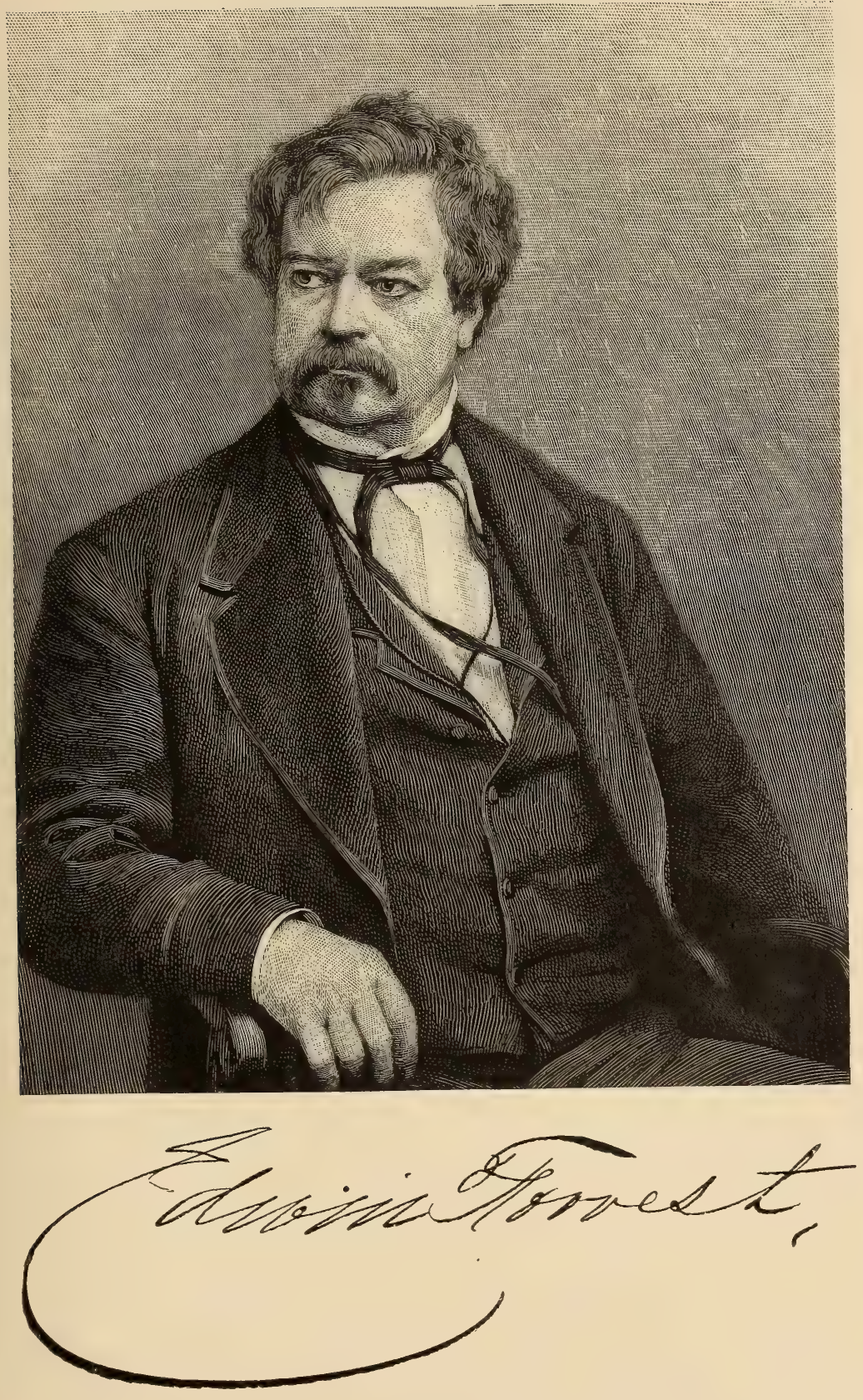

"Mr. Forrest, before you decide upon this step let me state an important fact, that perhaps has not crossed your mind." He saw I was in earnest, and stopped short to listen, as I resumed: "Mr. Ford, the manager, is absent, so I must take his responsibility to the public on myself. The blunders on the stage this morning have been unfortunate, perhaps culpable, but you must pardon me for saying that your excited manner and somewhat unreasonable demands have contributed not a little to confuse the company and bring about this disorder. But be that as it may, there is another and still more important matter to consider. Every seat in the theater is taken for to-night; the audience will crowd the house in expectation of a great dramatic treat, to which they have been looking forward for some time. If you decline to act, and so break your contract with the public, what course is left for me? Why, only this: I must wait for the vast concourse of people to assemble, and then go before them and explain the reason of your non-appearance. I shall have to make a clear statement of the case, and say that you have refused to act because there were some slight discrepancies and irregularities in the rehearsal. The public are, you know, quite unreasonable when their diversion is checked, and it is likely that they will be indignant at the disappointment, failing to see the reason as clearly as you may have done. Now consider for a moment: under these circumstances will it not be more magnanimous in 
you to overlook the shortcomings and go on with the rehearsal?"

He paused for a moment and said: "I will not go back to the rehearsal. I am too much excited, and my presence on the stage now will only make matters worse; but if you will see that details are attended to, I will act to-night."

I promised to do so, and we parted. I was only too glad to get rid of him on those terms, in his then intemperate state of mind. I went back to the stage and dismissed the rehearsal, cautioning the actors to do what they could to render the night's performance creditable. I now began to hunt up the delinquent and frightened property man, Jake Search, - an appropriate name for a fellow who needed so much looking after, - and discovered him hiding under a pile of old scenery. "Is he gone?" said Search. "Yes," I answered, "but he will return to-night; so see that your properties are in good condition, or he will be the death of you."

The night came and matters progressed favorably until the council scene. One of the characters here, being overcome with nervousness, reversed his questions to Metamora, giving the wrong lines, and of course receiving an absurd answer. The audience, recognizing the confusion of the dialogue, began to laugh, and of course this made matters worse. The act terminates with the Indian's great speech, "From the east to the west, from the north to the south, the loud cry of vengeance shall be heard," and here he hurls his knife 
into the center of the stage, where it quivers a defiance as the curtain falls. In his anger and excitement the blade failed to stick in the stage and bounded into the orchestra, the handle hitting the double-bass player on the top of his head, which was as innocent of hair as a billiard-ball, so as the curtain came down the old fellow was stamping about and rubbing his bald pate to the delight of the audience.

I realized now that the storm had burst in earnest, and that a total wreck would soon follow. Knowing that I could not avert the catastrophe, and having no desire to face the tragedian's wrath, like a politic but disloyal captain I deserted the ship and went in front to see it go down. Byron says of a battle, "Oh, what a sight to him who has no friend or brother there!" to which Prentice adds, "and is not there himself." The latter was now my case. I was not there myself, and I did not intend to be, so from the secure corner of an upper private box I watched the progress of the most disastrous performance I had ever seen.

As the curtain rises on the last act the tribe of Metamora should rush through the woods as their leader calls them; but by this time the braves were so frightened that they had become demoralized, and as the foremost rushed through the opening in the woods his long bow got crosswise between two trees. This not only precipitated the redskin over it, but the entire tribe followed, tumbling head over heels into the middle of the stage. I trembled now lest the "big Injun" 
would refuse to put in an appearance. At last, to my relief, the audience quieted down, and Forrest strode upon the stage. If I remember the story, at this point Metamora's wife and children had been stolen away and murdered. His pathos was fine, and by his magnificent acting he reduced his audience to attention and enthusiasm. All was now going well, and I looked forward to a happy termination of the play, which I was thankful to know had nearly reached its climax.

A funeral pile of burning fagots was then brought on, at which some pale-face was to be sacrificed. The two Indians in charge of this mysteriouslooking article set it down so unsteadily that a large sponge, saturated with flaming alcohol, tumbled off and rolled down the stage, leaving a track of fire in its wake. "Put it out!" said Forrest, "put it out!" whereupon the two Indians went down on their knees and began to blow alternately in a seesaw way, singeing each other's eyebrows at every puff. The audience could not stand this comical picture, and began to break forth in laughter. "Let the theater burn!" roared Forrest. At last one tall Indian, supposed to be second in command, majestically waved off the two who were blowing, and stamped his foot with force and dignity upon the flaming sponge, at which a perfect fountain of burning alcohol spouted up his leather legs. He caught fire, tried to put himself out, rubbing and jumping about frantically, and at last danced off the stage in the most 


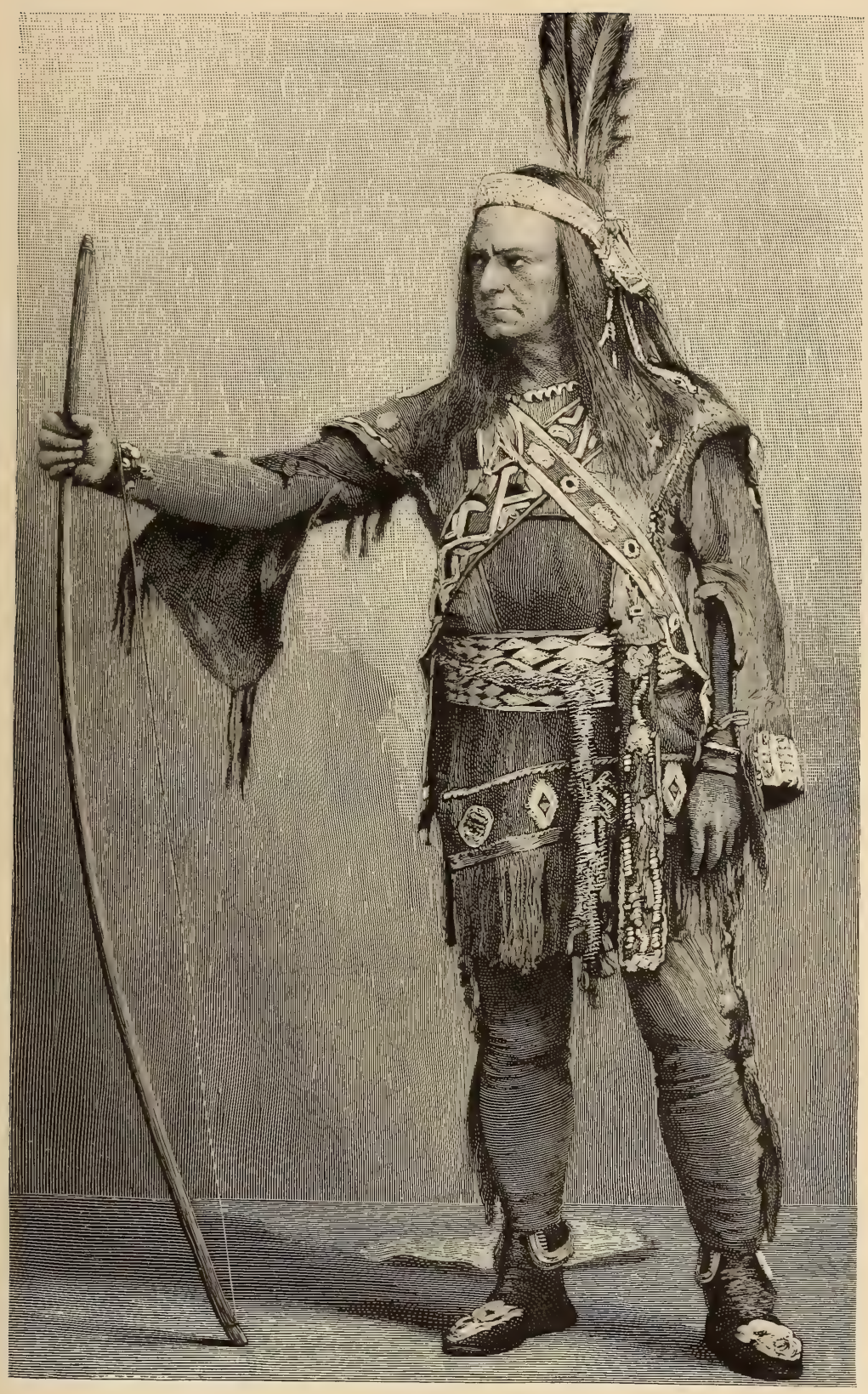

FORREST AS "METAMORA." 

comical agony. Forrest made a furious exit; the curtain was dropped, and the public, in perfect good nature, dispersed. I mingled with the crowd as it went forth, and I never saw the faces of an audience, at the end of a five-act comedy, wreathed in such smiles.

Forrest's first dramatic career in London was undoubtedly a success, though "The Gladiator" was an unwise selection for the opening night. It is a bloody piece of business altogether, and it is a play that could not fail to disgust the sensibilities of a select audience. An actor visiting England, as Forrest did, not only with a great reputation, but as unquestionably at that time the representative tragedian of America, naturally drew the first people of the land to meet him. It must be borne in mind that a first night's audience never represents the general public, particularly on an occasion of this kind. The event was an international one. It was the first dramatic challenge that America had ever given to England. The theater was filled with a critical audience. Statesmen and authors, with the nobility and gentry of the land, were assembled at Drury Lane to witness the début.

Upon an audience like this the most delicate coloring would have had its effect. An artist could scarcely be too subtle before an array of such nice discrimination. When the American actor came upon the stage the symmetry of his form, his manly bearing, and the deep music of his voice produced a strong impression upon the 
house; but as the play progressed, revealing only the tumult of brutal passions, disappointment fell upon the audience. This crude and extravagant drama ends with the central figure bathed in blood, biting the dust, and writhing in the agonies of death. Nothing but the fine acting of Forrest could have sustained this drama before such an audience.

As an actor he was a success, and the play, that caught the public taste, if it failed to please the judicious, was acted for several nights. There can be no doubt that if he had played Lear or Othello before the rare audience that came to witness his début, and which he could not hope again to assemble in such force, his success as a Shaksperean tragedian would have been pronounced.

Forrest's second visit was full of tumult. William Macready, then the reigning favorite as a Shaksperean actor in England, was an intimate friend of Mr. Forster, the dramatic critic; and Forrest publicly declared that it was in consequence of this intimacy that he had been abused in the papers, and more than hinted that Macready was in a conspiracy with Forster to malign him. History will never join with Forrest in this belief. Macready's position was so well assured in London that he could not possibly fear a rival. And the lifelong record of Macready clearly shows that he was too honorable a man meanly to connive at another's downfall.

After his engagement was over Forrest went to see his rival act, and because the latter introduced 
some business that Forrest disapproved of he hissed Macready from the front of the house. To say that this was in bad taste is to put too mild a disapproval upon such a rude and unprofessional act. It was the culmination of Forrest's waywardness and ill temper. But the unfavorable notices in London had stung him to the quick. The virus of adverse criticism rankled in his veins. The eagle of the American stage was in a frenzy; his plumage had been ruffled by the British lion. So giving that intolerant animal one tremendous peck, he spread his wings and sailed away.

I have no doubt that he had often acted Othello, Lear, and perhaps Hamlet with all that care and study could compass, but the audience refused to respond; and knowing that there was a "lurking devil" in him, they sat dumb and sullen until it was let loose.

A dramatic critic told me that he was paid a stated sum of money to go to the theater regularly every night during Forrest's engagements at the Broadway Theater in 1856 , for the purpose of writing him down. This gentleman (?) had lately come from England, and until this time had scarcely seen a Shaksperean play. $\mathrm{He}$ was a fluent writer, but had not the remotest idea of the thought and philosophy contained in the plays of which he was to write. He said he would get a book of the tragedy that was to be acted at night, read it up, then form his own conception of how the character should be acted, and if Forrest did not render it to his way of thinking,- - which for- 
tunately for the public he never did,- he, as the critic, would cut the actor all to pieces. These criticisms did more good to the actor than harm. Unjust abuse generally has this effect. Feeling that these articles were actuated only by malice, the public came in crowds to indorse the actor. Unfortunately the tragedian lost his temper and addressed the audience from the stage, pleading his own case and hurling anathemas at "the irresponsible assassins of the pen." There was no necessity for this. His friends had already taken up cudgels for him and rallied to his support. It was like a successful candidate asking his constituents, after they have elected him, to add to the obligation by throwing his unsuccessful rival out of the window.

Edwin Forrest, with all his faults, had warm and generous impulses. I know of one instance where a poor, old actress went to him in distress. In former years he had known her father and respected him. Touched by her appeal for assistance, he lent her a large sum of money, with the almost certain knowledge that he would never get it back again. It was never made public; no one knew of it but the receiver and myself. The Forrest Home has done much good, and is likely to do more; and those actors who either by age or by infirmities have been debarred the privilege of following their profession will naturally be grateful for this rich legacy.

Even in the days of his theatrical fame and prosperity Forrest was an austere man, and as he grew 


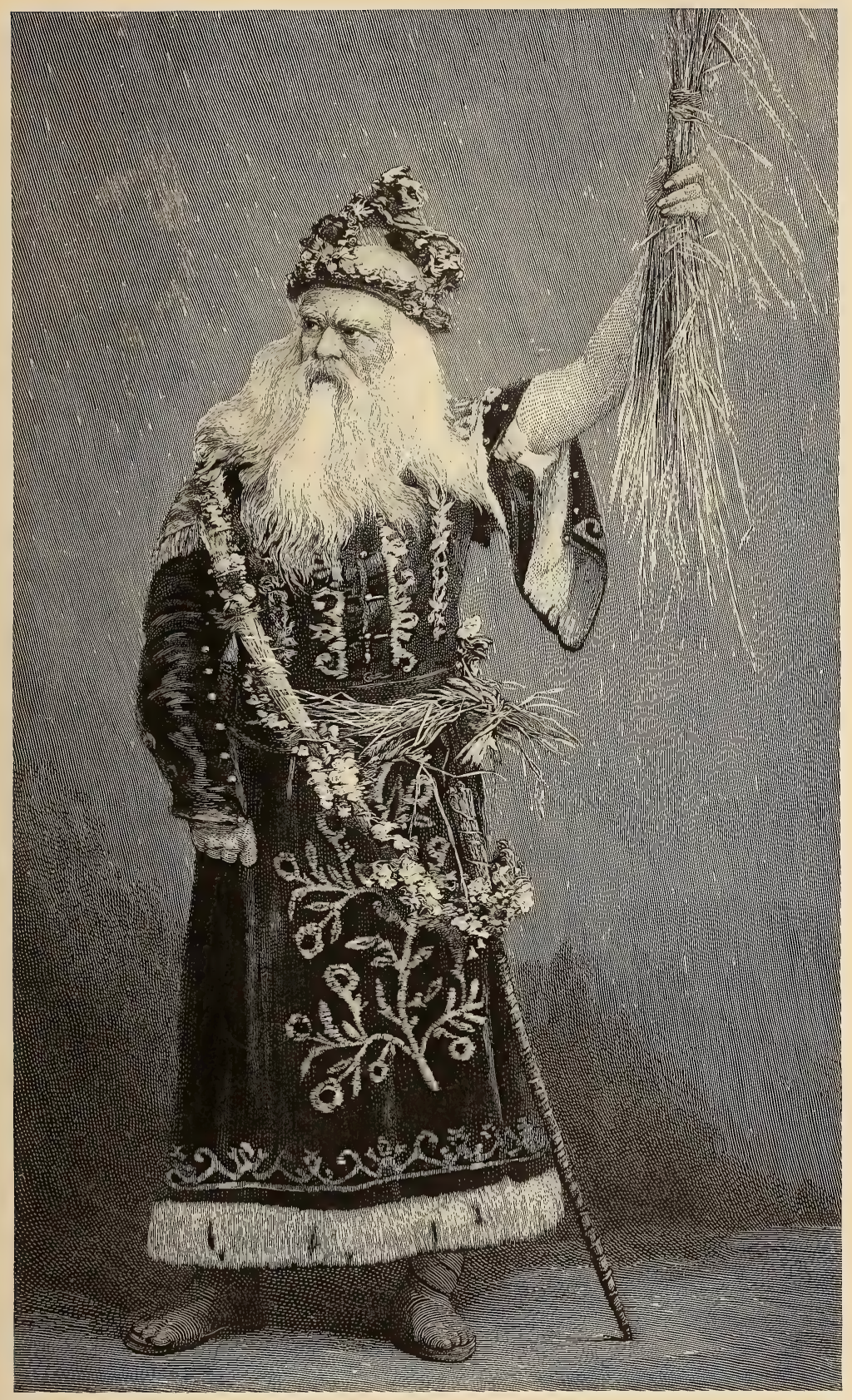

FORREST AS “KING LEAR." 

older he became morbidly misanthropical, holding himself aloof from all but his most intimate friends. The latter part of his life was embittered, too, by illness and the loss of public favor. Until the closing years of his career he had been blessed with perfect health; this became suddenly shattered, and the unexpected attack wrecked his dramatic power. He might have borne the stroke of illness, but to one whose imperious nature could not brook the faintest slight the loss of public admiration was a heavy blow; one, too, that would have shocked a wiser and more even-tempered man than Edwin Forrest. Still he toiled on, and was unjustly censured for acting past his powers. But what was he to do? His physicians told him that he must act if he would live; the wheel must be kept in motion or it would fall. His performances in the larger cities were given to empty houses, while bright and youthful aspirants were drawing from him all his old adherents. His former friends forsook him, and naturally, too; they could not bear the pain of witnessing their favorite of other days declining night by night. No actor can hope to hold an interest in his audience merely by what he has done in years gone by ; in acting it is the present that the public have to deal with, not the past. To witness age and decrepitude struggling to conceal their weakness in the mimic scene is too painful. The greater our affection for the artist the less can we bear to see him suffer and go down.

In the vain hope of struggling on, the old tragedian sought "the provinces." Here the people 
flocked in crowds to see the great actor that they had heard of from their childhood; not with the faintest hope that they would find the grandeur of the past, but from the curious desire to see a ruined tower just before it falls. 


\section{ChAPTER VI}

\section{FIRST VISIT TO EUROPE}

From London to Paris - An Early Comedy-In the Second-hand Shops-Return to America

T SAILED for England in the clipper ship Neptune, in June, I856. This was my first visit to 1 Europe, and London was a rare treat to me. It was rich in comedians and poor in tragedians. Robson and Wright were especially fine; Compton was quaint and legitimate, and Buckstone funny. Mr. Phelps was an actor of such versatility that he could scarcely be called a tragedian. His range was wider than that of any other actor in England. Macbeth, Sir Pertinax McSycophant, Malvolio, King Lear, Sir Anthony Absolute, and Bottom take in the vast area of the legitimate drama. I saw him in two of these characters only, but it is generally conceded that he was equally fine in all of them. 
From London I went to France. My mother's parents were from this lovely country, and I longed to see it. We arrived quite early in the afternoon, and then I looked for the first time on the picturesque city of Dieppe. What a transformation had taken place in a few short hours from London! Why, if a hole could have been bored at Waterloo Bridge and I had dropped through the earth, coming out at China, the contrast would not have been greater. Climate, costume, architecture, and language - the change was complete: eight-storied picturesque houses, with three-storied roofs, each story projecting a little beyond the other till at the top they almost meet, making it quite convenient for the occupants in the garret windows to shake hands with one another across the street; all the windows filled with the excited inhabitants chatting to one another and violently gesticulating. The streets were thronged with people: women in wooden shoes, blue petticoats, and high, stiff, white caps, carrying baskets and generally doing all the work; lazy men in blue blouses, quietly submitting to it without a murmur; they were lolling on the piers, slyly laughing and winking at one another as they guyed the cockney and Yankee tourists. A swell table d'hôte dinner, for swell tourists, was carefully avoided by myself and companion; so we slipped around the corner and got a cheap repast, consoling ourselves that by traveling economically you always have a better chance to study character. With this object partly in view, and with know- 
ledge of our slender purse, we purchased secondclass tickets on the train for Paris. It was midsummer, and as we started at 6 P. M. there were still three or four hours of golden twilight for us. What a panorama of beauty! We saw the quaint French farms and picturesque châteaux as we skirted along the lovely banks of the Seine; Rouen with its majestic cathedral loomed up as the moon rose over the river.

At eleven o'clock we arrived in Paris. I drove to Hôtel Byron in Rue Richelieu, and after supper determined to get a view that night of the church of Notre Dame. Past twelve o'clock and the full moon high in the heavens; it was just the time to see it. A cab had us there in twenty minutes. How grandly it stood out against the dark blue sky! We recrossed the Seine, and I stopped the cab to get out on the bridge. Straight before me were the gloomy towers in which Marie Antoinette was confined during the Reign of Terror. I almost fancied that I could see the pale face of the murdered queen gazing with anguish through the iron-grated windows. The French cabman did not quite get into his head what was the matter with me. I think my gloomy looks made him suspicious that I was contemplating suicide and had brought him there as an accessory; for he got quite close to me, evidently intending to grab me by the collar and force me into the cab at the first hint of a plunge. He heaved a sigh of relief as I got into the cab, and drove away from the bridge much faster than he came to it. 
Hôtel Byron was in the busy part of the city, so I was awakened at sunrise by a hum of voices and the rattle of cabs: bakers, milkmen, and venders of fruit and vegetables were trying to drown one another with their various cries. Perhaps a week later than this it would have been annoying, but now the sounds were so strange to my ears that I was only too delighted to be awakened by them. I had just finished dressing when I heard a fearful quarrel in the courtyard: looking out of the window I saw a most curious group of people. There was a fat man, in a white apron and cap, - the cook, - armed with a large wooden spoon, and a thin baker, with a long loaf of bread, measuring at least four feet, beating each other over the head and shoulders with these deadly weapons. The landlord had embraced the baker and was trying to tug him away; the landlady was endeavoring to do the same with the fat cook, but his dimensions defied her; a kindly milkman and two waiters got in between the belligerents, and in so doing received most of the punishment. Nothing could be more comical than to watch this exciting but bloodless encounter-the frantic yells of the landlord, the screams of the landlady, the milkman and the two waiters rubbing themselves as the spoon of the infuriated cook and the long loaf of the angry baker descended upon their heads. In the midst of the encounter and the thickest of the fight a huge milk-can was kicked over, and a foaming white flood deluged the middle of the yard. This dreadful accident stopped the fray at 
once-oil poured upon troubled water could not have been more effectual; economy is a passion with the people of Paris. There was a groan of horror from the milkman, who stood with his shoulders shrugged up to his eyes, his arms stiffened, his hands spread out, and his legs wide apart, surveying the disaster; his stock in trade, once pure and white as the driven snow, was slowly flowing down the middle of the yard, and as it "mixed with the baser matter" became a pearly gray, and so deepened into an inky hue as it reached the gutter of the street. The poor fellow was now the center of attraction. The belligerents crowded around him offering their sympathy; if they could not restore his merchandise, they could at least smother him with the milk of human kindness. The cook and the baker looked on in self-reproaching silence, the waiters assisted the unfortunate man to a chair, and the landlady soothed him with a glass of claret. Now a reaction set in. A faint smile mantled the milkman's face, then they all broke out into a roar of laughter as the comical side of the picture presented itself; the waiters fairly danced with merriment, the cook embraced the baker, who punched him in the stomach with delight, and so ended the first and only fight I ever saw in Paris.

After breakfast I consulted my memorandum and guide-book. What a list of things to see! How could I get through it in the time? Where should I go first? I have since seen my children 
in this uncertain condition in a toy-shop, and have always felt for them as I remembered this eventful time; for we are only children of a larger growth, and must have all felt this delightful torture. My guide was now engaged; his name was François. He was a capital hand at business, so far as industry was concerned; his vitality, too, was wonderful. Quick, agile, witty, and vivacious, nothing was a trouble to him so long as it was to his taste; but if I suggested some place to visit that he in his vocation was tired of, the humbug of his nature came into full play, and he would disparage the proposal with the true tact of a Frenchman. Not that he was dishonest; on the contrary, where money was concerned he was scrupulously particular, but the artistic side of his nature delighted to assert itself.

On my second visit to Paris, twenty years after, I was struck with some curious incidents that illustrate the devotion of the French to art and their uncertain loyalty to the reigning government. Over their doors and on the cornices of their public buildings the Republican motto "Liberty, Equality, and Fraternity" was painted; but the prices of admission to the Grand Opera were carved in the stone, as though they plainly said: "We only paint our patriotism on the walls, so if we desire a change in the government we can wash it out; but the price of admission to the grand opera can never be changed - jamais!" Again: when the revolution was over, the names of many streets and buildings were changed, all references to royalty or the empire were swept away, till they came to the 
Palais Royal: this sacred title was not disturbed, as it was the name of the theater within its walls.

How grand I felt on my first visit, to think that I was in Paris; not the Paris of to-day, with its gilded domes and modern grandeur, but the old, quaint, dirty, gay, strange city in the early days of the Second Empire, with its high, toppling buildings, narrow streets, and lively people. What pride I should take, when I got back to America, in talking familiarly of well-known localities, and getting the French pronunciation pat and glibrattling off the names with an easy air as if I had lived there for years. What boyish delight I felt in walking through the streets and looking in at the shop windows. Socrates, I think it was, who said, as he walked through Athens, "How happy I am that there are so many things here I do not want." If his philosophy was correct - and I have no doubt it was - I must have been very unhappy and very unlike Socrates, for there were so many things that I did want. Of course I could not get them, but could price and admire them. Now I must be careful ; the money had to be recounted, and there should be enough kept to get back with. I had been saving up two years' salary for this trip, so there must be no undue extravagance. This matter settled, I filled my purse with gold, hired a cab, and sallied forth with my guide to visit the theatrical wardrobe shops in the Temple. I shall never forget this lovely day, wandering into the little dens, sometimes in the cellars, sometimes in the garrets of the queer old places, 
rummaging over quaint hats, square-toed shoes, character wigs, embroidered court suits, charming long silk stockings in all the magic colors of the rainbow, high boots, lovely gaiters, striped waistcoats, and groves of old-fashioned liveries - it was a dramatic fairy-land.

The second-hand shops of Paris are very different from those of Chatham street and Petticoat Lane. In London and with us they are presided over by thrifty Jews, who glare at you with glittering black eyes and thrust their eager noses in your face, almost imploring you to buy. Not so in France: quiet old women sit in the doorways of their shops, or just outside, sewing or knitting ; no time is wasted by the women of France. They smile and nod as you pass by, but no rudeness, no urging you to buy; in fact, they seem so perfectly self-satisfied that at times it is quite provoking to the would-be purchaser. I was all eyes, and longing eyes at that. Now and then François would give me a gentle nudge and admonish me not to appear so anxious. At these times I would assume a careless manner as if such scenes were quite usual to me. At last François stopped in front of one of these shops: taking a survey with the air of a connoisseur, and nodding a cold approval of its contents, he invited me to enter. An old woman, - knitting, of course, - the exact counterpart of at least twenty we had already passed, followed us in. Here everything was in picturesque and artistic confusion-piles of curious costumes on the shelves, flowing scarfs, broad 
felt hats with ostrich feathers, russet boots, and big-hilted swords and rapiers arranged in a halfcareless, half-methodical way. There was an interior room from which issued sounds of merriment and laughter. I hesitated to pass through, but the old woman smiled and bade us enter, shrugging her shoulders and expressing in her way, "Only young people; they will have their sport." And so it was. Here were two sprightly young Frenchmen, evidently actors, and a pretty coquette of a girl - the daughter of madame - having a royal time at flirting and acting. For a moment our entrance damped their ardor and the "sport," whatever it was, came to a standstill. Then came some pantomime from my guide, who introduced me to the trio as an actor from America, at which they assumed an extravagant air of wonder and amazement, evidently guying me. So feeling themselves quite at ease, the merriment again proceeded. It was quite evident to me that there was a love affair between the pretty girl and the handsomer of the young actors. He was a graceful young fellow, with blond, curly hair and blue eyes, and I presumed he was the rising young lover of some small theater in the neighborhood. The other actor was undoubtedly a low comedian of the same establishment. He was the reverse of the blond lover, hideously ugly, with a turned-up nose, and a wide gash in the middle of his face for a mouth. He looked like a monkey, and was quite as full of tricks. Assuming a grotesquely tragic air, he grasped me by the hand 
as if I were his long-lost brother, then, pointing despairingly at the lovers, gave me to understand in pantomime that his life was blasted by unrequited affection. Then he fell upon his knees to the girl and implored her love; she laughed, of course. This started him to his feet, and with a sudden spring he picked up a Roman helmet, cocked it sidewise on his head, seized a poker, and rushed upon his rival. Then he paused, and, bursting into tears, relented. Now taking the lovers' hands he joined them in wedlock, invoked a blessing on them from Heaven, stabbed himself with the poker, and rushed out into the front shop amidst the laughter and merriment of his audience. To me this seemed a very happy party, and though I understood very little of what they were saying, it was quite enough to convince me that some of their fun was at my expense. The old woman now led the way up a dark, narrow staircase to a room of wonders above. The walls were hung with fantastic dresses, spears, shields, and masks with decidedly French expressions of countenance. She pointed quietly to all these things, but rather disparaged them.

Now she came to a high, black leather trunk with a round top and clamped all over with iron bands and hinges. This contained glittering suits of Roman armor. A shining breastplate was displayed to tempt me. I explained that that style of thing was not in my line. So with a sweet smile, somewhat tinged with pity, I think, she shrugged her shoulders and passed on to a large, flat, 
wooden box like a monster sea-chest with an old-fashioned padlock on it, big enough for the Bank of England. She pointed to the box with admiration, as though she would say, "Ah, you don't know what lovely things are stored there, and so cheap." She first displayed a black court suit with polished steel buttons, very fine, but too large and too somber. Next came a royal purple silk velvet one, embroidered with gold and foilstones. I lost my heart to this at once, and the sly old woman knew it. I tried to look as if I did n't care for it, but failed. It would n't do with her. She saw through me, and began to fold it up with a loving hand, as though she could n't part with it for the world. She spoke no English; and as I was equally skilled in French, we talked through my guide. He, of course, professed to be on my side, but, from certain suspicious intonations, I fancy he slightly favored the old woman.

"Well, what is the price?"

"Five hundred francs." She said this with an injured air, as if she hoped I would n't give it, but of course I did give it.

One article after another was tried on; some reluctantly cast aside, others eagerly purchased. As each new treasure came into my possession it was placed in the cab by my guide. I did not want them sent home - no, I would take them myself; then I had misgivings that the cabman might drive off with my booty. I must have made François take his number three times at least, and put it in my different pockets, fearing I should lose it. 
At last I had gone through all the shops in the Temple. The longing eyes of the old Frenchwoman followed me from door to door, the cab was full, the purse was empty, and now I had a feverish anxiety to get away. I was convinced I had bought these wonders at half their value, and I feared that the venders would regret having sold them, and before I could depart demand them back. So we jumped into the cab, gave the word, and drove to the hotel.

Three lovely weeks in Paris; it seemed like a dream. Then I awakened and sailed for home. 


\section{CHAPTER VII}

\section{WITH LAURA KEENE}

"The Hcir-at-Law" - Dramatic Action-"Our American Cousin" - A Theatrical QuarrelChanges in Old Plays - "The Duchess"

THE opening of Laura Keene's theater, in September, 1857, was an important event to me. I had been engaged for the leading comedy, and it was my first appearance on the western side of the city. Miss Keene had never seen me, either on or off the stage. It was looked upon as a kind of presumption in those days for an American actor to intrude himself into a Broadway theater ; the domestic article seldom aspired to anything higher than the Bowery; consequently I was regarded as something of an interloper. I am afraid I rather gloried in this, for in my youth I was confident and self-asserting; besides, there was a strong feeling among my artistic countrymen that the English managers had dealt unjustly with us, and I naturally shared in this feeling. I have since come to 
the conclusion that the managers do not open theaters for the purpose of injuring any one.

At all events, I was installed as the comedian at Laura Keene's theater, and opened in Colman's comedy of "The Heir-at-Law." One of the leading papers, in alluding to my performance, mentioned the fact that a " nervous, fidgety young man, by the name of Jefferson, appeared as $D r$. Pangloss, into which character he infused a number of curious interpolations, occasionally using the text prepared by the author."

The critic struck the keynote of a popular dramatic error that has existed through all time, and I shall make bold just here to call attention to it. Old plays, and particularly old comedies, are filled with traditional introductions, good and bad. If an actor, in exercising his taste and judgment, presumes to leave out any of these respectable antiquities, he is, by the conventional critic, considered sacrilegious in ignoring them. And, on the other hand, if in amplifying the traditional business he introduces new material, he is thought to be equally impertinent; whereas the question as to the introduction should be whether it is good or bad, not whether it is old or new. If there is any preference it should be given to the new, which must necessarily be fresh and original, while the old is only a copy.

Laura Keene's judgment in selecting plays was singularly bad; she invariably allowed herself to be too much influenced by their literary merit or the delicacy of their treatment. If these features were prominent in any of the plays she read, her 


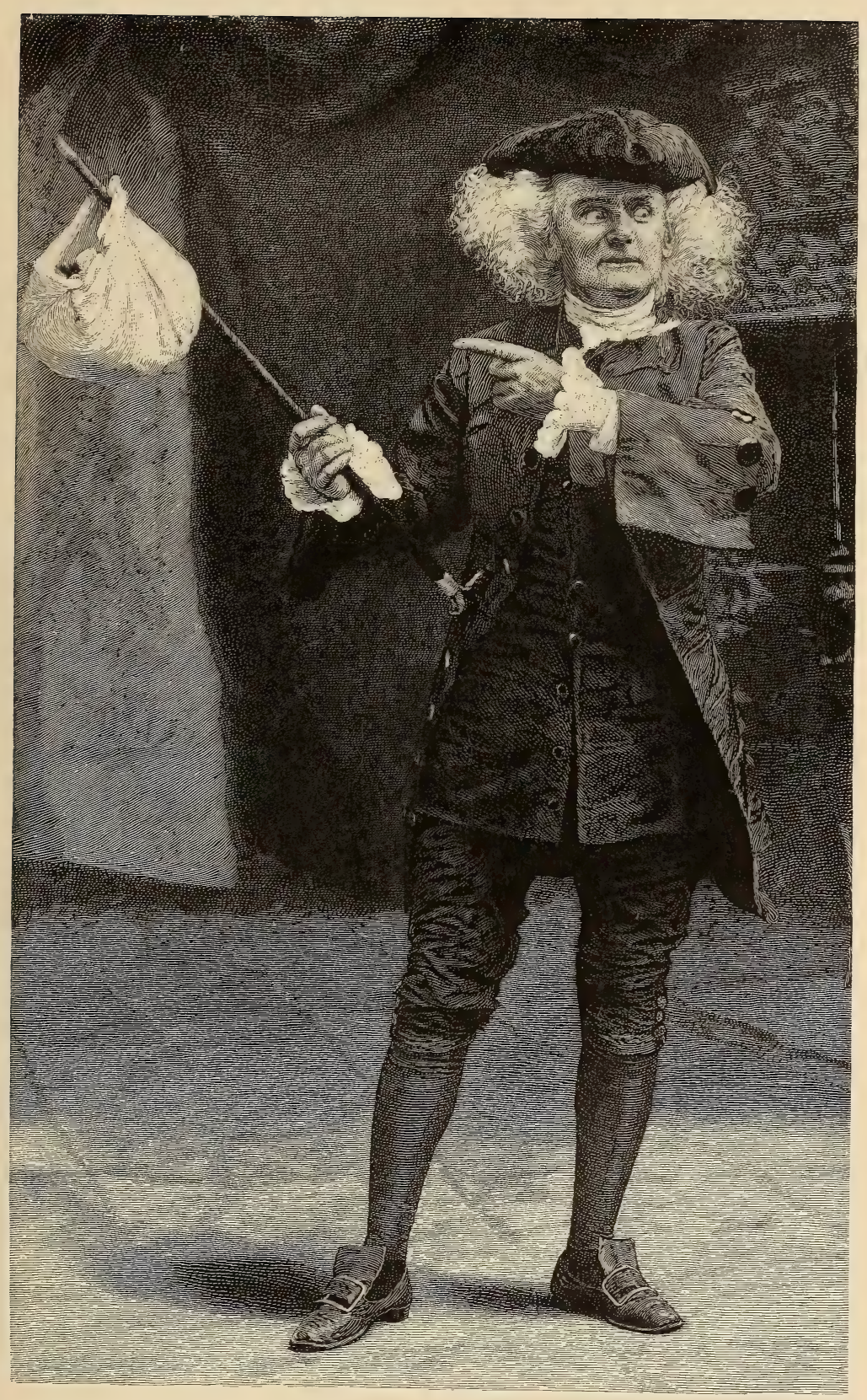

JOSEPH JEFFERSON AS "DR. P.INGLOSS." 

naturally refined taste would cling to them with such tenacity that no argument but the potent one of public neglect could convince her that she had been misled in producing them. I do not say that polished dialogue or delicately drawn characters are detrimental to a play - on the contrary, they assist it; but if these qualities are not coupled with a sympathetic story, containing human interest, and told in action rather than in words, they seldom reach beyond the footlights.

Perhaps it is well to define here, to the non-professional reader, what is meant by dramatic action, as sometimes this term is mistaken for pantomime. Pantomime is action, certainly; but not necessarily dramatic action, which is the most essential element in the construction of a play. A drama will often give one no idea of its strength in the reading of it; even in rehearsal it will sometimes fail to reveal its power. I have on several occasions seen even the author of a play surprised at the exhibition of its dramatic action on its first representation before an audience, he himself not being aware that his work contained the hidden treasure, until the sympathy of the public revealed it. Sometimes the point of unexpected interest consists in the relationship between two characters, or the peculiar emphasis laid upon a single word that has been spoken in a previous act. But to illustrate more fully what I desire to explain I will take two dramatic actions, one from comedy and the other from tragedy, to set forth the subject clearly.

In one of Victorien Sardou's plays - and this gentleman is perhaps the most ingenious playwright 
of our time - the following incident occurs. The audience are first made fully aware that a lady in the play uses a certain kind of perfume. This is done casually, so that they do not suspect that the matter will again be brought to their notice. She abstracts some valuable papers from a cabinet, and when they are missed no one can tell who has taken them. The mystery is inexplicable. Suspicion falls upon an innocent person. The audience, who well know how the matter stands, are on tenterhooks of anxiety, fearing that the real culprit will not be detected. When this feeling is at white heat one of the characters finds a piece of paper in the desk and is attracted to it by the perfume. He puts it to his nose, sniffs it, and as a smile of triumph steals over his face the audience, without a word being spoken, realize that the thief is detected. Observe here, too, the ingenuity of the dramatist: the audience are in the secret with him; they have seen the papers stolen; it is no news to them; but when the characters in whom they are interested become as much enlightened as they are the climax is complete.

For an illustration of this point, as applied to tragedy. After the murder of Duncan, Macbeth, standing with his wife in a dark and gloomy hall, looks at his bloody hands and apostrophizes them in these terrible words:

Will all great Neptune's ocean wash this blood Clean from my hand? No, this my hand will rather The multitudinous seas incarnadine, Making the green one red. 
Now there is a silence, and when he is alone there echoes through the castle a knocking at the gate. The friends of the murdered guest have come for him; and they thunder at the portals, while the blood-stained host stands as if stricken down with terror and remorse. It is not the dialogue, as powerful as it is, which strikes the audience with awe; it is simply a stage direction of the great dramatic master-a " knocking at the gate." It will, I think, be seen by these two illustrations that a fluent and imaginative writer may construct plots, create characters, and compose exquisite verse, and yet not succeed as a playwright unless he possesses the art or gift of creating dramatic action.

As an actress and manager Laura Keene was both industrious and talented. If she could have afforded it, no expense would have been spared in the production of her plays; but theatrical matters were at a low ebb during the early part of her career, and the memorable panic of 1857 was almost fatal to her. In the midst of financial difficulties she displayed great taste and judgment in making cheap articles look like expensive ones, and both in her stage setting and costumes exhibited the most skillful and effective economy. She was a highmettled lady, and could be alarmingly imperious to her subjects with but little trouble.

I call the panic of I 857 "memorable," for surely the actors and managers who struggled through the vicissitudes of that season must have a vivid remembrance of the various shifts and economical devices of that disastrous time-disastrous not 
only to theaters but to all kinds of commercial pursuits. Banks that had been thought impregnable were swept out of existence. Long rows of despairing depositors stood in lines eagerly besieging their delinquent trustees. One institution alone withstood the shock,- - the Chemical Bank,and naturally gained for itself a most enviable reputation. Wall street was in a collapsed condition, and placards of "To Let" stood out in bold relief upon private residences, almost as numerous as the houses themselves. People who had lived beyond their means found their extravagance checked by an unlooked-for depression of their precarious incomes. Horses and carriages were sold for a song. That conventional army of gentlemen who are always selling their teams, because they and their families are about to go to Europe, increased so alarmingly that column after column of the daily papers were filled with announcements of their intended departures.

Under such conditions naturally the theaters were great sufferers. Salary day - that ever-welcome Monday - was deferred first until Tuesday, then until Wednesday, then until Thursday-and finally disappeared altogether. The bands struck with one accord, and as usual got their money; the actors revolted and as usual did not get it. The public despondently staid at home, the theaters were empty, the managers depressed, and the actors jolly. This seems incredible, but the members of my profession, at least in the old time, were always in the best 


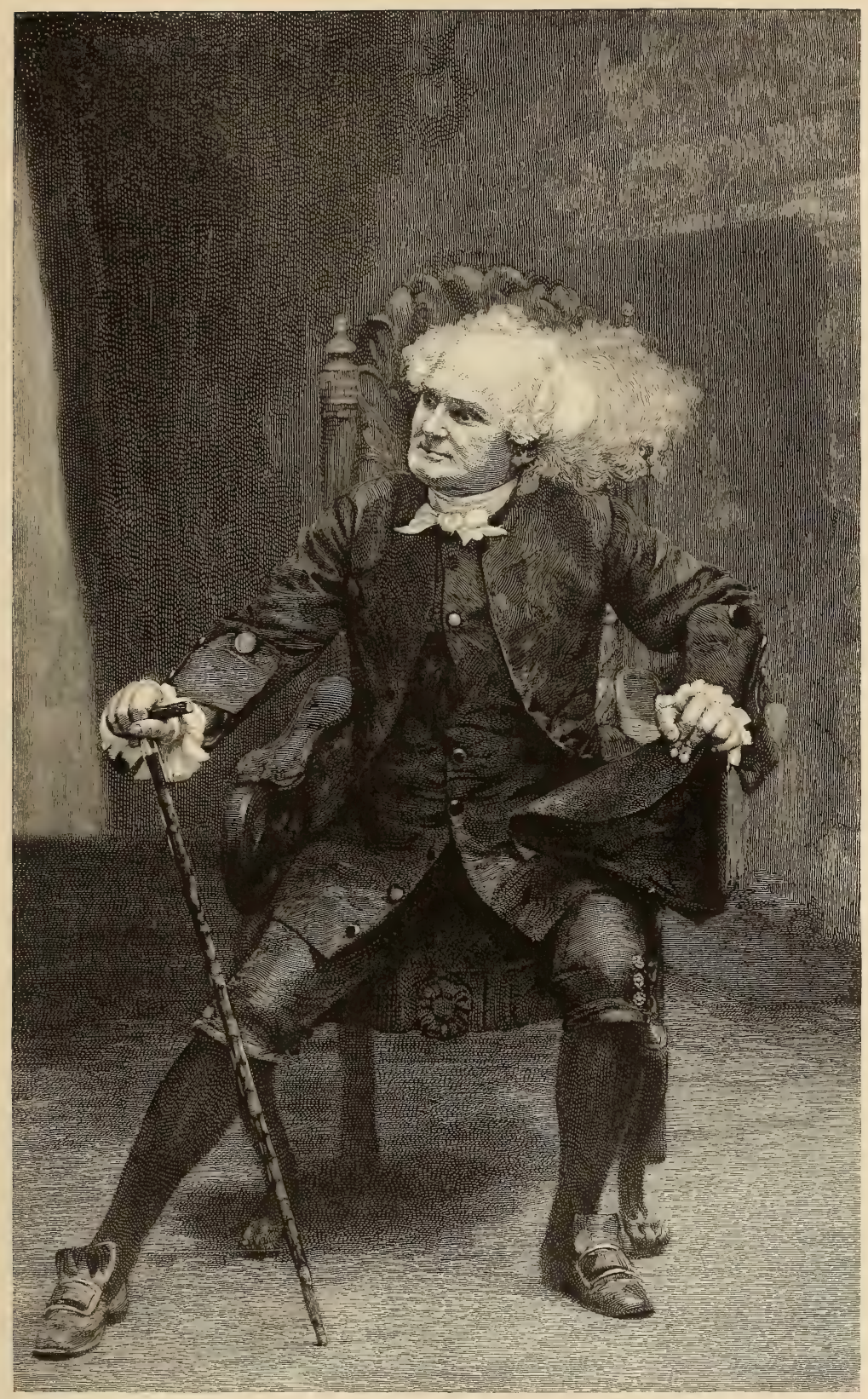

JOSEPH JEFFERSON AS "DR. PANGLOSS." 

of spirits when business was bad and salaries were uncertain.

Just at this juncture Miss Keene produced a local farcical comedy called "Splendid Misery" - a most appropriate title and well suited to the financial crisis through which the country was passing, and in keeping, too, with the straitened circumstances of many families that were suffering from their previous extravagance. There were several local hits in the play which pointed so plainly to the prevailing panic that they were much enjoyed by the slim audiences that beheld them.

Business had fallen off and the theater was in a fair way to follow in the train of bankruptcy that was dragging everything after it, when I hit upon the idea of producing what was deemed a shocking innovation in a legitimate Broadway theater. Casting about for a novel that might be turned into a strong military drama, I came upon George Lepard's Revolutionary story entitled "Blanche of Brandywine." Battles, marches and countermarches, murders, abductions, hairbreadth escapes, militia trainings, and extravagant Yankee comicalities boiled over in every chapter. James G. Burnett, the stage-manager, and I soon concocted a soul-stirring drama from this material and it was accepted by Miss Keene, the manageress.

She was most indefatigable in her rehearsals and spared neither time nor pains in planning her effects, but was greatly deficient in system, and while acknowledging that Mr. Burnett and I had prepared at least an effective play, 
she insisted upon arranging the business and conducting the rehearsals. Of course we gave way, being only anxious that success should be achieved, and were quite willing to allow her the credit of its production. She possessed but slight experience in melodrama, as her previous schooling had been mostly gained from the light comedy productions of the London Lyceum, or the legitimate plays that were produced at Wallack's Theater while she was a member of the stock company; so that when she got into the realm of red-hot conspiracies, blazing haystacks, and rifle-balls, she was quite at the mercy of the enemy.

The second act of our play ended with the battle of Bunker Hill, which I had arranged should be given as a tableau rather than as an action, from Trumbull's picture of the "Death of Warren" or "The Battle of Bunker Hill." It was so well known, and its leading features presented such a fine opportunity for effective grouping, that we decided to have the stage raised to represent a mound covered with grass, and to arrange the figures in exactly' the same manner as in the famous painting. On the morning the tableau was to be grouped, Miss Keene appeared with the engraving, which she unrolled with a proud air and Sir Oracle demeanor that was all the more amusing to me as I knew she was in deep water, and likely to sink at the first plunge. We (the company) were assembled and the stage-manager eyed us with a sidelong look of 
anything but approval. After a preliminary cough or two Miss Keene charged up the hill and prepared for action.

Looking over the scroll, which every now and then would keep rolling itself up, much to her annoyance and our smothered delight, she began to place us in our different and, I may say, difficult positions. One would be made to rest upon his elbow while another was arranged to stand over him with an uplifted gun. The next gentleman, a cruel British officer, was then told to be on the point of thrusting a bayonet into the vital regions of some American patriot. The wounded Warren was ordered to lie down in an uncomfortable position and be held by a friend. This was all very well, and for a brief period these attitudes could be maintained; but by the time Miss Keene had got through the militia the regular army was completely worn out. Then she began to badger Warren, telling him to lie with his head a little more that way, or a trifle more the other way, besides requesting him to look exhausted - which expression, however, under the circumstances, he had taken quite of his own accord.

"You are out of position again," Miss Keene would say to some old soldier. "Now observe, I want you to stand-well, look here," and away would go the scroll again as if it were on a spring roller.

"General Warren, you have got your head all wrong again."

"I cannot stand it," said the hero; "my head has been in that position for twenty minutes." 
I do not think that the original general could have suffered more than did his counterfeit on this occasion. By this time every one was exhausted, Miss Keene included, so there was nothing left but to dismiss the army and hold a council of war.

I now saw that the arrangement of a tableau from a picture with so many figures was a more difficult matter than I had at first imagined. Miss Keene declared that it could not be done at all, and I was myself beginning to think we were nonplussed, when Burnett came to the rescue with a simple suggestion which made the way clear at once. His idea was that the characters in the engraving should be cast just as they would be in a play. Thus each figure in the picture was marked with the name of the actor who was to represent it. The engraving was then hung up in the greenroom where each one could look at it and so study the attitude he was to take. This was caught up at once; their names were then marked upon the mound in chalk, and when the word was given to strike the tableau each one took the position, assumed his attitude, and the picture was complete.

I have alluded to this incident as I think it perhaps worth while to record a simple manner of arranging characters for a tableau from a picture.

Before concluding this incident I desire to pay my respects to Mr. James G. Burnett, as he was intimately connected with Laura Keene's theater both as an actor and stage-manager. Our friendship extended over a term of many years, and 


I cannot call to mind one act of his that was not characterized by honesty and truth. In the earlier part of his life he was sorely tried by an accumulation of domestic ills, and I know that he bore his troubles with patience and dignity. As an actor, during the latter part of his life he improved wonderfully; he acted Sir Anthony Absolute and Lord Duberly with me in St. Louis, and rendered them with fine effect.

During the season of $185^{8-59}$ Miss Keene produced Tom Taylor's play of "Our American Cousin," and as its success was remarkable and some noteworthy occurrences took place in connection with it, a record of its career will perhaps be interesting. The play had been submitted by Mr. Taylor's agent to another theater, but the . management failing to see anything striking in it, an adverse judgment was passed and the comedy rejected. It was next offered to Laura Keene, who also thought but little of the play, which remained neglected upon her desk for some time; but it so chanced that the business manager of the theater, Mr. John Lutz, in turning over the leaves fancied that he detected something in the play of a novel character. Here was a rough man, having no dramatic experience, but gifted with keen, practical sense, who discovered at a glance an effective play, the merits of which had escaped the vigilance of older and, one would have supposed, better judges. He gave me the play to read. While it possessed but little literary merit, there was a fresh, breezy atmosphere about the 
characters and the story that attracted me very much. I saw, too, the chance of making a strong character of the leading part, and so I was quite selfish enough to recommend the play for production.

The reading took place in the greenroom, at which the ladies and gentlemen of the company were assembled, and many furtive glances were cast at Mr. Couldock and me as the strength of Abel Murcott and Asa Trenchard were revealed. Poor Sothern sat in the corner, looking quite disconsolate, fearing that there was nothing in the play that would suit him; and as the dismal lines of Dundreary were read he glanced over at me with a forlorn expression, as much as to say, "I am cast for that dreadful part," little dreaming that the character of the imbecile lord would turn out to be the stepping-stone of his fortune. The success of the play proved the turning-point in the career of three persons Laura Keene, Sothern, and myself.

As the treasury began to fill, Miss Keene began to twinkle with little brilliants ; gradually her splendor increased, until at the end of three months she was ablaze with diamonds. Whether these were new additions to her impoverished stock of jewelry, or the return of old friends that had been parted with in adversity,-old friends generally leave us under these circumstances, - I cannot say, but possibly the latter.

The dramatic situation that struck me as the most important one in this play was the love scene 
in the opening of the last act. It was altogether fresh, original, and perfectly natural, and I notice that in this important phase of dramatic composition authors are conspicuously weak.

The love scenes in most all of our modern plays are badly constructed. In the English dramas they are sentimental and insipid, being filled with either flowery nonsense or an extravagance bordering upon burlesque; while the love scenes in the French plays are coarse and disgusting. Sardou has written but few female characters for whom one can feel the slightest respect. For instance, which one would a man select to be his mother were he compelled to make a choice? I think it would puzzle him. The love scenes between Alfred Evelyn and Clava Douglas, in Bulwer's play of "Money," are stilted, unnatural, and cold. The passages intended to display affection in the "Lady of Lyons" are still further from "imitating humanity," and the speech of Claude to Pauline, beginning with

In a deep vale shut out by alpine hills

is so glaringly absurd that the audience invariably smile at the delivery of this soft extravagance.

The greatest love scene that ever was or ever will be written is known as the balcony scene in "Romeo and Juliet." This is a perfect model, being full of the most exquisite humor.

Natural love off the stage is almost invariably humorous, even comic - not to the lovers' minds ; oh, no! ' $T$ is serious business to them, and that is just what makes it so delightful to look at. The 
third party, when there is one, enjoys it highly. The principals do the most foolish things: the gentleman cannot make up his mind what to do with his hat or with his hands, the lady is awkward and shy, and the more they love each other the more comical they are. They say stupid things, and agree with each other before they have half done expressing an opinion.

It was the opportunity of developing this attitude of early love, particularly love at first sight, that attracted me to the "Cousin." Simple and trifling as it looks, Mr. Tom Taylor never drew a finer dramatic picture. The relation between the two characters was perfectly original. A shrewd, keen Yankee boy of twenty-five falls in love at first sight with a simple, loving, English dairymaid of eighteen. She innocently sits on the bench, close beside him; he is fascinated and draws closer to her; she raises her eyes in innocent wonder at this, and he glides gently to the farthest end of the bench. He never tells her of his love, nor does she in the faintest manner suggest her affection for him; and though they persistently talk of other things, you see plainly how deeply they are in love. He relates the story of his uncle's death in America, and during this recital asks her permission to smoke a cigar. With apparent carelessness he takes out a paper, a will made in his favor by the old man, which document disinherits the girl; with this he lights his cigar, thereby destroying his rights and resigning them to her. The situation is strained, certainly, but it is very effective, and an audience 


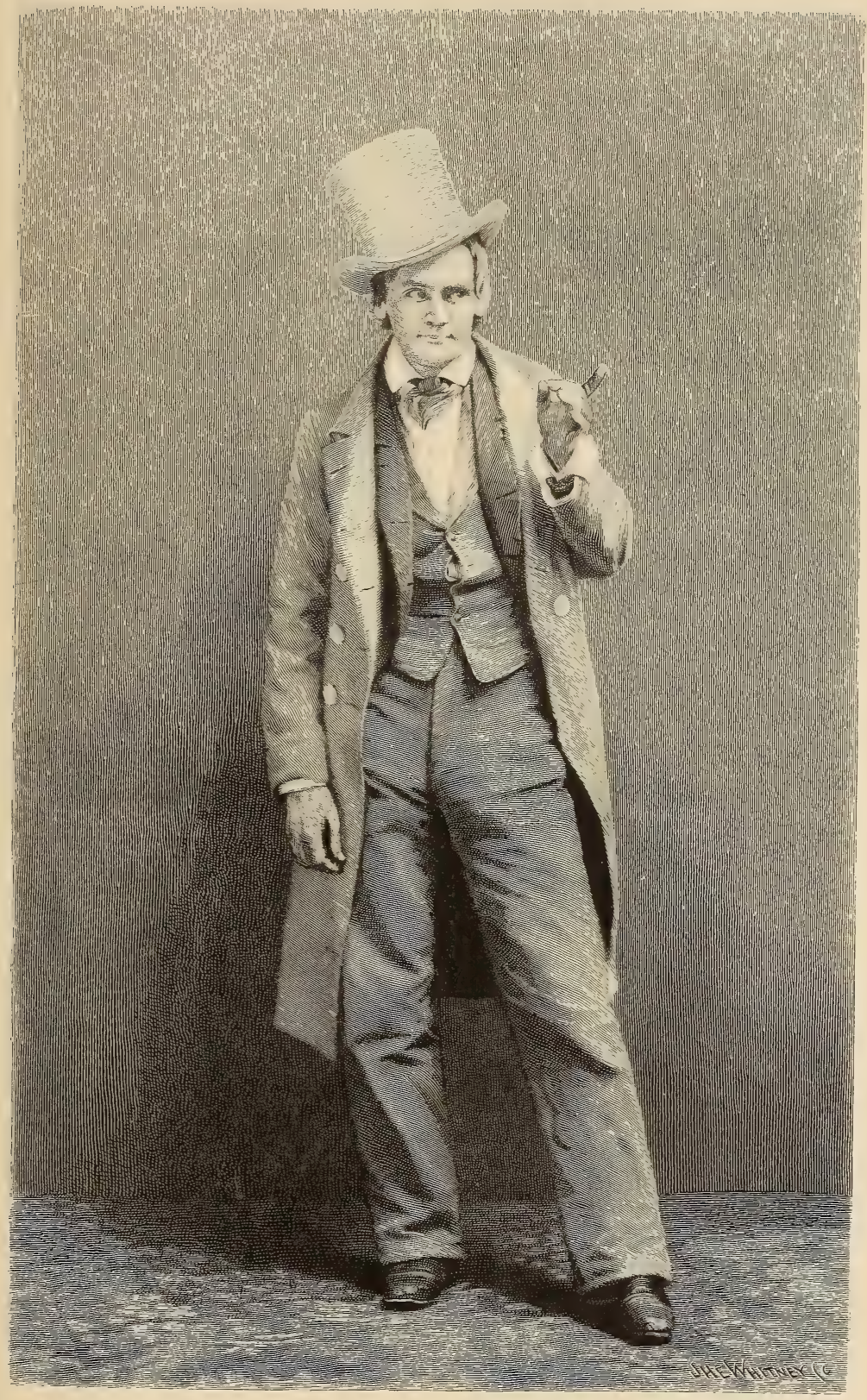

JOSEPH JEFFERSON AS "ASA TRENCHARD." 

will always pardon a slight extravagance if it charms while it surprises them. The cast was an exceedingly strong one - Laura Keene as the refined, rural belle, and Sara Stevens as the modest, loving, English dairymaid. Both looked and acted the parts perfectly. The Abel Murcott of Mr. Couldock was a gem, and the extravagant force and humor of Mr. Sothern's Dundreary, the fame of which afterwards resounded all over the Englishspeaking world, is too well known to need any comment, except perhaps to mention one or two matters connected with it of a curious nature.

As I have before said, Sothern was much dejected at being compelled to play the part. $\mathrm{He}$ said he could do nothing with it, and certainly for the first two weeks it was a dull effort, and produced but little effect. So in despair he began to introduce extravagant business into his character, skipping about the stage, stammering and sneezing, and, in short, doing all he could to attract and distract the attention of the audience. To the surprise of every one, himself included, these antics, intended by him to injure the character, were received by the audience with delight. He was a shrewd man as well as an effective actor, and he saw at a glance that accident had revealed to him a golden opportunity. He took advantage of it, and with cautious steps increased his speed, feeling the ground well under him as he proceeded. Before the first month was over he stood side by side with any other character in the play; and at the end of the run he was, in my opinion, considerably in advance of us all. 
And his success in London, in the same character, fully attests, whatever may be said to the contrary, that as an extravagant, eccentric comedian in the modern range of comedy he was quite without a rival. His performance of Sam which I saw at the Haymarket Theater, in London, was a still finer piece of acting than his Dundreary. It was equally strong, and had the advantage of the other in not being overdrawn or extravagant.

Miss Keene was undoubtedly delighted at Sothern's rising fame. I think she found that I was becoming too strong to manage, and naturally felt that his success in rivaling mine would answer as a curb, and so enable her to drive me with more ease and a tighter rein. I don't blame her for this : as an actor has a right to protect himself against the tyranny of a manager, the manager has an equal right to guard the discipline of the theater; and I have no doubt that I perhaps unconsciously exhibited a confidence in my growing strength that made her a little apprehensive lest I should try to manage her. In this she did me an injustice, which I am happy to say in after years the lady acknowledged. The first rupture between us came about somewhat in this way: The Duchess - as she was familiarly called by the actors, on the sly - had arranged some new business with Mr. Sothern, neglecting to inform me of it. I got the regular cue for entering, and as I came upon the stage I naturally, but unintentionally, interrupted their preconceived arrangements. This threw matters into a confusion which was quite apparent to the audience. 
Miss Keene, not stopping to consider that I had been kept in ignorance of her plan and that the fault was hers and not mine, turned suddenly on me, and speaking out so loudly and plainly that most of the audience could hear her, said, "Go off the stage, sir, till you get your cue for entering."

I was thunderstruck. There was a dead silence for a moment, and in the same tone and with the same manner she had spoken to me, I replied:

"It has been given, and I will not retire."

We were both wrong. No actor has a right to show up to the audience an accident or a fault committed on the stage, or intrude upon them one's personal misunderstandings. As two wrongs cannot make a right, it was clearly my duty to pass this by, so far as any public display of my temper was concerned, and then demand an explanation and an apology from her when the play was over. But

Who can be wise, amazed, temperate and furious, Loyal and neutral, in a moment?

Besides, I felt that no explanation of hers could set me right with the audience, and I was smarting under the injustice of her making me appear responsible for her own fault.

When the curtain fell she was furious, and turning on me with flashing eyes and an imperious air discharged me then and there. I might leave now if I liked, and she would dismiss the audience rather than submit to such a public insult. I told her that if she considered my conduct an insult to her, that it was a confession that she had insulted 
me first, as my words and manner were but a reflection of her own. This sort of logic only made matters worse. So I informed her that I could not take a discharge given in the heat of temper, and would remain. The play proceeded, but she was singularly adroit, and by her manner in turning her back on me through an entire scene, and assuming an air of injured innocence, undoubtedly made the audience believe that I was a cruel wretch to insult her in so public a way. She had the advantage of me all through, for when her temper was shown to me the play was proceeding, and I dare say that in the bustle and confusion of the scene very few of the audience could understand what she had done; whereas when I retaliated there had been a pause, and they got the full force of what I said.

When an actor shows his temper upon the stage the audience feel insulted that they should be called upon to sympathize with his private quarrels. The actor is the loser, depend upon it.

Mr. Rufus Blake was attached to our company during this season, but in consequence of the great success of "Our American Cousin," in which he was not cast, he had acted but little. He was a superior actor, with the disadvantage of small eyes, a fat, inexpressive face, and a heavy and unwieldy figure. There must be something in the spirit of an actor that is extremely powerful to delight an audience when he is hampered like this. Without seeming to change his face or alter the stolid look from his eyes, Mr. Blake conveyed his meaning 


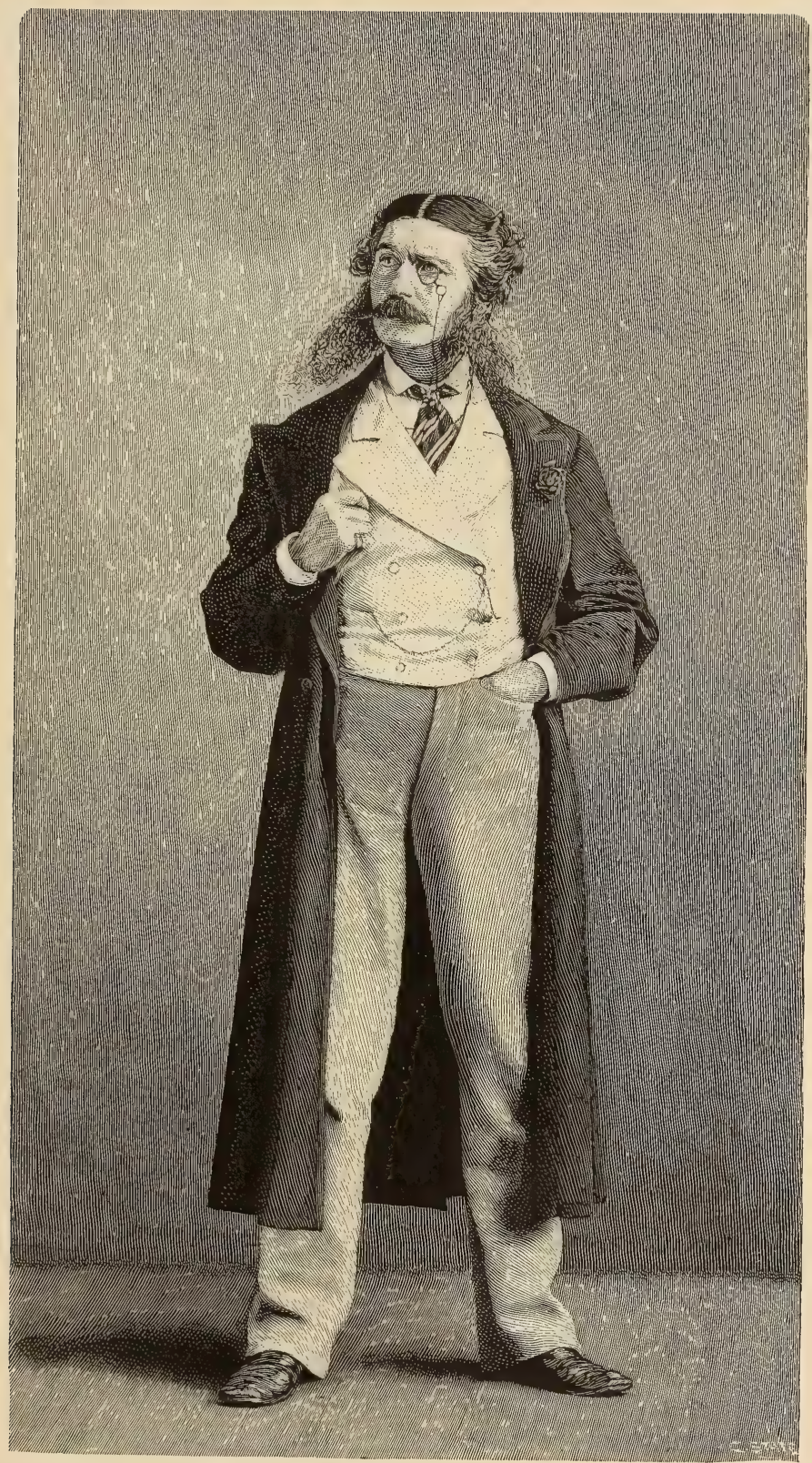

E. A. SOTHERN AS "LORD . DUNDREARY." 

with the most perfect effect. He was delicate and minute in his manner, which contrasted oddly enough with his ponderous form. We acted this one season together and were very good friends. On one occasion only was this harmony marred. He rated me for curtailing some of the speeches of a part in one of the old comedies. I told him that I had my own ideas on these matters, one of which was that the plays were written for a past age, that society had changed, and that it seemed to me good taste to alter the text, when it could be done without detriment, to suit the audience of the present day; particularly when the lines were coarse, and unfit for ladies and gentlemen to speak or listen to. He gave me to understand that he considered it a liberty in any young man to set himself up as an authority in such matters, and that my course was a tacit reproach to older and better judges, and even hinted that some people did that sort of thing to make professional capital out of it. I thought this was going a little too far for friendship. I therefore told him, with little reserve, that as he had taken the liberty to censure my course, I would make bold equally, and advise him, for his own sake, to follow my example.

I do not cite this quarrel as redounding to my credit. Mr. Blake was a much older man than $I$, and more than my peer as an actor besides. It was not only my words; I was angered, and doubtless my manner was more offensive than what I had said. I apologized, however, and we were friends. 
As Laura Keene's season drew to a close she and I had buried our differences and were comparatively good friends again; so the lady was somewhat surprised to learn that I was not going to remain with her during the following season, and seemed to consider it unkind of me to withdraw from the theater after she had done so much to advance my position. This is the somewhat unjust ground that managers often take when an actor desires to go to another house. This is unreasonable, for there must come a time when it will be for the interest of one or both parties that they should part; and it would be just as wrong at one time as at another. If an actor, when the season is concluded and his obligations are at an end, sees an opportunity of increasing his salary or bettering his position by going to another establishment, it would be an injustice to himself and to those who depend upon him not to do so. And by the same reasoning, if a manager can secure better talent, at a more reasonable price, he has a perfect right to replace one actor by another, having fulfilled his engagement. I have never known any manager to hesitate in pursuing this course, unless he retained the actor as an act of charity, and then, of course, the matter is a purely personal one.

Miss Keene, taking the unfair view I have alluded to, was highly incensed at my proposed departure. She considered that, having been the first to bring me to New York, to her my loyalty was due, and in common gratitude I was bound not to desert the theater for the purpose, as she sup- 
posed, of joining the opposition forces. I replied that, so far as my ingratitude was concerned, I failed to see in what way she had placed me under obligations; that I presumed when she engaged me for her theater it was from a motive of professional interest, and I could scarcely think it was from any affection for me, as we had never met until the engagement was made. This kind of logic had anything but a conciliating effect. So I concluded by saying that I had no idea of casting my lot with the opposition, but that it was my intention to star. "Star! Oh, dear! Bless me! Indeed!" She did not say this, but she certainly looked it; and as she turned her eyes heavenward there was a slight elevation in the tip of her beautiful nose that gave me no encouragement of an offer from her under these circumstances. With a slight tinge of contempt she asked me with what I intended to star. I answered that, with her permission, I purposed to act "Our American Cousin." "Which I decline to give. The play is my property, and you shall not act it outside of this theater." And she swept from the greenroom with anything but the air of a comédienne.

The houses were still overflowing, and there was every prospect that "Our American Cousin" would run through the season; but Miss Keene was tired of acting her part in the comedy, and was determined to take the play off and produce "A Midsummer Night's Dream," which had been in preparation for some time, and in fact was now in readiness. The management was anxious that 
Mr. Blake, who had been idle for some four months, should be in the cast, so that the play might contain the full strength of its expensive company.

The Duchess, being in high dudgeon with me, deputed her business manager, Mr. Lutz, to approach me on the subject of the cast, proposing that I should resign the part of Bottom to Mr. Blake, and at the same time requesting me to play Puck. This I positively refused to do. I told him plainly that Miss Keene had taken an antagonistic stand towards me, and that I felt that she would not appreciate a favor even if I might feel disposed to grant it, and would treat any concession that I should make as weakness. He said that Miss Keene had begged him to urge the matter, as she did not know how else to get Mr. Blake and myself into the cast. "Very well," said I; "if that is all, tell her I will play Bottom, and let Mr. Blake play Puck." And so we parted. Of course I did not suppose that he would carry this absurd message, as Mr. Blake would have turned the scale at two hundred and fifty pounds, and looked about as much like Puck as he resembled a fairy queen. But, not being familiar with Shakspere, and having no idea what the characters were like, he gave her my suggestion word for word. This put the fair lady in a high temper, and she did not speak to me for a week. But I stood on my rights, and was cast for Bottom, Miss Keene essaying the part of Puck herself. After three or four rehearsals I discovered I 


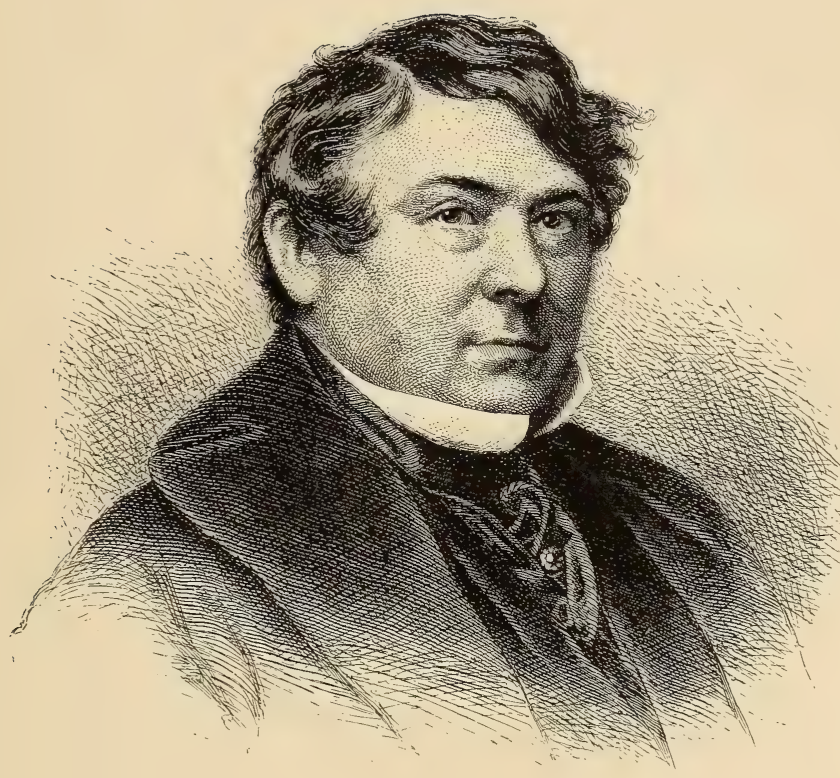

W. R. BLAKE. 

should fail in the part of Bottom, and therefore deemed it wise to make "discretion the better part of valor," and resign the character, which I did upon the condition that I might take the play of "Our American Cousin" upon a starring tour, and give the management one-half of the profits for the use of the play.

I have thought that perhaps it is scarcely in good taste that I should touch upon the little misunderstandings between myself and Miss Keene; but as these quarrels were not of a domestic or private nature, and as the public were made fully aware of them at the time, there is nothing sacred about them, and they may serve as lessons in the future to younger and as yet inexperienced actors. And then, too, Miss Keene and I were friends in after years; we had long since shaken hands and buried the hatchet - had talked and laughed over our rows and reconciliations, and had continued to get as much amusement out of the recollections as we had created trouble out of the realities.

When I returned from Australia we met again. She had lost her theater, and was traveling and starring with only partial success. Her early popularity had waned, but she battled against adversity with great courage. At last her health gave way, and she retired, but still with the clinging hope of returning to the stage again. She never did. The last letter she wrote was penned upon her death-bed, and was addressed to me. She sent me an ivory miniature of Madame Vestris, and a water-color drawing, by Hardy, of 
Edmund Kean as Richard III. Her letter was cheerful and full of hope; she spoke of feeling better, and seemed confident that in a few months she would be in harness again. She died the day after this was written.

She was esteemed a great beauty in her youth; and even afterwards her rich and luxuriant auburn hair, clear complexion, and deep chestnut eyes, full of expression, were greatly praised; but to me it was her style and carriage that commanded admiration, and it was this quality that won her audience. She had, too, the rare power of varying her manner, assuming the rustic walk of a milkmaid or the dignified grace of a queen. In the drama of "The Sea of Ice" she displayed this versatile quality to its fullest extent. In the prologue she played the mother, in which her quiet and refined bearing told of a sad life; in the next act, the daughter, a girl who had been brought up by savages, and who came bounding upon the stage with the wild grace of a startled doe. In the last act she is supposed to have been sent to Paris and there educated. In this phase of the character she exhibited the wonderful art of showing the fire of the wild Indian girl through the culture of the French lady. I have never seen this transparency more perfectly acted.

Laura Keene was in private life high tempered and imperious, but she had a good heart and was very charitable. I never heard her speak ill of any one but herself; and this she would sometimes do with a grim humor that was very entertaining. 


\section{Chapter VIII}

AT THE WINTER GARDEN ; AND " RIP VAN WINKLE"

The Winter Garden-"Caleb Plummer"-I Receive Good Advice - "The Octoroon"-Some Remarks on Guying - The Comedian's Disadvantage - The First Successful Star Comedian-How I Came to Play "Rip Van Winkle" - Failure in San Francisco - Harry Perry

$1 \begin{aligned} & \text { y starring venture was attended with what } \\ & \text { is termed qualified success; not with what } \\ & \text { could be called positive failure; still I felt }\end{aligned}$ that the time had not yet arrived for the continuance of such a rash experiment. Just at this juncture William Stuart made me an offer of an engagement at his new theater, the Winter Garden, which place was to be under the direction of Dion Boucicault. I accepted the offer, at a much larger salary than I had ever received, and was enrolled as a member of the company. The title of "Winter Garden" had been adopted from a place of amusement in Paris, where plays were acted in a kind of conservatory filled with tropical plants. If I remember rightly, the treasury of the 
management was not in what could be called an overflowing condition; and although the actors whom they engaged were quite strong, the horticultural display was comparatively weak. Some sharp-pointed tropical plants of an inhospitable and sticky character exuded their "medicinal gums" in the vestibule, and the dress circle was festooned with artificial flowers so rare that they must have been unknown to the science of botany. To give these delicate exotics a sweet and natural odor they were plentifully sprinkled with some perfume resembling closely the sweet scent of hair-oil, so that the audience as they were entering could "nose" them in the lobby. Take it altogether, the theater was a failure; for, added to the meager decorations, the acoustics were inferior, and the views of the stage from the auditorium unpardonably bad. To make amends, however, for these shortcomings, Mr. Boucicault had secured a strong company; not so far as great names were concerned, but they had been carefully selected with regard to the plays that were to be produced. The opening piece was an adaptation of Dickens's "Cricket on the Hearth," and called "Dot." It was a hit. The cast was as follows:
John Peerybingle . . . . . . Mr. Harry Pearson.
Caleb Plummer .. . . . . . . Mr. Joseph Jefferson.
The Stranger . . . . . . . Mk. A. H. Davenport.
Tackleton . . . . . . . . Mr. T. B. JoHnson.
Dot . . . . . . . . . . Miss Agnes Robertson.
May Fielding . . . . . . . Mrs. J. H. Allen.
Bertha . . . . . . . . Miss SARa Stevens.
Tillie Slowboy . . . . . . Mrs. John WoOd.
Mrs. Fielding . . . . . . . Mrs. Blake. 


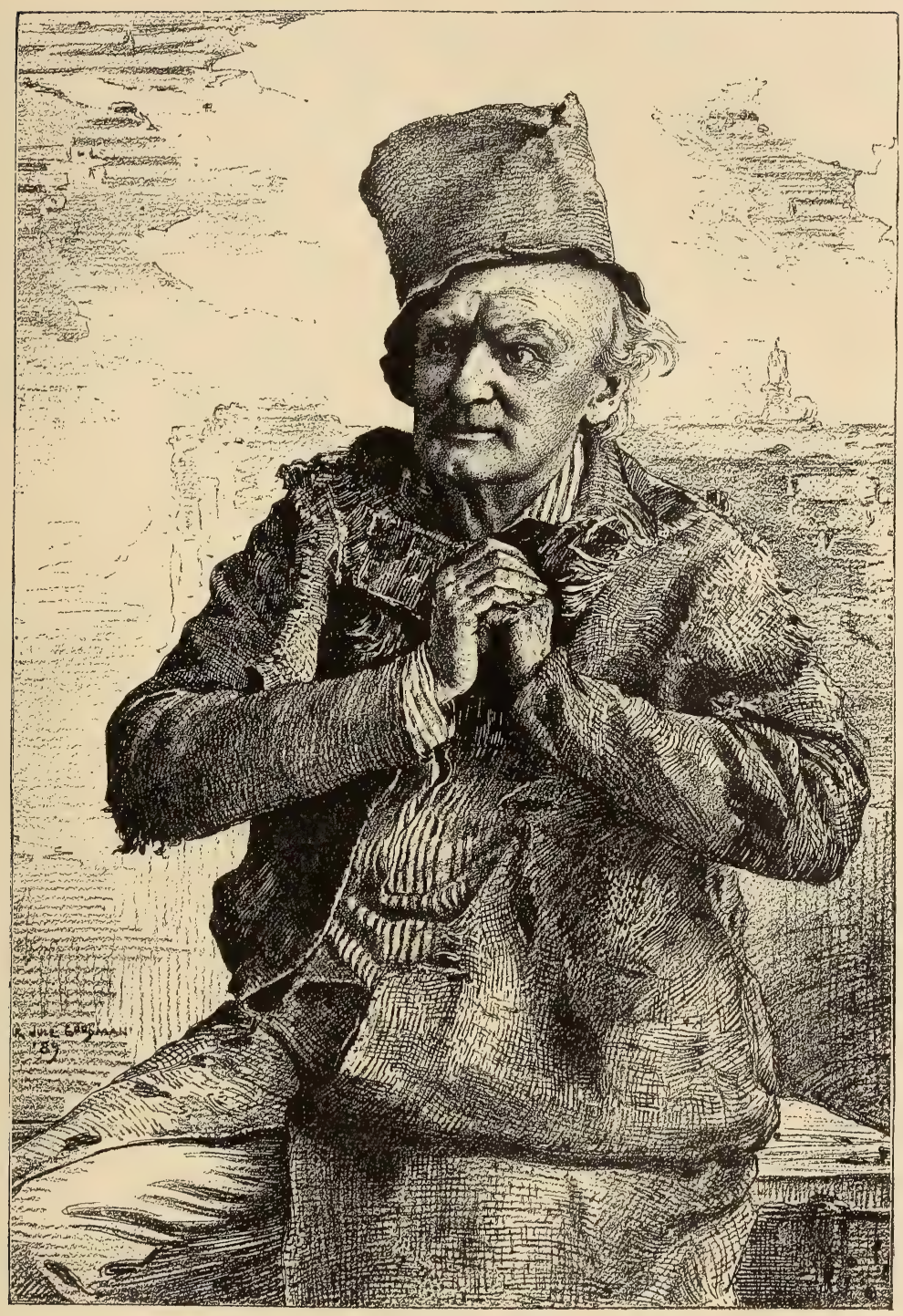

JOSEPH JFFFERSON AS "CALEB PLUMMER." 

The four ladies first named were the pictures of female grace and beauty. This season I acted Nerwman Noggs, Caleb Plummer, Salem Scudder, and several other characters; but the latter were not very important.

Previous to the commencement of the season, Mr. Boucicault and I had some conversation in relation to the opening bill. I told him I was rather apprehensive of my hitting the part of Caleb Plummer, as I had never acted a character requiring pathos, and, with the exception of the love scene in "Our American Cousin," as yet had not spoken a serious line upon the stage. He seemed to have more confidence in my powers than I had, and insisted that I could act the part with success. I agreed therefore to open in Caleb, with the understanding that I should finish the performance with a farce, so in the event of my failing in the first piece, I might save my reputation in the last. He assented to the arrangement, but warned me, however, that I would regret it; and he was right, for when the curtain fell upon "Dot," I should have much preferred not to have acted in the farce. So the little piece was taken off after the first night, as I was quite satisfied with Caleb alone.

An incident occurred during the first rehearsal of "Dot" that may be worth relating, as it bears upon a theory in acting that I have established for myself ever since it took place. Mr. Boucicault, I think, understood me, and felt from what I had said to him on previous occasions that I was not 
averse to suggestions in the dramatic art, and was in the habit of listening to advice, though I always reserved to myself the right of acting on my own judgment as to whether the proffered counsel was good or bad. During my rehearsal of the first scene, which I went through just as I intended acting it at night, I saw by his manner that he was disappointed with my rendering of the part, and I asked him what was the matter. He replied, "If that is the way you intend to act the part I do not wonder you were afraid to undertake it." This was a crushing blow to a young man from one older in years and experience; but feeling that there was something to learn, I asked him to explain what he meant. "Why, you have acted your last scene first; if you begin in that solemn strain. you have nothing left for the end of the play." This was his remark, or words to the same effect; and I am certainly indebted to him, through this advice, for whatever success I achieved in the part.

I am not sure whether Mr. Boucicault was aware of what a large field for dramatic thought he opened up, and if I did not clearly understand the importance of it then, I have found it out since, and so far as I have been able applied it as a general rule. These reflections taught me never to anticipate a strong effect; in fact, to lead your audience by your manner, so that they shall scarcely suspect the character capable of such emotion; then, when some sudden blow has fallen, the terrible shock prepares the audience for a new and 
striking phase in the character: they feel that under these new conditions you would naturally exhibit the passion which till then was not suspected.

Rising young actors usually guard their positions with a jealous eye, and, as I was no exception to this rule, it had been clearly understood between me and the management that my name should be as prominently set before the public as that of any other member of the company. This agreement was not carried out; for, on the announcement in the papers of the play of "The Octoroon," my name did not appear. I was to act one of the principal parts in the drama. I felt that I was something of a favorite with the public, and naturally became irate at this indignity; so I sent my part, Salem Scudder, to the theater, with a note to Mr. Stuart, saying that I considered my engagement canceled by my name being publicly ignored in the announcement of the play, and I concluded my resignation by saying that, as I had no wish to distress the management, if Mr. Stuart or Mr. Boucicault would call on me I would be pleased to enter into a new engagement with them when my claims should be written out to prevent any further misunderstanding; otherwise I must decline to act again in the theater. As the play was ready and to be acted on the following Monday night, this being Saturday, I felt pretty sure that my note of resignation would act as a bombshell and explode with considerable force in the managerial office. And it did. 
But I must now digress in order to show the sequel of the story. I had been for some time suffering with an attack of dyspepsia,- not a happy condition for an actor who is quarreling with the manager,-and conceived the idea that gentle exercise in the way of boxing would relieve me. So I engaged a professor, in the shape of an old retired "champion of light-weights," to give me lessons in the manly art of self-defense for the sum of two dollars per lesson, in consideration of which he was to allow me to pommel him over the head with soft gloves ad libitum. In our contract it was understood that I was the party of the first part, and the party of the second part agreed, never, under any consideration, to counter on the party of the first part. These lessons had been going on in my drawing-room - my teacher coming to the house - for several weeks, and I fancied that I was improving; certainly I was, so far as hittingout went, for, as I observed before, according to the contract I had it all my own way.

On the occasion I am now about to describe I had been perhaps taking unwarranted liberties with the "champion," who must have got a little excited, for before I knew where I was I found myself stretched full length under the piano. I expostulated with him, informing him solemnly that this was the second breach of contract I had suffered from him during the last two days, and begged him in the future to subdue the old warhorse within him. In fact, I said that I would prefer to pay a little extra if he would conform to 


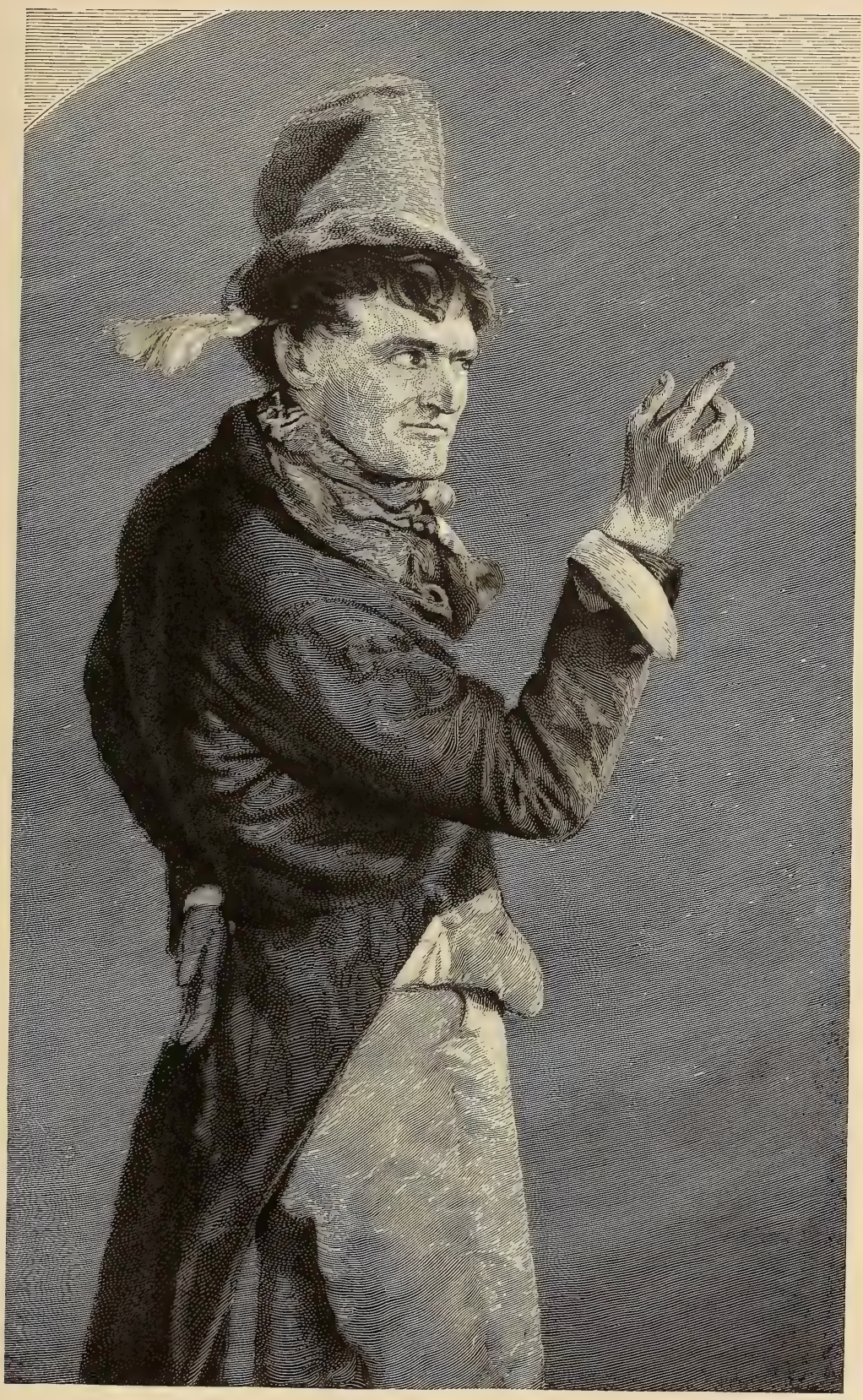

JOSEPH JEFFERSON AS "NEWMAN NOGGS." 

the contract more rigidly. We shook hands and began work again. My feelings were hurt, to say the least of it, and I was determined to get even with him. I now began to dance around my adversary in the conventional style, and had just given him "one for his nob," when looking over his shoulders I discovered the amazed faces of Dion Boucicault and William Stuart. Against the dark background of the room the two heads of these gentlemen loomed up like another pair of boxinggloves. They stood aghast at the scene, and I fancy it must naturally have entered their minds that I had invited them up to settle our difficulties by an appeal to science, and had secured the services of a professional bruiser to assist me. But the record of these gentlemen, like my own, proves that we are, pugilistically speaking, men of peace; so if they had any doubt, their alarm was soon set at rest by my dismissing the light-weight and politely begging them to be seated.

We soon came to a more explicit understanding, and the matter was settled without any reference to the "Marquis of Queensberry." The truth of the matter is that they were very anxious for me to act the part, and I was equally anxious to play it. With these feelings underlying the difficulty, there was no occasion for arbitration. The quarrels between manager and actor are never very serious. As with loving couples, the slightest advance on either side soon brings about a reconciliation.

The history of "The Octoroon" is well known. It dealt with the one absorbing subject of slavery, 
and was produced at a dangerous time. The slightest allusion to this now-banished institution only served to inflame the country, which was already at a white heat. A drama told so well had a great effect on the audience, for there was at this time a divided feeling in New York with regard to the coming struggle. Some were in favor of war, others thought it best to delay, and, if possible, avert it ; and it was deemed unwise, if not culpable, by many for us to act "The Octoroon" at such a time. Then there were various opinions as to which way the play leaned - whether it was Northern or Southern in its sympathy. The truth of the matter is, it was non-committal. The dialogue and characters of the play made one feel for the South, but the action proclaimed against slavery, and called loudly for its abolition. When the old negro, just before the slave sale, calls his colored "bredrin" around him and tells them they must look their best so as to bring a good price for the "missis," and then falling on his knees asks a blessing on the family who had been so kind to them, the language drew further sympathy for the loving hearts of the South; but when they felt by the action of the play that the old darky who had made them weep was a slave, they became abolitionists to a man.

When $Z o e$, the loving octoroon, is offered to the highest bidder, and a warm-hearted Southern girl offers all her fortune to buy Zoe and release her from the threatened bondage awaiting her, the audience cheered for the South; but when again 
the action revealed that she could be bartered for, and was bought and sold, they cheered for the North as plainly as though they had said, "Down with slavery." This reveals at once how the power of dramatic action overwhelms the comparative impotency of the dialogue.

Among the well-remembered characters of my dramatic life was an actor named Salisbury. The only influence that he exerted upon the stage during his career was, I regret to say, anything but a good one. "Guying" was formerly a slang term, but it has of late years become a technical one for trifling with a part upon the stage. The art of guying was Mr. Salisbury's forte, and it was the only thing that he did well. Life was one huge joke to him: he treated nothing seriously. He was the delight of actors and the bane of managers. It is related of him that he once sent a telegram to Mr. Rice of the Chicago Theater applying for an engagement. The manager sent back this answer: "I would not engage you if you would come for nothing"; to which Salisbury replied: "Terms accepted. Will be with you to-morrow."

This man's memory was so wonderful that it was almost impossible to ask him a question without getting a Shaksperean quotation in reply. If he was imperfect in his part, which was generally the case with him, he would interpolate speeches from other characters, talking the most absurd nonsense, and turning a serious scene into ridicule. Sometimes the audience, detecting this impertinence, would hiss. This rebuke was the 
only thing that would check him, for any slight put upon himself was keenly felt; but the next night the chastisement would be forgotten, and he would repeat his indiscretion. It was said of him that he was generous to a fault; and I think he must have been, for he never paid his washerwoman. One morning the poor old laundress was dunning him for her hard earnings. He was standing at the stage door, surrounded by a circle of admirers, and turning furiously upon the old woman, he paraphrased Macbeth's speech to the ghost of Banquo in the following words: "Avaunt, and quit my sight! Thy tubs are marrowless; there is no starch in my fine shirts that thou didst glare withal! Approach thou like the Russian manager, the Hyrcan critic, or the 'Old Rye whisky-us'; or, be alive again, and make it salary day. If, trembling then, I do inhibit thee, confess me but a babe of a Salisbury." The laundress fled in despair, only too glad to escape unpaid from the supposed lunatic.

Innocent mirth is most desirable, but not mirth expended at the cost of another's feelings; and Salisbury's unfortunate career, terminating as it did in sickness and poverty, is an example of a handsome man, possessed of fair ability, who, by utter disregard of loyalty to his manager and of respect for the public, gradually lost the confidence of all who knew him, and became a neglected wreck. The practice of guying is unpardonable, and the indulgence in it unworthy of an artist or a gentleman. The leisure hours passed in the dressing-room or the greenroom afford ample time for an 


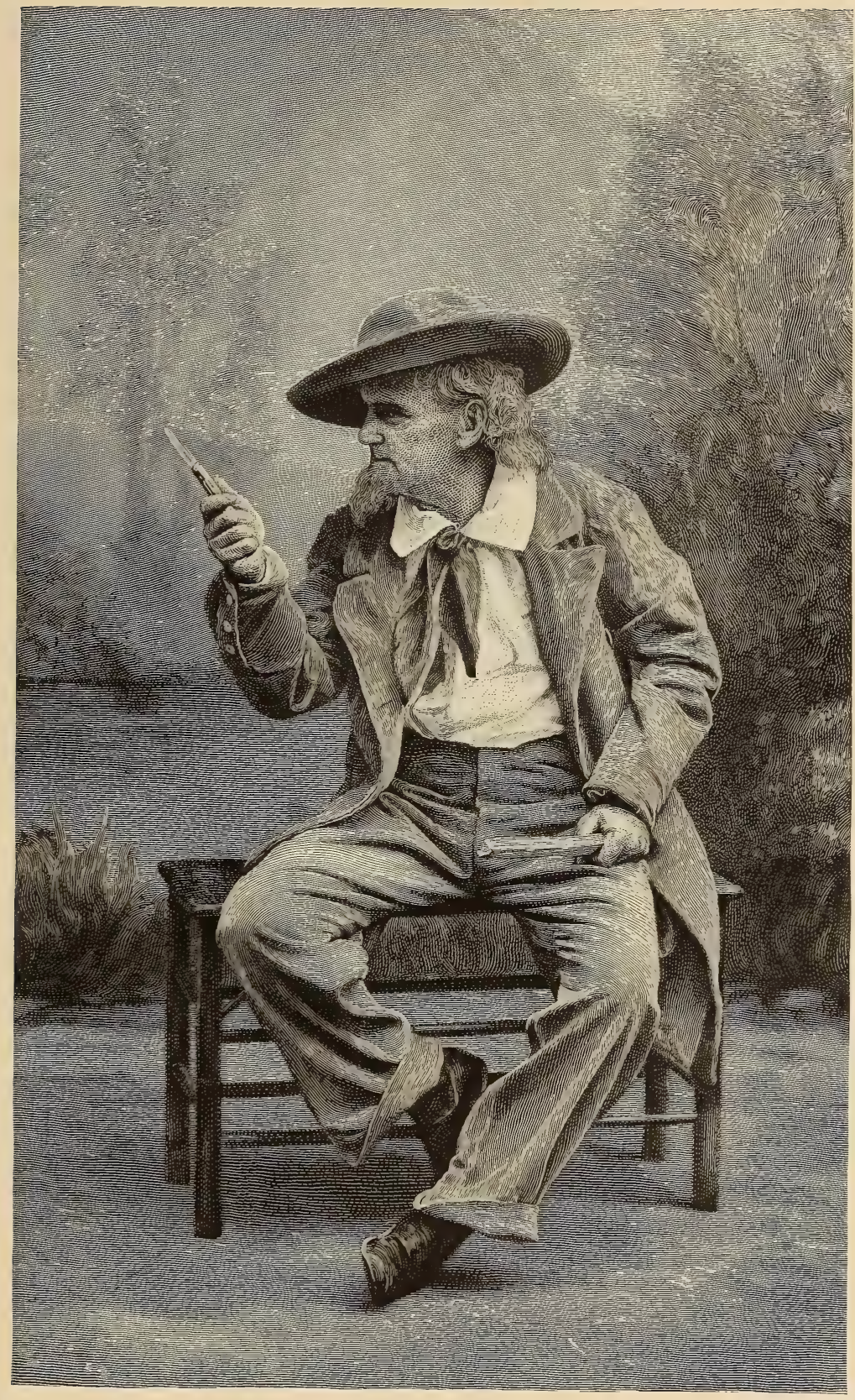

JOSEPH JEFFERSON AS "SALEM SCUDDER." 

actor's amusement without inflicting the exuberance of his personal humor upon the audience. The rehearsals and subsequent performances of a play are not his property, and he has no right to mutilate them. Managers and leading actors are altogether too lax in their rebuke of this senseless and ruinous practice. They should neither commit the outrage themselves nor permit it in others. "Where example leads the way" the multitude will follow, and no leader can rightly claim the respect of his company unless he shows it to them and the public. I have a suspicion that guying begins where ability leaves off, and that many actors exhibit this trifling to conceal their own shortcomings.

I believe it is the ostrich which runs his head into the sand, thinking that if he does n't see his pursuer his pursuer can't see him. I wish, for the sake of simile, that it were the goose. Actors are often under the erroneous impression that their auditors do not observe these little bits of trifling. They not only observe them, but they resent them in a quiet and dangerous way - they do not come again. Having paid their money, and perhaps foregone the pleasure they could have enjoyed somewhere else, it suddenly comes upon them that they have been taken in, and are sitting in front of the theater only to witness the enjoyment of the actors, who are reveling in some private joke and refuse to let them into the secret; and as they walk home, pondering on their experience, they determine within themselves never to risk a repetition of the occurrence. 
An actor, perhaps a good one, too, comes gaily on the stage. The audience like him and give him a hearty welcome; an evening's enjoyment has been promised, and they are in high expectation of the compact being fulfilled. Ah! who are those young fellows in the private box? Quite a jolly party, I declare. They know the comedian, too; see, he recognizes them. Now the comedianjust for fun, you know; he does n't mean any harm by it -introduces some joke: foreign to the play, to be sure; but then the private box recognize it at once as some allusion to their last merrymaking. How they do enjoy it! Now a friendly wink, they laugh again; it 's delightful. But how about the audience all this time? What are they doing while all this sport is going on? I will tell you. They are not hissing, to be sure,-well-bred American audiences seldom forget themselves so far, for they feel this breach of decorum would interfere with the enjoyment of others, - but they are determining within their minds that they are insulted, and that they will never come again to see that actor. He has taken a liberty with them that they will neither forget nor forgive.

I will not say that in my youth I never indulged in what I am now condemning. I did so, but I never obtained the position I coveted until I abandoned the pernicious habit. There is no other profession in which honest and serious attention to the matter in hand is so promptly rewarded as ours. 
Suppose, for an example of the harm that might be done, we take a case like this: An actor has worked for weeks patiently to study or perhaps create a character, and his success in it may prove the turning-point of his life. He is poor, and has a large family to support. If he but hit the part, his fortune is made, and he will not only serve the manager, the author, and the public, but be enabled to provide comforts for his home and an education for his children. Now, with all this at stake, some wanton actor deliberately "guys" his part and overturns the patient care of his comrade, undermining the foundation and causing the whole structure to fall to the ground. See what a wreck we have here! Think of a poor artist before a picture upon which he has spent days of toil and nights of thought. It is just ready for the Academy, and now some comrade steals up behind the easel and pours a pot of paint over the canvas, ruining the work. What shall be said of him? And yet he may have done no more harm than the actor who has ruined the bright prospects of his brother actor.

I do not say that guying is always the result of cruel mischief. A man may be really good-hearted and yet do all this damage; but whether it be from design or thoughtlessness, the result is the same, and the habit should be frowned down and checked by every honest actor. In making these assertions I do not put them forth as an argument. This subject does not admit of argument, for nothing can be said in defense. There is no other side 
to the question. But the actor who guys is as much to be pitied as condemned, for the crime carries the punishment along with it.

The repertory that naturally falls to a tragic actor gives him an immeasurable advantage over a comedian. Nearly all of the tragedies or serious plays, both of ancient and modern structure, have for their heroes one conspicuous and central figure, who is in a marked degree superior to the surrounding characters that support him, whereas the comedies, with but few exceptions, have been constructed with the view of displaying a group of actors.

If the starring system, as it is called, be an evil, then Shakspere is undoubtedly responsible for its existence, as his tragedies almost without exception contain one great character on whom the interest of the play turns, and upon whom the attention of the audience is centered. When he introduces two figures for this purpose, as shown in the attitudes of Othello and Iago, Macbeth and Lady Macbeth, they are so closely knit together that the double light shines only with a single ray. In the play of "Romeo and Juliet" it is supposed that Mercutio was killed early in the drama lest his brilliancy should dim the luster of the lovers. There are undoubtedly other splendid characters in the tragedies of Shakspere, but when brought in contrast with the magnitude of his heroes they are comparatively subordinate. In his comedies the characters are formed in groups, and are generally so arranged that they may be in some measure of 


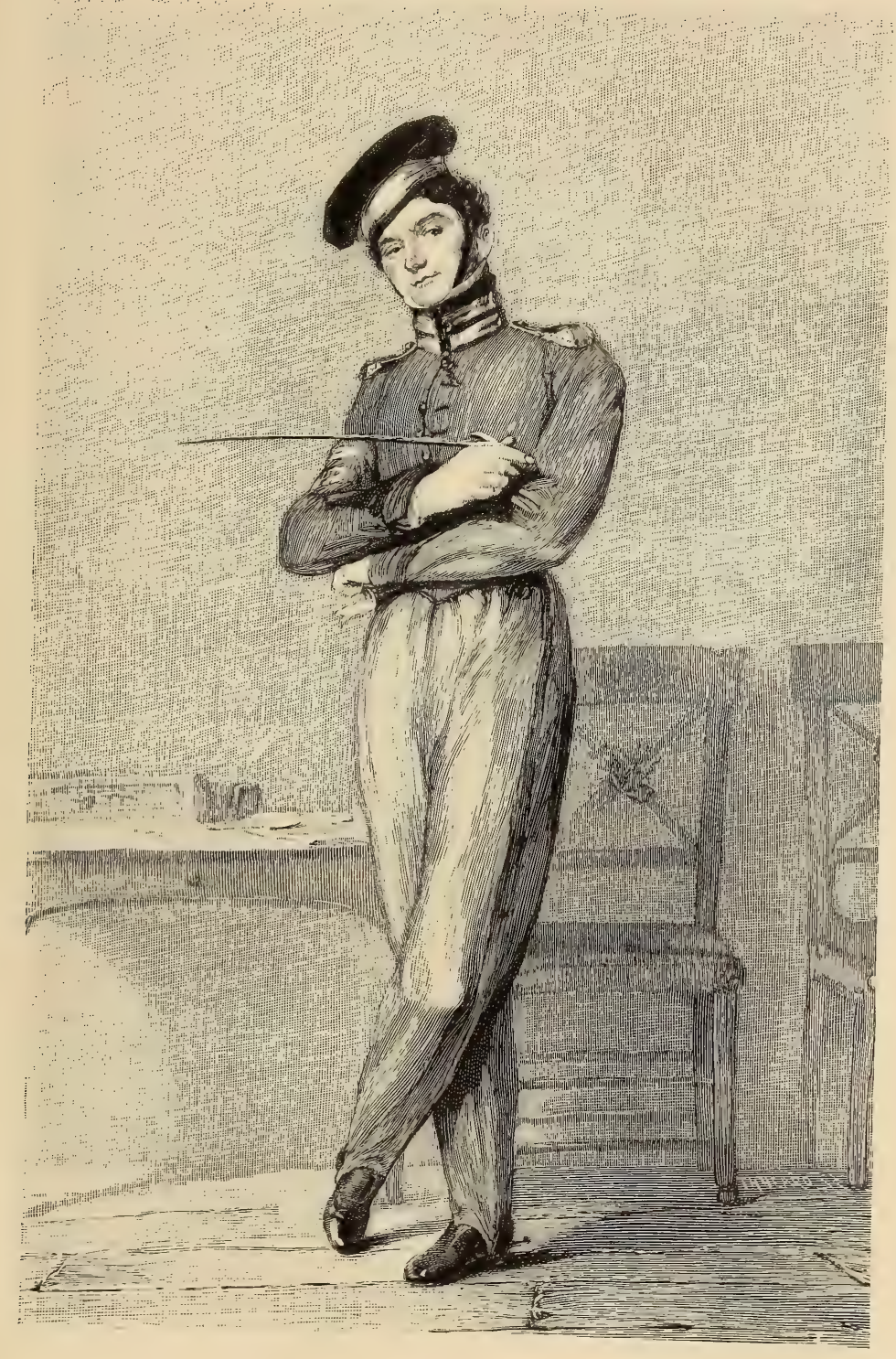

TYRONE POWER AS "CORPORAI, O'CONOR," 

equal value. Falstaff would seem to be an exception, yet even here the historical drama of "Henry IV.," in which the fat knight figures so conspicuously, is a play, not a comedy. Under these conditions the comedians of the olden time, though great favorites with the public, and in many instances superb actors, as individual attractions never drew large audiences. Possibly Sam Foote, who acted during Garrick's time, and later the elder Mathews, were notable exceptions; but even these actors, the legitimate comedians, were forced to abandon the old comedies and arrange special entertainments of their own, in which they gave imitations of popular and easily recognized public characters.

The first to command universal attention as a single magnet was Tyrone Power. Possibly he was no greater than the comedians that preceded him, but Irish comedy up to the time of his advent had been confined to characters that were less important. Fortunately for Power, a number of rollicking and effective plays were written for him, through which his own unique power shone with special brilliancy. Besides this, he was not a mushroom. His professional growth had been gradual and healthy. As the leading juvenile actor and light comedian of the Theater Royal, Dublin, he had been for four years the prime favorite of the city, and afterwards, as a leader in legitimate plays at the Haymarket Theater, in London, he held a no less important position. This career was a firm foundation upon which to 
build his lighter, but to the public more valued, work; so that his long theatrical experience, added to his new and effective repertory, ranked him as the greatest and most successful Irish comedian of his time. I am not aware what effect Power's success as a star had upon the English stage,- it is more conservative than our own,- - but his achievements here stirred up a new ambition among the comedians of America, and with national energy they immediately set to work developing their especial gifts; and these in many instances qualified them for becoming distinct features. Casting aside the old comedies, they came forward with novel and effective, if not legitimate plays. Dramatic portraits of Dutchmen, Yankees, Frenchmen, together with the Western and local characters of our own country, were speedily and vigorously exhibited, many of them commanding immediate attention. Among the most successful comedians may be mentioned Hackett, Hill, Marble, Burke, Chanfrau, Williams, and, later on, Owens, Sothern, Florence, Raymond, and a host of others.

For myself, like some of those already mentioned, I had always been, more or less, a legitimate actor, and the hope of entering the race for dramatic fame as an individual and single attraction never came into my head until, in I858, I acted Asa Trenchard in "Our American Cousin"; but as the curtain descended the first night on that remarkably successful play, visions of large type, foreign countries, and increased remuneration floated be- 
fore me, and I resolved to be a star if I could. A resolution to this effect is easily made; its accomplishment is quite another matter.

Art has always been my sweetheart, and I have loved her for herself alone. I had fancied that our affection was mutual, so that when I failed as a star, which I certainly did, I thought she had jilted me. Not so. I wronged her. She only reminded me that I had taken too great a liberty, and that if I expected to win her I must press my suit with more patience. Checked, but undaunted in the resolve, my mind dwelt upon my vision, and I still indulged in day-dreams of the future.

During these delightful reveries it came up before me that in acting Asa Trenchard I had, for the first time in my life on the stage, spoken a pathetic speech; and though I did not look at the audience during the time I was acting,- - for that is dreadful,- I felt that they both laughed and cried. I had before this often made my audience smile, but never until now had I moved them to tears. This to me novel accomplishment was delightful, and in casting about for a new character my mind was ever dwelling on reproducing an effect where humor would be so closely allied to pathos that smiles and tears should mingle with each other. Where could I get one? There had been many written, and as I looked back into the dramatic history of the past a long line of lovely ghosts loomed up before me, passing as in a procession: Job Thornberry, Bob Tyke, Frank Oat- 
land, Zekiel Homespun, and a host of departed heroes "with martial stalk went by my watch." Charming fellows all, but not for me. I felt I could not do them justice. Besides, they were too human. I was looking for a myth-something intangible and impossible. But he would not come. Time went on, and still with no result.

During the summer of 1859 I arranged to board with my family at a queer old Dutch farm-house in Paradise Valley, at the foot of Pocono Mountain, in Pennsylvania. A ridge of hills covered with tall hemlocks surrounds the vale, and numerous trout-streams wind through the meadows and tumble over the rocks. Stray farms are scattered through the valley, and the few old Dutchmen and their families who till the soil were born upon it; there and only there they have ever lived. The valley harmonized with me and our resources. The scene was wild, the air was fresh, and the board was cheap. What could the light heart and purse of a poor actor ask for more than this?

On one of those long rainy days that always render the country so dull I had climbed to the loft of the barn, and lying upon the hay was reading that delightful book, "The Life and Letters of Washington Irving." I had gotten well into the volume, and was much interested in it, when, to my surprise, I came upon a passage which said that he had seen me at Laura Keene's theater as Goldfinch in Holcroft's comedy of "The Road to Ruin," and that I reminded him of my father "in 


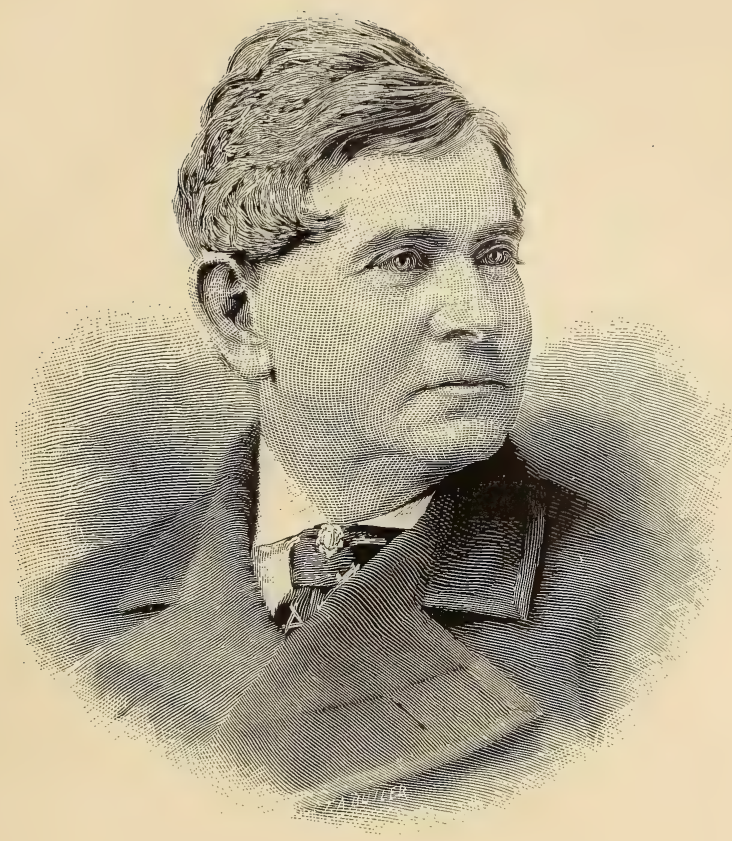

BARNEY WILLIAMS. 

look, gesture, size, and make." Till then I was not aware that he had ever seen me. I was comparatively obscure, and to find myself remembered and written of by such a man gave me a thrill of pleasure I can never forget. I put down the book, and lay there thinking how proud I was, and ought to be, at the revelation of this compliment. What an incentive to a youngster like me to go on!

And so I thought to myself, "Washington Irving, the author of 'The Sketch-Book,' in which is the quaint story of Rip Van Winkle." Rip Van Winkle! There was to me magic in the sound of the name as I repeated it. Why, was not this the very character I wanted? An American story by an American author was surely just the theme suited to an American actor.

In ten minutes I had gone to the house and returned to the barn with "The Sketch-Book." I had not read the story since I was a boy. I was disappointed with it; not as a story, of course, but the tale was purely a narrative. The theme was interesting, but not dramatic. The silver Hudson stretches out before you as you read, the quaint red roofs and queer gables of the old Dutch cottages stand out against the mist upon the mountains; but all this is descriptive. The character of Rip does not speak ten lines. What could be done dramatically with so simple a sketch? How could it be turned into an effective play?

Three or four bad dramatizations of the story had already been acted, but without marked success. Yates of London had given one in which 
the hero dies, one had been acted by my father, one by Hackett, and another by Burke. Some of these versions I had remembered when I was a boy, and I should say that Burke's play and performance were the best, but nothing that I remembered gave me the slightest encouragement that I could get a good play out of any of the existing materials. Still I was so bent upon acting the part that I started for the city, and in less than a week, by industriously ransacking the theatrical wardrobe establishments for old leather and mildewed cloth, and by personally superintending the making of the wigs, each article of my costume was completed; and all this too before I had written a line of the play or studied a word of the part.

This is working in an opposite direction from all the conventional methods in the study and elaboration of a dramatic character, and certainly not following the course I would advise any one to pursue. I merely mention the out-of-the-way, upside-down manner of going to work as an illustration of the impatience and enthusiasm with which I entered upon the task. I can only account for my getting the dress ready before I studied the part to the vain desire I had of witnessing myself in the glass, decked out and equipped as the hero of the Catskills.

I got together the three old printed versions of the drama and the story itself. The plays were all in two acts. I thought it would be an improvement in the drama to arrange it in three, making 
the scene with the specter crew an act by itself. This would separate the poetical from the domestic side of the story. But by far the most important alteration was in the interview with the spirits. In the old versions they spoke and sang. I remembered that the effect of this ghostly dialogue was dreadfully human, so I arranged that no voice but Rip's should be heard. This is the only act on the stage in which but one person speaks while all the others merely gesticulate, and I was quite sure that the silence of the crew would give a lonely and desolate character to the scene and add to its supernatural weirdness. By this means, too, a strong contrast with the single voice of Rip was obtained by the deathlike stillness of the "demons" as they glided about the stage in solemn silence. It required some thought to hit upon just the best questions that could be answered by a nod and shake of the head, and to arrange that at times even Rip should propound a query to himself and answer it ; but I had availed myself of so much of the old material that in a few days after I had begun my work it was finished.

In the seclusion of the barn I studied and rehearsed the part, and by the end of summer I was prepared to transplant it from the rustic realms of an old farm-house to a cosmopolitan audience in the city of Washington, where I opened at Carusi's Hall under the management of John T. Raymond. I had gone over the play so thoroughly that each situation was fairly engraved on my mind. The rehearsals were therefore not tedious to the actors; 
no one was delayed that I might consider how he or she should be disposed in the scene. I had by repeated experiments so saturated myself with the action of the play that a few days served to perfect the rehearsals. I acted on these occasions with all the point and feeling that I could muster. This answered the double purpose of giving me freedom and of observing the effect of what I was doing on the actors. They seemed to be watching me closely, and I could tell by little nods of approval where and when the points hit.

I became each day more and more interested in the work; there was in the subject and the part much scope for novel and fanciful treatment. If the sleep of twenty years was merely incongruous, there would be room for argument pro and con; but as it is an impossibility, I felt that the audience would accept it at once, not because it was an impossibility, but from a desire to know in what condition a man's mind would be if such an event could happen. Would he be thus changed? His identity being denied both by strangers, friends, and family, would he at last almost accept the verdict and exclaim, "Then I am dead, and that is a fact"? This was the strange and original attitude of the character that attracted me.

In acting such a part what to do was simple enough, but what not to do was the important and difficult point to determine. As the earlier scenes of the play were of a natural and domestic character, I had only to draw upon my experience for their effect, or employ such conventional methods as myself and others had used before in 
characters of that sort. But from the moment Rip meets the spirits of Hendrik Hudson and his crew I felt that all colloquial dialogue and commonplace pantomime should cease. It is at this point in the story that the supernatural element begins, and henceforth the character must be raised from the domestic plane and lifted into the realms of the ideal.

To be brief, the play was acted with a result that was to me both satisfactory and disappointing. I was quite sure that the character was what I had been seeking, and I was equally satisfied that the play was not. The action had neither the body nor the strength to carry the hero; the spiritual quality was there, but the human interest was wanting. The final alterations and additions were made five years later by Dion Boucicault, and will be referred to in their place.

At the death of my wife, which occurred in March, I86I, I broke up my household in New York, and, leaving three of my children at school, left home with my eldest son for California.

Through the act of an overzealous agent, my engagement in San Francisco was an unmistakable failure. Before my arrival I had been "overbilled," as it is technically termed. If a circus had been coming the placards could hardly have been more numerous. Those fatal documents known as the "opinions of the press" had been so freely circulated that every one was aware not only of what I could do but what I had done, and must therefore take for granted what I was going to do. All power of judging for themselves had been denied 
both to the public and the local press. I felt that I should fail, and I did fail.

One of the first actors I met on my arrival was Harry Perry. I had known him years before, and we had acted together in our youth. $\mathrm{He}$ was standing in front of the theater reading, rather quizzically, I fancy, one of the many cards on which were printed the previously mentioned, and, I think, always to be avoided, "opinions of the press." After we had shaken hands, he looked at me with the same old twinkle of mischief in his eye that I had remembered years ago, and said, pointing to the "opinions," "You must have improved greatly since we last met."

Harry Perry was one of the handsomest men on the stage, and a capital actor too. His animal spirits and personal magnetism, however, were the raw materials out of which his popularity was manufactured. In those parts that belonged to a farce light comedian he was quite unequaled. Youth, vivacity, and a ringing laugh made him altogether one of the most captivating fellows in his line. His figure was lithe and graceful, and, as was said of one of the old light comedians years ago, he had a five-act comedy in each eye. On the occasion I speak of he was quite intoxicated with happiness, being in the height of a honeymoon. His bride was Miss Agnes Land,- now Mrs. Agnes Booth, - a young lady who had lately arrived from Australia, and whose talent and beauty combined with his own made them valuable members of the theatrical profession. 


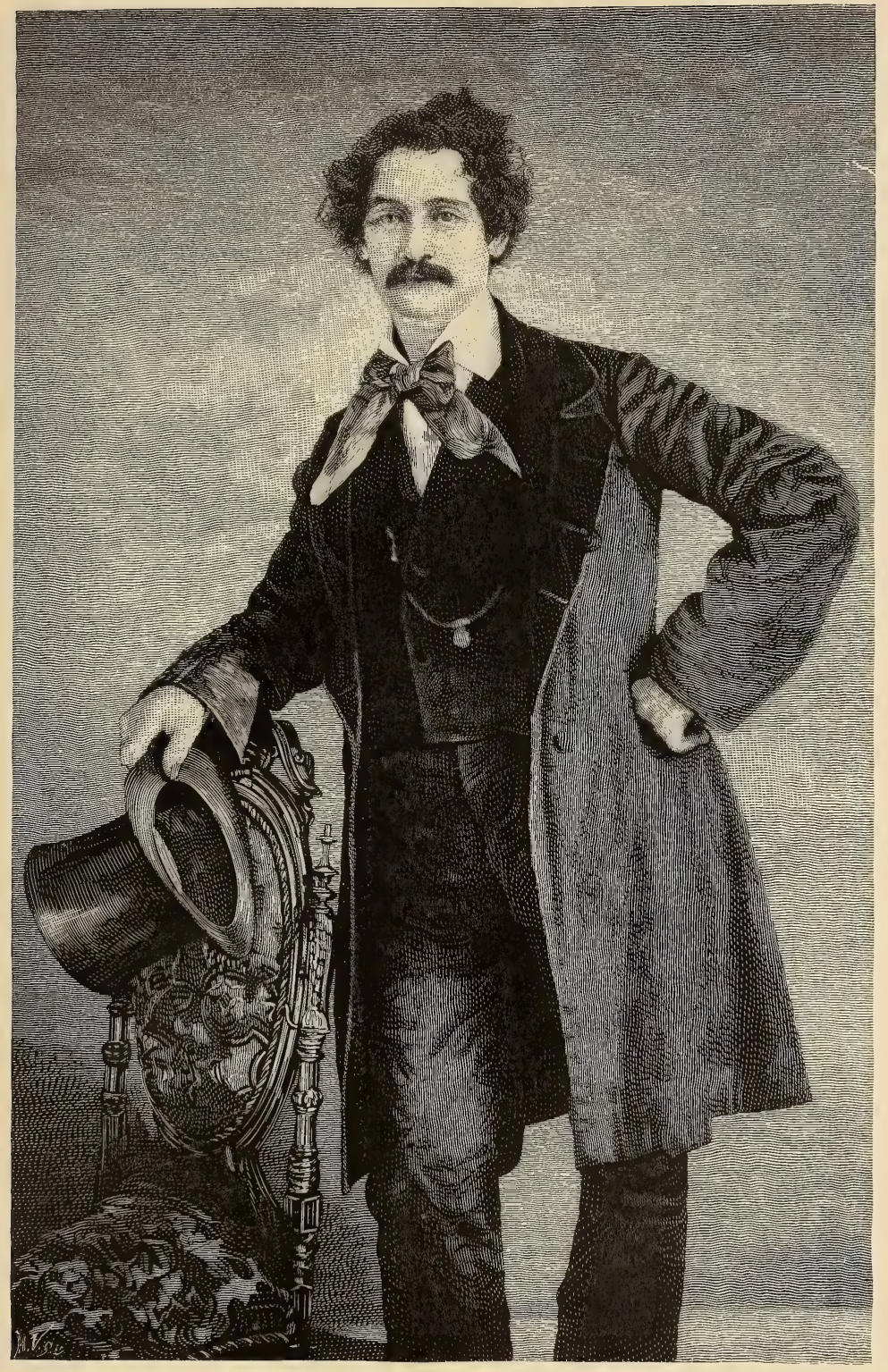





\section{CHAPTER IX}

IN AUSTRALIA, VAN DIEMEN'S LAND, AND NEW ZEALAND

From California to Australia-Sydney-Melbourne - The Skeleton Dance - The ShepherdAn Australian Tragedy-A Terrible Audience - The Keans - A Chinese Theater

$\mathrm{N}$ the roth of September, I86I, I sailed from San Francisco in the fine ship Nimrod, bound for Port Phillip and the harbor of Sydney. I had only my son, my agent, and my agent's mother with me. There were two or three other passengers besides ourselves, of one of whom I must make special mention: he was a Catholic priest, a cheerful, pleasant man, named Father O'Grady.

From California to Australia is what the sailors call a fair-weather passage, most of it being made through the trade-winds. Our voyage was a pleasant, uneventful trip of fifty-seven days. I passed most of the time in reading, sketching, and trying to divert Father O'Grady from celibacy; I told him he was altogether too good a fellow for a single 
man, and assured him that he would never know what true happiness was till he got a wife by his side and had half a dozen children on his knee. Our theological arguments on the quarter-deck were a source of great amusement to ourselves and the passengers. O'Grady, when he became excited, would walk up and down the deck, tossing his long arms wildly about as if he were making signals of distress.

We passed to the south, and just in sight of Norfolk Island, which is said to be the loveliest spot in the Pacific Ocean. It was formerly a convict station, but the prisoners had been removed for many years, and the place was then, and I believe is now, occupied by a colony called the Pitcairn Islanders. The "mutiny of the Bounty," it will be remembered, occurred during the latter part of the last century, and the people now living on Norfolk Island are the descendants of the mutineers.

On the 4 th of November the coast of Australia loomed up before us. A great wall of rocks rises almost perpendicularly from the ocean, and the narrow opening directly in front of us is called Sydney Heads. When a ship arrives in sight of this formidable place it is customary for the sailors to inform the passengers that this is the most dangerous spot in the world. A thrilling story at this point of the voyage seems to be in order, and one of the crew is generally called upon to relate an awful catastrophe that once occurred in the very sight of the spot where the ship is sailing. We 
stood out well to sea that night, as the weather had a threatening aspect, and at daylight, the wind being fair, made again for the land. The pilot sighted us, and brought the ship safely over the treacherous shoals into the beautiful harbor of Sydney. Once inside, if the day be fine, what perfect fairyland is here: the rocks are of a beautiful siena tint, surmounted with rich foliage in every shade of green ; numerous little crescent bays edged with white sand curve in and out, meeting the deep blue water; islands crowned with tall and graceful trees; parrots in the gaudiest coats of plumage fly in flocks chattering and screaming through the air; and the whole harbor is dotted with white sails and gaily colored streamers. In the middle distance is the beautiful city of Sydney: a long, low line of shipping stretches in front, and as the high bluff rises behind the tapering masts, the town, with its tall, white stone buildings and church spires, finishes the picture. As our ship sailed into this dreamland of beauty there was a rich purple haze veiling the scene; the sun shone like gold in the far-off horizon, and as it sank behind the city the purple deepened into blue. We reached the town and dropped our anchor, the night came slowly on, the new constellations of stars (not seen in our firmament) sparkled over our heads, myriads of lights in the city and the surrounding shipping were reflected in the water, and all these glittering gems twinkled and flickered like fireflies about us.

The next morning I rose early, and rejoiced after fifty-seven days' rolling about to get my feet once 
more upon land. As I stepped ashore I had that curious sensation which all must feel when for the first time they find themselves in a new country where, though they speak the same language, not a soul knows or has ever heard of them. I walked through the busy streets holding my son by the hand, and tightly too, for it was comfort to feel that there was some one near who knew and felt an interest in me. I seemed to regret that I had come so far from home, and wondered whether I should ever be able to raise any interest among the vast crowd of strangers that surrounded me.

I met my agent by appointment at the little hotel where we stopped, and he handed me the money he had gone in quest of. The first thing to do now was to purchase new clothes, something that would at least faintly resemble the costumes of the people, which mine certainly did not in any degree. The hat is always the first thing to change; everybody looks at your hat as soon as you arrive in a strange country. These little matters were soon amended, and in a short hour I looked quite like the people, but not a bit like myself. My agent had been a manager in Australia some years before, so he knew everybody. We went to the theater, where he introduced me to the manager; and as I shall have some little business relations with this gentleman of an interesting sort, perhaps it will be as well to describe him, he being almost an historical character. He was an under-sized, round-shouldered little cockney, named Rolamo. Where he got this remarkably Italian appellation I cannot say, but if 
his ancestors belonged to the "land of song" they must have strayed into the very heart of Whitechapel just previous to the birth of their son and heir, as his dialect was strongly impregnated with the drawling twang of that locality. It is recorded of him that he never was known to put an $h$ in the right place, and his talent for reversing the $w$ and $v$ almost amounted to genius. He had originally been lamplighter in the theater, but by his industry and intelligence he rose to be its manager, and he was in the zenith of his fame when I arrived in Australia. After my agent had introduced me to Mr. Rolamo as the coming man who was to make his (the manager's) fortune, that worthy cast a patronizing eye over me, but did not seem at all overwhelmed, taking my arrival with provoking coolness. This chilling atmosphere pervaded the office until my agent unrolled some highly inflammable printed matter, the novel character of which seemed to attract the great man's attention, and condescending to address me, he said, "You see, Mr. Jeffries - oh, beg pardon; Jimmison, I mean, - with all due respect to you, there 'as been so many blawsted Yankee comics over 'ere that we are kind o' sick on 'em. You may be a hextra good lot for all I know, but lately the queerest mummers we 've 'ad 'ave come from Amerikee. This printed stuff you've got looks spicy, - in fact, I don't know as I ever see spicier,- but it don't prove nothink, does it?"

My agent here broke in with the assurance that I was a legitimate actor and not a mummer. 
"Legitimate!" said the manager. "Well, that's the worst rot of all. The legitimate would wentilate my theeater on the first night; and as for that dismal old guy 'Amlet, I would n't 'ave 'im at no price."

I told him that Hamlet was not upon my bill of characters, and that so far as I was concerned the reputation of his theater would be in no way desecrated by any Shaksperean productions. Besides, I admitted his perfect right to protect himself against fraud, and, as I was a stranger, I proposed first to show him what my material consisted of, and wound up by offering to rent his theater and company, pay him a good bonus to relinquish the management into our hands for a month, and, if we could agree upon terms, give him his money in advance. At this proposal the hard features of Mr. Rolamo softened into an oily sweetness that was lovely to behold; he gently put out both hands to grasp mine, his eyes fairly beamed on me with affection, and his heart seemed so touched that it quite choked his utterance.

"My dear lad," said he, " that 's the way I likes to hear a cove talk; for I always believes in a cove wot believes in hisself."

Terms were soon agreed upon, and it was settled that the contract should be signed that evening and the first advance paid. In due time our printing was posted on the walls, and the lithographs a novel feature in those days - were placed in the shop windows. I passed my time in wan- 
dering about the streets, observing the startled inhabitants as they scanned the pictures, stopping from time to time to listen to their remarks.

Of course my first night in Sydney was spent at the theater, always an attractive point to the actor. It is said that few men are in love with their vocation, but this remark cannot be applied with justice to members of the theatrical profession; some actors will play without salary rather than not act at all. On this occasion, however, it was more a matter of business than pleasure that took me to the play. I was anxious to see the kind of acting that was most effective here, and also to examine the qualities of the company in reference to their fitness for the characters in my list of plays. I found the acting much better than I expected; in fact, throughout the colonies I was invariably impressed by this dramatic excellence. The actors had originally come from England to Australia to star. Afterwards in many instances they had settled here, making it their home, and as their novelty wore off had dropped into the different stock companies, and so had become admirable supporters to the stars that followed. I sat in front of the theater on the night referred to, and, as the actors came upon the stage one by one, I plainly saw that I had my work cut out if I expected to stand prominently forward amidst such surroundings. It was also quite evident that the delicate sensibilities of Mr. Rolamo had failed to appreciate the fine legitimate qualities of his company, and had moreover underrated the taste of his patrons. In a few 
days it was settled that the company should assemble in the greenroom, where I was to be formally introduced previous to reading my opening play to them. The introduction was given under the "auspices" of the manager, who performed the ceremony after the following manner: Ushering me into the presence of the company, he made an awkward bow, forgetting to take off his hat,-a tall, black, semi-conical-shaped article with a large dent in it,- and announced me as "Mr. Jimminson from Amerikee."

I found the company obliging, and, as I expected, thoroughly competent. Matters progressed favorably, the pieces for the first week were rehearsed, and all things were duly prepared for the opening. The house was quite good on that night, and the audience generous and sympathetic; they seemed to appreciate what a thorough stranger I was, " and as a stranger gave me welcome."

When the curtain fell, I was congratulated by the company and Mr. Rolamo, who I fancied was a little annoyed to think that he had not made other terms with me, as his compliments were couched in the following remark: "I say, mister, I took you for a green un when I first see you; you got a kind o' innocent look about you, but you 're sharp, do you know that?" I told him that I did not think I was particularly sagacious, but thanked him for the delicacy of his compliment, and hoped that I might live to deserve it.

I was fortunate in bringing with me to Australia a large amount of new material in the matter of 
plays. "Rip Van Winkle," "Our American Cousin," and "The Octoroon" were all novel, and their reception was most satisfactory.

At the expiration of my Sydney engagement we took the steamer to Melbourne. Fawcett Rowe was the manager here of the Princess Theater, and the same arrangements were entered into with him that had been made at Sydney. Our success in Melbourne was even more flattering than it had been in Sydney, and it was quite evident from the impression made that we were likely to continue our season for some time. The audiences were numerous and fashionable, and the articles in the daily papers referring to our plays and acting were of the highest literary character; those in "The Argus," written by the accomplished critic James Smith, were models in style and strength.

My engagement at the Princess extended to one hundred and sixty-four consecutive nights. At its conclusion my agent and I dissolved our temporary partnership, he assuming the management of the new Haymarket Theater, and I going into the small mining and provincial towns to reap the benefit of the reputation I had acquired in the two larger cities. Ballarat, Bendigo, and Adelaide had all good stock companies, and were visited in their turn, generally with pleasant and profitable results.

During this provincial tour I was acting in one of the mining towns called Castlemaine, and after tea as I was strolling leisurely towards the theater my ears were suddenly saluted by the violent ringing of a bell, and a sonorous bass voice roaring out 
my name in full. I looked in the direction of this unaccountable noise and saw a little fat man, in a high white hat and a seedy suit of black, standing on a barrel in front of the theater and surrounded by a crowd of boys. Gesticulating violently with his left hand, he swung in the right an enormous bell. Now suddenly stopping, he seemed to swell and got red in the face as he delivered himself of the following: "Oh, yes! Oh, yes! Oh, yes! Step up, ladies and gentlemen; now or never is your only chance to see the greatest living wonder of the age, Joseph Jefferson, the great hactor from Amerikee. His power of producing tears and smiles at vun and the same time is so great that he caused the Emperor of Roushia to weep on his weddin' night, and made her gracious Majesty the Queen bu'st out laughin' at the funeral of Prince Albert. He is the bosom friend of the President of Amerikee and the hidol of 'is Royal 'Ighness the Prince of Wales."

I always had a horror of orators. They are seldom sincere, and never hesitate to say the wrong thing instead of the right one if they can say it best. To most of them epigram is more sacred than truth, and we are often so fascinated with the manner that we forget somewhat the matter. It must have been the comical earnestness and bombastic attitude of this extraordinary creature that had interested the crowd; certainly they did not believe what he was saying, for they were roaring with laughter at every word, while his face was as serious as the fifth act of a tragedy. At this junc- 
ture I rushed into the theater and demanded that themanager should make the bellman stop. "Why, we always have it done here, and thought you'd like it," replied the manager.

"Like it!" said I. " If he is not stopped at once I shall not act." So the little fat man was ordered to cease his harangue and come down from his barrel: but no, he said he would n't budge; he was n't half through, and it would injure his business and ruin his reputation to be cut off " in the heye of the public," and he would "be blowed" if he stirred till he finished. The manager now appealed to me to let him go on. " Now, mark me," said I. "If he rings that bell again, or opens his mouth, I don't act." This settled it. The little fat man now stood with his arms folded, glaring defiance at the manager and his myrmidons, but they seized him and a tremendous struggle ensued. The tall white hat was completely mashed over his eyes, and in stamping violently with his rage the head of the barrel burst in, letting him through till only a fat head just appeared above the top. They tipped the barrel over and rolled him off inside, to the great amusement of the bystanders, who had been roaring with laughter all the time.

After having been in the colonies about a year, during which time I had acted quite steadily, I determined to take a long rest and see a little of the interior life of the country. At the invitation of the Winter brothers I visited their station, the land they owned, and the Government lease controlled by them, extending over an area of seventy 
miles in length and fifty in breadth. There are many such stations in Australia, but the pasturage was thin, and the interior of the country badly watered, so that these vast tracts of land would not support with much profit the large flocks of sheep that grazed upon them. My son and I lived with the Winter brothers several weeks. They placed their house, servants, and horses at our command, to which they added their own pleasant company and warm hospitality. I staid three weeks with these gentlemen, shooting, fishing, and riding. At the end of this time I sent my son back to Melbourne to finish his term at the Scotch college, and having a desire to penetrate farther into the country, started for the Murray River, where I was told I could see a wild and interesting region.

There are little settlements along the river to which the aborigines pay periodical visits to beg for ammunition and hold their "corrobories," as one of their mystic ceremonies is called. In a few days I reached the river, and, having a letter of introduction to the owner of a large station, took up my abode there for a fortnight, meeting with the same kind welcome that I was assured would attend my visit.

A party of "blacks," as the natives are called, was encamped near here, so I had full time to witness their sports, if sports they can be called, for more dismal games can scarcely be imagined. One of the features of the "corrobory" is the "skeleton dance." I saw this weird performance, which is conducted in a curious way. A long row of fagots 
or broken sticks was stretched upon the ground for a distance of forty feet; these were ignited, making the footlights to illuminate the performance. The audience was made up of myself and a few visitors, paying what we chose to give the natives for their artistic display. We were seated on logs, stumps, and rudely made benches in front of this elongated fire, huge logs being arranged between us and the blaze, so as to shield the light from our eyes. The actors always select a dark and moonless night for this exhibition, so that before the performance began all we saw was a dismal forest of tall, gaunt trees, faintly illuminated by the footlights. Now far off a strange sound was heard, moaning and faint cries of distress; then came the dismal beating of a drum, and in the distance, out of the darkness, appeared forty or fifty skeletons. They came forward slowly, hand in hand, with a strange halting gait, till they were close to the fire. There they paused, and for full ten minutes were as still as death. The effect is produced by painting their black bodies with white earth or chalk. The bones of the human anatomy are as perfectly marked out as if done by a surgeon and an artist - attenuated white stripes down their legs, with bulging knee-caps and broad, white hips, the breastbone and ribs, shoulder-blades and arms, all clearly defined, and the long neck surmounted by a hideous skull. Their black bodies mingle with the darkness that surrounds them, and the fire shining upon the white pigment makes the illusion quite complete. Not a sound is heard for full ten minutes; 
even the audience speak in whispers. At some mysterious signal, so arranged that no one can detect it, every alternate skeleton begins to move slowly, the others remaining rigid, then they jerk violently and spasmodically, and suddenly stopping, they become rigid; then the alternate skeletons begin to move, and so go through the same fantastic actions. Now they all screech and dance together, and suddenly, turning their backs, plunge into the deep woods and disappear. The spectators seem to breathe more freely after they are gone, and, looking around on one another, exclaim that it is the strangest sight they have ever witnessed.

The next morning I visited the camp, such as it was, for they seemed to have little or no shelter. The tribe numbered about sixty blacks, and a more miserable lot of human beings I never saw - long, thin legs and arms, big stomachs, huge, fat heads covered with large shocks of unkempt hair. I noticed there were only two or three children among them, which seemed rather curious in so large a tribe. I asked one of the women if that was her only child which she was holding by the hand, to which she replied, "Yes, me only keep dat one." On inquiry of the landlord of the little hotel what she meant by that, he explained that he supposed she had drowned all the other small members of the family. It seems that after a child is born, if it is of much trouble to the mother, she tosses it into the river. With these exhibitions of maternal affection it is no wonder that the aborigines of the 
country are fast disappearing. I don't suppose that they make away with their children from cruelty, - for they do not seem to possess either that quality or affection, - but simply because they do not want to be troubled with the care of them. They do not appear to buy anything or to offer anything of consequence for sale, and as they wander listlessly from town to town they are followed by the most dreadful lot of cur dogs of all sizes, sorts, and shapes, attenuated and half-starved animals, that look even more miserable than their wretched masters.

One of their sports is the throwing of the boomerang. This instrument is made of hard wood and shaped somewhat like a carpenter's square. If they wish to strike an object, they hurl the boomerang in an opposite direction from the mark. It shoots forward at tremendous speed, and then suddenly stops for a moment, and, making a sharp turn, comes backward almost to the place it started from, and so strikes the object aimed at. Some people think that this eccentric movement is caused by the shape of the instrument; but be that as it may, no one can throw it with any precision but the native blacks.

The scenery in the interior of Australia is in many respects uninteresting, having but little variety. The blue-gum tree, or eucalyptus, grows everywhere. This tree is said to have the virtue of absorbing malarious poisons from the air, and has been introduced in California and the Southern States with marked success. 
On one of my excursions, riding through the blue-gum forest, I had galloped about twenty miles from the home station; dismounting from the horse, I sat down to rest and take a lunch. A large flock of cockatoos, those beautiful white parrots with yellow crests, came circling around and lighted in the trees overhead. I was watching the curious manœuvers of these birds as they were chattering and hopping about among the limbs, when they stopped suddenly as if alarmed. Something was evidently approaching of which they were in dread. They set up an awful scream, and with a tremendous flutter spread their white wings and sailed away. Just at this moment a large black collie dog came bounding out of the bushes and suddenly stopped in front of me. For a moment I was startled. The dog paused and eyed me keenly, then coming slowly up walked round me, and at last approached and licked my hand, which I had held out to him. In a moment more he bounded away, leaving me astonished at his strange conduct. I had never seen a dog act in so singular a manner, and was wondering what it could mean, when a sharp, joyful bark warned me that he was returning; and, sure enough, he had come back wagging his tail and followed by a tall, gaunt figure of a man thinly clad, barefooted, and with a wide-brimmed, frayed straw hat on his head. He was about fifty years of age, and as he removed his hat and made me a wellmannered, dignified bow, I could see that, though he was undoubtedly a shepherd, he had once been 
a gentleman who had seen better days. As he stood bareheaded before me the wind blew his long, thin, sandy hair about his brow, and he regarded me with a strange, far-off look in his eyes, as if I had been miles away. I met several shepherds after this, and noticed that same strained expression. They live so much alone, sometimes being three and four months without seeing a human being, that they form this habit by looking over the plains, hoping that they may catch sight of some one to relieve the awful monotony of their lonely lives. "Thank Grod! God bless you, sir! I hope you are quite well," he said. There was not much expression in the man's face. I almost fancied that he looked like a sheep, but there was enough to prove that he was glad to see me; and would have been to see any one else, for the matter of that. "Sit down, my friend, and have some lunch with me," said I. "Thank you, I will," said he. "Well, Jack, you are right, quite right; you always are, old boy." This was said to the dog, who never once took his eye off his master, but stood in front of him wagging his affectionate tail, that expressed as much love for the poor, tattered, wasted shepherd as it could have done had he been an emperor in purple robes. "Yes, always right and true, eh, old boy?" The dog answered by licking the shepherd's hand and rubbing his head against his master's legs.

"I knew you were here," said he. "You knew I was here? How could you tell that? What do you mean?" "Oh, when I say that I mean that 
I knew it was a friend, or at least not an enemy; and Jack knew, if I did n't. About an hour ago, the dog began to get uneasy. He ran about sniffing the air and giving little short barks; then all of a sudden he broke away and left me. I thought he was on the lookout for something strange, so I just sat down among the sheep and waited for him. Presently he came back quite pleased at what he had discovered; then he gave some more of those little short barks and ran off towards you and back again; then wagged his tail impatiently. He could not have spoken plainer if he had been a Christian. The loving beast knows the lonely life I lead, and how I yearn sometimes for a human face to look at. That 's why he went on so-God bless him! It 'll be a shame for us to live in the other world if Jack don't go there. Look at him now; can't you see in his face that he knows that I have been talking about him?-and every word I 've said, for the matter of that, I believe." And sure enough, the look in the dog's face was almost human.

The man now sat down quietly beside me, and ate sparingly and rather mechanically of the lunch, always sharing his morsel with Jack. I took out a flask of whisky, and, pouring out some of it into a cup, offered my guest a drink. His eyes beamed with a longing look as he saw the liquor, and, turning on me a strange, frightened look, said: "No, none of that for me. Put it away, please; I don't like the sight of it." It now dawned upon me that my friend was a reformed drunkard, who had come 
out to this lonely part of the world to avoid temptation. I had heard that there were many such in Australia, and that the shepherd's life was chosen as being the most isolated one that could be found. I rose to take my departure, when he put his hand gently on my arm, and with an appealing look said: "You won't go back to-night, will you? It 's too late. I wish you 'd stay in my hut tonight, it 's so long since I 've seen a human faceover three months now. A man only comes once in a great while to bring provisions, and that 's all we see of humanity from one year's end to another. Do stay to-night, won't you ?" “I 'd like to oblige you," I replied, "but they 'll be uneasy about me at the home station. I must be twenty miles from there now, and it will be long after dark before I get back, even at a smart gallop." "But are you sure you know the way? - you might get lost," said he. "Oh, no; I 've only to keep on the banks of the Murray and I'm all right."

The poor fellow hung his head, looking the picture of despair. "Well," said I, "I 'll stay." He brightened up at this. "How far is your hut from here?" I asked. "Not a mile, I assure you." So he started off at a good pace, fearing I might change my mind, I suppose. The dog bounded ahead, barking away, and I followed on horseback. We soon came upon his charge - a large flock of sheep. As they heard the dog's bark the stupid creatures pricked up their ears and looked surprised, just as if they had never heard it before; then they took to their heels and galloped off, with the dog in full 
pursuit, running first in front, and then at the side, as some stray wether showed a disposition to rebel, then circling round and round till he got the fold just where he wanted them. He now went in and out among the sheep as though giving orders that they were to put up for the night. They seemed quite to understand him, so they quietly lay down in little family groups. By this time we had reached the hut, and the dog came up wagging his tail, as much as to say, "It's all right; there 's none of them missing." The hut was built of mud, sticks, and straw, with the hard earth for a floor. I hobbled my horse so that he might browse about in safety, the shepherd prepared a cup of tea, - the usual beverage of the bush,- and the dog, not a whit tired, stood bolt upright overlooking his distant charge with the air of a general reviewing his army.

The sun had gone down behind the low horizon with the same effect that it does at sea, and as we sat outside upon a couple of rude blocks of wood, drinking our refreshing tea, the moon rose up, shedding its soft light over this mysterious scene; there was no sound but the distant tinkle of a sheep-bell and the crackling of the little fire that was boiling the tea. The smoke went straight and silently up into the still air; the loneliness was bad enough with two men - what must it have been with one !

I felt there was something more in my profound acquaintance than I had yet learned, so I lighted my pipe and began to draw him out. It is curious that a man being alone among dumb creatures loses 
after a time something of his human expression and acquires that of his dumb companions, and that a dog under the same circumstances retains his individuality. Here was a man who, to judge from his manner and speech, must have been tenderly reared and highly educated, and one too who had practiced the busy calling of the law; yet in a few years of isolation the bright mind had become faded, and the human look of the face changed almost to the blank expression of a sheep, while a dog under the same circumstances had retained his perfect individuality. Jack's eyes sparkled like diamonds. His character was marked by intelligence, faithfulness, and affection. $\mathrm{He}$ would lie with his head between his paws, and his sharp nose flat on the ground, turning up the whites of his eyes to watch us as we talked. Now and again he would heave a deep sigh of satisfaction, as much as to say, "The old man is all right to-night; he's got some one that can talk to him."

I questioned the shepherd about his past life. It seems he had been educated at Eton; then became a fast youth in London, where he studied for the law, and in a short time rose to be a successful barrister. He had married early, and had one child, a daughter, born to him. After two years of wedded life he lost his wife and child. Despairingly he took to drink, and, being weak and desperate, went downhill and lost his position; that once lost in London is seldom regained. Not so in America. Here, when a man falls, if he has the strength to brace up again he goes to the West, and rubbing 
up against a new society absorbs fresh magnetism and recuperates at once: but London is compact; the Englishman hates to leave his home; his failings are known, and if he remains they are flung in his face. There is no escape for him; and, as his friends shun him, he falls deeper into disgrace. This was the trouble that had beset the shepherd, who, having a sensitive and perhaps weak mind, succumbed to the pressure that surrounded him. And so after a time, with a broken spirit, he left England and came to the colonies. He practiced law in Melbourne for some time successfully, but the old habit came back upon him, and, as he could not resist temptation, he buried himself on this station. This was the tale he told me, and there could be no doubt of its truth. After he had finished he turned his strange, far-off look on me again, and said, "Are you superstitious?"

"Well, I think I am a little. Most people are, if they would own it," said I. " I did n't use to be," he said with a sigh; " but since I 've lived here I seem to have become so, and it 's all Jack's fault." The dog, not looking up, beat his tail on the ground gently, as if to say, "Yes, blame it all on me; it 's all my fault."

"I have never seen anything ghostly or mysterious myself, but I think Jack does sometimes. When we 're alone - and God knows that 's often enough - he 'll start up and look around slowly as if his eyes were following something in the hut; at these times he will give a low, strange kind of moan, and, putting his tail between his legs, seem 
to be frightened, peering up into my face with an inquiring stare, as if he said, 'Don't you see it, too?" "The dog during this recital kept slowly beating time with his tail, as if he were endorsing every word his master said. "After noticing this with the dog," said the shepherd, "I called to mind the strange look I used to see in the beautiful face of my baby when she was only six months old. The little thing would sometimes stare at vacancy, and then smile sweetly and turn its head around as if it were following something - just as that dog does. What 's your opinion of this sort of thing? Do you think the spirits of those we loved in life can return and stand beside us?"

I told him that his question was a difficult one to answer ; that different people held different opinions on these mysterious matters, and the chances were that nobody had hit it quite right yet. "Well," said he, "if they can come, I know who it is that the dog sees when we 're alone."

It was now getting late, and the shepherd insisted on my taking his couch, an old canvas cot with a plain gray blanket spread upon it; so, as I was quite tired, I accepted the offer, and lay down for a night's rest. My companion stretched his tall figure on the grass outside. The dry climate of Australia admits of this ; there is no danger in sleeping on the ground; the chances are there would not be a drop of dew during the night, and that the grass in the morning would be as dry as hay. Jack lay down between us, and seemed, by one or two satisfactory sighs that escaped him, to be quite happy. 
I was awake for some time, and happening to look towards my new acquaintance, found that he was lying upon his back with the moon shining full upon his pale face. I had heard that it was dangerous in this climate to sleep in the moonlight. People have been known to go mad, or to have been struck with paralysis, for committing this indiscretion. I called to him to move into the shadow, but he did not heed me; so, thinking he had dozed off, I let him alone.

The strangeness of the scene, together with the strong tea, seemed to banish sleep from me, and I must have been there an hour with my eyes closed, but quite awake, when presently I heard something stirring, and, opening my eyes, saw the shepherd sitting up in the doorway with his head resting in his hands. After a time he arose and went out into the night air. He seemed uneasy, and began restlessly to pace up and down in front of the hut. The dog remained still, but I felt that he was awake and watching his master, as he walked nervously backward and forward in the moonlight. Presently the shepherd stopped in front of the hut, and came, with a hesitating and irresolute step, towards the door. He entered slowly, and, stooping down upon his hands and knees, crawled stealthily to the chair on which my coat was hanging; he put his hand in the breast pocket and drew forth the flask of liquor. And now he seemed bewildered, as if some strange emotion had seized upon him, and then fell upon his knees as if in prayer. Suddenly he seemed to rouse himself, and, instead of drink- 
ing the liquor, placed the flask untouched back in the pocket of the coat; then stretching himself on the floor, with an apparent air of comfort and satisfaction, went off to sleep. The whole proceeding so haunted me that it was broad daylight before I closed my eyes. When I awoke, the sun was high in the heavens. It must have been midday. My host had prepared breakfast - some bread freshly baked, tea, and salt beef. He seemed quite calm, and had lost the nervous, wearied look that was noticeable the evening before. After our meal, he spoke freely of the night's proceedings to me. I told him I had seen all that had taken place. "I thought perhaps it might be so," said he. "The old craving came upon me again, so strong too, but if ever I prayed for strength it was then. Well, at that moment there was a hand laid on my head; a calmness came over me that I had not felt for years; and when I returned the flask to your pocket I knew then, as I know now, that another drop of liquor will never pass my lips; and, as God is my judge, I believe it was the angel hand of my dead wife that rested on my feverish head. It 's all over now, thank Heaven, and I can leave this lonely place and return to the world again with safety."

I started to ride for the home station; the shepherd walked some distance by the side of my horse, and at last we shook hands and parted. I looked back after a time, and in the distance saw his tall figure against the sky, waving his old straw hat to me, while the faithful dog by his side was looking up into his face and wagging that expressive tail. 
I traveled still farther into the interior-in fact, quite far enough for safety; for not over one hundred miles from where I now stopped there had been living in a stronghold in the mountains a band of desperate men, and though lately their career had been checked, I deemed it prudent to suppress any desire that I had for further explorations.

The bushranger of Australia is an offshoot of the highwayman of England. Convicts had been sent from the old country for this unlawful practice, and after finishing out their time, or being pardoned for good conduct, remained in the colonies, instead of returning to their native land. Gold had been discovered; the country was growing rich, and offered a fine field for the "terror of the road." In all new and thriving countries there is a class of lazy, cunning, and desperate men who prey upon society, looking upon honesty as weakness, and society, by way of punishing these criminals, wastes a good deal of sympathy and sentimentality upon them. The villains know this, and enjoy the joke. Ladies, I regret to say, are especially attached to this kind of animal. The Claude Duvals, Jack Sheppards, Lafittes, and Massaronies of the past were just such cunning sneaks. Their praises have been versed, and we are made to believe that they were a race of persecuted heroes. Byron well describes one of these miserable wretches as sitting in a graceful attitude on the quarter-deck, with a thoughtful brow and a noble air, as if he were turning over 
in his mind how he could best benefit mankind. Our own Cooper describes the "noble red man" as only delaying his departure to the "happy hunting-grounds" in order that he may unburden himself of a large stock of ready-made gratitude which he constantly keeps on hand; whereas it is well known that no Indian could possibly be happy in any hunting-ground unless it was on the reservation of some other tribe. I think we rather suspect the sincerity of the poets who dignify these rascals.

Just such a worthy as one of the pirates referred to had been occupying the attention of Australia the year before I arrived. The ladies vowed that Morgan, the man's name, had the most manly form that ever was seen, surmounted by a perfectly classic head: the latter certainly ought to have been very fine, for the Government had offered a thousand pounds for it, but up to the present time Mr. Morgan had not offered it for sale. He evidently looked upon it as a cash article at any time, and determined that, as it was the only one he possessed, he would not force it on the market. "If they want it," said Morgan, playfully, "they must call for it." It seems that they had called for it on several occasions, but always failed to carry it away with them, for the bushranger was a wary fellow, and had a head able to look after itself.

The station where I was now staying had been, some time back, the scene of this fellow's exploits. He and his gang had "stuck up" the place. One 
brave lad resisted, and was killed by Morgan. The sister of this unfortunate boy was concealed in the house, and witnessed from her hiding-place the cruel murder of her brother. The scene preyed upon the poor girl's mind, and the spirit of revenge took possession of her. Morgan, being quite a star in the bushranging firmament, paid annual visits to the profitable stations, and, hearing that there was a fine race-horse on the place, thought he would call again and make an exchange for the worn-out beast he was then riding. After paralyzing the small community he took the horse, and just before his intended departure the girl purposely threw herself in his way, offering to prepare a meal for him. Being good-looking, she attracted his attention, and with a full and aching heart the half-crazed creature made an assignation with him for that night, to be held at a secluded spot some distance from the house. The matter settled, the bushranger rode away to await the appointed hour. The desperate girl mounted a fleet horse and rode twelve miles to police quarters, giving the alarm, and telling what she had planned. An ambush was prepared that night, and as the girl approached the point of meeting she waved her handkerchief for Morgan to appear. The stealthy murderer approached, and at the next wave of the handkerchief fell dead, riddled with bullets.

A large sum of money was subscribed by the wealthy people of the colony and given to the girl, besides half of the reward, which was divided between her and the captain of police; but the men- 
tal strain told upon her, and she never recovered from the shock.

Having had a long rest from acting, I returned to Melbourne to play a short engagement with my former partner at the Haymarket, and then sailed for Van Diemen's Land, now called Tasmania. This lovely island had formerly been a convict station, where life-sentenced prisoners from England had been sent. There was at the time I speak of, and is now, a most refined society in Tasmania, though among the lower classes there was a strong flavor of the convict element. I acted "The Ticket-ofLeave Man" for the first time in Hobart Town, and there was much excitement in the city when the play was announced. At least one hundred ticket-of-leave men were in the pit on the first night of its production. Before the curtain rose, I looked through it at this terrible audience; the faces in the pit were a study. Men with low foreheads and small, peering, ferret-looking eyes, some with flat noses, and square, cruel jaws, and sinister expressions,-leering, low, and cunning,-all wearing a sullen, dogged look, as though they would tear the benches from the pit and gut the theater of its scenery if one of their kind was held up to public scorn upon the stage. This shows the power of the drama. An author might write an article abusing them, or an artist paint a picture showing up the hideous deformity of their features - all this they could bear and even laugh at; but put one of their sort upon the stage in a human form, surrounded by the sympathetic story of a play, and they would 
no more submit to an ill usage of him than they would to a personal attack upon themselves.

The first act of the play progressed with but little excitement. These men seemed to enjoy the humorous and pathetic side of the story with great relish; but when I came upon the stage in the second act, revealing the emaciated features of a returned convict, with sunken eyes and a closely shaved head, there was a painful stillness in the house. The whole pit seemed to lean forward and strain their eager eyes upon the scene; and as Bob Brierly revealed to his sweetheart the "secrets of the prison house," there were little murmurs of recognition and shakings of the head, as though they fully recognized the local allusions that they so well remembered; deep-drawn sighs for the sufferings that $B o b$ had gone through, and little smothered laughs at some of the old, well-remembered inconveniences of prison life; but then, $B o b$ was a hero, and their sympathies were caught by the nobleness of his character and his innocence of crime, as though each one of these villains recognized how persecuted he and $B o b$ had been.

As the play progressed, their enthusiasm increased. Whenever Bob was hounded by a detective or ill-treated by the old Jew, they would howl their indignation at the actors; and when he came out unscathed at the end of the play, a monument of persecuted innocence, they cheered to the very echo. This performance rendered me extremely popular with some of the old "lags" of Hobart Town; and I was often accosted on the street by 
these worthies and told some touching tale of their early persecutions. In fact they quite looked on me as an old "pal." These courtesies were very flattering, but the inconvenience that I was caused by being poked in the ribs and winked at now and then, as much as to say, "All right, old boy, we know,- you 've been there," rendered my favoritism among these fellows rather irksome.

An English audience is as loyal to an old favorite as the nation is to its queen. Therefore the visit of Mr. and Mrs. Charles Kean to the colonies was hailed with delight by the public.

Old Londoners who remembered young Charles Kean and Ellen Tree in the springtime of their lives were charmed to think that they would not only renew their acquaintance with these celebrated artists, but could take their children to see the favorite actors who had delighted their fathers and mothers in days gone by. The Keans on their opening night were welcomed with great warmth; the audience rose from their seats and cheered them as they came upon the stage; old ladies and gentlemen waved their handkerchiefs and stood up to applaud their former favorites as though they would have said, "Welcome, welcome to our new home. Age has dimmed our eyes and wrinkled our brows, but, thank Heaven, it has not weakened our affection."

The engagement was a financial success, for every one was anxious to see the Keans; but time had told upon them, and there was a feeling of disappointment in the audience that with all their 
kindness they could not shake off or conceal - the veterans had tarried too long. Mr. Kean felt this, and regretted that he had come so far only to shatter his reputation.

About a week after their appearance I was walking through St. Kilda Park, when I came suddenly upon an old gentleman sitting alone upon a bench; he seemed to be looking out upon the bay with a sad and thoughtful expression. I had not seen Charles Kean upon the stage since I was a boy: he was then young, vigorous, and in the zenith of his fame, full of hope and ambition, and just married to that gifted actress Ellen Tree; and here he sat an old man, in a far-off land, and from the melancholy look upon his face was perhaps thinking that the closing scene of his career was near at hand. I had been regarding him for some time, when at last he looked up and caught my eye; he stared at me with no very pleased expression: my apparent rudeness had evidently offended him, so I at once told him who I was, and he seemed glad to see me. "Sit down," said he. "I was just going to write you to call on me; you ought to have done so before: I am the last comer; and, between you and me, I am sorry that I came." I told him that I had intended to call, but had heard that he was suffering from dyspepsia, so I thought I would delay paying my respects to Mrs. Kean and himself until he had quite recovered.

"Well," said he, " as I said, I was going to write you ; and, curiously enough, I believe I was think- 
ing of you while you stood in front of me. By the way, what was I doing while you were looking at me? - anything foolish; making faces or any nonsense of that kind, eh?"

"Oh, no!" said I, laughing at his anxiety. "You were quite correct, I assure you."

"Well," said he, "you know an actor when alone is very apt, if he is thinking of his part, to frown and stare in a very unmeaning way. I remember once in London I had ordered lunch at Verey's in Regent street, and while I was waiting for it, began, in an abstracted kind of way, going over one of the scenes of 'Louis XI.' to myself. Suddenly I saw two young fellows talking to one of the waiters and pointing at me; then they passed out, apparently laughing at something I had done. I was quite indignant, and called the waiter to ask what they said. Well, sir, it all came out: I had been frowning and staring, first one way and then another, going over my part, and those fellows thought I was mad"; and here he burst out in an immoderate fit of laughter. "Well, come," said he; "I have had a good laugh, at all events, and, as it is the first for a week, I have enjoyed it. Now, then, I wish to consult you on a matter of some importance; and as it is in reference to our approaching visit to America, I am quite sure that you can, and will, give me all the information I require. I heard that you were in front several times during the last week: now tell me candidly,- don't be afraid of giving offense,- - what do you think of our engagement here?" 
"Well, in the first place your reception was one of the warmest I ever remember to have seen," I said.

"Yes, yes," said he; "the reception was cordial. But after that there was a coldness, a lack of enthusiasm; and this feeling has characterized the audience during the entire week: now don't you think so?"

This question was rather a poser. I felt that every word he had spoken was true, but I knew he was ill and needed encouragement more than facts; so I put a bold front on the matter, and told him that I thought he was oversensitive, and only fancied that the audience was cold, and that the crowded houses ought to convince him of this.

"That is what my wife says," said he; "but she is so full of hope and cheerfulness that nothing daunts her. Well, now then, to the point. We go from here to California, and then to New York, Philadelphia, and so on. What play would you advise us to open in - 'The Gamester'?"

"By no means," I replied.

"Why not? Don't you think it a good play?" said he.

"It was a good play fifty years ago," I replied, "but not now. It is old-fashioned and beyond endurance, and details the misery of a married couple in a most mournful way. Just think of sitting through five acts of woe unrelieved by one touch of humor. The theme is a gloomy one; and, believe me, when you lay it upon the shelf it will gather dust and mildew. I would suggest that 


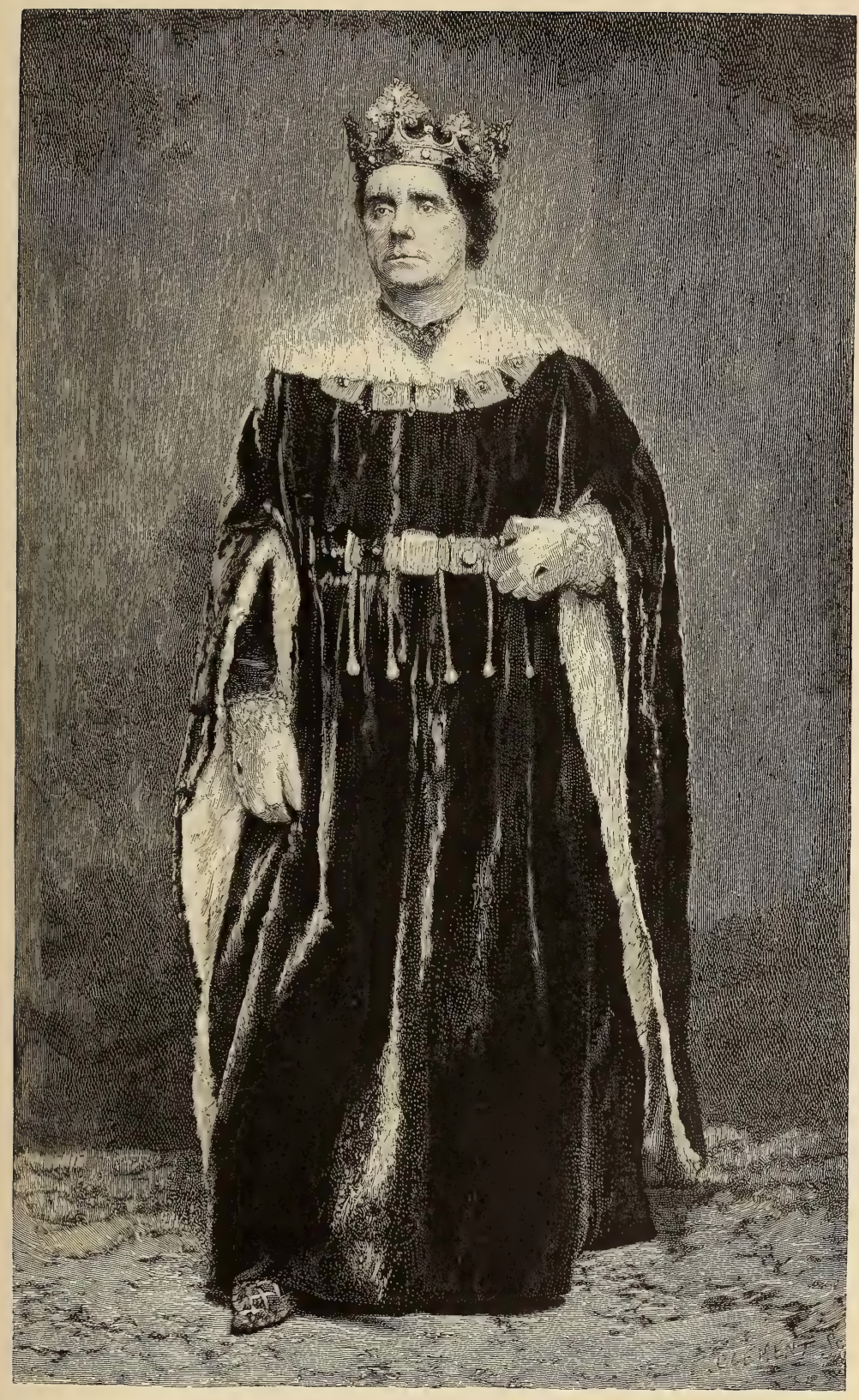

MR. CHARLES KEAN AS "KING JOHN." 

you open in 'Louis XI.' Without Mrs. Kean your name will be sufficient to attract on the opening night; then bring out your wife as Queen Catherine, yourself playing Wolsey; follow this with Macbeth and Lady Macbeth: in fact, I should not, if I were in your place, extend the repertory beyond these plays; if you confine yourself to this prescription, your success is assured. 'The Wife's Secret' and 'The Gamester' are all well enough here: your audience is largely made up of friends who remember you both with pleasure - the plays, too, memories; but you have been so long away from America that the present generation of playgoers will be new acquaintances, who have no former remembrance of you, and will only look at the entertainment for just what it is, and not for what it was."

"Humph!" said Kean; "that is rather a delicate way of hinting that Mrs. Kean and I should act parts better suited to our age." And here he eyed me with a sly, peering look.

"Well," I replied, "you have asked me to be candid, and that is just what I mean."

"And I believe that you are quite right," said he; "but my wife will have it that we are as young and beautiful as ever. I believe that she would act Juliet now if I were fool enough to play Romeo with her." And here he had another good laugh.

Although Charles Kean was irritable at times, he was delightful company, and told a good story with great glee. Some of his anecdotes of the London stage were most amusing. While we were 
chatting, a party of some three or four blacks came in sight. I hailed them, thinking that Kean might like to see the throwing of the boomerang.

A tall, gaunt fellow, with scarcely a pound of flesh on his ungainly bones, and evidently the leader of the party, astonished us with his dexterity. $\mathrm{He}$ walked three or four paces forward with a swinging kind of gait, and, casting his eye behind, pointed to where he intended to make the weapon strike; now whirling it straight forward it shot into the air, and, making a sudden turn, came back and struck the spot he had indicated.

"Ah," said Kean, " they may well call Australia the antipodes; when the natives want to hit a mark in the west, they hurl the weapon towards the east."

The black came up for his exhibition money, and stood in front of us with his limp hand extended and an idiotic grin on his face; and surely he was a sight to look at - as lean as a skeleton, and as black and shining as a piece of polished ebony. His attenuated form was crowned with an ugly head, covered with a bushy shock of unkempt hair, and his face was blank and expressionless. What a contrast he made to the intellectual and thoughtful face of the tragedian! Here was a Shaksperean scholar, who had been educated at Eton, standing side by side with this uncouth savage, so low down in the scale of humanity that he was barely conscious of his own existence; and yet the actor was rewarding the black for the performance of a dexterous feat that would have puz- 
zled the old Eton boy to accomplish if he had tried it until doomsday.

Nothing would do now but that I should join him at luncheon, so we walked to the hotel, where I was presented to Mrs. Kean, who was in a high state of anxiety at the prolonged absence of her husband. There was no affectation in her solicitude; one could see at a glance that she was a noble companion for her liege lord, and full of care and affection for him. He at once turned the conversation on the disappointment he felt on the result of their first week's engagement; his wife laughed at the idea, and I joined in with her. After we had settled this matter, he detailed to her our late conversation in part, out of pure mischief, I believe, beginning somewhat in the following strain: "My dear, Mr. Jefferson thinks that it is high time for two such old fools as you and I to give up playing young parts and go into characters whose antiquity will be more suited to our dilapidated appearance." I felt like throwing a loaf of bread at his head for daring to place me in such a false position, and endeavored to explain to Mrs. Kean how he had forced the whole affair upon me, while he was laughing immoderately and enjoying my discomfort. However, she took the matter so good-naturedly that I felt satisfied that she understood me in relation to his fabrication as well as she did her husband's exaggerations. As soon as my mortification was over I began to enjoy the joke. Kean was in high spirits, though now and then, in the midst of his hilarity, a sad and despair- 
ing expression would force itself into his face. $\mathrm{He}$ went out on the balcony to enjoy his cigar, leaving Mrs. Kean and me alone. During his absence her cheerful manner altered, and it was plain to me that she had taken in the situation of their engagement more clearly than he had, for she said to me, with tears in her eyes, "Thank you for keeping up his spirits ; he needs it."

Ten years after this, I met Mrs. Kean at a garden party in London; she was then a widow. This estimable lady has since that time passed away. Peace and happiness be with her! As an actress, she was for years the delight of the public; and as a wife, a comfort and an honor to her husband.

During my visit to Australia I acted at Daylesford, and after the performance, by the invitation of a friend, I visited a Chinese theater. We rode through the woods for three miles to a camp or gold-diggings worked by the Chinese. There was a large population of them here-about two thousand. It was past twelve o'clock when we reached the theater, where the actors were hard at it, and had been from sundown. The theater was under a tent, looking like a small modern circus cut in two. The seats were arranged in a half-circle, the stage coming out well among the audience. The Chinese manager had been apprised of our visit, so he had reserved seats in the center of the tent, which was quite full of Chinamen. The orchestra was at the back, and the music - if the hideous sounds they made can be dignified by that name-was played at inter- 


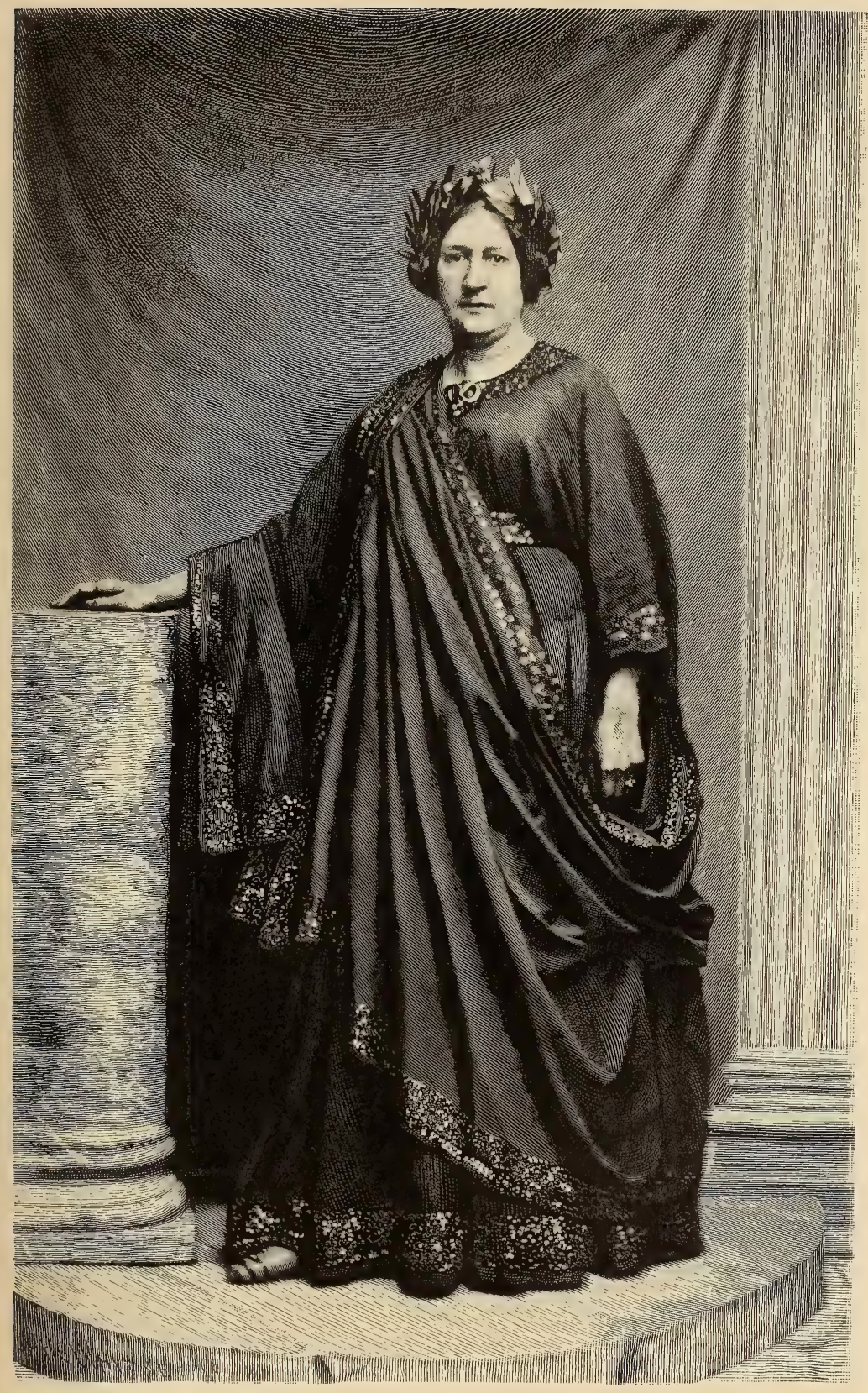

MRS. CHARLES KEAN AS "HERMIONE." 

vals during the whole performance. I recognized the play by its action to be our old friend, "The Young Scamp." In French it is called "Le Gamin de Paris"; in Chinese, "The Mother's Pet"; and I suppose every nation in the world has a free translation of this universal piece of humanity. What on earth the music has to do with a Chinese play, I could never discover. The band will remain perfectly quiet for five or ten minutes, and then, apparently without the slightest provocation, burst forth upon the audience, splitting their ears with the most dreadful din - the scraping of catgut, the tooting of pipes, tinkling of triangles, and banging of gongs, altogether making a most discordant clatter. Now dead silence; then a long speech by some actor, punctuated by little taps on a small sheepskin drum, the catgut man now and then scraping a parenthesis. The musicians sit bolt upright, staring in front of them, without any movement or expression, looking like a lot of badly made wax-figures in a museum. Then, when all is quiet and you least expect it, they will bob their heads up and down, banging and tooting and scraping everything they can lay their hands upon. The interpreter tried to explain to me that this was done sometimes to attract the attention of the audience, but to me it would seem to have the contrary effect.

The dialogue began to get monotonous, and I asked permission of the manager that I might go behind the scenes and see some of my Chinese brother actors. This, after some red tape, was 
allowed me. Instead of the actors getting themselves ready to go home, as I naturally supposed at this time of night, or rather morning, they would do, the entire company was preparing for another play-enrobing themselves in richly embroidered costumes, and covering their faces with all the colors of the rainbow, which they got out of little round pots filled with oil paint. As the manager was given to understand that I was in my way a "star" from America, he insisted that I must only be introduced to his "star"; so I was ushered into a small tent set apart for that celebrity.

This person seemed to have got through with his portion of the entertainment before I came. Of course we could only talk through our interpreter, who seemed to have the faculty of explaining everything the wrong way. I understood, however, that it would give the great actor much pleasure if I would have a little gin and smoke a pipe of opium with him. Upon my declining these delicacies, he faintly smiled on me in a pitying and sympathizing way, as much as to say, "Ah, these barbaric Americans; they have no idea of comfort or refinement." He was himself already well under the influence of the fatal drug, and, whatever the end might produce, was certainly now on good terms with himself and all the world. I could not help thinking what a curious incident this was - to be here at the antipodes, sitting in the dressing-room of a Chinese tragedian. I looked at his fat and inexpressive face, and wondered if he had even heard of 
Shakspere. He sat there in front of me nodding his head as if he were answering my question and saying: "Oh, yes, young man. Shakspere? Oh, yes, very often; but he 's quite a mistake, I assure you."

My friend now entered the tent, and admonished me that it was near daylight and time to go home. As I went out, I turned back for a last look at my Oriental companion, who had by this time entirely succumbed to the influence of the narcotic. $\mathrm{He}$ was stretched out in a chair, his smooth yellow face widened out with an imbecile smile of idiotic bliss, and his two conventional Chinese eyes elevated at an angle of forty-five degrees. The fresh air revived me; so we mounted our horses and rode away just as the day was dawning, while the gongs and the tooting and the scraping were going on in the distance.

In April, I864, I took a steamer from Melbourne to New Zealand. This was a rough and treacherous voyage. The great island has an iron-bound coast, and the ragged rocks were horrible to look at as we approached the harbor of Dunedin.

On my arrival I found the theater in which I was to act doing a great business with some novel attraction that had just hit the public taste. Clarence Holt, the manager, requested me, in consequence of the sudden and unexpected success that had attended his new enterprise, to delay my opening for two weeks. As time was no great object to me, I consented, deciding to spend the interim at a Maori village on the coast called Wik- 
awite, where there was good fishing and shooting; and, as I had been quite ill for the month previous to leaving Melbourne, I felt that the rest and seabathing would strengthen me, and perhaps assist to fill out my attenuated form; so I took up my abode for a week at a little hotel at this place, surrounded by the native Maoris. Of course these people were in a semi-civilized state, though they had formerly been cannibals, and when out fishing with them I could not help smiling at Sydney Smith's description of a New Zealand lunch, "with cold missionary on the sideboard," and his solemn farewell to the minister who was leaving England for the purpose of christianizing the Maoris. "Good-by, my reverend friend," said he ; "and if they eat you, I hope you 'll disagree with them." I felt quite safe among them, however, for, as I was very thin, I presented anything but a tempting morsel to these voracious warriors. The Maoris are said to be the finest race of savages in the world. They are giants in size and strength, and their symmetrical bodies are tattooed in grotesque figures and patterns, sometimes from head to foot.

I saw a party of them act in a play that had been written to show off their sports and ceremonies, and in one of the scenes where they were tracking an enemy the grace and earnestness with which they moved were surprising.

My engagement in New Zealand was quite successful, the old comedies, strange to say, being preferred. I now returned to act in Sydney, from 
which place I had been absent nearly three years. On my arrival Father O'Grady called on me, and, to my surprise, introduced me to his wife. He was still faithful to his Church, but had given up his orders and had married. I did not blame myself for making him an apostate; for it was evident, from the beauty of the lady, that not my advice, but her black eyes, had been too much for the "good St. Anthony."

From Sydney I returned to Melbourne, to play my farewell engagement in the colonies and bid adieu to the many friends I had made. And as I look back upon the four years I passed in Australia I can only recall a dear remembrance of the kindness that was shown to me by the refined and hospitable people of that country. For a long time after I left there I contemplated paying it another visit, but year after year rolled on, and now I fear it is too late. To wander through the streets that I so well remember and find them altered would be nothing; we are too used to these changes in our own country to be affected by the wonderful growth of cities and the sudden shifting of localities; but I should feel lonely indeed to miss the faces that were so familiar, and to think over the olden time when I was young and full of hope - surrounded by loving companions who had gathered around me when I was a stranger among them. It is a quarter of a century since I left that distant land and those dear friends, but I have never forgotten them, and I am told that there are many who still remember 
me. And now farewell, Australia! I have no feeling but loving gratitude for you, and should these pages meet the eye of some old friend, let us feel that we have come once more together upon this earth and shaken hands. 


\title{
CHAPTER X
}

\author{
IN SOUTH AMERICA
}

Callao-Lima-A Midnight Funeval-A Beggar on Horseback - The Theater in Callao-A Religious Tableau-A Tropical City-Leaving South America - An Incident in Panama

T LEFT Melbourne in a sailing vessel in the month of April, i865, bound for South Amer-

1 ica on my way to England. We were fiftyseven days at sea - a long and dreary voyage. During the whole passage we saw but one vessel. This portion of the Pacific is a waste of water, unbroken by land or any moving object, save the flight of the lonely albatross. This large bird sometimes measures ten feet from tip to tip of its wings, and as it sails around the ship it turns its head slowly from side to side with a wise and dignified look. The flight is graceful and mysterious. At times it will poise itself in the air, seemingly without motion. We caught several of these birds with a hook and a piece of meat. When seen closely they lose much of their mysterious beauty. 
They are not good sailors, and their sea-legs are treacherous. As soon as they stand on deck they become seasick and disgorge their food. As few ships cross the track of vessels in this region, the dreary waste is called by the sailors "the wilderness"; and the thought will force itself upon one that, if an accident should occur here, and the crew and passengers be compelled to take to the open boats, there would be but a slight chance of being picked up for many days.

We had several passengers, two of whom enlivened the trip with their political arguments. One was from South Carolina, the other from Massachusetts, and their disputes were quite violent. I was a kind of mediator between these hostile parties, and helped to settle some of their quarrels. At times they were the best of friends, and really liked each other very much. We would often see them walking up and down the deck, almost affectionate in their manner towards each other; suddenly a chance shot would be fired, and then their feelings would burst forth in a blaze of excitement. They would break away and stride furiously from one end of the ship to the other, and when they met would face each other like a pair of bantam fighting-cocks, with their arms akimbo and their heads violently wagging away until one would think they must soon come to blows.

On the fifty-seventh day we dropped anchor in the bay of Callao, six miles from the beautiful city of Lima, on the coast of Peru. A heavy fog settled over the town just as we arrived, and all sur- 
rounding objects were quite invisible: not even the lights of the place could be seen, and we only knew our position in relation to the town by the howling of innumerable dogs on shore; one of the passengers facetiously remarking at breakfast that he had been kept awake all night by the heaviest dose of Peruvian bark he had ever taken. In the morning the fog was still heavy and impenetrable, and we were waiting for it to clear off so that we could land and get some news. The two belligerents were uneasy and restless, eagerly desiring some bulletins of the war. Presently we heard the plash of oars, and a boat darted suddenly out of the mist, stopping close beside the hull of our vessel. It was rowed by two swarthy looking Peruvians, and in the stern there sat, or rather leaned lazily back, a tall, thin man with his legs wrapped round each other and a cigar tilted up so high in his mouth that it must have scorched the wide rim of his Panama hat. He was unmistakably my countryman, and if there had been any doubt of this he soon set it at rest by exclaiming as he caught sight of my face, "Joe Jefferson, by thunder!" There was a general surprise at this unexpected remark, and I was quite startled, though I confess somewhat pleased, at a recognition in this strange land. Of course I rose to a high premium now in the eyes of the passengers, and was deputed to interrogate my friend as to the latest news from the seat of war; but, like a true Yankee, he was n't to be pumped without filling his own bucket at the same time. 
"My friend," said I, " as you seem to recognize me, perhaps you will kindly give us some news of the war." He answered this question by asking me how long it was since he saw me act in New York with Laura Keene. I told him about six years, but that I would be very much obliged if he would give me the latest news concerning Richmond.

"Where's old Ned Sothern now ?" said he to me. I was between the two belligerents, who were both writhing in agony at the cool delay of my new-found acquaintance. I told him that Mr. Sothern was in England, but that I really could not answer any more questions until he told me something about the war.

"Is he actin' old Dundreary now before the Britishers?" said he. Finding I could get no satisfaction from him, I turned to the captain and said: "You had better interrogate this man yourself. Perhaps you will be more fortunate than I have been."

Here the captain broke in, hailing him with, "My friend, I am the captain of this ship, and would like to get a paper from you concerning the war, as you don't seem to be very communicative yourself."

"Will your ship want calkin', Captain, before she loads?" said the impenetrable calker - for that, it seemed, was his profession.

"You don't calk my ship, or have anything to do with her, until you answer my question," said the captain. 
The man now became thoughtful, and, I presume, turning over in his mind that he might lose a job if he did not comply, said, "Oh! the war - that 's all over; the South caved in, and Richmond is took."

The crestfallen gentleman from South Carolina sank upon a stool in the middle of the deck, and the lively gentleman from Massachusetts danced a hornpipe over him, whistling "The Star-spangled Banner" as an accompaniment.

That part of the Pacific coast that borders on South America is an interesting region, though the title of Pacific is somewhat of a misnomer, for the locality is in a continual state of commotion, both civil and military; and when the occasional visitations of tidal waves and earthquakes are added to the human, or rather inhuman, turmoil that constantly rages through this feverish land, the traveler is more anxious to bid it farewell than ever again to tax its hospitality.

The town of Callao has always been singularly unfortunate during these external and internal disturbances. Situated in a somewhat exposed harbor, it presents a fine mark for bombardment in times of war, and a convenient spot for the passage of a tidal wave in times of peace. It is said that on a quiet moonlight night some hundred years ago, while the inhabitants were innocently slumbering and not dreaming of disaster, one half the town, having no desire to disturb the repose of the other half, slipped quietly away from its foundation and slid gently into the bay. I was told that some 
distance out in the harbor, when the tides were extremely low, the roofs of the submerged houses and the spires of the old Spanish cathedral could be seen beneath the clear waters of the bay. We got into the boat of the custom-house officer, who directed the men to row us to the shore, and as we landed we discovered that the town was in a wild state of commotion. Soldiers and policemen hurrying from the barracks and station-houses, brokenpated rioters under the escort of guards, and a general stampede of frightened women and children, made up an animated but rather unattractive picture for the entertainment of peaceful strangers. In the midst of this excitement there appeared upon the scene an old man in his shirt sleeves, attended and arrested by at least a good half-dozen policemen, who were hurrying him along to prison.

I was afterwards told that the disturbance and arrest had grown out of an attack upon two Chilians by some Peruvians, and that the former had fled to the house of the French consul, M. Valrie, who had protected them and offered the defenseless parties a sanctuary on his premises. A mob had collected about the place, and when the consul came out to ask their patience till a proper inquiry could be made, the rioters became incensed; and at his offering protection to the Chilians the unruly crowd attacked the old man, who, seeing himself dangerously surrounded, snatched a sword from the hand of one of his assailants, and clearing a circle in the midst of the crowd fought his way out amid a shower of stones and sticks. The scene as 
it stood when we came upon the ground was animated and dramatic.

As we arrived in front of the jail, the policemen had unloosened their tight hold on the consul, who stood calm and unruffled, with his arms folded and with a look of utter contempt at the mob; the blood streaming from an ugly gash in his forehead had stained his white hair, which seemed to stand up defiantly. The expressive features of the old man had a fine aristocratic cut, and contrasted strongly with the low-browed, swarthy Peruvians who surrounded him. They hissed their anger at him and brandished their sticks and knives about his head; but the resolute look from his clear blue eye, and the quiet smile on his pale face, told of the supreme satisfaction he felt as he gazed in triumph at the well-battered heads of the enemy, and, old as he was, but few would have liked to trifle with him upon even ground.

I have mentioned this little incident as I afterwards became intimate with this interesting old gentleman, and had some curious experiences with him.

I consulted the list of departures, and found that I could not possibly leave for Panama inside of ten days; so, with the rest of the passengers, I determined to spend that time in Lima. This city was founded by Pizarro in the year I535, and a magnificent cathedral built by him still stands in the center of the plaza. Through each one of the principal streets of Lima flows a clear stream of water. Pizarro had viaducts constructed from the 
foot of the Andes for the purpose of running these useful sewers through the city. It is a bright and sparkling place. The ladies are considered the most beautiful in the world, while the men are the most insignificant. My South Carolina friend was particularly susceptible to female beauty, and, being unable to restrain his enthusiasm, would start back as every new and beautiful face presented itself: pausing suddenly and grasping me by the arm, he would point at some lovely beauty, and go off into an ecstasy of delight. Many of them would veil their faces, while their cavaliers would look stilettos at my enthusiastic friend.

The South American cities are extravagant in the use of gas, and Lima at night is brilliantly illuminated. There was a French comic-opera troupe at the theater, so we wended our way in that direction. The crowd was great, and we had difficulty in procuring seats, which at last we accomplished by paying high prices to the speculators. The dress circle is reserved entirely for ladies, who have their open private boxes which encircle the whole tier. They never go into the parquet, so that part of the house was filled with gentlemen, and, as the curtain fell, they all got out their opera-glasses, and, turning around, began surveying the beauties in the circle. This is the custom; it is not considered rude; on the contrary, the fair ones expect it, and prepare their toilets to meet the demands of this masculine scrutiny. If we were struck with the handsome 
ladies on the plaza in the daytime, what was our amazement at the fascinating scene before us as we stood with our backs to the curtain and gazed in wonder at the audience! The circle was ablaze with beauty, the black eyes of the señoras and the señoritas vying in brilliancy with the diamonds in their raven hair. Their toilets were exquisite flowing, gauzy silks in pale pink, blue, white, and amber; light and delicate fans waved with a grace only to be accomplished by those who have Castilian blood in their veins. A Frenchwoman is graceful and knows it, but a Spanish woman is graceful and does n't know it. There is such a difference in the effect of this! The extraordinary part of the sight was, that hunt where you would, there was no discovering a plain face-nothing but beauty. These bewitching sirens have a lovely olive complexion, tinged with deep carmine, singularly white, pearly teeth, and eyes so deep and black that I said to myself: " Oh, Father O'Grady, it was lucky for the little Sydney maiden that you did n't stop in Lima on your way to Australia." The good St. Anthony himself could never have withstood such glances as were here revealed.

Just before the end of the opera it is customary for the señors to vacate the parquet and station themselves in a long line to watch these lovely creatures pass out; and as they move slowly through the line of admiring gentlemen they begin to undulate those fascinating fans that almost speak, and bow and smile so sweetly 
that everybody seems to be making love to everybody else.

After the opera we walked through the Grand Plaza. The majestic old cathedral of San Francisco loomed up grandly in the dark night. The rich stained-glass windows were illuminated, and a dismal peal from the organ, accompanied by a low, wailing chant from the monks, told that a midnight funeral service was being held. The body was laid out in front of the altar, with kneeling friends and relatives about it. The dirge was in Latin, and was chanted in a minor key, producing an awful effect, and one that I should think would be anything but consoling to those who are left to mourn the dead. I never saw a funeral service at night before, and the contrast just after the merriment of the opera was very striking. In the morning (it being a fast day) we went to the same church to hear mass. The outside of the cathedral had a cheap and tawdry appearance in the daylight, resembling theatrical scenery under the same circumstances. The plastering, broken and decayed, was painted a pinkish yellow; the doors and windows blue and green; the ironwork and figures were gilded with cheap Dutch metal - giving the whole building the tone of a decomposed Christmas cake.

On entering the church our ears were saluted by a magnificent orchestra playing the overture to "Masaniello." There are no pews in this cathedral; the great open space in the center is flagged with stones, and hundreds of people were on their 
knees at prayer; a motley group composed of all grades of society - native Peruvians, half-castes, and pure Spanish, all mixed together. A lame old mendicant, with his feet swathed in bandages and his crutches by his side, was groveling on the pavement, possibly asking relief from agonizing pain; farther on was a little market girl with a basket of flowers in her hand; between these knelt a stately and beautiful señora in rich and costly black lace, her raven hair done up with a jeweled comb, and sparkling gems in her ears and upon her fingers. This seemed to me the pure democracy of religion. Out of the church these people had their different spheres; their roads in life were widely separated; but here, where they prayed to God, they seemed to be upon a common level, and the lady and the beggar offered up devotions side by side.

After breakfast we walked out into the courtyard, and there I saw, for the first time in my life, a beggar on horseback - not the proverbial fellow who, having suddenly come into a fortune, bestrides a prancing steed and goes galloping over the heads of his old comrades, but a beggar mounted on his own charger. He got down from his saddle, and, taking off his sombrero, walked slowly and in a cringing sort of way from one point to another, asking alms. He had a villainous walk, and shambled along with a halt first in one leg and then in the other, almost dragging his unshapely limbs after him, his shoulders dropped and his face turned up with a hypocritical smirk upon it; but with all his fawning, his snake-like eyes had a 
searching, eager look that seemed to charm the unwilling charity out of the guests, and upon receiving each donation he would roll up his eyes and invoke a benediction on the giver. Nobody wanted to give him anything, yet most of them did; our group was disgusted, and declined to be blessed on this fellow's terms, at which he gave us a look not at all resembling a prayer, and most threatening in its aspect. After browbeating most of the bystanders out of their money he coolly sat down to count it, and then, without the slightest look of gratitude, lighted his cigarette, mounted his horse, and rode leisurely away.

I was naturally curious to find out something about this fellow, and in a conversation with the landlord learned that there were many of his class living on the outskirts of Lima. It seems they are a kind of half-beggar and half-brigand people, and prowl about at night in the dark streets near the edge of the town, begging from strangers. They seldom commit murder, but have a way of terrifying their prey into submission; the one we saw was especially bold, plying his trade in the open day. Their victims generally think it better to give something and so quietly get rid of them.

After I had been about a week here my old New York friend, the calker, who had hailed me on my arrival, called on me, as he said, to talk over old times; not that we had ever met in America, but, as he put it:

"Don't you know when a fellow in a foreign land sees another fellow from the same place he's from, 
he kinder wants to pump him out, don't you know?"

"Pump him out" I naturally presumed was a technical phrase of his profession, being an operation to which a ship is subjected previous to calking. I asked him if I was right in my surmise. "Quite," said he; "you are watertight on that point."

"Have you been long in South America?" I said.

"What 's become of Laura Keene?" he replied.

From my past experience I saw that he was going to do all the pumping, so I quietly submitted. He began asking the whereabouts of the actors that had played in "Our American Cousin." $\mathrm{He}$ seemed to have treasured their names as if they had been old friends. I wondered at this, and thinking I might venture on a question, asked him why he was so anxious to know all about them.

"Well," said he, "the actors a fellow sees in his young days, don't you know, he never forgets, though he has never spoken to 'em. He seems to kinder know'em. Why, I could go on and tell you the names of all the old companies for years back - at Wallack's, Burton's, and even way off in the days of Mitchell's Olympic. Blake, Chanfrau, Mr. and Mrs. Barney Williams, Charles Walcott - yes, and a hundred more. They seem like old friends to me." Here he paused for a moment, as if calling up some old theatrical memories. At last he seemed to wake up, and said, in a mysterious way, "Did you ever see a 'fandango'?" 
“No," I said; "what is it?"

"Well, it 's a place where Spanish girls sing and dance, and play the guitars and castanets. The company is kinder mixed, and it 's a leetle dangerous sometimes."

I told him the latter part of the programme would certainly have no attraction for me.

"Well," said he, "there 's one thing in Callao I want you to see; it 's the Spanish theater. I shan't tell you what it 's like; but you won't regret going, for it 's the darnedest, queerest theatrical performance you ever saw or ever will see."

I was now, naturally, interested, and went with him that evening to Callao, six miles from Lima, to visit the Spanish theater. We got seats in the dress circle, where we could have a good look at the entertainment and the audience. The cheap part of the house was quite full. In the pit there were entire families of men, women, and half-grown children. They appeared to be quite respectable, but very hilarious. The place was filled with smoke, the cigarettes being plied with great vigor in every direction. The performance opened with a farce. There was little or no dialogue, but plenty of practical fun. The characters seemed to be in a continual state of excitement, suffering, and terror. A man with a white face would go up the chimney and come down black, a baby was thrown out of a window, and an old lady burned her husband with a red-hot poker. The audience were very much amused at this, and I noticed that their glee was at its height when any one suffered physi- 
cal pain. After this performance came Spanish dancing of an excellent kind, full of graceful poses and not at all vulgar. The dancing was followed by instrumental music and singing.

As I traced the plot of the next play through the action I discovered it to be "The Prodigal Son," illustrated by dialogues and tableaux. The parting of the father with his boy was exceedingly well done, and many of the audience were in tears. The temptation scene at Memphis, where the prodigal gambles and is lured away by beautiful women, was well acted and realistic. Then came the return of the prodigal, which ended the play.

I fancied that now the entertainment was over. but the alert calker laid his hand on my arm, saying with earnest meaning, "Wait a minute."

The theater was darkened, the cigarettes were put out, and a solemn hush went up from the audience. The place was as still as death. The people almost stopped breathing. I seemed to be the only one who did not know what was coming. Now there came a low moan of anguish, as if from a great distance; so expressive of sorrow, and yet so gentle we could scarcely hear it. An invisible organ began a solemn dirge, and as the curtain rose there before me was Mount Calvary with a complete tableau of the crucifixion, the whole scene represented by living figures - Christ upon the cross, the two thieves, and a group of female figures kneeling upon the ground. I was startled at this unexpected sight, but I saw at once by the reverence of the audience, and the earnest manner in 
which the tableau was given and received, that no sacrilege was intended. On the contrary, the beholders were devout: some were on their knees; men were praying, women were weeping, and nearly all made the sign of the cross and bowed their heads. I was transfixed with wonder as I looked upon the scene. In the distance there were dark and ominous clouds, streaked at the horizon line with a blood-red color as the sun was going down. The walls of the distant city were dimly visible, and against this dark mass the three weird crosses stood out with a bright light shining upon them. The patient anguish of Christ was wonderfully represented in the upturned face, while the heads of the two thieves hung down in abject, groveling misery. The contrast was marvelous, and the terrible grief of the women stretched out in agony upon the ground was full of reality. The curtain slowly fell as the organ pealed out a solemn hymn, and the audience rose and left the theater with a quiet, noiseless step, as if they were going from church.

Here is a subject that at once opens up a field for thought and discussion. The religious tableau that I saw in Callao is, undoubtedly, the same one given at the close of the Passion Play in Ober-Ammergau, which thousands of devout Christians assemble to witness. They pay for their admission, and look upon the exhibition with no other feeling than that of reverence; yet if the same picture were presented here by the same people the audience would be shocked and distressed. And this is be- 
cause, in the first place, we naturally feel the influence of the country we happen to be in, and imbibe sympathetically the sensations of those who surround us. In the foreign lands we know that time and custom have made it with them a sincere and holy illusion; whereas if this entertainment were sprung suddenly upon us here it would give great offense, because we should recognize that the subject was merely a catchpenny. It is the motive, therefore, which renders the same act religious or sacrilegious; and what is perfectly right in Bavaria or South America would not be tolerated in England nor in the United States. But I saw, from witnessing the impression of this performance on the ignorant minds of people who could neither read nor write, how effectively the Church in the olden time must have used the drama as a mode of illustrating religious history.

No rain ever falls in Lima. A heavy mist settles upon the city just before daylight and hangs like a pall over the place. About ten o'clock the sun breaks forth, quickly dispelling the misty veil as if touched by a fairy wand. The sky in an instant becomes azure blue, and the atmosphere so bright and transparent that, as you look at the far-off Andes, the crevices of the mountains are as clearly defined as if you were viewing them through an opera-glass. The gaudily painted shops and dwelling-houses, and, above all, the bright-colored walls and steeples of the churches, are crude and offensive when you are close to them, but viewed in the distance the effect is very different. 
There is an antique bridge of quaint Spanish architecture some three miles from the city, through which falls, or rather tumbles, a cataract of foaming water. Standing on this structure and looking back on the city at sunset, the rich colors melt into each other with the most ravishing gradations. Above the red-tiled roofs of the old houses rise the innumerable tall, gray towers and gilded spires of the different churches. They seem to flash in the sunlight and stand out clearly against the deep-green background of tropical foliage that skirts the base of the Andes. These lovely mountains rise one above another, melting from deep green to blue and purple. The peaks, full six thousand feet above the level of the sea, are capped with snow, glowing pink and golden against the clear blue sky.

Nothing can exceed the brilliancy of this tropical city. The costumes of the people are very picturesque. The ladies wear no hats, but wind about their heads and shoulders a graceful scarf called the rebozo. This is passed across the face, leaving only one eye of the lady exposed. Whether this is done to preserve the complexion, or to give a coquettish air to the wearer, I do not know, but the effect is full of mystery and romance. The children dress precisely like the grown people. Little señoritas six or eight years old wear the "rebozo," and peep their one little eye out in quite a comical way, and the boys go about in black swallow-tail coats and high silk hats, looking like so many General Tom Thumbs. 
The streets swarm with lottery offices, and the hawkers stop you in the plaza, or waylay you at the corners, offering tickets for sale. Gambling is the besetting sin of the country. Men, women, and children of all grades indulge in this passion. In the quiet summer evenings it was delightful to walk by the dwellings and pause to look in at the courtyards. Many of these are illuminated and decorated with fountains and with orange trees bearing fruit and blossom at the same time; señors and señoritas swinging in hammocks, smoking cigarettes, and playing their guitars. It was a very dreamland of romance.

Since I was there this lovely city has been desolated by war. The majestic churches and beautiful homes have been battered down by the armies of Chili, the proud people subjugated, and the whole country of Peru laid in waste and ruin.

We sailed from the port for Panama early in August. On our second day out I recognized the old French consul at Callao. $\mathrm{He}$ and his wife were promenading the deck arm in arm, their little son clinging affectionately to his father's hand. To my surprise the consul stopped me, and, offering me his hand, exclaimed: "Ah, Monsieur Jefferson, permettez-moi. I have known you exceedingly very often. I was been consul in Sydney when you arrive zer four times a year ago!" He introduced me to his wife, who was an exceedingly bright, witty little lady, and as my agent spoke French fluently, we made the trip 
through the tropics the more agreeable by an interchange of civilities and ideas.

It was fortunate that my agent was a good interpreter, for if in his fracas with the Peruvians M. Valrie's head had been as badly broken as his English, he never would have left South America alive. He and his wife and his son were bound up in one another's love. The lad was not more than twelve years of age, quite young to be the son of such an elderly couple, and he seemed to be the sunlight of their lives. He would often pat his father's hand and kiss his mother's cheek in the warmth of his affection, and at such times the old people would glance first at the child and then at each other, as though they were saying, "Was there ever such a boy as ours?" One could not look at this Arcadian trio without shuddering at the thought that their happiness came so near being destroyed by a ruthless mob of South American ruffians, whose whole lives were not worth one drop of the blood they would have shed. M. Valrie, like all his countrymen, was devoted to the drama and the opera. As I had been in France, and was familiar with the acting of the favorite comedians, we would compare notes as to our opinion of the reigning favorites of the French stage. He delighted in these conversations, sometimes wandering off in imagination to the Opéra Comique, singing the overtures to "Zampa" and "Fra Diavolo" all out of tune, and giving imitations of some of the noted actors, shrugging his shoulders and grimacing to the delight of us all. 
At such times it was curious to contrast this innocent, vivacious little man with the calm and dignified consul whom I had seen behave so courageously when in the hands of the rioters, and difficult to realize that it was the same person.

The moon shines with great brilliancy in the tropics, and when the Pacific is on its good behavior the long, low swells, as smooth as glass, reflect great streaks of light in fantastic shapes across their surface with splendid effect. During these glorious nights our little party would sit out on the deck of the steamer, humming old tunes and keeping time with the beat of the machinery, and generally finishing the evening with a game of whist, the agent and Madame against the consul and me. The French are bad whist-players, and surely M. Valrie was a champion in this respect; he never would return my lead, and whenever I took a trick he would trump it triumphantly if he could.

"My dear M. Valrie," I would say, "why trump it? the trick was already ours."

"Ah, mon Dieu!" he would exclaim; "how treacherous I am! Ah, well! we bos take him tergezzar, so we make sure of him, eh? it is always ze same t'ing."

A singularly interesting old gentleman called to see me while I was acting in Australia. He had been in the colonies for a number of years. His early life had been passed in the society of actors, and his memory of the celebrities of the theatrical profession was quite remarkable. He knew the 
Kembles, Mrs. Siddons, Jack Bannister, and Elliston intimately. He had witnessed the O. P. riots and Kean's first night in London. As he had a rich fund of theatrical anecdotes, I was charmed to cultivate his acquaintance. We passed many hours together, walking and chatting in the Botanical Gardens, and in these rambles I gleaned from him much of the unwritten history of the English stage during the reign of George the Fourth.

I mentioned to him that I was about to visit England by way of South America. "Then," said he, "you will pass through Panama?" I told him that I should do so. He became very much agitated, and said: "My young friend, I have a dear daughter living in that city. She is the wife of an English merchant. I have not seen her for fifteen years. My only child! God knows how I have longed to look upon her dear face again. Will you not see her, and tell her that we have met? I know that she will feel anxious to hear of her old father. We are separated by thousands of miles, and shall never meet again upon this earth, but it will be a great comfort to me if you will let me know that you will bear her this message."

He gave me the name and direction of the merchant, and I promised him faithfully that I would see the old man's daughter when I passed through Panama.

On my arrival there I felt much pleased to think that I should possibly see the daughter of my old Tasmanian friend and bear to her the loving message of her father. I detest the tropical cities, and 
have always been miserable until I could get out of them, with the single exception of Lima. The humid atmosphere, filled with the rank odor of vegetation, the sweltering heat, the lazy and inanimate inhabitants - all combine to make one restless and unhappy. So it was a comfort to contemplate an approaching sensation of a domestic character. Besides, there was a touch of the dramatic in the prospect of telling a long-lost daughter of her long-lost father, and I quite felt my heart beat as I approached the house of the English merchant. The name on the door was quite correct, and, in accordance with the old gentleman's direction, I rang the bell and sent in my card by a warm, red-faced footman, who returned and ushered me into the presence of his master. The gentleman remained seated as I entered, and seemed to be looking directly over my head. The day was broiling hot, but the coolness of this reception seemed to lower the temperature at least twenty degrees. I had entered the house with some agitation, so I confess that this unexpected freezing rather disconcerted me. The man sat bolt upright in his chair at a writing-desk. The conventional English frockcoat was conventionally buttoned from the waist to the breast (and that, too, with the thermometer at a hundred); a starched white cravat (nothing could have melted on this gentleman), a great parrot nose, drooping eyelids, together with a crisp and bristling head of gray hair, completed the picture of the stiffest piece of humanity I had ever seen. There was a pause. 
"Well," said he, "what is it? I don't know you?"

I was so enraged at the whole proceeding that I was going to reply that if he kept on looking two feet over my head the probability was that he never would know me; but I restrained myself, and merely replied that I had a message for his wife from her father in Tasmania. He looked as dead and unmoved at this as if he had not heard me at all, and apparently addressing the footman, but with his eyes still directed over my head, said, "Show this person up-stairs and inform your mistress."

He took his eyes from the wall and began to examine some papers with that kind of earnestness that seemed to say, "I don't want any remarks from any one on any subject whatever; go away at once, and oblige me by not returning." His manner admitted of no appeal, so I followed the man, and was ushered into a large, gloomy apartment where he left me to announce my visit to her ladyship. In the tropics all the dwellings are closed tightly against the light, so as to render them cool during the heat of the day; but surely this was the darkest room that I had ever seen, and when I entered, having just come out of the bright glare of the street, the objects in it were scarcely visible, and only revealed themselves one by one. Little sharp streaks of yellow sunlight forced themselves through the closed windowblinds, and gradually I discovered that the walls were dead white; not a picture or ornament of 
any kind hung upon them; there was no carpet on the floor, and the only articles for use were a halfdozen of those uncomfortable and inhospitable mahogany chairs covered with dismal black haircloth, and a long sofa made of the same mournful material. The high backs of this unfriendly furniture were stiff and straight, or perhaps inclined a little forward, as though they were designed to tip the visitor gently out, the smooth hair-seats rather assisting in the process. I fancied that the grizzly ogre of this gloomy place kept his young and lovely wife a kind of prisoner here, and tortured her with these unsympathetic surroundings; and if this were so, I thought how her heart would beat and her eyes fill with tears as she listened to one who bore a father's blessing to his child, and I blamed myself for not having written just a line to prepare her for my visit that she might have time to recover from the shock, for I felt now that the meeting might be embarrassing to both parties. I was working these thoughts in my mind when the door of the adjoining room opened slowly and her ladyship appeared.

She was dressed in white, and as she glided slowly into the dark room one would almost have fancied she was a ghost. Her figure was tall and graceful, and her bearing aristocratic and selfpossessed.

I was standing when she entered, and as she seated herself upon the sofa she motioned me to a chair without speaking a word. I was disappointed in her cold and stately manner, for her temperature 
was quite as low as her husband's, and she received me if possible a trifle more frigidly. Her face was very beautiful, but so cold and quiet that I felt nothing short of a domestic communication could melt such a piece of marble.

In a few words - for I was really anxious to get out of the place - I told her that I bore an affectionate message to her from her father.

"Oh, indeed. Poor father! I hope he is quite well? May I offer you some luncheon?"

I could no more have swallowed a morsel in that house than I could have embraced the master of it. The face of her father rose up before me. I called to mind the tears in his eyes and the trembling emotion of his voice when he spoke of his only daughter, and I thought how years ago that fond old man had perhaps looked forward to the birth of his child, and when it came into the world how he had taken it in his arms with loving care and attended its early life; and now, in his old age, thousands of miles away, with his heart still yearning to see her, she sat there, cold and impassive, receiving his loving message with chilling indifference. I could stay no longer, and rose to depart.

" Madam," I said, "I came here to deliver a message with which I was charged, and fancied that the nature of it might give you some pleasure; but I feel satisfied that I have unintentionally been intruding."

"No," she replied; but it sounded so much like "yes" that I took up my hat and bowed myself out. 
The hot and narrow streets of the town were an agreeable change after the freezing I had just gone through, and I was only too glad to get out of this charnel-house. I do not know nor can I tell to this day the cause of my unlooked-for reception. At first it crossed me that perhaps the father had committed some crime, and that they were ashamed of him; but when I recalled his simple, honest face I felt how unjust were my suspicions; so I could therefore only conclude that it was the natural austerity of the merchant and his wife.

It is over twenty years since the little incident I have just narrated took place, and if this cheerful couple are still alive I do not envy them the many hours of stately misery they must have passed in each other's society.

I was glad to get out of Panama. Our party, consisting of my son, a friend from Australia who was now acting as my agent, and myself, crossed the Isthmus, and took an English mail steamer from Colon to Southampton, passing through the group of West India Islands, touching at St. Thomas and Jamaica, and arriving in London about the middle of June, I 865 . 


\section{CHAPTER XI}

\section{IN LONDON}

The New "Rip Van Winkle"-English Relatives - John Brougham - Tom RobertsonArtemus Ward

N my arrival in London I met Dion Boucicault. He asked me if I intended to act; I told him that I certainly did if I saw an opening offering a fair chance of success.

"What material have you got?" said he.

I replied that I had a great part in an indifferent play, "Rip Van Winkle."

Boucicault did not seem to fancy the selection, thinking the subject stale, but we talked the matter over and soon came to terms. He undertook to rewrite the drama for a consideration agreed upon between us. He never seemed to think much of his own labor in this play; but I did, and do still, with good reason.

While the work was in progress I made an engagement with Benjamin Webster to act the part at his theater, the Adelphi. I sent to America for 
my three other children to join me in London, and took up my abode at No. 5 Hanover Street, Hanover Square. It was generally supposed that four years of success in Australia had enabled me to return home a millionaire. Quite a mistake, I assure you. Not poor, certainly, but not rich ; just in the condition that is most desirable for all; neither too poor nor too rich, with something to give one security in case of accident, constant employment, and a moderate income. Less than this may be inconvenient at times; more than this is a nuisance. But I must stop writing speculative philosophy and stick to facts, or I shall turn from a biographer into a lecturer.

The play was finished in due time, and a day was set for reading it to the company. The time arrived, and I hastened to the theater with some anxiety, for I am always attacked with a nervous fit when I am to meet a new assemblage of actors and actresses. I cannot get over the feeling, and to this day it is the same. I of course had expected both Boucicault, the author, and Webster, the manager, to meet and assist at the reading, but when I got to the theater I found letters from both, saying that they could not attend. There seems to have been an old feud between Webster and Boucicault, and I presume they did not desire to meet; so I read the play. Among the actors who were present at the reading was Paul Bedford. The name of this cheery old man is scarcely known in this country except among professionals who have been abroad, but in England it is cherished with 
much affection. He had been a member of the Adelphi company for forty years, perhaps longer; he sat opposite to me during the reading, and was an attentive and sympathetic listener.

When I came to the entrance of Nick Vedder in the opening scene, "Ah, that 's me, my lad; that 's me," said he.

He chuckled over the humor of the play, and at times he wiped the tears from his eyes as the pathos of the language moved him. "I say, my lad," said he, "I 'm told there is twenty years to elapse between the third and fourth acts?" "Yes," I replied. "Well, I ain't alive then, am I ?" “No, Mr. Bedford," said I; "you are cut off in the flower of your youth." "What, die in the first act? Good!" And so he went on with a running fire of fun altogether at variance with good discipline.

Mr. Billington, who was to act in the play, and who was considered an authority in such matters, said, "There 's a hundred nights in that play; am I right, Paul?" To which Bedford replied, quoting from his old character of Jack Gong, "I believe you, my boy"; and then, taking me by the hand, he said with marked solemnity, "My transatlantic kid, I welcome you to the classic precincts of the royal Adelphi."

While the play was in rehearsal I was desirous that Boucicault should see how I had arranged the business of the scene, as I knew that his judgment and opinion upon what I had done would be of value, and would serve to strengthen the effects. So it was arranged that a full rehearsal of the play 


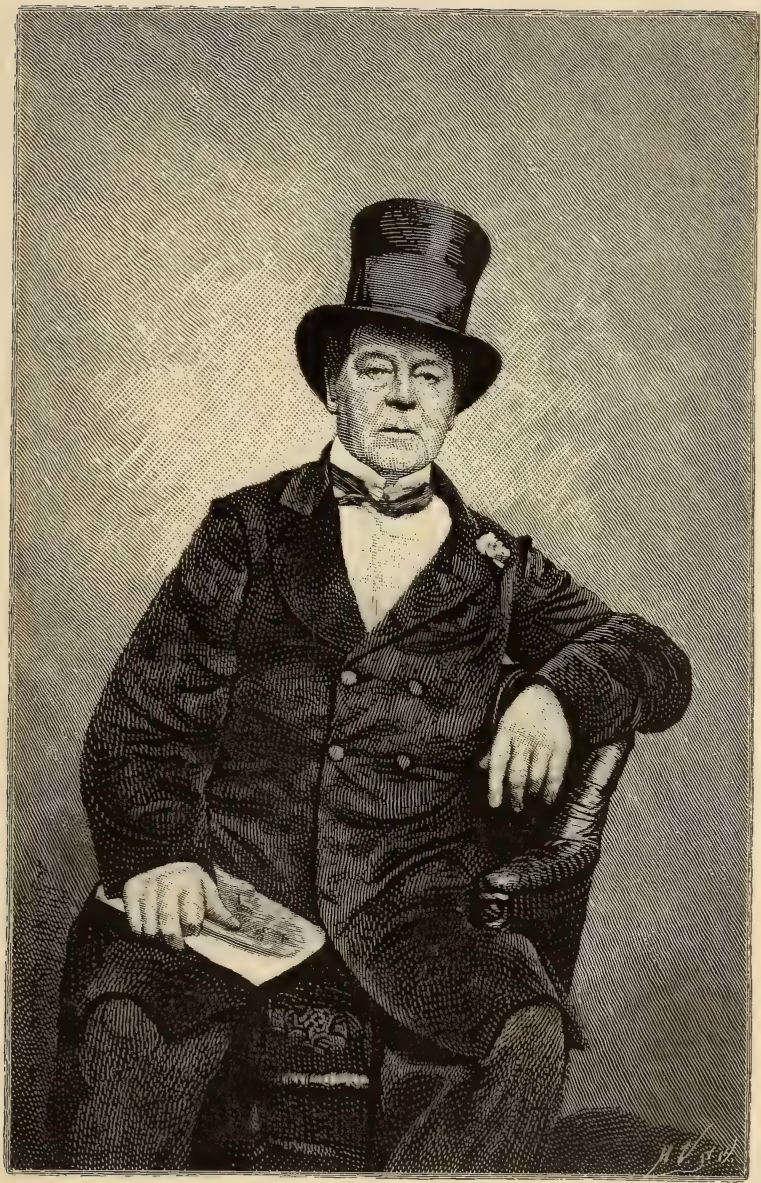

PAUT, BEDFURD 

and the scenery should take place on the Monday preceding its production, and that he was to be present.

With my portion of the work he seemed well pleased, but during the setting of the scenery something went wrong; nothing of very great importance, I fancy, or I think I should remember the details of it. It was, however, enough to start him off, and in a rage he roundly abused the theater and its manager. As I before mentioned, he and Mr. Webster had been at variance for some months. The latter gentleman was hot-tempered and highly sensitive. Previous to my arrival in London he and the author had been quarreling and wrangling over their respective rights and wrongs. Mr. Boucicault, now that an opportunity offered of his speaking his mind before Mr. Webster's company, launched forth against the manager, the theater, and its misrule with great energy. He denounced the whole establishment, spoke of his own experience on that stage, and likened the present to the former imbecility of management to which he had been subjected, and so revenged himself on the absent manager by holding him up to scorn before the actors. After the rehearsal was over, and the enraged author had departed, I found that the company were very indignant at Boucicault's abuse of their absent chief. Mr. Phillips, the stage-manager, took me aside and told me that he feared much trouble would arise from the scene that had just taken place; and to my surprise informed me that Webster, knowing that Boucicault would be 
present, was there himself, concealed behind the curtains of a private box, where he had heard the whole affair. Webster was very bitter when transformed into an enemy; and I can imagine the furious glare that must have been in his fierce eyes as he listened to the abuse of Boucicault, who, quite innocent of his presence, had been thus denouncing him. If ever there was an occasion when listeners heard no good of themselves, surely it was on that memorable morning. I was about leaving the theater in quest of Mr. Webster when the call boy handed me a note from him. It was short, but entirely to the point; it referred in no very complimentary terms to the scene that had just taken place and to the author of it, and concluded by saying that he could not allow any play of Mr. Boucicault's to be acted in his theater. Here was an unexpected check. I at once asked where I could find Mr. Webster, and was told that he had gone home. I got the address and jumped into a cab, making a hot pursuit after the irate manager. Mr. Webster lived upon the Surrey side, I think; I know that we passed the celebrated old madhouse of Bedlam on our way. But bridges, steeples, and madhouses almost merged into one during this exciting ride, so far as my mind was concerned; for I had looked upon the approaching Monday night as the most important professional one of my life, and I was not going to have my golden opportunity snatched from me without a struggle.

As I turned the corner of the street in which he lived, I saw that the old manager had arrived and 
was striding up the steps of his house; his hat was firmly set on his head, and the very back of his coat seemed to be in a rage. He entered, and I followed close upon him. The old housekeeper admitted me and took my card. She said that her master had just gone up-stairs ; and at that moment I heard a door bang with an angry thud that echoed through the old house like the ominous thunder that precedes a storm. The place had a bare and lonely look, being scantily furnished and very dusty. The old housekeeper, who was scant of breath, came to the head of the stairs and beckoned me up. When I reached the landing she pointed rather timidly towards a side door, and said to me cautiously and in an undertone, "That's his den, as he calls it." I thought the name most appropriate just at the present time; I felt there would be a scene, but there was nothing left except to have it out. I knocked at the den, and the lion growled, "Come in!" I opened the door, and enter Daniel. The old manager was quite pale, and if he were then not in a towering rage, the effects of one were plainly visible upon his angry face. His gray eyes, wonderfully expressive, snapped with the reaction of temper; and his black wig - one of those unmistakable articles with a hard parting on one side and a strong tendency to get away from the back of the head-had got awry, and this gave him anything but a reconciliatory appearance. We had a long and stormy scene. Of course he was not unreasonable enough to blame me, but his opinion of the whole affair was 
delivered in language more tinged with billingsgate than "choice Italian." I told him that any interruption of my opening would be very injurious to me; that the play, scenery, and actors were even now fully prepared for action; that I felt quite sure of myself in the part, as I had already played it with success in the old version; and that to interrupt the present arrangement was to imperil my future. He suggested that we should discard Boucicault's play and substitute the old version. To this I answered nay, explaining to him that not only was Boucicault's play infinitely superior to the old one, but that I had made my agreement with the author, and it must be kept. I insisted that I would not submit to act the Mercutio in the matter, and so fall because of a quarrel between the Montagues and the Capulets, and finished by showing him that it might be disastrous to his season to throw aside a good play ready for production and trust to chance to fill up the vacancy. He began at last to see the matter in the light in which I had placed it, and withdrew his objections, though with much reluctance.

My approaching appearance was the important dramatic event of my life. I had been five years from America, and was on my way home, and I felt satisfied that if this new version of "Rip Van Winkle" succeeded in London, my way was quite clear when I returned to the United States.

On Sunday evening, being alone in my lodgings, I got out for my own admiration my new wig and beard - the pride of my heart - which I was to use in the last act. I could not resist 


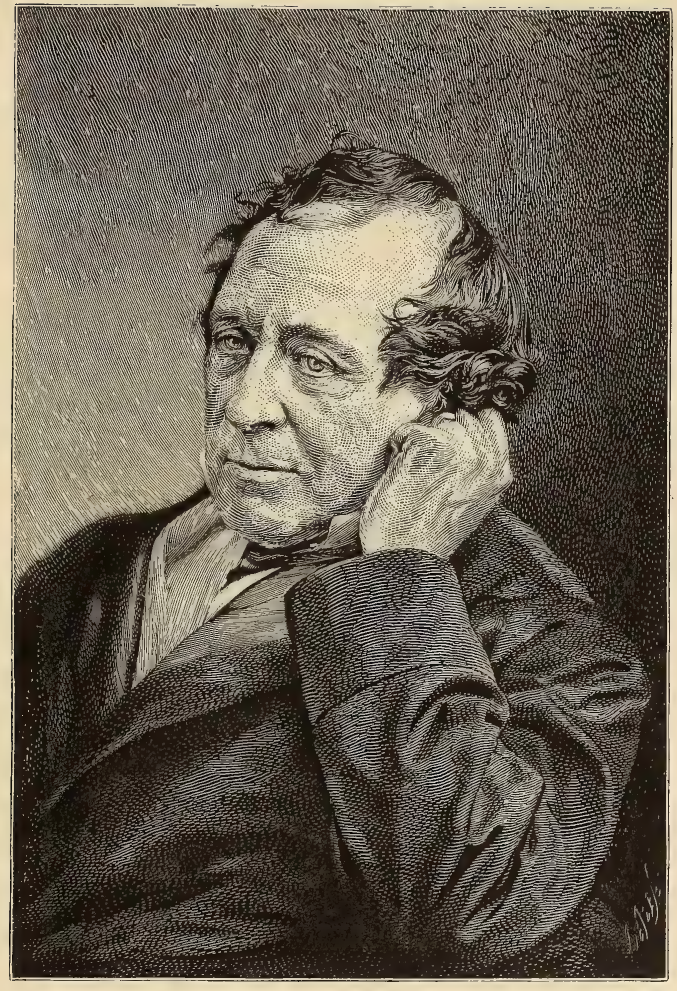

BENJAMIN WEBSTER 

trying them on for the twentieth time, I think; so I got in front of the glass and adjusted them to my perfect satisfaction. I soon became enthused, and began acting and posing in front of the mirror. In about twenty minutes there came a knock at the door.

"Who's there?" said I.

"It's me, if you please," said the gentle but agitated voice of the chambermaid. "May I come in?"

"Certainly not," I replied; for I had no desire to be seen in my present make-up.

"Is there anything wrong in the room, sir?" said she.

"Nothing at all. Go away," I replied.

"Well, sir," she continued, "there 's a policeman at the door, and he says as 'ow there 's a crazy old man in your room, a-flingin' of his 'arnds and a-goin' on hawful, and there 's a crowd of people across the street a-blockin' up the way."

I turned towards the window, and to my horror I found that I had forgotten to put down the curtain, and, as it seemed to me, the entire population of London was taking in my first night. I had been unconsciously acting with the lights full up, to an astonished audience who had not paid for their admission. As I tore off my wig and beard a shout went up. Quickly pulling down the curtain, I threw myself in a chair, overcome with mortification at the occurrence. In a few minutes the comical side of the picture presented itself, and I must have laughed for half an hour. I had been suffering from an attack of nervous dyspepsia, consequent upon the excitement of the past 
week, and I firmly believe that this continuous fit of laughter cured me.

On Monday, September 5, I made my first appearance before a London audience, and was received with a cordial welcome. The play of "Rip Van Winkle" was entirely new to the English public, and its success secured for it a run of one hundred and seventy nights. The company worked with a good will and never flagged in their energy.

After I had been acting a short time in London I received, to my surprise, the following letter:

Hackney, September 30, 1865.

DEAR SIR: Somewhere about the year I80I an uncle of mine, bearing your name and belonging to your profession, went to America.

On seeing the announcement of your appearance at the Adelphi I was naturally curious to know if you were a distant relative of mine or not. My wife and I sat in the front of the theater last night, and when you came upon the stage we were quite certain that you had the honor of being my first cousin. My father, Lieutenant Frank Jefferson, commanded the queen's yacht at Virginia Water - you may have heard of him. I am the father of an English family, in comfortable circumstances, so you need not be alarmed lest you should have stumbled upon a batch of poor relations, and if you will dine with us next Sunday we shall be glad to give our Yankee cousin a hearty cockney welcome. Under any circumstances let me say that it gave me great pleasure to see a face from a far-off country so unmistakably like the Jeffersons.

My wife and children join me in hoping that you will come.

The inclosed diagram and address will show you how to find us. We dine at three (not fashionable people, you see), and I shall be at the gate on the lookout for you. Yours truly,

TOM JEFFERSON. 
I was much pleased at the tone of this letter, and replied that I was undoubtedly a cousin of his, but a second one, as his uncle was not my father, but my grandfather; writing him also that I would join his family party on the following Sunday.

Sure enough, he was at the gate; and as he gave me a hearty shake of the hand I looked in his face, and it seemed to me as though my father stood before me: the likeness was indeed wonderful. His wife and a host of children were waiting inside, and they received me right royally.

We all sat down to dinner - roast beef and plum pudding. My cousin said that they did not usually have the latter dish till Christmas, remarking that he looked upon it as a national institution, not to be trifled with, and that I must feel myself highly complimented at being treated to this formidable article; but as he knew that I never got anything so delicate in America, my enjoyment of it would console him for leaving the beaten track.

In ten minutes the ice was broken, and I was one of the family. Of course I had a thousand questions to answer about America, and my glowing accounts of the New World filled the boys with a desire to emigrate at once. Tom was a wag, and told the youngsters that he had heard when I first arrived that I was quite black; but a few months' sojourn in the clear atmosphere of London had restored me to the natural color of my ancestors, at which the little ones wondered and the big ones laughed. 
We had another family reunion at Christmas, when all the Jeffersons we could hunt up dined with me at Verey's. In the afternoon the whole party went to Astley's to see the pantomime. Of course there was the usual crowd about the doors that always assembled during this festive season at the theater. I was elbowing my way to the box office for the purpose of purchasing tickets, when I was accosted by E. T. Smith, the manager.

"I cannot allow you to buy tickets," said he.

"I am obliged to you," said I ; " but I have my family with me, and could not think of intruding them on your good nature."

"Your family - take my box," said he. "You are quite welcome. Where are they?"

"There," I replied, pointing to the group. "Twenty-four of them."

"Twenty-four!" said he, aghast.

"Yes," said I, "and as they are not professionals, I must insist on buying the tickets. All I ask is your good offices in getting us seats together."

This was done, and in the center of the theater sat four-and-twenty Jeffersons " all in a row."

If there is one thing more amusing than an English pantomime, it is the English audience that go to see it. Men, women, and children who are intelligent enough on ordinary occasions seem, under the influence of this potent spell, to lose all control of themselves. Before the curtain rose, the faces in front were expressive and even thoughtful. But when the entertainment was in full swing, all sense of propriety was thrown off. 


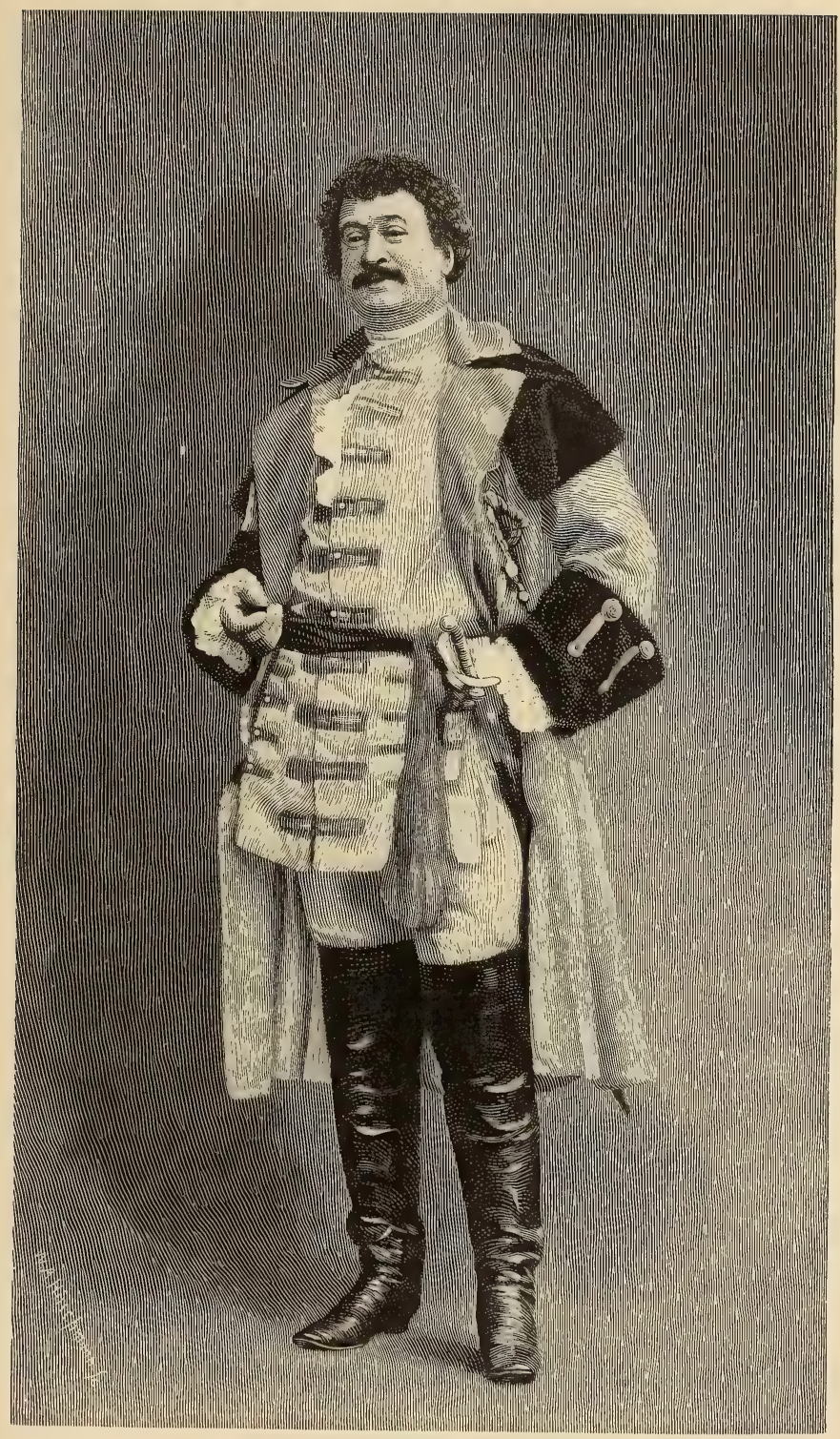

JOHN HROUGHAM AS THE "O'GRAdY" IN "ARRAh NA POGUE." 

The audience were carried away and delighted beyond measure, and swallowed the most idiotic nonsense with one broad grin that seemed to mantle the face of the whole house. Shout after shout went up when the clown sat on the baby; and as the cockney swell appeared, extravagantly conscious of his own dignity and charmed by the effect of his personal appearance, the heartless public sat in eager expectancy, well knowing that some disaster was about to befall him; and when a half-barrel of flour was poured upon his devoted head they would burst forth in the most boisterous manner. Any catastrophe that occurred to the police was always hailed with delight. Why is it that these guardians of our safety are held in such contempt theatrically? When a double-dyed villain gets his quietus, and the innocent heroine is restored to the arms of the first walking gentleman, we applaud with delight. Surely under these circumstances one would suppose it to be our duty to resent any affront offered to the "force"; but no, the slightest indignity bestowed upon a virtuous policeman, such as the emptying of a bucket of water over his helmet, seems to give us joy.

It was very pleasant to meet with some of the artists, actors, and men of letters in London. To sit and chat with renowned people that I had heard of from boyhood - to have the erratic and domineering advice of hot-headed, kind-hearted Charles Reade pounded into one; to be patted on the back by dear old Planché; and to be glared at through 
the fierce but honest spectacles of Anthony Trollope, was a treat indeed. I had come unheralded and unexpectedly among them, and they made me very welcome.

At this time (1865-66) Boucicault's play of "Arrah na Pogue" was in the height of its wellmerited success at the Princess's Theater. It is one of the best of the Irish sensational dramas, as they are styled, though to my mind this play deserves a higher title. I had been three or four months on the ocean, and it was a treat to see a play again, particularly so good a one, and one mounted with such excellent taste and acted so admirably. The O'Grady played by John Brougham was certainly the best piece of acting I had ever seen at the hands of this comedian. The character is that of a gay, graceful Hibernian gentleman, full of wit, good spirits, and geniality; in short, it was John Brougham. He threw a jaunty air into the part that gave it the flavor of an Irish soldier of the last century. The cunning author had taken the just measure of the actor and fitted him with a character that the artist could scarcely get out of. I have never thought that Brougham was a great actor; that he was a pleasing one and a great favorite with the public there can be no doubt, but he never seemed in earnest. He invariably acted a part as though it were a joke. But his handsome face and winning manner made him hosts of friends, and they liked him too well to pass critical judgment upon his performances. As a writer he made some pleasing additions to the light dramatic liter- 
ature of his time. "Pocahontas" is certainly the wittiest American burlesque that has been written. His table-talk and after-dinner speeches were ever welcome, and his presence at convivial meetings was much enjoyed. No one was more desired at the festive board than "Genial John." He particularly shone in addressing the audience on "benefit" occasions, or in making an apology to them for some unavoidable accident that had occurred during the performance. He assuredly had much experience in these matters, for during his management of Brougham's Lyceum, afterwards Wallack's, the mishaps were quite frequent. His easy good nature entirely unfitted him for the duties of a theatrical conductor. Discipline and order were not among his virtues; he lacked the forethought, too, that might prevent catastrophe, and the firmness that sets things right when they happen to go wrong. If, however, he was deficient in discipline, his ready wit was more than a match for the negligence of his company. And it was once surely put to the test during the performance of "Pocahontas." I think, however, that the matter I shall speak of took place after his theater had fallen into the hands of the elder Wallack. The actress who had been playing the leading part suddenly left the city, having accepted an engagement in Baltimore without giving notice to the management. No word of this proceeding reached the theater till a few minutes before the curtain was to rise on the performance. Of course for some minutes there was a deadlock. No one could suggest the faint- 
est remedy, and Brougham was nonplussed. At last he went in front of the curtain and explained the situation. He confessed he was at his wit's end, - a long distance for him to travel, - and really did not know what to do unless the audience felt disposed to accept the burlesque of "Pocahontas" with the gentle savage omitted. He said there was an old theatrical anecdote setting forth that on one occasion the character of Hamlet had been so wretchedly acted that on its next representation that part had been omitted by particular request. "Now if 'Hamlet' can be acted without the hero, why may not 'Pocahontas' be played without the heroine? You all know that 'Pocahontas' is a much finer play than 'Hamlet'; and if you do not, I do, for I wrote it myself. Will you permit us to make the experiment?" The cries of "Certainly," "Go on!" were so encouraging that Brougham retired amidst applause and the curtain was rung up. The burlesque proceeded admirably until the music was played for the entrance of the absent squaw. The audience wondered what Brougham could possibly do. He was acting the father, Powhatan, and was on the stage awaiting the approach of his daughter. He immediately addressed the audience somewhat in the following words: "Ladies and gentlemen, that is the sweet strain which is supposed to bring Pocahontas on the stage; you are aware that she is at present in Baltimore, and the law of the land will not permit a Christian, much less a savage, to be in two places at once. You can yourselves vouch for the alibi; but if she 


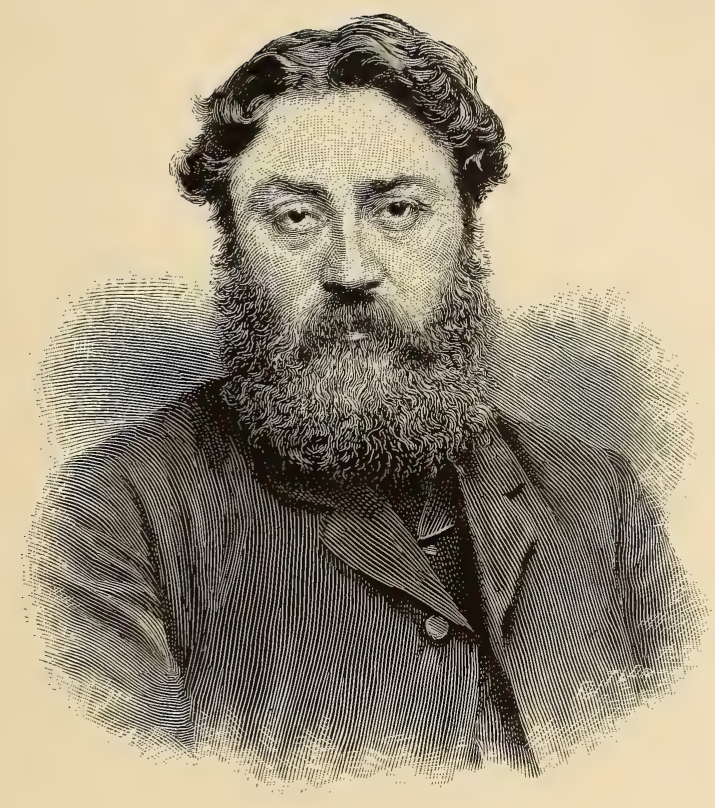

T. W. ROBERTSON 

were here she would say - " and here assuming the look and tones of the absentee, Brougham spoke her part first, then assumed his own character, and so kept up the dialogue. The audience were convulsed with laughter at the admirable imitation, and by their applause acknowledged that Brougham had outdone himself through the wit with which he had mastered the difficulty.

Among the many new friends I made in London none was more delightful to meet than Tom Robertson. During my engagement at the Adelphi he was writing his domestic comedies for the Prince of Wales's Theater, then under the management of that vivacious actress and industrious little manager Marie Wilton.

Robertson's plays were nearly all successful, and deservedly so too, for they contained original characters, bright and witty dialogue, and were entirely free from the French coarseness that had characterized so many of their predecessors. All honor to the memory of Tom Robertson, who was at least among the pioneers in working this reformation; and to his successors too, who following in his wake gave to the public musical extravaganzas more humorous and melodious than the Parisian burlesques, without one tinge of their impertinent vulgarity; proving incontestably that wit and harmony in comic opera need not depend for their effects upon sensual music and licentious libretto.

Tom Robertson was of all the men I have ever talked with the most entertaining. His descrip- 
tions of people, performances, and incidents that had passed before him during the early portion of his life were exceedingly brilliant. Events that would have been commonplace when described in an ordinary way were so colored and illumined by his vivid imagination that they became intensely interesting. At No. 5 Hanover Street, Hanover Square, Tom usually dined with me once a week. He was perfectly familiar with dramatic literature and discoursed delightfully upon the plays of the past. Goldsmith was his favorite author, whom he considered the very finest and purest writer of English comedy that had lived during the last century; and though I did not quite agree with him in this idea, he said much that strengthened his argument, pointing out the ingenious construction of his plots, the unstrained wit of his dialogue, and the natural conduct of his characters.

Robertson came to my dressing-room one night just as I had finished acting, and asked me to go with him to Drury Lane to see the last two acts of "Macbeth," then being played at that house. We arrived at the theater just at the opening of the fourth act, and ensconced ourselves snugly in a private box. It seemed that matters had gone wrong during the whole play, and when mishaps do occur in the earlier scenes of a drama, particularly a Shaksperean one, they are apt to continue to the end. We were seated well back in the private box and could enjoy the tragedy without being observed, which as it happened was quite fortunate. The solemn cave scene 
opened with the three witches at their ghastly work about the caldron. Mr. Phelps, as Macbeth, came upon the stage with the martial stride and dignity that characterized this excellent actor, and the weird sisters summoned their phantom confederates to appear. At last one of the apparitions slowly rose to the surface only to disappear suddenly without giving Macbeth warning or receiving any himself; there was a slight crash, but nobody was hurt. Next came the passing by of the six ghostly kings, the first one of whom lost his crown, and in stopping to recover it was run down by the other five monarchs, who came so rapidly upon the heels of their leader that the several dynasties were all in a heap, creating a spiritual revolution that fairly convulsed the audience.

In the last scene, just as Mr. Phelps had given orders to have his banners hung on the outer wall, that frail edifice gave way before it was besieged, and tumbled the king of Scotland into the middle of the stage, where, with uplifted claymore and in a sitting posture, he presented a sight of harmless indignation that would have revenged Macduff for the murder of his entire family.

I have no idea what ever became of the tyrant after this, for Tom and I were compelled to flee from the theater and seek some dark alley in Drury Lane, where we pounded each other in the exuberance of our mirth. Nothing could exceed the drollery of what we had witnessed except Tom's description of it the next day. 
Artemus Ward arrived in London just as I was leaving it. He brought me a letter of introduction from my cousin William Warren. I was much impressed by Ward's genial manner. He was not in good health, and I advised him to be careful lest the kindness of London should kill him. I had never seen his entertainment, but I was quite sure from what I had heard of it that he would be successful, and told him so, cautioning him to give only his Sunday evenings to his friends, and on no account, in his delicate state of health, to expose himself after his entertainment to the pernicious effects of a London fog. But he was weak, and yielded to the influence of his many admirers, so his career was brilliant but short. He had that unfortunate desire for the second round of applause that is so fatal to the health and position of an actor.

See how unfair you gentlemen are who fancy that you are the friends of the actor. You sit quietly among the audience during the whole evening, enjoying an actor's performance and resting yourself at the expense of his labor. When this is over you are thoroughly recuperated and he is weary; yet you ask him now, when he needs the rest that he has given you, to sit up till daylight-for what? To amuse you again.

Artemus Ward died not many months after his London début, attended to the last by Tom Robertson. A strong attachment had sprung up between them, and the devotion of his new-found English friend was touching in the extreme and characteristic of Robertson's noble nature. Just before 


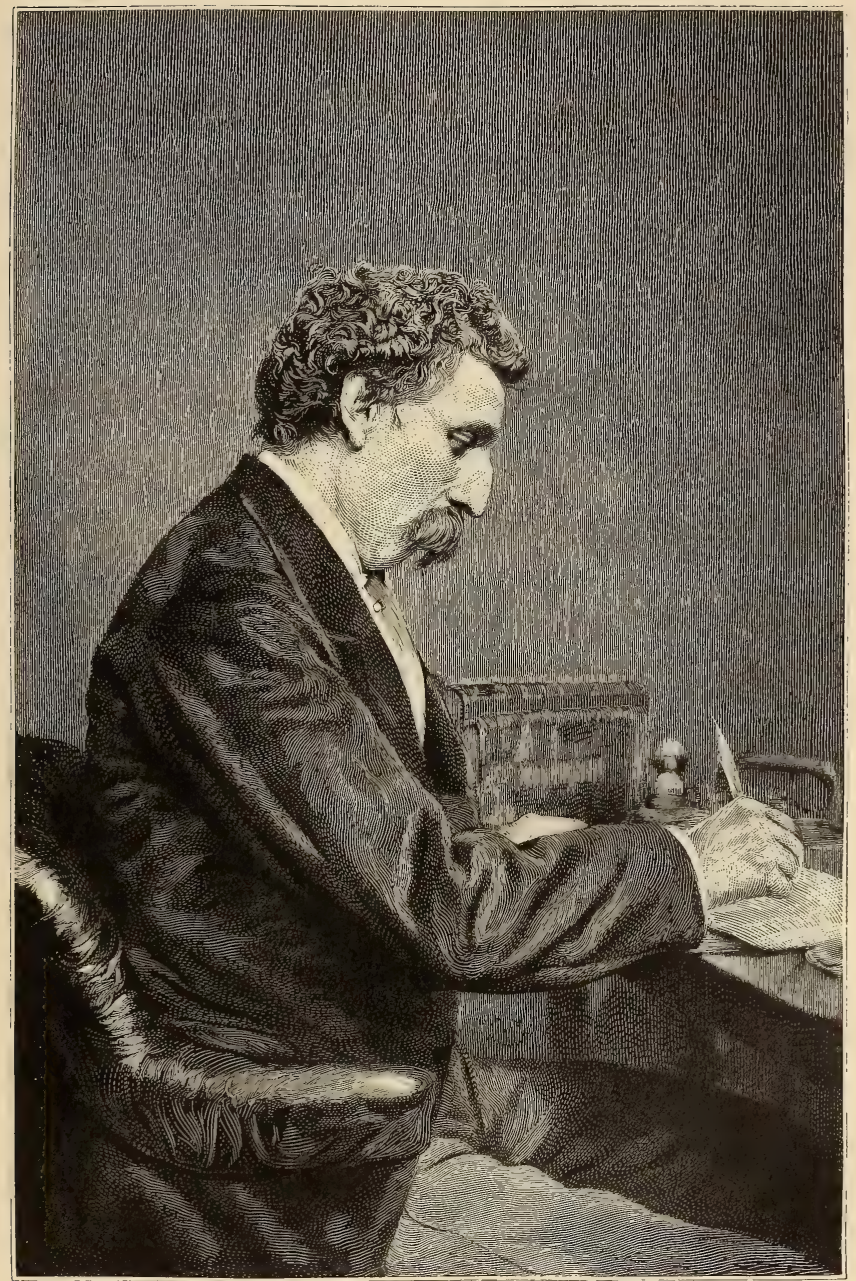



Ward's death Robertson poured out some medicine in a glass and offered it to his friend. Ward said, "My dear Tom, I can't take that dreadful stuff."

"Come, come," said Robertson, urging him to swallow the nauseous drug; " there's a dear fellow. Do now, for my sake; you know I would do anything for you."

"Would you?" said Ward, feebly stretching out his hand to grasp his friend's, perhaps for the last time.

"I would, indeed," said Robertson.

"Then you take it," said Ward.

The humorist passed away but a few hours afterwards.

At the conclusion of my London engagement I acted in Manchester, playing Rip Van Winkle and a new part in "The Parish Clerk," a beautiful little drama written by Dion Boucicault. The piece did not succeed; partly because it weakened after the second act, and partly in consequence of my failing to hit the leading character. I then acted in Liverpool, and at the end of my engagement took a sailing vessel (the Sunrise) and embarked for New York. This was considered rather a romantic idea by my friends; but if one has the time, I do not know anything pleasanter than a clipper-ship voyage across the Atlantic in July. 


\section{CHAPTER XII}

\section{EAST AND WEST}

Edwin Adams - The Combination System George D. Prentice - Tom Glessing againGeorge Holland - " The Little Church Around the Corner" - Charles Fechter

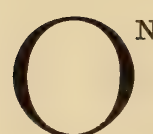

NE of the first to call on and welcome me on my return to America was Edwin Adams. He had acted under my stage management at Baltimore many years before: he first came to me almost as an apprentice; step by step he rose from the ranks, and before we parted he was playing the heroes of the stage with much promise. During the time I had been in Australia and England he had become, as he expressed it, a "war star." This was the technical term given by the old legitimate stars and actors to satirize those self-lighted luminaries who had flickered during the national strife and who had gone out after the cessation of hostilities. The claim of Adams, however, to a prominent artistic position was sufficiently strong to retain its hold, and I found him enjoying 
his well-earned success among other fine actors of the day. The animation of his face, the grace of his person, and, above all, the melody of his voice, well fitted him for the stage. While he could not be fairly called a great artist, he was something often more highly prized - a born actor, a child of nature if not of art, swayed by warm impulse rather than by premeditation. His Enoch Arden, so far as the character is related to the stage, was a creation entirely his own, and one, too, that touched the sympathy of his audience. As a man he was loving and beloved, and his honest hand was ever ready with its charity. I regarded him with something more than friendship; and this was natural, for I had known him when he was a youth, and his likeness to my brother in character, expression, and voice was quite remarkable. Their careers, too, were singularly alike - brilliant, but brief. Those who remember them both will recall the strange resemblance that existed between Charles Burke and Edwin Adams. They never met.

On the 20 th of December, 1867 , and in the city of Chicago, I was married to my second wife, then Miss Sarah Warren. I fancy now that my reader is somewhat alarmed lest I should pour upon his devoted head a heavy shower of matrimonial intelligence; but he may breathe freely, for I have no intention of committing such an impertinent intrusion. But as reticence upon this subject may be misconstrued, I must crave permission to express my reasons for sparing him the infliction. 
If I dwell lightly upon domestic matters, I do so, not from any want of reverence for them, but from a conviction that the details of one's family affairs are tiresome and uninteresting. I shall endeavor, therefore, to subdue any rising desire I may feel to descant upon the wonderful talents of our children, as it is quite possible that we may take more interest in them than the public do. We fond parents are in the habit not only of overrating the intelligence of our offspring, but also of recounting to strangers the wonderful remarks that "so astonish a mother," and in our innocence fancy that those to whom we relate these marvels are as much interested in them as ourselves, when in truth they care little about them, and are generally bored by the recital of such trifles. Repeating this nonsense not only renders us ridiculous, but it is unfair to others, who, out of mere civility, are obliged to look amazed and to appear to be entertained.

After finishing an engagement in Chicago, I decided to play in Detroit and other cities throughout Michigan where opera houses had lately been built; but as there were no stock companies attached to these new places, I engaged one for a short season to travel with me. In Detroit I met Mr. Windham, who was acting a play called "The Lancers" there, with a company of his own. These were the first two combinations that I remember: there may have been others before, but not to my knowledge; so if this system is as pernicious as its enemies say that it is, I fear I am responsible for assisting in this new departure which seems to 


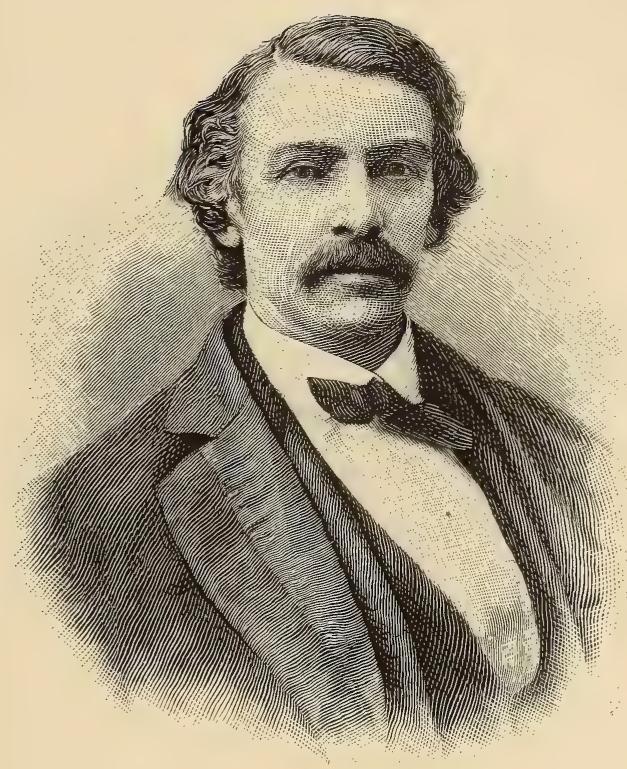

EUWIN AIMAMS. 

have worked such a revolution in theatrical matters. Whether the present system will be hurtful or beneficial, time alone can tell; I think it will be beneficial. I am tolerably conservative, but when I cling to an old custom it is not for the reason that it is old, but because I think it is good. Any change that offers an improvement-and there are few that do not-we gladly welcome. This socalled combination system has occupied so much attention lately, and, rightly or wrongly, has given rise to so many professional discussions, that I may be pardoned for desiring a hearing on the subject. I do not lay claim to having been the first to explode this theatrical bombshell; but certainly if any harm comes of it I should bear some of the blame, for I was at least among the pioneers. It is natural, then, that I should desire to defend it; but in so doing I shall lay bare both sides of the question, and the reader must judge for himself, as I fancy most readers generally do.

The conservative element within us always arrays itself against any fresh movement, seldom stopping to consider whether the new departure is beneficial or hurtful. I remember when my father had his flint-lock gun altered to the new percussion system that serious-looking, iron-gray old sportsmen shook their wise and melancholy heads, and hinted that they had thought better of him. One ancient Nimrod scratched his perfectly round conventional pate, saying, "What will you do if you get out of caps?" This intelligent question rather nonplussed my father; and the old sports seemed 
relieved to think that the punishment for his rash step would soon follow the crime, forgetting that as the demand was made for the gun, the supply of caps would follow it up. The breech-loader met with the same prejudice; and ever since Galileo made the world move, discoverers and inventors have been persecuted. It was quite reasonable, therefore, that when the tide of the "combination system" set in condemnation of it should naturally follow. That there are two serious objections to the new departure must be admitted.

First, the necessity for constant travel keeps the actor away from his home and family the greater portion of the year. This is a domestic inconvenience that is to be regretted. The second objectionable feature is, that as in many cases an actor plays only one part in a year, he gets no varied experience in his profession, and is apt to grow careless in his performance by constant repetition. But, apart from this consideration, the system has been an artistic and commercial success beyond all doubt; and the agreeable result - to the public, at least - is so evident that it seems quite unnecessary to argue in favor of it. I will, therefore, only point out a few of its advantages.

The old stock companies had to be limited to a certain number of actors, who were compelled to perform in a multitude of plays - the whole round of the Shaksperean drama, old English comedies, Yankee farces, nautical pieces, and pantomime; and at times the cracked voices of "respectable utility" and second old men "in dismal discord 
sang." I myself well remember leading the choruses for the Seguin company; where I led them to I have not the slightest idea. It is unreasonable to suppose that any stock company could do full justice to this varied bill of fare, no matter how efficient. The actors were in many instances among the best I ever saw, but they were very often not adapted to the parts for which the manager was compelled to cast them. Under the new régime a Shaksperean company are selected with special reference to the plays for which they are required. Thus an old English comedy may be cast to actors whose early training fits them to the task. For domestic dramas, comic operas, and sensational plays actors are selected whose talents not only suit the particular characters for which they are engaged, but whose temperament and personal appearance harmonize with them. The performers themselves are no better than those who acted under the old form of dramatic government, but on the principle of "selection" a more perfect unity has been evolved. And further, the vast continent of America, with its wonderful and progressive cities thousands of miles apart, seems to have demanded the establishment of this important institution. The inhabitants of these distant places, having fine opera houses, enjoy the advantages of seeing the same plays acted by the same companies as those of the larger cities. If they can afford and appreciate it, then they deserve it, and these entertainments can only be administered by the combination system. The theatrical profession is, 
and always has been, in a transient state, but it is progressive; it does not retrograde. Actors may not be any greater now than they were a hundred years ago, but the systems by which their talents become distributed are adapted to the growth of the country. What new invention has been cast aside, after once having been fully approved, to return to an old one? I cannot remember any. The old-fashioned tinder-box is used now only as a curiosity. We prefer matches. What midnight student, however poetic, would return to the penny dip after he had once tasted the delights of his first gas jet? We do not ride in a stagecoach in preference to a modern drawing-room car, and when the first balloon express bears us across the continent we shall look down upon the locomotive.

In Louisville I was introduced to the editor of the "Louisville Journal," George D. Prentice, poet, satirist, journalist, and wit, whose caustic paragraphs and frequent serious encounters with political enemies had made him a man of mark in more than one sense.

When I met Mr. Prentice his fame and health were both declining, and he was just on the eve of resigning his control of the "Journal" into, as he said himself, younger and abler hands. His reception of me was cold and formal; but I had already been warned that it was his way, so of course I was prepared not to take offense. Besides I felt, as I had no business matters to speak of, that my visit was somewhat of an intrusion. Curiosity to see 
and talk to a remarkable man is not an exceedingly high motive, and I deserved no warmer greeting than I received.

As my friend and I entered the sanctum Mr. Prentice was seated at his desk. He had an abstracted look, and scarcely moved his position till I was introduced. He then slowly turned his head, and regarded me without an expression on his face that denoted the slightest interest. $\mathrm{He}$ looked a picture of careworn loneliness that might awaken the sympathy of any considerate man - a tall, gaunt figure wrapped in a faded calico dressing-gown; thin black hair, streaked with gray, and straggling over a high forehead; black, bushy eyebrows, shading a pair of dull, dreamy eyes, that seemed to have lost their fire. I found afterwards, however, that they could be rekindled at the shortest notice.

After a few frigid civilities, my friend suggested that perhaps Mr. Prentice might enjoy an evening at the theater during the week that I was to act. He replied that he seldom went to the theater, and that acting, unless it were extremely fine, always bored him. This was not a cheering remark, certainly, but it left me in no doubt as to the justice of his reputation as a satirist. With a hopeless endeavor to thaw him out and return good for evil, I ventured to remark that some two weeks since I had dined with General Hancock in Washington, and that the general had, during the evening, highly entertained us by reading some of his (Mr. Prentice's) poetry; to which he replied, "I am 
glad that you were so easily pleased." This seemed to make matters a little worse; so our common friend, with admirable tact, came to the rescue, and changed the subject by launching into politics. Here the old war-horse was at home; and he brightened up wonderfully, being much more interested in such matters than he could possibly be in me, and taking no pains to conceal it. Before taking our departure Mr. Prentice brought up the subject of the theater, and reluctantly, I think, requested a seat to witness the performance on the following evening. I told him that I would have a private box placed at his service. He said he would prefer this arrangement, so that if he felt wearied during the performance he could withdraw without attracting attention. I was naturally grateful for this consideration, but I could not quite see the compliment of it.

In my brief acquaintance with Mr. Prentice I could scarcely judge of the true quality of his humor, but to me it seemed grim rather than genial. His skill in journalism was exhibited in his epigrammatic style of paragraphing, rather than in a knowledge of political economy. The journalist of a quarter of a century ago was a slow, old-fashioned gentleman, who would look like a curious piece of bric-à-brac in an editorial room of to-day. But Mr. Prentice was a man possessed of rare literary skill, and must have felt the necessity of his abdication very keenly. His sad face told that he plainly recognized that his day of usefulness was over. 
He came to see the play, and I fancied that the desolation of Rip must have reminded him of his own loneliness, for when the curtain fell upon the last act he came to the door of my dressing-room, and, giving me his hand, thanked me for a pleasant evening. I was on the point of retorting that I was glad he was so easily pleased, but I did not. This kind of resistance is always best, for one seldom regrets one's silence upon any subject.

During the season of I868 and I869, while I was acting through the Western country, I met my old friend and companion Tom Glessing; we had not seen each other for about eighteen years. He lived in Indianapolis, where, by hard work, he had managed to buy a lovely little cottage, in which his widow afterwards lived. The house was surrounded by and covered with roses, all of which had been planted by his own hand; among them were many choice varieties for which he had sent to England. He had great knowledge of plants, and for the warmth and growth of his pets had built a little greenhouse close to the kitchen, through which he had cut a hole to let in the heat, and so economize in fuel. He told me that, knowing it was necessary for ventilation that an opening should be made to let the hot air out again, he cut another hole back into the kitchen; and he said he never could tell which way the hot air came in or which way it went out.

Glessing had a most ingenious way of arguing, 
and would turn a misfortune into a blessing with a few words. It so chanced that the management of the theater at which he painted was seized with a sudden desire to economize, and proposed, among other methods, to reduce Tom's salary. He acceded to the proposition without the slightest demur, and told me of it in the most cheerful way; in fact, one would have supposed, by his manner, that his income had been increased by the reduction. I was about to sympathize with him, but he would only treat the matter in an easy and delightful way, assuring me that he considered himself the gainer by the new arrangement.

He explained that he always fidgeted during his summer vacation, and that while he was enjoying himself at the old farm-house, down by the seaside, his pleasure was often spoiled by the knowledge that he was sacrificing so much time and money there, when he might have been at work and under salary. "You see then I got $\$ 75$ a week," said he; "now I only get $\$ 50$, so it is a clear gain of $\$ 25$ a week in my favor, at least during the vacation."

As I have before said, the attachment between Tom Glessing and me was warm and sincere; he would have been as welcome to a share in my worldly goods as he was to a large corner of my heart; and I am quite confident that he felt the same affection for me that I did for him.

When he decided to leave his old home in Indianapolis he determined to take with him as many little remembrances of it as he could con- 
veniently carry, among which was a moss-rosebush that he had sent to England for, and had tended for years in his garden. He asked me to keep it and have it cared for, as he now had no place to shelter it; so it was left with me. From the time he parted with it the plant drooped; this, of course, I considered due to changing it from its old home to a new one, or perhaps from some lack of nutriment to which it had been accustomed. For seven years it languished in my garden, and during all that time never bloomed. Its position was shifted each year, our gardener using all his care and judgment, but it did not thrive.

About this time it was decided that Tom with his family should pay us a visit: this was in April, just seven years since he had left the plant with me. From this time it began to revive, and in June, when he arrived, it was in full bloom, as though to welcome him. Of course this may have been a mere coincidence, but it is an interesting one, and bears out the old superstition that a tree or plant which has been reared by a loving hand will wither and die when its owner passes away. Since Tom's death the rose has languished again, and is now dying away.

There are many causes for such matters without attributing them to supernatural agencies; but to me there is something so pleasant in believing them to be mysterious that I am afraid I often cherish the idea that they are the offspring of a spiritual growth rather than a real one. My friend 
says, "What good can such things do?" I can only answer, "What harm can they do?"

The calm and happy life of Glessing seemed not only to grow out of a naturally contented nature, but from a love of retirement. I have scarcely ever seen true happiness except in one who was comparatively obscure. An insatiate ambition that craves for notoriety is always in a distressed condition. It feeds on adulation, and starves unless the appetite is continually fed with praise. There is an excitement and a kind of false grandeur about this existence that may delight the idol; but such a position is only reached at the expense of never knowing who are your friends, and a dread of the time that must come when the dream will be dispelled. No man need be envied who is the center of a group by whom he is flattered and petted, for even while such adulation lasts it is not strengthening; it only stimulates. There can be no healthy nourishment in such poor stuff, and gradually the very sight of those who administer it becomes as sickening as the diet itself. They know this, too, and when the time comes for their idol to topple over they wink and nudge each other as he falls.

In strong contrast to Glessing, I will relate a melancholy instance of a fallen man that once came under my notice. We were not only acquaintances, but friends. He was both genial and hospitable, and entertained with grace and splendor. Upon his walls hung costly pictures, and 
his cellar was filled with rare wines. At his board one always met interesting people-wits, statesmen, belles, and beaux. If not the most refined, it was at least the gayest house, when his various guests were assembled, that I can remember. $\mathrm{He}$ was a man of culture and taste, and one who, I would have supposed, could never have borne the shock of a fallen estate. His extravagance was boundless, and I think that this passion grew out of another - the desire of making a display and posing as an important central figure.

I knew this hollow splendor could not last, and one day told him so. He laughed, "Oh, yes, it is all right." His hope was large, and his nature so buoyant that he felt confident of pulling through. The storm was coming, but he would not see it. At last it burst. The entertainment had been superb; I was the last guest. Just as I was going out - he had been merrier that night than usual he detained me for a moment, and, taking my hand, said with a cheerful smile: "Well, old chap, you were right; it 's come. This is my last Sunday here; everything will be sold out on Saturday next." I asked if his wife and daughter knew it. "No, not yet; they will in the morning" - with a smile. "Good night." When the door of this dazzling and ill-fated house closed on me I stood in the dark street and wondered what would be the sad fate of this butterfly of a man; and I felt that under the genial and hospitable garb he wore for the world there must be a cold and stony heart - that could be so gay while knowing that in a 
few hours his wife and child would feel a shock that would break their hearts.

The blow came, the house was sold, and all the pictures and the costly furniture were sacrificed under the hammer of an auctioneer. The women bore it bravely, and set to work in good earnest to retrieve their fallen fortunes. The mother took boarders, the daughter taught music; but the extravagance of a selfish man was too great a drain on their slender earnings, and so they dropped down, down, from bad to worse. What eventually became of the family I never knew, but the man dwindled into a mere hanger-on of society, watching the arrivals at the hotels in the hope of catching some old acquaintance. He is living still, and his attenuated figure may be seen gliding in and out of the different hotels, or lounging in the readingroom, where he pretends to look over the papers, while the eyes in his gaunt, wan face search eagerly for some familiar friend of whom to ask a loan. Now and then he meets an acquaintance who, for the sake of "auld lang syne," has not the heart to refuse him. Then his face lights up with the old selfish smile, and he will chuckle with delight as he talks of bygone merrymakings, just as though he had enjoyed one yesterday and would have another to-morrow. Hope, eternal hope, has kept him up all through, and will do so to the last. $\mathrm{He}$ still thinks that his troubles will soon end; and so they will, poor fellow! - in a pauper's grave.

George Holland was distinctly an actor of the old school, invariably introducing even into modern 


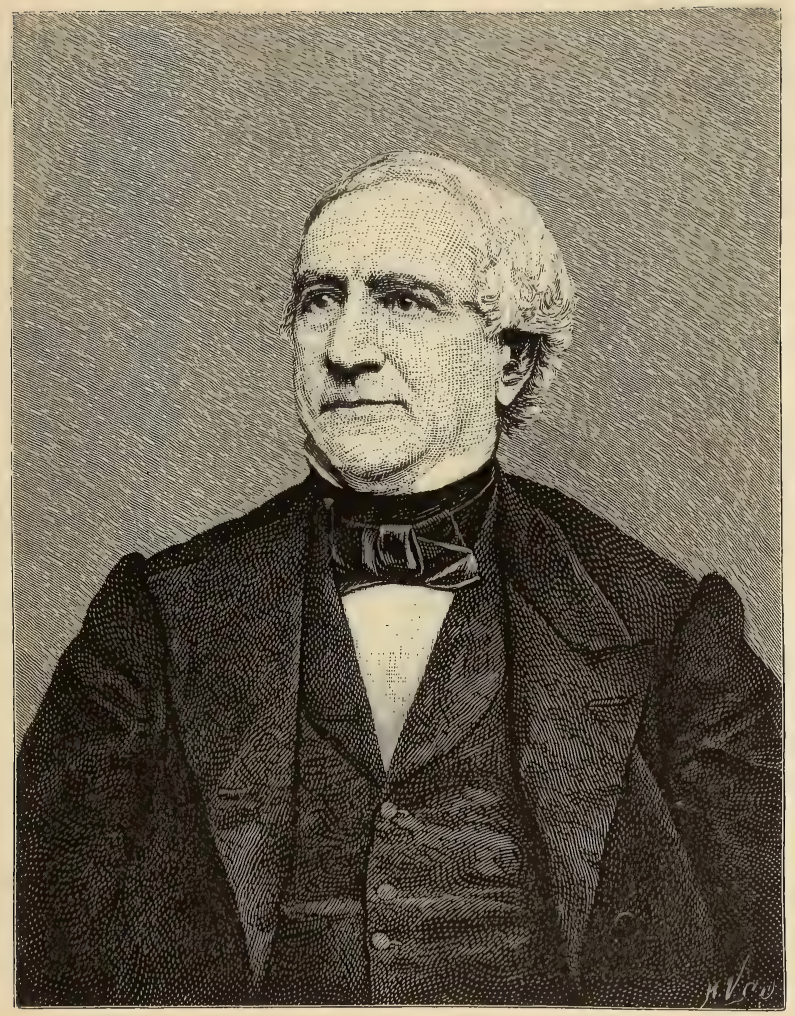

(iEORGE HOLLANI) 

characters its traditions and conventionalties; his effects were broadly given, and his personality was essentially comic. He was quite an old man when I first knew him, and I had serious doubts as to whether our acquaintance in the theater would be an agreeable one; for by the terms of my engagement I was to hold a leading part as the comedian of the company, and he, who had always occupied that station, was placed as second to me. I naturally thought that feeling himself comparatively subordinate, and that I, a younger man, was to outrank him, he would, by his manner at least, resent my intrusion upon his former ground. I was, however, agreeably mistaken; for I found him too generous a man to harbor any jealous feelings, and to my gratification we were friends from our first meeting. It is pleasant also to know that this relationship extended over many years, and up to the day of his death.

The useful career and unblemished character of George Holland will be recalled by all who knew him. He lived, a bright and cheerful spirit, in this world for eighty years, for time could not age his youthful heart. He was the merriest man I ever knew. Practical joking was a passion with him, and though his pranks were numerous, by some good fortune they always ended innocently and with harmless mirth. I remember that on one occasion, when some goldfish had been placed in the ornamental fountain in Union Square, Holland dressed himself in a full sporting suit, and with a fish-basket strapped upon his shoulder, a broad-brimmed 
hat upon his head, and a rod in his hand, he unfolded a camp-stool, and quietly seating himself in front of the fountain began to fish, with such a patient and earnest look in his face that no one could have supposed that it was intended as a practical joke. This strange spectacle soon attracted a curious crowd about the sportsman, who, with a vacant and idiotic smile, sat there quietly awaiting a nibble. A policeman soon forced his way through the crowd and arrested Holland, who explained with a bewildered look that he was fishing in his own private grounds. The policeman naturally concluded that the intruder was some harmless lunatic, and, patting him kindly on the shoulder, bade him go home to his friends. Holland burst into a flood of tears, and while affectionately embracing the guardian of the law contrived to fasten the fish-hook into the collar of the policeman's coat, who walked slowly and sympathetically away, unconsciously dragging the line and rod after him. The crowd, seeing the joke, roared with laughter as Holland quickly made his way to the nearest omnibus, which he reached before the infuriated policeman could catch him.

Upon the announcement of the death of George Holland, I called at the house of his family, and found them in great grief. The sister of Mrs. Holland informed me that they desired the funeral to take place from the church, as many of Mr. Holland's friends would like to mark their love and respect for him by their attendance, and that the house in which the family lived 
was too small to receive the large gathering of people that would be likely to assemble. The lady desired me to call upon the pastor of her own church, and request him to officiate at the service. I at once started in quest of the minister, taking one of the sons of Mr. Holland with me. On arriving at the house I explained to the reverend gentleman the nature of my visit, and the arrangements were made for the time and place at which the funeral was to be held. Something, I can scarcely say what, gave me the impression that I had best mention that Mr. Holland was an actor. I did so in a few words, and concluded by presuming that probably this fact would make no difference. I saw, however, by the restrained manner of the minister and an unmistakable change in the expression of his face that it would make, at least to him, a great deal of difference. After some hesitation he said that he would be compelled, if Mr. Holland had been an actor, to decline holding the service at the church.

While his refusal to perform the funeral rites for my old friend would have shocked under ordinary circumstances, the fact that it was made in the presence of the dead man's son was more painful than I can describe. I turned to look at the youth, and saw that his eyes were filled with tears. $\mathrm{He}$ stood as one dazed with a blow just realized; as if he felt the terrible injustice of a reproach upon the kind and loving father who had often kissed him in his sleep, and had taken him on his knee when the boy was old enough to know the mean- 
ing of the words, and told him to grow up to be an honest man. I was hurt for my young friend, and indignant with the man-too much so to reply; and I rose to leave the room with a mortification that I cannot remember to have felt before or since. I paused at the door and said:

"Well, sir, in this dilemma is there no other church to which you can direct me, from which my friend can be buried?"

He replied that "there was a little church around the corner" where I might get it done; to which I answered:

" Then, if this be so, God bless 'the little church around the corner';" and so I left the house.

The minister had unwittingly performed an important christening, and his baptismal name of "The Little Church around the Corner" clings to it to this day.

While acting my first engagement at the Boston Theater I met Charles Fechter. By the terms of my agreement it was arranged that I should give five nights' performance and a matinée each week, Fechter playing only on Saturday night. I had not seen him act since my visit to France in 1855 , so that I had an opportunity of witnessing his performance here some three or four times. His Claude Melnotte and Don César were unquestionably the best I had ever seen. The arrangement of his dramatic pictures was graceful and unconventional.

William Warren, Charles Fechter, and I were living at the same house during my engagement 


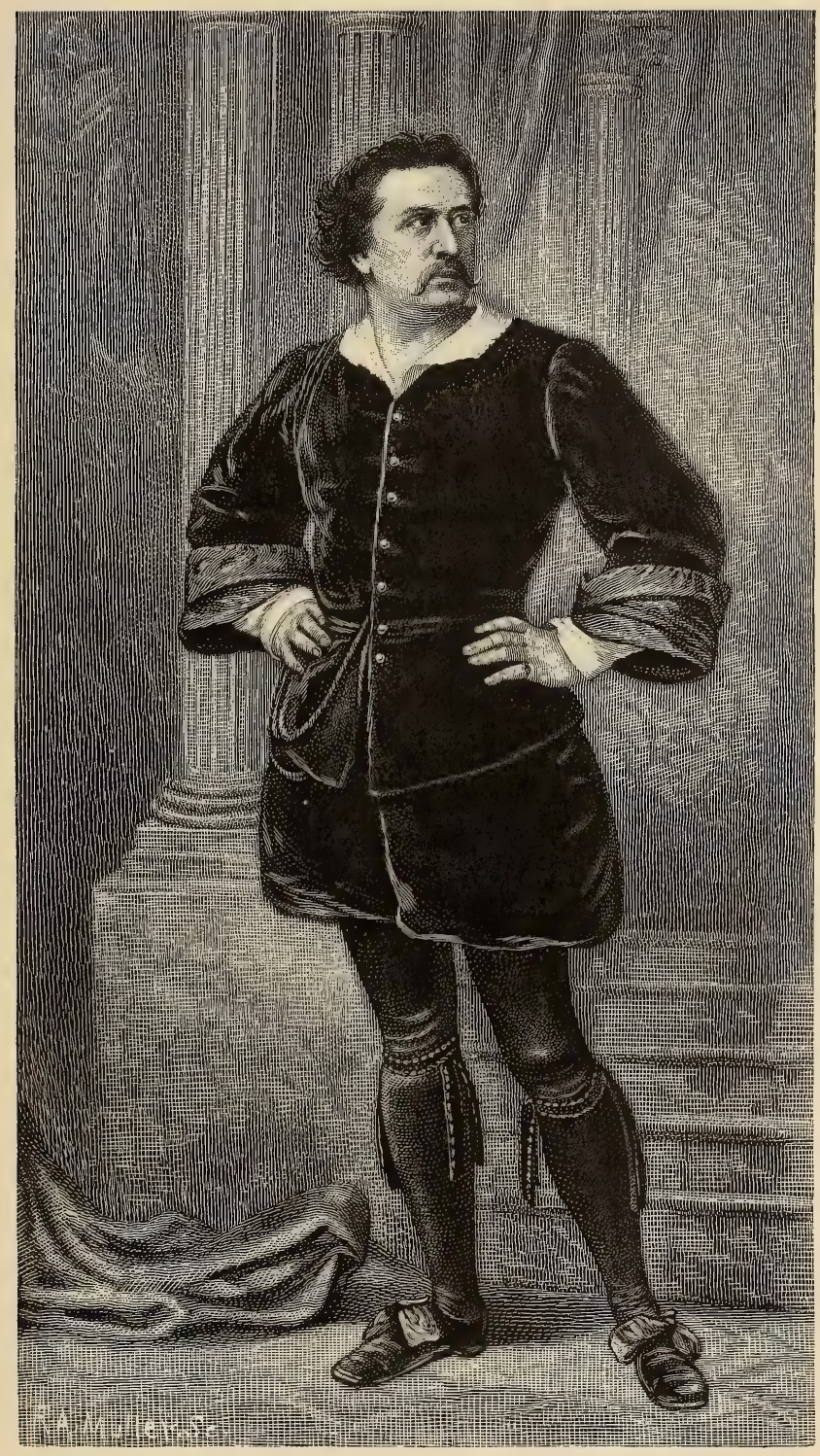

CHARLES FECHTER. 

in Boston, and usually met at supper after the play. This is not only the witching time of night for an actor, but it affords a golden hour for theatrical chat. Charles Fechter was a most agreeable and entertaining man. He had a rich fund of theatrical anecdotes relating to the French stage and told them with excellent dramatic effect. Frédérick Lemaître was an especial favorite with him, and it struck me from what he said in relation to him that his own style of acting was founded upon that of his idol.

I think Fechter was less greedy of public approbation than he was of the applause of his brother actors; he seemed to delight in portraying scenes from his different characters before them. William Warren and I made an excellent audience on such occasions, as we not only thought highly of his artistic qualities, but were naturally interested in the great actors of the French stage, of whom we had heard so much and seen comparatively so little. His description of Lemaitre in the character of Belphégor was wonderfully graphic. I think Warren and I were the only ones present on the occasion of this illustration. He acted it to the life. We were deeply interested; and he, catching, I suppose, the spirit of our appreciation, became enthusiastic. The art was so fine and the feeling so intense that we seemed to be looking at the scene. The gardens of the château, the fine company supposed to be assembled, were not required to give life to the acting. He addressed the imaginary guests with 
such force that they seemed to stand before us. As the mountebank, with his starving child clinging to him, weakened from the want of food, with tears choking his utterance, he carried us completely away. And when in a burst of grief he caught his fainting boy in his arms, I think we were both in tears.

In this respect Fechter seems to have somewhat resembled Garrick, who, we are told, was as entertaining off the stage as he was on it. This peculiar faculty has given rise to the rather unjust suspicion that Garrick was not so great an actor as his biographers would make us believe.

There is no doubt that many great actors are unable to become sufficiently enthused to act well off the stage, and there are some very indifferent ones who can entertain privately with considerable effect; but there is no reason why artists may not possess both faculties.

Mr. Fechter was thought to be somewhat erratic both as a manager and in the conduct of his private business; he certainly failed in both England and America in the former character. His directorship at the Lyceum in London and his managerial career in New York and Boston were not successful.

There are two striking instances of Mr. Fechter's benevolence that I think were not made generally public, and which I shall take the liberty of mentioning. He retired from the directorship of the Globe Theater in Boston in consequence of some disagreement with the proprietor. The public, 
considering him the injured party, tendered him a benefit, which I believe netted him something like five thousand dollars. He accepted the compliment but declined to receive the money, requesting the committee who had been most active in the movement to name five public charities of Boston to which he might give the proceeds. His request was complied with, and he gave the five thousand in accordance with the committee's selection. This was certainly a generous gift, particularly as Mr. Fechter was not a rich man, and as there can be no doubt that at that time the money would have been most useful to him.

Just previous to this occurrence a company of French actors had been playing in Boston with ill success, and had gradually fallen into financial trouble. In their distress Fechter came to the rescue. He was at that time a drawing card, and his name announced for the benefit of his national brother artists drew a crowded house, the proceeds of which relieved them from their embarrassment. Shortly after this a committee of actors from the relieved company called on their generous comrade and presented him with a testimonial of their gratitude and a silver cup upon which was the following inscription:

À Charles Fechter, les artistes français de New York, Boston, I6 Avril, I87o.

This same cup was discovered in a pawnbroker's shop in New York several years after Mr. Fechter's death, and was rescued by William Warren from 
the destruction to which the unrelenting crucible would have condemned it. Warren presented it to me, and I have it still.

Much comment has been made on the usual reception given to an American actor in England, and vice versâ. London and New York are naturally selected as the initial points for the appearance of plays and players, and it is reasonable to suppose that in such large communities, containing, as they do, thousands of actors and hundreds of critics, there should be a small band of histrionic and literary assassins, whose natures are embittered by their lifelong failures. But the great public of both hemispheres have no spleen to exercise; they welcome a new entertainment with the heartiest warmth, if it affords them gratification. They have neither the time nor the inclination to persecute strangers. Of course if some element of national pride is wounded there are always enough turbulent spirits to begin a disturbance, as was the case with the Forrest and Macready riots in 1849 ; but these occurrences are exceptional, and at no time are they approved by public opinion. The spirit of fair play circulates freely in Anglo-Saxon blood on both sides of the Atlantic.

An excellent English actor may visit us, the local features of whose performance are not understood; or an American will perhaps take an indifferent play to London, and the public decline to receive it-not because it is American, but because it is bad. As soon as these weak spots appear the assassination begins the churlish actors 
wag their tongues, and splenetic critics draw their pens-points envenomed, too. The unfortunate victim returns home in either case under the natural, but erroneous, impression that the country has been up in arms against him.

With these convictions and the agreeable remembrance of my professional success in 1865, I had no apprehensions of failure when I visited London ten years later. Shortly after our arrival in London I entered into an engagement with Mr. Chatterton to appear at the Princess's Theater in November, and straightway proceeded with my family to France, where we passed the summer. 


\section{CHAPTER XIII}

\section{SCENES AND THOUGHTS ABROAD}

Once More in Paris - French Acting - French and English Painters-English Acquaintances - The Reverend Joseph Jefferson - Gainsborough - In Scotland - In Ireland

T $\mathrm{N}$ Paris we were delightfully situated, having apartments at the Hôtel Mirabeau, which 1 looked out upon a quaint and pretty courtyard, filled with plants, birds, flowers, and fountains. Our party consisted of nine. This was altogether too large a family to secure any privacy for ourselves; and it is quite likely that our four children did not secure privacy to any one else. We were therefore delighted to get away from this charming place, and I have no doubt that the remaining guests shared our pleasure. We took a furnished flat in Avenue d'Eylau, where we could study French in sight of the Arc de Triomphe; and for this laudable purpose I engaged a celebrated teacher, Madame Somebody, who would have talked us to death if we could ever have understood what she said. 
She was a great character-fat, fair, and fifty, I should say; always dressed in the extremes of tawdry fashion, full of flounces and frills, with a large head decked out in an enormous bonnet and smothered with a flower-garden in full bloom. Under her left arm she hugged three or four big books, and with her right hand she flourished a formidable blue cotton umbrella. She usually came about ten in the morning, entering the room all radiant with smiles and good humor, making an extravagant courtesy, and saluting the assembled family with, "Bon jour, mes chèrs amis." She would then pause for an instant, with her head on one side, as much as to say, "You see I address you in French always; we must lose no time."

After seating ourselves around a large centertable Madame would adjust her spectacles, and, looking over the top of them, begin to hurl her terrible verbs at our heads. My children, who were well versed in French, received and caught them neatly, but they seldom struck me. She promised to teach us in three months; but I think, from what I remember of her pronunciation of our own language, that we could not have taught her English in as many centuries. However, we had all pledged ourselves to stick to it and master the language at once: none of your reading, and writing, and translating-oh, no! that would n't do for us; it was to be practical, the pure solid mother tongue, with a full Parisian accent. My progress was of so wonderful a character that at 
the end of the first month, by hard study and close application, I knew less about it than I did when I began. The verbs became denser and denser; so I retired from the academy, and, like an indulgent father, abdicated in favor of my children.

The villages near Paris are most attractive for sketching, being full of glimpses of beautiful scenes: through the trees some old château or French cottage, with those tall poplars so full of character stretching out in the distance or reflected in a stream. In this artistic atmosphere one who is fond of painting feels a mysterious craving for his canvas. I painted pictures all day and dreamed of them all night.

Madame Vert, the lady to whom the property belonged, was a widow. M. Vert, it seems, had bequeathed her the estate just previous to his death on the dog-in-the-manger condition that she would remain single for the rest of her life, it being understood that in the event of her proving false to this one-sided bargain the property was to revert to his family. It is presumable that this liberal-minded gentleman fancied that he would slumber more peacefully in Père La Chaise if he were sure that his widow, after wearing out a long life of single misery, would join him there unaccompanied by another husband.

The man who took the inventory of the furniture confided to me the strange and selfish conditions of the will, and told me, moreover, that Madame Vert was extremely unhappy under its restraint; and, 
as she was quite young and very beautiful, I have no doubt that he told the truth, particularly as the matter had nothing to do with his business, in which latter department his veracity was more than questionable.

The morning we took possession of the apartments Madame dropped in-by the merest chance, of course. She stood for a moment in the doorway, a lovely picture of insincerity, regarding us (the agent included) with her beautiful shoulders and eyebrows elevated, and in an attitude of sweet but melancholy surprise,-just as if she did n't know all about it, - and then the agent explained it to her just as if he had n't done so the day before. The charming widow was tastefully arrayed in half mourning, that non-committal gray check trimmed with deep purple, a sort of compromise between grief and cheerfulness, cut and fitted in so stylish and graceful a fashion that I wondered whether these becoming weeds were worn out of respect for the lost one, or with a design of capturing the next one-except that the fatal clause in her husband's testament made the latter quite impossible.

Madame regarded us with a sad smile, also in half mourning, and was so charmed that her old home was to be occupied by my family that we felt much complimented; and when she departed I think we were under the impression that our landlady would have been distressed if any other party had been before us in securing the place. 
I had just been displaying to my family my last picture in the shape of a landscape. I know now, as I did not know then, how vain I was of the miserable work, and call to mind the adroitness of our new landlady in discovering my weakness at a glance. She went into ecstasies over my daub of a picture. This captured me at once, and when she said that the style reminded her of Corot's I would not have rented a house of any other lady in Paris for the world.

She stood in the center of the drawing-room, pointing to the different articles of comfort and beauty that surrounded her, and gave us to understand that all belonged to my family and myself: for her they possessed no further interest; use or destroy them, if we liked, she cared not. In fact, I think she rather preferred the latter treatment, as, when we gave up the place, we were charged double for every scratch or spot that could be found by the innocent agent. The whole house appeared to have been arranged so that it would fall to pieces on the slightest provocation. Expensive bits of bric-à-brac had been so ingeniously poised upon inadequate brackets that the vibration of a passing cab made us tremble together. Dents, scratches, and stains that were quite invisible when the inventory had been taken broke out in the parlor furniture, and soon became contagious. Firetongs, that had apparently been on friendly terms when we first came, refused to unite; annoying little bits of inlaid marquetry had fallen out with the old veneering, and defied our ingenuity to match them 
back again. An arm-chair with a compound fracture in the right leg had let me down in a most inhospitable manner, and when the French cook appeared, displaying some damaged long-handled copper utensils, I felt that the epidemic had reached the kitchen.

The letting of furnished houses in Paris and London should be classed as one of the black arts. There is no necromancy equal to it. The so-called smart American is an imbecile in their crafty hands. “'Will you walk into my parlor?' said a spider to a fly"; and when you are once in the web nothing can extricate you but your check-book. Don't attempt to struggle; you will only entangle yourself the more.

London is worse, if possible, than Paris. During the two years I was in the former city I rented two furnished houses. I told the agent of the first one how I had been treated in Paris. "Ah, yes, yes! those fellows are dreadfully treacherous; but did you have no one to represent you? No! Now see how differently we manage these matters. Here we have a man to take an inventory, with a list of whatever damages have already been sustained; you have your own man to do the same; they perform this work together, so there can be no mistake or fraud." This seemed quite fair. The agent recommends me to a man who will work in my interest, which of course he does not. The end is $£ 50$ damages for two months. My next landlord was a private gentleman who was so confiding that he would not dream of taking an 
inventory; it would imply a suspicion- $\_75$ damages for three months. No appeal except to the law : oh, no! keep clear of that in London; it is worse than house agents.

But while I am telling these tricks of the French and British spiders - which I do in hopes of warning some tourist fly-let me say a word in favor of honest Scotland. I lived with my family for six months at "Morningside," near Edinburgh, in a finely furnished old mansion, and the damages were placed at the moderate sum of five pounds.

Art is so sacred in Paris that its conventionalities once established no change of government could affect them. Whether the country be imperial, republican, or monarchical, the subsidies of the Grand Opéra and the Théâtre Français remain unaltered. In our own country the amount of subsidy would possibly fluctuate according to the artistic views of the "present Administration." The leading man might be discharged if it were discovered that he had voted for the unsuccessful candidate.

The admirable acting at the Théâtre Français, though highly finished, is not without conventional faults. The actors often address themselves to the audience, particularly in soliloquy. No matter how great an actor may be, he weakens his effect when he does this. It is foreign to nature, and away "from the purpose of playing." It jars upon an audience; and, be it ever so well done, it looks as if a beautiful piece of mosaic had fallen out of the picture. 
I saw "L'Ami Fritz" at the Théâtre Français, and in this play there occurs one of the sweetest scenes in domestic drama. It is between the young village maiden and the Jewish rabbi. They are seated by a spring, and the innocent girl is relating to the old man the story of her love. He leans forward, attentively listening to every word. She, with her low, sweet voice, murmurs forth her bashful confession, and with downcast eyes gracefully moves her hand round and round in the water, as though she were tracing her story in the pool. When she has finished her head is bowed down, and her tears seem to be mingling with the brook. The rabbi sits regarding her in silent admiration, and then suddenly bursts forth with the exclamation, "She is charming!" In speaking these words the actor, instead of looking intently at the girl, addressed them directly to the audience. The chain was broken as soon as he committed this error. And yet he was one of the finest artists of this the most important theater in France. The same fault occurred several times during the play, but at this particular point it was glaring and offensive.

An intimate friend was at the theater with me, and as he was an admirable art critic, and had been born in Paris, I questioned him after the play on this subject. I mentioned that nowhere in France was the fault more common than at the very theater where one would have least expected to find it; and in fact at the Palais Royal, and at several of the minor theaters, I had not noticed it at all. He 
agreed with me that it was a glaring defect, and that it was a common occurrence at the Français, but was passed by unnoticed, or rather accepted as one of the conventionalities of the theater.

The next morning we met at breakfast, and he told me that he could hardly sleep all night for thinking of what I had said about stepping outside of the dramatic picture, and that he fancied he had hit upon the reason for this error having crept into the drama of the night before.

It seems that the comedies of Molière are acted only at this house, and in these plays the characters are often required to address the audience directly, like the chorus in the old Greek plays, and also, as in some of the plays of Shakspere, inform the audience of what has taken place between the acts. Therefore, addressing the audience was, under these conditions, a feature of the play, and it became as imperative that an actor should study how to step out of the picture and return to it again gracefully as it was to perfect himself in any other detail of his art. And so the custom sometimes intruded itself into domestic drama from the mere force of habit. Of course this is some excuse, but it does not wholly pardon the offense, and certainly cannot undo the mischief.

At the Théâtre Français we are accustomed to see the most finished acting that is given in Paris. I confess I have been there but seldom, for, though I admit the importance of a scholastic dramatic institution, it does not afford me the pleasure that I get from the less polished but fresher acting of some 
of the other theaters. Its influence, however, on actors is unquestionably a good one; the discipline of the stage, the refined style of its professors, and the strict adherence to the rules of grammar and methods of pronunciation, keep it aloof and above all other theaters. It acts, too, as a check upon actors at other establishments who would perhaps run riot with their successes, and it enables the managers to point to this legitimate temple as a model. But I enjoyed the little comedies at the Palais Royal, and the productions at the Opéra and the Opéra Comique, beyond all the theatrical entertainments that $I$ saw in Paris.

In wandering through the art galleries I looked one day upon a domestic picture by Millet that filled me with a sad kind of pleasure. The subject and treatment were simple and masterly-two women sewing upon a shroud; it is a shroud, too, of some one they both loved; for, while they ply their needles with care and earnestness, they seem stunned by a sudden blow-some recent affliction: it would seem as if the two figures were the mother and sister of the lost one. The harmony of color made the little canvas glow with beauty, and the composition was perfect. These qualities are, of course, important, but the indescribable mystery of feeling that filled the picture was its great charm: one could not look at the work without wondering at the deep emotion of the painter while he was lost in this subject. Gentle and tender-hearted Millet, you will never die! When we think that the power and creative- 
ness of this artist were subjected for years to the cold judgment of unsympathetic professors, and by them treated with scorn and refused their rightful place upon the walls of the Salon, it makes us wonder where the law of compensation begins. The pretty painters of the ruling school were shocked at the bold treatment of the peasant painter, and one of them wondered why so good a draftsman did not put more beauty into the faces of his country girls; to which Millet replied, "The beauty of a peasant is in the earnestness with which he does his work." Had such an answer been given to me it would have rung in my ears till the crack of doom.

The French school of landscape painting attracted me very much, and after carefully studying its philosophy I am of the opinion that the greatest landscapes are works of the imagination rather than transcripts of realities. Nature refuses to be imitated, but invariably rewards the artist who has the modesty to suggest her. The painter who attempts to give an exact picture of a natural scene will find himself surrounded by insurmountable difficulties. As an example let us suppose that he takes for his subject a certain view with which we are familiar; the sky, water, the foreground, trees, and distance may be painted in the exact form, color, and perspective proportions of the original, and yet fail to give one an idea of the spot. What is the reason of this non-resemblance when all the details have been so carefully mitated? What is it that has no existence in the picture, and 
that so pervades nature? Where are the sweet sounds of the woods? Where is the singing of the birds, the hum of busy insects, and the murmur of the brooks? Where is the movement of the clouds, the graceful bending of the trees, and the perfume of the pines and woodland flowers? He cannot paint these, and so his realistic work is cold and lifeless. But if in modest truth he suggest his work, omitting hard details and impertinent finish, the simple picture will lead us in our imagination to supply the artistic impossibilities of sound and movement.

When I first saw the works of Constable and Corot I did not like them. They seemed to be devoid of subject, and there was an unfinished look about them that gave me the idea of mere sketches carelessly painted. But as I became familiar with these pictures I gradually began to understand what they meant. I then discovered that it was I who was at fault, not the artists, and I felt ashamed to think that I had seen so much and knew so little. Such painters as Corot, Millet, Daubigny, Diaz, Constable, and Rousseau approached nature in a spirit of reverence; they dared not imitate her. That they studied minutely there is no doubt, because it was necessary to be familiar with and imitate all the details of nature, that they might suggest her in their pictures, like the elaborate rehearsal of a part previous to its free and spontaneous performance. But this care belongs to the study, not the picture, just as it does to the rehearsal and not to the performance. And those 
landscapes are the most pleasing that have form without hardness, strength without blackness, suggestion without vagueness, and delicacy without weakness.

The early works of Turner seem to be more highly esteemed than his later ones, but to me they have nothing like the charm of the pictures painted near the close of his life. They are finished and scholarly, but so carefully painted that they fail to produce an absorbing effect. We should, however, feel grateful for these, as they undoubtedly led the way to the masterly works that followed. I do not mean that all art should be treated in a merely suggestive way, but that I enjoy it best when it is so rendered. For as tastes vary, so should there be different methods to meet each desire. We are generally too dogmatic, and praise only those works that chime with our own fancy, forgetting that all artists are laboring for the public. Each painter exerts his own peculiar style to please his own particular audience. To toil for critics only would leave the workman in a sorry plight.

Censuring a chromo because we do not enjoy it is as narrow and illiberal as it would be to condemn the publication of a poem because we would prefer to read it in the author's handwriting; for it is only another form of publishing the works of great masters, so that those who cannot afford the originals may relish and be educated by the copies. If farmers are too poor to buy pictures, give them cheap and inferior art rather than no art at 
all, and so let them have their chromos as broadcast as their barley. Besides, to one who is devoid of imagination a pre-Raphaelite work, where each detail is clearly defined, is more agreeable than a suggestive one; therefore he should have it. The discordant scraping of a Chinese orchestra is dreadful to us, but if it falls harmoniously on the ear of a Chinaman it is useless to recommend Beethoven to him. The Christian and the pagan are alike infidels to each other, and it is this very kind of intolerance that begets half of the turmoil in the world. So long as the art diverts and does not degrade we should be lenient, and remember, as Dogberry says, that "All men are not alike, good neighbor."

After leaving Paris I returned to London, where I played a long engagement at the Princess's Theater. Here I renewed an acquaintance with some of my old friends, and made a few new ones. Dinner-giving in London is almost a fine art. I do not mean as to the quality of the viands or the decoration of the table,- these matters are, of course, quite perfect,_-but in the nice judgment of the host in the selection of his guests. I have seen a scientist, a statesman, a painter, a composer, an actor, and a divine at the same table-each one a leading light in his profession. Not only is this varied talent selected for its brilliancy, but for the harmony with which it will unite. In the assembling of such an intellectual group the next care is to dispose them at the table. People who have never met before are cunningly placed side by side that they may 
converse together for the first time; and I have often seen the host and hostess nervously watching the effect of their preconceived arrangements. Sometimes the party at a London dinner will consist chiefly of actors and dramatic authors. Such guests generally know each other, and as there is no ice to break, the spirit and enjoyment are entered into at once.

I had a memorable lunch at the Star and Garter, that lovely spot on the banks of the silver Thames. Charles Kingsley, Robert Browning, and George Augustus Sala were of the party. Mr. Browning surprised and delighted me. I was surprised because he displayed a faculty I was not prepared for. His mind seemed to be stored with that useful and practical kind of knowledge one would scarcely expect to find in a poet. If any of the company opened a subject, Mr. Browning knew more about it than anybody else. Not that he intruded his information; on the contrary, it was given with so much modesty and good taste that we were only too glad to be enlightened from such a well-spring of learning. One of the guests, whose mind seemed to be stored with misinformation, and who was not so retiring as the great poet, seeing that he himself was falling behind and losing ground, sprang to the front with his adventures in Italy. He endeavored to take us through the picture galleries and describe their wonders; but while descanting upon the great painters of the past, he got the company tangled up in such a labyrinth of mistakes that 
he had to appeal to the poet to get us out. The latter came cheerfully to the rescue, and in doing this had to set our guide straight in so many matters in which he had gone astray that he retired in confusion and did not appear again upon the conversational platform during the evening.

I was fortunate in being placed next to Mr. Browning, and it was delightful to talk to him, or rather have him talk to me. I asked him how he could manage to go so frequently into company and yet preserve his health and spirits. $\mathrm{He}$ told me that he made it a rule to drink only one kind of wine at dinner; if he began with sherry, he kept to it. "And then," said he, "I retire early, and always get a good night's rest. Sleep is the great doctor, young man"- patting me gently on the back. I don't know which I enjoyed most, the pat from the poet or his calling me a young man, for I was verging upon fifty; however, that is a young man in London.

A few days after this I received a letter from Mr. Browning, inviting me to lunch with Lord $\mathrm{C} \longrightarrow$, his lordship's sister, and himself. I replied that I would be glad to accompany him, and the next day we met by appointment and sallied forth to call on Lord C C and his sister. On the way he gave me an account of his meeting with Longfellow and the pleasant intimacy that had existed between them. I listened with national pride to the encomiums he passed on the writings and character of the American poet. These wise and loving gentlemen had walked arm in arm 
through the quaint and sacred old haunts of London; and while Mr. Browning recounted their various rambles I thought as they elbowed their way through the streets how many citizens of crowded London had jostled up against them unaware of the wisdom and learning that was possessed by this gentle pair of poets in double harness. He told me that on one occasion they were walking together, and, being overtaken by a summer shower, got into a cab. The rain began to beat down heavily, and Longfellow insisted on handing his umbrella out of the window to the driver. Browning told him that he thought it was very kind and thoughtful of him, but quite unnecessary, as it would be harder to find a dry cabman in London than a wet one.

The quiet simplicity of Lord C- seemed to extend itself to the entire household. The very butler was devoid of pomposity. The fine old mansion in which this aristocratic family resided was homelike and cheerful. The host and hostess gave Mr. Browning and me an unostentatious welcome.

The clubs of London I know but little of, having visited only the Garrick and the Savage. The pictures at the Garrick attracted me very much; a fine example by David Roberts and a vigorous marine by Stanfield - both scenic artists - hang on the walls, and character portraits of Garrick, Munden, Knight, and a host of theatrical celebrities make the rooms exceedingly interesting.

Many of the actors, authors, and painters of London have, I think unwisely, expended their 
earnings in building costly residences, where they entertain their guests most sumptuously. They seem blind to the fact that they must, now and forever, toil on that they may keep up this generous hospitality. Of course they naturally console themselves with that old-fashioned and conventional comfort, that should matters go a little wrong they will cut off that expense, and curtail this little elegant bit of extravagance, and so set themselves right again; but it is more difficult to retrench than they seem to realize.

In a great city one would suppose that the absence of details, should one desire to economize, would pass unnoticed; but this is a mistake. London society moves in little cliques, whose eyes are vigilant and notice at once the slightest variation in social entertainments. The flavor of the cigars, the brand of the wines, the appearance of the butler, the ornamental decorations of the table, and above all the cuisine, are rigidly criticized, and the least retrenchment is fatal to one's social reputation.

We seldom stop to consider how hollow and what a sham it is to entertain those whom we do not care for, and who do not care for us. Is this artificial nonsense so much coveted that we are to sacrifice the comforts of our lives to obtain it? What! live in fear and anxiety that we may outdo our neighbor by putting a more costly pair of boottops on our coachman? Burden ourselves with a life of toil simply to increase the pomposity of our butler? I am satisfied that domestic melancholy sets in with the butler. $\mathrm{He}$ is the melo- 
dramatic villain of society. Give me a tidy girl, with a clean calico frock and a neat little white cap - that 's the height of my ambition! Look at her! there she stands with a cheerful smile and a willing hand, ready to administer to your comfort and laugh at your old jokes - aye, though she has heard them fifty times. What a delightful audience! I am satisfied that no butler ever laughs at the same joke twice: I have tried it.

To see one's own name on a card belonging to another person gives one quite a start. While living in Belsize Avenue a card was brought to me by the maid, with the following inscription in pencil: "Rev. Joseph Jefferson and wife." I remembered having heard that there was a first cousin of my father's who was a clergyman living in Yorkshire. I at once went out to receive them. Seated on the hall-chair was the old clergyman, and by his side stood his loving helpmate. I say loving, for the attitude of this, to me, very interesting couple revealed the wife's solicitude for her husband. He was seated; she was standing. In one hand she had a large umbrella and her husband's broad-brimmed hat; the other she rested gently on his shoulder while she regarded him with a respectful affection. It seemed to me that just a moment before she must have said to him, "Now, Joseph dear, give me your hat and do just sit down, if only for a moment; it will rest you, and I am not a bit tired." She was dressed in a plain black silk gown, with no superfluous material in the skirt, and had on a simple straw bonnet 


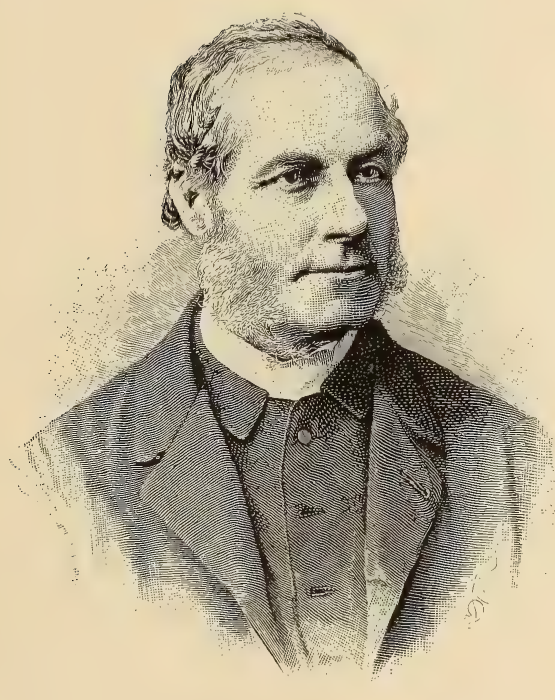

THE REVEREND JOSEPH JEFFERSON. 

about as unfashionable in shape as it well could be; he, with his quaint-cut suit of black, his soft, unstarched, and amiable-looking white cravat the group making as complete a picture of an old English clergyman and his wife as ever David Wilkie could have painted. They had been married many years, but I fancy that his bent figure had in her eyes the grace of youth, and the wrinkles in her loving face were as dimples to him. They had lived so long together that they seemed to resemble each other. His face was like my father's, and reminded me of my own. Surely his features were cast in the classical mold of the Jeffersons - not the noble Roman or the simple Grecian, but the pure nut-cracker; or as Sheridan says, when he traces the resemblance of a certain lady's face to a congress at the close of a general war, "where the nose and chin were the only parties likely to join issue."

I do not quite remember whether the old clergyman and his wife had come up to London especially to see me or not, but they had certainly made it a point not to go back to Yorkshire without carrying with them some remembrance of their "American cousin."

The old gentleman asked me many questions regarding our family, and seemed much interested in what I told him of it. I gave him an abridged account of our pioneer wanderings in the West and our early struggles connected with it, and in return he told me of his life in Yorkshire and described the simple routine of an English clergy- 
man's life, referring now and again to the labors of himself and helpmate among their poor parishioners; and when he spoke of his wife he would take her hand and look kindly in her face. And she too, I remember, asked me to allow her to close the window, lest the draft might affect dear Joseph's voice, as he had to preach upon the next Sunday. I thought at times that they looked at me as though they were ashamed of showing so much solicitude for each other. It was a pleasant sight, and made one think of what a long life of quiet happiness this cozy couple must have passed together.

After an introduction to my wife and grown-up children, of course the most wonderful baby in the world was brought down for the inspection of its new relatives. They seemed to take special interest in this particular cousin, - it having been born in England,-and rather chuckled over the fact that America did not have it all its own way, as their little third cousin was a "John Bull"; and curiously enough they treated the matter with the utmost seriousness, insisting upon it that the baby was a British subject, and that we could not get over that, do what we would. We laughed at this, but the old man in his great loyalty waxed quite warm over the matter. "No, sir, you cannot alter it; he 's an Englishman; for instance, now, he could not be President of the United States, could he?" "No," said I, "I am afraid that in coming to England previous to the child's birth we did perhaps display great lack of forethought in depriving him of that privilege." "Still he could 
be Prime Minister of England, could he not?" Of course I could not deny this, and mentioned that perhaps we might console ourselves in future years that though we had lost for him one distinguished honor we had gained for him another.

Our reunion was very pleasant, and we quite regretted it when the time came for them to go. It was a warm July day, and the sun was shining with great heat upon them as they passed down the avenue; but the careful wife, ever mindful of her husband's comfort, raised the huge umbrella over his head. I had no idea of its ample size until I saw it expanded; it quite extinguished them, and was large enough not only to shield the clergyman and his wife from the sun, but to have put his entire congregation into the shade.

The celebrated portrait of the Duchess of Devonshire painted by Gainsborough was at this time attracting much attention in London. It had lately been sold under the hammer to the Messrs. Agnew. These gentlemen were prominent dealers in art, and had paid 10,000 guineas for the picture. Mr. Frith, who always delighted in giving pleasure to his friends, sent me a line to say that if I would meet him at Agnews's he would show me the picture, which, it seems, he had already seen. I was only too glad to accept the invitation to look upon the painting of a master; and to have as a companion a distinguished artist of the modern school was a privilege not to be lost. 
I had before this seen several paintings by Gainsborough. At the Loan Exhibition held at the rooms of the Royal Academy, in this same year, there were two lovely portraits of departed female royalty that breathed refinement. Close to these aristocratic beauties, and in strong contrast with them, was a rustic picture by the same artist called "Going to the Spring" - a barefooted peasant girl crossing a brook, with a pitcher in her hand and a young puppy hugged tightly to her heart. Gainsborough's portrait of Garrick which I saw at Stratford was not so pleasing. The eyes of the great actor sparkle with a diamond fire, but the attitude is affected, and the patronizing air with which he leans against the pedestal is scarcely in good taste. He really looks as though he monopolized the bard entirely, and this was too near the truth to be pleasant for other members of the theatrical profession; for in Garrick's day Shakspere was only permitted upon the stage of the patent theaters, the minor ones not being allowed to act his plays. Now it is otherwise, and Hamlet can be seen upon the Surrey side and at the East End; and Richard III. can ride about Bosworth Field on horseback at Astley's Circus.

I am here reminded of an anecdote of a gifted tragedian playing the crook-backed tyrant and bestriding White Surrey at the battle. In the excitement of the fight in the last scene he forgot to dismount at the proper time, and came prancing upon the stage shouting, "A horse, a horse, my kingdom for a horse!" 


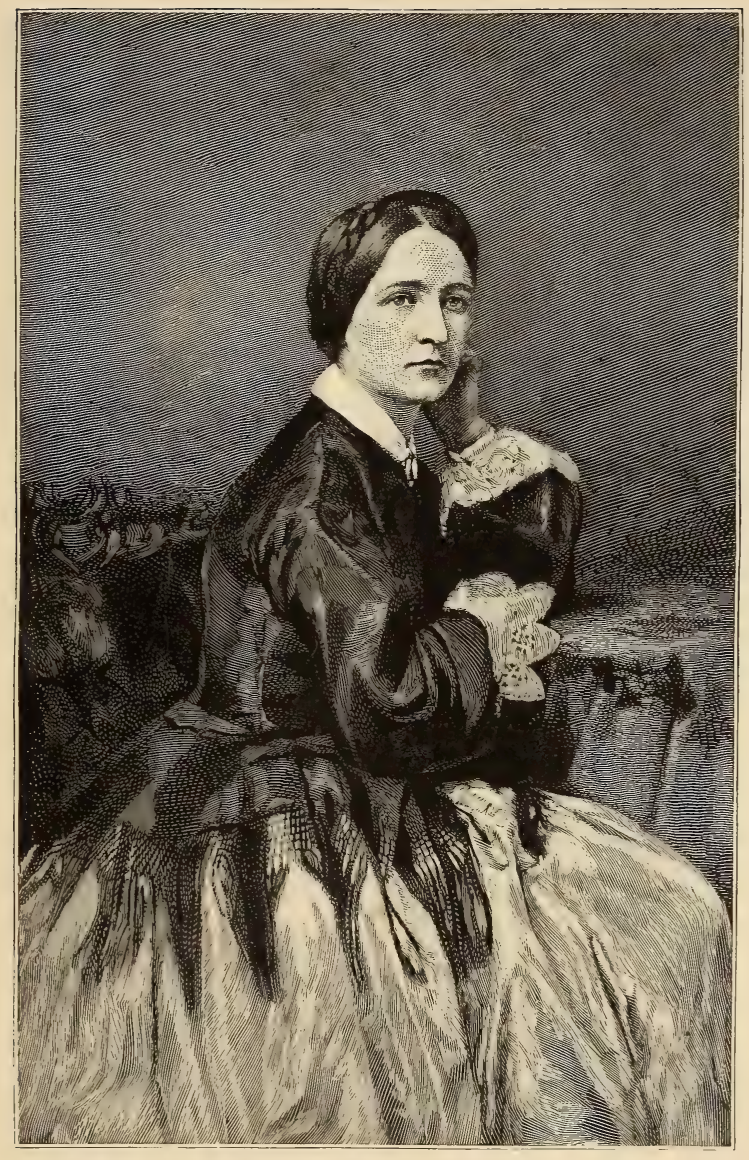

AGNES ROBERTSON. 

The Duke of Gloucester has made me ungallant enough to forget the Duchess of Devonshire; so, asking her Ladyship's pardon and my readers' for the digression, I will return to the picture.

It was a half-length figure of a perfect English beauty in the full bloom of youth and health, with violet eyes, and looking like a June rose. The broad hat with feathers that takes its name from the picture made an effective background for such a face. The cherry lips, half open as if about to speak - to think that those lovely lips once kissed the butcher! The story runs that her Ladyship was so anxious for the election of Fox that she canvassed the county in person, and on the trip met with a refractory butcher who swore he 'd ne'er vote for Fox unless her Ladyship would give him a kiss. Whereupon her Ladyship jumped from her carriage, and gave him a bouncing buss. Happy butcher! who would not have envied thy chops? The resolute look of the lady told of one who would kiss the butcher, the baker, and the candlestick-maker if she once had a mind. The picture was removed that day to some gallery where it was to be exhibited to the public, as a desire to see the famous duchess was universal.

The next morning at breakfast I was startled by an announcement in "The Telegraph" that the picture had been stolen. Some thief or madman, it is supposed, had concealed himself in the gallery during the day, and in the night had cut the picture from the frame, and he and it were gone forever. I say forever, for, though it is now fifteen years since it disappeared, no trace of it has 
been found; and I don't believe that the death of the real duchess, when she was gathered to her illustrious ancestors, caused more stir in London than the loss of her picture.

Lord — owned a princely estate in Scotland,a domain containing, I think, some ten thousand acres of land,- - situated amidst the most picturesque scenery of the Highlands. Lord and Lady — had invited me to stay a fortnight, but I found on my arrival that the castle was quite filled with guests, so I made my excuses and only stopped a week. The whole of this time was passed in a round of sporting excursions and picnics, grouse-shooting and salmon-fishing.

As Lord - came out in the spacious hall to welcome me he was a picture - six feet in height, with a florid complexion and light blue eyes full of expression, his hair and beard of a golden red; and being in complete Highland costume he looked like a Scottish chief of the olden time. The warm greeting given me by this frank and stately Highlander was so hearty, and so full of unaffected hospitality, that I felt quite at home with him at once. In half an hour I joined the company at dinner.

The routine of high life in the country was quite new to me, and I felt interested in observing its comforts and its cares. Of course the donors of the feast get some pleasure in welcoming their friends and relatives; but many strangers must be entertained in whom the host and hostess take but little interest, and they are often obliged to show civilities to people whom they have met in 
the city or at foreign courts-diplomats and titled persons.

His Lordship was fond of farming, and I walked with him over the land to see his imported American machinery shear the fields of their golden grain. He was a capital shot, and, as his domain was well preserved, we had good sport with the grouse. Among the guests there was a remarkably interesting lady, a daughter of an earl. She was a queenly beauty of the Diana type-witty, aristocratic, haughty, and satirical; of course she was surrounded by several butterflies, who vied with one another in paying her court. And I do not wonder at it, for she was radiant with all those attractive qualities that are bewitching to young men.

I suppose there must have been a homespun flavor in my American manner that amused her, for she made a dead set at quizzing me. I did not detect it at first, and answered some of her absurd questions about America quite innocently. She kept her face so well that I might never have discovered this but for the idiotic grin upon the smooth face of one of her boyish admirers; and then I felt, for the honor of my country, that if she ever made another thrust at me I would parry it if I could. I had not long to wait; for, emboldened by her late success, she turned upon me and said, "By the by, have you met the queen lately?"

"No, madam," I replied with perfect seriousness; "I was out when her Majesty called on me." 
She colored slightly and then turned away, and never spoke to me again; but I was revenged.

At Glasgow I acted at the Theater Royal. This place was once under the management of a Mr. Alexander, who, I believe, built the theater, and his admiration for Shakspere and Scott was exhibited by placing their statues on the sides of the proscenium arch; but, as self-esteem is a noble quality in human nature, the modest manager displayed this virtue by placing a statue of himself in the middle.

I visited the churchyard of St. Mungo, where the grave of the lamented Mr. Alexander was pointed out to me. The original tomb was invented by himself as a modest and appropriate tribute to his own memory. It represents the proscenium of a theater; the curtain has fallen: this, of course, is a delicate suggestion that the life of Alexander the Great has ended; or it might have a more sweeping meaning, and one of grander significance, by inferring that in his dissolution the curtain had fallen on the dramatic world and closed its career forever. Hamlet says, "Alexander died, Alexander was buried, Alexander returneth to dust." Of course this allusion is to another gentleman, inasmuch as the indestructibility of matter is in this instance traced till we find it "stopping a bung-hole" - and of course this latter indignity could never have happened to our Alexander of Glasgow.

During the following summer I lived at Morningside, just a mile from "Edinboro Town," in the 
mansion-house erected by one Dr. John Gregory about one hundred and fifty years ago. This quaint old building was, at the time I occupied it, in the possession of Miss Gregory, a granddaughter of the original owner. The house contained about twenty rooms, rambling and irregular in their construction, and filled with antique furniture and pictures; some of the latter were very fine portraits of the family painted by Sir Henry Raeburn. The library contained many rare works, and upon taking possession of the house $I$ insisted that this valuable collection should be sealed up. The grounds contained about six acres, and were surrounded by a high stone wall; all of the old residences at Morningside, where this mansion was situated, are environed by these prison-like inclosures. In the days when they were built there is no doubt that this security was necessary; and it is a comforting sign of the times, and an unmistakable evidence of the improvement in the conduct of the world, that the homes in the suburbs of our great cities of to-day have in many instances scarcely more than a low curbstone to separate them from the highway.

The Gregory mansion was an interesting old house; the ivy had covered the walls long ago, and was now climbing upon the roof. The lawn was shaded with fine old oaks, planted by the original owner, and the grounds were tastefully laid out and kept in trim by an interesting Scotch gardener. His father and grandfather had been servants in the same house; and he himself, then 
past seventy years of age, told me of many interesting events that had happened in the auld lang syne.

Dr. John Gregory had entertained within these walls many of the celebrities of his time. Byron, Jeffrey, John Wilson, and Burns had all dined and slept under this roof, and in the after-time his son had feasted Sydney Smith, Thackeray, Dickens, and Washington Irving. Upon a moonlight night I have sat in the shadow of a weird old oak and tried to fancy the forms of these departed heroes roaming, as they must have done in life, about this mysterious place.

Our surroundings have much to do with enlarging our thoughts: just as when standing on an eminence we have a more extended view; so will some hallowed spot, filled with the associations of great men and their noble work, inspire us with a deep reverence; and when I look back upon the time I lived at Morningside I feel that I did not fully appreciate the privilege of it, and wasted much time in commonplace affairs that I could have used to a better purpose.

The old Scotch gardener was an exception to his class; they are generally reticent, but he was proud of the Gregory family, and only too glad to talk of the wonders they had accomplished, the honors they had gained, and the great men whom they had known and entertained. The traditions of the family had come down to him through several generations of gardeners, and he would recount the great learning and the almost 
sacrilegious knowledge of one of the Gregorys, who, it seems, was a great astronomer: "He kenned a'thegither too much," said the old man. "He was on familiar terms wi' the very stars themsel's, and could ca' them by their ain names - Jupiter, and Venus, and Cupid, and the whole clan o' them; he kenned jeist how fast they were ganging, and where they were ganging to : it is awful to think how a great mon like that could dare to go pryin' into the private affairs o' the Laird himsel'."

While the old fellow delighted to chatter about the public career of the Gregorys, he was truly loyal to his clan, and as dumb as an oyster upon all private matters relating to them, following the advice of Burns to his friend:

But still keep something to yoursel' Ye scarcely tell to ony.

The ivy vine in England, Ireland, and Scotland adds materially to the beauty of the scenery; all of the sharp corners and straight lines of the old buildings are softened by its luxurious growth; it piles itself up over the walls of the castles and churches like rich green velvet, preserving the form of the architecture, while it conceals the harder lines beneath; but its beauty is often enjoyed at the expense of health. The house at Morningside was damp; the sun scarcely ever shone upon it; and often during the warmest days in summer a cold chill would fall upon us as we came out of the sunlight into the gloom of the house. 
My wife had been ill for some days, and we were alarmed at her low condition. One evening I was sitting by her bedside reading when my son came to look for some article in one of the closets at the far end of the room; he had a candle in his hand, and was peering at something that had attracted his attention on the top shelf. Suddenly he gave a start and a half-suppressed cry of fear, and as he turned his face towards me I saw that he had grown quite pale, while his hair seemed to stand on end with fright. I was about to ask him what had shocked him, when he made a nervous motion for me to be quiet, and leaving the room hurriedly beckoned me to follow him. It was quite evident that something in the closet had startled him, and that he did not wish my wife to know what it was. When we were alone in the entry he gave me the light, saying, "Go back, and look on the top shelf of the closet." I took the candle from him, and, returning to the room, sat down to read, so as not to attract my wife's attention. She asked me what had startled Tom, to which I replied, "Oh, nothing; it was only some of his nonsense." I waited anxiously until my wife dropped off to sleep. She was in a critical state of health, and the least excitement or shock might have killed her; so I took up a light, and standing upon a chair saw, to my horror and surprise, a child's coffin. It had been put far back and well out of sight, which accounted for no one of the family having seen it before.

I took it down, and walked stealthily out of 
the room with the burden under my arm. I went directly to the library with it, and calling my son and a friend who was staying in the house with me I locked the door, and called a council as to what course it was best to pursue. The coffin was something over two feet long, just about the size of one that would contain a new-born infant. We were somewhat puzzled, and many plans were discussed. I thought over the reticence of the Scotch gardener in all matters connected with the family, conjuring up a suspicion that some dark mystery surrounded the house. We next thought of sending for the coroner, and placing the matter in the hands of the authorities. At last I determined on opening the coffin myself, rather than make any stir before I was sure that the case was one needing public attention. We got a screw-driver, and with some considerable agitation we began to open the lid, and as we removed it we discovered the dead body of a large poll-parrot. We were all dreadfully sold, and burst out laughing at the mystery and precaution in which we had been lately indulging. It all came out the next day: it was a favored pet of Miss Gregory, and the gardener was to have buried it in her absence, but had forgotten it.

From Edinburgh I went to Dublin, where I acted under the management of John and Michael Gunn, two brothers who were jointly lessees of the Gaiety Theater. My reception in Ireland was not flattering. The attendance was slight, and the applause delicate. Many American actors have 
been cordially received here, meeting with great success; but from that "unknown cause" which I have before mentioned, the Dublin audience either did not understand or did not care for my acting. One of the managers (I think it was Mr. Michael Gunn) seemed to have a presentiment of my failure; for, after witnessing the rehearsal, he asked my agent if he thought I could be prevailed upon to make Rip Van Winkle an Irishman. I thought at first that this suggestion was meant as a joke; but upon asking Mr. Gunn if he were serious he assured me that he was, adding that he was quite certain that the audience would understand and appreciate the character more fully if I would give the performance a Hibernian coloring instead of a Dutch one. I told him that if I did this, in order to make an harmonious entertainment it would be necessary to alter the entire play-lay the scene in Ireland, and change the names of all the characters; that poor Rip would have to be called Misther O'Winkle; and to me these alterations would be very absurd. The manager argued that such violent changes were not necessary, and he only suggested that I should act the part with just a "shlight taste of the brogue." I told him that a taste of my brogue would be so slight that the audience would never recognize the flavor.

After rehearsal, as I came from the stage-door into the street, I was hailed in the richest Irish accents I ever heard by a bustling, energetic man whose manner, dress, and figure were particularly 
striking. The whole appearance of this person was the embodiment of what is erroneously known as the "shabby genteel." That he was shabby there could be no doubt, but his gentility seemed to be questionable, for he had that self-satisfied and confident bearing which rarely shows itself in a gentleman. My new acquaintance was gotten up in the most elaborate style. He wore a faded black dress-coat, buttoned up to the chin, and a black silk handkerchief wrapped high about his throat, while his head was covered with a drab hat, jauntily cocked on one side and dented in various directions. His nether garments consisted of a pair of light buff-colored trousers, worn threadbare, and strapped underneath a loose pair of slippers. On his hands were a pair of soiled yellow kid gloves; and with a bright, fresh rose in his buttonhole, and a light bamboo cane under his arm, one would have supposed that he was an eccentric comedian of a theatrical company, in the costume of a dilapidated swell. He welcomed me to Dublin with the patronizing air of an exgovernor-general, giving me to understand that my fame had even reached him. He admonished me to be on my "mettle," and gave me to understand that a Dublin audience was a rare one and was considered the most critical tribunal before which an actor could be tried; assuring me that if I once passed unscathed through the fiery ordeal of their judgment I might defy the opinion of the civilized world, and wound up his speech with a modest request that I should favor him with 
free admission tickets for himself and family during my engagement. If I had needed any further assurance that the Dublin audience was a "rare one," the scarcity of that article during my entire engagement would have convinced me of that fact; Mr. Gunn's prophetic sagacity had discovered at the rehearsal that I would fail.

Belfast was our next point, and here, strange to say, the character made a decided hit. Dublin and Belfast are only a few hours distant from each other, yet the same entertainment that failed dismally in one place succeeded admirably in the other. What was the cause of this? I had been only ten days in Ireland, and in that time I could not have unconsciously acquired a brogue. I have concluded, therefore, that I was paralyzed by the wet blanket that Mr. Gunn threw over me; and my modesty will not allow me to account for the Dublin failure in any other way. 


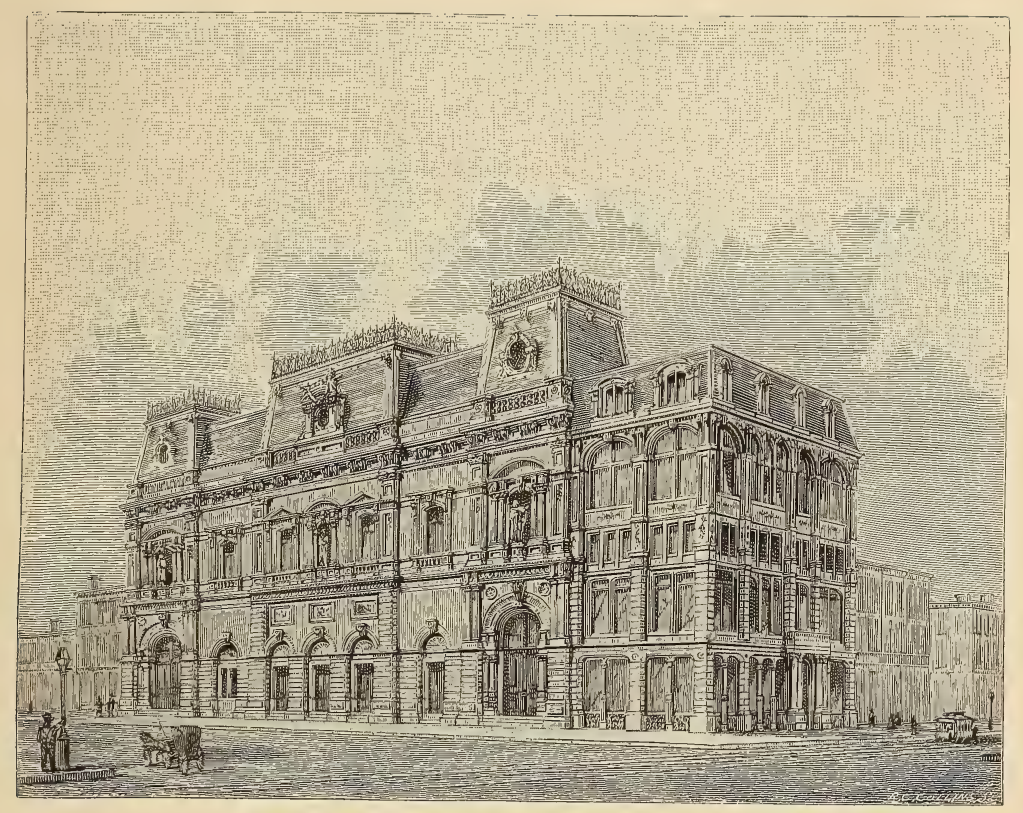

BOOTH'S THEATER. 



\section{CHAPTER XIV}

AT HOME AGAIN

Booth's Theater - Talks with Charles Mathews on Acting-John B. Rice-"The Rivals"William Warren

T Returned to America in October, i876, and began an engagement under the management 1 of Augustin Daly at Booth's Theater. This was my fourth and last engagement in this superb house, which was demolished a few years afterwards. Unfortunately, Booth's Theater, after it passed from the hands of its original owner, did not fall into the possession of artistic people. I say unfortunately, because as a place for public amusement it was quite perfect; no expense had been spared to make it safe for the audience and comfortable for the actors.

I cannot endure destruction of any kind, and it was a sorry sight to me when one day I stood by and saw its downfall and its ruins. Busy men, in a cloud of lime dust, were gutting the building of 
its costly decorations, and the noble structure, which should have remained as a monument to the distinguished actor who sacrificed a fortune in building it, was being pulled down. In a few months it gave place to the most unsightly dry-goods box of a store that could well be imagined. It is a great pity that it could not have been rescued.

My first engagement in St. Louis, since the memorable season when as a youth I was hissed from the stage, was played at Deagle's Theater. The stage-manager was my old friend James Burnett. We had acted together as far back as I854 at the Museum in Baltimore, and afterwards, as I have said before, we were in the stock company of Laura Keene during the panic of 1857 .

Overtures were made to me from the directors of the Cincinnati Dramatic Festival to appear with my company in the comedy of "The Rivals." I declined, without giving my reasons for so doing; for I knew that any explanation I could make would be unsatisfactory to the committee, as my objections pointed to the immense size of the hall in which the entertainment was given, and the affair had progressed so far that it was too late for argument, or the adoption of any suggestions that would conflict with the ideas of the committee. I was not present at the Festival, but I am told that there were many mishaps, both of a serious and a comic nature, during the week's entertainment. Unforeseen accidents would naturally occur in so extensive an enterprise in which numerous actors and auxiliaries were brought together and 
marshaled with but little discipline and under inexperienced management. It is reported that during the performance of "Julius Cæsar" matters went fearfully astray, and were in one instance literally wrong end foremost, so that when Mark Antony bent forward to uncover the serene features of the departed general he discovered only the turned-up toes of "Imperious Cæsar" to the astonished gaze of his constituents.

Grand operas, or spectacular plays, where choruses, marches, and ballets are prominent features of the entertainment, require a large theater to give them full effect; but a comedy, wherein wit and subtle action are combined, must lose force in a wilderness of space. A theater of great magnitude may permit a prima-donna to chant her woes, or a fat basso to bellow forth remorse, or a long line of cotton-velvet lords and ladies to attend a forced marriage ceremony, with considerable effect. Richmond could overcome Richard, Mark Antony harangue the citizens of Rome, or even Hamlet exhibit terror at the appearance of his father's ghost, and suffer but little by the dimensions, but Benedick and Beatrice must be cheek by jowl with the audience as well as with each other. If one is obliged by circumstances to act in a larger theater than one is accustomed to, the volume of the performance should be proportionately increased.

Charles Mathews once told me that he was charmed to act in the Madison Square Theater (then called the Fifth Avenue), as the stage was 
so constructed that he felt as if he were playing in a drawing room-all his lines told. He said that the slightest twinkle in his eye seemed to make a point. "I acted at the Boston Theater one engagement," he said, "and I never will again. Why, I might just as well have played on the Common for all the effect I created. You have just finished an engagement in that graveyard of comedies, and do you mean to tell me that the delicate points of the characters hit with the same force as they do in a small theater?"

"Certainly not," said I; "they lose much strength, but by enlarging the execution the same effect is almost accomplished."

"What do you mean by enlarging the execution?" he inquired.

"I mean," I replied, "that a portrait may be painted the exact size of life if it is to hang in a drawing-room, where it will be nearly on a line with the people who will look at it; but when designed for a panel to be set in the walls of a large hall, or to be placed at an extra height, the artist should increase the size in accordance with the distance from which it is to be viewed; and though he must preserve the proportions, the details should be suppressed, and the strong and simple lines that give character should be brought out with perfect clearness."

If in a picture gallery we see a work that attracts us we can move forward or backward so as to reach the point from which the artist intended his picture to be viewed: if it is broadly painted, we 


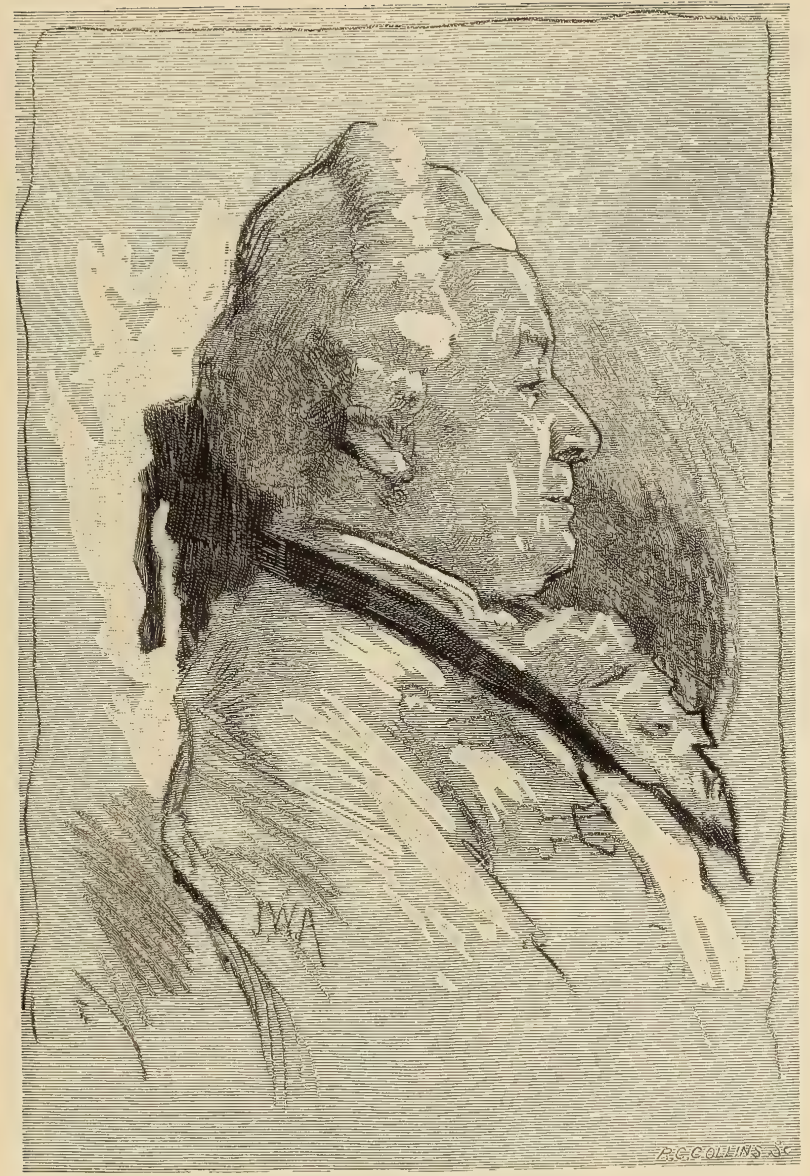

JOHN GILBERT AS "SIR PETER TEAZI.F." 

retreat; if, on the other hand, the treatment is minute and delicate, we examine it closely.

Millet and Meissonier should be looked at from two different points; but in a theater the audience cannot shift their positions. The actor therefore must go to them ; and, moreover, he should average his strength so that while it is sufficiently powerful to reach those who are distant it must not be forcible enough to offend those who are near. He should take sufficient time to allow those who are slow of apprehension to digest his work, and while so doing be careful to interest others who catch the point at once, else the latter will be wearied by the delay.

Again the painter, the musician, and the writer have a direct following, - generally from a class whose taste and understanding are pretty evenly balanced,- - whereas a theater is divided into three and sometimes four classes, the prices of admission to a certain extent indicating their intelligence; consequently the law of average must be well considered, so that the entertainment shall strike a balance and hit with equal force the different grades that confront it.

But to return to Mathews. He took great enjoyment in what might be called intellectual trifles, particularly those of his own creation, and had much talent in sketching grotesque faces, and writing chatty letters and comic verses; and as he would spend days together in scribbling his amusing nonsense, the knack for this kind of light literature was always in a high state of cultivation. 
I once traveled with him from London to Edinburgh on the lightning express train called the "Flying Scotchman." He had supplied himself with pencils and paper, and as soon as the train started began sketching away with all the delight of an enthusiastic young artist, though he was at this time over seventy years of age. He became absorbed in his work, which he continued for some time, interrupted only by an occasional delicate bit of profanity at the jolting of the "Scotchman," which, he said, seemed to be dancing a Highland reel over the rails. After he became weary of drawing he applied himself to the writing of a comic song, the theme of which, he said, had haunted him all the night before. He called it the "Mad Arithmetician," and it was filled with an absurd mixture of addition, multiplication, and the Rule of Three. As each verse was finished he would insist upon my laying down the book I was interested in to listen to his rhyme. Then, of course, I had to give him a round of applause, and off he would go again, perfectly delighted with what he had done and I had praised. In fact, I think he craved the approbation of his friends more than he did that of the public.

I once dined with him in London with Mr. Planché and Harry J. Byron, two favorite burlesque writers, and certainly I never listened to brighter conversation than I did on that occasion. I wish I could remember one-half of it, or, what would have been still better, that I had put it down in writing, though to have done so I must have been an 
accomplished stenographer. At one time I remember the conversation turned upon the novel of "Adam Bede." Mathews said it had no attraction for him, for it was not possible that he could feel interested in a virtuous carpenter. "Perhaps," said Byron, "you have more admiration for the virtue of the opposite sex." "What do you call the opposite sex to a carpenter?" said Mathews. "A joiner," said Planché before. Byron had time to reply.

Charles Mathews was a natural-born philosopher; he looked upon life in a plain, practical, and cheerful way, always making the best of the worst, having no regrets for the past and great hopes for the future. By many he was thought to be cold and selfish; I do not think he was so. His cool, gay manner, which was perfectly natural to him, gave one the idea that he was devoid of feeling; but a circumstance that occurred in connection with myself proves quite the contrary.

It was arranged that he should spend a week with me in the country for the purpose of troutfishing, sketching, and chatting over matters connected with art; our conversations upon this latter subject usually ended in highly exciting arguments, for we seldom agreed in our ideas of the stage. Well, he arrived in due time, and we spent the first morning on the banks of a trout-stream pleasantly enough except that there was a cloud hanging over my head that made me rather dull; he noticed this, and asked me what was the matter and why I was more serious than usual. I told 
him that the next day was to be an eventful one to me, and that he would have to excuse my absence for a week, as I should be imprisoned in a dark room and denied communication with any one. Of course he was surprised at this, so I explained that I was threatened with blindness, and that an oculist would arrive on the following day for the purpose of performing an operation on one of my eyes. For a moment he seemed horrorstricken, and was as pale as death. "What," said he, "and have you invited me here to enjoy myself, knowing that you were to undergo a surgical operation?"

Of course I told him that when the invitation was made I had no idea of the impending trouble, but had refrained from making any alteration in the date of his visit, thinking that he would amuse himself about the place till I could join him.

"My dear boy," said he, taking my hand, while the tears stood in his eyes, "you can't imagine how you have shocked me. Let me go at once; I could not stay under this roof while you were being cut and maimed; it is too dreadful to think of."

His manner was perfectly sincere. There was not the slightest suspicion of sham in it, nor was it only the horror of the idea,-though, of course, this affected him,- but a sincere sympathy for me; so within an hour he had departed. I may mention here that the operation, under the skillful hands of Dr. Reuling, was entirely successful, and that I have never had any trouble 

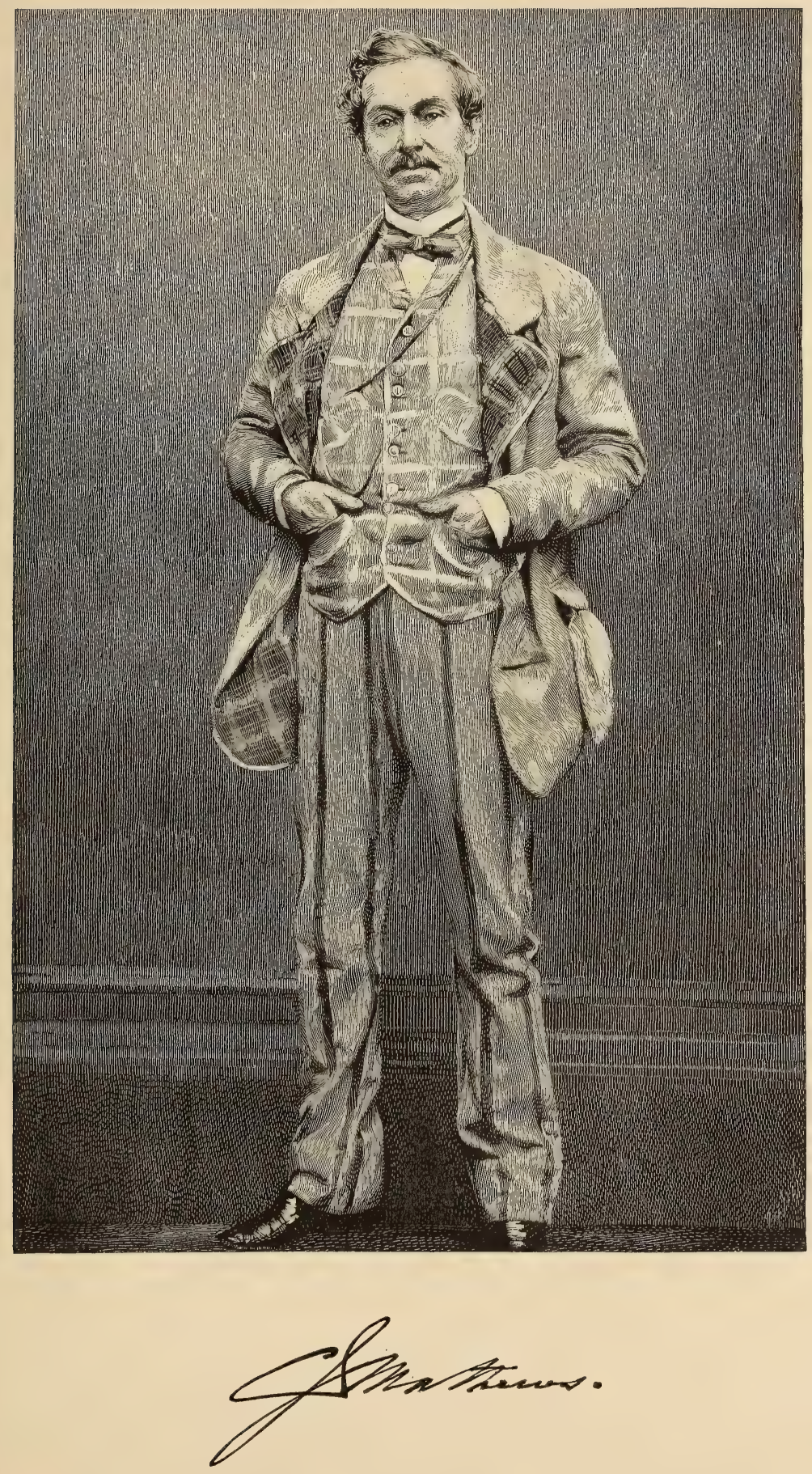

with my sight since that, to me, most eventful time.

I have often been taxed with idleness for not studying new parts and adding them to my répertoire. The list of plays that I have acted of late years is certainly a very short one, and the critic who becomes weary of witnessing them over and over again naturally protests against their constant repetition. Setting aside the fact that every one must be the best judge of how to conduct his own affairs, there are other matters connected with the course I have pursued that may have escaped the attention of those who have rated me for my lack of versatility; and reference to a conversation between Charles Mathews and myself on this very subject may serve to illustrate what I mean. We were good-humoredly quizzing each other about our different styles of acting, when he rallied me somewhat after this fashion:

"You call yourself a comedian," said he. "Why, you can only play one part. You are the prince of dramatic carpet-baggers, and carry all your wardrobe in a gripsack. Look at that huge pile of trunks - mine, sir, mine! Examine my list of parts! Count them - half a hundred, at the very least; you ought to be ashamed of yourself. Where is your versatility?"

"My dear Charlie," said I, "you are confounding wardrobe with talent. What is the value of a long bill of fare if the stuff is badly cooked? You change your hat, and fancy you are playing another character. Believe me, it requires more 
skill to act one part fifty different ways than to act fifty parts all the same way." And here we ended our rather comical argument.

Charles Mathews was playing an unsuccessful engagement, so far as numbers were concerned, at the Boston Theater. He was a guest at No. 2 Bulfinch Place; and, being quaint and old fashioned in his tastes, relished with many of us our late suppers in the old kitchen. One evening after the performance, with all that light and brisk manner which was so characteristic of this antique youth, he exclaimed to us who were already attacking the supper, "Waiting for me, I see. Well, that is kind. What a magnificent pile of lobsters! Looks like one of the pyramids. Rather fresher. Touched up for the occasion, I dare say." If ever there was an aristocratic democrat it was this merry, irreverent, elegant man. He could shake hands with a prince and crack jokes with a butler at the same moment, while the potentate and the servant would both think him quite on their own level. After he had seated himself the usual query that one actor generally puts to another after the play: "Well, and how was the house to-night, Mr. Mathews ?” “Splendid, splendid! I don't think I ever saw a finer house, only there was nobody in it. Well, when I say nobody, I don't quite mean that. Of course there was - well, myself for instance, and the ladies and gentlemen of the company (the old man did n't know a line, by the by); and then there were the gentlemen of the orchestra; and then the ushers too; I must n't 
forget them, though they really had done nothing worth remembering. Oh, there may have been, just here and there, you know, a few dismal individuals, but they were so far apart that it was quite impossible to count them. I verily believe that if I had fired off a cannon, loaded to the muzzle with grape-shot, point-blank at the middle of the parquet I should not have wounded a critic; and that would have been hardly fair, considering how often they have wounded me."

There was a ripple of laughter all through this speech, which was given with superb gravity till the end, when there was a round of applause such as I believe he had not received during his whole engagement. From what I remember of Mathews I feel quite sure that he enjoyed making such a speech and receiving the approbation of his comrades more than he would have done in acting a fine part to a crowded house. "Hello!" he exclaimed, "there 's some one missing. Where's Povey?" Mr. John Povey, I should mention, was the agent of Mathews, and came over from London with that gentleman ostensibly to look after the financial affairs of the star. "I hope you have n't poisoned him in my absence," said he ; "for he 's the best-natured, kindest-hearted, useless old fellow that ever lived. It 's his business to look after the money matters in front of the house, but during the time he ought to be there I find him asleep in my dressing-room. I do hope you have n't poisoned him." While he was discussing the merits and demerits of his agent there came a ring at the 
door-bell. "That 's John now. Don't say I 'm here; just draw him out for me." And in a moment Mathews had opened the door that led to the cellar and disappeared. Enter Povey. "Hello!" said John. "Has n't Mathews come yet?"-looking round the table. "Well, you see he is not here," said one of the party. "Ah! just like him. $\mathrm{He}$ sent me in front to count up the house and promised to wait for me. Then he pops off. I thought certainly to find him here. I shall go back to England; I won't be bothered in this way looking after him." Then came the old question, "How was the house, Povey?" "Oh, bad, bad! Wretched! They don't want him at all. He 's too old fashioned. All very well twenty years ago. There's no fun left in him." Whereupon Mathews popped his head out of the door, and glaring comically at Povey exclaimed, "Is n't there, John? Well, what do you think of this for a bit of fun, eh?" If there had been a trap in the kitchen floor I think we should have found Povey at the bottom of the cellar the next minute. It certainly was the most cruel joke that ever was perpetrated. Povey was overcome with mortification, and Mathews made the very cups and saucers on the mantelpiece vibrate with his laughter.

John B. Rice was a connection of mine by marriage, having been united to my cousin Miss Mary Anne Warren, sister of William Warren, the comedian, and of Harry Warren, the theatrical manager of Buffalo. Mr. Rice was a prominent citizen of Chicago, having been at one time its 


theatrical manager, its mayor, and afterwards a Representative in Congress. Those who remember this wise and honorable man, whose life was devoted to usefulness, will recall the valuable services he rendered to his adopted State and city, and to those by whom he was surrounded. The conduct of his life was simple and dignified, and he received the smiles and frowns of fortune with an equal bearing, and was ever ready to assist the needy with either his purse or counsel. Contented and cheerful, I scarcely ever saw him look grave except when contemplating the prospect of another one's misfortune. He was liberal, but wisely prudent, and often rated me for my extravagance. He once said to me, "You 're a young man now, with an extra large family, and it behooves you as a duty to that family to save some of your earnings; and I don't believe you do." I told him that I thought he did me an injustice. I acknowledged that I was making money, but I contended that I had invested it. "Listen to this young man talk. He buys a large plantation in the South with nothing left of the sugar-house but the chimney, all the fences and everything in a dilapidated condition, takes his family down to this wonderful place, isolates them from the world, lives in a tumble-down house that he has to prop up with logs, shoots half a dozen wild ducks, fancies that he 's enjoying himself, and then calls it an investment." I ventured to suggest that perhaps the orange groves in time might - "Orange groves! What do you know about orange groves? The 
negroes steal your oranges, don't they?" I could not help admitting that a few had been missed. "Ah! quite likely. You had better buy United States 4's registered, and get out of those orange groves as soon as possible. You'll make more money by acting than you will by oranges."

When, some years afterwards, my son informed me that he received from St. Louis for a large shipment of this delicious fruit, after deducting expenses, three two-cent postage stamps, I concluded that Uncle John was about right. I recall his smile - and what a smile it was!-when I told him of this disastrous commercial transaction. John Rice and Edwin Forrest had been friends for many years, but their intimacy had been broken off by the frankness of one and the ill temper of the other. Forrest, it seems, wanted some information or assistance from Rice in connection with a lawsuit that was at one time creating much annoyance to the tragedian. Rice declined to give it or to meddle in the matter, as he deemed Forrest in some respects at fault and had the courage to tell him so. This annoyed the old actor, who never forgave an affront. To differ with him as to the lawsuit was to make an enemy of him; but when a matter of right and wrong was to be considered John Rice was a Brutus, and would decide the matter according to his honest belief, regardless of the opinion of friend or foe.

Among Rice's old acquaintances was a leader of the orchestra, one John C-. Quite a 
musical genius was $\mathrm{C} \longrightarrow$, and a great character. He was a perfect know-all; no subject, either artistic, musical, or scientific, could be broached in his presence on which he did not at once present himself as an authority. If a fast horse was mentioned $\mathrm{C}-$ had a father or an uncle who owned one that could distance the animal in question with ease. Should any one venture to give an account of a remarkable storm where the hailstones were as large as hens' eggs, the old leader was down on him with goose eggs at once. On a certain Sunday afternoon John Rice and a party of his friends were sitting on the back porch of his house, listening to some of the marvelous experiences of $\mathrm{C}-$, when the host, getting a little tired of these wonders, exclaimed: "C C—, you seem to be an authority on most matters; now I want your solution of a curious fact that is staring us in the face. Look at that apple tree over the fence"-pointing to one in the orchard at the back of the house. "You see it has no apples on it, and all the rest of the trees are full of fruit; now how do you account for that?" C_ ran his eye over the orchard with a profound look, and rising slowly from his seat mounted the fence, let himself down upon the other side with as scientific an air as the performance would admit of, and going down upon his knees began to examine the roots of the barren tree. The company during all this time were watching the proceeding with becoming gravity. $\mathrm{C}$ _ 
the tree, wiped his eye-glasses and examined the specimen with great care. At last he smiled with a placid kind of triumph and exclaimed, "Ah! I thought so." Again climbing the fence, he returned to the group who had been watching him and said: "Now observe. You see that gray color on the edge of the bark?" They did. "Well, that is called fungi mortem, and whenever that deadly sign appears at the root of an apple tree it never bears fruit."

"I don't think you are quite right about it," said Rice; "for that tree was full of apples yesterday, but the owner came this morning and gathered them."

There was a shout of laughter, and C - was dumfounded. It was a dreadful blow, and it had the effect of curtailing the scientific discourses of $\mathrm{C}$ - for some time.

For many years I had remarked a growing disinclination on the part of the general public to listen to dialogue unless it revealed the plot of the play or abounded in easily understood wit. The question may be asked, Why should this be? Is not the audience of to-day as intelligent as that of a hundred years ago? This may be so, but by degrees it has been accustomed to a supply of entertainments for the eye rather than for the ear, and like a child who has been lately fed upon sugar-plums, it has lost its taste for daintier morsels. Our modern theatrical managers have recognized this demand, and embellish even their most classical productions with splendid scenery, 


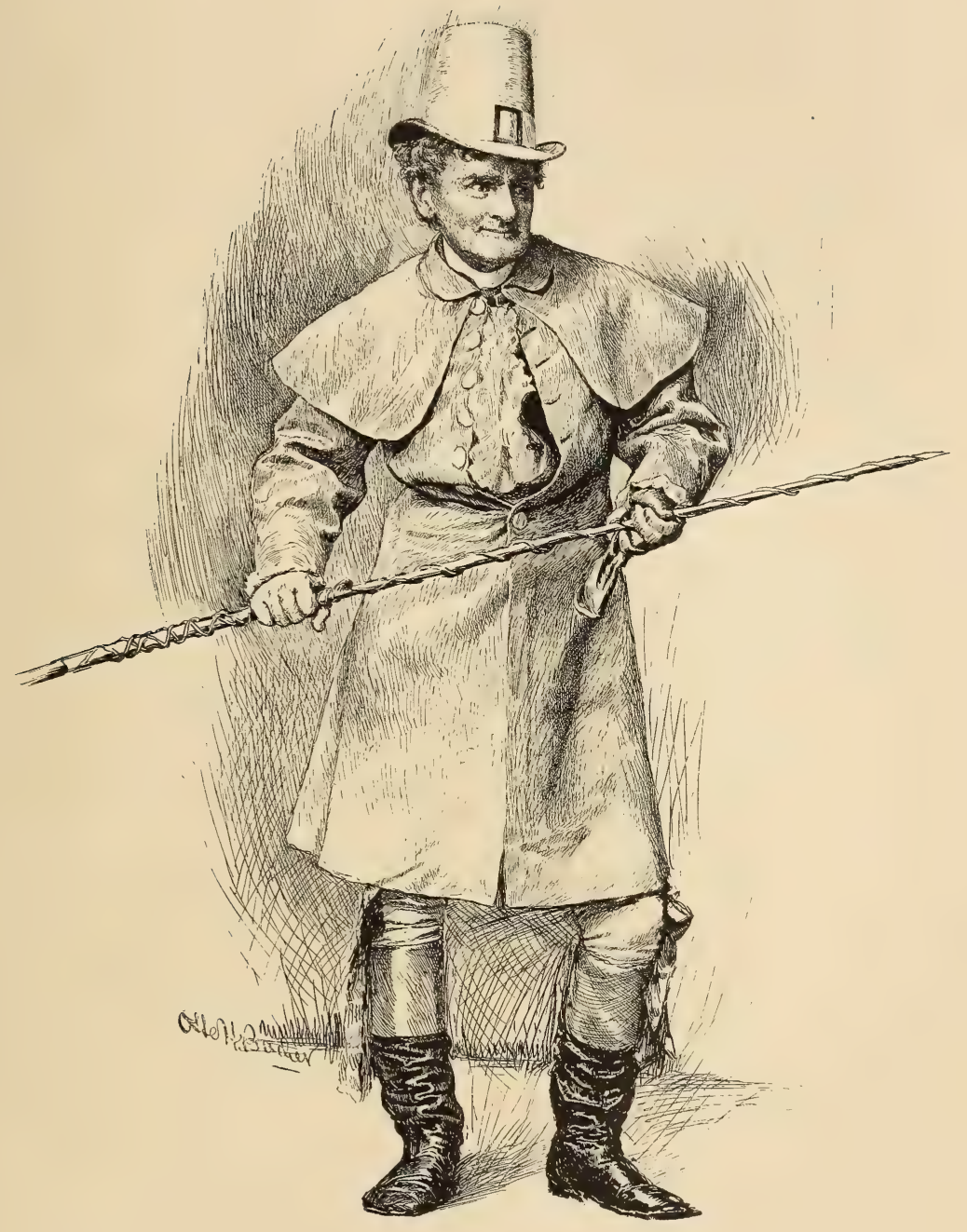

JOSEPH JEFFERSON AS "BOB ACRES." 

magnificent costumes, and mechanical contrivances. Dramatic authors are alive to it also, and seldom introduce poetical speeches or philosophical discussions into their works, confining themselves to action or to the realistic representation of local pictures with which the public eye is familiar. The monthly magazines and journals are filled with splendid illustrations, and even the daily papers crowd into their columns crude and hastily drawn pictures of current events. It is no disparagement to say this; on the contrary the supply is in legitimate accordance with the demand, for it is both wise and useful to minister to pronounced if not immoral public desire.

With these facts clearly before me I set about altering and condensing Sheridan's comedy of "The Rivals." "The School for Scandal" has always been considered the finer play of the two, and in many respects it is so, but I felt that there was no character in this play to which I could do justice; and though as a literary work "The School for Scandal" is undoubtedly superior to its companion, I consider "The Rivals" to be the more effective dramatic production.

That two such comedies should have been produced within a couple of years by a mere youngster must always remain among the wonders of dramatic composition. As "The Rivals" bears the fresh impress of youth, one can comprehend the fact that it was written by a mere boy; but the "School for Scandal" smacks of matured age and ripe experience, dealing as it does 
with intrigue, worldliness, and almost actionable defamation of character. Yet these two prodigies were born but a short time apart, and were the offspring of the same parent. The greatest wonder is that being almost twins there should be such a slight resemblance between them.

The artificial quality of "The School for Scandal " has been complained of by some critics, but it should be remembered that the scene of the comedy is laid in town and takes place during the season of fashionable entertainment; the quaint society of high life during the middle of the last century was, according to the history and pictures of the period, extravagantly artificial. Hogarth's belles and beaux strut through the Strand with dainty step and arms akimbo ; the old fop takes his pinch of snuff with the grotesque air of a dancingmaster. If in the play, therefore, the characters remind us of figures in Dresden china, they are poised with such grace that we pardon their lack of warmth; for if actors are the "abstract and brief chronicles of the time," an artificial period could not be depicted if this quality were wanting. The play does not seem to be intended to excite our sympathies, but rather to challenge our intelligence. We must enjoy the quarrels of Lady Teazle and Sir Peter Teazle, though we may not care who gets the better of it.

It has been objected also that many of the characters talk too brilliantly, the servants particularly, their wit being beyond their station. But an author can easily bear the censure that taxes 
him with having written too well. "The School for Scandal" at the time in which it was written must have been quite perfect; its fault now grows out of the fact that the present taste considers it too coarse to be acted in its original form. The theme itself, too, is somewhat indelicate. An intrigue runs through the plot, and, though it terminates innocently, while it is in progress it has an unpleasant suggestion, so that however much of the language may be omitted it can have but little effect upon the action. No such charge can be laid to "The Rivals," for after the excision of a dozen lines there remains a pure dramatic production. There is a rural flavor about it too, imparted by the introduction of Bob Acres and his old and attached servant David, that warms the wit with a glow of humor.

This comedy kept running in my head of late years with almost the same persistence that "Rip Van Winkle" had done in the olden time. Bob, too, was an attractive fellow to contemplate. Sheridan had filled him with such quaintness and eccentricity that he became to me irresistible. I would often think of him in the middle of the night. At odd times, when there was apparently no reason for him to call, he would pop up before me like an old acquaintance, - for I had acted him years before,- - but always with a new expression on his face. The variety of situations in which the author had placed him; his arrival in town with his shallow head full of nonsense and curl papers, and his warm heart overflowing with love for an 
heiress who could not endure him in the country because he used to dress so badly; a nature soft and vain, with a strong mixture of goose and peacock; his aping of the fashion of the town, with an unmistakable survival of rural manners; his swagger and braggadocio while writing a challenge; and above all the abject fright that falls upon him when he realizes what he has donecould the exacting heart of a comedian ask for more than these? Surely here was the best material to work out that I could desire. I had acted the part a quarter of a century before, and possibly I may have blundered by a kind of intuition into some of the effects which now occur to me, but I am quite sure that at that time I could not have reproduced them from night to night with any certainty. I will not say that the methods by which I treated the various phases of the character were all thought out previous to its revival. Some of them came to me after, and many at the time of their representation; for during the late run of the comedy I had acted Acres at least a dozen times before I had hit upon a satisfactory effect with which to end the second act, and even then it did not strike me until the very moment of its execution.

During our first rehearsal of the comedy in Philadelphia, Mrs. John Drew, who had evidently been considering the part of Mrs. Malaprop with great care, introduced some novel business in her first scene with Captain Absolute that struck me as one of the finest points I had ever seen made. 


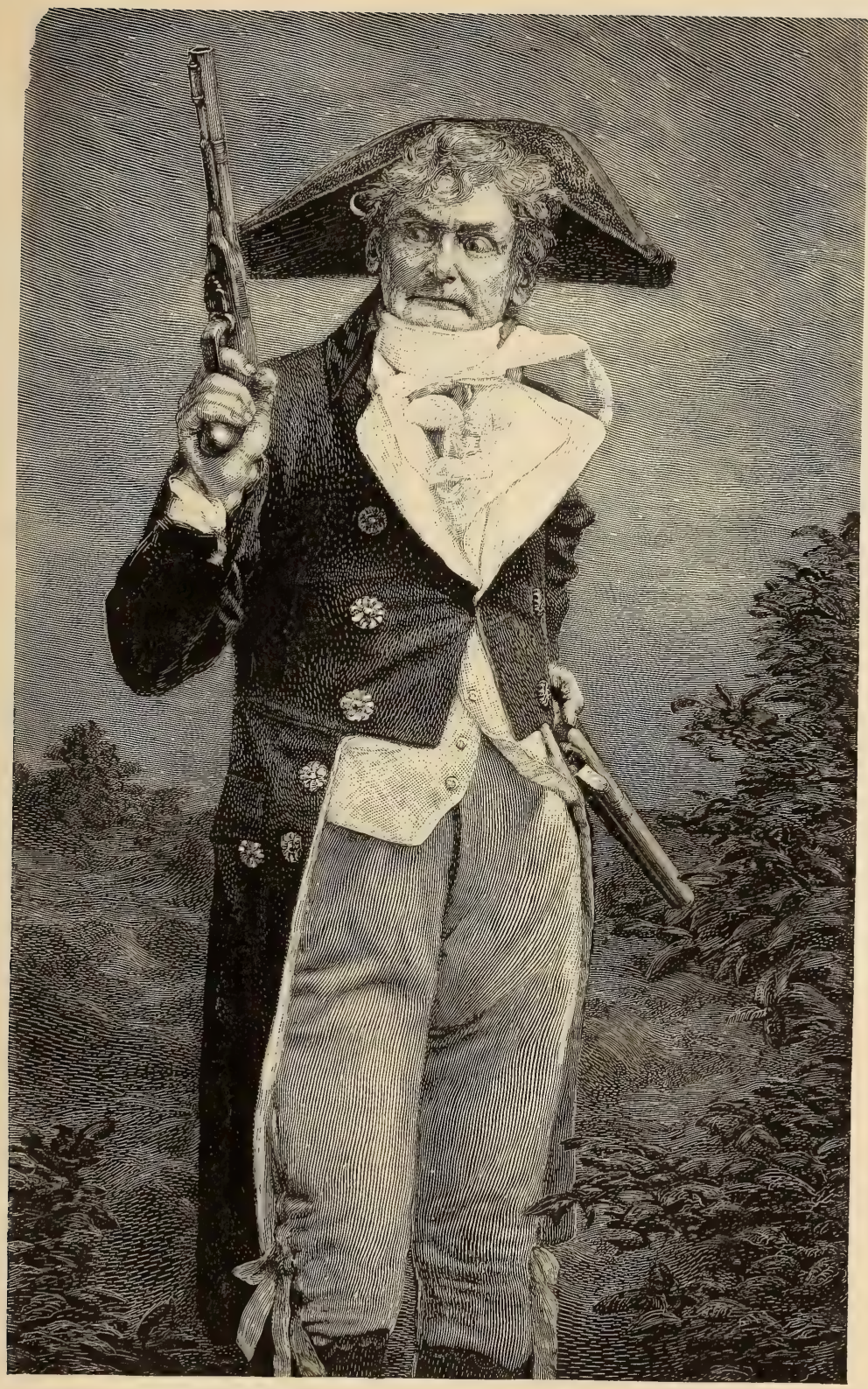

JOSEPH JEFFERSON AS "BOB ACRES." 

When Mrs. Malaprop hands the letter for the Captain to read, by accident she gives him her own love-letter lately received by her from Sir Lucius O'Trigger. As the Captain reads the first line, which betrays the secret, Mrs. Drew starts, blushes, and simperingly explains that "there is a slight mistake." Her manner during this situation was the perfection of comedy. She asked me if I thought that the introduction was admissible. I replied that I not only thought it admissible, but believed that Sheridan himself would have introduced it if the idea had happened to occur to him. It would have been curious if I had not acquiesced in this original business after the liberties I had myself taken with the comedy. I had not only condensed the play from five acts into three, but I had cut several of the characters entirely out of it, brought down the curtain on the first and second acts with terminations not intended by the author, and concluded by having the courage to write an epilogue. It must be admitted that these were sweeping alterations, and in the event of their failure they were likely to endanger whatever reputation I had acquired as a legitimate comedian. They succeeded, however, and I was only subjected to some slight critical censure from the press and a little quizzing from a few old school members of the profession, who were naturally and honestly shocked at my having taken such unwarrantable liberties with their past heroes. Some of the satirical remarks made at my expense deserve mention. 
William Warren on leaving the theater one evening after seeing the play was asked what he thought of the alterations. He replied, "It reminded me of that line in Buchanan Read's poem, 'And Sheridan twenty miles away.'" This was not quite original with him; it had been said before by one of my own company, but I heard that it was given with that quizzical humor which belonged only to William Warren.

John Gilbert said that it was sacrilegious, and it would serve me right if the shade of Sheridan should haunt me.

One Christmas Eve during the run of the revived comedy a merry meeting of the company was arranged after the play; a Christmas tree had been erected, and it was understood that each one should hang a present for the other on it, and that no one should know the donor. A gentleman was selected to take down the different parcels from the tree and present them. The choice proved an excellent one, as he bestowed the various gifts with wit and humor. His opportunity was exceedingly good, however, as many of the presents were suggestive of our weak points and our various positions. Our manager, for instance, received a bundle of railway guides, the advance agent a paste-pot and brush, and I a book of "The Rivals" with all the parts cut out of it but my own.

But, seriously, if I needed any excuse for my emendations of "The Rivals," I have discovered one lately in Doran's “Annals of the English Stage," wherein it is recorded that Sheridan altered Sir 
John Vanbrugh's comedy of "The Relapse" and entitled his play "A Trip to Scarborough." Apparently as an excuse for this liberty he makes one of his characters say, "It would surely be a pity to exclude the productions of some of our best writers for the want of a little wholesome pruning, which might be effected by any one who possessed modesty enough to believe that we should preserve all we can of our deceased authors, at least till they are outdone by the living ones." Here is a confession that he not only sanctioned the liberty, but that he took it himself; so that should the shade of Sheridan ever rebuke me, I shall defend myself by confronting him with his own words.

A monumental figure in Boston, and one whose vacant place upon the stage has not been filled, was William Warren. The humorous characters presented by this gifted actor covered the entire range of legitimate comedy, and from the great length of time that he performed at the Museum, and the constant change of entertainment that was a prominent feature of this establishment, it is safe to conclude that this versatıle comedian studied and created more parts than any other actor of his day. The great respect of the public, and the warm affection of his personal friends, was reciprocated by his loyalty to the city that by universal consent made him its dramatic ideal. For years his benefits were the events of the season; and the last testimonial of public favor, upon his fiftieth anniversary upon the stage, given just previous to his final retirement, was marked by a depth of 
feeling that neither the recipient nor the donors could ever forget.

His career as a stock actor was a most remarkable one. I say a stock actor in no disparagement of his ability to be the leading feature of a theatrical entertainment. On the contrary, there were during his day few, if any, of those who traveled as stars who were superior to him as a comedian. $\mathrm{He}$ was offered many inducements to star, but it was only for one season that he could be prevailed upon to give up his regular engagement. He soon wearied of the constant change of scene, and, longing for the quiet and domestic comfort that could not be obtained while constantly moving about, he returned to his old position and to the audience whom he had missed and who had missed him. His welcome on his re-appearance, and his own delight at receiving it, proved that the affection between him and his audience was mutual. He had entered the Boston Museum during its early struggles, and became from the first the foundation upon which its prosperity was built, as he remained to the last the pillar which supported its dome. His talent as an actor, his sacred duty to the public, and his loyalty to his temple, were the principal causes of the success that for so many years attended the dramatic productions of the Boston Museum. While he was undoubtedly the principal feature of the company, he never presumed upon the strength of his position, nor at any time during his lifelong service did he offer the slightest obstruction to any change in 


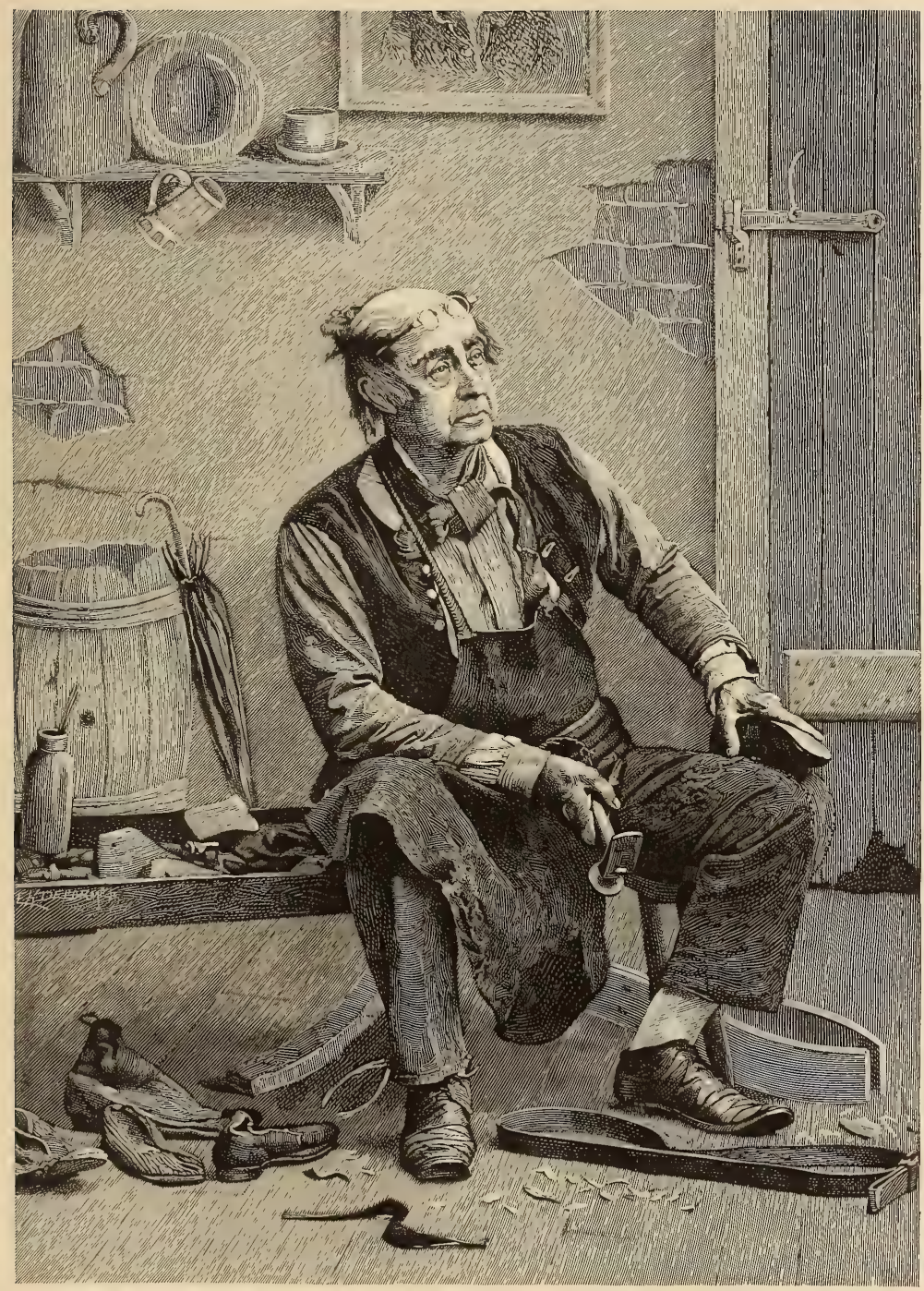

IVILLIAM WARREN AS "HERR WEIGEL." 

the managerial policy of his dramatic home. If it was found necessary to bring forward one of those sensational or catchpenny actors who sometimes hold for a brief period the esteem of the public to the exclusion of better stuff, he never complained; but, yielding to the decision of his manager and the caprice of the public, he would step gracefully aside and make place for the ruling mushroom, and so allow some new-fledged and popular buffoon to be sandwiched between his legitimate efforts. $\mathrm{He}$ seemed to have that gallant confidence in his own worth that made him soar above the pangs of petty jealousy.

There are few living who remember William Warren so far back in the past as I do. I was about ten years old when I first saw him. He was attached to my father's company, sharing in all our fortunes and misfortunes in the far West. He was then a tall, handsome young man about twenty-five years of age. He had fine, expressive eyes, a graceful figure, and a head of black, curly hair that must have been the envy of our juvenile tragedian, who was himself quite bald. William was at that time what is technically called a heavy actor, and played such parts as Rashleigh Osbaldistone in Scott's "Rob Roy," and Beauseant in Bulwer's "Lady of Lyons." My father's comedian disappointing him, Warren was cast in that line of characters known as low comedy. He had been highly educated in his youth, and having a mind that applied itself diligently to whatever it undertook, he soon became famous as an actor. Always 
modest, and not endowed with an abundance of self-reliance, it was to his talent rather than to any particular energy that he owed his advancement in the dramatic art. Conscientious to an inordinate degree, he neglected nothing in the preparation of costumes or the study of his characters to render his acting worthy of his audiences. He was universally acknowledged to be one of the most finished artists of his time. It was the pride he took in his profession and the wisdom which characterized the important actions of his life that warned him not to return to the stage after he had bid it farewell. Once having made this resolution nothing could tempt him to venture again before an audience. He was a veteran, certainly, when he retired, but he had not staid too long, and if there was any vague suspicion that his powers had weakened, it was in his own mind, and his conscientious nature would not permit him to linger before the public when he felt that he could no longer do his duty; so that up to his final exit from the stage his audience retained the best impression of his acting.

I recall him in the very prime of his life when I went to Boston first to join the stock company at the Howard Athenæum. He was the reigning favorite of the town, and all who remember him well know that he remained so to the end.

Again I went - this time to play a star engagement, when I had the not very cheering assurance of the manager that I was the only one by whom he had lost money during that season. This would have been a crushing blow indeed, but I had the 
consolation of knowing that, when he could get away from the Museum, Warren came to see me act if no one else did.

At this time we lived at the same house in Bulfinch Place. There was a grand old kitchen here where, in company with many passing stars, we supped together after the play. Warren always sat at the head of the table, and was usually concealed behind a huge pile of lobsters, and as he served them liberally the scarlet edifice would slowly sink as if it were going through the stage in pantomime, revealing as it descended the fine face of the genius of the feast. For many seasons after this, when I came to act in Boston, our suppers in the old kitchen were among the agreeable features of the engagement.

James Wallack, Charles Mathews, Fechter, Walter Montgomery, Peter Richings (dear me, I am the only one left!), and many others. Such jokes, old and new; such reminiscences, foreign and domestic; tales of the Drury Lane, legends of the Thêatre Français, and romances of the old Bowery; then the discussion as to whether the actors of the past were better than those of the present - all of the old actors insisting on it that they were, and all the young ones insisting on it that they were not.

Again I recall Warren as one of the bright features of a memorable feast-Mrs. James $T$. Fields at one end of the table and her husband at the other. Beside William Warren sat Dr. Oliver Wendell Holmes, while Mr. Longfellow 
sat facing me - I the youngest man of those assembled, and greatly pleased to be one of such a group. Here was table-talk indeed - a feast of wit as well as viands. As I think now of that interesting day I seem to listen to the brilliancy of Fields, the wisdom of Longfellow, and the wit of Holmes. Then Warren modestly joins in the conversation, planning his words to the theme under discussion - so adroitly too, that no joke is suspected until the climax. This is indeed the very art and perfection of an anecdote.

Time rolled on and we met quite often, always in the summer. To sit and talk with Warren under the trees was ever a treat to me. He had known me when I was but a boy, and now he knew me as a grandfather. No lack of retrospect and reminiscence with such acquaintances!

Then came the fiftieth anniversary of his début. I was not there to see it, but I know of it as though the scene had passed before me. Thousands flocked to witness it. Gray-haired men who had been taken to see him when they were boys, hurried to bid for places that they might do him honor. There was a loving-cup from those who cherished him; flowers from a whole city; a token of affection from his old comrades. I saw him shortly after this, and there was a shade of sadness in his face. He seemed to feel that all was over. A laurel wreath will cheer its wearer when it is bestowed on one who is in the zenith of his victory, but it weighs heavily upon a retired head. 


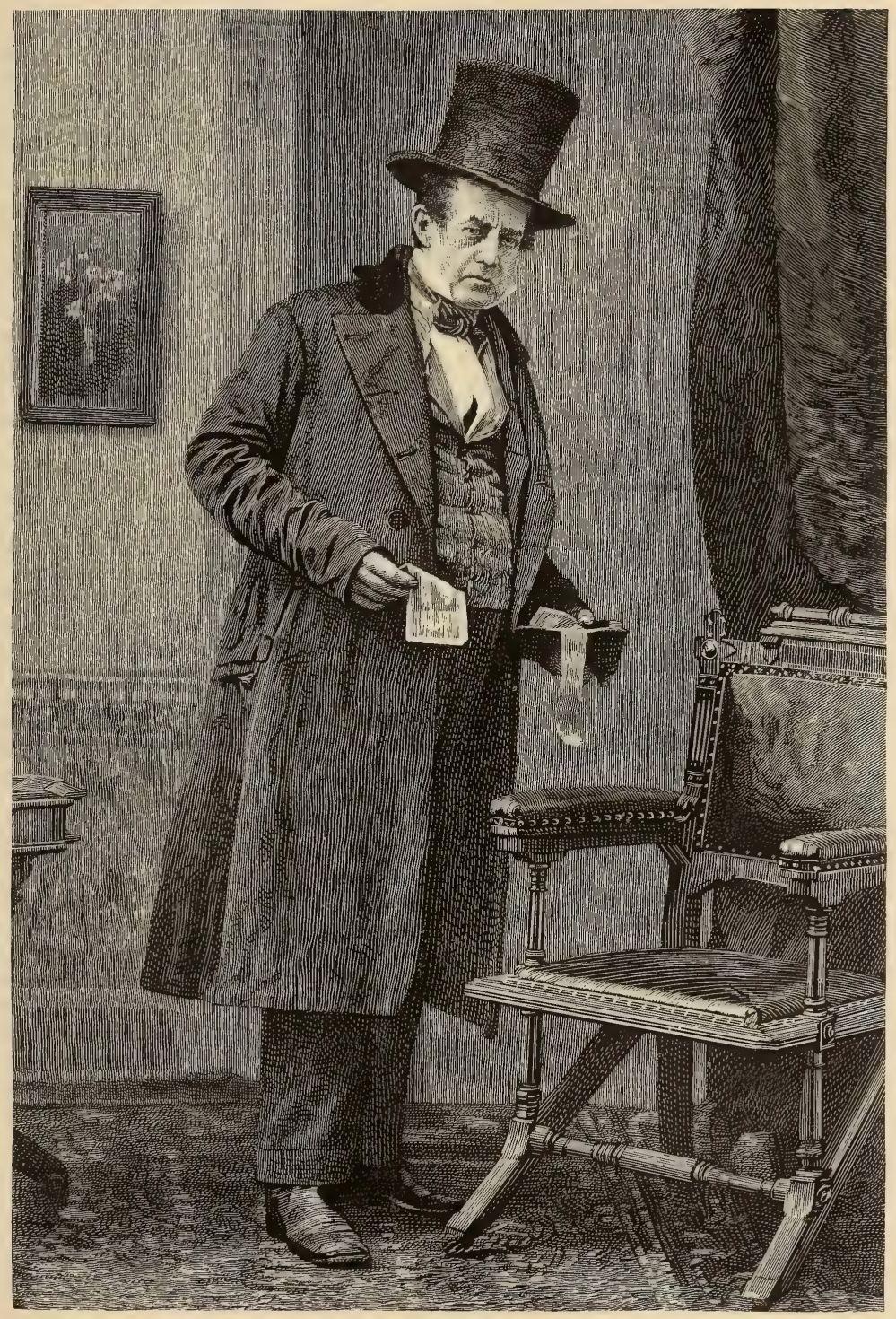

WILLIAM WARREN AS "JEFFERSON SCATTERING BATKINS." 

William Warren bore up bravely under the burden of seclusion; but time, and the loss of that more than magnetism which is imbibed by an actor from the warm appreciation of his audience, and which had stimulated him for so many years, gradually told upon his health, and then his bright mind faded and he passed away. Boston's best sons and daughters were present to witness the ceremonies that attended upon his final rest. Those who had lived and wept with him in his art showed, by their presence and unsuppressed emotion, how they were saddened by so great a loss.

Relatives and friends, who stood in groups about the tomb, were overcome with sorrow. John Gilbert stood gazing into the grave with streaming eyes and a dazed look. He felt that the time was fast approaching when he would join his comrade. 


\section{Chapter XV}

\section{SOME OLD FRIENDS}

Mr. and Mrs. Barney Williams - John Drew Charlotte Cushman-Mrs. Drake - F. S. Chanfrau-John T. Raymond - John McCullough - The Lester Wallack Benefit - Actors of ToDay and Yesterday

R. and Mrs. Barney Williams attracted much attention, shortly after their mar11 riage, as American stars. The association of the Irish boy and the Yankee girl was a novelty, and as a dramatic feature strong in contrast.

Williams had been quite popular even before his marriage, and his union with Mrs. Charles Mestayer (also very popular), and their joint appearance in Irish drama and musical farce was at once a success and placed them among the theatrical attractions of the day. The laugh of Mrs. Williams was infectious, and her droll singing of "Independence Day" made it the favorite local song of the time. Williams was an effective 
actor, and his graceful figure and attractive face made him always welcome to his audiences.

Barney and I were once walking together in a heavy shower of rain, and were near his own house, where dinner was awaiting us. As we reached the gate the Irish girl was discovered watering the flower-beds in the garden. She, like ourselves, was sheltered from the storm by an ample umbrella, but a high wind was blowing at a terrible rate, and had turned her protector inside out. With the now useless shelter in one hand and the watering-pot in the other she was whirled about like a weather-cock in a stiff breeze, and in this helpless condition was pouring an auxiliary shower on the already drenched and dripping plants. Barney hailed her reprovingly, and demanded to know why she was doing such a stupid thing. "Sure, sir, ye told me to be after watering the flowers every day." "Yes, but not on a rainy day," said the master. "Sure, sir," said Biddy, "I thought a rainy day was every day as well as any other day." "Why, you are drenched with the rain," said Barney; "go into the house." "I will, sir, indeed," said she; "for if the posies have had enough of it, I am sure I have."

It is said that John Brougham, who wrote the domestic drama of "The Irish Emigrant," and had acted the hero with some success, declared upon seeing John Drew play the part that he would never attempt it again. I have myself a most vivid remembrance of Drew in this character. 
(This gentleman was the father of the present John Drew and the husband of the distinguished actress who now bears his name.) He acted a star engagement under my management in Richmond, Virginia, in 1856 , appearing in a round of Irish characters with marked success. I saw him in Handy Andy, O'Flanaghan, and the Emigrant, and his entrance in the latter character was one of those simple, bold, and unconventional effects that invariably command recognition from an audience, be they high or low, rich or poor, intelligent or ignorant. A figure passes an open window and pauses for an instant to look into the room; then a timid knock. "Come in!" The door slowly opens, and upon the threshold stands a half-starved man, hunger in his gaunt form and hollow cheeks, but kindness and honesty in his gentle eyes. What a pathetic sight is this! As the character is developed through the incidents surrounding it, you see always the same man, changed only as he would be by the circumstances through which he passes.

There is a sincerity in this kind of artistic treatment that wins for it a lasting remembrance in the minds of those who have witnessed it. To do bright and sparkling things that for a moment trick an audience of its applause, though they be entirely out of keeping with a character, is a grave error. With whatever variety a character may be treated, the audience should feel that it is the same man whose different moods are 


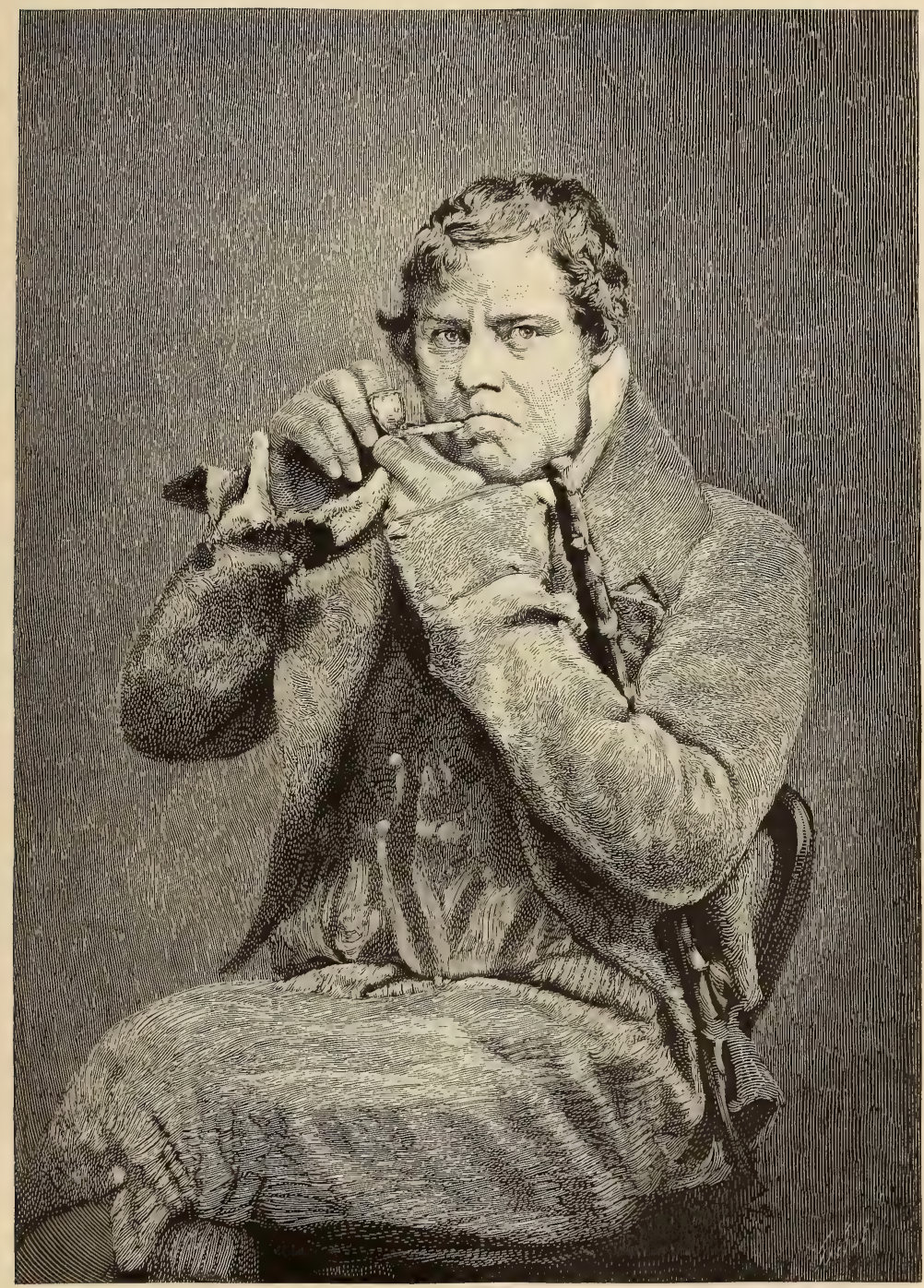

JOHN DREW AS "HANDY ANUY." 

developed by the change of his position in the story. I think it has been generally conceded that since Tyrone Power there has been no Irish comedian equal to John Drew. Power, as a light and brilliant actor, with piercing eyes, elegant carriage, and polished "school," dazzling his audiences like a comet, was undoubtedly unparalleled in his line, but I doubt if he could touch the heart as deeply as did John Drew.

We were afterwards together in Philadelphia; he played Sir Lucius O' Trigger with me in "The Rivals," Mrs. Drew appearing as Lydia Languish. There was one part that he acted during this brief engagement which made a strong impression upon me and revealed his versatility perhaps more than any other character I had seen him in. It was that of a young English squire, gay and desperate, warm-hearted and profligate, whose condition changed from wealth and station to poverty and almost degradation, from the bowling green of the quiet village to the gambling hell of a great city - these vicissitudes of fortune being brought upon him by his own careless nature, which passed from gay to grave, deeply touched by the misfortunes of others and reckless of his own. Drew's treatment of this character, while it was not widely known, won for him great admiration from his artistic comrades.

Charlotte Cushman was a prominent figure in the dramatic history of her day-tall and commanding in person, with an expressive face, whose 
features might have been called plain but for the strength and character in them. She was selfeducated, and had consequently stored her mind with just that sort of material that would serve to develop it. The most cultivated society of England and America delighted to entertain her, and her hospitality and kindness to Americans who visited this lady during her sojourn in Italy won for her the esteem and gratitude of many rising young artists, whom she took great pleasure in bringing into notice. Her dramatic career was a long and brilliant one; and in the legitimate drama she was more prominent than any other actress of her time.

Mrs. Warner was the nearest approach to Miss Cushman. Her face was classic, and there was a grace and majesty in her presence that was very charming; but in force and fire Miss Cushman far outshone her English rival. She had great tact in society, being perfectly at ease and making every one else so. Her faculty for either entertaining or being entertained was remarkable. She could do all the listening or all the talking, whichever was the most agreeable to her guest. As Lady Macbeth and as Queen Catherine she was regal from head to foot; but her most popular character with the public was Meg Merrilies, in "Guy Mannering." As Scott's heroine, critics objected to her extravagant acting and the liberty she took in standing aloof from the novel, and in her re-creation of the character. As I have been guilty of the same thing, it will not do for me to complain. But be 
this as it may, her acting was amazingly effective, and that quality covers a multitude of dramatic sins. She was witty and agreeable, with an immense flow of animal spirits, and I never met her without having a good laugh, either at our own expense or that of somebody else. She had a warm heart, and her charities were very numerous.

Before Charlotte Cushman reached the height of her popularity the leading tragic actress of America was Mrs. A. Drake. She was an accomplished lady, and during her whole life held an enviable position both on and off the stage. When a boy of sixteen I acted with her the page Cyprian Gossamer in "Adrian and Orrilla." She taught me the business of the part with great care, coming to the theater an hour before the rehearsal so as to go over the scenes with me before the actors assembled. She had a queenly bearing, and was, during her dramatic reign, undoubtedly the tragic muse of America.

Her son, some years ago, knowing that I had a great regard for his mother, gave me three letters which relate to theatrical matters in general, and to Mrs. Drake in particular. I shall therefore take the liberty of inserting them here. They have never been published before, and as two of them are from John Howard Payne, the author of "Home, Sweet Home," and the other is from Washington Irving, they cannot fail to be interesting. One of Mr. Payne's letters is to Daniel O'Connell, the great Irish statesman, introducing Mrs. Drake to his notice. 
John Miller, EsQ.,

Louisville, Kentucky, Sept. 4, 1832 .

Agent for the American Legation, London.

My DEAR SIR: As you are well versed in theatrical affairs, I would ask your advice and services for Mrs. Drake, an American lady, who is about to try her fortunes on the London boards. You may already have heard of her success in the United States. I have merely had the pleasure of witnessing her powers one evening, in the Widow Cheerly ("The Soldier's Daughter"), and the part of Mary in the "Maid of the Inn"; but from those specimens am led to form a very high opinion of her talents both in the serious and comic lines of the drama. I cannot but think that, if she has a fair chance, she will make a very favorable impression on the London public.

A personal acquaintance with Mrs. Drake has still more interested me in herself and her fortune; and I shall feel it as a kindness to myself if you would do anything in your power to facilitate her views in England.

With kindest remembrances to Mrs. Miller,

Yours very truly, WASHINGTON IRVING.

Dan'l O'Connell, Esq., M. P., London.

New York, May 20, 1833 .

$$
\text { (Hand by Mrs. Drake.) }
$$

My DEAR SIR: A lady of the highest standing both as a gentlewoman and an actress - Mrs. Drake of the Western region of our Western World - visits Europe and intends to make a professional experiment in London. I have thought I could greatly serve her and gratify you by making you known to each other; and as Mrs. Drake will probably visit Ireland, I shall consider any attention she may receive there through you as a compliment from you to our republic, as will my countrymen. Mrs. Drake is one of the few among us who are allowed by Mrs. Trollope to possess first-rate talent ; and the Duke of Saxe-Weimar, in his Travels, speaks of her with more enthusiasm than even Mrs. Trollope. I prefer, for reasons which I need not name, giving you upon this subject the opinions of foreigners, especially of such as are supposed to be rather prejudiced against us.

I write in great haste, being apprised of the departure of Mrs. 


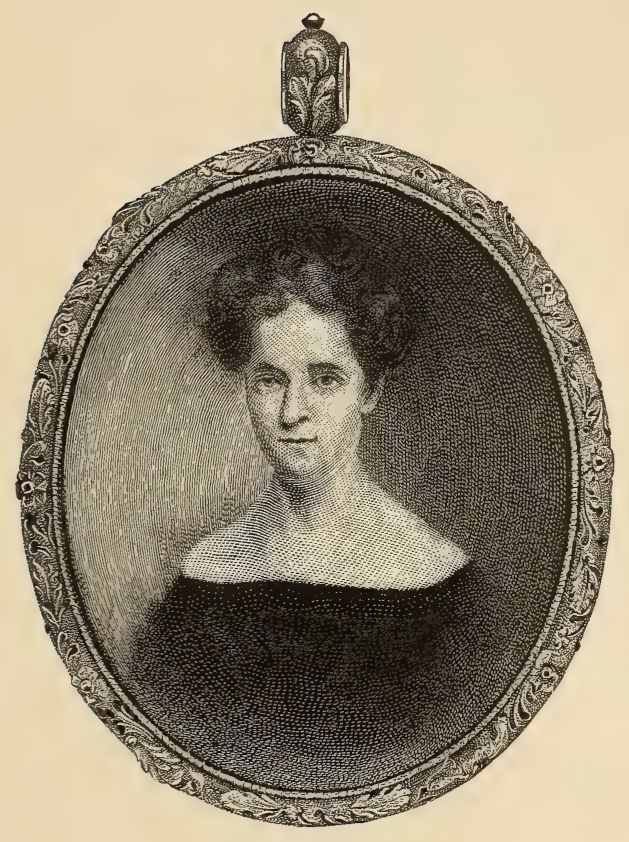

MRS. A. DRAKE. 

Drake for England only as I am myself departing for the Southern States of America. I can only add how infinitely I shall feel obliged by any attention it may be in your power to offer Mrs. Drake. She travels in company with a particular friend of hers, Mrs. White, who (with her husband, a member of the United States Congress for Florida, Colonel White) is desirous of seeing Europe. Should you meet them you may wonder a little that a part of the world so recently a wilderness should produce such poor specimens of savageness and unrefinement.

With best and most grateful remembrances to Mrs. O'Connell and all your family who may still bear me in recollection, believe me, my dear sir, with great respect,

Your obliged and faithful friend and servant,

Dan'l O'Connell, Esq., M. P.

J. Howard Payne.

New York, 67 Varick St.,

Hudson Square, Oct. 20, 1833 .

My Dear Mrs. Drake: You will doubtless think me most ungallant in having so long omitted to answer your kind letter of July I. But be assured the neglect has not been of the mind, for I have often thought and spoken of you and always intended to write to you - to-morrow; the to-morrow is now here; but whether it will guide my remembrance to you is a question which it would delight me to find answered speedily in the affirmative by your own fair hand.

My attention since I heard from you has been entirely taken up by the project of a new periodical I am preparing - Mr. Hyde, of Schenectady, obliges me by conveying you a prospectus. I must have five thousand subscribers before I can start, and as yet the names come in slowly. People seem astonished by the plan and still more by giving two guineas for literature! I have only about 230 of the five thousand as yet, but I mean to persevere. I have great hopes from the Western States, and should be most happy to confer with you upon some plan for taking the warm hearts you tell me of there by storm. The scheme is one I am much devoted to, and surely a nation like this ought to yield from her whole population five thousand supporters for such a project. I mean to travel through the United States myself, and in each place send out a person to solicit 
names. It is humiliating enough to have to solicit even by a second person - but if no other names offer I will do it by myself rather than fail. I shall take Albany, of course, on the way; but when, is yet uncertain. I am very desirous, however, of ascertaining as early as may be what chance that good city offers me; and Mr. Hyde, who is a worthy and enthusiastic young man, a student of Union College and the editor of a magazine published there, has most handsomely undertaken to try what he can do towards the increase of my list. I have desired him to see you, and to get your advice. The ladies are the best friends after all, and not only know how these things ought to be managed, but can point out the readiest way of giving their knowledge effect.

May I hope you will favor me with a line very soon, mentioning what you are about and whether I can be of any use to you in return for the commission with which I am troubling you.

Yours in haste,

Most faithfully,

Mrs. Drake. J. Howard Payne.

These simple letters from two gifted and delightful men attest not only Mrs. Drake's dramatic qualities but her private worth. And it is a pleasure and a privilege to publish them, and so revive the memory of an honorable and talented lady. Had they been commonplace letters of introduction from unknown people I should not have intruded them on the reader; but as it is I feel sure that no apology is needed for their insertion.

A little incident connected with the meeting of Mrs. Drake in Louisville has been brought to my recollection while I have been writing of her. There is nothing particularly interesting about it except that it has a humorous side, and I cannot resist the temptation of noticing it here.

We had, at that time, a lady attached to our company who was a great character. Her thirst 


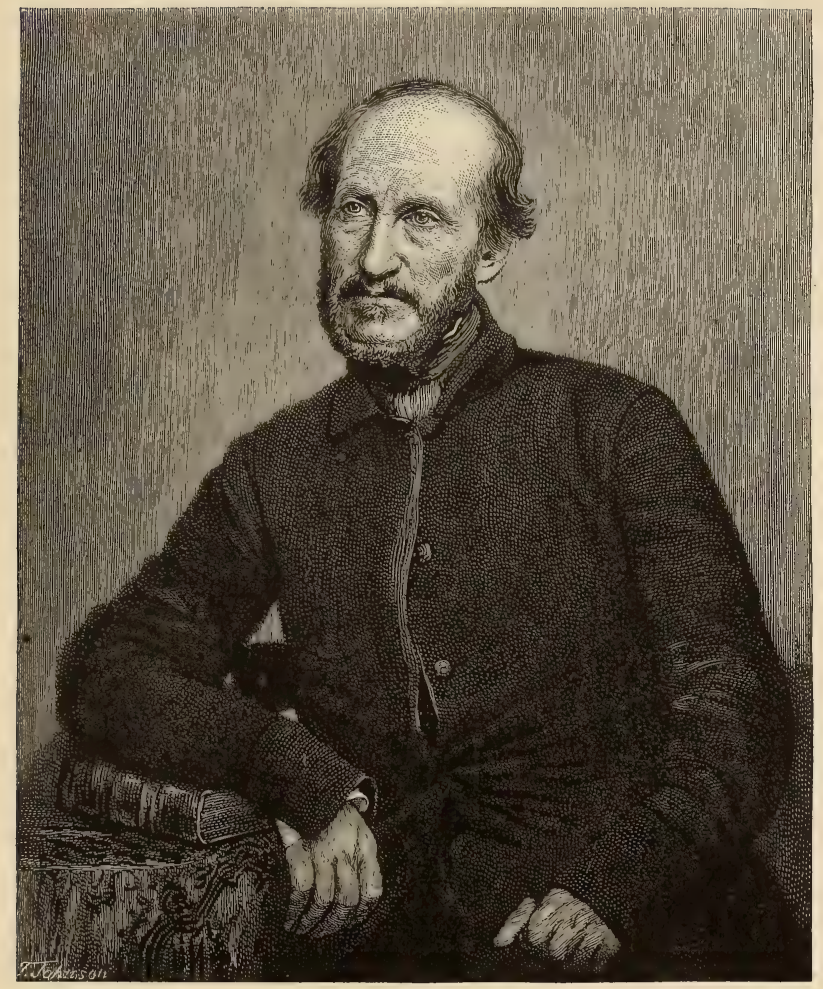

JOHN HOWARD PAYNE. 

for autographs was unquenchable, and I have never seen a more perfect specimen of the female lionhunter. She knew most of the celebrities in the country, and always kept on hand a large assortment of introductory letters ready for presentation at the shortest notice. This is an innocent kind of pastime, and if it does no good it certainly does no harm. This lady had a weakness for not remembering names. This was singular, too, as half her time was employed in collecting them; but they seemed to revenge themselves for their imprisonment in her album by escaping from her memory; and it was comical to observe the woebegone expression of her face when she related some of her unfortunate mistakes.

"It is so dreadful, my dear," she would say, "to commit these blunders, and there is no excuse for them. Just imagine my being introduced to a gentleman by the name of Smith and calling him Mr. Montgomery five minutes afterwards."

Of course she was anxious to meet an interesting lady like Mrs. Drake, and, armed with an introduction which I gave her, called on the retired actress, hoping that she would be able to collect some theatrical matter for a book that she was writing, and desiring to get the much-prized, but rather conventional, actor's autograph with a Shaksperean quotation.

In due time Mrs. Drake returned the call and was ushered into the vast parlor of the Galt House, where a number of ladies and gentlemen were assembled to pay their respects to the lion-hunter. 
Mrs. Drake was distinguished for a majestic bearing at all times, and any ceremonious occasion would naturally intensify her dignity. The tragedy queen was therefore with more than usual loftiness led into the center of the apartment and introduced by her hostess as Mrs. Duck. A slight titter of quiet mirth rippled over the assembled company as Mrs. Drake glared with a reproving Lady Macbeth eye at the nervous little hostess, who was so overcome with mortification that she burst forth with, "Oh, I beg your pardon, I mean Mrs. Goose." This of course settled it.

F. S. Chanfrau, while he acted a vast number of characters with success, will be best remembered by those who go back some thirty years ago, as "Mose," the fire boy. He was the talk of the town for two seasons or more - when I first saw him he was extremely handsome. He was modest, too, and manly. These qualities are so rarely allied to beauty that Chanfrau comes back to my remembrance as quite a novelty. He had success enough to have turned his head, but he bore it bravely, so that he must have been as well poised in his mind as he was in his person. His imitations of Forrest, the elder Booth, Macready, and Burton won him hosts of admirers.

John T. Raymond, like Florence, J. S. Clarke, Owens, and myself, was known as a legitimate comedian. This is a somewhat technical term, usually applied to those actors who confine themselves as strictly as possible to the acting of characters in old English and Shaksperean comedies. 


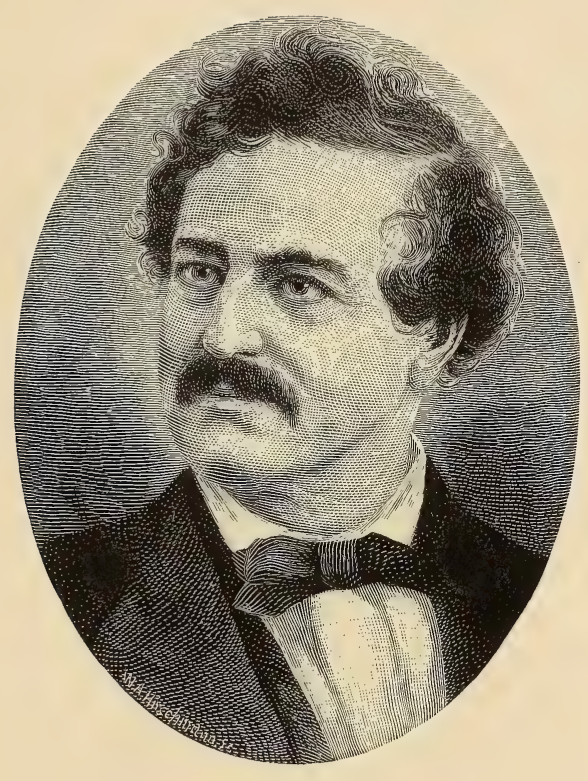

F. S. CHANFRAU. 

Raymond was also, like those actors previously mentioned, a creator of American characters. He appeared as Ichabod Crane in a dramatization of Washington Irving's "Wolfert's Roost," and also as Col. Sellers in Mark Twain's "Gilded Age." The latter character he acted with great success for many seasons in this country, though the play failed to create any enthusiasm in England.

I preferred him in his acting of Ichabod Crane. It was a quaint and strong performance; his love scene with Katrina was acted in the best spirit of comedy; the serio-comic expression that he threw into this woe-begone, love-sick swain was irresistibly droll. Raymond was energetic and industrious, acting up to the very night before his death.

I saw McCullough act but once, and then he was ill, so that I could scarcely give a fair judgment of his talent. He was undoubtedly a great favorite with the public, and much admired by his friends both as a man and an actor. The loss of his mind in the very prime of his life was a mystery that medical skill was unable to account for. From a gentle, yielding nature he changed completely, and at times became quite violent. His career as a tragedian was most prosperous, and he died leaving hosts of friends and admirers.

The Lester Wallack Testimonial, which was given at the Metropolitan Opera House on the evening of Monday, May 2I, I888, brought together a number of actors so celebrated that I desire to chronicle the cast in these pages. The 
play on this occasion was "Hamlet," and the distribution of characters was as follows:

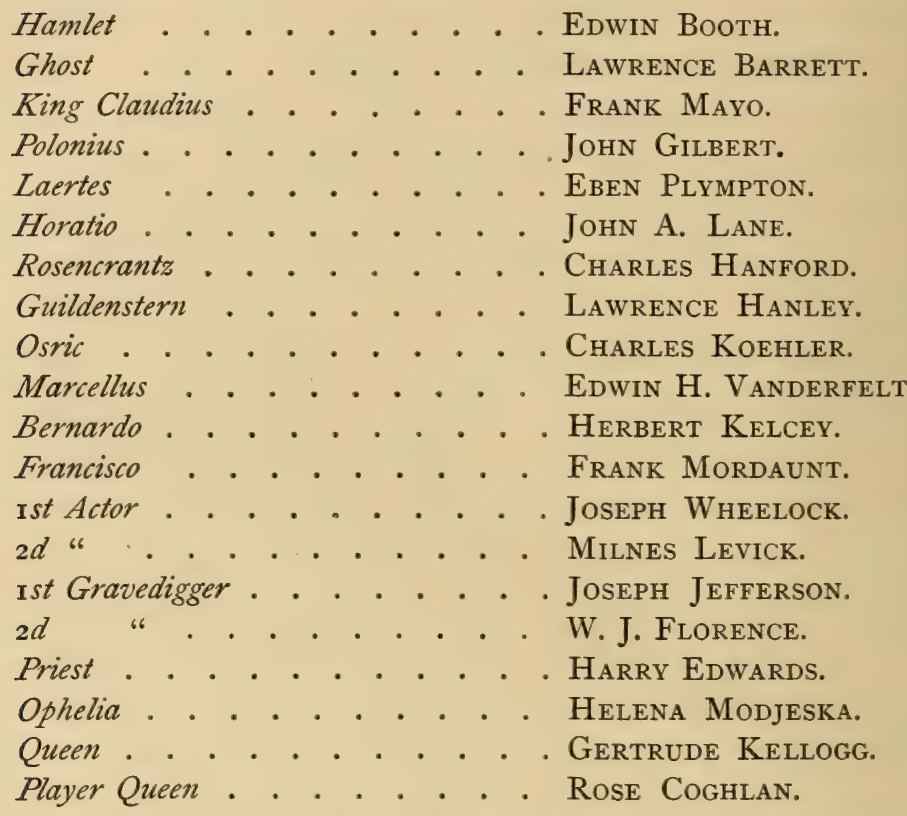

On the bill of the play were printed the names of about one hundred and forty actors and actresses who volunteered as auxiliaries.

The reception to those who volunteered to act was most cordial; and when Mr. Wallack responded to a universal call he did so in wellchosen words; and as he retired from the stage his audience, who seemed to be composed of old friends, applauded as though they were bidding him adieu for the last time; and so, indeed, it turned out to be.

In dealing freely, and I hope fairly, with the players of the past, I have, for obvious reasons, 


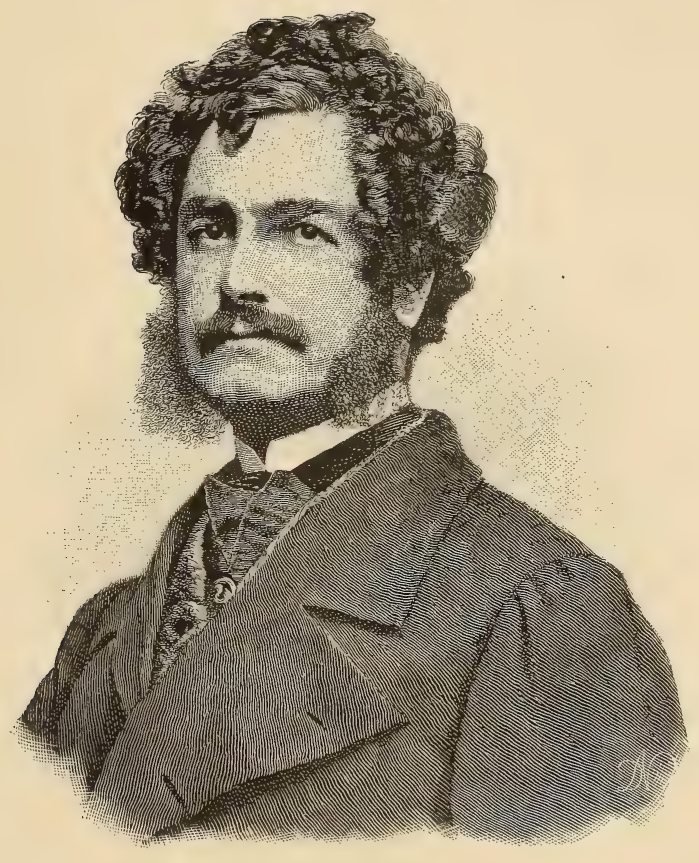

LESTER WALLACK, 

refrained from passing judgment on the actors of the present. I belong to the latter group, and have therefore no right to criticize it. There are many both in England and America that I would be pleased to praise and praise highly, but in doing this I should tacitly censure others, and this is not my mission. The first group have passed by, but we are before the public, which alone has the right to pass judgment. Besides, actors are not by any means the best judges of acting; we have our prejudices, which naturally bias fair criticism; and, in referring to the past history of the stage, I find that all actors of genius and originality have given great offense to the conventional school that their brilliancy disturbed. Quin said of Garrick, "If he is right, then we are all wrong"; the Kembles were shocked at the fire of Edmund Kean; and so it has gone on, and ever will.

Original painters seem to suffer still more than actors, and I honestly believe it is because artists are at the heads of the academies, where they sit in judgment and at times denounce the work of an original painter, refusing to hang his picture because he has had the courage to be unconventional. Corot and Millet were for years refused admittance to the Salon, and are striking proofs of the unfairness or prejudice of their brother artists; and it is quite likely if actors and authors sat in judgment on their kind that many original actors and authors would be tabooed; but fortunately the great public gets at them first and praises or condemns unbiased by professional jealousies. The painter has 
no such advantage; before his work can reach the public it must be filtered through the judgment of his brother artists of the Academy; if they are conventional (as they generally are), he is doomed to obscurity. Corot was fifty years old before his work was honored by a place in the Salon, and he did not sell a picture until he was past that age. After the first sale had been made, the dear old man said to his friends, "Well, I have sold a picture; but I am sorry for it, for now my collection is incomplete."

We have, I think, a natural tendency to dignify the events of the past beyond their deserts, and so we often throw a glamour of excellence over departed actors which we would not accord to them if they were here. This, of course, is erring upon the safe side. The only danger is that our reverence may at times cause us to disparage the good qualities of those who are among us. Dramatic affairs, too, have undergone a change that renders a fair judgment almost impossible. For instance, the actors of, say, forty years ago rarely visited the smaller cities: they were concentrated in the larger ones; but now the demand for dramatic excellence is so great, and the facilities for travel are so extended, that the same amount of talent is diffused all over the world; so we are apt to fancy that it does not exist because it is not with us. If all the great actors of to-day were concentrated into a few companies as was formerly the case, we would be amazed at the entertainment they would give us. 


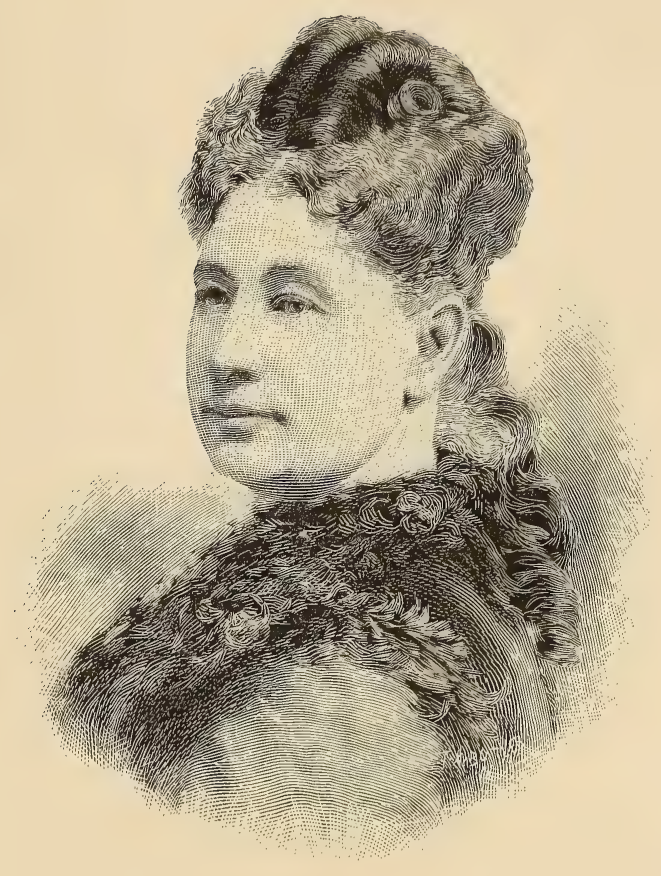

MRS. BARNEY WILLIAMS. 



\section{CHAPTER XVI}

REFLECTIONS ON THE ART OF ACTING

The Dramatic Instinct - Spontaneity and Preparation-Rehearsals - A Warm Heart and a Cool Head - Taking Time - Advice to Beginners Remarks suggested by "Rip Van Winkle" Realism and Idealism - Dramatic Writing

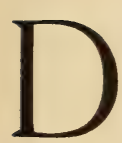

RAMATIC instinct is inherent throughout the human family. Savages, even of the lowest type, are never so enthusiastic as when they indulge in ceremonies representing death and destruction. They will start upon an ideal warpath, suddenly stopping to scalp an imaginary enemy. The New Zealanders, who both physically and intellectually are far above the ordinary savage, are excellent in pantomimic action. They will even act scenes and crudely represent historical traditions of their tribe.

Watch the little boy in frocks - not two years old. If you would delight him, fold a piece of paper in the shape of a cocked hat, pop it on his head, then give him a stick, and in a moment the 
little fellow will straighten up and begin to march about, pretending that he is a soldier. If in another year you supply him with shovel and wheelbarrow you will see him trudge off, joining others of his own age who are building embankments or digging canals, and calling one another by names that do not belong to them, acting and pretending that they are somebody else. A group of little girls will not have been in the room together twenty minutes before one will play lady, as if she had just called, and another pretend she is the hostess, and the smallest of all act mother, and nurse her doll with loving care. After a time the grown-up people in the room will draw one another's attention to this little drama, and, not wishing to interrupt the play, will quietly nudge their neighbors and nod approvingly.

The lawyer often clears his guilty client by depicting the sorrow of a family who will be stricken with grief if the jury should convict. The influence of the stage has crept into the pulpit, which to-day contains some of the finest actors of our time.

Here then we have evidence not only that this dramatic instinct pervades all classes of humanity, but that its possessors insist upon displaying their artistic qualities. And the encouragement of this desire is as universal as the gift; for theaters, opera-houses, lecture-rooms, and churches all over the world are filled with eager audiences anxious to witness any and all brilliant dramatic achievements. The demand, too, is increasing. Half a 
century ago there were but few good theaters in America, and even these were badly lighted, poorly heated, and indifferently appointed. In many of the small towns the only places used for dramatic entertainments were the dining-rooms of the hotels, from which, after tea, the tables were removed and the chairs set back that the play might be acted. Now, in nearly all of the new and rising cities, the theater or the opera-house is centrally located; and it is generally the finest building, both in point of size and architecture, to be seen-heated with steam, lighted by electricity, and provided with every comfort. Within these temples, actors, opera-singers, minstrels, and ministers hold forth, and the same audience goes to hear them all. The desire for dramatic entertainment has resolved itself into a tidal wave that nothing can stop, particularly as there is no desire to impede it. It has not the fleeting character of a political movement that might change with the new influence of the next Administration; it belongs to no party; it is born of no sect; but it is the outcome of a universal passion.

Naturally, other members of my profession have given as much consideration to matters connected with their art as I have-perhaps more. It is therefore likely that a few may think as I do, many may differ with me, though possibly some may not have thought about the matter at all.

If I err I shall be glad to throw off my preconceived ideas and adopt other, better, and newer methods. In fact, I have already dis- 
carded many pet theories, and, as I have grown older and more experienced, have been taught by my own observations and the successful achievements of others that there is always room for reform.

Acting has been so much a part of my life that my autobiography could scarcely be written without jotting down my reflections upon it, and I merely make this little preparatory explanation to apologize for any dogmatic tone that they may possess, and to say that I present them merely as a seeker after truth in the domain of art.

In admitting the analogy that undoubtedly exists between the arts of painting, poetry, music, and acting, it should be remembered that the three former are opposed to the latter, in at least the one quality of permanence. The picture, oratorio, or book must bear the test of calculating criticism, whereas the work of an actor is fleeting: it not only dies with him, but, through his different moods, may vary from night to night. If the performance be indifferent it is no consolation for the audience to hear that the player acted well last night, or to be told that he will act better to-morrow night; it is this night that the public has to deal with, and the impression the actor has made, good or bad, remains as such upon the mind of that particular audience.

The author, painter, or musician, if he be dissatisfied with his work, may alter and perfect it before giving it publicity, but an actor cannot rub out; he ought, therefore, in justice to his 


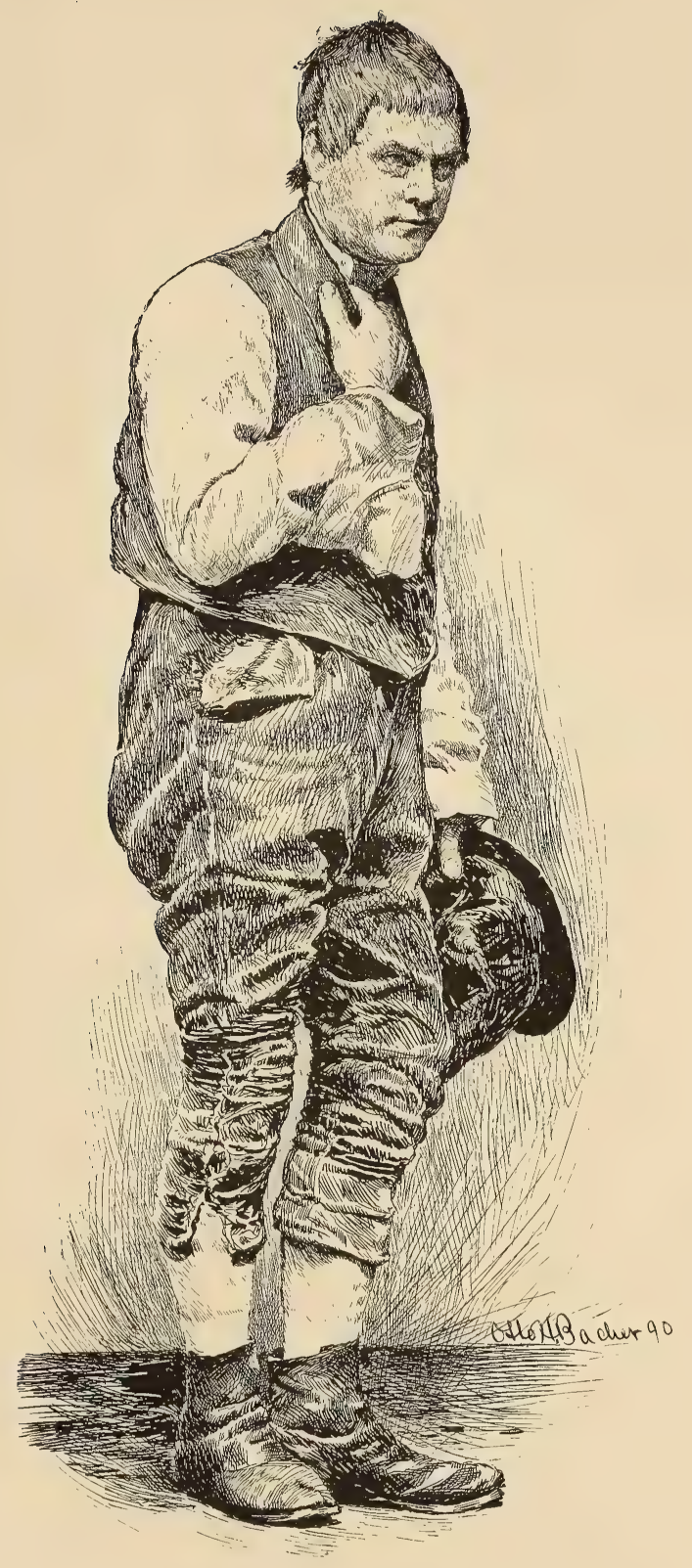

JOHN DREW AS "THE IRISH EMIGRANT." 

audience, to be sure of what he is going to place before it. Should a picture in an art gallery be carelessly painted we can pass on to another, or if a book fails to please us we can put it down. An escape from this kind of dullness is easily made, but in a theater the auditor is imprisoned. If the acting be indifferent, he must endure it, at least for a time. He cannot withdraw without making himself conspicuous; so he remains, hoping that there may be some improvement as the play proceeds, or perhaps from consideration for the company he is in. It is this helpless condition that renders careless acting so offensive.

The supremacy in both the writing and acting of comedy has been for many years accorded to the French stage. My opinion upon this subject will be of little value. An American comedian acting only in the English language could scarcely speak with confidence on this subject unless he understood and spoke the French language as well as the French actors themselves. In tragedy the matter would be quite different. The expressions of love, jealousy, hate, revenge, pride, madness, or despair are so pronounced in tragedy that we can judge of their intensity and effect in any language. Comedy has but little to do with the violent exhibition of these passions. Its effects are more subtile and depend much upon minute detail accompanied by slight but most important inflections of the voice, and by delicate pantomime. No one not thoroughly and practically acquainted with the French lan- 
guage could offer a fair opinion upon French acting. I can only say that I saw much of French comedy in France and was delighted with it. Its grace and finish were quite perfect, and in acting their own comedy I should say that the comedians were exceptionally fine; but, with all their excellence, there is one glaring fault which I think I may venture to express condemnation of, no matter in what language it occurs, and which I think they themselves could hardly defend-I mean the unnatural trick of speaking soliloquy and side speeches directly to the audience. We should act for the audience, not to the audience.

To appeal every now and then to the front of the theater for recognition is an exhibition of weakness. An actor who cannot speak a speech with his back to the audience when the situation demands it has much to learn. As soon as we acknowledge the presence of the public we dispel its attention and ruin its enjoyment. We were forced to do this in the days when we were his Majesty's servants, and when it was considered disrespectful to turn our backs on royalty. How absurd to see a courtier present a document at the foot of the throne in the play and sidle up the stage with his back to the mimic king because the real article is in the royal box!

I have seen impulsive actors who were so confident of their power that they left all to chance. This is a dangerous course, especially when acting a new character. I will admit that there are many instances where great effects have been produced 
that were entirely spontaneous, and were as much a surprise to the actors who made them as they were to the audience that witnessed them; but just as individuals who have exuberant spirits are at times dreadfully depressed, so when an impulsive actor fails to receive his inspiration he is dull indeed, and is the more disappointing because of his former brilliant achievements.

In the stage-management of a play, or in the acting of a part, nothing should be left to chance, and for the reason that spontaneity, inspiration, or whatever this strange and delightful quality may be called, is not to be commanded, or we should give it some other name. It is, therefore, better that a clear and unmistakable outline of a character should be drawn before an actor undertakes a new part. If he has a well-ordered and an artistic mind it is likely that he will give at least a symmetrical and effective performance; but should he make no definite arrangement, and depend upon our ghostly friends Spontaneity and Inspiration to pay him a visit, and should they decline to call, the actor will be in a maze and his audience in a muddle.

Besides, why not prepare to receive our mysterious friends whether they come or not? If they fail on such an invitation we can at least entertain our other guests without them ; and if they do appear, our preconceived arrangements will give them a better welcome and put them more at ease.

Acting under these purely artificial conditions will necessarily be cold, but the care with which 
the part is given will at least render it inoffensive; they are, therefore, primary considerations, and not to be despised. The exhibition of artistic care, however, does not-alone constitute great acting. The inspired warmth of passion in tragedy and the sudden glow of humor in comedy cover the artificial framework with an impenetrable veil: this is the very climax of great art, for which there seems to be no other name but genius. It is then, and then only, that an audience feels that it is in the presence of a reality rather than a fiction. To an audience an ounce of genius has more weight than a ton of talent; for though it respects the latter, it reverences the former. But the creative power, divine as it may be, should in common gratitude pay due regard to the reflective; for Art is the handmaid of Genius, and only asks the modest wages of respectful consideration in payment for her valuable services. A splendid torrent of genius ought never to be checked, but it should be wisely guided into the deep channel of the stream from whose surface it will then reflect Nature without a ripple. Genius dyes the hues that resemble those of the rainbow; Art fixes the colors that they may stand. In the race for fame purely artificial actors cannot hope to win against those whose genius is guided by their art; and, on the other hand, Intuition must not complain if, unbridled or with too loose a rein, it stumbles on the course, and so allows a well-ridden hack to distance it.

Very numerous rehearsals are not always necessary to attain perfection; on the contrary, it is the 


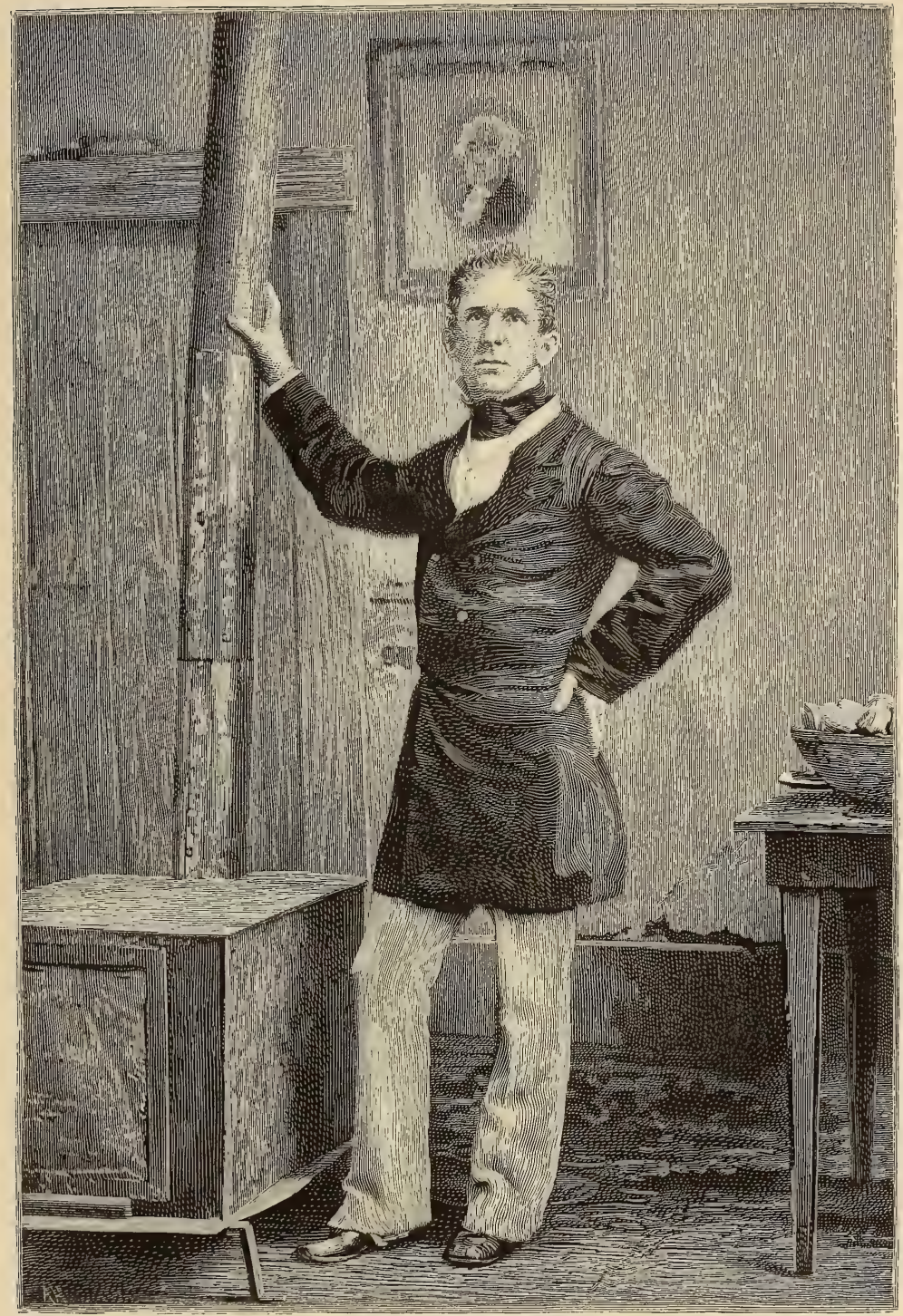



quality, not the quantity, that is important. Tedious preparation day after day will sometimes pall upon a company of actors, who, wearied by constant repetition, lose the freshness with which their performance should be given; and that quality once lost is seldom regained. It is vain for a manager to argue that he pays the actor for his time and attention. He has a perfect right to these, certainly; but the feeling and enthusiasm with which the time and attention should be given he can no more command than he can alter the human nature of his company.

Just as an early impression is the most indelible, so the first rehearsal is the most important, and being so should never be called until the author and stage-manager shall have fully digested their plans and thoroughly understand what they intend to do. This course not only saves labor but begets the respect of the company, who feel that their time will not be wasted and that they are in the hands of patient and conscientious directors.

It is the time-honored excuse of some actors that they cannot study a part until they have rehearsed it, forgetting that it is not possible to rehearse properly until they are perfect in the words. A part is more easily studied after a rehearsal of it, certainly; but I am not discussing ease, remember, but propriety. How can we watch the action and progress of the play if our eyes are bent upon the book? It is merely a bad habit, and one that has grown out of a desire that some people have to shirk their duty; being naturally inclined to procrastination they 
shelter themselves under this weak and conventional excuse.

Usually the scenery and properties of a play are brought into requisition during the later rehearsals, and increased in detail till they culminate at the last rehearsal.

This is working from the wrong direction. It is at the first rehearsal that these adjuncts should be used, and if they are not ready substitutes should be put in their places; for if the set of the scene, the chairs, tables, and other mechanical arrangements are placed upon the stage for an initial rehearsal, the manager and the actors know then and ever afterwards where to find them and how to arrange their groupings, exits, entrances, and stage business in accordance with the position of these useful materials; but if, after all the stage business has been arranged, the company suddenly find at the last rehearsal that chairs, tables, seats, etc. are met upon the stage in unexpected places, they become obstacles to the actors instead of adjuncts.

I do not mean to say that the entire business of a play can be arranged at the first rehearsal. New ideas continually crop up during the early stages of preparation which upon consideration may be more valuable than the original ones, and actors may have suggestions to make, the effect of which had not struck the author. But while a good general shows his genius best when dealing with an emergency, he does not disdain to plan the battle before the action takes place. 
Better have no rehearsal at all than one that is long, rambling, and careless: a clearly cut and perfectly defined outline gives precision and finish to the work. If it were possible the pantomime and action of a play should reveal its meaning to an audience without the aid of dialogue; this would give force to the language and enable those who do not catch all the words fully to comprehend their meaning.

An audience should understand what the actors are doing if it does not hear all that they are saying. It is eager to do this, and quite competent, if we only give it a fair opportunity; but inarticulate delivery and careless pantomime will not suffice.

We must not mistake vagueness for suggestion, and imagine that because we understand the matter we are necessarily conveying it to others. Sheridan, in his extravaganza of "The Critic; or, a Tragedy Rehearsed," gives a humorous illustration of this error. During the rehearsal of $M r$. Puff's play the character of Lord Burleigh enters, walking slowly and majestically down to the footlights. The noble knight folds his arms, shakes his head solemnly, and then makes his exit without saying a word.

"What does he mean by shaking his head in that manner?" asks Mr. Dangle, a theatrical critic.

To which Mr. Puff replies: "Don't you know? Why, by that shake of the head he gave you to understand that even though they had more jus- 
tice in their cause and more wisdom in their measures, yet, if there was not a greater spirit shown on the part of the people, the country would at last fall a sacrifice to the hostile ambition of the Spanish monarchy."

"Did he mean all that by shaking his head?" asks $M r$. Dangle.

To which $M r$. Puff replies, "Yes, sir; if he shook it as I told him."

As this satire was written over a hundred years ago, it is quite evident that the vanity of vagueness is not a new histrionic development.

And here the quality of permanence as allied to the other arts and not to acting presents itself. If we do not at first understand a great picture, a fine piece of music, or a poem, each of these, being tangible, still remains; so, should we desire it, we can familiarize ourselves with it, and as we grow older and become more highly cultivated we will understand a school of art that was at first obscure. But there must be no vagueness in acting. The suggestion should be unmistakable; it must be leveled at the whole audience, and reach with unerring aim the boy in the gallery and the statesman in the stalls.

A reminiscence of some forty years ago will serve to illustrate the value of careful preparation at rehearsal.

The production at Burton's Theater of "Dombey and Son," dramatized by Mr. Brougham, was a curious combination of failure and success. Much was expected of Burton's Captain Cuttle, and to the 


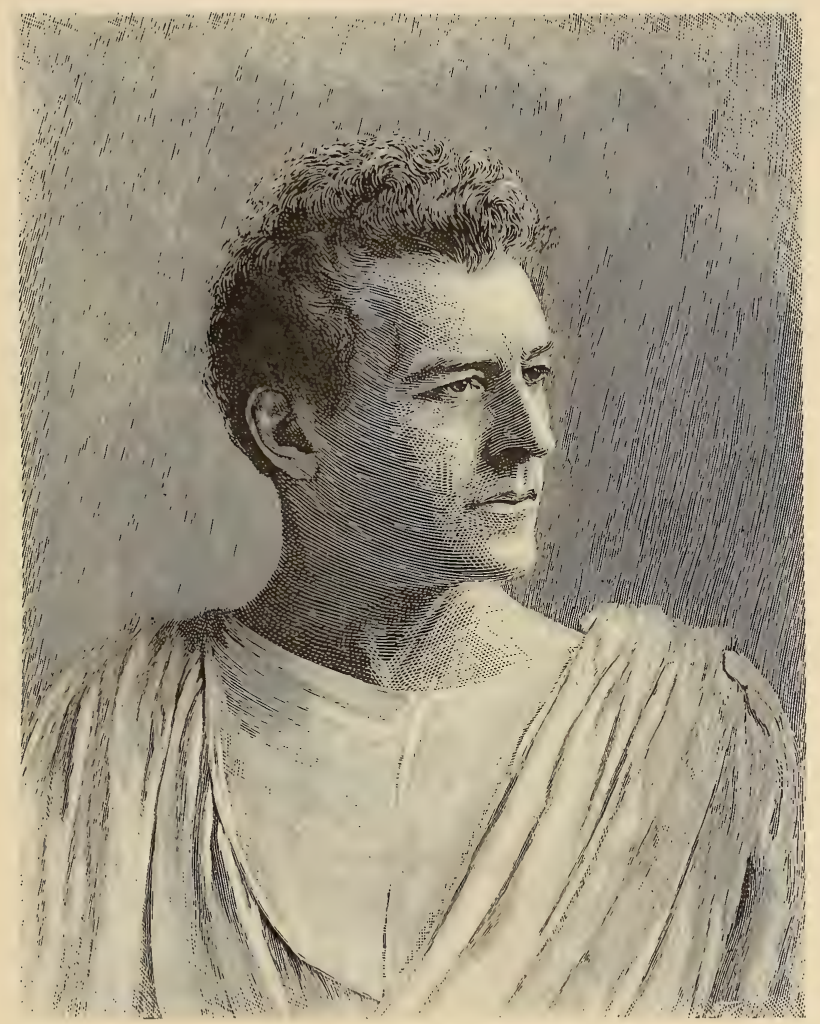

JOHN MECLILOUTH AS "VIRGINIUS." 

surprise of the expectant critics and of Burton himself he did nothing with it. Brougham was equally dull as the two B's, Bunsby and Bagstock; the hit of the piece, at least on its first production, was made by Oliver Raymond as Toots. This gentleman had been previously an obscure actor, but on making a success in a play wherein Burton had failed, he came to the front at once and was the lion of the hour.

Burton's failure as Cuttle was easily accounted for. He had studied the character carelessly, and not only was imperfect in the text but had been absent from many of the rehearsals, relying too much upon his great powers and the spontaneity of his dramatic resources. He was usually able to command them, but during the first run of this piece they played him truant. Dismayed at his own failure and mortified at young Raymond's success, the manager took the drama from the bills and substituted another programme. Not satisfied with Brougham's adaptation, - for the novel had been badly dramatized, - he and the adapter worked together to reconstruct the play.

The great comedian now set himself seriously to work on the character, perfecting himself in the words, and amplifying the part by the introduction of stage-business and by-play. In this kind of ingenious elaboration he was a master, and clearly proved it on the revival of the discarded play. His performance was in magnificent condition when I witnessed it, and who that ever saw Burton as Captain Cuttle, Mariner, can ever forget it? What 
expression! what breadth! what humor! and what tenderness!

In the scene with Florence Dombey where he is trying to reveal to her that her lover, supposed to be drowned, was rescued, he sits awkwardly shifting his position from side to side, puffs his pipe, and tells his tale, letting the story go from him little by little and hauling it back lest the joyful tidings should be too great a shock, his fat face drawn down with serio-comic emotion, his eyes protruding in a solemn, stupid stare, and his utterance choked with tears that seem to force themselves out and mingle with the smoke. As the door bursts open and the returned lover clasps his sweetheart in his arms, the captain jumps from his seat, cocks his tarpaulin hat over his eyes, folds his arms tightly, and, trying to whistle a tune, bursts into tears and dances a sailor's hornpipe around the loving couple. I had heard of his missing the part at first; but he was in the height of his triumph when I saw the performance, and it was amazing to see into what a superb success he had elaborated a failure.

If any proofs were wanting that an actor, no matter how great, should arrange the mechanical details of his work before he presents it to the public, the failure and ultimate success of Burton's Captain Cuttle offer sufficient evidence. Here stood an actor to whom dramatic genius was universally accorded. Yet even he had been taught a lesson, and learned not to place too much confidence in the spur of the moment. 
Much has been written upon the question as to whether an actor ought to feel the character he acts or be dead to any sensations in this direction. Excellent artists differ in their opinions on this important point. In discussing it I must refer to some words I wrote in one of the early chapters of this book:

The methods by which actors arrive at great effects vary according to their own natures; this renders the teaching of the art by any strictly defined lines a difficult matter.

There has lately been a discussion on the subject, in which many have taken part, and one quite notable debate between two distinguished actors, one of the English and the other of the French stage. These gentlemen, though they differ entirely in their ideas, are, nevertheless, equally right. The method of one, I have no doubt, is the best he could possibly devise for himself; and the same may be said of the rules of the other as applied to himself. But they must work with their own tools; if they had to adopt each other's they would be as much confused as if compelled to exchange languages. One believes that he must feel the character he plays, even to the shedding of real tears, while the other prefers never to lose himself for an instant, and there is no doubt that they both act with more effect by adhering to their own dogmas.

For myself, I know that I act best when the heart is warm and the head is cool. In observing the works of great painters I find that they have 
no conventionalities except their own; hence they are masters, and each is at the head of his own school. They are original, and could not imitate even if they would.

So with acting, no master-hand can prescribe rules for the head of another school. If, then, I appear bold in putting forth my suggestions, I desire it to be clearly understood that I do not present them to original or experienced artists who have formed their school, but to the student who may have a temperament akin to my own, and who could, therefore, blend my methods with his preconceived ideas.

I think it is generally conceded that imitators are seldom fine actors, though they are usually great favorites with the public. I confess that I enjoy the exhibitions of this kind of talent exceedingly. There is something very attractive and even strange to see one man display the voice, manner, and expression of another-particularly if that other be not yourself. We may enjoy the imitation of our dearest friends, but our smiles vanish and our faces elongate if the mimic attempts to give "a counterfeit presentment" of the party of the first part. I have heroically tried on several occasions to enjoy imitations of myself, but have never succeeded. These ingenious transcripts contain a slight touch of ridicule that always offends the original. An anecdote of Mr. Buckstone, the English comedian, will serve to illustrate what I have said. He was an actor whose mannerisms were so marked that they infused them- 


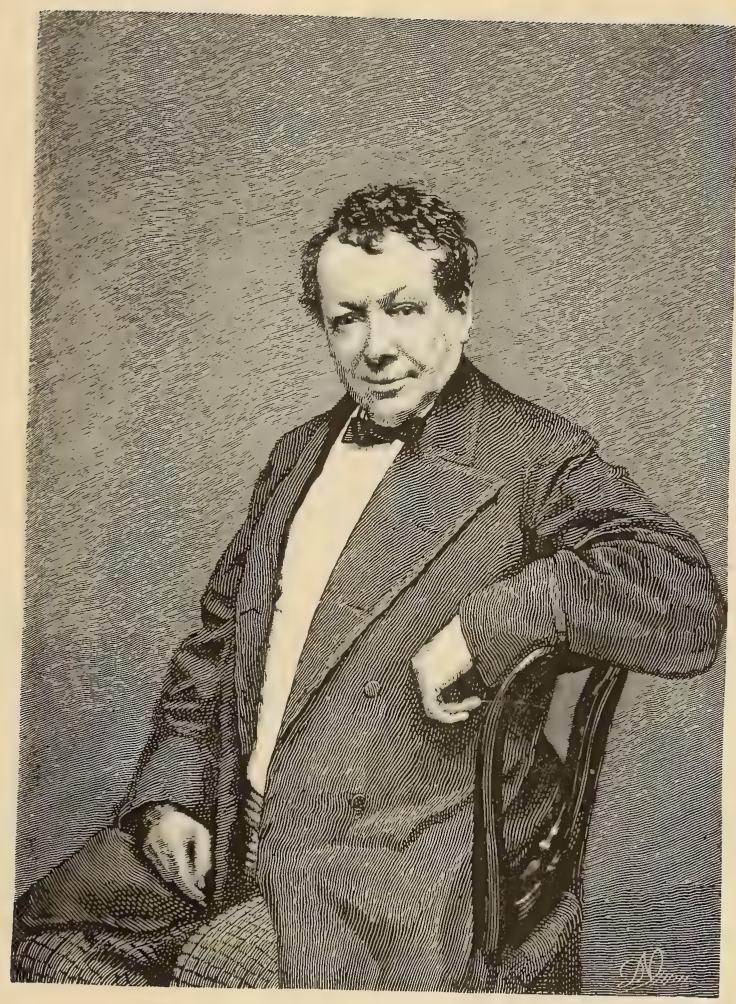

J. B. BUCKSTONE 

selves through all the characters he played. $\mathrm{He}$ was undoubtedly humorous, or, more properly speaking, funny; but whether he acted Sir Andrew Aguecheek or Cousin Joe he seemed to have no power of embodying the character-rendering each of them with the same voice, manner, and attitude; consequently, he was an admirable subject for imitation.

At the close of a dinner party he had been given to understand that there was a person present who gave an excellent imitation of himself. Buckstone at once desired the gentleman to let the company have a test of his quality. The gentleman politely declined, saying that he might give offense; but the comedian would not let him off, insisted on the exhibition, and, rubbing his hands together with great glee, settled himself down for unlimited enjoyment. The imitator, seeing that there was no escape, arose, and amid breathless silence began. His hit was immense, and as he sat down the guests broke forth in loud laughter and applause: the whole table was in a roar of merriment; every one was in ecstasy except Buckstone, who looked the picture of misery.

“Well, Mr. Buckstone," exclaimed a wag, who was quietly enjoying the comedian's discomfiture, "don't you think the imitation very fine?"

"It may be," he replied, "but I think I could do it better myself."

Acting is more a gift than an art. I have seen a child impress an audience by its natural grace and 
magnetism. The little creature was too young to know what art meant, but it had the gift of acting. The great value of art when applied to the stage is that it enables the performer to reproduce the gift, and so move his audience night after night, even though he has acted the same character a thousand times. In fact, we cannot act a character too often, if we do not lose interest in it. But when its constant repetition palls on the actor it will as surely weary his audience. When you lose interest - stop acting.

This loss of interest on the part of the actor may not be visible in the action or pantomime; but unless care and judgment are observed it will assuredly betray itself in the delivery of the language, and more particularly in the long speeches and soliloquies. In dialogue the spirit of the other actors serves to stimulate and keep him up; but when alone, and unaided by the eye and presence of a companion, the old story fails to kindle the fire. An anecdote of Macready that I heard many years ago throws a flood of light upon this subject; and as I think it too important a one to remain in obscurity I will relate it as I got it from Mr. Couldock, and then refer to its influence upon myself and the means I used to profit by it. The incident occurred in Birmingham, England, some forty years ago. The narrator was present and naturally listened with interest to a conversation upon art between two such able exponents of it as Mr. Macready and Mrs. Warner. What they said referred to an important scene in the tragedy 
of "Werner," which had been acted the evening before.

Mr. Macready, it seems, had much respect for Mrs. Warner's judgment in matters relating to the stage, and desired to consult her on the merits and demerits of the preceding evening's performance. As nearly as can be remembered, his question and her reply were as follows:

"My dear madam," said Macready, "you have acted with me in the tragedy of 'Werner' for many years, and naturally must be very familiar with it and with my manner of acting that character. I have noticed lately, and more particularly last evening, that some of the passages in the play do not produce the effect that they formerly did. There is a certain speech especially that seems to have lost its power. I refer to the one wherein Werner excuses himself to his son for the 'petty plunder' of Stralenheim's gold. In our earlier performances, if you remember, this apology was received with marked favor, and, as you must have observed, last evening it produced no apparent effect ; can you form any idea why this should be? Is it that the audience has grown too familiar with the story? I must beg you to be candid with me. I shall not be offended by any adverse criticism you may make, should you say that the fault is with me." "Well, Mr. Macready, since you desire that I should speak plainly," said Mrs. Warner, "I do not think it is because your audience is too familiar with the story, but because you are too familiar with it yourself." 
"I thank you, madam," said Macready; "but how does this mar the effect of the speech?"

"Thus," said Mrs. Warner. "When you spoke that speech ten years ago there was a surprise in your face as though you then only realized what you had done. You looked shocked and bewildered, and in a forlorn way seemed to cast about for words that would excuse the crime; and all this with a depth of feeling and sincerity that would naturally come from an honest man who had been for the first time in his life accused of theft."

"That is as it should be given," said Macready. "And now, madam?"

"You speak it," said his frank critic, "like one who has committed a great many thefts in his life, and whose glib excuses are so pat and frequent that he is neither shocked, surprised, nor abashed at the accusation."

"I thank you, madam," said the old actor. "The distinction may appear at first as a nice one, but there is much in it."

When I heard the story from Mr. Couldock it struck me with much force. I knew then that I had been unconsciously falling into the same error, and I felt that the fault would increase rather than diminish with time if I could not hit upon some method to check it. I began by listening to each important question as though it had been given for the first time, turning the query over in my mind and then answering it, even at times hesitating as if for want of words to frame the reply. 


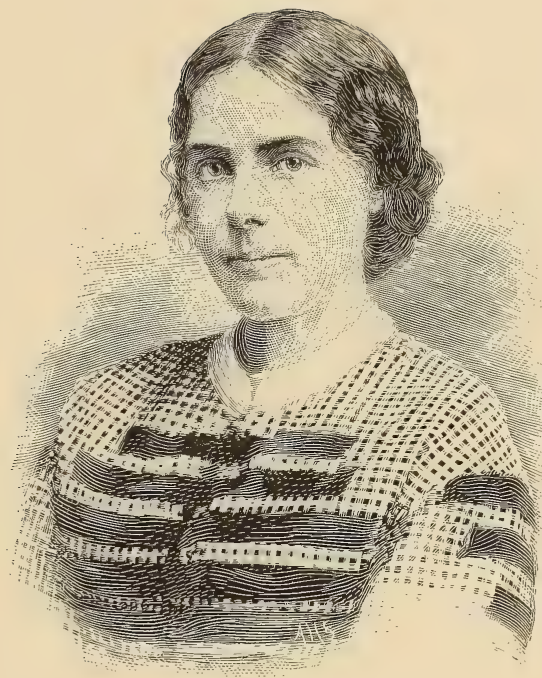

SARAH STEVENS. 

I will admit that this is dangerous ground and apt to render one slow and prosy; in fact, I was accused, and I dare say quite justly, of pausing too long. This, of course, was the other extreme and had to be looked to, so that it became necessary that the pauses should, by the manner and pantomime, be made sufficiently interesting not to weary an audience; so I summed it up somewhat after the advice of Mr. Lewes - to take time without appearing to take time.

It is the freshness, the spontaneity, of acting that charms. How can a weary brain produce this quality? Show me a tired actor and I will show you a dull audience. They may go in crowds to see him, and sit patiently through his performance. They have heard that he is great, they may even know it from past experience; so they accept the indifferent art, thinking, perhaps, that they are to blame for a lack of enthusiasm.

Pantomimic action, unless it is in perfect harmony with the scene, is fatal to the effect of a delicate point. If the situation be a violent one, such as the preparation for battle in "Richard," or where Hamlet's uncle rises from his seat in the play scene, dismissing the audience, the situation being pronounced and the action strong, indifferent pantomime upon the part of the actors might not be noticed in the bustle and excitement. But, to exemplify my meaning, let us take a point where the audience is called upon, not for enthusiastic applause but for rapt attention; where the situation is so subtile that the head bowed slowly 
down, or a movement of the eye, will reveal the meaning. Now, at this critical point, if one of the actors should even remove his hat, or unmeaningly shift his position, he will destroy the effect. The finer the acting the more easily the effect is destroyed, just as a scratch will disfigure a polished surface that would not show on the face of a cobblestone.

The audience cannot look in two places at once; the eye is such a tyrant that it distracts from the subject "then necessary to be considered," directing the attention to a useless and intrusive movement. The value of repose is so great that it is difficult to estimate it.

At rehearsal the amateur having finished his speech invariably asks the stage-manager what he should do next. As soon as he ceases to be the interesting figure he should observe the action of the other characters; this is the most natural byplay and the least likely to do harm. It acts like the distance in a picture, which, by being subdued, gives strength to the foreground. But the tyro is generally fearful that he will fail to attract attention, whereas obscurity instead of prominence may at that time be the most desirable. To do nothing upon the stage seems quite simple, but some people never acquire this negative capacity.

It is David's speech (in "The Rivals") that terrifies Acres. How could an audience get the full value of what David says if they were looking at the face of Acres? The two characters would conflict with each other, and so rob the picture of clearness. 
But if Acres here will subdue his personality and sink, as it were, into the background, the audience will get the full force of what David says, and become as perfectly saturated with its meaning as Acres himself. Now see how fully they are prepared to receive the expression of fear from the latter. After David's scene is over, Acres has the audience at his full command - the slightest suggestion from him is taken up at once. They know his character and realize his position as vividly as he does himself; it is because they have had the full and uninterrupted benefit of the previous scene. If, during David's speech, I, as Acres, show my face to the audience or pull out my handkerchief and weep, I might gain a temporary advantage, but I should weaken David, and in the end mar the effect of my own character; and, believe me, an audience is always grateful to an actor who directs its attention the right way. The traveler thanks the truthful finger-post, but never forgives the rascal who has misdirected him.

Nothing in art is more distressing than to see an actor attract the attention of the audience, from an interesting point in the performance, by the introduction of some unimportant by-play. At times this is done from ignorance, but, I regret to say, often through jealousy. This unfair spirit reflects back upon the guilty party, for the public resent it quietly while the offender least suspects it: their enjoyment has been marred, and the obnoxious cause of it has only consoled them by a display of unmeaning activity; they 
refuse this rubbish and inwardly mark the individual who has had the impertinence to offer it. But as two pigs under a gate make more noise than one, it is still worse to see a pair of ranters or a couple of buffoons trying to outdo each other. There is but one recompense; they are both self-slaughtered in the conflict,

As two spent swimmers, that do cling together, And choke their art.

Many instructors in the dramatic art fall into the error of teaching too much. The pupil should first be allowed to exhibit his quality, and so teach the teacher what to teach. This course would answer the double purpose of first revealing how much the pupil is capable of learning, and, what is still more important, of permitting him to display his powers untrammeled. Whereas, if the master begins by pounding his dogmas into the student, the latter becomes environed by a foreign influence which, if repugnant to his nature, may smother his ability.

It is necessary to be cautious in studying elocution and gesticulation, lest they become our masters instead of our servants. These necessary but dangerous ingredients must be administered and taken in homeopathic doses, or the patient may die by being over-stimulated. But even at the risk of being artificial, it is better to have studied these arbitrary rules than to enter a profession with no knowledge whatever of its mechanism. Dramatic instinct is so implanted in humanity 


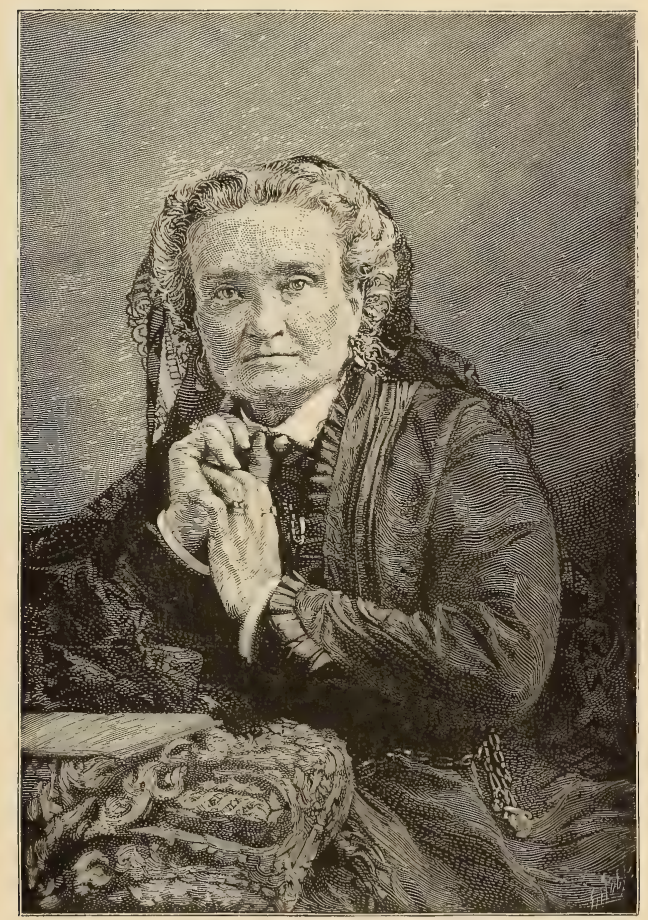

CHARLOTTE CUSHMAN 

that it sometimes misleads us, fostering the idea that because we have the natural talent within, we are equally endowed with the power of bringing it out. This is the common error, the rock on which the histrionic aspirant is oftenest wrecked. Very few actors succeed who crawl into the service through "the cabin windows"; and if they do it is a lifelong regret with them that they did not exert their courage and sail at first "before the mast."

Many of the shining lights who now occupy the highest positions on the stage, and whom the public voice delights to praise, have often appeared in the dreaded character of "omnes," marched in processions, sung out of tune in choruses, and shouted themselves hoarse for Brutus and Mark Antony.

If necessity is the mother of invention, she is the foster-mother of art, for the greatest actors that ever lived have drawn their early nourishment from her breast. We learn our profession by the mortifications we are compelled to go through in order to get a living. The sons and daughters of wealthy parents who have money at their command, and can settle their weekly expenses without the assistance of the box-office, indignantly refuse to lower themselves by assuming some subordinate character for which they are cast, and march home because their fathers and mothers will take care of them. Well, they had better stay there!

If Edmund Kean had been wealthy the chances are that he never would have submitted to the 
insults of the manager and some of the actors during the memorable rehearsal at Drury Lane Theater. He perhaps would have broken his engagement and retired from the stage in disgust; but half-starved and threadbare, his loved wife and child living in a garret, he had a noble motive to stimulate his power, and I believe that Kean on the night of his first appearance in London was a greater actor than he had ever been before. His situation was desperate, and aroused the slumbering genius within him. The whole history of that eventful night impresses one with the idea that he himself was surprised at what he did.

Fitzgerald, in his admirable "Romance of the English Stage," says that "Kean had a gallant confidence in himself all through." There is nothing in the story that implies this. He had courage, no doubt, or he could not have made the effort; but it was fitful and uncertain. Genius is seldom confident. Fitzgerald himself quotes the last words Kean said as he left his house for the theater. "He kissed his wife and infant son, and muttered, "I wish I were going to be shot." "There is no confidence in these terrible words. They show the brave nature of the man because he was not confident. Who can say how fervently he may have prayed as he trudged through the dark, wet streets, with a beating heart and a nervous foreboding of disaster in the approaching trial. His hit was tremendous, and, when the manager congratulated him on 
his wonderful success, in Kean's own description of the event he said, "The pit rose at me." This sounds confident, I admit; but the remark was made after the battle was won.

The whole picture is more interesting and truthful when we view the man as being fully alive to the danger of the situation and apprehensive lest the invisible genius within him should fail to appear. When this mysterious influence, which comes unbidden, burst forth at the theater that night, the public were amazed, the critics stunned, and Kean himself was surprised. No intellectual effort could have created this effect. The source of genius is in the soul; it seldom aims at the brains of the audience, but oftener shoots at their hearts through its own. It shrinks from assuming the arrogance that commands attention, and modestly invites it.

But whether you are rich or poor, if you would be an actor begin at the beginning. This is the old conventional advice, and is as good now in its old age as it was in its youth. All actors will agree in this, and as Puff says, in "The Critic," "When they do agree on the stage the unanimity is wonderful." Enroll yourself as a "super" in some first-class theater, where there is a stock company and likely to be a periodical change of programme, so that even in your low degree the practice will be varied. After having posed a month as an innocent English rustic, you may, in the next play, have an opportunity of being a noble Roman. Do the little you have to do as well as 
you can; if you are in earnest the stage-manager will soon notice it, and your advancement will begin at once. You have now made the plunge, the ice is broken; there is no more degradation for you, and every step you take is forward.

A great American statesman said, "There is always plenty of room at the top." So there is, Mr. Webster, after you get there. But we must climb, and climb slowly too, so that we can look back without any unpleasant sensations; for if we are cast suddenly upon the giddy height, our heads will swim and down we go. Look also at the diffculties that will beset you by beginning "at the top." In the first place, no manager in his senses will permit it; and if he did, your failure - which is almost inevitable — not only will mortify you, but your future course for some time to come will be on the downward path. Then, in disgust, sore and disheartened, you will retire from the profession which perhaps your talents might have ornamented if they had been properly developed.

While acting once in Boston I received a note from the publisher of "The Atlantic Monthly," to know if I would call at the publishing house to meet Mrs. Harriet Beecher Stowe. It seems the lady had been at the theater where I had acted the night before, and in a note to the publisher had expressed a desire to see me. We had a long and, to me, a very pleasant chat. In speaking of her visit to the theater she said she was struck by the scene in which Rip meets with his daughter, and that it reminded her of the situation between Lear 


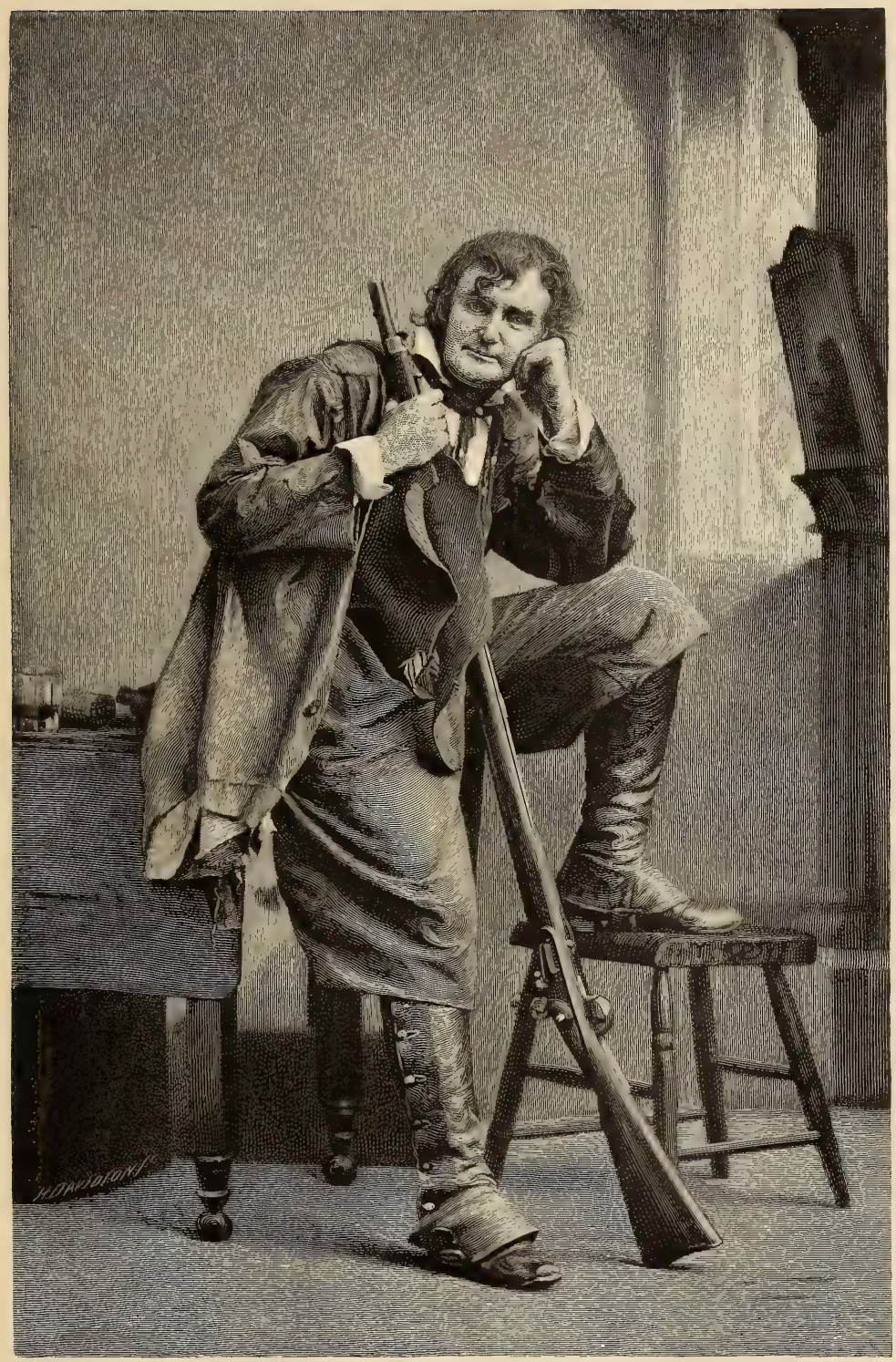

JOSEPH JEFFERSON AS "RIP VAN WINKLE." 

and Cordelia. I told her that the scene was undoubtedly modeled on the one from Shakspere, and perhaps the white hair and beard floating about the head of the old Knickerbocker had some share in this likeness. She said she was sure that I could play Lear. I was sorry to differ with a lady, but I told her I was quite sure that I could not.

Shortly after this I met another lady of equal intelligence, who seemed much interested in Rip Van Winkle. Among the many questions she asked of me was how I could act the character so often and not tire of it. I told her that I had always been strangely interested in the part, and fearing that I might eventually grow weary of it, I had of late years so arranged my seasons that I played only a few months and took long spells of rest between them, but that my great stimulus, of course, was public approval, and the knowledge that it must cease if I flagged in my interest or neglected to give my entire attention to the work while it was progressing.

"Another question, please. Why don't you have a dog in the play?"

I replied that I disliked realism in art, and realism alive, with a tail to wag at the wrong time, would be abominable.

"But don't you think that the public would like to see Schneider?"

"The public could not pay him a higher compliment, for it shows how great an interest they take in an animal that has never been exhibited. No, no; 'hold the mirror up to nature' if you like, but 
don't hold nature up - a reflection of the thing, but not the thing itself. How badly would a drunken man give an exhibition of intoxication on the stage! Who shall act a madman but one who is perfectly sane? We must not be natural but appear to be so."

"One question more, and I have done. Why do you not refuse the cup that Gretchen offers you at the end of the play?"

To which I replied: "Should $R$ ip refuse the cup the drama would become at once a temperance play. This subject has both its adherents and its opponents, and has, moreover, of late become a political question. The action would have a local and even a modern flavor. I should as soon expect to hear of Cinderella striking for high wages or of a speech on woman's rights from old Mother Hubbard as to listen to a temperance lecture from $R i p$ Van Winkle; it would take all the poetry and fairy-tale element completely out of it. I would prefer that the impression on the audience as the curtain falls should be suggestive, so that they might terminate it in a manner most agreeable to themselves. Let us not suppose in the end that Rip and his wife get ill, send for the doctor, take pills, and die, but that they sit like Darby and Joan by the fireside and eventually go up the chimney in the smoke. If "Rip Van Winkle" had been treated in a realistic manner it never would have lived so long."

What is called the moral drama is artificial and insincere, and I doubt if it ever taught a whole- 
some lesson. Mr. Gough's mission was a different one from mine. In his entertainment he announced himself as a temperance lecturer. The audience were prepared to hear and approve of his views. In my case it would be a deception to announce a play and preach a sermon, and the very people who ask for it would consider it an impertinence if it had been gratuitously offered.

The beautiful lessons contained in many of the plays of Shakspere are not thrust upon the audience. They are so delicately suggested that the listener takes the splendid truths and hugs them to his heart. The great dramatist does not stand forth and dogmatically expound his views on acting, but mark with what modesty he shows us the way to tread. One of his characters, Hamlet, has a play, and with kind consideration takes aside the actors who are to perform it and tells them how he would have his play delivered. These simple instructions, of not more than a dozen lines, contain the whole art of acting; the player need go no further for instruction; those who entangle themselves in a labyrinth of arguments over the proper or improper way of rendering plays or characters can settle all their disputes by this little speech.

Again, Polonius does not sermonize his audience. As his only son is leaving home, the youth kneels at his father's feet and asks a blessing: who would not wish that his boy should go through life freighted with such precepts? These are the lessons that Shakspere has taught us, and this 
must surely be the way to teach them. So it would seem that Shakspere, in giving his lessons to the world, is like a kind father who when his son has been guilty of a grave offense, instead of storming at him in a temper, waits until the wrong is half forgotten, and then when they are the best of friends takes the little fellow on his knee and tells him for his own sake what he would have him do.

Realism and idealism are important factors in the dramatic art. No one, I think, will question the fact that imagination has given us the highest dramatic compositions, and that it enters largely into the best form of acting; and there is a strong belief that the introduction of realism in plays of a highly poetical character often goes far to weaken their effect.

We are told by an authority that no one seems inclined to dispute that the judgments of the judicious "should outweigh a whole theater of others"; but then who are in this case the "judicious"may it not be the many instead of the few?

That manager is unquestionably the most useful who entertains the greatest number when he does not degrade them, and certainly there is no degradation in the realistic productions in question. So the matter stands just where it did; the audience must decide which it prefers, and the actor must consider how far these introductions may assist or mar his work.

It was my good fortune during the earlier part of my dramatic career to add the romantic story of "Rip Van Winkle" to my repertory, under 


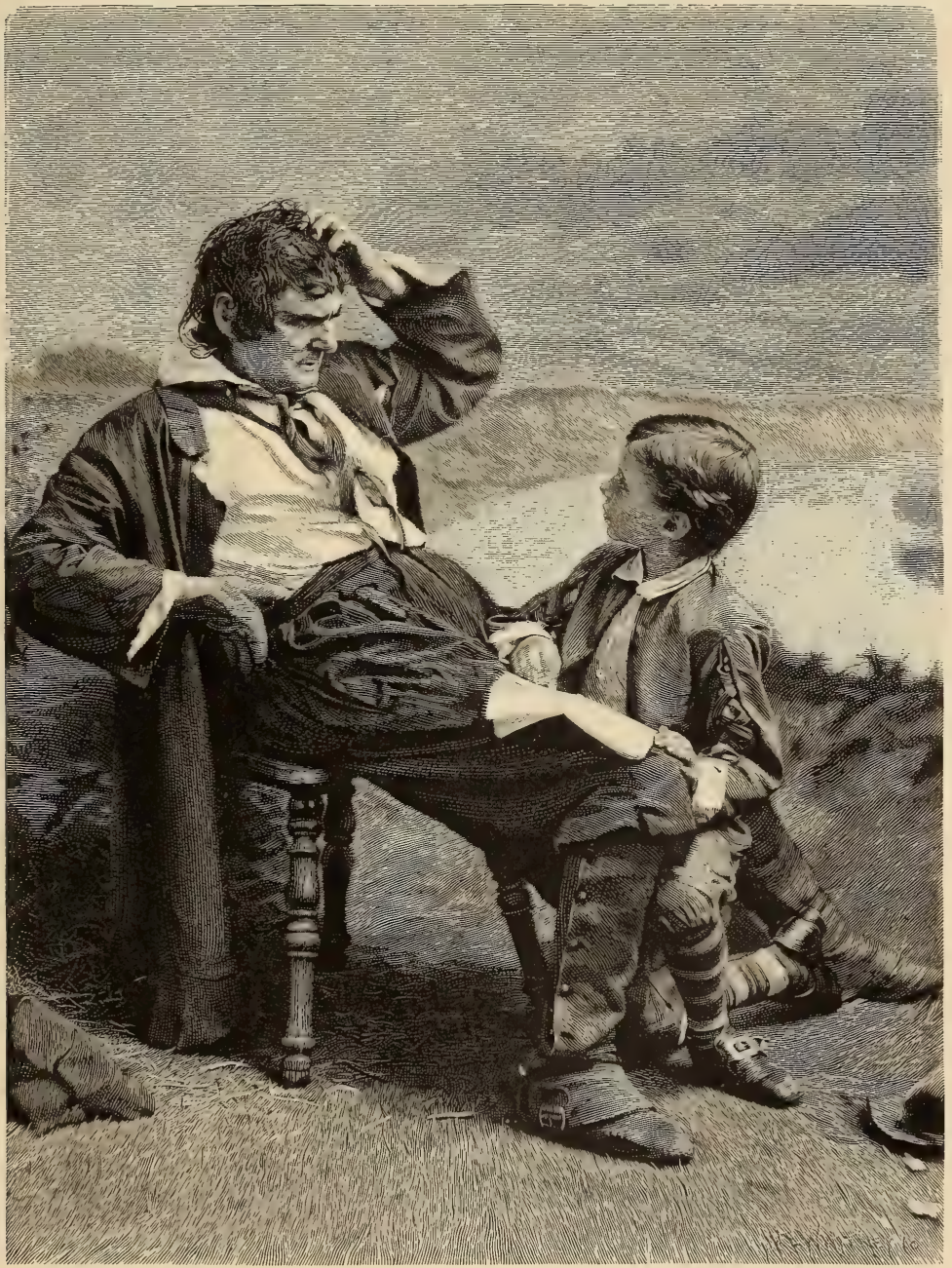

JOSEPH JEFFERSON AS "RIP VAN WINKLE." 

circumstances elsewhere related. I was attracted by the poetic nature of the legend, and endeavored to treat it in harmony with that feature. After acting it for many years I had various suggestions made to me for elaborating the spectacular and scenic effects of the play, among which were the introduction of several fat old Knickerbockers smoking their long pipes and quarreling in Dutch, a large windmill with the sails to work, dairymaids with real cows, mechanical effects for the sudden and mysterious appearance and disappearance of Hendrik Hudson's crew, and in the last act the Continental army with drums and fifes, a militia training, and the further introduction of patriotic speeches about American independence.

So unreal a theme could not have been interwoven with all this realism without marring the play. If I were a stage-manager and were producing a plain, matter-of-fact nautical drama, where the characters are mere commonplace everyday people, I would exert all my ingenuity in the invention of realistic effects. The ship should be perfectly modeled, the masts round, the sails canvas, and the coils of rope of undoubted veracity. On the village green I would place cottages built out and thatched with veritable straw, and the garlands of roses that hung from the May-pole should perfume the auditorium, if Lubin's extract of new mown hay could do the business; but I should hesitate before I placed smoking hot joints on the banquet tables of "Macbeth." It does seem out of place that the audience should have 
their nostrils saluted with the odor of baked meat while they are gazing at the awful ghost of "the blood-boltered Banquo." According to this view of the subject, realism should halt before it trenches upon or vulgarizes the effect of a poetical play.

A curious incident occurs to me that is connected with the play of "Rip Van Winkle"; let me put it down and I have done.

There is in the village of Catskill a Rip Van Winkle Club. This society did me the honor to invite me to act the character in their town. I accepted, and when I arrived was met by the worthy president and other members of the club, among whom was young Nicholas Vedder, who claimed to be a lineal descendant of the original "old Nick." Emulating the spirit of evolution, the citizens had turned the skating-rink into a theater, and a very respectable-looking establishment it made, though in its transition state the marks of rollers did "cling to it still." I was taking a cup of tea at the table in the hotel, when I was attracted to the colored waiter, who was giving a graphic and detailed account of this legend of the Catskill Mountains to one of the boarders who sat nearly opposite to me.

"Yes, sah," he continued, " Rip went up into de mountains, slep' for twenty years, and when he came back hyar in dis berry town his own folks did n't know him."

"Why," said his listener, "you don't believe the story's true?" 
"True? Ob course it is; why," pointing at me, "dat's de man."

The town was filled with farmers and their wives who had come from far and near to see the opening of the new theater, and also, I think I may say, to see for the first time on the stage the story which Washington Irving had laid almost at their very doors.

As I drove to the theater the rain came down in torrents, the thunder rolled and the lightning played around the peaks of the distant mountains under the very shadow of which I was to act the play. It gave me a very strange sensation. When I got to the theater I could scarcely get in, the crowd was so great about the door - countrymen trying to get into the ticket office instead of the proper entrance, and anxious and incredulous old ladies endeavoring to squeeze past the doorkeeper but refusing to give up their tickets. The rush over, the play began. The audience was intent on the scene as it progressed, and seemed anxious not to lose a word. During the scene in the last act where Rip inquires of the inn-keeper, "Is this the village of Falling Water?" I altered the text and substituted the correct name, "Is this the village of Catskill?" The crowded house almost held its breath. The name of the village seemed to bring the scene home to every man, woman, and child that was looking at it. From this time on the interest was at its full tension. Surely I had never seen an audience so struck with the play before. 
There was a reception held at the club after the play, and the worthy president in introducing me to the company was so nervous that he announced me as "Mr. Washington Irving."

If I dwell at length upon so old a subject as this well-worn drama it is not only because the play and its hero were important to me, but for the reason that there are incidents connected with its career from which a lesson may be drawn; and while I do not aspire to be a teacher of Art or set myself up as a Sir Oracle, or a finger-post to point out the road to dramatic success, I cannot resist the desire I have to give some of my young friends on the stage a few hints in relation to the conduct of their professional lives that may be useful even if they are dry and uninteresting.

The rules that would seem to promote success upon the stage are so shifting and at times so inscrutable that the most diligent and experienced actors often stand amazed at the disappointing results which have attended honest and intelligent labor. I have known members of the theatrical profession who, though possessed of great ability and an untiring industry, have never met with one cheering success, and I have seen novices come upon the stage knowing nothing of dramatic art and possessed of no talent whatever, startle the public and command its attention at once, and all this from the mere exhibition of youth, beauty, and confidence. This latter kind of popularity, however, is not lasting, nor does it ever revive after it has once lost its power, and here is just 


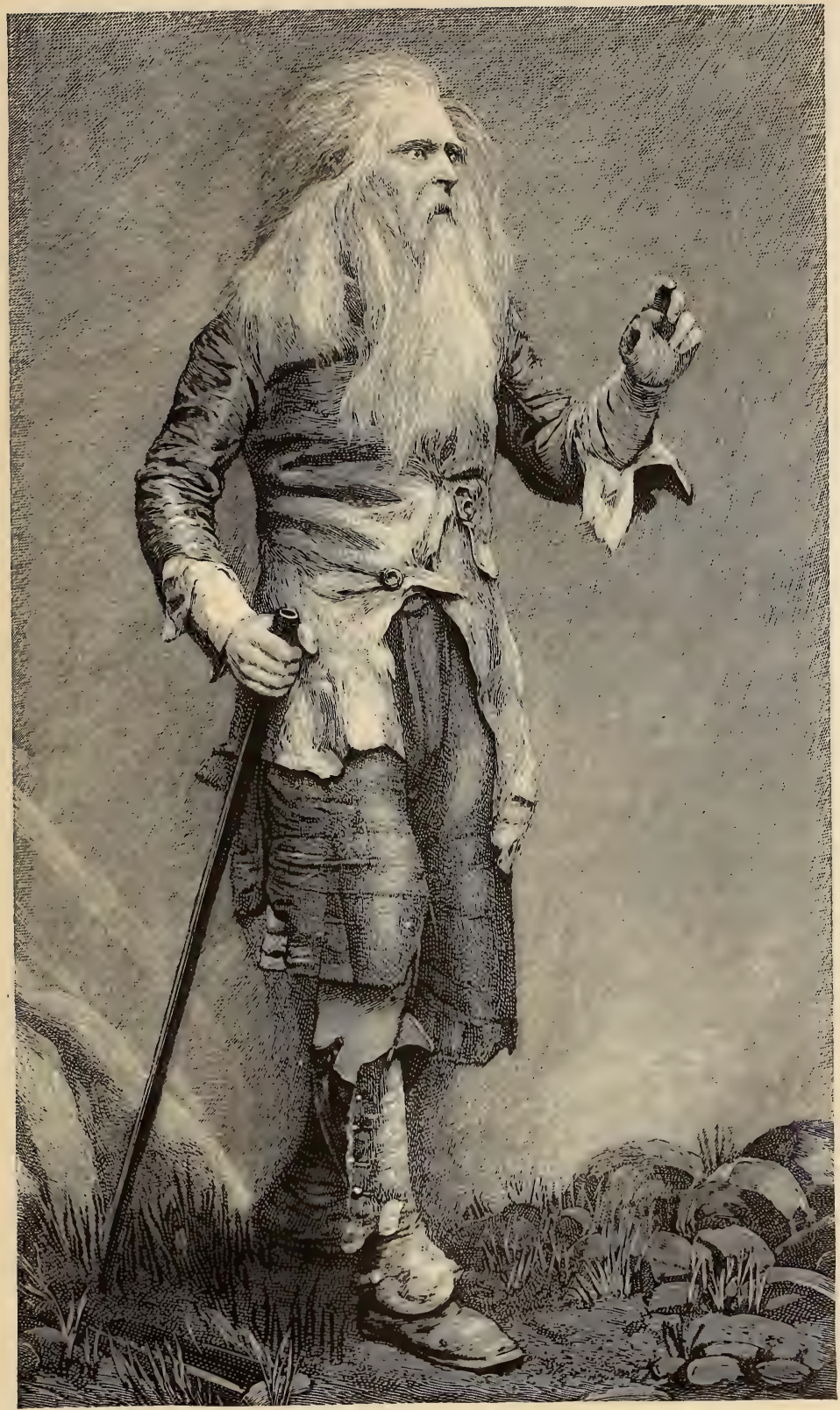

JOSEPH JEFFERSON AS "RIP VAN WINKLE." 

the point in question: an ephemeral success is worse than no success at all, for all the feverish flattery and hollow applause that may have attended it in the beginning cannot atone for the disappointment that follows upon neglect. The once petted favorite sinks under the desolation which comes from public indifference. A legitimate and well-earned success is almost perennial, if pursued by the artist to the end with the same love of his work that characterized its beginning. "Rip Van Winkle" was not a sudden success. It did not burst upon the public like a torrent. Its flow was gradual, and its source sprang from the Harz Mountains, an old German legend, called "Carl the Shepherd," being the name of the original story. The genius of Washington Irving transplanted the tale to our own Catskills. The grace with which he paints the scene, and, still more, the quaintness of the story, placed it far above the original. Yates, Hackett, and Burke had separate dramas written upon this scene and acted the hero, leaving their traditions one to the other. I now came forth, and saying, "Give me leave," set to work, using some of the beforementioned tradition, mark you. Added to this, Dion Boucicault brought his dramatic skill to bear, and by important additions made a better play and a more interesting character of the hero than had as yet been reached. This adaptation, in my turn, I interpreted and enlarged upon. It is thus evident that while I may have done much to render the character and play popular, it has not been the 
work of one mind, but both as to its narrative and its dramatic form has been often molded and by many skillful hands. So it would seem that those dramatic successes that "come like shadows, so depart," and those that are lasting, have ability for their foundation and industry for their superstructure. I speak now of the former and the present condition of the drama. What the future may bring forth it is difficult to determine. The histrionic kaleidoscope revolves more rapidly than of yore, and the fantastic shapes that it exhibits are brilliant and confusing; but under all circumstances I should be loath to believe that any conditions will render the appearance of frivolous novices more potent than the earnest design of legitimate professors.

One word on dramatic writing: On the discovery of a mysterious murder, when all are at loss as to who has committed the deed, the first thing the detective searches for is motive. If the murderer be not insane a motive must exist; and as the actions of our lives, when we are in a state of reflection and cool deliberation, spring from this cause, so must the playwright, in the construction of his plot and the action of his characters, give us motive.

Again, an audience should never be kept in the dark as to the true state of all matters connected with the play, particularly in comedy. Let the characters be deceived and entangled in a perfect labyrinth of difficulties if you will, but the audience must know just how the matter stands, or they 
cannot enjoy the confusion of the actors. For example, in "She Stoops to Conquer," when young Marlow makes love to Miss Hardcastle he thinks that she is the barmaid, but the audience know perfectly well that she is not; hence they enjoy his mistake. If they had not been let into the secret the effect would be lost ; but an "equivoke" scene, wherein both characters are deceived as to each other's identity, is the most enjoyable and requires perhaps more ingenuity in its construction than any other branch of writing in comedy. Such a scene, too, must be rendered with great skill and the most perfect seriousness; if a smile should steal over the actor's face, showing that he inwardly sees the humor of the situation, the whole effect will be lost. The bewilderment of the characters must be supreme, and as the scene progresses and they become more and more entangled, their blank looks of amazement delight the audience, who alone are in the secret. 


\title{
Chapter XVII
}

\author{
IN LOUISIANA
}

The "Pirate of the Gulf" - Pierre Landry and his Wife -Under the Live-Oaks - Conclusion

THE plantation I purchased in Louisiana was at one time the property of a prominent 1 Spaniard named Carline, to whom it had been granted when the State was under the dominion of Spain. He had made his selection with considerable judgment, as the large tract that had been ceded to him contained an island of two hundred acres, which stood at an elevation of about ninety feet above the sea, and was covered with grand live-oak and magnolia trees. When it passed from Carline it fell into the hands of an old Scotchman named Randolph, who was, from all accounts, as sagacious as the Spaniard. He added to the beauty of the island by planting it with pecan and orange trees, which were in full bearing when I purchased the place.

It is currently reported by the peasantry of this region that Captain Lafitte, who was also 
celebrated under the high-sounding title of the "Pirate of the Gulf," often visited the island. This hero's virtues have been extolled in a romantic novel, several love songs, and a bad nautical drama; and history has in some measure tried to elevate him beyond the average of mankind because he refused the overtures of General Pakenham and joined the forces of General Jackson at the battle of New Orleans. But the truth is, that the captain had plenty of money; the British bribe possessed no fascination for him, as the United States Government had set a price upon his head; and there is consequently a slight suspicion that self-preservation and not patriotism induced him to cast in his lot with America. $\mathrm{He}$ was undoubtedly a highly cultivated bucaneer; and having with care and industry amassed a large fortune by robbing his fellow-men, he retired from business in the prime of life and secluded his virtues under the shade of $\mathrm{Mr}$. Randolph's peaceful orange groves. It is said that he became so stung with remorse at the retrospect of his piratical career that he eventually atoned for his crimes by going into the slave trade. It is further hinted that the gallant captain made this place his headquarters in the summer.

The cares of piracy and slave stealing would naturally, in time, undermine the constitution of a sensitive nature, and it was therefore necessary that during the heated term - an unpleasant season for the latter business - he should require 
time for recuperation, and an opportunity to hide his treasures. It is said that he generally performed this ceremony in the moonlight assisted by his gallant band, who were sworn to secrecy, and, being men of honor, could of course be depended upon. It being a foregone conclusion that this story is true, it was natural that I should have been warmly congratulated when I became the rightful owner of all this ill-gotten gold - that is, if we ever find it. I have never looked for it myself. In the first place I have never had time, and in the next I really am afraid that I should not find it. I wish the rest of the community were as skeptical of its presence as I am, for then they would stop disfiguring the shore around the lake and digging holes under every tree upon which some mischievous fellow has cut a cross. Nothing has been discovered so far except an old long-bladed knife, of a size and shape quite convenient for pirating, and a silver dollar; but as the latter was coined in 1829 , it is quite evident that Lafitte was buried first, so it could not have been his property.

These treasure-seekers have periodical attacks of this insanity, like the same class of idiots who ruin the clam business on Long Island by digging up the shore in hopes of discovering the treasures of the late lamented Captain Kidd.

The scenery and villages along the Bayou Teche have for years been famous for their romantic beauty, and the fine islands - on one of which we live - are still a mystery to the geolo- 
gists who have examined them. Of course they all have their theories, but I fancy that they differ in their opinions. One of these beautiful spots is called Salt Island, and is owned and occupied by the Averys, a charming and hospitable family, who have lived there for many years, and who are the owners of the celebrated salt mine which the place contains. It is a weird and beautiful cavern. Arch after arch stretches far away; looking down the dark and gloomy avenues one is amazed at the inexhaustible deposit, and when it is artificially lighted up millions of crystals flash and sparkle with wondrous splendor.

Five miles from this charming place is our island. During the first eight years of our southern journeys the beaten track of commonplace travel ended at Brashear, which was then the terminus of the railroad. Here we used to get on board of a little stern-wheel boat, so small that, contrasted with the leviathan Texas steamers anchored in the bay, it looked like a toy. Our route lay westward up the Bayou Atchafalaya to where it met the Bayou Teche. This is the point where Gabriel and Evangeline are separated in Longfellow's poem.

Our passage up the Teche was extremely picturesque. The stream is narrow, and the live-oak and cypress trees stretch their branches over it till in places they fairly meet and interlock. When the darkness came on pine knots were burned in the bow of the boat, and as she steamed up the narrow river a strong light fell on the gaunt trees 
that suddenly started out of the black night like weird specters. The negro deck-hands, some bare to the waist and others in red and blue shirts, would sit in lazy groups chanting their plantation songs, keeping perfect time with the beat of the engine. It was delightful to light a pipe and sit on the deck, to look upon the novel scene and listen to these strange sounds; to feel that the season had closed, and to anticipate three months of perfect rest - no letters to write, no engagement to keep, no dreadful appointments hanging over one's head!

As I have been living here for the past eighteen winters there is naturally some curiosity among the peasantry, both white and black, as to the precise nature of my vocation. The town near us has had no theater or hall of any kind until lately, so that the only public amusements with which they are familiar have been confined to the circus.

The country people know me very well, and it is a mystery to them what I can possibly do in a "show," as they call it. I had been out duck shooting and was being paddled slowly along the bayou in a canoe by my "man Friday," a colored boy about eighteen years of age. As a rider of buck-jumping ponies he was a wonder either with or without a saddle, and the perfect ease with which he handled a canoe made him invaluable as a guide; he would dip the paddle deep into the stream and with a firm and steady hand move the boat with great speed, and yet with such skill and so silently that he made no splash or ripple in the 


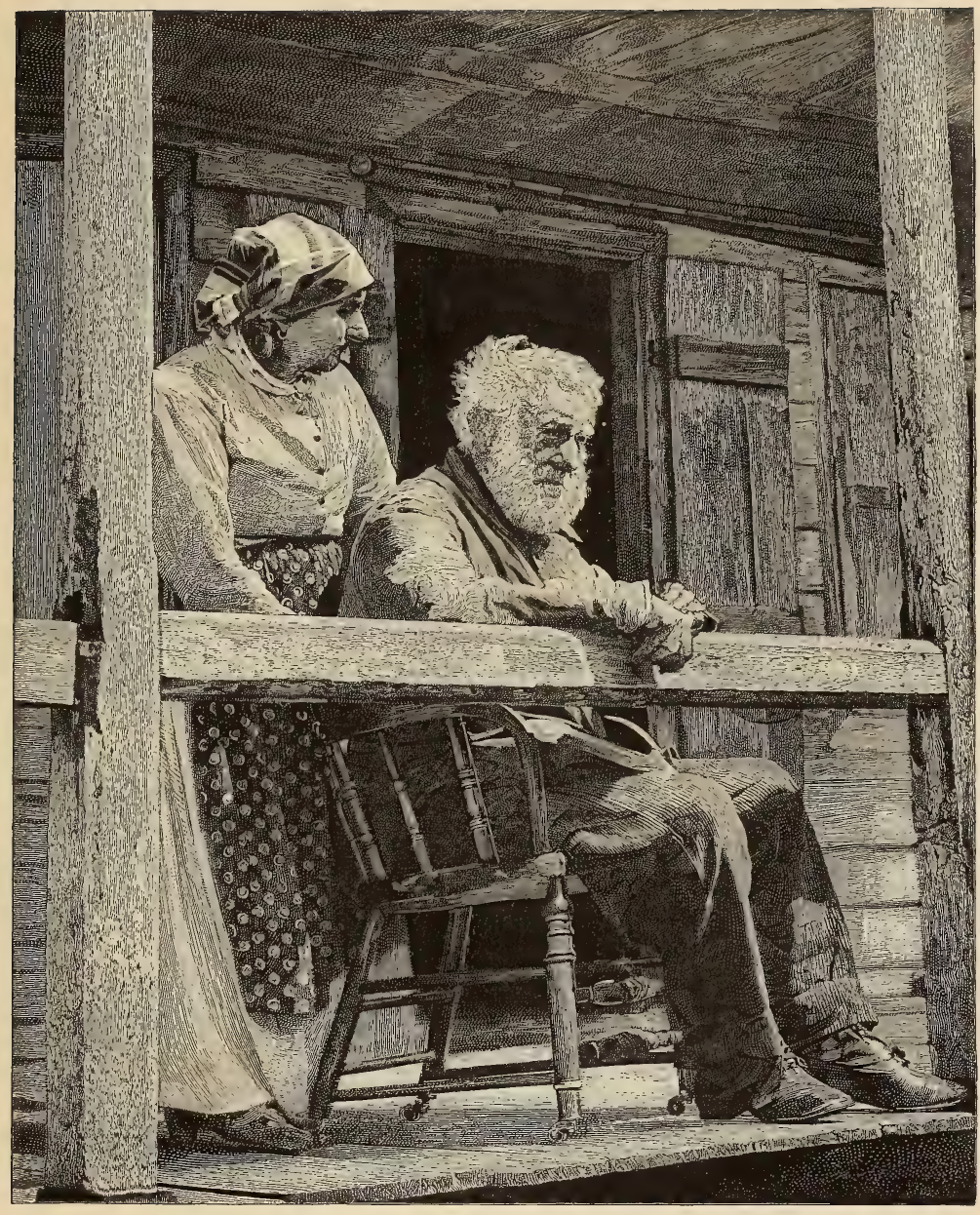

PIERRE LANDRY AND HIS WIFE. 

water. I have often sat with my back to him in the quiet of a sunset evening and listened if I could catch the slightest sound; but no; though we glided along the water like an arrow, John's paddle was quiet as a mouse.

On the excursion referred to the silence was broken by John's voice. "Mr. Joe, will you be mad if I ax you somefen?" "No, John; what is it?" There was a pause, then calling up all his courage he broke forth with a question which I have no doubt he had meditated upon and could contain no longer. "What does you do in a show?" I told him that it would be rather difficult for me to explain to him what my peculiar line of business was. "Well," said John, "does you swallow knives?" I told him that I had no talent whatever in that way. "Well, your son told me that you swallowed knives, and forks, and fire, and de Lord knows what all, and I believe he was just foolin' me." I agreed with him, saying that he was quite capable of it. "Well, dere 's one thing certain," said John; "you don't act in the circus." I asked him how he could be sure of that. Here he burst into an immoderate fit of laughter, almost tipping the canoe over in his violent mirth, "Oh, no - oh, no, sah ; you can't fool me on dat. I 've seen you get on your horse ; you ain't no circus actor."

Near our plantation lived a famed Acadian named Pierre Landry. When he was a boy he had seen Lafitte, the "Pirate of the Gulf," and many tales of this bold bucaneer were traditional in his family. I had heard much of this old man; 
and being curious to see him, set out with the intention of taking a photograph of him and his family, and of getting perhaps some interesting matter relating to Lafitte. About three miles from the entrance gate of our plantation runs the Bayou Petite Anse. Its low banks are fringed with tall, gaunt cypress trees, hung with tangled vines and drooping moss. It would have had a mysterious and even dismal look but for the few quaint little houses scattered throughout the woods; some of these are painted with faded pink wash, others are colored yellow, with blue and green windowshutters, and some are white, giving the place a more cheerful look. The little salmon-colored store and post-office is situated near a long and rambling bridge, made of cypress logs and earth embankments.

Strung along this crossing on a Sunday are to be seen from ten to a dozen negro women and children fishing in the bayou. This is a holiday for them and they are dressed in their best attire - clean blue cotton jean in various faded shades, according to the age of the material; some in deep sunbonnets, and others, generally the older branches of the family, with their heads done up in gaudy colored bandanas. Upon the western side of this bayou stands a picturesque cottage with a high gabled roof, and on its wide porch, covered with rose vines and honeysuckle, sat Pierre Landry and his wife and daughter.

The old man could not walk, and had been wheeled out in his chair to enjoy the lovely spring 
morning. He was a fine specimen of an Acadian patriarch; his complexion was of a rich brown, and his snow-white hair floated about his reverend brow. He had been for years the arbitrator in all questions of importance among his people-a grand old peacemaker, whose wisdom and justice settled the petty and important quarrels of his more irritable neighbors with unerring justice; and many misunderstandings that would have lapsed into ruinous lawsuits were arranged by him without a murmur from either plaintiffs or defendants, so that the attorney of the village looked upon him as a mortal foe, and on one occasion threatened to sue him for damages.

There was a cheerful aspect about the place: the birds were singing, the bees were buzzing amid the flowers, and the whirl of a spinning-wheel upon the porch, turned by old Landry's daughter, gave the spot a homelike look that told of love and peace. As we entered the little garden gate, Madame rose from her chair, and with rustic French politeness invited us to enter. "Entrez, monsieur," she said, in kindly tones. I told her the intention of our visit: she seemed pleased, and said, through our overseer, that she had been informed of it, and was quite ready. She then began arranging her husband, her daughter, and herself into what would have been, I am afraid, a rather stiff family group. I told her there was no hurry, and that I preferred she should take her former position, and that I would wait until some fitting picture presented itself. 
I asked the driver to tell her that my visit was not one of mere idle curiosity, but that I had heard what an interesting character her husband was, and that, as the house was so quaint and pretty, I had taken a fancy to photograph it and give the picture to some magazine for illustration, and that then they would become quite famous.

She laughed at this, and whispered something to her husband, who looked at us in a dazed and bewildered kind of way as if he did not quite understand what was going on ; she patted him cheerfully on the back and seemed quite childlike in her joy at the prospect of becoming historical. In chatting about various matters I asked if her husband were ill. "Oh, no," said she; "but old, very old - not able to walk now." And the tears came into her honest eyes. Her daughter knelt upon the steps and looked up into her father's face. "My darling husband," the wife continued; "we have been married many years. He has been all his life so good, so brave, so noble - my own dear Pierre." She laid her hand upon his shoulder, and, half-turning her head from me, looked down upon him with as much affection as she could have done upon her wedding-day. Now was the time. "Stay that way for a moment," I said - and the picture was taken.

She could scarcely believe it was over, never having seen the operation before, and wanted to look at the picture at once. I told her that she must wait, and that I would bring the picture at some future time; and so we parted. Just one 


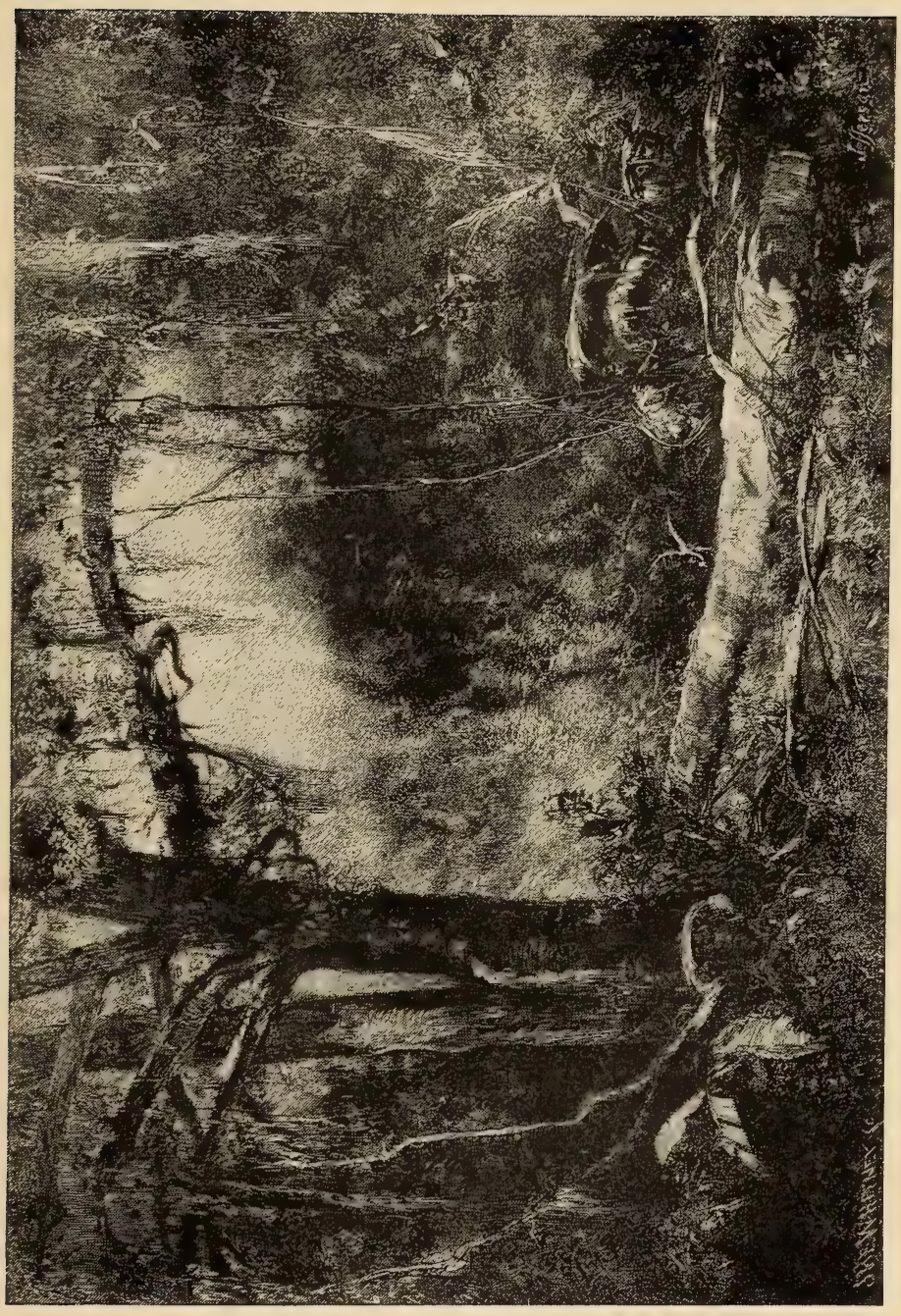



year after this my wife and I, driven by our overseer, stopped at the garden gate in front of this same cottage. How glad I was that I had taken the picture and could give it into the hands of Pierre Landry's widow; for in the mean time he had been called away to plead his own cause in another world, and if virtue and honesty be weighed in the balance there, the chances are that he has been acquitted. The place looked much the same, but there was a curious stillness about it that seemed almost sacred, or I fancied so. The roses and honeysuckles of the year before had gone, like him whose hand had reared the vines; but new ones were in their place, and old Madame Landry sat in her husband's chair upon the porch. Coming down to greet us with some flowers in her hand to give my wife - for the driver had told her we were coming - she was about to hand them when I gave her the picture. The dear old woman for a moment seemed bewildered, the freshly gathered flowers fell unheeded at her feet, and, gently kissing the likeness of her husband, she burst into tears and sank upon her knees; then clasping the picture closely to her bosom she cried out, " $\mathrm{O}$, my darling, my own, my noble Pierre! you have come back to me." My wife and I looked into each other's faces with moistened eyes, and, respecting her sacred sorrow, stepped quietly into the carriage and drove away. As I glanced back I saw the dear old woman had risen from the ground, and was tottering towards the gate. With one hand she clasped the picture 
to her heart, waving the other almost wildly overhead in an ecstasy of grief and joy.

As we passed the corner of the field the driver pointed to a mound marked by a simple cross and covered with blooming roses.

AND now I must end my life, not "with a bare bodkin," but with a harmless goose quill ; and however painful the suicide may be to me, it is a satisfaction to know that with the same blow I have put an end to the sufferings of my readers. Besides, an extended sojourn here, either in a literary or a personal state, may after all be of little moment. Seneca says, when writing to his friend Lucilius on this matter, "Life is like a play upon the stage; it signifies not how long it lasts, but how well it is acted. Die when or where you will, think only on making a good exit."

In Louisiana the live-oak is the king of the forest, and the magnolia is its queen; and there is nothing more delightful to one who is fond of the country than to sit under them on a clear, calm spring morning like this. The old limbs twine themselves in fantastic forms, the rich yellow foliage mantles the trees with a sheen of gold, and from beneath the leaves the gray moss is draped, hanging in graceful festoons and swaying slowly in the gentle air. I am listening to the merry chirp of the tuneful cardinal as he sparkles like a ruby amid the green boughs, and to the more glorious melody of the mocking-bird. Now in the distance comes the solemn cawing of two crafty crows; they 
are far apart; one sits on the high branch of a dead cypress, while his cautious mate is hidden away in some secluded spot: they jabber to each other as though they held a conference of deep importance; he on the high limb gives a croak as though he made a signal to his distant mate, and here she comes out of the dense wood and lights quite near him on the cypress branch : they sidle up to each other and lay their wise old heads together, now seeming to agree upon a plan of action: with one accord they flutter from the limb and slowly flap themselves away.

I am sitting here upon the fragment of a broken wheel ; the wood is fast decaying, and the iron cogs are rusting in their age. It is as old as I am, but will last much longer. Most likely it belonged to some old mill, and has been here in idleness through generations of the crows; it must have done good service in its day, and if it were a sentient wheel perhaps would feel the comfort in old age of having done its duty.

Over my head the gray arms of two live-oaks stretch their limbs, and looking down into the ravine I see the trees are arched as though they canopied the aisle of a cathedral; and doubtless they stood here before the builder of the mill was born. Behind a fallen tree there stands another; and on the trunk, from where I sit, I plainly see the initials of my wife's name, cut there by me on some romantic birthday many years ago. We live here still, and it is legally recorded in the archives of the parish that this place belongs to 
us; and so it does, just as it did to the man that built the mill.

And yet we are but tenants. Let us assure ourselves of this, and then it will not be so hard to make room for the new administration; for shortly the great Landlord will give us notice that our lease has expired. 
INDEX 



\section{INDEX}

Abel Murcott, Charles W. Couldock as, Adelaide, S. A., appear in, 329.

$$
\text { I94, } 197 \text {. }
$$

Acadian home, an, 470, 47I.

Acting, harmony in, 108, 109; artistic, 109, 412, 413; intense, 129, I30; combined with elocution, 153 ; compared with a picture, $157,428,429$; a model of, 355 ; reflections on, 425-463; analogy between painting, poetry, music, and, 428 ; offensiveness of careless, 429 ; thorough preparation in, 43I ; a child's, 44I, 442; a gift, 44I, 442 ; charm of, 445 .

Action, dramatic. See Dramatic action.

Actor, commercial career of a retired, 59; compared with musician, 157 , 385 ; effect of combination system on, 326-328; contrasted with painter and writer, 385 ; relations of audience and, 385 ; work of, fleeting, changeable, and ineffaceable, 428; proper preparation due to his audience, 428,429 ; should he feel a part? 439, 440 ; a tired, 445 ; how to become an, 451, 452; compared with temperance lecturer, 455 .

Actors, pursuits in hard times, 52 ; love for the theater and their vocation, 78, 237; generosity, 45, I 17, 343; personal vanity, 132; elastic spirits, 188, 189; drawbacks to health of, 320 ; capabilities on and off the stage, 342 ; extravagance of some in London, 362, 363; impulsive, 430, 431 .

Adams, Edwin, as Snake, I5I; as Pythias, $15^{8}$; career, personal appearance, and character, 322, 323; as Enoch Arden, 323; likeness to Charles Burke, 323 .
Adelphi Theater, London, "Rip Van Winkle" at, 302-310.

"Adrian and Orrilla," Mrs. Drake in, 4I5; play Cyprian Gossamer in, 415 .

Adversity, parting with old friends in, I94; sweet uses of, 449,450 .

Adulation, sorry food, 334 .

Affection, Australian maternal, 244; parental and filial contrasted, 296301.

African Sal, success in London, I05. Age, effect of, on an actor, 261, 262, $265,267,268,408,409$.

Agnew, Messrs., purchasers of Gainsborough's "Duchess of Devonshire," 367 ; their loss, 369,370 .

Ague, dramatic, I3I.

"Ajax Defying the Lightning," 6.

Alamo, fall of the, 75 .

Albatross, the, 275,276 .

Alessandro Mazzaroni, James Wallack, Sr., as, 40, 4I.

Alexander, Mr., manager of Theater Royal, Glasgow, 372 ; modesty of, 372 ; tomb, 372 .

Alfred Evelyn, scene between Clara Douglas and, 195 .

Alleghany Mountains, crossing the, $84-88$.

Allen, Mrs., I42 ; as May Fielding, 208 ; beauty of, 209.

Amateur, signs of an, 138,139 .

Ambition, ill effects of too much, I08.

American sailor and Greek pirate, I4, I5.

American Theater, New Orleans, closed, 80.

Amphitheater, Philadelphia, union of

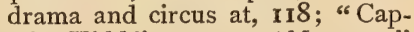
tain Kidd" at, I2I ; "Mazeppa" 
at, 123; "St. George and the Dragon" at, 125-127.

Andes, the, 292.

Andrews, George, as Sir Oliver Sur. face, $\mathbf{I} 5 \mathbf{I}$.

Animals, cruelty to, II.

"Annals of the English Stage," 402, 403.

"Antigone," at Arch Street Theater, 102; at Theater Royal, Dublin, I02; appear in the chorus, IO4.

Apple-tree, a barren, 395, 396.

Arch Street Theater, Philadelphia, managed by W. E. Burton, 57, 83, I08; take Charles Burke's place at, 88; "Antigone" at, IO2I04; "A Glance at New York" at, 105, I06; managed by Wheatley \& Drew, I49, I50.

"Arrah na Pogue," success at Princess's Theater, 3I4.

Art, devotion of French to, contrasted with their loyalty, I76, I77; combination of nature and, 208; an actor's sweetheart, 223; probable result of mingling American politics with, 352; sacred in Paris, 352; cheap better than none, 358,359 ; the handmaid of Genius, 432 ; foster-mother of, 449 .

Art and literature, powers compared with drama, 259.

Art criticism, 22, 23.

Art galleries of Paris, 355 .

Art gallery and theater compared, 429.

Artist, assistant, am billed as, 36 .

Artistic work in acting, I09, 412, 4I3.

Artists, prejudiced at hands of brethren, 423,424 .

Asa Trenchard, in character of, 194, $222,223$.

Assassins of the pen, $168,344,345$.

Assignation, a deadly, 258 .

Astley's Circus, London, I18, I24; a family party at, $3 \mathbf{1 2}$.

Astronomer, a Scotch gardener's opinion of an, 374,375 .

Audience, distracting an, I2I, I22; an aristocratic, 137 ; danger of disappointing an, I6I; a pleased, I65; insulting an, 217,218 ; a sympathetic, 259-26I ; a select, 34I, 342 ; addressing the, in acting, $352-354,430$; a delightful, 364; a rare, 379,380 ; playing to different classes of, 385 ; relations of actor and, 385 ; proper preparation by actor due to, 428, 429; virtual imprisonment of, 429; a dull, 445 ; ocular attention of, 446,447 ; observant critics, 447,448 ; judgment of the, 456 ; must possess secret of the play, 462,463 .

Australia, stock companies in, 237 ; skeleton dance, 242-244; scenery of the interior, 245 ; a strange meeting in, 246; bushrangers in, 256; reminiscences of, 273,274 .

Australian black contrasted with Charles Kean, 266, 267.

Australian station, an, 241, 242.

Author compared with actor, 428 .

Authors, extravagance of some in London, 362, 363 .

Authorship, first attempts at, 3, 4 .

Autograph-hunter, an, 4I9.

Avery family, 467 .

Badger, Edward, comedian, 67; partnership with, 68-74, 77 .

Ballarat, Victoria, appear in, 239.

Baltimore, birth of sister in, 9 ; establishment of telegraph line from Cumberland to, I I I, II2.

Baltimore Museum, become stagemanager at, $\mathbf{I} 5 \mathbf{I}$.

Bannister, Jack, 296.

Barn-storming, 54-57

Barrett, Lawrence, as The Ghost, 422.

Barron, J. M., as Sir Harry Bumper, I 5 I.

Battles: Palo Alto, 66; Resaca de la Palma, 67; Fort Brown, 67.

Bavaria, contrast of religious tone of England and United States with that of, 29I.

Bayou Atchafalaya, romance of, 467 .

Bayou Petite Anse, 470.

Bayou Teche, 466-468;

Beauséant, William Warren as, 405.

Bedford, Paul, geniality, 303, 304; as Jack Gong, 304; as Nick Vedder, 304 .

Beggar on horseback, a, 285, 286.

Beggars, conventional, 93 ; in Lima, $285,286$.

Belfast, success in, 380 .

Bellman of Castlemaine, the, 239-24I.

Bendigo, Vict., appear in, 239.

Bernardo, Herbert Kelcey as, 422.

Bertha, Sara Stevens as, 208.

Bickford, George, I 5.

Billington, Mr., opinion of "Rip Van Winkle," 304.

Birth, date of my, $\mathbf{1 4}$.

Black arts, one of the, 351 .

Blacks, Australian, sports and ceremonies of, 242-245; maternal affection among, 244 . 
Blake, Mrs., as Mrs. Fielding, 208.

Blake, William Rufus, as Malvolio, I07; personal appearance, 200, 204; friendship for, 201 ; difference with, 20I; a curious figure for Puck, 204.

"Blanche of Brandywine," produced by Laura Keene, 189-I92.

Blindness, threatened, 388 ; operation for, 388 .

Blue-gum tree, virtues of, 245 .

Bob Acres, in character of, 150 ; characteristics of, 399, 400 ; evolution of the part, 400 ; notes on scene between David and, 446, 447.

Bob Brierly, in character of, 260; sympathetic audience for, 260.

Bob Tyke, 223.

Boomerang, throwing the, 245, 266.

Booth, Agnes, 230.

Booth, Barton, apothegm on, I Io.

Booth, Edwin, as Hamlet, 422.

Booth, Junius Brutus, early recollections of, 5 ; in Mobile, $4 \mathrm{I}$; character, 4I, 43-45; versatility, 44; generosity, 45 ; imitations of, 87 , 420 ; kindness of, 129; as Sir Ciles Overreach, I29-I3I; wonderful acting, I29, I30; presence of mind and good taste, I 30 .

Booth's Theater, appear at, under Augustin Daly, 38I ; pulled down, 381,382 .

Borrower, a professional, 93-96.

Boston Indians, Buck Wallace's opinion of, 76 .

Boston Museum, William Warren's connection with, 404, 405.

Boston Theater, first engagement at, 340; Fechter at, 340; Charles Mathews's dislike of, 384 .

Bottom, Samuel Phelps as, I7I ; propose to play, 204, 205.

Boucicault, Dion, at Ford's Theater, Richmond, I57; manager at Winter Garden, 207; valuable advice from, 209-2II; difference with, 2II-2I3; rewrites "Rip Van Winkle," 302 ; feud with Webster, 303, 305-308; judgment, 304 ; temper, 304, 305; author of "The Parish Clerk," 321.

"Bounding Brothers of the Pyrenees," the, I39.

Bounty, mutiny of the, 232.

Bowie, Capt. James, inventor of th bowie knife, 75; assassination of 75.

Boxing, take lessons in, 212, 213.

Boyhood, I7 et seq.
Brashear, 467 .

Brazos Santiago, voyage from Matamoras to, 78 .

Breakfast, a coach-office, 84,85 ; soothing influences of a good, 86 .

"Brigand, The," James Wallack, Sr., in, 40, 4I.

Brogue, Rip with a "shlight taste" of the, 378 .

Brother Sam, E. A. Sothern as, 198.

Brougham, John, at Palmo's Theater, IO7; as O'Grady, 3I4; character and ability, 3I4-3I7; author of "Pocahontas," 315, 316; manager of the Lyceum, 3 I5; as Powhatan, 316; as Pocahontas, 3I7; author of "The Irish Emigrant," 411 ; dramatizer of "Dombey and Son," 436; as Captain Bunsby, 437; as Major Bagstock, 437.

Browning, Robert, meetings with, $360-$ 362 ; character and talents, 360 , $3^{6} \mathrm{I}$; lunch at Lord C_-'s with, 361,362 ; intimacy with Longfellow, 36r, 362 .

Buckstone, J. B., I 7I ; imitation of, 440, 44I; as Sir Andreze Aguecheek, 44I; as Cousin Joe, 44I.

Buffalo, I9; Harry Warren, manager at, 392 .

Bulfinch Place, Boston, suppers in the old kitchen in, 390, 407; William Warren's home in, 407 .

Bulwer, Edward, Lord Lytton, author of "Money" and "Lady of Lyons," I95.

Bunker Hill, tableau of the battle of, I90-192.

Burke, Charles, my half brother, 8; with company in Mississippi, 52, 53; engagement at Arch Street Theater, 57; invites me to Philadelphia, 83 ; meets me in Philadelphia, 88; affection, 88; joins the Bowery Theater, 88 ; at Palmo's Theater, I07; harmony in acting with Burton, I08, 109; short life of, ro9; reputation, I09; contrasted with Burton, I Io; character, style, genius, personal appearance, and domestic traits, I Io; objects to my marriage, 127; uses influence in my behalf, I28; successful comedian, 222; plays early version of "Rip Van Winkle," 226, 46I.

Burlington, Ia., 27.

Burnett, James G., joint adapter of "Blanche of Brandywine," I89; arranges a tableau, I92; our friendship, I92; character, I93; as Sir 
Anthony Absolute, 193; as Lord Duberly, 193; manager of Deagle's Theater, 382 ; plays at Baltimore Museum, 382 ; in Laura Keene's stock company, 382 .

Burns, Robert, good advice from, 375 .

Burnt-cork knight, the first, 6.

Burton, W. E., manager at Arch Street Theater, 57,83 ; married to Tom Glessing's sister, 90; prominence, 96, 97; character, style, and genius, I0o-IIo; as Captain Cuttle, IOo, 436-438; as Micawber, Ioo; as Van Dunder, Ioo; literary talents, IOI ; editor of the "Gentleman's Magazine," IOI ; fondness for lawsuits, IOI, IO2; humor on the witness stand, IO2; success with "The Naiad Queen," ro2; produces "Antigone" at Arch Street Theater, IO2-IO4; apologizes for Sophocles's non-appearance before the curtain, $\mathbf{I O}_{2}, \mathrm{IO}_{3}$; loss on "Antigone," I04; domestic happiness, I04, I05; produces "A Glance at New York" at Arch Street Theater, I05, I06; success, I06; purchases Palmo's Theater, Io6; successfully opposes Mitchell of the Olympic Theater, IO7; as Sir Toby Belch, Io7; death, I08; harmony in acting with Burke, I08, I09; contrasted with Burke, IIO; personal appearance, IIO; Chanfrau's imitations of, 420 ; reasons for failure in Captain Cuttle, 437, 438; ultimate success, 437 , 438.

Burton's Theater, "Dombey and Son " at, 436-438.

Bushrangers, origin of, 256; Morgan, 257, 258.

Butcher's lucky chops, a, 369 .

Butler, the melodramatic villain of society, 363,364 ; superiority of handmaid over, 364 .

By-play, compared to distance in picture, 446; natural, 446; proper and improper use of, $446-448$.

Byron, Henry J., dinner with Planché, Cat Mathews, and, $386,387$.

Byron, Lord, comment on a battle, I63; sentimentality of, 256 .

C- - John, character and genius of, 394, 395; marvelous experiences, 395 ; diagnoses the case of an apple-tree, 395, 396; scientific discourses curtailed, 396.
C- L Lord, lunch with, 361,362 ; simplicity of life, 362 .

Cabin windows, through the, 449 .

Cairo, Ill., 47.

Calanthe, Edwin Forrest's parting with, $158-160$.

Caleb Plummer, in character of, 208210.

California, start for, 229.

Calker, an imperturbable, 278,286 , 287.

Callao, from Melbourne to, 275, 276; arrival at, 276 ; unfortunate situation and history, 279, 280; riot in, 280, 28r ; incident in life of French consul at, 28o, 28I ; Spanish theater in, 288-29o ; religious tableau contrasted with Passion Play at OberAmmergau, 290, 29I ; leave for Panama, 293.

Calvary, the scene on, 289-29I.

Camp, a floating, 62 .

Candle-boxes, a new use for, 145 , 146.

Candor, Mrs., Kate Horn as, I5I.

Captain Absolute, 400, 401.

Captain Bunsby, John Brougham as, 437.

Captain Cuttle, W. E. Burton as, Ioo, $436-438$.

"Captain Kidd," engagement in, at Amphitheater, Philadelphia, I2I, I22.

Cardinal Wolsey, 265.

Careless, A. H. Davenport as, $\mathbf{I} 5$ I.

"Carl the Shepherd," origin of "Rip Van Winkle," 46r.

Carpenter, the opposite sex to a, $3^{87}$.

Cartlidge, John, leading man at Astley's Circus, 123; cast for The Khan at the Amphitheater, Philadelphia, I 23, 124; grief at deposition, 123, 124

Carusi's Hall, Washington, first performance of "Rip Van Winkle" at, 227-229.

Castlemaine, the bellman of, 239-24I.

"Castle Spectre," success of, I06.

Cathedral and theater by daylight compared, 284 .

Catskill, N. Y., Rip Van Winkle Club in, 458; play "Rip Van Winkle" in, 458, 459; waiter identifies me as the original Rip, 458,459 ; reception at the club, 460.

Cemetery, my early playground in New York, 15, I6.

Chambers Street Theater, New York, managed by W. E. Burton, Io8. 
Chanfrau, F. S., successful comedian, Coach-office breakfast, a, 84, 85 . 222, 420 ; personality, 420; imi- Coffin, a mystery in a, 376,377 . tations of Booth, 420; as Mose, 420. Coghlan, Rose, as The Player Queen,

Chapman company, floating theater of, 62 .

"Charcoal Sketches," I I.

Charity, a doubtful, 37 .

Charles Surface, J. E. Murdoch as, I 5 I-154; criticism of the character, I53; Charles Mathews as, I53.

Charleston, season at, I46-I49.

Charleston Hotel, description of, $\mathbf{r}_{3} 6$.

Chatham Theater, New York, engagement at, I28, I29.

Chemical Bank, New York, in panic of 1857,188 .

Chestnut Street Theater, Philadelphia, under management of John Gilbert, I49; appearance at, I49, I 50.

Chicago, rise of, I7; first visit to, 2I ; theater at, 22; married in, 323; appear in, 324 ; connection of John B. Rice with, 392, 393.

Chief Osceola, a valiant, 59 .

Childhood, my, 1-16.

Children, dramaticinstinct in, 425, 426.

Child's acting, a, 44I, 442.

Chili and Peru, war between, 293.

Chinese orchestra, a, 268, 269; value in its place, 359 .

Chinese theater, visit to a, 268-271.

Chinese tragedian, a, 270, 27 I.

Chorus, function of the Greek, 354 .

Choruses, requirement of space for, 383 .

Christ, in religious tableau at Callao, 289, 290.

Christmas tree, a theatrical, 402.

Chromos, place in education, 358 , 359.

Church, the, use of drama by, 29r. 422.

Colman, George, author of "The Heir at Law," I84.

Colonel Sellers, John T. Raymond as, $42 \mathrm{I}$.

Combination, with Windham, 324; the system discussed, 324-328.

Comedian, hiring by weight, I20; tragedian's advantage over, 220; must preserve gravity, 463 .

Comedians, two great, I08, I09; dangerous innovations by modern, I54; excellence and fault of French, 430 ; legitimate, 420.

Comedy, physical, I20; James E. Murdoch's style in light, I 53, I 54; compared with tragedy, 220, 429; fine details of, 429 ; work of the French Stage in, 429, 430; the life of, 432 ; important for audience to possess secret of, 462,463 .

Competition and opposition contrasted, ror.

Compton, Henry, I $7 \mathbf{I}$.

Conservatism, 325 .

Constable, John, nature of his work, 357.

Conventionality, violation of, 226, 423 , 424.

Cool reception, a, 297-30r.

Cooper, James Fenimore, Buck Wallace's opinion of his novels, 76; sentimentality of, 257.

Cordelia, 453.

Corot, Jean B. C., a rival to, 350 ; nature of his work, 357 ; tardy admittance to the Salon, 423, 424 .

Corrobories, Australian, 242.

Cibber, Colley, complains of degen- Costume, in Lima, 283, 292 ; increased eracy of the stage, Io6.

Cincinnati, O., Alexander Drake Couldock, Charles W., with Laura manager in, 62 .

Cincinnati Dramatic Festival, invited to produce "The Rivals" at, $3^{82}$; mishaps at, 382,383 .

Circus, union of drama with, I 18.

Clairvoyant dog, a, 252, 253.

Clara Douglas, scene between Alfred Evelyn and, 195.

"Clari, the Maid of Milan," 27.

Clarke, J. S., 420.

Clarksville, Tenn., a night at, 46 .

Classics, mastering the, I5o.

Claude Melnotte, absurd speech for, I95; Fechter as, 340.

Clergyman, life of an English, 365, 366. Keene's company, I94; as Abel Murcott, 194, 197; anecdote of Macready, 442-444.

Country management, trials and fascinations of, I I4, I I 5, I 3 I.

Courage and self-confidence contrasted, 450.

Cousin Joe, J. B. Buckstone as, 441.

Crabtree, Thomas Placide as, I5 I.

"Cricket on the Hearth, The," 208.

"Critic, The; or, A Tragedy Rehearsed," illustrations from, 435, 436,451 .

Criticism, remarkable, 87; in the dressing-room, 97; newspaper, importance to an actor, II5; one 
way of writing, 167,168 ; effect of selfishness on, 194; of acting at Théâtre Français, 352-355; dogmatism in, 358,359 ; just and unjust, 422-424; of tragedy, 429; conditions for, of French comedy, $429,430$.

Crocker, John, goes to Wilmington by schooner, I42 ; as Romeo, I45, I 46.

Crockett, Davy, 75 .

Crucifixion, tableau of the, 289-291.

Culinary odors, incongruity of ghosts and, 457,458 .

Cumberland, Md., terminus of stageroad across the Alleghanies, 88; opening of telegraph line from Baltimore to, III, II2; a good house in, II3; hard work in, II4, II5.

Cumberland River, down the, 46 .

Cushman, Charlotte, compared with Mrs. James W. Wallack, Jr., 8o ; personal appearance, career, and kindness, 4I3, 4I4; compared with Mrs. Warner, 414; as Lady Macbeth, 4I4; as Queen Catherine, 4I4; as Meg Merrilies, 414.

Cyprian Gossumer, in character of, 4 I5.

Daly, Augustin, manager of Booth's Theater, $38 \mathbf{I}$.

"Damon and Pythias," at Ford's Theater, Richmond, I 58.

Dance, Australian skeleton, 242-244. Dangle, Mr., 435, 436

Daubigny, Charles F., nature of his work, 357 .

Davenport, A. H., as Careless, 151 ; as The Stranger, 208.

David, 399; notes on scene between Bob Acres and, 446, 447.

Dawson, I. M., as Sir Benjamin Backbite, I $5 \mathbf{I}$.

Daylesford, Australia, visit a Chinese theater in, 268-27I.

Deagle's Theater, St. Louis, appear at, 382 ; under management of James Burnett, 382 .

Dean, Julia, at the Mobile Theater, I46-I48; versatility, I46; a step to fame, I47, I48; as Lady Priory, I47, I48; appearance in Charleston, I48, I49; brings success to Ellsler and myself, I48, I49.

Dean \& McKenney, managers of company in Buffalo, 19, 20.

Desertion, trial on a charge of contemplated, 97-100.
Detroit, play in, 324; form combination with Windham in, 324 .

" Devil and Little Mike, The," 19.

Devlin, Mary, as Maria, I5I.

Dialogue, effect of action compared with, 214,215 ; decline in public favor, 396; supplemented by action, $435,436$.

Diaz, N. V., nature of his work, 357 .

Dickens, Charles, Burton's portrayal of his characters, Ioo; author of "The Cricket on the Hearth," 208.

Dieppe, $\mathbf{1} 72$.

Discipline of a theater, I98-200.

Distance in picture compared to byplay in acting, 446 .

Doctor Ollapod, his harmless prescription, 97 ; in character of, $\mathbf{I} 50$.

Doctor Pangloss, in character of, 150 , 184.

Dog, an intelligent, 246-253, 255; absence of, in "Rip Van Winkle," 453.

Dogberry, wisdom of, I16, 359.

"Dombey and Son," at Burton's Theater, 436-438; reconstruction of, 437 .

Don, Sir William, first meeting with, I33-136; engagement of, I35; in "Used Up" and "The Rough Diamond," I36; stage fright, I37, I 38 ; engagement a financial success, 138; character of his acting, 138, 139; unappreciated at Wilmington, r39; animal spirits of, 139; in "The Bounding Brothers of the Pyrenees," I39; in "The Sprite of the Silver Shower," I39; letters from, I40, I4I ; criticized in Boston, 140; in Ludlow Street jail, I40, I4I.

Don Casar de Bazan, James Wallack, Sr., as, $4 \mathrm{I}$; Fechter as, 340.

Doran, John, "Annals of the English Stage," 402, 403.

"Dot," at Winter Garden, 208, 209.

Dot, Agnes Robertson as, 208.

Drake, Alexander, manager in Louisville and Cincinnati, 62.

Drake, Mrs. A., personal characteristics and ability, 4I5, 416, 418; in "Adrian and Orrilla," 415; letters relating to, 4I5-4I8; as Widow Cheerly, 4I6; as Mary, 4I6; Mrs. Trollope's opinion of, 416; Duke of Saxe-Weimar's opinion of, 416 ; letter from John Howard Payne to, 417,418 ; ludicrous incident in Louisville, $418-420$. 
Drama, a rustic patron of the, 55; union of circus with, II 8 ; power of the, 259-26I; used by early Church, 29r ; character of moral, 454,455 ; what will be the future of the? 462 .

Dramatic action, definition of, 185I87; distinguished from pantomime, 185-187; effect of, in comedy, 185, 186 ; in “ Macbeth," I86, I87; preferable to words, I85-I 87 ; compared with dialogue, $214,215$.

Dramatic ague, I3I.

Dramatic author, duties as to rehearsal, 433 .

Dramatic company, likened to a machine, I55, I56; to a piece of mosaic, I 56 .

Dramatic effects, way to attain the best, ro8, rog.

Dramatic instinct, 425-427.

Dramatic picture, stepping out of the, 354.

Dramatic scene spoiled, a, 297-30I.

Dramatic success, hints on, $460-462$; ephemeral and legitimate contrasted, 460, 46I ; foundation and superstructure of, 462 .

Dramatic writing, importance of motive in, 462 .

Drew, John, as The Emigrant, 4II, 4I2; plays in Richmond, Va., 412; as Handy Andy, 412; as O'Flanaghan, 412; ability, 412, 4I3; as Sir Lucius O' Trigger, 4I3; compared with Tyrone Power, 4I3; versatility, 413.

Drew, Mrs. John, 412 ; as Mrs. Malaprop, 400, 40I ; success of, 400, 40I; as Lydia Languish, 413.

Drop curtain, a wonderful, 22.

Drumming in Vicksburg, 52.

Drunkard, a reformed, 248-255.

Drury Lane Theater, London, Macready's Shaksperean revivals at, I54; "The Gladiator" at, 165, I66; mishaps in performance of "Macbeth," 3I8, 3I9.

Dublin, play at Gaiety Theater, 377 , 378 ; poor success, $377,378,380$.

Dubuque, Ia., good season at, 27.

Duchess, The, 198, 204.

Duchess of Devonshire, Gainsborough's portrait of, 367,369 ; a good canvasser, 369 ; kissing the butcher, 369 ; theft of the portrait, 369,370 .

Duck, Mrs., 420.

Duck-shooting on the Cumberland Fair play, 344. River, 46.
Duke of Gloucester, James W. Wallack, Jr., as, 79-8r.

Duncan, 186.

Dunedin, N. Z., horrors of the coast, $27 \mathrm{I}$.

Dusty Bob, success in London, 105.

"Dutch Governor, The," W. E. Burton in, 100.

Dying Gladiator, The, 6.

Dyspepsia, treatment for, 212 ; a cure for, $309,310$.

Earliest appearances, my, 3, 5-8.

Eavesdroppers, 97, 98.

Economy, practising, I4I ; a passion in Paris, 175.

Editor, an old-time, 328-331.

Education, place of chromos in, 358,359.

Edwards, Harry, as The Priest, 422.

Ellis, Mr., as Rowley, I5I.

Elliston, Robert W., 296.

Ellsler, John, partnership with, I3II49.

Elocution, combined with fine acting, I53; study of, 448 .

Emigrant, The, John Drew as, 4II, 412.

Emulation and imitation contrasted, I 52, 153 .

England, America's first dramatic challenge to, I65; sail for, I7I; contrasted with France, I 72 ; religious tone of Bavaria contrasted with that of, 29I; reception of American actors in, 344, 345 .

English drama, love scenes in, 195.

English people, loyalty of, 26I.

Enoch Arden, Edwin Adams as, 323.

Enthusiasm, professional, 308, 309; influence of, as compared with money, 433.

Equestrian drama, 122.

Equivoke scene, enjoyability of an, 463 .

Erie, Lake, 20.

Erie Canal, traveling on the, $\mathbf{I} 8$.

Error, a popular dramatic, $\mathbf{1 8 4}$.

Ethics of the stage, 199-203.

Eucalyptus, virtues of, 245 .

Europe, first visit to, I 7I-I82.

Evangeline and Gabriel, parting of, 467.

Execution, enlarging the, 384,385 .

Exit, importance of making a good, 474 .

Extravagance, sad results of, 334-336.

Eye, growing preference for appeals to the, 396,397 .

Fairyland, a dramatic, I 77-182. 
Fairy Star, The, $\mathbf{5} 57$.

Falling Water, identifying with Catskill, 459.

Fame, 277; on the road to, 225.

Family reunion, a, 3 II, 3 I2.

Fandango, a, 287, 288.

Farmers as patrons of the drama, 5557.

Farren, William, 155.

Fechter, Charles, meeting with, 340 ; plays at Boston Theater, 340 ; as Claude Melnotle, 340 ; as Don Casar de Bazan, 340; friendship with William Warren, 340, 34I ; plays to a select audience, $34 \mathrm{I}$; personal qualities and talents, 34I-343; imitation of Lemaître as Belphégor, $34 \mathrm{I}$; resemblance to Garrick, 342 ; failures as manager, 342; generosity of, 342,343 ; retirement from Globe Theater, 342, 343; benefit, and disposition of its funds, 343 ; cup presented to, its fate and rescue, 343,344 ; in the Bulfinch Place kitchen, 407 .

Feeling a part, $439,440$.

Fielding, Mrs., Mrs. Blake as, 208.

Fields, Mr. and Mrs. James T., at a memorable feast, $407,408$.

Fifth Avenue Theater, New York, $3^{8}{ }_{3}$.

Fight, a Paris, I 74, I 75.

First Actor, Joseph Wheelock as, 422.

First Gravedigger, in character of, 422 .

First love, my, 73.

First night's audience, nature of, $\mathbf{1} 65$.

Fitzgerald, Percy, author of "Romance of the English Stage," 450; story of Edmund Kean, 450.

Flatboat, down the Cumberland River on $\mathrm{a}, 46$.

Flattery, effect of, 350 .

Fletcher, John, 6.

Florence, W. J., 222, 420; as Second Gravedigger, 422.

Florence Dombey, 438.

Florida, murder of actors by Indians in, 60 .

Fly, the spider and the, $35 \mathbf{I}$.

Flying artillery in Mexican War, 66.

Fool, The, Placide as, Io7.

Foote, Sam, character of his work, 22 I.

Forbes, William C., company attacked by Indians in Florida, 60.

Ford, John T., I 57.

Ford's Theater, Richmond, become manager at, I57; "The Sea of Ice " at, I 57; "The Naiad Queen" at, I57; "Damon and Pythias" at, 158 .
Forrest, Edwin, imitations of, 87, 420 ; at Ford's Theater, Richmond, I57I6o; personal appearance, acting, and character, I 57-I 70; as Jack Cade, I57; as Virginius, I57; as Metamora, I60; laughable mishap at rehearsal, I58-160; series of mishaps in Metamora, I60-165; my ultimatum to, I6I; career in London, 165-167; appearance in "The Gladiator," 165; second visit to England, I66; jealousy of. Macready, 166, I67; as Cthello, I67; as King Lear, 167; as Hamlet, I67; attempted persecution of, I67, I68; violent temper, I68; generosity, I68; decline, I68-I 70; quarrel with John B. Rice, 394 .

Forrest and Macready riots, 344 .

Forrest Home, the, 168.

Forster, John, English dramatic critic, I66.

Fort Brown, bombardment of, 67 .

Fortune, guarding a, I I3, I I4.

Foster, Charles, as Mazeppa, I23; as St. George, 125, 126.

Foster, Joseph, stage-manager at Philadelphia Amphitheater, II8; career and abilities, II8, I19, I22, I23; gives me an engagement, II9, I20.

Foster-mother, my, 8-Io.

Fox, Charles James, an eager canvasser for, 369 .

"Fra Diavolo," 294.

France, first visit to, I72; contrasted with England, I72; spend summer in, 345 ; contrasted with United States, 352.

Francisco, Frank Mordaunt as, 422.

Frank Oatland, 223.

French and Spanish women contrasted, 283.

French comedians, glaring fault in, 430.

French comedy, I79, I80, 429, 430; conditions for criticism of, 429 , 430.

French consul at Callao, incident in life of, 280, 28I.

French drama, love scenes in, 195.

French loyalty and art contrasted, I 76 , I 77 .

French teacher, our, 346, 347 .

French thrift, 37,38 .

Frith, W. P., invitation from, 367 .

Funeral, a midnight, 284 .

Fungi mortem, the deadly apple-tree disease, 396 .

Furnished houses, drawbacks in hiring, 350-352. 
Gabriel and Evangeline, parting of, 467.

Gaiety Theater, Dublin, play with poor success at, $377,378,38$.

Gainsborough, Thomas, portrait of Duchess of Devonshire, 367,369 , 370 ; "Going to the Spring," 368 ; portrait of Garrick, 368 ; other paintings, 368 .

Galena, Ill., 24; perilous journey to Dubuque from, 25 .

Gallatin to Lebanon, walking from, 45 .

Galveston, Tex., engagement in, 57 ; feeling about Mexican War in, 65 .

Gambling in Lima, 293.

"Gamester, The," in Charles Kean's repertory, 264; criticized, 264, 265.

"Gamin de Paris, Le," in a Chinese theater, 269.

Gardener, an old Scotch, 373-375.

Garrick, David, contemporary of Foote, 22I ; resemblance of Fechter to, 342 ; portrait at the Garrick Club, 362 ; portrait by Gainsborough, 368 ; criticized by Quin, 423 .

Garrick Club, London, pictures at, 362.

Generosity compared with caution, 35.

Genius, 432, 450, 45I ; Art the handmaid of, 432 ; compared with talent, 432 ; source of, $45 \mathrm{I}$.

"Gentleman's Magazine, The," edited by W. E. Burton, IOI ; contributed to by Poe, IOI.

Germon, Jane, as Lady Sneerwell, I 5 I.

Gesticulation, study of, 448 .

Ghost, The, Lawrence Barrett as, 422.

Ghosts, incongruity of culinary odors and, 457,458 .

Gilbert, John, manager of Chestnut Street Theater, 149; criticism on my changes in "The Rivals," 402 ; at William Warren's grave, 409; as Polonius, 422.

"Gilded Age, The," John T. Raymond in, $42 \mathrm{I}$.

"Gladiator, The," Edwin Forrest in, 165.

"Glance at New York, A," at Arch Guying, 215-220. Street Theater, 105, 106.

Glasgow, appear at Theater Royal, Hackett, James H., in New Orleans, 372.

Glavis, 46.

Glen Cove, W. E. Burton builds country house at, ro8.

Glessing, Tom, scenic artist at Arch Street Theater, 88-93; our friend- ship, 88-9o, 332 ; adventure with an Indian, 91, 92 ; rehearsing a speech, 9I-93; re-meeting with, $33 \mathrm{I}$; his roses, 33I ; ingenuity, mechanical and argumental, 33I, 332.

Globe Theater, Boston, Fechter's retirement from, 342 , 343 .

"Going to the Spring," picture by Gainsborough, 368 .

Goldfinch, in character of, 224.

Goldsmith, Oliver, works of, sometimes overshadowed by inferior plays, I06; Robertson's estimate of, 3 I8.

Golightly, Mr., criticism of the character, 153 .

"Good Old Days of Adam and Eve, The," 87.

Goose, Mrs., 420.

Gough, John B., his mission contrasted with mine, 455 .

Grand Gulf, Miss., experiences in, 52.

Grand Opera, Paris, I 76 .

Grand operas, requirement of space for, 383 .

Grand Spanish Saloon, Matamoras, in refreshment business in, 68; murder in, 76,77 .

Greek pirate and American sailor, I4, I5.

Greek tragedy, W. E. Burton's predilection for, I02, I04.

Greenroom, early recollections of the, 4,5 ; a perfect gem, 23 .

Gregory, Dr. John, 373 .

Gregory mansion, 373-375; celebrities entertained in, 374 .

Gregory, Miss, 373; favorite parrot, 377.

Gretchen, 454 .

Guide, a Paris, I76-179, I81, I82 ; a misleading, $360,36 \mathbf{I}$; an invaluable, 468,469 .

Guildenstern, Lawrence Hanley as, 422.

Gunn, John, 377.

Gunn, Michael, 377 ; suggests making Rip Van Winkle an Irishman, 378.

Hackett, James H., in New Orleans,
48; defects in his acting, I38; a successful comedian, 222; plays early version of "Rip Van Winkle," 226, 46I.

Hamlet, 445; Edwin Forrest as, 167; an Australian manager's opinion 
of, 236; adapted for large theaters, Hotels, playing in, 54, 42.7 .

383 ; Edwin Booth as, 422 ; sim- Houston, Tex.,playing in, 57 ; " Richplicity of instructions to the Players, 455 .

"Hamlet," a finer play than, 316; Lester Wallack testimonial, 422.

Hancock, Gen. W. S., dine with, 329

Handy Andy, John Drew as, 4I2.

Hanford, Charles, as Rosencrantz, Iago, 220. 422 .

Hanley, Lawrence, as Guildenstern, 422.

Hardcastle, Miss, 463 . ard III." in, 62-65.

Howard Athenæum, Boston, in stock company at, 406 .

Howe, J. B., as Trip, 151.

Huron, Lake, sunset on, 20.

Ichabod Crane, John T. Raymond as, 421.

Harmony, in acting, 108, I09; im- Illustration, increase of, in magazines portance in works of art, 156 .

Hartz Mountains, source of legend of Imagination, fertile, II, I2 ; influence "Rip Van Winkle," $46 \mathbf{r}$.

Havana cigars made in Vicksburg, Imitation and emulation contrasted, 52.

Haymarket Theater, London, J. E. Imitators, $87,420,440$; anecdote of Murdoch at, 153, 154; Tyrone Power at, 22I.

Haymarket Theater, Melbourne, 239; appear at, 259.

Heart and head in acting, 439.
"Heir at Law, The," at Chestnut Indianapolis, Tom Glessing's cottage Street Theater, I50; at Laura Keene's Theater, 184.

“Henry IV.," 22 I.

Hercules and the Lion, 6.

Hidden treasure, 466.

Highland castle, a, 370 .

High life in the country, $370,37 \mathbf{I}$.

Hill, George H., 222.

Hill, Barton, as Lord Lovell, $\mathbf{1} 3$.

Hissing, decline of, 49,50; rare in America, 218.

Hobart Town, Tasmania, "The Ticketof-Leave Man" in, 259-26I; a sympathetic audience, 259-261 ; triumphant success in, 260 .

Hogarth, William, artificiality of characters, 398.

Holcroft, Thomas, author of "The Road to Ruin," 224.

Holland, George, 336 ; friendship with, 337-340; character and practical jokes, 337,338 ; death and funeral of, $33^{8}-340$.

Holmes, Oliver Wendell, at a memorable feast, 407,408 .

Holt, Clarence, manager of Dunedin Theater, $27 \mathrm{I}$.

"Home, Sweet Home," under difficulties, 27.

Hope, 35,336 .

Horatio, John A. Lane as, 422.

Horn, Kate, as Mrs. Candor, I 5 I.

Horsemanship, a ludicrous exhibition of poor, $125-127$.

Buckstone, 440, 44I.

"Independence Day," Mrs. Barney Williams's song, 4IO.

Indian, Tom Glessing's adventure with an, 9I, 92.

$$
\text { at, 331, } 332 \text {. }
$$

Indians, the stage variety contrasted with the genuine, 59; murder actors in Florida, 60 ; in the toggery of the legitimate drama, 60 ; hung for murder, 60 ; their respect for the drama distrusted, 60; theatrical weapons against, $6 \mathbf{I}$; murder Buck Wallace's wife and child, 75; Wallace's opinion of "Boston Indians," 76; how to deal with, 92 ; Cooper's erroneous description of, 257.

Industry the superstructure of dramatic success, 462 .

Informers, theatrical, 97,98 .

Ingenuity, dramatic, 186,463 .

Inspiration, 43I, 432 .

Instinct, dramatic, $425-427$.

Instruction in the dramatic art, 448 , 449.

Interest in character, importance of actor feeling, 442-445.

Introductions (interpolations), actor's right to make, 184 ; in "The $\mathrm{Ri}$ vals," 4 or.

Intuition, 432 .

Inventors, fate of, I I 2, 326 .

Investments, dubious, 393, 394.

Ireland, Joseph N., "Records of the New York Stage," I4.

Irish blood, an attribute of, ror.

" Irish Emigrant, The," John Drew in, 4I I, 4I 2 . 
Irish servant girl, Barney Williams's, 4 II.

"Iron Chest, The," 44.

Irving, Washington, "Life and Letters of," 224; am complimented by, 225; "The Sketch Book," 225; "Rip Van Winkle," 225; letter to John Miller, 4I5, 4I6; author of "Wolfert's Roost," 421 ; am introduced as, 460 ; exaltation of "Carl the Shepherd" into " Rip Van Winkle," $46 \mathbf{r}$.

Itinerant actor, hopeful disposition of, 57.

Itinerant theatricals, pleasures of, II I. Ivy, beauty and ill effects of, 375 .

Jack Cade, Edwin Forrest as, 157.

Jack Gong, Paul Bedford as, 304 .

Jarrett, Henry C., the railroad manager, 15I; produces "The School for Scandal " in Washington, 15 I, $152,154-156$.

Jealousy, sometimes useful, 82 ; professional, I I6-II 8, 2 I1, 447 .

Jefferson, Joseph (my father), hopeful nature, 17 ; death, 36 .

Jefferson, Margaret C., death of, 229.

Jefferson, Sarah, sickness of, 376 .

Jefferson, Cornelia F. T., as Clari, 27; keeps boarding-house, 37 ; vicissitudes in life of, 54 ; death, II8.

Jefferson, Cornelia, acts as bridesmaid at my wedding, 128.

Jefferson, Lieut. Frank, commander of Queen Victoria's yacht, 310.

Jefferson, Rev. Joseph, visit from, 364-367.

Jefferson, Tom, letter from, and hospitality of, 3 IO, 3 II .

Jefferson features, 365 .

Jem Baggs, 103.

"Jim Crow," 6-8.

Job Thornberry, 223.

John, my Man Friday, 469.

John Bull, a little, 366 .

John Peerybingle, Harry Pearson as, 208.

Johnson, T. B., as Tackleton, 208.

Joke, a cruel, 39I, 392.

Joseph Surface, J. W. Wallack, Jr., as, I 5 I.

Juliet, 265 ; playing under difficulties, $145,146$.

"Julius Cæsar," mishaps in, at Cincinnati Dramatic Festival, 383 .

\section{Katrina, $42 \mathrm{I}$.}

Kean, Charles, in New Orleans, 47, 48 ; in the English colonies, 261; success of, 26I ; effects of age on, $261,262,265,267,268$; character, 265-268; comment on the boomerang, 266; contrasted with Australian black, 266, 267.

Kean, Mrs. Charles, in New Orleans, 48 ; in the English colonies, $26 \mathbf{1}$, $262,265,267,268$; character, 267 , 268.

Kean, Edmund, as Richard III. drawing of, 205, 206; offends the Kembles, 423 ; early trials of, 449 , $45^{\circ}$; success on first appearance in London, 450, $45 \mathrm{I}$.

Keene, Laura, opens theater in New York, 183 ; engages me for leading comedy, 183 ; judgment in regard to plays, 184, 185; ability and industry, 187, I89-I9I, 205; produces "Splendid Misery," 189; produces "Blanche of Brandywine," I89-192; earlier experience, 190; arranging a tableau, 190-192; produces "Our American Cousin," I93; her diamonds, 194; in "Our American Cousin," 197 ; misunderstandings with, 198-200, 202-204; produces "A Midsummer Night's Dream," 203-205; as Puck, 204; last days of, 205 ; parting gifts from, 205, 206; death, 206; personal appearance, versatility, and character, 206; in "The Sea of Ice," 206.

Kelcey, Herbert, as Bernardo, 422.

Kellogg, Gertrude, as The Queen, 422.

Kemble, Charles, traces of his school of acting, I52; as Mercutio, I54.

Kemble, Fanny, early recollections of, 5 .

Khan, The, John Cartlidge cast for, I23, 124 .

Kidd, Captain, 466.

" Kidd, Captain," at the Amphitheater, Philadelphia, I21, I22.

Killmist, Mr., offers me place at Washington Theater, 97; theater burned, roo.

King, the mimic before the real, $43^{\circ}$.

King Claudius, Frank Mayo as, 422.

King Lear, Edwin Forrest as, 167; Samuel Phelps as, I7I ; compared with Rip Van Winkle, 452, 453.

Kingsley, Charles, meeting with, 360.

"Kiss in the Dark, A," at St. Charles Theater, 79.

Koehler, Charles, as Osric, 422. 
Lady Anne, warned to beware of a bigamist, 64 .

Lady Macbeth, 220, 265 ; Charlotte Cushman as, 4I4.

"Lady of Lyons, The," at Clarksville, Tenn., 46 ; in Mississippi, 56 ; love scenes in, I95; William Warren in, 405.

Lady Priory, Julia Dean as, I47, I48.

Lady Sneerwell, Jane Germon as, I 5 I.

Lady Teazle, 398; Lizzie Weston as, I5I.

Laertes, Eben Plympton as, 422.

Lafitte, Captain, buccaneer and slavetrader, 464-466, 469; at battle of New Orleans, 465 .

"L'Ami Fritz," at the Théatre Français, 353 .

Land, Agnes, 230.

Landry, Pierre, an Acadian patriarch, 469-474; as peacemaker, 47I ; grave of, 474 .

Landscape painting, French school of, 356,357 ; difficulties of, 356,357 ; secret of, 356,357 .

Landslip, a great, $279,280$.

Lane, John A., as Horatio, 422.

Language and action compared, 2 I4, 215.

Laughter a cure for dyspepsia, 309, 3 I0

Laurel wreath, pleasure and pain with a, 408 .

Lawsuit, exhilarating effects of a threatened, 99.

Lawyer meets his match, I02.

Lawyers, dramatic wiles of, 426.

Legitimate comedians, 420.

Lemaître, Frederic, Fechter's admiration for, $34 \mathrm{I}$; imitation of, 34I, 342.

Lepard, George, I89.

Le Vert, Madame, 38-40.

Levick, Milnes, as Second Actor, 422.

Lewis, Monk, author of "Castle Spectre," Ic6.

"Life in London," I05.

Likeness, family, 310, 3 II.

Lima, Peru, visit to, 28I-293; sewerage, 281,282 ; beauty of ladies, 282,283 ; cavaliers, 282,283 ; use of gas, 282 ; theater, 282 ; manners and customs of the theater, 283 , 284 ; costume, 283,292 ; the Grand Plaza, 284; the cathedral, 284, 285 ; beggars, 285,286 ; lack of rain, 29I ; scenery, 29I-293 ; gambling, -293.

Lincoln, Abraham, in defense of the drama, 30.

Lion-hunter, a female, 4 I9.
Listeners, the usual fate of, 306 .

Literature and art, powers compared with drama, 259.

Lithographs, early use of, 236, 237.

Little Church Around the Corner, christening the, 340 .

Littleton Coke, criticism of the character, $\mathbf{1 5 3}$.

Liverpool, appear in, $32 \mathrm{I}$.

" Living Statues, The," 6.

London, first visit to, I7I ; arrive in, 301 ; settle in, 303 ; first appearance in, 3Io; remarkable effects of its atmosphere, $3 \mathbf{I}$; pleasant society in, $3 \mathbf{I} 3$; reception of American actors in, 344-345; revisit in 1875, 345; engagement with $\mathrm{Mr}$. Chatterton, 345 ; letting furnished houses in, 35I, 352 ; return from Paris to, 359 ; play long engagement at Princess's Theater, 359 ; dinner-giving in, 359,360 ; clubs of, 362 ; critical society of, 363 ; live on Belsize Avenue, 364 .

Longfellow, Henry Wadsworth, intimacy with Browning, 36r, 362 ; kindness of, 362 ; at a memorable feast, 407, 408; scene from " Evangeline," 467 .

Lord Burleigh, 435, 436.

Lord Duberly, James G. Burnett as, I93.

Lord Dundreary, Sothern's early dread of the character, 194; Sothern as, 197, 198.

Lord Lovell, Barton Hill as, 130.

Louisiana, my plantation in, 393, 464476.

Louisville, Alexander Drake manager in, 62 ; meet George D. Prentice in, 328 .

"Louis XI.," a private rehearsal in a public place, 263; in Charles Kean's repertory, 265.

Love scenes, general weakness of dramatic, I95; English and French compared, I95; Sardou's, I95 ; Bulwer's, I95; " Romeo and Juliet," I95.

Loving couple, a, 364-367.

Loyalty, of French contrasted with their devotion to art, I76, I77; of English people, 26r.

Lucilius, Seneca's advice to, 474.

Ludlow \& Smith, managers of St. Charles Theater, 47, 79; theatrical partnership, II 5 ; managers of Mobile Theater, I46.

Ludlow Street Jail, Sir William Don in, 140; an invitation to, I4I. 
Lunatic asylum, a floating, 47 .

Lutz, John, recognizes merits of "Our American Cousin," I93; manager for Laura Keene, 204.

Lyceum, New York, under management of Brougham, 315; under James Wallack, 315.

Lyceum Theater, London, Fechter's failure at, 342 .

Lydia Languish, Mrs. John Drew as, 413.

McAllister, keeper of billiard saloon in Memphis, 32.

McAllister, Mrs., an appeal by one woman to another, 34 .

Macbeth, 186, 187, 220, 265; Samuel Phelps as, I 71, 319 .

"Macbeth," dramatic action in, $\mathbf{1 8 6}$ I87; mishaps in, at Drury Lane Theater, 318, 319; impropriety of realism in, 457,458 .

McCullough, John, 421.

McKenzie \& Jefferson, build theater in Springfield, Ill., 28, 29; dissolution of partnership, 3 I.

Macon, Ga., successful season in, 132 .

Macready, William, early recollections of, 5 ; in Mobile, 41 ; character, 4I-44; singeing his wig, 42; as Werner, 42, 442-444; on the war-path, 43 ; influence of his style upon James W. Wallack, Jr., 80 ; Shaksperean revivals at Drury Lane Theater, I54; troubles with Forrest, 166, 167; Chanfrau's imitations of, 420; Mrs. Warner's criticism of, $442-444$.

Macready and Forrest riots, 344 .

"Mad Arithmetician, The," by Charles Mathews, 386.

Madison Square Theater, New York, Charles Mathews's fondness for, 383,384 .

"Maid of the Inn, The," Mrs. Drake in, 416 .

Major Barstock, John Brougham as, 437.

Major Oakly, criticism of the character, I53.

Malaprop, Mrs., Mrs. John Drew as, 400, 401.

Malvolio, W. R. Blake as, Io7; Samuel Phelps as, I 7r.

Management, love for, I4I.

Manager, enthusiasm of a, 58, 59; qualities of a successful, I31, I32; a star in search of a, 135; from lamplighter to, 235; the most useful, 456 .
Managers, a word as to, $\mathbf{1} 83, \mathbf{1} 84$.

Manchester, play "Rip Van Winkle" and "The Parish Clerk" in, $32 \mathbf{I}$.

Mandillos, 70.

Maoris, physical features of, 272.

Marble, Danford, 20, 222.

Marcellus, Edwin H. Vanderfelt as, 422.

Maria, Mary Devlin as, I5I.

Marie Antoinette, thoughts of, 173 .

Mark Antony, 383 ; in a queer predicament, 383 .

Marlow, 463.

Marrall, cast for, 129.

Marriage, my first, I27, 128; my second, 323 .

Mary, my foster-mother, 8-Io; death, 40.

Mary, Mrs. Drake as, 416.

"Masaniello," overture in Lima Cathedral, 284.

Massachusetts vs. South Carolina, $276,278,279$.

Matamoras, Mex., occupied by United States army, 67; reopening old Spanish theater in, 67; close of theater, default of manager, and dissolution of company, 67 ; open coffee and cake stand, 68; penalty for murder, 69; early closing, 71, 72; houses and life in, 72; voyage to Brazos Santiago from, 78.

Maternal affection in Australia, 244.

Mathews, Charles (the elder), character of his work, 22 I.

Mathews, Charles, as Charles Surface, I53; as Roderigo, I54; on the character of Mercutio, I54; fondness for Madison Square Theater, 383,384 ; character, talents, and humor, 385-392; trip on Flying Scotchman with, 386; dinner with Byron, Planché, and, 386, 387 ; philosophy of, 387 ; sympathy and affection, 387,388 ; repertory of, 389; unsuccessful engagement at Boston Theater, 390 ; jokes on the subject, 390-392; in the Bulfinch Place kitchen, 407.

May, Capt. Charles A., charge of, at battle of Resaca de la Palma, 67.

May Fielding, Mrs. J. H. Allen as, 208.

Mayo, Frank, as King Claudius, 422.

"Mazeppa," at Amphitheater, Philadelphia, 123.

Mechanical contrivances, increase in use of, 397.

Mechanical ingenuity, 144. 
Meg Merrilies, Charlotte Cushman as, 414 .

Meissonier contrasted with Millet, 385 .

Melbourne, Vict., from Sydney to, 239, 273; successful season at Princess's Theater, 239; Haymarket Theater, 239; return to, 259; play at Haymarket Theater, 259 ; voyage to New Zealand from, 271 ; to Callao from, $275,276$.

Melbourne Argus, excellence of criticisms in, 239.

Melodrama, duties of low comedian in, I20, 121 .

Memphis, 47 ; first visit to, $3 \mathrm{I}$; interview with mayor of, $3 \mathbf{I}$; passage to Mobile from, $33-36$.

Mercutio, 220, 308; Charles Kemble as, 154; Charles Mathews on the character of, 154 .

Mestayer, Mrs. Charles, marries Barney Williams, 4IO.

Metamora, Edwin Forrest as, 160; series of mishaps to Forrest in, I60-165.

Metropolitan Opera House, New York, Lester Wallack's testimonial at, 421,422 ; cast, 422 .

Metta, $73,74,77,78$.

Mexican War, outbreak of, 65 .

Mexico, life in, 72.

Micawber, W. E. Burton as, 100.

Michigan, Lake, 2 I.

“Midsummer Night's Dream," produced by Laura Keene, 203-205.

Miller, John, letter from Washington Irving, 415, 416.

Millet, J. F., a sad picture by, 355 ; apostrophe to, 355 ; treatment by the Salon, 356,423 ; nature of his work, 357 ; contrasted with Meissonier, 385 .

Mirabel, criticism of the character, I53.

Missionary, New Zealand use for, 272.

Mississippi, Charles Burke with company in, 52, 53; barn-storming in, 54-57; traveling through, 57 .

Mississippi River, scenery in the, 25 ; fishing in, 35 ; up the, 48 ; floating theater on, 62 .

Missouri River, floating theater on, 62.

Misther O'Winkle, 378.

Mitchell, William, manager of the Olympic Theater, I07; conflict with W. E. Burton, I07; stricken with paralysis, I07.
Mobile, arrival at, 36 ; benefit in, 39 ; James Wallack, Sr., in, 40.

Mobile Theater, under management of Ludlow \& Smith, 146; “Wives as They Were, and Maids as They Are," at, I47, I48.

Modjeska, Helena, as Ophelia, 422.

Molière, comedies of, at the Théâtre Français, 354.

"Money," love scenes in, 195.

Monterey, march on, 67 .

Montgomery, Walter, in the Bulfinch Place kitchen, 407.

Moonlight, acting by, 56 ; musings by, I 73, 374; sleeping in the, 254 .

Moral drama, character of, 454,455 .

Mordaunt, Frank, as Francisco, 422.

Morgan, Australian bushranger, 257 , 258.

Morningside, Scotland, residence at, 352,372 .

Mose, F. S. Chanfrau as, 420 .

Moses, appearance as, $\mathbf{1} 5 \mathbf{I}$.

"Mother's Pet, The," in a Chinese theater, 269.

Motive, importance of, in dramatic writing, 462 .

Mowatt, Anna Cora, in New Orleans, 48; defects in her acting, 138 .

Munden, Joseph S., portrait of, at Garrick Club, 362 .

Murdoch, James E., as Charles Surface, 15I-I54; versatility and originality of, I52-1 54; style in light comedy, 153, 154; at Haymarket Theater, London, I $_{53}, \mathbf{I}_{54}$.

Murray River, visit to region of, 242-255.

Mystery, pleasure in, 333; a dark, 376,377 .

"Naiad Queen, The," at Ford's Theater, Richmond, 157.

Nashville, Tenn., 45.

Natchez, Miss., Tom Glessing's adventure at, 9I-93.

Nature, resentment of imitation, 356 , 357 ; on the stage, 453,454 .

Nautical drama, propriety of realism in, 457 .

Neal, Joe, II.

Neal, Mrs., II-I3.

Necessity the foster-mother of art, 449.

Neptune, The, sail for England in, I7I.

Nervousness at meeting new company, 303.

New Englander, how depicted, 20.

Nezuman Noggs, in character of, 209. 
New Orleans, voyage from Brazos Santiago, to, 78 ; American Theater closed, 80; Lafitte at battle of, 465.

Newspaper controversies, IoI.

Newspaper criticism, importance of, to an actor, 115 .

Newspapers, increase of illustration in, 397.

"New Way to Pay Old Debts, A," play Marrall in, 129.

New York, great fire of 1835,13 ; first appearance in, 14, 15 ; early residence in James Street, 15 ; my cemetery playground in, 15, 16; marriage at old church in Oliver Street, I28; shipping actors to Wilmington by schooner from, I4I-I43; fishing in Union Square, 337, 338; Fechter's failure in, 342; reception of English actors in, 344, 345.

New Zealand, from Melbourne to, 271 ; success in, 272; use for missionaries in, 272; to Sydney from, 272 .

New Zealanders, dramatic instinct in, Nick 425 . ick Vedder, Paul Bedford as, 304.

Nimrod, The, embark from San Francisco for Sydney on, 23I.

Norfolk Island, 232.

North $v s$. South, on the stage, 213215.

Notoriety, evil effects of desire for, 334.

Notre Dame, Paris, moonlight view of, 173 .

Novices, ephemeral success of some, $460,46 \mathrm{I}$.

Ober-Ammergau, religious tableau at Callao contrasted with the Passion Play at, 290, 291.

O'Connell, Daniel, letter from John Howard Payne to, 4I6, 4I 7.

"Octoroon, The," difficulty with the management in, $21 \mathrm{I}-2 \mathrm{I} 3$; powerful influence of, $213-215$; produced in Sydney, 239.

O' Flanaghan, John Drew as, $4 \mathbf{I} 2$.

O'Grady, John Brougham as, 3I4.

O'Grady, Father, fellow-passenger on the Nimrod, 23I ; calls on me in Sydney, with his wife, 273 ; apostrophe to, 283.

Ohio River, down the, 46,47 ; floating theater on, 62 .

Old friends, disloyalty of, 194 .
Olympic Theater, New York, managed by William Mitchell, I07; end of conflict between Burton and, I07.

O. P. riots, 296.

Opera, the, Paris, 355.

Opéra Comique, the, Paris, 294, 355.

Operas, grand, requirement of space for, 383 .

Ophelia, Helena Modjeska as, 422.

Opposition and competition contrasted, IOI.

Orange groves, profits from, 394.

Oratorio compared with acting, 428.

Orchestra, a panic-stricken, 126, I27; a Chinese, 268 ; perils surrounding an, $\mathbf{I} 63$.

Originality in acting, $152,153$.

Osric, Charles Koehler as, 422.

Othello, 220; Edwin Forrest as, 167.

"Our American Cousin," early rejection of, 193; produced by Laura Keene, 193; success of, 193, 194, 196-198, 200, 203; value of the love scene in, 194-196; strong cast in, 197; secure right of starring with, 205; results, 207; my first serious work in, 209; as Asa Trenchard in, 222; produced in Sydney, 239.

Overbilling, evil effects of, 229.

Owens, John E., 222, 420; as Mr. Pittibone, 79, 81, 82; his fine acting, $81,82$.

Pacific coast, a misnomer, $279,280$.

Pacific Ocean, 275, 276.

Painters, extravagances of some in London, 362,363 ; subject to bias at hands of brother artists, 423,424 .

Painting, 348, 350 ; secret of landscape, 356,357 ; compared with acting, $384,385,428$; analogy between poetry, music, and, 428 .

Pakenham, General, 465.

Palais Royal, Paris, I77, 353, 355.

Palmo's Theater, New York, purchased by W. E. Burton, 106; strength of company at, 107.

Palo Alto, Mex., battle of, 66.

Panama, voyage from Callao to, 293295; cool reception in, 297-301; leave for England, 30I.

Panic of 1837 , effects on theatrical matters, 52 .

Panic of $1857,187-189$.

Pantomime, distinguished from dramatic action, 185-187; English, 3 I2, 3I3; value of, 435,436 ; necessity of harmony with scene, 445 . 
Paradise Valley, Pa., summering at, Philosophical discussions, decline of, 224. in modern plays, 397.

Paris, first visit to, $\mathbf{1 7 3}$; Hotel Byron, Philosophy, inborn, 33, 34 .

I 73; a terrible fight at, I 74 ; econ- Physiognomy, a curious fact about, omy in, $\mathbf{I 7 5}$; second visit to, $\mathbf{I 7 6}$, 177; a guide in, I76-179, I81, I82; theatrical wardrobe shops in, I77-182; guyed in, I79, 180; return to America from, $\mathbf{I} 82$; third visit to, 346 ; Hotel Mirabeau, 346; our flat in Avenue d'Eylau, teacher in, 346,347 ; scenery around, 348; furnished houses in, $35 \mathrm{I}$; sacredness of art in, $35^{2}$; art galleries of, 355 .

"Parish Clerk, The," play in Manchester in, $32 \mathrm{I}$.

Parrot's coffin, a, 376, 377 .

Partnerships, theatrical, I15, II6.

Passion Play at Ober-Ammergau contrasted with religious tableau at Callao, 290, 29 I.

Past vs. Present, 422-424.

Patent theaters, privileges of, 368 .

Patriarch, an Acadian, 469-474.

Pauline, 195.

Paul Pry, I03.

Pawn, getting an actor's wardrobe out of, $\mathbf{I} 36$. 250, 25 I.

Pigs and "Home, Sweet Home," 27, 28.

Pioneer, The, canal-boat, 18.

Pirate of the Gulf, the, 465,469 .

Pitcairn Islanders, 232.

Pittibone, Mr., John E. Owens as, 79, 8I, 82.

Pizarro, 28I.

Placide, Henry, as The Fool, I07; as Sir Peter Teazle, 151, 154, 155; follows style of Farren, I55; his career, 155 .

Placide, Thomas, as Crabtree, $\mathbf{1 5}$ I.

Planché, James R., 3I 3 ; dinner with Mathews, Byron, and, $386,3^{87}$.

Plantation songs, 468 .

Play, community that never saw a, 55-57; likened to a picture, 157 ; on altering text of, $20 \mathrm{I}$.

Player Queen, The, Rose Coghlan as, 422.

Players, The, simplicity of Hamlet's instructions to, 455 .

Payne, John Howard, author of "Clari, Plays, literary merit of, I84, I85; oldthe Maid of Milan," and of "Home, Sweet Home," 27; letter to Daniel O'Connell, 4I5-4I 7; letter to Mrs. Drake, 4I $7,4 \mathrm{I} 8$; scheme for periodical, 417 .

Pearson, Harry, as John Peerybingle, 208.

Pedestrian exercise, 45 .

Pekin, Ill., play in a pork house in, 27.

Peoria, Ill., 27.

Perry, Harry, 230.

Persecutions, early, 9, 10.

Peru and Chili, war between, 293.

Peruvian, scalping a, 5, 6 .

Peruvian bark, a heavy dose of, 277.

Phelps, Samuel, versatility of, $\mathbf{I} 7 \mathbf{I}$; as Macbeth, I7I, 319; as Sir Pertinax McSycophant, I II ; as Malvolio, I7I; as King Lear, I7I; as Sir Anthony Absolute, I7I; as Bottom, I7I.

Playground, a strange, 15, 16.

Playhouse, my first, I-5. fashioned, 264, 265 .

Plympton, Eben, as Laertes, 422.

"Pocahontas," written by John Brougham, 315, 316; played under difficulties, 315-3I7.

Pocahontas. John Brougham as, 317 .

Pocono Mountain, Pa., summering near, 224.

Poe, Edgar Allan, contributes to the "Gentleman's Magazine," IOI ; quarrels with Burton, IOI.

Poetical speeches, decline of, in modern plays, 397 .

Poetry, anaiogy between music, acting, painting, and, 428 .

Point Isabel, Tex., voyage to, 66.

Point of view to be regarded in painting and acting, 384,385 .

Poker, a British estimate of, 136 .

Police, theatrical contempt for, 313 .

Policeman, hooking a, 338 .

Philadelphia, my place of birth, 14; Politics and art, 352 .

Arch Street Theater managed by Polonius, John Gilbert as, 422 ; simW. E. Burton, 57,83 ; a desperado from, 75 ; death and burial of my mother at, II8; the Amphitheater at, I I 8 .

Phillips, Mr., stage-manager at Adelphi Theater, 305 . plicity of advice to his son, 455 .

Pork-house, playing in, 27 .

Port Gibson, Miss., Charles Burke's company in, 53 ; arrival at, 54 .

Posturing, 6.

Pot-luck, definition of, I40. 
Povey, John, agent for Charles Mathews, 39I ; cruel joke on, 39I, 392.

Power, Tyrone, early recollections of, 5 ; an early star, 22I ; abiiity and success of, 221, 222; at Theater Royal, Dublin, and Haymarket Theater, London, 22I ; influence on the American stage, 222 ; compared with John Drew, 4I3.

Powhatan, John Brougham as, 316, 317.

Practical joker, a, 337, 338 .

Prairie, a journey over, 24, 25 .

Prejudice in criticism, 423, 424.

Prentice, George D., editor of "Louisville Journal," 328 ; manner, personal appearance, and talents, 328 $33 \mathrm{I}$.

Preparation in acting, $43 \mathrm{I}$.

Pre-Raphaelite work, value of, 359 .

Present vs. Past, 422-424.

Priest, Harry Edwards as, 422.

Prince of Wales's Theater, under Marie Wilton, 3I 7 .

Princess's Theater, London, “Arrah na Pogue," at, 314; engagement at, 345,359 .

Princess's Theater, Melbourne, successful season at, 239.

Private rehearsal, 308,309 ; in a public place, 263 .

Procrastination, 433.

"Prodigal Son, The," at Spanish Theater, Callao, 289 .

Profit-sharing in early days, 57,58 .

Properties, drying out, 26; use of, at rehearsal, 434.

Provincial companies, customs of, I43, I 44.

Pruning, value of, 403 .

Public, the, I05, Io6; fair play of, 344 .

Public approval, a great stimulus, 453.

Puck, refuse to play, 204; Laura Keene as, 204.

Puff, Mr., 435, 436; wisdom of, $45 \mathrm{I}$.

Pulpit, actors in the, 426 .

Pumping, 277, 278, 286, 287.

Pythias, Edwin Adams as, 158 .

Quarrels between actor and manager, 213.

Queen, The, Gertrude Kellogg as, 422.

Queen Catherine, 265; Charlotte Cushman as, 4I4.

Queen Elizabeth, Mrs. J. W. Wallack, Jr., as, 79,8 o.
Queen's yacht, commanded by Lieutenant Frank Jefferson, 3 I 0 .

Quin, James, criticism on Garrick, 423 .

Quincy, Ill., playing in court house, 27.

Quizzing, an actor's fondness for, 127, I 28.

Raeburn, Sir Henry, portraits by, in Gregory mansion, 373 .

Railroad manager, the, I $5 \mathrm{I}$.

Rashleigh Osbaldistone, William Warren as, 405 .

Ray, Mrs., I 43.

Raymond, John T., a successful comedian, 222 ; manages " Rip Van Winkle" at Carusi's Hall, Washington, 227; a legitimate comedian, 420; as Ichabod Crane, 42I; as Colonel Sellers, 42I ; ability, 421.

Raymond, Oliver, at Palmo's Theater, I07; as Mr. Toots, 437; sudden rise, 437 .

Reade, Charles, $3 \mathbf{I} 3$.

Realism, in art, 453, 454; important factor in dramatic art, $456-45^{8}$; out of place in "Rip Van Winkle," 457 ; propriety of, in nautical drama and rural scenes, 457 .

Rebozo, the, 292.

Reception, a cool, 297-301.

"Records of the New York Stage," I4.

Re-creation of characters, 4I4.

Rehearsal, a private, in a public place, 263 ; private, 308,309 ; quality, not quantity, 432, 433; importance of the first, 433 ; stage-manager's, author's, and actor's duties as to, 433 ; use of scenery and properties at, 434; importance of thoroughness in, 435 ; value of careful preparation at, $436-438$.

Rehearsing under difficulties, 89.

Reign of Terror, thoughts of the, I 73 .

"Relapse, The," 402, 403.

Religion, the drama and, 29, 30; democracy of, 285 .

Religious tableau, a, 289-29I.

Repose, value of, 446 .

Resaca de la Palma, battle of, 67 .

Reuling, Dr., oculist, 388.

Reunions, family, 3II , 3I2.

Revenge, a sister's, 258.

Rice, John B., Salisbury's telegram to, 215 ; married to Mary Anne Warren, 392 ; theatrical manager in Chicago, 393; mayor of Chicago, 393; member of Congress, 393; 
character, 393-395; ridicules my investments, 393, 394; quarrel with Edwin Forrest, 394; dumfounds a scientist, 394-396.

Rice, T. D., 6-8.

Richard Dazzle, criticism of the character, 153.

Richard III, Pudding Stanley as, 62-65; drawing of Edmund Kean as, 205, 206; ludicrous blunder in playing, 368.

" Richard III," 445; at St. Charles Theater, 79-8I.

Riches, philosophizing on, 303 .

Richings, Peter, in the Bulfinch Place kitchen, 407.

Richmond, Va., become manager of Ford's Theater, at, I57; in search of news from, 278, 279; season in, 412.

Ringgold, Major Samuel, wounded at battle of Palo Alto, 66.

Rip Van Winkle, monologue for, 227; strikes a sympathetic chord in G. D. Prentice, $33 \mathrm{I}$; suggested change to an Irishman, 378; compared with King Lear, 452, 453; not a temperance lecturer, 454 ; am identified as the original, 458,459 .

"Rip Van Winkle," evolution of 223-229, 302, 456, 46r, 462 ; early dramatizations of, $225,46 \mathbf{r}$; first rehearsals of, 227, 228; analysis of the long sleep in, 228 ; results of first presentation of, 229 ; remodeled, 229; produced in Sydney, 239; rewritten by Boucicault, 302 , 46I; engage to play at Adelphi Theater, 302 ; reading, 303 ; rehearsal, 304-306; an important production of, 308 ; first production in London, 310 ; success of, $310,380,45^{8}, 459$; appear in Manchester in, 321 ; success in Belfast, 380 ; not a temperance play, 454 ; poetic element in, 454 ; suggested end of characters in, 454; impropriety of realism in, 457 ; play in Catskill, 458, 459; a new reading in, 459; lessons to be drawn from its career, 460-462.

Rivalry, II6-II8.

" Rivals, The," am invited to produce at Cincinnati Dramatic Festival, 382; compared with, "The School for Scandal," 397-399; altering and condensing, 397-403; purity of, 399 ; introduction by Mrs. John Drew, 40I ; epilogue, 401 ; criticism of my changes in, 401,402 ; justification of changes, 402,403 ; in Philadelphia, $4 \mathrm{I} 3$; effects in, 446 , 447.

"Road to Ruin, The," at Laura Keene's Theater, 224.

Robbers, in dread of, II/3, II4.

Roberts, David, picture by, at the Gar- . rick Club, 362 .

Robertson, Agnes, at Ford's Theater, Richmond, I57; as Dot, 208; beauty of, 209.

Robertson, Tom, meeting with, 317; writing comedies for Marie Wilton, 317 ; success and good qualities of his plays, 317 ; character and genius, 317-319; as raconteur, 317,318 ; views of Goldsmith, 318 ; sense of humor, 319 ; attachment for Artemus Ward, $320,321$.

"Rob Roy," 405.

Robson, Mr., I 7I.

Roderigo, Charles Mathews as, 154.

Rolamo, Mr., manager of theater at Sydney, 234; cockney tongue of, 235 ; industry and success of, 235 ; estimation of Yankee comics, 235 ; opinion of "the legitimate," 236.

Rolla, 5 .

Romance, a dreamland of, 293.

"Romance of the English Stage, The," 450.

Romeo, playing, under difficulties, I45, I 46.

"Romeo and Juliet," 220; in Wilmington, I44; ludicrous accident in, 144-146; perfection of love scene in, I95.

Rosebush, a sympathetic, 333.

Rosencrantz, Charles Hanford as, 422.

Roses, Tom Glessing's, 331, 333 .

Rouen, I73.

"Rough Diamond, The," produced in Savannah, $\mathbf{1}_{3}^{6-1} 38$.

Rousseau, T., nature of his work, 357.

Rowe, George Fawcett, manager of Princess's Theater, Melbourne, 239; contract with, 239.

Rowley, Mr. Ellis as, I5I.

Royal Academy, Loan Exhibition at, 368.

St. Andrew, ludicrous mishap of, 125127.

St. Anthony, a modern, 273, 283 .

St. Charles Theater, New Orleans, acting in, 47; "Richard III" at, 79-8I ; under management of Ludlow \& Smith, 79; "A Kiss in the 
Dark" at, 79; James W. Wallack, Search, Jake, property man at Ford's Jr., Mrs. Wallack, and John E. Owens at, 79-82.

St. David, I25. Theater, 160; hides from Forrest's wrath, 160, 162.

St. George, Charles Foster as, 125, 126.

"St. George and the Dragon" at Amphitheater, Philadelphia, I25-I27.

St. Louis, Mo., a summer's acting in, 48,49 ; hissed off the stage at, 49 , 382 ; play with Burnett in, 193 .

St. Patrick, 125.

Sala, George Augustus, meeting with, 360.

Salem Scudder, in character of, 209; resign part, 2 I I.

Salisbury, Charles, guying tendency, 215 , 216; telegram to Rice, 215 ; wonderful memory, 215; dunned by laundress, 216 .

Salon, Paris, treatment of Millet, $35^{6}$; prejudice in admitting members, 423,424 .

Salt Island, 467 .

Sampson, in character of, 44 .

San Antonio, Tex., offer to play in, 58,59 .

San Francisco, Cal., failure in, 229; sail for Sydney from, 23I.

San Francisco cathedral at Lima, 284, 285.

Sardou, Victorien, estimate of, 185 ; dramatic action in one of his comedies, 185, 186 ; coarseness of, 195 .

Savage Club, London, 362.

Savannah, Ga., ill success in, I32, I 33 ; its beauty, $\mathbf{I} 33$.

as, 422.

Second-hand shops of Paris and London contrasted, $\mathbf{I} 78$.

Sefton, John, I5; partnership with, I I I-I I 6.

Seguin company, as leader of chorus in, 327.

Seine, scenery of the, I 73 .

Self-confidence and courage contrasted, 450.

Self-defense, take lessons in, 212, 213.

Selfishness, incentive to favorable criticism, 194 .

Seminole War, murder of actors during, 60 .

Seneca's advice to Lucilius, 474 .

Shabby gentility, $378-380$.

Shakspere, William, works sometimes overshadowed by inferior plays, I06; starring system attributable to, 220; magnitude of his heroes, 220 ; characters in his comedies, 220, $22 \mathrm{I}$; former restrictions regarding his plays, 368 ; simplicity of presentation of his lessons, 455 , 456.

Shaksperean productions, improvement in modern, I08.

Shaksperean revivals, at Drury Lane Theater, Macready's, 154 .

Sharing scheme, $a, 57,5^{8}$.

Saxe-Weimar, Duke of, opinion of Mrs. Drake, 4r6.

Sheep-farming in Australia, 242.

Shepherds, Australian, 247.

Scenery, dipped in the Mississippi Sheridan, Richard Brinsley, works River, 25 ; a new use for, 46,47 ; acting without, 54; increased splendor of, 396 ; use of, at rehearsals, 434.

Schenectady, playing in, I7, 18 .

Schneider, public interest in, 453 .

Scholastic dramatic institution, importance of, 354, 355 .

School, influence of the free, 50. sometimes overshadowed by inferior plays, 106; description of a lady's face, 365 ; alters "The Relapse" to "A Trip to Scarborough," 402, 403.

Sheridan twenty miles away, 402.

"School for Scandal, The," produced Sign-painting, from scene-painting to, by Jarrett at Washington, 15 I, I52, 154-I 56 ; artificiality, 398 ; indelicacy, 399; compared with "The Rivals," 397-399.

Scotland, honesty in, 352 ; sport in, 370,371 .

Scottish chief, a, 370 .

"Sea of Ice, The," at Ford's Theater, Richmond, 157; Laura Keene in, 206.

"She Stoops to Conquer," deception of characters in, 463 .

Siddons, Mrs., 296. $3 \mathrm{I}, 52$.

Sir Andrew Aguecheek, Lester Wallack as, I07; J. B. Buckstone as, 441 .

Sir Anthony Absolute, Samuel Phelps as, I7 I ; James Burnett as, I93.

Sir Benjamin Backbite, I. M. Dawson as, I5I.

Sir Edrvard Mortimer, J. B. Booth as, 44 . 
Sir Giles Overreach, J. B. Booth as, Speech, rehearsing a, 9I-93. I29-I3I.

Spider and the fly, the, $35 \mathrm{I}$.

Sir Harry Bumper, J. M. Barron as, Spiritualism, 252, 253, 255. I 5 I.

Sir John Falstaff, 221.

"Splendid Misery," produced by Laura Keene, I89.

Sir Lucius O'Trigger, 40I ; John Spontaneity, 43I, 432, 437, 445. Drew as, 4I3.

Sports, Australian, 242-245.

Sir Oliver Surface, George Andrews Springfield, Ill., 27; building a theater as, 151. in, 28.

Sir Pertinax McSycophant, Samuel "Sprite of the Silver Shower, The," Phelps as, I7I. I39.

Sir Peter Teazle, Henry Placide as, Stage, tricks of the, 65 ; complaints of I5I, I54, I55.

Sir Toby Belch, W. E. Burton as, ro7.

Sister's revenge, a, 258 .

Skeleton dance, Australian, 242-244.

Slavery question, the, 213-2I 5 .

Slave-stealer, a, 465 .

Sleep, the great doctor, 36r.

Smith, E. T., manager of Astley's Circus, 3 I2.

Smith, James, theatrical critic of Melbourne "Argus," 239.

Smith, Rev. Sydney, description of a New Zealand lunch, 272 ; earnest wish of, 272.

Snake, Edwin Adams as, $15 \mathbf{r}$.

Snoring, the philosophy of, 85,86 .

Social position in England and America contrasted, 251 , 252.

"Soldier's Daughter, The," Mrs. Drake in, 416.

Soldiers, United States, sufferings in Mexico, 78 .

Soliloquy, addressed to audience, 430 ; importance of keeping up interest in, 442 .

Sophocles, "Antigone," ro2-ro4; called before the curtain by a Philadelphia audience, I02, I03.

Sothern, E. A., early dread of character of Lord Dundreary, 194, 197; plays the part with success, 197, 198; as Brother Sam, I98; a successful comedian, 222.

South vs. North, on the stage, 213215.

South Carolina vs. Massachusetts, 276, $278,279$.

Southern circuit, I32-I49.

Spanish, learning, 74 .

Spanish and French women contrasted, 283 .

Spectacles, fate of their inventor, II2.

Spectacular plays, requirement of space for, 383 .

"Spectre Bridegroom, The," by moonlight, 56 . degeneracy of, 106; ethics of, I99-203; nature on, 453, 454.

Stage-coach traveling in $1846,84-88$.

Stage direction, importance of a, 187 .

Stage fright, 48, 137, 138.

Stage-management, thorough preparation in, 431 .

Stage-manager, duties as to rehearsal, 433

Stanfield, Clarkson, marine picture by, at Garrick Club, 362 .

Stanley, George, prompter at Mobile Theater, I47.

Stanley, Pudding, 58-65; as Richard $I I I, 62-65$; his career, 62,63 .

Star, in search of a manager, I35; advertising a, I36; a war, defined, 322.

Star and Garter, Richmond, a memorable lunch at, 360, 36r.

Star chamber, a theatrical, 97-99.

Starring, my first thoughts of, 222, 223.

Starring system attributable to Shakspere, 220.

"Star-Spangled Banner, The," given under difficulties, 48 .

Stevens, Sara, in "Our American Cousin," 197; as Bertha, 208; beauty, 209.

Stiff piece of humanity, a, 297.

Stimulus, a noble, 450; public approval, a great, 453 .

Stock companies, character of Australian, 237; contrasted with combinations, 326,327 .

Stock company, my first, 3,4 .

Stock theater, qualities of successful manager of, I3I, I32.

Stowe, Harriet Beecher, meeting with, 452, 453; comments on resemblance between Rip Van Winkle and King Lear, 452, 453.

Stranger, The, A. H. Davenport as, 208.

Stuart, William, engage with at Winter Garden, 207; difference with, 2II-2I3. 
Success, ephemeral and legitimate contrasted, 460, 46I ; the foundation of, 462 .

Suggestion compared with vagueness, 435,436 .

Sunrise, The, sail from Liverpool to New York on, 32 I.

Super, beginning as a, 451, 452 .

Superstition, 252, 253, 255, 333 .

Supper time, the actor's golden hour, 341 .

Swordsmanship, James W. Wallack, Jr.'s, superb, 8I.

Sydney, N.S.W., sail from San Francisco for, 23I; beauties of the harbor and city, 233; character of company in, 237; introduction to company, 238; first appearance in, 238 ; success, 238 ; leave for Melbourne, 239; from New Zealand to, 272; meet Father O'Grady in, 273; to Melbourne from, 273.

Sydney Heads, terrors of, 232.

Syracuse, playing in, 18.

Tableau, arranging a, I90-I92; a religious, 289-29I.

Tackleton, T. B. Johnson as, 208.

Talebearing, 97, 98.

Talent, confounded with wardrobe, 389 ; compared with genius, 432 .

Tasmania, from Melbourne to, 259 convict element in, 259-26I.

Taylor, Tom, author of "Our American Cousin," I93, I96.

Tea, the beverage of the Australian bush, 250.

Telegram, my first, I I I, I 12. Telegram, my first, I I I, I I2.
Temperance lecturer compared with Twain, Mark, author of "The Gilded actor, 455 .

Temperance play, a, 454 .

Temptation, a terrible, 248, 254, 255.

Tennessee, traveling through, 45 .

Texans, refining depraved tastes of 59.

Text of play, on altering, 201 .

Thames River, 360 .

Theater, lighting a, fifty years ago, 29; an improvised, 56 ; a floating, 62 ; discipline of a, I98-200; attraction for actors, 78, 237; daylight effects on cathedral and, compared, 284 ; playing to different classes in, 385 ; compared with art gallery, 429.

Theater Royal, Dublin, "Antigone" at, 102 ; Tyrone Power at, 22 I.

Theater Royal, Glasgow, appear 372 ; its modest manager, 372 .

Theater Royal, London, Edmund Kean's trials at, 449,450 .
Theaters, infants in, 28; large and small contrasted, $3^{8} 3,3^{84}$; increase of, and improvement in, 427 .

Théâtre Français, Paris, criticism of acting at, $352-355$; "L'Ami Fritz" at, 353 ; comedies of Molière at, 354 .

Theatrical profession, progressive nature of, 328.

Thompson, Lysander, at Palmo's Theater, 107.

"Ticket-of-Leave Man, The," at Hobart Town, 259-26r.

Tillie Slowboy, Mrs. John Wood as, 208.

Timour the Tartar, a daunted, 122.

Titus, Master, 14.

Tony Lumpkin, wisdom of, 52.

Toots, Mr., Oliver Raymond as, 437. 220 ; compared with savage, 266, 267; a Chinese, 270, 271.

Tragedy, compared with comedy, 220, 429; criticizing, 429.

Training, natural talent aided by, 448 , 449.

Treasure, hidden, 466 .

Tree, Ellen, 261, 262.

Trip, J. B. Howe as, 15 I.

"Trip to Scarborough, A," altered from "The Relapse," 402, 403.

Trollope, Anthony, 314.

Trollope, Mrs., opinion of Mrs. Drake, 416.

Tropics, discomforts of the, 297.

Trumbull, John, I9o.

Turner, J. M. W., early and later

Age," 42I.

"Twelfth Night" at Palmo's Theater, I07, 108 .

United States, first dramatic challenge to England, 165 ; hissing rare in, 218; religious tone of, contrasted with that of Bavaria, 29I ; reception of English actors in, 344,345 ; contrasted with France, 352.

"Used Up," produced in Savannah, 136-138.

Utica, playing in, 18 .

Vagueness, compared with suggestion, 435,436 ; illustration from "The Critic," $435,436$.

Valrie, M., French consul at Callao, 280, 28I ; meeting with, on voyage from Callao to Panama, 293; broken English, 294; domestic
Tragedian, advantage over comedian, 
happiness, 294; fondness for drama and opera, 294; as a whist-player, 295.

Vanbrugh, Sir John, author of "The Relapse," 402, 403.

Vanderfelt, Edwin H., as Marcellus, 422.

Van Diemen's Land, from Melbourne to, 259; convict element in, 259$26 \mathrm{I}$.

Van Dunder, W. E. Burton as, Ioo.

Vanity, I 16, 226, 308, 309.

Vedder, Nicholas, $45^{8}$.

Verey's, London, family reunion at, 3 I 2 .

Versatility, lack of, 389 ; of actors, 146.

Vert, Mme., 348-35 I.

Vestris, Mme., 205.

Vicksburg, Miss., drumming in, $5 \mathbf{2}$; Havana cigars made in, 52 .

Viola, Lizzie Weston as, 107.

Virginia Water, Queen's yacht on, 310.

Virginius, Edwin Forrest as, 157.

Walcott, Charles, 287 .

Wallace, Buck, adventures of, 75, 76; wife and child murdered by Comanches, 75; murdered, 76, 77; opinion of Cooper's novels, 76 .

Wallack, James, Sr., in Mobile, 40 ; character, 40 ; in "The Brigand," 40, $4 \mathrm{I}$; succeeds Brougham at the Lyceum, 315; in the Bulfinch Place kitchen, 407.

Wallack, James W., Jr., personal appearance and acting of, 79-8I ; swordsmanship, 81; as Duke of Gloucester, 79-81; influence of Macready's style upon, 80 ; in "Antigone," I04; as Joseph Sur. face, I5 $\mathbf{I}$.

Wallack, Lester, cousin of James W. Wallack, Jr., 79, note; as Sir $A n$ drew Aguecheek, I07; testimonial at Metropolitan Opera House, 42I, 422.

Wallack, Mrs. James W., Jr., as Queen Elizabeth, 79, 80; her acting, 80; compared with Charlotte Cushman, 80; in "Antigone," I04.

Wall Street, in panic of $1857,188$.

War, effect upon theatrical finances, 80.

Ward, Artemus, in London, 320 ; character and humor, 320,321 ; death, 320, 321 ; attachment for Tom Robertson, 320,321 .

Wardrobe, confounded with talent, 389.
Warner, Mrs., compared witn Charlotte Cushman, 4I4; criticism on Macready, 442-444; in "Werner," 442-444.

Warren, General, sufferings of, 191, I 92.

Warren, Harry, theatrical manager in Buffalo, 392.

Warren, Mary Anne, married to John B. Rice, 392.

Warren, Sarah, my marriage to, 323.

Warren, William, introduces Artemus Ward, 320 ; friendship with Fechter, 340, 34I ; rescues Fechter's cup from the crucible, 343,344 ; criticism on my changes in "The Rivals," 402; prominence in Boston, 403, 404; versatility, 403; character, talents, and career, 403 409; fiftieth anniversary of his debut, 403-408; as a star, 404; connection with the Boston $\mathrm{Mu}$ seum, 404, 405; early recollections of, 405, 406; personal appearance, 405; as Rashleigh Osbaldistone, 405; as Beauséant, 405; retirement of, 406,408 , 409 ; at a memorable feast, 407 , 408; last days, death, and burial, 409.

War star defined, 322.

Washington, D. C., early recollections of, I ; T. D. Rice in, 6; Killmist's theater burned, I0o; with Ford's company at, I60; open with " Rip Van Winkle" at Carusi's Hall, 227-229.

Watches, purchasing, for self and wife, I49; value of mine, I49.

Webster, Benjamin, engagement for "Rip Van Winkle" with, 302 ; feud with Boucicault, 303, 305-308; temper, 305-308.

Werner, Macready as, 42, 442-444.

West, power of recovering lost position in the, $251,252$.

Weston, Lizzie, as Viola, I07; as Lady Teazle, I 5 I.

Wheatley \& Drew, managers of Arch Street Theater, $149, \mathbf{1} 50$.

Wheeling, W. Va., coach office at, 84.

Wheelock, Joseph, as First Actor, 422.

Whist, a queer idea of, 295.

White, Col., 4I 7 .

White, Mrs. 4I 7 .

Widow Cheerly, Mrs. Drake as, $4 \mathbf{I} 6$.

Wife, a loving, $364-367,472,473$. 
"Wife's Secret, The," $26_{5}$.

Wikawite, N. Z., Maori village, 27I, 272.

Wilderness, a marine, 276 .

Wilford, 44.

Wilkie, David, 365 .

Williams, Barney, acts as my groomsman, I28; a successful comedian, 222 ; marries Mrs. Charles Mestayer, 4IO; popularity of, 410.

Williams, Mrs. Barney, popularity of, 410.

Wilmington, N. C., playing at, I39, I43.

Wilton, Marie, manages Prince of Wales's Theater, 3I7.

Windham, Charles, form combination with, 324 .

Winter, Messrs., hospitality of, 24I, 242.

Winter Garden, engagement at, 207; a combination of nature and art, 208; "Dot" at, 208, 209.
"Wives as They Were, and Maids as They Are," at Mobile Theater, I47, I48.

"Wolfert's Roost," John T. Raymond in, $42 \mathrm{I}$.

Wood, Mrs. John, as Tillie Slowboy, 208; beauty of, 209.

Wood \& Warren, theatrical partnership, I I 5 .

Wrecked life, a, 25 $\mathrm{I}$.

Wright, Mr., I7I.

Yankee, characteristics of a, 277-279.

Yates, Frederick H., plays early version of "Rip Van Winkle," 225, $46 \mathrm{I}$.

Young man, a London idea of a, 36I.

"Young Scamp, The," in a Chinese Theater, 269

"Zampa," 294.

Zekiel Homespun, 224.

Zoe, $214,215$. 






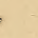




SMITHSONIAN INSTITUTION LIBRARIES

||||||||||||||||||||||||||||||||||||||||||||||||||||||||| 